Universidade de São Paulo

Faculdade de Educação

ISADORA REBELLO JOAQUIM

O PAPEL DA LINGUAGEM POÉTICA NO LETRAMENTO CONTÍNUO: UMA PERSPECTIVA METODOLÓGICA

São Paulo

2020 


\title{
O PAPEL DA LINGUAGEM POÉTICA NO LETRAMENTO CONTÍNUO: UMA PERSPECTIVA METODOLÓGICA
}

\author{
Versão corrigida
}

Tese apresentada ao programa de pós-graduação da Faculdade de Educação da Universidade de São Paulo (FE/USP), para a obtenção do título de Doutora em Educação.

Área de concentração: Linguagem e Educação

Orientador: Prof. Dr. Claudemir Belintane

SÃO PAULO

2020 
Autorizo a reprodução e divulgação total ou parcial deste trabalho, por qualquer meio convencional ou eletrônico, para fins de estudo e pesquisa, desde que citada a fonte.

Catalogação da Publicação

Serviço de Biblioteca e Documentação

Faculdade de Educação da Universidade de São Paulo

Ficha elaborada pelo Sistema de Geração Áutomática a partir de dados fornecidos pelo(a) autor(a) Bibliotecária da FE/USP: Nicolly Soares Leite - CRB-8/8204

Rebello Joaquim, Isadora

O PAPEL DA LINGUAGEM POÉTICA NO LETRAMENTO

CONTÍNUO: UMA PERSPECTIVA METODOLÓGICA / Isadora

Rebello Joaquim ; orientador Claudemir Belintane. --

São Paulo, 2020 .

$356 \mathrm{p}$.

Tese (Doutorado - Programa de Pós-Graduação

Educação, Linguagem e Psicologia) -- Faculdade de

Educação, Universidade de São Paulo, 2020.

1. Oralidade. 2. Letramento. 3. Poesia. 4. Emancipação. 5. Educação estética. I. Belintane, Claudemir, orient. II. Título. 
JOAQUIM, Isadora Rebello. O papel da linguagem poética no letramento contínuo: uma perspectiva metodológica.

Tese apresentada à Faculdade de Educação da Universidade de São Paulo para a obtenção do título de Doutora em Educação.

Aprovada em:

Banca Examinadora:

Prof. Dr.

Instituição:

Julgamento:

Prof. Dr.

Instituição:

Julgamento:

Prof. Dr.

Instituição:

Julgamento:

Prof. Dr.

Instituição:

Julgamento:

Prof. Dr.

Instituição:

Julgamento: 
A meu filho Joaquim e meu companheiro Rafael, que tanto me dão forças para existir, resistir e seguir trilhando a sinuosa poética da escola e do ensino. 


\section{AGRADECIMENTOS}

Ao professor Claudemir Belintane, meu orientador, que não só me orienta há dez anos na pesquisa, como, desde então, segue me apoiando e enfrentando de braços dados os desafíos políticos, pedagógicos, culturais e sociais que se transformam no campo educacional e nos fazem mover de cabeça erguida e confiantes de que estamos lutando do lado certo da história. Agredeço muito sua dedicação e paciência ao me ensinar valorosos conceitos, demonstrar amplas práticas e pensar conjuntamente diversas estratégias para atuar no chão da escola enquanto professores e pesquisadores, sempre tendo em vista a democratização do acesso à escolarização, o direito à literatura, à arte e à fruição estética da vida.

Aos professores Paulo Henrique Fernandes Silveira e Lívia de Araújo Doninni Rodrigues pelas sugestões, provocações e orientações enriquecedoras que me foram apresentadas no momento de qualificação da tese.

Às pesquisadoras do grupo GOLE pelo trabalho e responsabilização coletiva do ato de ensinar e lutar por uma educação básica de qualidade para todos. Agradeço a parceria que construímos há uma década e as contribuições para concluir este trabalho. Tenho muito orgulho de fazer parte deste grupo e admiro cada uma de vocês: Natália Bortolaci, Kátia Arilha, Mariana Giorgion, Laura Battaglia e Paulo Chagas. Vocês são incríveis!

À querida equipe da escola Alef Peretz, especialmente ao coordenador-geral, Rogério Giorgion, quem me abriu as portas e sempre agitou projetos inovadores, proporcionando maravilhosas experiências em sala de aula. À coordenação pedagógica, pelas discussões acaloradas e instigantes sobre nossos passos e suas reverberações no termômetro da escola, em especial à Joana Goes, Aline Leite, Daniel Rehfeld, Mônica Camargo e Nancy Nery. Nesses últimos quatro anos, amadureci enquanto professora e pude aprender sobre respeito e compartilhamento das práticas educativas! Um imenso obrigada! Aos valiosos professores e funcionários, queridos amigos, que trabalharam entusiasmadamente ombro a ombro nesses anos de pesquisa: Marina Simas, Victor Vigneron, Gabriela Kaufmann, Marco Antonio, Julia Milaré, Amanda Calazans, Renata Bazan, Mayara Pinho, Marília Esther, Natália Albuquerque, Pedro Henrique, Julia e Nina Jacomini, Bruna Villani, Marinalva Amorim, Fábio Dias e Gabriel Santos. Agradeço muito as várias risadas, aprendizados e principalmente a força que me transmitiram. 
Ebenso geht mein Dank an das Team der Kita Pelikan, mit dem ich in den letzten Monaten des Doktorats zusammengearbeitet und viel gelernt habe. Ich bedanke mich besonders bei Nadine Krejsa, Arife Misimi und Charoula Tsimenidou für ihre Freundschaft und auch für ihre Geduld, die sie mit mir hatten, da sie mir so oft zugehört haben, als ich über den schwierigen Weg des Schreibens der Dissertation gesprochen habe.

Com muito amor e carinho, agradeço minha família por toda ajuda, pelos cuidados com o Joaquim, pela atenção e apoio a minha trajetória de mãe, professora, pesquisadora e militante. Sem vocês não saberia por onde começar... agradeço meus pais Flávia e Evandro, minha irmã Iandara, meu marido Rafael, meu filho Joaquim, meu sogros Teco e Sandra, meus cunhados Fernando e Paulo, minha concunhada Cris, meus sobrinhos Mel e Tom e minha tia Angela por cada conversa acolhedora e cada gesto de carinho. E, apesar de pequenino, já me sinto imensamente grata ao bebê que me habita, me faz crescer e amadurecer desde fevereiro desse ano. Logo você virá ao mundo para descobrir como pode ser graciosa e deslumbrante a poética da vida.

Agradeço também meus amigos-irmãos, Vinícius Zaparoli e Luisa D'Avola, pela linda amizade que construímos e pelos momentos de sol, sombra e água fresca em que estivemos planejando nosso futuro na última década. Obrigada às amigas da Letras com quem ainda caminho de mãos dadas mesmo quando distantes: Raiana Araújo, Giselle Moura, Verônica Garcia e Elisa Zanetti.

E o agradecimento mais essencial desta tese se dirige aos meus corajosos alunos e alunas de Paraisópolis que me fizeram compreender a urgência e o verdadeiro significado da necessidade de resistir e insurgir. Nossas experiências dentro e fora da sala de aula me ensinaram sobre o valor e a grandeza da palavra poética enquanto potência para o processo de subjetivação e emancipação diante dos desafios da leitura e da escrita. Vocês, sem dúvida, sabem arrancar alegria ao futuro! 


\section{RESUMO}

JOAQUIM, Isadora Rebello - O papel da linguagem poética no letramento contínuo: uma perspectiva metodológica. Tese (Doutorado) - Faculdade de Educação, Universidade de São Paulo, São Paulo, 2020.

O presente trabalho propôs investigar e analisar a potência da linguagem poética no Ensino Médio de uma escola em Paraisópolis (SP). Nosso objetivo foi, por meio da poesia, propiciar espaços para o reposicionamento subjetivo dos alunos frente aos desafios da leitura e da escrita, de modo que os alunos não só desenvolvessem habilidades e competências relacionadas ao letramento, mas o fizessem também com vista a sua emancipação política e intelectual. Dando continuidade a hipóteses parcialmente constatadas no mestrado acerca da relação entre oralidade poética e alfabetização (Joaquim, 2016), apoiamo-nos na premissa de que o trabalho com a poesia, a partir de um entrelaçamento com a tradição oral, é capaz de potencializar subjetividades mais afeitas à aprendizagem da leitura e da escrita. Nessa direção, elaboramos uma metodologia de pesquisa e de ensino baseada na pesquisa-ação e nos conceitos de performance e corporalidade, a fim de repensar o ensino da Língua Portuguesa, retomando os valores estéticos de nossa cultura. Em 2018, acompanhamos duas turmas do Ensino Médio e, de tudo que foi proposto e produzido no curso durante esse ano, focamos nossa análise nos exercícios de leitura, interpretação, performance e produção de textos poéticos, tanto em sala de aula, quanto em outros eventos da escola como o sarau literário e a Mostra de Artes e Ciências. Ao longo da pesquisa, os alunos foram convidados a experimentar a palavra ritmada e seus recursos mnemônicos, tendo a possibilidade de dinamizar o "espaço vazio" de suas indagações sobre o mundo e, ao mesmo tempo, de lidar com diferentes modos de apreender a língua e a arte. A partir da leitura de poemas, cordéis, repentes e letras de rap e da análise de suas figuras semânticas, sintáticas e sonoras, pudemos adentrar nas questões raciais, de classe e de gênero, na realidade socioeconômica e nas histórias de vida compartilhadas pelos alunos. Com os exercícios de escrita e com a performance oral de produções poéticas autorais, exploramos a prédisposição dos alunos em se expressar artisticamente, traduzindo seu sofrimento, suas angústias e desilusões em rimas, versos, jogos de palavras e figuras de linguagem. Nesse processo de domínio e manejo da palavra poética, observamos os alunos se deslocando do lugar estigmatizado do não-saber, sentindo-se, assim, capazes de se representar discursivamente e de sustentar a visibilidade política de suas vozes na sociedade contemporânea. A partir de uma perspectiva psicanalítica da constituição do sujeito e dos dados coletados, compreendemos a importância do olhar docente para os processos complexos de alteridade e para as singularidades dos alunos. Além disso, procuramos buscar soluções para lidar com os problemas de estigmatização do processo escolar dos jovens que não se encontram mais na oralidade primária comum às crianças do Ensino Fundamental, mas são confrontados pela realidade de uma alfabetização considerada frágil. Logo, atendo-se às circunstâncias da experiência em sala de aula frente a uma determinada conjuntura sociopolítica, evidenciamos em nossa metodologia de pesquisa e de ensino, a capacidade da poesia em provocar uma dupla ação nos sujeitos que se encontram na etapa final de seu percurso escolar: a partir das dinâmicas da oralidade poética, de leituras inferenciais e do exercício de escrita criativa por meio do trabalho com a poesia, mostramos resultados do manejo da heterogeneidade das turmas que possibilitaram emergir potencialidades para a subjetivação política e para a emancipação intelectual dos alunos.

Palavras-chave: Oralidade. Letramento. Poesia. Educação estética. Emancipação. Subjetividade. 


\begin{abstract}
JOAQUIM, Isadora Rebello - The role of poetic language in continuous literacy: a methodological perspective. Thesis (Doctorate) - Faculty of Education, University of São Paulo, São Paulo, 2020.
\end{abstract}

This work aims to investigate and analyze the power of the poetic language in a secondary school in Paraisópolis (SP). Our goal was, through poetry, to provide spaces for the subjective repositioning of students in the face of the challenges of reading and writing so that students would not only develop skills and competencies related to literacy but would do it in view of their political and intellectual emancipation. Continuing the hypotheses partially verified in the Master's degree about the relationship between poetic orality and literacy (Joaquim, 2016), we rely on the premise that working with poetry, starting from its intertwining with oral tradition, is capable of potentializing subjectivities into to a much more devoted process of learning how to write and to read. In this direction, we developed a research and teaching methodology based on research-action and the concepts of performance and "corporality", in order to rethink the teaching of the Portuguese language while reclaiming the aesthetic values of our culture. In 2018, we followed two high school classes and, of all that was proposed and produced in the course during that year, we focused our analysis on the exercises of reading, interpretation, performance and production of poetic texts, both in class as well as in other school events such as the literary reading and the school's Arts and Science Fair. Throughout the research, students were invited to experience the rhythmic word and its mnemonic resources, having the possibility to stimulate the "empty space" of their enquiries about the world and, at the same time, to deal with different ways of learning language and art. From the reading of poems, Cordel literature, repente and rap lyrics and the analysis of its semantic, syntactic and sound patterns, we were able to get into issues about race, class and gender and into the socioeconomic reality and oral tradition of the life stories shared by the students. From the writing exercises and oral performances of authorial poetic productions, we explored the students' pre-dispositions to express themselves artistically, translating their suffering, anguish and disillusionment into rhymes, verses, word games and figures of speech. In this process of mastery and handling of the poetic word, we observed the students moving away from the stigmatized place of not-knowing, and starting to feel, thus, able to represent themselves discursively and to sustain the political visibility of their voices in contemporary society. From a psychoanalytic perspective of the constitution of the subject and the data collected, we understood the importance of the teacher's gaze to the complex processes of otherness and to the singularities of the students. Furthermore, we sought solutions to deal with the problems of stigmatization of the school process of young people who are no longer in the primary orality common to children in primary school, but are confronted by the reality a literacy that is considered fragile. Therefore, taking into account the circumstances of classroom experience in front of a certain socio-political conjuncture, we show in our research and teaching methodology the capacity of poetry to provoke a double action in the subjects who are in the final stage of their school career: from the dynamics of poetic orality, inferential readings and the exercise of creative writing through the work with poetry, we showed the results of managing heterogeneity in the school classes, which made possible the emergence of potential for political subjectivation and intellectual emancipation of the students.

Keywords: Orality. Literacy. Poetry. Aesthetic education. Emancipation. Subjectivity. 


\section{LISTA DE TABELAS}

TABELA 1. Dados socioeconômicos dos alunos da $1^{\text {a }}$ série do Ensino Médio - p. 207

TABELA 2. Dados socioeconômicos dos alunos da $2^{\mathrm{a}}$ série do Ensino Médio - p. 208

TABELA 3. Planejamento do curso de Língua Portuguesa para a $1^{\text {a }}$ série do E.M. - p. 228

TABELA 4. Diagnóstico dos níveis de leitura dos alunos - p. 232

TABELA 5. Diagnóstico dos níveis de escrita dos alunos - p. 232

TABELA 6. Diagnóstico dos elementos de textualização das produções de texto dos alunos de $1^{a}$ série do Ensino Médio - p. 238 


\section{LISTA DE FIGURAS}

FIGURA 1. Esquema paradigmático e sintagmático - p. 32

FIGURA 2. Inversão do algoritmo de Saussure - p. 84

FIGURA 3. Ilustração das massas amorfas - p. 86

FIGURA 4. Eixos metafórico e metonímico - p. 87

FIGURA 5. Estrutura da metáfora - p. 90

FIGURA 6. Desenho de Escher, Moëbius Strip II - p. 97

FIGURA 7. Rasura na leitura do sujeito - p. 99

FIGURA 8. Espaço de convivência dos alunos na Escola Alef Peretz - Paraisópolis - p. 135

FIGURA 9. Grafo do desejo - p. 150

FIGURA 10. Plataforma Moodle - p. 219

FIGURA 11. Ilustração para o panfleto do sarau "O que te move?" - p. 300

FIGURA 12. Foto da exposição de poemas na Mostra de Artes e Ciências - p. 302

FIGURA 13. E-mail da aluna Raquel - p. 303

FIGURA 14. Livro de poemas da aluna Raquel - p. 322 


\section{SUMÁRIO}

Introdução: linguagem poética, educação estética e os desafios contemporâneos no contexto escolar.

Capítulo 1 - A questão do letramento: contrapontos entre o oral e o escrito . p. 36

1.1 Reflexões sobre oralidade p. 42

1.2 A cultura da escrita p. 64

Capítulo 2 - A questão do letramento: sob o crivo da subjetividade p. 95

2.1 Letramento e função poética p. 96

2.2. Leitura e efeito estético p. 122

Capítulo 3 - A tomada entusiasmada da palavra poética p. 162

3.1 Elementos de uma possível cultura não-repressiva p. 170

3.2 A política da literatura p. 188

Capítulo 4 - A palavra poética em sala de aula: uma experiência metodológica a partir da dimensão oral, estética e emancipatória da poesia p. 200

4.1 Os principais desdobramentos com o texto poético p. 244

4.2 A organização do sarau literário p. 283

4.3 Veia artística, essência poética p. 304

4.4 Reflexões acerca da metodologia proposta p. 323

Considerações Finais p. 331

Referências Bibliográficas

Anexos 


\section{Introdução: Linguagem poética, educação estética e os desafios contemporâneos no contexto escolar}

“A cultura é de todos: devemos começar por aí.” (Raymond Williams, 1958)

Toda sociedade apresenta diferentes modos de expressar sua cultura, fato primordial de nossa organização. As instituições, a arte e o conhecimento de cada sociedade, segundo Williams (1958), são marcos da cultura e da civilização em desenvolvimento, cujo processo se constrói e se reconstrói em cada modo de pensar individual. A cultura constitui o fundamento da vida em sociedade e, inversamente, vida social implica necessariamente cultura (Zumthor, 2016). Independente de seu aspecto multifacetado, de como cada cultura se afirma frente às diferentes formas de vida, há dois aspectos da formação desse modo individual de pensar presentes na cultura sobre os quais nos interessa refletir: um direciona e orienta os indivíduos a cumprirem seus deveres na sociedade e o outro os faz observar, refletir e dar novos significados àquilo que é apresentado e experimentado por nós. "Usamos a palavra cultura nesses dois sentidos: para designar todo um modo de vida - os significados comuns; e para designar as artes e o aprendizado - os processos especiais de descoberta e o esforço criativo" (Williams, 1958: p. 4). A esse segundo aspecto da cultura atribuiremos a característica de que, no íntimo pessoal de cada ser, há a necessidade de fruição, do gosto, da necessidade ao lúdico e ao belo que a arte proporciona (Candido, 2004). Tal sensibilidade e percepção estética da cultura podem ser estimuladas nos indivíduos por meio das representações artísticas, como a literatura, a música, a pintura etc., e sua capacidade de nos conduzir à forma e ao pensamento sensíveis pela beleza de suas obras.

No entanto, desde os estudos da Escola de Frankfurt, podemos reconhecer de maneira mais profunda a estreita relação entre cultura e industrialização (Adorno; Horkheimer, 1985). Com o advento do capitalismo sabemos que, apesar da massificação do consumo de cultura, este se dá apenas no âmbito do que é produzido em massa pela indústria cultural, fazendo com que o acesso à educação voltado para uma formação estética, minimamente crítica e reflexiva, ainda seja restrito à formação das elites. Sabemos, portanto, que a cultura que dirige e orienta os indivíduos a contribuírem com a sociedade a partir de suas obrigações caminha como demanda de todos, já a cultura que desvenda o simbólico, que permite descobertas para além de seu papel literal, que busca a criação e fruição estética não é, infelizmente, de acesso a todos. 
As experiências com a arte e a fruição estética limitam-se a condições de classe, de privilégios e, por vezes, de favorecimentos raros da camada dominante à população pobre. Podemos dizer, contudo, que a iminência da democratização do acesso à cultura estética se encontra na educação escolar e em seu ensejo de impulsionar a emancipação intelectual e política de crianças e jovens em processo de letramento e de busca por conhecimento. A cultura e a educação estética, como sistemas das relações sensíveis e figurativas na sociedade, serão, portanto, desígnios para defesa e resistência desta tese ao apresentar os objetivos de nossa pesquisa, que têm como foco a poesia no processo de letramento contínuo de jovens da periferia.

É por isso que, em tempos de alienação do saber, padronização técnica e controle excessivo das formas de transmissão de conhecimento, em que o consumismo e a indústria transfiguram a cultura e a educação, procuramos evidenciar a presença da poesia na escola como capaz de corresponder a uma estratégia pedagógica de letramento que não se dissocia de uma intenção de formação voltada para a emancipação social. Acreditamos que a poesia, em sua convergência de unidades expressivas, de som e sentido, de paixões e razão, de polissemias, de beleza e de condensação de um estado de espírito, pode ser um vantajoso acesso à vivência estética durante o processo escolar de ensino e aprendizagem de um letramento contínuo voltado à arte. Assim, valemo-nos da premissa de que cultivar sentimentos estéticos por meio da palavra poética pode ser um caminho perspicaz para reposicionar subjetivamente crianças e jovens diante dos desafios da leitura e da escrita e diante da alienação na sociedade contemporânea em que os indivíduos estão subjugados ao trabalho e às tarefas domésticas.

Na contramão desta premissa, sobre a sociedade contemporânea e a educação básica no Brasil, observamos medidas regressivas sendo tomadas de forma acelerada pelo Ministério da Educação desde 2016, ano em que uma manobra parlamentar desconstruiu garantias democráticas conquistadas a partir do fim da ditadura militar. Neste cenário em que as forças reacionárias prevalecem, o campo da educação é um dos mais atacados pelos retrocessos políticos nos últimos tempos. As mudanças propostas para a nova Base Nacional Comum Curricular (BNCC), a supressão de termos como "identidade de gênero" e "orientação sexual" nos documentos oficiais, a aprovação da reforma do Ensino Médio, o projeto de lei "Escola sem partido" já aprovado em algumas cidades e outros projetos similares que tramitam por todo o Brasil originam-se da concepção conservadora de educação do atual governo. O papel emancipador do espaço escolar vem sendo aniquilado pela participação crescente do setor 
empresarial, o qual atribui à escola um papel mercantilista e utilitarista, não apenas devido à extinção de disciplinas como História, Geografia, Filosofia e Sociologia que, segundo a reforma, pouco preparam para o mercado, mas também devido ao pragmatismo do ensino técnico, à influência do empreendedorismo, da competitividade, do individualismo em detrimento do pensamento crítico coletivo, autônomo e democrático.

Elizabeth Macedo (2015), estudiosa das negociações políticas em curso na elaboração da nova Base Nacional Comum Curricular (BNCC), afirma que a influência do movimento "Escola sem partido" tem aumentado e impactado decisões importantes em novos projetos de Lei das Diretrizes de Base da Educação Nacional (LDB). As demandas conservadoras destes novos programas podem ser resumidas em argumentos de que é preciso: i) retomar o espaço privado da família, a quem caberia toda a formação moral e ética das crianças, destinando o espaço público da escola apenas ao aprendizado de conteúdos; ii) desvincular o currículo das propostas de trabalho com a diversidade cultural; e iii) retirar a ideologia de gênero do currículo. Segundo Macedo, a normatividade neoliberal proposta na nova BNCC tem como principal jogo político o controle, excluindo a diferença e tornando-a explícita. A tentativa de homogeneização do currículo, da metodologia e didática dos professores e dos sujeitos escolares e seus modos de aprender ataca o direito às diferenças e às representações dos grupos sociais oprimidos que lutam por visibilidade na esfera pública.

Além das consequências negativas no campo político-educacional, o estreitamento curricular previsto pela nova BNCC, cujo objetivo é privilegiar o ensino de apenas algumas disciplinas a partir das séries do Ensino Médio, pauta-se por uma quantidade exagerada de avaliações externas, no intuito de reduzir a formação docente e sua prática escolar a meios padronizados e desvinculados da concepção sócio-histórica e emancipadora presente no processo de ensino-aprendizagem. O Programa de Residência Pedagógica (PRP) apresentado às Instituições de Ensino Superior (IES) no ano de 2018 anuncia abordagens e ações obrigatórias para os cursos de Licenciatura e de formação de professores que devem seguir as habilidades e competências previstas na nova BNCC. Assim, as ementas dos cursos de Licenciatura das IES devem tratar de temas pertinentes aos eixos norteadores dos conteúdos propostos pela BNCC, uma vez que, segundo o MEC/ Capes (edital número 6, 7/2018), os cursos são muito teóricos e é preciso reorientá-los para a aplicação prática da nova base curricular. Essa orientação não apenas fere a autonomia universitária, como reduz a prática intelectual docente a regras de como fazer e o que ensinar. 
Para concentrar a crítica às mudanças propostas para nossa área de pesquisa (o ensino de Língua Portuguesa), apontamos um grave problema da nova BNCC: não há uma orientação clara que propõe um trabalho diversificado e abrangente com textos literários e seus diferentes gêneros, enquanto o trabalho com os vários usos da tecnologia e suas ferramentas é explorado em quase cada item da BNCC, como um grande meio formador para o ensino e aprendizagem da Língua Portuguesa. Ou seja, a diversidade do gênero textual está agora focada nas novas tecnologias e não nos textos literários e nas manifestações artísticas, tendo em vista a valorização de recursos digitais multissemióticos em vários itens na área de Língua Portuguesa e a quantidade de vezes que palavras como blog, vlog, podcast ou até mesmo memes e gifs aparecem nesta parte do documento. Sabemos que há muita literatura online de qualidade e com aspectos inovadores, tanto em conteúdo quanto na forma, porém, a reforma implementada e aquela que neste ano de 2019 está em curso com a posse dos novos secretários no Ministério da Educação, não apontam para um projeto que visa pesquisar, explorar e conhecer os gêneros literários e as obras divulgadas na Internet. Inclusive as poucas habilidades a serem desenvolvidas no campo artístico-literário apresentadas na nova BNCC têm o uso das novas tecnologias como forma de apreciar e fruir os textos, ou mesmo são tomadas como orientação para produzir textos autorais a partir das experiências estéticas, como vemos no item EF69LP46 da versão final da BNCC (p. 155):

\footnotetext{
Participar de práticas de compartilhamento de leitura/recepção de obras literárias/ manifestações artísticas, como rodas de leitura, clubes de leitura, eventos de contação de histórias, de leituras dramáticas, de apresentações teatrais, musicais e de filmes, cineclubes, festivais de vídeo, saraus, slams, canais de booktubers, redes sociais temáticas (de leitores, de cinéfilos, de música etc.), dentre outros, tecendo, quando possível, comentários de ordem estética e afetiva e justificando suas apreciações, escrevendo comentários e resenhas para jornais, blogs e redes sociais e utilizando formas de expressão das culturas juvenis, tais como, vlogs e podcasts culturais (literatura, cinema, teatro, música), playlists comentadas, fanfics, fanzines, e-zines, fanvídeos, fanclipes, posts em fanpages, trailer honesto, vídeo-minuto, dentre outras possibilidades de práticas de apreciação e de manifestação da cultura de fãs. (BRASIL, Ministério da Educação, BNCC, 2017, p. 155).
}

Ao orientar enfaticamente o uso das novas tecnologias e não pautar com rigor o ensino de Língua Portuguesa a partir da diversidade dos gêneros literários e de suas manifestações artísticas, podemos afirmar que a BNCC prioriza o aprendizado e domínio de recursos midiáticos e tecnológicos, uma vez que há mais habilidades a serem desenvolvidas a partir dos gêneros que lidam com a funcionalidade tecnológica do que com textos literários. $\mathrm{O}$ documento apresenta uma quantidade tão grande de habilidades a partir do uso das novas 
tecnologias que se o tomarmos como critério para o planejamento didático-metodológico do curso de Língua Portuguesa, o aspecto funcional das novas mídias irá se sobrepor ao estudo do texto e da literatura. Além disso, essa orientação da BNCC afasta o caráter reflexivo, problematizador e transformador da educação e impõe à sala de aula uma mera reprodução dos meios midiáticos, com produção de memes e gifs, sem a reflexão necessária sobre quais impactos tais recursos geram na sociedade.

Tais sintomas são possíveis de entrever de maneira mais impactante nos anos finais da escolarização. No entanto, na ponta inicial da educação formal, vemos outro fenômeno de tecnificação do saber que ocorre no processo de alfabetização aplicado aos pequenos alunos que ingressam na escola. O ensino e aprendizagem da leitura e escrita nas escolas públicas têm como concepção pedagógica dominante o trabalho com gêneros discursivos do cotidiano, ou seja, os materiais didáticos e o fomento à formação de docentes alfabetizadores, a partir das diretrizes governamentais, valorizam textos de uso diário, instrumental e pragmático em detrimento da arte e da literatura. Bulas de remédio, receitas de bolo, logomarcas e outros gêneros do mercado ocupam as salas de aula de alfabetização com o pressuposto de que aquilo que a criança vive em sua realidade (em seu universo de letramento) deve ser ponto de partida para sua aproximação com a linguagem e com o domínio do código.

No mestrado, pudemos atestar que são as contações de histórias da tradição oral com seu universo mítico e folclórico que despertam nas crianças o desejo e o entusiasmo pela leitura e escrita. Por meio de nossas experiências ao longo de um projeto de alfabetização executado em algumas Escolas de Aplicação do Brasil, aprendemos sobre a importância de introduzir nas salas de aula atividades ricas em aventuras, fantasias, reflexões sobre sua existência e sobre a origem dos seres e das coisas, que valorizam a oralidade poética e apresentam um mundo desconhecido à criança.

A concepção funcional da língua imersa em um universo "real", que se diz mais propenso a alcançar as crianças e os jovens no momento de leitura e escrita, não só inibe a entrada desejante na linguagem, como impulsiona as crianças ao consumismo. Contrapondose a essa ideia, dedicamo-nos ao longo do mestrado à pesquisa sobre o alcance dos textos da oralidade poética no percurso de aprendizagem da leitura e escrita de crianças de seis a nove anos. O contexto da pesquisa recobriu os anos de consolidação da alfabetização (primeiro a terceiro ano do Ensino Fundamental I), a fim de refletir acerca das experiências das crianças com a linguagem poética e com os ludismos linguageiros que ela estimula. Desde então, partimos de uma perspectiva de apropriação da linguagem que leva em conta a 
importância das narrativas orais e escritas (mitos, lendas, contos acumulativos, poemas, cantigas, parlendas) vinculadas à função e ao ludismo poético da língua para esboçar, em uma pesquisa teórica e prática, a importância do trabalho com a oralidade poética nos efeitos do processo de alfabetização não tão bem consolidados nos anos finais da escolarização.

No mestrado, junto ao grupo de pesquisa e ao projeto "O desafio de ensinar a leitura e a escrita no contexto do Ensino Fundamental de nove anos" financiado pela CAPES/ INEP (Edital No 038) de 2010 a 2014, pudemos desenvolver uma teoria que abordou de modo original a conexão entre oralidade e escrita, envolvendo conceitos da Psicanálise, da História da Escrita, da Linguística e de alguns campos da Filosofia, como a Teoria Crítica e a Fenomenologia, para pensar uma nova metodologia de alfabetização que alcançou análises e resultados surpreendentes (Belintane, 2017; Nanci, 2013; Battaglia, 2013; Bortolaci, 2015; Joaquim, 2016; Dalcheco, 2016, Giorgion, 2018). A seguir, retomaremos os principais posicionamentos teóricos que embasaram a metodologia de alfabetização desenvolvida pelo projeto supracitado para justificarmos e esclarecermos o objetivo da nossa tese em questão.

\section{O ponto de partida}

Apoiamo-nos na premissa de que o trabalho com a oralidade poética é capaz de potencializar subjetividades mais afeitas à aprendizagem da leitura e da escrita. Um bom repertório de histórias permite aos alunos a capacidade de evocar de memória textos para incursão de intertextualidades, referenciações e comparações de experiências vividas a partir da literatura oral e escrita. Quando falamos de oralidade, não estamos nos referindo à fala pragmática/ cotidiana em sua fragmentação, em seus imperativos ("venha cá”, "durma agora”, “termine isso"), mas sim ao conjunto de textos orais em manutenção e preservação da tradição e cultura de determinados povos que é, até hoje, transmitido de geração em geração.

Deste modo, em nossa pesquisa de mestrado, o foco permaneceu no papel da oralidade poética como medium para o reposicionamento subjetivo da criança, promovendo a possibilidade de alfabetização a partir do entrelaçamento da tradição oral e da cultura escrita no âmbito da uma visão psicanalítica da constituição do sujeito. Partimos de uma ideia de subjetividade que leva em conta a integração da memória às memórias expandidas (escrita e outros meios contemporâneos) como processos complexos de alteridade. O sujeito é compreendido como excêntrico, ou seja, ele está fora de seu centro e em vez de ser concebido como propenso a construir o conhecimento em uma posição de manejo direta, ele é 
compreendido como intervalar, pois emerge nos espaços de entre-textos ${ }^{1}$ e de entre suportes e meios. Nesse sentido, o foco é posto na tensão entre sujeito e Outro (na dimensão escolar, a escola, o professor, a escrita e outros meios e recursos são compreendidos como polos dessa alteridade). Nesse eixo tensivo, o sujeito não é senhor do seu discurso; ao contrário, alterna sua posição entre saber e não saber, construir e desconstruir (Belintane, 2010, retomando Lacan). O campo da oralidade infantil (a diversidade de gêneros com que a maternância e a cultura da infância enredam a criança) é compreendido como um conjunto de recursos mnemônicos e linguageiros que potencializa a dinâmica da escrita e da leitura. Compreendemos que o corpo e o psiquismo da criança dependem dessas memórias textuais (acalanto, cantigas, parlendas, narrativas e outros), que tendem a estabelecer as relações sociais, sejam com pais, com outras crianças ou com professores, mediadas pela palavra poética.

Portanto, levamos em consideração que a função poética da língua assume um importante papel na alfabetização infantil, aguçando a criatividade discente por intermédio da arte, da literatura, possibilitando uma significativa combinação entre o sujeito e a riqueza da realidade oral com seus ritos, repetições, gestos e jogos de palavras. Outras hipóteses como essa foram levantadas no mestrado e serão melhor articuladas com base no estado da arte da estética e da poesia ao estabelecer o eixo teórico da tese.

Ainda assim, é importante ressaltar que, ao tratar da lida escolar com textos poéticos, estamos trabalhando com um conceito alargado de poesia, que não diz respeito apenas ao texto canônico em sua forma escrita, delimitado por unidades expressivas que se vinculam a noção de poema escrito. Como vimos acima, poesia aqui se define pela especificidade de uma função poética da linguagem que se apoia na unidade entre som e sentido, tanto no campo da oralidade como na escrita, em que os recursos mnemônicos do ritmo, das figuras sonoras, da metáfora e da metonímia estão em prevalência. Nos textos reconhecidamente poéticos, há uma singular unidade de estrutura em que forma e conteúdo são indissolúveis. Assim, este conceito de poesia se afasta do conceito escolar e se vincula diretamente a um sujeito que age com e em meio à linguagem a partir dos recursos linguísticos mencionados.

\footnotetext{
${ }^{1}$ Subjetividade de entre-textos diz respeito aos possíveis posicionamentos do sujeito diante da diversidade textual, como se o sujeito se movesse nos intervalos, em contínuos posicionamentos e reposicionamentos, cuja unidade possível seria uma síntese provisória de sua posição (um sentido sempre provisório, que remete a novas aberturas, novos reposicionamentos - no caso, querer ler ou não querer, memorizar um texto ou não são possibilidades de posicionamentos).
} 
Essa hipótese do potencial da oralidade poética foi parcialmente constatada no mestrado (Joaquim, 2016) a partir do trabalho com crianças em processo de alfabetização. Os resultados da dissertação motivaram a continuidade da pesquisa neste campo de atuação a partir das dúvidas que permaneceram em nós: como seria esse processo de letramento contínuo com adolescentes nos anos finais da escolarização, partindo de pressupostos teóricos e metodológicos semelhantes, alterando, no entanto, os sujeitos da pesquisa e seu contexto sócio-histórico? Seria possível reposicionar subjetivamente alunos adolescentes em relação à leitura e à escrita literária por meio da palavra poética, contribuindo para sua emancipação política e intelectual?

Diante dessas questões, o presente trabalho se apoia nos pressupostos teóricos expostos acima, mas se coloca novas questões: é possível pensar em um trabalho escolar com a poesia que possa - além de desenvolver a oralidade poética com foco no letramento inferencial, autoral e contínuo - possibilitar um papel ético-político? Ou seja, é possível potencializar os sujeitos por meio do contato com a estética e a poética e os auxiliar na busca de um posicionamento subjetivo em direção à emancipação social? Essas questões nos fazem perceber que o que está em jogo é a intersecção entre poesia (na sua dimensão da oralidade poética), a subjetividade intervalar e a emancipação social no contexto escolar, uma vez que os percalços no processo de alfabetização é uma realidade na vida de centenas de jovens brasileiros. Portanto, os resultados apresentados na dissertação de mestrado revelaram somente uma parcela da importância do trabalho com poesia em sala de aula, contextualizado no processo de alfabetização e pautado principalmente pelos campos da Linguística e da Teoria Literária. O que pretendemos com a tese em questão é expandir este trabalho com a poesia para uma compreensão teórica e metodológica que vá além da sua contribuição ao letramento em uma perspectiva meramente pedagógica, pois a ideia é investigar também o seu potencial político, emancipatório e libertário em um contexto social e cultural específico.

\section{O objetivo da tese e sua metodologia}

Enquanto a metodologia desenvolvida ao longo do projeto "O desafio de ensinar a leitura e a escrita no contexto do Ensino Fundamental de nove anos" focou nos anos iniciais do processo de escolarização, nosso objeto de estudo no momento procurou investigar o processo de letramento nos anos finais, já no Ensino Médio. Assim, nossa primeira hipótese durante essa pesquisa foi que a teoria que desenvolveu a metodologia de alfabetização focada 
nos primeiros anos do Ensino Fundamental era mais abrangente que a metodologia aplicada no mestrado e, com isso, nosso objetivo com o trabalho de campo do doutorado foi mostrar como essa teoria poderia ser aplicada em contextos avançados da experiência escolar. Essa hipótese foi investigada reaproveitando parte das teorias que embasaram a aplicação metodológica de todo o projeto financiado pela CAPES, com a diferença de que elas deveriam ser deslocadas, em parte como fizemos no mestrado, para um ponto fulcral - a poesia. Dessa forma, o aporte teórico fundamental e essencial para a nossa tese atual é a teoria da corporalidade $^{2}$, desenvolvida pelo professor Claudemir Belintane (2013, 2017), coordenador e orientador do projeto.

Com esta teoria - a ser melhor explicada e analisada nos primeiros capítulos desta tese - e com o estudo de campo colocado em prática ao longo da pesquisa do doutorado, pretendemos demostrar que, em uma perspectiva metodológica, ela:

- é de grande abrangência, superior a sua aplicação nos primeiros anos do Ensino Fundamental;

- pode se desdobrar em uma metodologia não apenas voltada para a alfabetização nos anos iniciais, como método de formação, mas também em etapas avançadas do processo de escolarização, em que serviria como reconfiguração do letramento já vivido pelos alunos até o momento, lidando com questões que são frequentemente consideradas como "problemas de aquisição da linguagem", "fracasso escolar" ou "lacunas do aprendizado";

- auxilia na investigação de soluções para a estigmatização presente no processo escolar dos jovens a partir de uma perspectiva não reificada do saber, que possa lançar mão do trabalho com a oralidade e com os textos poéticos;

- contribui para investigar os sujeitos da pesquisa que não se encontram mais na oralidade primária comum às crianças nos primeiros anos do Ensino Fundamental, mas são confrontados por essa realidade de um letramento

\footnotetext{
${ }^{2}$ Palavra-valise cunhada por Belintane (2013) para representar a imbricação dos dois termos e a ideia de que a oralidade passa pelo corpo. A relação dos jovens com a linguagem está cada vez mais tensionada por diversos recursos e meios de expressão dinâmicos. Nesse fenômeno intervalar de apropriação da linguagem e da dimensão da alteridade, os alunos necessitam se posicionar subjetivamente para concentrar as energias do corpo (antes imerso apenas no oral e agora posto diante dos desafios da leitura e da escrita) para lidar com os enigmas dos textos grafados. Em tal reposicionamento surge então uma corporalidade.
} 
estigmatizado (considerado "incompleto") ao longo de todo seu percurso escolar;

- e é a base para adaptar a metodologia de alfabetização investigada no mestrado para uma metodologia de letramento contínuo que pretende lidar com essa realidade que assombra centenas de jovens com dificuldades na leitura e escrita de textos, em sua diversidade de gêneros discursivos, e que os coloca à margem da formação superior e universitária.

Tendo em vista as hipóteses expostas acima, ao aplicar a metodologia de ensino da Língua Portuguesa com a intenção de promover o letramento contínuo de jovens no contexto periférico, a tese procurou investigar, por meio da metodologia da pesquisa-ação ${ }^{3}$, como a poesia, a partir da sua dimensão oral e estética, pode ser capaz de provocar uma dupla ação nos sujeitos em processo de escolarização: o letramento inferencial, de leituras significativas e escrita autoral (tendo como perspectiva uma metodologia de letramento que possibilite potencialidades de subjetivação política) e a emancipação intelectual dos alunos.

A investigação do papel da palavra poética no reposicionamento subjetivo dos alunos com base na metodologia de letramento contínuo foi feita na comunidade de Paraisópolis, em uma fundação privada da comunidade judaica paulistana, chamada Alef Peretz, que concede bolsas de estudo integrais para 96 alunos de $1^{\mathrm{a}}$ a $3^{\mathrm{a}}$ série do Ensino Médio. Enquanto professora-pesquisadora responsável pelo curso de Língua Portuguesa focado na abordagem da estética e da poética, pude convidar os alunos a refletir e experimentar a palavra ritmada e entrelaçada aos recursos mnemônicos e à linguagem figurada, extrapolando os modos de compreender a linguagem e a língua.

Assim, para a investigação da tese, analisamos i) o processo de seleção dos alunos para as vagas e concessão de bolsas da Escola Alef Peretz (avaliação de Língua Portuguesa e questionário socioeconômico); ii) entrevistas com os alunos de $1^{\mathrm{a}}$ e $2^{\mathrm{a}}$ séries do Ensino Médio que revelaram dados sobre leituras inferenciais e produções poéticas autorais; iii) a pesquisa feita pelos alunos sobre a produção e repercussão da poesia na comunidade de Paraisópolis (realizada ao longo de dois anos no projeto de orientação monográfica da Escola Alef Peretz); iv) exercícios de leitura e interpretação das poesias trabalhadas no curso de Língua Portuguesa; v) produções de textos versificados a partir de outros textos motivadores, como paródias e produções autorais; vi) avaliações diagnósticas bimestrais baseadas nos quatro

\footnotetext{
${ }^{3}$ A metodologia da pesquisa-ação será explicada no quarto capítulo da tese.
} 
instrumentos avaliativos da escola (provas, cadernos, projeto de síntese e avaliação não escrita) ${ }^{4}$; e, por fim, vii) as performances dos alunos no sarau literário e na Mostra de Artes e Ciências ao final do ano letivo.

Vale ressaltar que tal investigação só foi possível de ser feita uma vez que o trabalho realizado em sala de aula teve como pressuposto uma metodologia de ensino que vislumbrasse o reposicionamento subjetivo dos alunos em relação à leitura e escrita literária. Nosso objetivo de investigação se encontrou, portanto, neste eixo teórico e prático: como a poesia, em conjunto com as experiências que tivemos a partir da metodologia aplicada no universo da alfabetização infantil, considerando a oralidade poética como ponto de partida, pode ser capaz de reaproximar os jovens da leitura e da escrita de maneira autônoma e autoral, auxiliando-os no processo de emancipação intelectual e política.

Sabemos que os dados coletados na pesquisa de campo poderão servir para a investigação e análise do manejo didático-metodológico no ensino aprendizagem da Língua Portuguesa no Ensino Médio a partir da poesia e dos textos versificados selecionados no curso, além de seus desdobramentos no que diz respeito aos reposicionamentos subjetivos dos alunos diante dos desafios da leitura e da escrita. No entanto, sabemos também que não devemos lançar mão do corpus utilizado para inferir, a partir desta investigação, resultados positivos ou negativos sobre os possíveis processos de emancipação intelectual e política.

Com esta tese, expandimos a teoria da corporalidade para o desenvolvimento de uma metodologia de letramento contínuo com foco nos sujeitos escolares do Ensino Médio e expandimos também a função da poesia como potencializadora do letramento para a ideia de emancipação social, ainda sob a premissa de que com a experiência poética há a possibilidade de uma subjetividade mais afeita ao domínio de outros aspectos da linguagem e da escrita, como os recursos estéticos e mnemônicos implícitos no texto que podem auxiliar no aprendizado da leitura inferencial e na escrita criativa. Contudo, estamos conscientes de que em uma pesquisa de campo como a nossa, não devemos ter a ambição de reunir elementos para comprovar essa segunda função da poesia. Por isso, trataremos da hipótese de que a poesia é capaz de auxiliar o processo de emancipação investigando como ela contribui para um novo posicionamento subjetivo dos alunos em relação à linguagem, ao ser capaz de perceber que esta é uma ferramenta da qual devemos nos apropriar e com a qual podemos

\footnotetext{
${ }^{4}$ O projeto da Escola Alef Peretz e seus instrumentos de avaliação serão explicados e analisados no quarto capítulo da tese.
} 
enfrentar adversidades e injustiças sociais e nos posicionarmos na luta de classes. O desejo pelas possibilidades de trilhar caminhos em direção à emancipação intelectual e política por meio do trabalho com a poesia será modalizado pelo discurso teórico e filosófico ao longo da tese.

Tendo em vista a parte factível e metodológica deste trabalho e considerando o debate realizado até aqui, principalmente a partir do diagnóstico desta situação em que o ensino da língua se desprendeu da arte e da literatura e que o desmonte progressivo das ciências humanas está em pauta, fica patente a necessidade de se pensar em um projeto de metodologia de pesquisa e ensino da língua que aponte também para a dimensão da reflexão política e estética.

Verificamos ao longo da aplicação do curso de Língua Portuguesa que muitos jovens que chegam aos anos finais de sua escolarização ainda apresentam processos mal consolidados de alfabetização e domínio do código. Por meio de diagnósticos realizados no início do curso (Anexos 2 e 3), foi possível identificar entraves e percalços na inferência de leitura por parte dos alunos de primeira e segunda série do Ensino Médio. Dos 64 alunos avaliados, 48 não apresentaram habilidades e competências de leitura e escrita esperadas para a faixa etária ${ }^{5}$. Falta de compreensão de enunciados, incapacidade para extrair informações de um texto previamente trabalhado em aula, inabilidade para leituras retroativas ${ }^{6} \mathrm{e}$ intertextuais, não identificação de elementos implícitos e referências de dêiticos e pronomes, dificuldade em estabelecer coerência e coesão textual, escrita sem estabelecimento da ordem sintática da língua portuguesa, falta de conhecimento das regras ortográficas e até mesmo falta de motricidade fina para a grafia legível das palavras foram situações diagnosticadas nos exercícios de leitura, compreensão e produção de texto.

Em suma, para concluir este ponto introdutório, a partir do diagnóstico e do trabalho com a oralidade e a estética da poesia realizados nas salas de aula com alunos de 15 a 17 anos,

\footnotetext{
${ }^{5}$ Os dados do diagnóstico inicial coletados nas primeiras semanas do ano letivo serão expostos no quarto capítulo da tese, aprofundando a análise dos instrumentos e contextualizando histórica e socialmente os sujeitos da pesquisa.

${ }^{6} \mathrm{O}$ processo de leitura retroativa que esperamos dos alunos ao trabalhar com textos poéticos será mais bem explicado no capítulo teórico, mas vale adiantar que a poeticidade da língua, repleta de figuras de linguagem, paradoxos e ambiguidades, só pode ser compreendida se o leitor for capaz de fazer a retroação, isto é, quando o leitor termina de ler o último elemento do verso ou da frase, ele deve estar pronto para interpretar o sentido dos primeiros termos, atribuindo significado às imagens, ideias e figuras lidas do poema.
} 
emergiu a necessidade de dar continuidade à dissertação de mestrado apresentada na mesma área de Linguagem e Educação, transpondo os conceitos e métodos de análise do processo de alfabetização infantil para fornecer subsídios à investigação do letramento contínuo de jovens do Ensino Médio na periferia de São Paulo. Assim, o trabalho que foi proposto na Escola Alef Peretz, unidade Paraisópolis, com a oralidade poética - que é, antes de mais nada, trazer a palavra cantada de volta à escola e explorar a riqueza da unidade entre o som e o sentido dos versos e do ritmo fundante da linguagem - trouxe resultados interessantes no que diz respeito ao reposicionamento dos sujeitos na lida com o saber e o mundo. A cada aula e a cada proposta de leitura e de análise de textos versificados orais e escritos, vimos como a poesia foi capaz de dinamizar o "espaço vazio" das indagações sobre o mundo e de, ao mesmo tempo, ser um objeto lúdico, de fruição, de aprimoramento linguístico e de motivação para a emancipação intelectual.

A seguir, consideramos importante trazer para a introdução deste trabalho alguns aportes teóricos fundamentais, a serem sintetizados nos próximos tópicos, a fim de já elucidar o aproveitamento das premissas da pesquisa do mestrado. Estas premissas serão aprofundadas no primeiro capítulo da tese diante de um novo contexto escolar, cujo foco não enquadra mais os anos iniciais da alfabetização, mas a etapa final da vida escolar dos alunos do Ensino Médio.

\section{Principais posicionamentos teóricos:}

\section{a) A oralidade poética}

No sentido da oralidade poética, fundamentamos tal conceito com os estudos de Ong (1998) e diferenciamos oralidade poética da oralidade pragmática tendo em vista duas denominações distintas: a oralidade primária e a secundária. Em Oralidade e cultura escrita: a tecnologização da palavra, Ong caracteriza a oralidade primária como a cultura de certas civilizações que não tiveram contato com a palavra escrita e apenas conhecem a palavra enquanto som e articulação, pois não identificam nenhuma matéria visual ou gráfica que possa caracterizar a palavra pronunciada. Nos dias de hoje, poucas civilizações têm a oralidade primária como única em sua cultura, pois os processos de disseminação da escrita se encontram ilimitados. Assim, há na atualidade a predominância da oralidade secundária, em que a cultura é sustentada pelos meios textuais e eletrônicos, como os livros, o rádio, a 
televisão e a internet, que dependem da escrita e da divulgação midiática para existir.

Se levarmos a sério a tipologia de Ong, teremos de assumir que já não é possível restituir em nossa sociedade a oralidade primária como única forma de disseminação da cultura, pois sua existência como forma de expressão autônoma à escrita foi extinta. Como frequentemente ocorre nos processos ditos "civilizatórios", o preço a se pagar pelo "progresso" é sangue, marginalização e esquecimento. No entanto, se quisermos nos contrapor a essa noção, devemos compreender que o conceito de oralidade primária, como objeto de estudo, pode nos fornecer categorias conceituais e chaves de interpretação de processos estético-linguísticos, e que, portanto, deve ser revisitado e apropriado no bojo de uma releitura da tradição inscrita na teoria do letramento.

Há séculos nossa cultura e civilização estão dominadas pela palavra escrita e suas tecnologias. À escola foi, portanto, atribuído um importante papel de instituir tal tecnologia a partir dos processos de alfabetização e letramento das crianças. A problemática desse processo situou-se no momento em que a escola desprivilegiou a oralidade primária como objeto de estudo, deixando em segundo plano os estudos e análise da tradição estética e do discurso poético, literário e artístico que se encontram no patrimônio de nossa cultura oral. Compreender o valor da cultura oral é também compreender a história da escrita e do processo de alfabetização, que é justamente a transição, forçada, se assim podemos dizer, de um domínio da linguagem oral para o da linguagem escrita.

A transição da oralidade poética para a escrita é um processo que deve ser cuidado ao longo da escolarização. Sabemos que a escrita não é natural ao ser humano, é uma prática social, um aprendizado. A escrita é historicamente produzida e socialmente adquirida, sendo assim, passível de transformação e interferência, muitas vezes de ordem subjetiva e particular. A criança pré-escolar, ao se deparar com traçados de letras em um papel, pode imaginar que aqueles rabiscos sejam desenhos confeccionados como uma garatuja qualquer. Ao entrar na escola, ela aprende que aqueles rabiscos devem ser decifrados e compreendidos como compreendemos as palavras articuladas no ato da fala. O corpo da criança, até então acostumado ao convívio com as palavras apenas no âmbito oral (acompanhadas do ritmo, dos movimentos e marcações corporais), passa a sofrer mudanças para a entrada da letra escrita:

Ong (1998) reforça os estudos de Havelock mostrando como a cultura oralista é visceralmente corporal, agônica, presencial, integrativa, copiosa e dependente de uma estética mnemônica (alegorias, metáforas, antíteses, aliterações, paralelismos, etc.). A passagem dessa cultura festiva para a assepsia e a solidão da cultura escrita 
Tais mudanças causadas pela força da escrita não abalam apenas crianças ao longo do processo de alfabetização, mas também jovens e adultos que se confrontam com os desafios do código e de sua decifração. Por isso, mesmo nos anos finais de escolarização, é importante considerar a cultura oral e estética como base e suporte para o aprofundamento do trabalho de leitura, interpretação e escrita, uma vez que a riqueza dos efeitos rítmicos e sonoros da oralidade poética, bem como sua intertextualidade, podem ser vistos como portas abertas à leitura fluente, à escrita criativa, bem como a possíveis encontros e releituras que envolvem os processos de constituição subjetiva e emancipatória dos alunos.

No primeiro ano de aplicação do curso de Língua Portuguesa no Ensino Médio de Paraisópolis, levantamos uma hipótese de que nos processos dominantes da oralidade secundária, há uma brusca ruptura dos jovens com a oralidade poética sem antes ter garantido o domínio do código e a entrada significativa no universo da palavra escrita. Este fenômeno aponta para um problema no ensino e aprendizagem da leitura e escrita, em que o afastamento dos campos da estética e da poética diminui as possibilidades de um letramento de fato social, politicamente emancipatório e sensível às artes. Ou seja, em muitos casos presentes em nossas salas de aula, podemos dizer que os alunos não se encontram mais na oralidade poética, não retomam textos de memória e não realizam intertextualidades a partir de uma matriz de narrativas orais, tampouco se encontram na escrita formular, no domínio do código e nas possibilidades de expressão verbal gráfica de maneira legível, clara, coerente ou coesa. O que pudemos diagnosticar também é uma ruptura na consolidação da alfabetização de alguns alunos, cujos processos escolares ainda dependem de um cuidado efetivo no letramento contínuo, conceito que iremos brevemente delinear no próximo item.

\section{b) O letramento contínuo}

Quando situamos os alunos do Ensino Médio em um estágio de letramento contínuo, valemo-nos do conceito de letramento desenvolvido pela professora doutora Leda Verdiani Tfouni (2006) que procura diferenciar o que é decodificação e habilidades adquiridas para leitura e escrita, dos processos sócio-históricos da aquisição de tais competências das práticas da linguagem. Alfabetizar por meio do processo de escolarização da instrução formal das habilidades e competências de práticas da linguagem não garante o letramento de caráter 
social e político, em que o sujeito pode se tornar capaz de se posicionar como autor de seu próprio discurso.

O conceito de autoria também é investigado por Tfouni e deverá ser melhor exposto no segundo capítulo da tese. Adiantamos apenas que, ao pensar na urgência da tarefa política que assumimos enquanto professores da Educação Básica, em deslocar o aluno do lugar de um mero decofidicador para exercer a função "autor", pensamos em um deslocamento em que a leitura e a escrita dos alunos possam extrapolar os sentidos de interpretação e compreensão do texto e dos significados das palavras. Segundo Tfouni, a autoria na leitura, na escrita ou até mesmo na oralidade, dá-se com a possibilidade de abrir o texto para os efeitos de sentido inferidos pela deriva, tanto em sua dispersão como em sua contenção: “O gesto de autoria está em, ao mesmo tempo conter a deriva dos sentidos e subverter o significado já naturalizado do significante (...), remetendo-o a outra dimensão do sentido, ou seja, o de uma abertura para outros sentidos possíveis de se ligarem a esse significante" (2008, p. 145).

Sabemos que o leitor jovem e contemporâneo está posicionado em uma subjetividade de entre-meios, em que muitas tecnologias disputam o ato da leitura, ou seja, a subjetividade do aluno está posicionada entre as mídias e redes sociais, nas quais prevalecem a leitura fragmentária, rápida, complementada por imagens e dominada pelo consumo. Nas bordas dessas mídias e redes, a dispersão e a deriva fazem seus efeitos e, em geral, somente são amarradas (ponto de estofo) ${ }^{7}$ por certa tendência ao consumo, ao jogo, ao gozo fácil e desmobilizador.

Tem sido cada vez mais difícil para as instituições escolares diagnosticar as competências leitoras dos alunos diante da velocidade de recepção e disseminação de informações por meio das redes sociais, que muito ocupam o tempo de leitura dos jovens. As habilidades de escrita, por sua vez, são ainda mais complexas de serem trabalhadas em um contexto de atomização do ensino de literatura, das ciências humanas e das artes. Em nossa opinião, para que a deriva proposta por Tfouni ocorra enquanto função autoral no contexto escolar, os alunos devem ter a possibilidade de fruição estética no contato com textos poéticos, além de leituras impulsionadas por outros campos artísticos e filosóficos inseridos

\footnotetext{
${ }^{7}$ Ponto de estofo (ponto com que o tapeceiro une as diferentes partes de um estofado) é uma metáfora criada por Lacan (1998) para explicar a apreensão dos sentidos em determinada cadeia de significantes, ou seja, a ideia de uma unidade de sentido que retroage a partir dos deslizes e expressões não intencionais que contribuem para a criação dessa cadeia.
} 
nas disciplinas do Ensino Fundamental e Médio (ainda em resistência aos novos projetos de lei que têm a intenção de retirar a obrigatoriedade das Ciências Humanas nos currículos do Ensino Médio).

Assim, para nós, é essencial pensar na contribuição da teoria sobre a corporalidade e alfabetização, uma vez que temos como intuito aprofundar a concepção metodológica pensada para os anos iniciais da escolarização em uma perspectiva de letramento contínuo, com base na função poética, na educação estética e nos elementos da psicanálise para compreender os sujeito excêntrico e entre-meios, procurando ter cuidado para não infantilizar os adolescentes sujeitos da pesquisa e, principalmente, considerar suas potências em vez de enxergar apenas lacunas e apontar sistematicamente para as falhas no processo de aquisição das habilidades e competências de leitura e escrita.

\section{c) A função poética}

Pensando na ideia de investigar como a palavra poética pode ser um mecanismo de reposicionamento subjetivo diante da leitura e da escrita, é importante dizer que, ao fruir um texto poético, nesse movimento de autoria e deriva, o aluno é estimulado a ser capaz de esvaziar os sentidos estanques das palavras, jogando-os momentaneamente fora, para dar espaço a novos sentidos. Como exemplo, os versos do poema "Cartão Postal" de Murilo Mendes (2001) trazem palavras em efeitos de contextura que manifestam diferentes sentidos comparados ao que estamos acostumados a interpretar: "Domingo no jardim público pensativo./ Consciências corando ao sol nos bancos,/ bebês arquivados em carrinhos alemães/ esperam pacientemente o dia em que poderão ler o Guarani.” (grifo nosso). A escolha dos adjetivos e verbos para descrever a cena nos remete a uma imagem fora do comum. Dizer "jardim público pensativo" em vez de "florido" ou "ensolarado", e "bebês arquivados" em vez de "deitados" ou "encolhidos", por exemplo, é resultado do trabalho de escolha do poeta em permitir que seus versos ganhem outras dimensões que vão além das expressões semânticas usuais. Já no verso "esperam pacientemente o dia em que poderão ler o Guarani”, nota-se que o absurdo não está mais na escolha verbal, e sim na contextura das palavras, uma vez que bebês não têm a consciência de que um dia poderão ler o Guarani.

Nesse caminho dialético, a poesia apresenta, portanto, certa potencialidade de criar relações entre o texto - por meio de seus recursos estéticos que despertam sensibilizações na compreensão da unidade de forma e conteúdo, de som e sentido, além de livres associações -, 
e o leitor/ouvinte, quando ele é capaz de esvaziar o sentido das palavras cotidianas para preenchê-las com o sentido poético dos versos no poema, buscando a identificação da linguagem figurada, das projeções da metáfora, da metonímia, da antítese, entre outros recursos estéticos e mnemônicos.

A capacidade de a poesia distorcer os sentidos das palavras e imagens apresenta, assim, uma importância estrutural no movimento de aquisição das práticas de linguagem apoiadas em demandas sociais e políticas, em que a sensibilidade às possibilidades poéticas constitui traços de autoria e de reposicionamento subjetivo diante da necessidade de intertextualidade dos discursos que se impõem na sociedade. Deste modo, o nonsense poético permite subverter os sentidos das coisas e deixar restos preciosos para atribuir significados e inferir elementos que nem sempre estão explícitos. Belintane (2013: p. 35) diz que esvaziar o sentido consensual das palavras poéticas é uma operação fundamental da linguagem e da leitura e "é por este viés do 'esvaziamento', da permuta de formas e sentidos, que enxergamos as cantigas e os jogos linguageiros da infância como matrizes textuais da leitura e da própria literatura".

Para compreender o uso das técnicas poéticas e das figuras de linguagem no trabalho escolar com a língua portuguesa, valemo-nos da pesquisa realizada no mestrado, que discutiu a capacidade da poesia em condensar em si um vasto efeito de polissemia, tornando possível apreender seus efeitos estéticos de forma consciente ou inconsciente. Na pesquisa anterior, foram apresentadas as três formas de manifestação da poesia sintetizada na tríade melopeia, fanopeia e logopeia, de Ezra Pound (2006) para conceber a ideia da linguagem poética "ser carregada de plurissignificados até o máximo grau possível” (p. 36). Esses conceitos são extremamente proveitosos para o planejamento de um material didático diversificado (principalmente na elaboração da coletânea de textos em versos orais e escritos) que ainda pode ser utilizado na metodologia de ensino dos anos finais da escolarização na Escola Alef Peretz em Paraisópolis, campo de nossa atual pesquisa.

$\mathrm{Na}$ tentativa de assimilar a estrutura da linguagem poética, recorremos à linguística de Jakobson (2010) e dos estruturalistas russos que pensaram no caráter palpável dos signos e discorreram sobre a forma como a poesia opera na projeção do eixo paradigmático (de seleção, com a metáfora) sobre o eixo sintagmático (de combinação, com a metonímia). Assim, segundo Jakobson, o eixo de seleção opera como princípio organizador da poesia, uma vez que na escolha de palavras que irão compor o verso, o poeta parte do princípio de equivalências (semânticas e sonoras) e o sobrepõe à sequência ordinária das palavras (do eixo 
de combinação), como vemos no esquema a seguir:
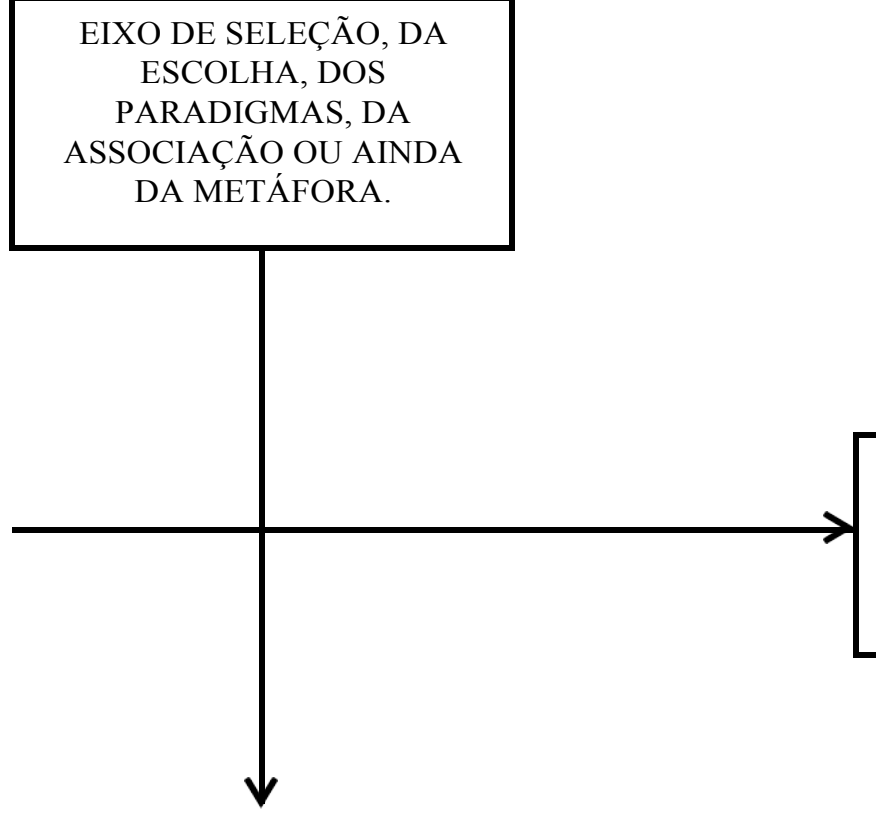

EIXO DE COMBINAÇÃO, DA SINTAXE, DA

CONTEXTURA OU AINDA

DA METONÍMIA.

\section{FIGURA 1. ESQUEMA PARADIGMÁTICO E SINTAGMÁTICO}

O eixo paradigmático ou associativo representa a relação entre os elementos do sistema linguístico suscetíveis de figurar no mesmo ponto do enunciado, no qual um elemento poderia ocupar o lugar de outro sem que a estrutura do enunciado precisasse ser reformulada, colocando os elementos sob um prisma de igualdade. Nas palavras de Jakobson (2010: 49), o eixo dos paradigmas é "uma seleção entre termos alternativos que implica a possibilidade de substituir um pelo outro, equivalente ao primeiro num aspecto e diferente em outro". Assim, as relações paradigmáticas podem ocorrer por alguns princípios associativos, como, por exemplo, o critério da expressão significante (mente - pente - sente - gente) ou o critério do significado (mente - razão - pensamento - lógica). Já o eixo sintagmático é uma relação de combinação entre os signos que obedece a um padrão definido pelo sistema, no qual os elementos se encontram em uma relação de dependência em relação aos outros. Nesse eixo de combinação, "qualquer unidade linguística serve, ao mesmo tempo, de contexto para unidades mais simples e/ou encontra seu próprio contexto em uma unidade linguística mais complexa" (idem).

Como observado nos textos reconhecidamente poéticos, Jakobson (2010: 71) afirma 
que a interação desses dois elementos (de seleção e combinação, do paradigma e do sintagma) se dá de forma particularmente marcante, e diferentes razões podem determinar a predominância da escolha entre eles. Assim, a unidade das equivalências faz que nos impressionemos com a capacidade da poesia em nos causar estranhamentos e nos sensibilizar. Logo, essa explanação teórica nos é ainda imprescindível para apreender os efeitos psíquicos de livres-associações e subjetividades de entre-textos que emergem da leitura de textos poéticos e que dão à poesia seu caráter formativo e emancipatório.

Não por outro motivo, valemo-nos também dos conceitos de condensação e deslocamento estabelecidos por Freud (1987) na interpretação dos sonhos, os quais foram relacionados à teoria linguística de Jakobson por Lacan (1998), ao atribuir à condensação o papel da metáfora e ao deslocamento o papel da metonímia. Com a Psicanálise e a busca pela compreensão do funcionamento inconsciente, vimos que a condensação, como a cadeia associativa do eixo de seleção, é a síntese das ideias e imagens do sonho que se relacionam e são análogas entre si. Já no processo de deslocamento, substituímos uma ideia por fragmentos constituintes do sonho, que evidencia ou foca um detalhe de algo representado, como ocorre na cadeia combinatória, em que as unidades linguísticas servem de contexto para unidades mais simples ou encontra seu próprio contexto em unidades mais complexas.

Essa relação entre os conceitos da Psicanálise e da Linguística nos ajuda a entender que o inconsciente é estruturado como linguagem e não pela linguagem. Lacan explica que, entre as ordens do significante e do significado, há uma barra de resistência à significação, fazendo com que o significante prevaleça no signo psicanalítico. Para evidenciar que há, na estrutura da linguagem, o conceito de subjetividade dentro de um processo de busca incessante do sujeito por querer se identificar por meio de sua linguagem e de seu discurso, Lacan inverte a relação do signo saussuriano em que significado corresponde a um significante e o coloca em uma relação não fixa entre ambos, já que o significante nem sempre levará ao significado correspondente e esperado. Assim sendo, o significante constitui o elemento que se sobrepõe ao significado, uma vez que, ao ser representado em uma cadeia de significantes, é a subjetividade do falante e a do receptor que estão em jogo. Retomando o que foi explicado no mestrado por meio dos estudos em Lacan, o que ouvimos não é o significado das coisas, e sim seu significante, portanto, a linguagem não é um código fixo, e sim um sistema essencialmente ambíguo. O significado das palavras é efeito de uma cadeia significante, em que os significantes se unem pelas metáforas e metonímias e só existem quando se articulam entre si. 
Para nós, professores, a importância de compreender o caráter subjetivo e inconsciente da linguagem se deve ao fato de poder conceber, em nossas práticas metodológicas e didáticas, a potência dos textos poéticos na formação de leitores e escritores no processo de letramento contínuo. Nessa direção, entendemos que a poesia apresenta grande capacidade de distorcer os sentidos das palavras e das imagens (assim como os processos oníricos), constituindo, portanto, uma importância estrutural no movimento de aquisição da linguagem e de sua sensibilidade às possibilidades poéticas.

Logo, a partir da abordagem metodológica de pesquisa-ação e do levantamento de dados que nos ajudarão a repensar o letramento na contemporaneidade, pretendemos realizar a investigação sobre o reposicionamento subjetivo dos alunos do Ensino Médio à luz de um referencial teórico amplo que permite nos auxiliar na compreensão de um processo tão complexo. Para isso, estruturamos a tese da seguinte maneira: os dois primeiros capítulos retomam os princípios teóricos que embasam a metodologia desenvolvida nesta pesquisa, como os conceitos de oralidade, letramento e corporalidade, a partir das elaborações epistemológicas dos campos da psicanálise e da pedagogia. Nesse sentido, concentramo-nos nos estudos de Jacques Lacan, psicanalista francês, que articulou o conceito de sujeito do inconsciente formado, de um lado, pelas pulsões e desejos que se expressam em objetos fantasiados e representações manifestadas no Imaginário, e de outro, pela linguagem originada no Simbólico; e de Leda Tfouni e Claudemir Belintane, que desenvolveram conceitos importantes como o do letramento e da corporalidade para compreender os processos de aprendizagem da leitura e escrita no contexto escolar. O primeiro capítulo constitui um bloco teórico sobre letramento de forma mais diacrônica, enquanto o segundo procura estabelecer uma sistematização teórica mais estruturalista e sincrônica.

Já o terceiro capítulo procura aprofundar os conceitos de estética, educação, sujeito, emancipação e política na arte poética, valendo-se dos escritos de Herbert Marcurse e Jacques Rancière, filósofos contemporâneos que articulam a ideia do sujeito inserido na arte com o interesse universal pela emancipação humana, uma vez que se entende que a sensibilização provocada pela poesia é também chave para a mobilização política dos sujeitos. A partir da resistência e da crença de que o gênero literário não pode ser substituído por bulas de remédio, receitas de bolo ou outros textos prosaicos, refletimos sobre a importância de despertar o entusiasmo dos jovens em buscar compreender o mundo a nossa volta a partir da literatura e da sua capacidade estética de encantar, intrigar e propiciar o autoconhecimento. Além disso, ainda no campo da filosofia, valemo-nos dos estudos de Marcuse sobre a cultura 
repressiva e sua leitura de Schiller, quem se preocupou em aliar uma educação estética a uma conscientização política, cujo diagnóstico de época foi feito de maneira impetuosa, escancarando um problema instaurado na formação do estado burguês que decorre até os dias de hoje. A fim de compreender o surgimento do conceito de cultura estética e de uma proposta de educação em que o belo artístico se mostra como a via capaz de propiciar harmonia no indivíduo e na sociedade ao mesmo tempo, fez-se necessário, portanto, remontar alguns passos desses filósofos e colocá-los em diálogo com a psicanálise para identificar como o desenvolvimento de tais teorias a partir de uma visão sobre aquela época nos ajuda hoje a pensar nos princípios de sua superação.

O quarto capítulo expõe o trabalho realizado na pesquisa-ação, a coleta de dados e a análise do corpus, bem como discute os resultados da teoria da corporalidade deslocada para a metodologia de letramento contínuo aplicada, apresentando os potenciais políticopedagógicos da metodologia de ensino da Língua Portuguesa desenvolvida na tese, partindo da necessidade de mudanças com relação à metodologia de alfabetização desenvolvida no mestrado, principalmente tendo em vista a substituição do tipo de registro oral que funcionou como suporte (textos orais infantis - parlendas, cantigas de roda, travas-língua, adivinhas), para o uso de textos poéticos mais complexos e a compreensão dos desafios da adolescência e da conjuntura política atual. Com as contribuições filosóficas, políticas e pedagógicas de nossa fundamentação teórica, buscaremos respaldar nossas hipóteses metodológicas de um ensino da leitura e escrita desenvolvido por meio da poesia, da cultura estética, da tradição oral e do ludismo literário. 


\section{Capítulo 1. A questão do letramento: contrapontos entre o oral e o escrito}

Em meio a tantas discussões sobre os métodos de alfabetização que vêm sendo rechaçados pelo atual governo federal e em meio a tantas mudanças reacionárias que o Ministério da Educação tem implementado na área de Língua Portuguesa e no sistema escolar em geral $^{8}$, faz-se mais que necessário para nossa tese discorrer sobre o conceito de letramento na perspectiva de Tfouni e Belintane e sobre as contribuições de estudiosos da linguagem no campo da alfabetização, cujas inquietações transpassam a instrução formal da leitura e escrita e acolhem preocupações sócio-históricas em que os processos de decodificação e de inferência estão inseridos. Por mais que nossa abordagem tenha como foco o processo de letramento contínuo de adolescentes, representando diferentes tipos e níveis de habilidades e conhecimentos, bem como diferentes práticas sociais do uso da leitura e da escrita, a discussão em torno do conceito de letramento vinculado à alfabetização e à oralidade poética, mesmo no contexto do Ensino Médio, ainda precisa ser considerada e aprofundada. Isso porque tem sido recorrente ouvir por parte dos órgãos oficiais no setor da educação que a culpa do "fracasso escolar" é ou dos professores que não estão bem formados e qualificados para o cargo ou dos alunos e suas famílias que já não se interessam mais pelos conteúdos ensinados na escola, ou seja, explicações reducionistas para a complexidade do problema. É evidente, no entanto, que é preciso repensar o sistema escolar como um todo, ainda mais com os resultados do IDEB e do SAEB de 2017 que mostram uma pontuação abaixo de 5 (menos que a metade do total de pontos e abaixo da meta anual), indicando ainda que, apesar de algumas melhorias nas avaliações externas do governo, apenas 25\% dos alunos de escolas públicas no Brasil concluíram o Ensino Fundamental com habilidades e conhecimentos linguísticos esperados para a faixa-etária.

Abordar a questão da alfabetização e do letramento no contexto do Ensino Médio em uma perspectiva da performance da oralidade poética é também refletir sobre as dificuldades no processo de aprendizagem e reconhecer as questões sociais relacionadas ao discurso institucionalizado sobre fracasso escolar, não apenas para melhor orientar o trabalho docente, mas também para que nossos alunos se sintam capazes de persistir e vencer obstáculos. É fácil seguir uma visão simplista de que o fracasso dos alunos se encontra na desestruturação

\footnotetext{
${ }^{8}$ Adiante elucidaremos de forma mais embasada as reformas que o currículo de Alfabetização e Língua Portuguesa vêm sofrendo desde o atual governo federal de 2019.
} 
familiar e por isso não há maneiras de a escola intervir nessa realidade e, por outro lado, também não nos parece correto afirmar que a escola está ali para reparar ou "consertar" as falhas na educação e formação familiar dos alunos.

O discurso que está presente ideologicamente em nossa sociedade sobre o fracasso escolar tenta ocultar as falhas de um modelo de educação que não oferece lugar para a diferença ou para as singularidades dos alunos (Tfouni, 2009: p. 13). É importante levar em consideração que os alunos, independente da faixa-etária, aprendem em ritmos distintos, necessitam olhares e atendimentos que lidem com a heterogeneidade do grupo-classe e os ajudem a ressignificar a visão que tem de si mesmos, muitas vezes uma visão estigmatizada do "não sei ler", "não sei escrever direito", "não adianta me ensinar, pois sou incapaz de aprender".

Na contramão dessa compreensão, no dia 6 de setembro de 2019, o Diário Oficial divulgou o decreto número 10.004 que instituiu o Programa Nacional das Escolas CívicoMilitares (Pecim) com a finalidade de "promover a melhoria na qualidade da educação básica no ensino fundamental e no ensino médio" com ações ao fomento e ao fortalecimento das escolas cívico-militares, adotando um modelo de gestão baseado nos colégios militares, ou seja, crendo em um modelo de educação completo e universal, sustentado por um discurso autoritário que ignora as diferenças. Como bem lembra Tfouni:

\begin{abstract}
Em uma sociedade de classes, fundamentada não mais na ordem do nascimento como na Idade Média, mas na ordem econômica da propriedade privada e da acumulação de riquezas, um discurso (DPE) que atribui ao indivíduo a responsabilidade pelo seu destino, seu sucesso ou seu fracasso, é indispensável para a manutenção do equilíbrio social. Daí expressões muito conhecidas como tem que estudar para ser alguém na vida, quem não estuda não é ninguém, ou ainda você não estudou porque não quis. Esse discurso, (...) ao mesmo tempo em que cria algumas condições para que haja uma divisão social do trabalho eficaz - pois propõe um modelo de educação que não respeita a singularidade, e assim produz inevitavelmente o fracasso escolar - responsabiliza o sujeito pelo seu próprio fracasso, e assim, também, pela sua própria condição de excluído e de explorado. (TFOUNI, 2009: p. 13).
\end{abstract}

A responsabilização pelo ato de educar é coletiva, tendo vários agentes em seu processo, no entanto, os professores cumprem um papel fundamental no reconhecimento das singularidades de cada aluno, singularidade essa que se faz presente em toda subjetividade e não pode ser descartada nos diversos modos de aprendizagem, assim como a origem e o contexto histórico-cultural dos alunos devem ser respeitados em sala de aula. Porém, salas 
com trinta, quarenta e até quarenta e cinco alunos, com apenas um professor em sala, tendo que se responsabilizar pelo aprendizado de todos, não é responsabilização coletiva. Entendemos que enxergar o professor como profissional isolado, que trabalha sozinho, a portas fechadas, é uma opção política, própria do mundo neoliberal, que prejudica a compreensão da heterogeneidade presente em qualquer turma. O trabalho em equipe é condição sine qua non para respeitar as diferenças, caso contrário, não há professor que consiga fazer milagres em uma sala de aula lotada.

$\mathrm{O}$ direito à diferença é também uma bandeira do ensino democrático, inclusivo e libertário. Assim, de um lado, a metodologia de letramento que almejamos deve ser para todos os alunos, não apenas para aqueles que tiveram uma estrutura familiar com condições favoráveis à oralidade poética, por outro lado, essa mesma metodologia não deve trabalhar com a percepção de indivíduos repletos de lacunas e problemas que devam ser corrigidos pelo sistema escolar, mas sim com a ideia de formação contínua e emancipatória.

Com a contribuição dos estudos de Leda Tfouni (2010, 2014), Claudemir Belintane (2013, 2017) e de outros pesquisadores implicados em questões contemporâneas sobre letramento, alfabetização, oralidade, leitura e escrita, ganhamos mais espaço para reivindicar novos posicionamentos e políticas focadas na inclusão, justiça e equiparação intelectual das camadas sociais, principalmente através dos mecanismos educacionais. O conceito de letramento garantiu a ampliação da ideia individual de aquisição da leitura e escrita, para uma ideia que se propõe abordar também aspectos sócio-históricos de toda uma população em transformação cultural diante de seu sistema fonográfico, simbólico, político e econômico.

Nesse sentido, é preciso esclarecer no início deste capítulo que os desdobramentos das pesquisas sobre a transição da oralidade para a leitura e escrita trouxeram, não apenas para a sociolinguística e para a psicologia, mas principalmente para o campo pedagógico e político, a ideia de letramento com foco nas práticas de linguagem que circulam na sociedade, sejam elas práticas desenvolvidas no contexto escolar ou fora dele. O termo "letramento" é um neologismo criado a partir da palavra traduzida do inglês, "literacia", e recentemente foi incorporado ao vocabulário brasileiro. Com ele, conseguimos discutir a questão da alfabetização para além da compreensão da aprendizagem de habilidades de leitura, assimilação e aplicação do código escrito, por meio do processo de escolarização das crianças limitado a processos individuais de desenvolvimento cognitivo.

Neste eixo teórico em que se conjugam fatores linguísticos, sócio-históricos, políticos e econômicos, deparamo-nos com problemas relacionados ao poder e à manipulação das 
classes dirigentes. Sabemos que a língua e seu sistema escrito não são neutros, muito pelo contrário, são mecanismos sociais suspeitos, de complexas e intrínsecas relações de poder e dominação em civilizações grafocêntricas.

Por séculos e em várias sociedades orientais e ocidentais, o sistema de escrita esteve associado a mecanismos de exclusão de uma camada social que não podia ser "educada" a ler e escrever para não ferir questões ideológicas de ordem religiosa e econômica que deveriam, segundo interesses da classe dominante, permanecer imutáveis. Portanto, enquanto a sociedade se apresentar dividida em classes sociais com interesses divergentes, os enunciados e seus discursos estarão contidos em espaços de luta entre vozes sociais, inevitavelmente apontando para lugares de contradição e exclusão.

A contradição na sociedade de classes se aprofunda quando os processos escolares de instrução formal da alfabetização focam na padronização da língua e na deslegitimação de determinados discursos sociais. Principalmente no ano de 2019, período em que estamos regredindo a passos largos rumo a um modelo ultraliberal de escola, cuja intenção é eliminar a criatividade para reduzir o ensino da língua a uma sistematização e formalização de normas, percebemos como é clara a predominação de um pensamento autoritário com relação à alfabetização. O retrocesso conservador no campo da alfabetização é reconhecido nas práticas educativas que concebem o processo de aprendizagem da leitura e escrita em termos mecânicos e funcionais. Nessa concepção, a escrita da língua passa a apontar para formalidades do que se deve ou não fazer ao pronunciar a língua ou escrever um texto, reduzindo o domínio da língua a regras gramaticais e a usos pragmáticos dos gêneros textuais.

A contradição está exatamente no fato de que, embora a alfabetização tenha se tornado um item educacional necessário, obrigatório e em evidência, tal processo se reduziu ao domínio de habilidades fundamentais subjugadas às necessidades do capital, à produção de cidadãos eficientes, capazes de repercutir o Estado burocrático moderno, tornando-os indivíduos de fácil acesso aos meios de comunicação padronizados. Essa é uma tendência antiga do desenvolvimento do capitalismo e da modernidade, no entanto, o atual governo vem demonstrando de maneira mais enfática o desejo de situar o campo da alfabetização em um programa neoliberal e desenvolvimentista, cujo domínio financeiro se atrela ao domínio político conservador.

Observando o evidente paradoxo, pretendemos advertir como questão urgente a se tratar no campo educacional, a necessidade de repensar as práticas de ensino da língua tornando primordiais os aspectos sócio-históricos da aquisição do sistema escrito. Para isso, é 
preciso mirar objetivos de aprendizagem que vão além da mera codificação e decodificação dos sinais gráficos, ou seja, as metodologias de ensino carecem de respeito ao processo de simbolização das leituras significativas e das produções criativas no sistema escolar.

Deste modo, tendo em vista os conceitos de letramento e educação estética ao pensar práticas de ensino que reflitam sobre a subjetividade dos alunos em suas relações entre leitura/ escrita e política, vemo-nos com a atenção voltada não apenas para as habilidades e competências a serem desenvolvidas a partir do trabalho com os textos literários e poéticos, mas também para as características da estrutura social a que os alunos estão submetidos.

Para isso, neste capítulo temos a intenção de aprofundar a questão do letramento tencionado à dimensão política a fim de melhor firmarmos o lugar de onde falamos e o objetivo da pesquisa em questão. O contexto da cultura escrita de nossos alunos será melhor apresentado no quarto capítulo, porém, vale retomar que se trata de turmas alfabetizadas com capacidade de decodificar sonoramente os textos (em diferentes níveis de fluidez) que, no entanto, apresentam níveis de inferência textual baixos para a faixa-etária. Isso significa que utilizaremos o conceito de letramento também para analisar os dados de produção oral e escrita de um grupo de alunos do Ensino Médio, cujo contexto sociocultural de famílias não alfabetizadas e de baixa renda impõe outros obstáculos para além daqueles que a própria linguagem e o processo de subjetivação já impõem no cotidiano escolar. Assim, é importante dizer que consideramos a alfabetização e o letramento como "processos interligados, porém separados enquanto abrangência e natureza" (Tfouni, 2010: p. 25). Além disso, consideramos o letramento como um continuum, não havendo a possibilidade de existir, em nossa sociedade moderna, o letramento "grau zero" ou o "iletramento", uma vez que os indivíduos estão inseridos em vários modos de ser letrados. Podemos considerar graus de letramento, a depender das demandas cognitivas que a sociedade impõe aos indivíduos, alienando-os "de seu próprio desejo, de sua individualidade e, muitas vezes, de sua cultura e historicidade" (idem, p. 28).

Apesar de todos os esforços em procurar definir aquilo que acreditamos estar por trás do termo letramento, é salientável que sua conceituação seja considerada complicada não apenas pelos linguistas que alargaram seu sentido, mas também pelos estudiosos da pedagogia, sociologia, psicanálise entre outros campos teóricos que abordam o processo sócio-histórico da aquisição e domínio da linguagem por diferentes sujeitos e culturas. Mais correto seria utilizar o termo no plural, como a ideia de multiletramentos (Rojo, 2012), uma 
vez que os vários letramentos (social, eletrônico, crítico, artístico) refletem os vários textos que circulam em nossa sociedade.

Não há trabalho teórico algum que encerre a questão do que é o letramento, em contrapartida, há muita confusão que ainda não foi esclarecida, principalmente porque o termo letramento está misturado com as perspectivas "individualista-restritiva", meramente cognitiva ou enquanto um produto do desenvolvimento tecnológico a partir do termo literacy. No contexto escolar, ao empregar a ideia de "práticas letradas", a ênfase está sempre nas práticas de leitura/ escrita de texto e em uma constante preocupação de gerar resultados e produtos a partir destas. Tfouni, em seu livro "Letramento e alfabetização" (2010), aprofunda a polêmica da teoria da "grande divisa", cuja superposição entre letramento e alfabetização se encontra na ideia de que a aquisição generalizada da escrita traz consequências que modificam a comunicação em sociedade, existindo usos orais e usos letrados da língua isolados, em atos divididos, separados (p. 35). Segundo essa tese, no caso do uso oral "teríamos por trás um raciocínio emocional, contextualizado e ambíguo" e no uso letrado "um raciocínio abstrato, descontextualizado e lógico" (idem), como se a partir da prática escrita, haveria a possibilidade de tornar todo o nosso pensamento legível, esclarecido e completo. Para nós, um dos grandes problemas do discurso grafocêntrico se encontra nessa tentativa de exibir a escrita como uma "força superior", com a qual aqueles que a detêm podem reproduzir progressiva e linearmente o discurso social. Além de reificar os processos de leitura e escrita, remetendo-os ao sistema produtivo, essa concepção de triunfo da escrita sobre a oralidade desconsidera, ou mais do que isso, renega a riqueza e variedade comunicacional de várias sociedades ágrafas e coloca em risco nossas políticas pedagógicas responsáveis pela elaboração do programa de alfabetização escolar que tendem a estabelecer metas de leitura e escrita sem prever nenhum trabalho com a oralidade poética e formular.

Nesse sentido, ao discorrer sobre a ideia de letramento, devemos ter em mente que este é um processo mais amplo do que a alfabetização, no entanto, ainda está intimamente relacionado com a cultura escrita. Por isso que dissemos acima que talvez fosse mais correto utilizar o termo letramentos (no plural), por ser um fenômeno multifacetado com diferentes abordagens críticas, que surge conforme o avanço tecnológico e as transformações sociais. Os diversos letramentos também se aplicam a diferentes contextos, como o digital, o acadêmico, o escolar, o midiático, apresentando-se a partir de múltiplas linguagens, uma vez que o uso da língua é também uma prática heterogênea relacionada ao tempo, ao espaço e às características sócio-históricas dos falantes. 
A linguagem permeia toda nossa existência e é por meio dela que nos conhecemos e nos constituímos. Através da linguagem e de seus recursos (a fala, a língua, o discurso) estabelecemos relações de afeto, de desejo e de poder. Deste modo, não será suficiente discorrer apenas sobre a gramática de uma língua ou sobre a origem de determinados discursos em nossa sociedade. Isso não bastaria para refletir sobre a complexa realidade em que vivemos, tampouco para aprofundar o conceito de letramento, subjetividade e poesia. Nossos processos psíquicos e nossa história civilizatória geraram uma tensão entre o que é o real e o que a linguagem é capaz de captar, traduzir, esclarecer. Assim, após a introdução aqui exposta e após a justificativa para discorrer sobre o conceito de letramento no contexto do Ensino Médio, este capítulo e o próximo pretendem se desdobrar em três grandes eixos vinculados à ideia de letramento sob o aporte teórico da linguística, da psicanálise e da teoria literária: i) a oralidade, ii) a escrita e iii) a leitura, atrelando-os à ideia de alfabetização como aquisição continua, em lato sensu, do uso da linguagem e do domínio da língua.

\section{Reflexões sobre oralidade}

Na Grécia Antiga, em que pensamento não se separava de imagem e a memória e a imaginação eram reconhecidas como dons a serem exercitados, o medo do esquecimento e da perda da memória coletiva movia os poetas, aedos e rapsodos a entoarem e cantarem "de cor" os feitos dos grandes guerreiros de suas histórias. Para os gregos, a deusa Mnemosine, titânide que personificou a memória, era responsável por preservar a história de seu povo e protegê-la do Rio Lete, cuja força das águas podia arrastá-la para a região dos mortos, do esquecimento. Evocando a mãe das musas e suas talentosas filhas, os rituais gregos memoravam as epopeias e os ensinamentos dos deuses, sobre o mundo e a moralidade, transmitidos de geração em geração desde a mais tenra infância dos cidadãos gregos.

A importância da memória para a sociedade grega foi tão persistente que as histórias cantadas há quase três mil anos se fazem presentes em nossa cultura até hoje, em cada "calcanhar de Aquiles" onde a dor nos fisga pelo caminho, a cada vez que temos a sensação de estar "carregando o mundo nas costas" ou a cada "presente grego" que recebemos. A perspicácia da memória coletiva grega estava fundamentalmente no estado de linguagem de seu povo que, sem nenhum tipo de registro gráfico ou de memória estendida, havia transformado a palavra em canto a partir de uma mnemotécnica suntuosa, de versos rimados e metrificados. A tradição da poesia evoluiu com as tragédias e epopeias gregas em busca do 
Kleos, de narrativas e histórias aficionadas por alcançar a glória eterna. A tradição da memória coletiva dos gregos impulsionou as aventuras de heróis como Odisseu, Aquiles, Édipo, Héracles entre outros, a se tornarem imortalizadas, transformando-se em reminiscências ecoadas para sempre no futuro das próximas gerações. A necessidade do Kleos na cultura grega era a necessidade da vitória da memória, da permanência e resistência de um tempo, de um acontecimento e da cultura de um povo guerreiro e vencedor. Graças à arte poética, à música e à dança, foi possível reter na memória, nos corpos dos sujeitos atores e espectadores, os grandes eventos da Antiguidade Clássica.

Ao longo da história grega, a poesia, como arte da linguagem, passou a ganhar características formulares com métricas bastante fixas e rígidas, nas quais Homero e outros rapsodos se apoiavam para transmitirem oralmente as histórias dos deuses e dos homens da Grécia Antiga. Eles reproduziam em cantos o modo de falar do seu povo e de seu tempo: seu estado de linguagem tinha a palavra como canto. Havelock (1996), à luz das pesquisas realizadas por Milman Parry e Albert B. Lord acerca da tradição formular das composições homéricas e da estética da literatura oral grega, discute em seu livro Prefácio a Platão como o alfabeto tornou a palavra falada em objeto e, consequentemente, transformou as narrativas em discursos conceituais. Os estudos de Havelock, que procuraram complementar as obras de Parry e seu discípulo Lord, são indispensáveis quando falamos de poesia, tradição oral e surgimento da escrita.

No século XX, por meio do registro da Ilíada e da Odisseia, foi possível para Parry e Lord (1997) investigarem com profundidade o uso dos hexâmetros dactílicos, fórmulas poéticas para versificação oral com um esquema rítmico de alternância de sílabas longas e breves. Os epítetos recorrentes ligados aos nomes próprios dos guerreiros apontavam para uma fórmula baseada principalmente no efeito sonoro e métrico dos versos, mesmo que a expressão do conteúdo não resultasse imediatamente em um sentido totalmente lógico. $\mathrm{Ou}$ seja, a hipótese de Parry e Lord era de que os poetas compunham o arranjo das palavras mais por critérios de versificação (e encaixe métrico) do que pelos seus sentidos. Mesmo que um poeta apresentasse à tradição da poesia oral alguma contribuição original, esta deveria ser antes aceita pela cultura das fórmulas já estabelecida pelo grupo de poetas e ouvintes. A teoria dos estudiosos levou como hipótese central que a técnica de composição e as diversas possibilidades formulares dos versos das grandes obras da literatura europeia não tiveram ajuda da escrita e eram, portanto, primordialmente técnicas orais. Assim, os trabalhos de 
pesquisa de Parry e seu discípulo Lord deram a entender que tais obras não são frutos do trabalho de um só homem e sim de toda uma geração inscrita nessas formas de produção oral.

As epopeias, antes de ganharem corpo gráfico, chegavam ao público por meio da performance e dos recursos mnemônicos dos cantadores (com dramatização, dança, música) que favoreciam sua memorização. Com suas devidas diferenças, também notamos os cantadores de repente no Nordeste brasileiro, os quais ainda narram pelo sertão, através da técnica do improviso, as aventuras dos cangaceiros ao som da cantoria. Esses narradores, que possuíam suas raízes no seio da cultura popular, eram capazes de congregar o povo em torno de um único interesse: ouvir histórias e compartilhar experiências. E por que o professor em sua sala de aula não poderia se colocar também nesse papel de contador de histórias, de declamador de poesias, e envolver as crianças e os jovens com poemas e narrativas contadas de memória, de forma ritualística e inspiradas na tradição oral?

Segundo Zumthor (2010: p. 29), o fenômeno da oralidade parte de múltiplas estruturas de manifestações simultâneas com graus muito desiguais de desenvolvimento, entretanto seu substrato comum permanece sempre perceptível. Isso ocorre devido à especificidade linguística de toda comunicação vocal, a partir do investimento de energia psíquica de pelo menos dois sujeitos (locutor e ouvinte) que compartilham valores míticos, sociais e linguísticos. "Tão fortemente social quanto individual, a voz mostra de que modo o homem se situa no mundo e em relação ao outro" (idem). Nesse sentido, cabe-nos relembrar que, para nós, oralidade se difere da fala cotidiana e pragmática, uma vez que tomamos por transmissão oral toda comunicação poética "em que, pelo menos, transmissão e percepção passem pela voz e pelo ouvido" (p. 32) a partir da performance do corpo. Dessa forma, enquanto o falado engloba todo enunciado proferido pela boca, a oralidade é um enunciado formalizado de modo específico, cujas metáforas, os elementos ficcionais ou outras figuras da linguagem promovem o diálogo entre indivíduos a um valor marcado por elaborações poéticas, envolvendo desde chistes, provérbios e causos a outros jogos de palavras que demonstram uma aproximação entre o inconsciente, a linguagem poética e a performance oral. Logo, o enunciado da oralidade carrega uma estrutura que recusa a intenção meramente pragmática de comunicação de uma mensagem, permitindo que forças de ordenação dos discursos afirmem o lugar social da performance.

A ideia de performance foi amplamente explorada por Zumthor $(2010,2014)$ em seus estudos medievais e de poéticas do oral sobre o forte papel que a voz e o corpo desempenham na sociedade. Segundo o historiador e crítico literário, a performance é "a ação complexa pela 
qual uma mensagem poética é simultaneamente, aqui e agora, transmitida e percebida. (...) Na performance se redefine os dois eixos da comunicação social: o que junta o locutor ao autor; e aquele em que se unem a situação e a tradição." (2010, p. 31). Em geral, a tradição se dá pela repetição do fenômeno oral a partir da qual se caracteriza a existência do poema, não antes, é claro, de o mesmo ter sido produzido, transmitido, recebido e conservado por toda uma geração ou por um determinado grupo social. Tal fenômeno somente é possível de acontecer por meio da oralidade que a voz, socialmente, realiza entre os sujeitos. $\mathrm{O}$ autor nos adverte para o fato de que não é a voz em si, através do seu aspecto psicofísico, que sustenta esse fenômeno, mas sim a voz como extensão de um corpo que está autorizado a ocupar o lugar de enunciação por meio da força ilocutória de sua voz, garantindo, assim, um certo valor de sua autoridade enquanto enunciador. Além disso, outras forças de ordenação do discurso cumprem um papel fundamental na performance, como o grupo social enunciatário, ou seja, o público que recebe a enunciação oral e as circunstâncias da fala, como o gênero do texto e a dimensão ritual que procura manter a coesão social a partir da relação transferencial que se estabelece por meio desse fenômeno. $\mathrm{O}$ ato de autoridade do sujeito que se expressa é testemunhado pelas causas e consequências do seu poder de persuasão diante de um determinado grupo social. Nesse caso, podemos reconhecer duas formas de oralidade, aquela fundada na experiência imediata de cada sujeito e outra preservada por uma tradição, pela ideia de um eterno retorno da palavra, o que Zumthor (2010: p. 33) chamou de "afirmação e união":

o conhecimento ao qual eu dou forma ao falar e de que, pela via do ouvido, você se apodera, se inscreve num modelo ao qual ele faz referência: ele é reconhecimento. Ele se predispõe a dar justificativas habituais e se desenvolve em uma trama de crenças, de hábitos mentais interiorizados, constituindo a mitologia do grupo, qualquer que seja ele.

Somente a partir desse fenômeno oral na sociedade é que o sujeito pode se reconhecer no mundo e na ordem simbólica que o constitui. Isso porque, é por meio dos atos de reconhecimento do outro e de si mesmo, no desvelamento do que está por trás dos mitos e na busca por atribuir significado aos traços de escrita que nos marcam que é possível nos localizarmos no discurso do Outro. Chegamos ao mundo obrigados a acompanhar uma linguagem que já está em curso e impelidos a nos apropriar de um discurso pré-existente. Posto de outro modo, tornamo-nos sujeitos somente a partir da enunciação do outro e não nos 
é possível desenvolver uma subjetividade autônoma, pois a linguagem nos domina, o desejo do outro sobre nós se inscreve em nosso corpo por meio das palavras, desenhando nosso destino e nosso discurso. Essa relação transferencial caracteriza o efeito poético em si como uma identidade entre o saber e o não-saber, ou melhor, entre procedimentos conscientes e inconscientes, efeitos do processo primário da língua, da oralidade primeira das epopeias e das tragédias.

Pressuposto isso, a importância da tradição oral e do poder das palavras deve ser reconhecida e valorizada mesmo com toda midiatização a que estamos submetidos e mesmo com todas as redes que nos atravessam, uma vez que o sujeito é inevitavelmente marcado por um sistema de convenções significantes que compõe a mítica do inconsciente e o localiza no mundo através da linguagem, da tradição e da cultura conservadas pela tomada da palavra poética.

Além disso, não nos parece correto analisar o conceito de oralidade realçando-lhe os traços que a contrastam com a escritura (Zumthor, 2010: p. 24). A oralidade não deve ser vista como uma lacuna ou um fenômeno incompleto que só avançou após a tecnologia da escrita se encarregar de realizar as tarefas que a tradição oral não foi capaz de realizar. Muito pelo contrário, a oralidade deve ser reconhecida como "sobrevivência, reemergência de um antes, de um início, de uma origem" e não ser taxada com estereótipos "primitivos" (p. 25). Principalmente porque a escrita não é um fenômeno óbvio, mas sim um processo complexo e sofrido, pelo qual o indivíduo se subjuga.

Já o corpo e a voz podem ser compreendidos como uma "arquiescritura", entidades capazes de carregar marcas que se inscrevem de outro modo no discurso, por meio da memória, do inconsciente e das provocações do Outro. A voz humana "nada mais é que disfarce de uma escritura primeira", cuja linguagem inerente é capaz de transmitir a tradição de um pensamento milenar.

Além disso, não é correto afirmar a existência de uma sociedade de oralidade pura ou uma que ignora qualquer forma de escrita. A escrita pode estar presente em um bloco de pedra, marcada com um traço significando propriedade, quantidade, tamanho, pode estar presente em tatuagens ou pinturas no corpo, em máscaras e ornamentos, em estampas, desenhos, riscos. Por isso, Zumthor (2010) procura definir com precisão espécies ideais de oralidade em que a poesia atua: a oralidade primária, uma oralidade mista e outra midiatizada. A oralidade primária é aquela sem contato com a escrita que possa ser codificada e traduzível em língua (nesse caso, o termo escrita não se encaixa no conceito amplo que exemplificamos 
acima). Já a oralidade mista é o fenômeno coexistente com a escrita, podendo sofrer influência parcial, como atualmente nas massas não alfabetizadas dos países pobres ou podendo se recompor a partir da escrita em um meio em que esta é predominante sobre os valores da tradição oral na prática e no imaginário. E por fim, o que temos como predominante, é a oralidade mediatizada, o rádio, os discos e a televisão que tornam o fenômeno oral mecânico, podendo diferenciá-lo e difundi-lo no tempo e no espaço.

A oralidade primária (ou pura) definiu a civilização da voz viva, cujos valores e tradições eram preservados por meio da palavra das várias formas de discurso moral e poético. As formas poéticas produzidas três mil anos atrás "se distinguem globalmente de qualquer poesia escrita, pelo fato de não oferecerem nem aos críticos ulteriores, nem aos historiadores, muito menos a seu público, documentos manipuláveis e passíveis de serem inscritos em uma cronologia" (Zumthor, 2010: p. 37). Assim, não há como negar a importância do papel cultural da linguagem versificada para a evolução da comunicação oral e da técnica letrada da antiguidade. A memorização dos textos dependia do ritmo, e o registro escrito dos mesmos, por sua vez, dependia da memorização. O que se sucedeu na Grécia Antiga é que, com o advento da escrita, Homero e Hesíodo foram os principais meios para preservar e manter as convenções sociais da cultura grega, bem como suas narrativas epopeicas e toda ciência dos deuses. Mesmo assim, sem a memória coletiva conservada pelos rituais de contação de histórias, da encenação no teatro, da cantoria nos festivais, a cultura das sociedades orais não teria sido carregada adiante por meio de técnicas gráficas. Não é à toa que as vozes que ainda estão fortemente presentes em nossa sociedade e que ressoarão ainda amanhã são essas vozes que permearam toda espessura da escritura (idem, p. 29).

A dimensão ritual evocada pela performance permite uma relação transferencial entre o enunciador e o público receptor. E, mesmo com a técnica escrita, sem a tradição de uma memória coletivizada e sem rituais marcados pelas artes populares, a cultura de um povo se esvazia e os laços sociais podem se afrouxar a ponto de se perderem. Infelizmente, "se tivermos de fato um esvaziamento total desses recursos de Mnemosine, muito provavelmente não teremos povo e sim hordas. Num mundo sem memória coletivizada, seria difícil imaginar a situação de cada indivíduo sem aproximá-la do mundo animal” (Belintane: 2017, p. 19). Sem a memória em forma de linguagem, organizadora das trocas simbólicas e das estruturas elementares da cultura, não é possível levar adiante a tradição instaurada pelas experiências da comunidade e pela substância do discurso. 
Tal preocupação com relação às diferenças entre os indivíduos organizados em uma tradição de cultura oral sobrevivente e aqueles sem o desenvolvimento da linguagem no campo narrativo, da troca de experiências, foi também parte dos estudos de Jean-Jacques Rousseau. Por mais ambíguas que foram suas ideias no que diz respeito à aquisição da escrita e a seu interesse sobre a existência de uma linguagem "natural" (Havelock, 1996), é importante reconhecer a influência de suas obras para o estudo da questão da oralidade, principalmente quando, em ressonância, tratamos da poesia.

A obra Ensaio sobre a origem das línguas (1997), que apenas durante a década de 1960 ganhou notoriedade no campo filosófico e linguístico, traz reflexões bastante interessantes sobre o surgimento da linguagem articulada na tríade necessidade-paixãoconhecimento e, não à toa, os pós-estruturalistas franceses como Derrida, Deleuze e LéviStrauss deram tanto valor a essa obra publicada postumamente. Por mais intrigante que seja a discussão sobre tantas aporias formuladas em torno da história da evolução e desenvolvimento da linguagem apresentadas por Rousseau, o intuito de retomar brevemente seu ensaio póstumo é articular a estreita ligação que o filósofo francês apresenta entre a origem das línguas, as necessidades e a memória constituída pela prosódia da fala com a ideia de oralidade poética que queremos explorar neste item. Alguns comentadores da obra a criticam por discorrer sobre a teoria da linguagem sem levar em consideração as funções cognitivas do ser humano, como suas capacidades de aquisição do conhecimento. No entanto, não entraremos nesses pormenores, pois nos interessa agora adentrar um pouco mais na concepção de oralidade e poesia e este ensaio traz uma máxima pertinente para a concepção de memória, quando diz que: "foram em verso as primeiras histórias, as primeiras arengas, as primeiras leis. Encontrou-se a poesia antes da prosa, e haveria de assim suceder, pois que as paixões falaram antes da razão" (1997: p. 186).

Para o filósofo francês, no início da comunicação entre os seres humanos, não havia distinção entre música, poesia e discurso, uma vez que elas todas seriam derivadas das paixões que proporcionam as variações das inflexões da voz e do acento. Segundo Rousseau, a paixão faz o corpo falar e modular a voz, e a voz proferiu primeiramente em versos e em cantos as primeiras palavras compassadas em ritmos, alternando sílabas fracas e fortes, entoando a cadência da linguagem. Isso porque, segundo Havelock (1996: p. 90), a solução que o cérebro do ser humano antigo encontrou para conseguir converter pensamento em fala foi usar o ritmo já percebido por ele na natureza, a fim de provocar a repetição necessária para reter as ideias na memória. Ou seja, o ritmo fornecia elementos monótonos presentes em uma 
"cadência recorrente criada pelas correspondências dos valores puramente acústicos da língua, tal como pronunciada, a despeito do sentido", permitindo assim o nascimento da poesia (idem). Logo, o ritmo, fundamento de todos os prazeres biológicos, que segundo Havelock, podem ser considerados todos os prazeres naturais, inclusive o sexo e também prazeres intelectuais, reuniu a poesia, a música e a dança, associando-as ao trabalho da memória através da repetição. Como vimos na introdução da tese, poder reter na memória histórias, canções, poemas e poder performatizá-las no seu todo ou em parte por meio de nossas próprias palavras é uma habilidade que nos dá prazer e nos aguça a capacidade de fruição estética.

Assim como para Rousseau, junto com o nascimento da língua, surgiram a poesia e a música (que em seu entendimento não eram outra coisa senão a própria língua) e esse aspecto passional do apoderamento da arte em forma de memória e performance ressoa em sua afirmação na obra Discurso sobre a origem e os fundamentos da desigualdade entre os homens: "o entendimento humano deve muito às paixões, que, de comum acordo, também lhe devem muito: é pela sua atividade que nossa razão se aperfeiçoa; só procuramos conhecer porque desejamos gozar" (2005: p. 26).

Ao elucidar que o inconsciente se encontra na linguagem, na enunciação, no discurso, na fala e na escrita, Lacan afirma que, nesse sentido, o desejo é estruturante do ser humano e nos move na medida em que nos colocamos como objeto de desejo uma demanda nova, um objeto inatingível. Segundo o psicanalista (1998: p. 353), "é na medida em que a demanda está para além e para aquém de si mesma, que, ao se articular com o significante, ela demanda sempre outra coisa", um desejo infinito e sempre insatisfeito, o desejo do desejo do Outro (seu significante). Se a essência do homem é vazia, composta pela falta e dada por aquilo que não temos, o desejo de preencher esse vazio é o que nos move. Mas Lacan nos alerta que desejo não é pura vontade, planos e metas, pois isso são apenas máscaras para encobrir o desejo real, tampouco esse desejo que nos move é o de possuir objetos e bens. Desejo é “a chave mesma, ou a mola em nós, de toda uma série de ações e de comportamentos que são compreendidos como representando o mais profundo de nossa verdade" (Lacan, 2002: p. 504). O que queremos possuir é o desejo do outro, mas não o que ele dispõe (de dotes, trabalho, casa), e sim desejamos que o outro deseje aquilo que nós queremos, o nosso próprio desejo, o que se torna impossível. Movemo-nos, assim, na busca incessante pela experiência da satisfação, em uma cadeia metonímica que se relaciona sempre com algo para além da demanda, que vai se transformando por contiguidade conforme se enuncia e fracassa ao ser 
enunciado, já que o desejo não se inscreve todo na linguagem, há elementos que ficam sempre de fora, pois as palavras faltam. Movemo-nos, portanto, em busca de um objeto desejado que jamais será conquistado, mas que é a chave para manter a engrenagem do desejo em movimento.

Visto de outro ponto de vista, desenvolvido bem antes da psicanálise lacaniana, um tópico essencial da filosofia de Rousseau nesta obra supracitada é que a possibilidade de comunicação só surgiu após o reconhecimento que os indivíduos tiveram de suas paixões (elemento divergente daquele desejo que não somos capazes de reconhecer). Foi a partir das paixões que o homem se reconheceu enquanto ser sensível, pensante e semelhante a ele próprio, reconhecendo também a vontade de comunicar por meio da fala seus pensamentos e sentimentos. Para a época, o filósofo francês foi suficientemente ousado em sua teoria ao discorrer sobre a linguagem e as línguas humanas, no entanto, é com base na teoria psicanalítica e na linguística que embasamos nossa compreensão sobre as marcas expressivas dos significantes e do significado que nosso corpo retém e com as quais ele se comunica. Se por um lado Rousseau afirma que não foram as necessidades que estimularam a evolução da comunicação humana e sim as paixões, Freud, por outro lado, afirma que é a necessidade que deixa registros na memória a partir das experiências de satisfação e gozo, e que as imagens mnêmicas que carregamos no inconsciente estabelecem um movimento psíquico de investimento do nosso corpo para reencontrar a satisfação ora sentida: "Uma moção desta índole é o que chamamos desejo; a reaparição da percepção é o cumprimento do desejo e o caminho mais curto para este é o que leva desde a excitação produzida pela necessidade até o investimento pleno da percepção" (Freud, 1987: p. 194). A partir daí e em uma possível harmonia com a ideia de Rousseau, de que só procuramos conhecer porque desejamos gozar, Lacan diz que o gozo está fundamentado na linguagem, pela nomeação e significação que impomos por meio da ordem significante. Para gozar é preciso falar, é com as palavras e trocas simbólicas que nos transformamos e lidamos com os sintomas que carregamos no corpo.

\section{A performance e a potência da voz}

Ao localizar o gozo em conexão com o efeito da cadeia significante, a relação que sutilmente podemos estabelecer entre as duas teorias (da filosofia de Rousseau e da Psicanálise) é que da linguagem gestual ditada pelas necessidades foi então empregada a 
linguagem da fala ditada pelas paixões, pela busca ao objeto desejante. Os gritos e a vocalização já não eram mais suficientes para transmitir a complexidade dos desejos e dos impulsos humanos. O emprego da linguagem fundamentado em um exercício fônico de sons e elementos significantes enraizou toda a poesia e o canto das tradições orais. Graças à composição da voz humana, o indivíduo é capaz de ocupar o lugar da ausência e do silêncio com o concreto dos sons, com a vontade de existência, transformando o tom em matéria e presença. Cada voz é capaz de ser uma coisa, um registro diferente em cada timbre, cada entoação, cada altura e expressão que fazem surgir um novo significado. A suplência da voz é para Bosi (2010: p. 71) um novo modo da presença, uma vez que, diferentemente das outras manifestações do corpo, ela age quase sempre à distância ou na ausência do objeto. Quando um pintor modifica a matéria, suas mãos estão submetidas aos seus desejos de transformação. Já a voz não move ou modifica diretamente a matéria, ela a substitui e a evoca, "faz que ela dance com outras coisas, leva-a rápido da esfera da imagem para a do conceito e a traz de volta, no ritmo e na melodia, ao estado de pura sensação" (idem).

Os sons que saem de dentro de nós e fazem vibrar o corpo (nosso e dos outros que nos escutam) estão carregados de significâncias e emoções e fazem chegar ao mundo a matéria que antes não estava presente. A voz representa a complexidade e a intensidade do simbólico e faz surgir a palavra, cuja significação nem sempre é a que almejamos expressar ou nem sempre é capaz de representar o que sentimos. Somos sujeitos da linguagem, subordinados a ela. Em função da constelação simbólica, somos interpelados por essa estrutura muitas vezes traiçoeira, que pode nos enganar com seus recursos inconstantes e flexíveis, com os atos falhos, os trocadilhos e chistes da formulação inconsciente. Bosi retoma a frase "O ser da linguagem é o não-ser do objeto" de Lacan para nos lembrar que a linguagem pode imaginarizar até um ser que não existe, como a mentira, o “demoníaco poder da voz".

Como abordamos anteriormente, para Zumthor (2010: p. 11), a voz é mais que a linguagem vocalizada em palavras, é mais que conjuntos de fonemas expressos na emissão do tom. A voz ultrapassa a palavra e representa mais que meros objetos do mundo. Ela designa o sujeito a partir da linguagem e constitui no nosso inconsciente uma forma arquetipal. Carregamos em nós uma voz interna que antes de se tornar matéria já representa nossos sentimentos, configura nossos pensamentos, estrutura nossas experiências. Ainda enquanto imagem, a voz "mergulha suas raízes numa zona do vivido que escapa às fórmulas conceituais e que se pode apenas pressentir: a existência secreta, sexuada, com implicações de tal complexidade que ultrapassa todas as suas manifestações particulares" (idem). Assim, a 
voz pode servir como nossa protetora, preservando-nos do papel destruidor da nossa própria linguagem e do papel ingênuo de acreditar em uma comunicação perfeita, elucidando o desejo de buscar uma expressão que vá além do limite dos gestos e do conflito em representar os traços mais profundos e primitivos da própria expressão de si. Lacan, similarmente, afirmou que a fala serve mais para esconder nossos reais desejos, disfarçando-os, do que para revelar a verdade.

Mesmo assim, dos gritos para os sons adocicados e suaves ou para aqueles extravagantes e graves, - a depender do sentimento que se pretendia exprimir, fez-se o uso articulado da fala. Além de reproduzir o que hoje conhecemos como características da estrutura poética (cadência, ritmo, métrica e rima), era utilizado também o uso retórico da metáfora inerente às paixões ou às angústias e medos. Para Rousseau, a metáfora foi a expressão imediata, antecedendo a articulação convencional dos signos. A metáfora era o signo no estado de coisa, a significação antes dos significantes, utilizada figurativamente para representar diretamente a ideia do objeto. Em seu estágio inicial, a linguagem foi capaz de expressar metaforicamente a paixão ou o medo, tendo a figuração como o primeiro uso retórico, e depois, pelos pontos de articulação dos acentos e dos sons, o artifício do significante se fazia ouvir através do canto.

A linguagem humana se apegou tanto ao recurso da metáfora e à arte de unificar palavra e imagem que os primeiros registros literários são carregados de transferências de significado, de analogias e comparações. Por intermédio de metáforas, a memória humana vem sendo capaz de armazenar conhecimentos milenares de diversas civilizações e culturas. $\mathrm{Na}$ tentativa de explicar os mistérios do mundo, de driblar o medo do desconhecido e buscar respostas para as incertezas da vida, as mitologias ocidentais se valiam das metáforas para representar sentimentos universais dos indivíduos e procuravam dar forma épica àquilo que opera na estrutura dos sujeitos (Lacan, 1999: p. 53).

Não por outro motivo, o psicanalista francês se apoiou na antropologia estruturalista de Lèvi-Strauss e em seu estudo sobre o parentesco, os mitos e as trocas econômicas e sociais estruturadas na relação com a linguagem para vincular o sistema simbólico ao sistema mítico, uma vez que somente é possível encontrar a constância de certos elementos simbólicos no contraste da variação entre as diversas versões que existem dos mitos, ou seja, nos elementos constantes que se reiteram nas variantes. A análise mítica esclareceu a função dos elementos que se repetem na estrutura da cadeia significante, fornecendo, assim, a explicação para a compulsão à repetição estudada por Freud. 
Foram vários os mitos de culturas ocidentais e orientais que representaram a origem da voz humana. Como exemplo, no canto XII da Odisseia, Homero retrata o encontro de Ulisses com o feitiço do canto das sereias nos rochedos próximos à ilha de Capri. Ulisses já tinha conhecimento sobre o perigo do encantamento das sereias que, enquanto cantavam, tentavam atrair os homens para as profundezas do oceano. Assim, o guerreiro ordenou aos seus marinheiros que tapassem seus ouvidos e exigiu que eles o amarrassem no mastro do navio para não sucumbir à sedução das lindas vozes que ouviria. Além de já saber sobre o encantamento das sereias, Ulisses demonstra ter também conhecimento da carência, da impulsividade, fragilidade e do descontrole humano quando se tratava dos desejos carnais e das paixões, vendo como única saída o seu aprisionamento temporário. Ulisses consegue atravessar as armadilhas sem se entregar às sereias, por mais que seu corpo tenha insistido em se desamarrar e seguir o feitiço. Os nós em que estava envolto o corpo do viajante eram tão fortes que Ulisses ficou conhecido como um dos poucos sobreviventes ao encantamento das sereias e talvez o único a guardar na memória o som da deslumbrante voz daqueles seres perigosos.

No mito das sereias, a voz é a representação da sedução e do erotismo, essas são imagens relativas ao impulso primitivo da entrega do corpo. Os três significantes que aparecem no texto de Homero para descrever essa voz que toma o corpo são "phthoggos", “op's" e "aoïde", que segundo Bentata (2009) ${ }^{9}$, retomando a teoria psicanalítica, são três expressões que antecipam as três dimensões estruturais lacanianas representadas na voz das sereias, a dimensão Real, a Imaginária e a Simbólica, respectivamente:

- Phthoggos designa o canto enquanto grito; pode ser apenas um puro som, a reproduzir até mesmo o rosnar do Ciclope; traz em si algo de inarticulado e é associado à morte.

- $O p$ 's, ao contrário, faz sempre referência aproximada à palavra, beira a sedução; "neste termo predomina o sentido físico com uma forte conotação de harmonia, frequentemente associada a uma voz de mulher...”.

\footnotetext{
${ }^{9}$ BENTATA, Hervé. O canto de sereia: considerações a respeito de uma incorporação frequente da voz materna. In: Reverso [online]. 2009, vol.31, n.57, pp. 13-20.
} 
- Aoïde, enfim, não é um recipiente, mas um conteúdo: não é a voz, e sim, o próprio hino. Associa-se ao saber prometido, a uma transmissão simbólica.

Lacan aproxima a ideia da primeira expressão do canto das sereias com o estado de escuta permanente em que a mãe se encontra ao ter um neném. Mesmo com toda exaustão do puerpério, a mãe se vê extremamente concentrada em todos os ruídos da casa para captar qualquer possível sinal de seu filho, seja através de um grito de afeto, de felicidade ou de um grito de apelo. $\mathrm{O}$ choro do bebê é a voz mais presente na cabeça de uma mãe recém-nascida e pode ecoar até mesmo quando tudo está em silêncio, como uma alucinação auditiva. Já não se pode mais perceber o que é o real, não se sabe onde ele começa, do que ele é feito. A alegria de estar com o filho, em uma tentativa de representação harmônica e orgânica do real, é confundida com o caos, com a estrutura trágica e disparatada da realidade. Sem o grito e o choro que sai pela boca do bebê não seria possível a uma mãe perceber se ele está vivo, saudável, satisfeito ou faminto. Assim, é pela boca que o bebê terá as primeiras experiências com o mundo. Não é à toa que boca em latim (os, oris) vem da ideia de "origem", e este orifício não é apenas a saída da voz, mas também entrada do alimento, fonte de nutrição e sobrevivência. É o lugar dos lábios mamando no seio e da repercussão da potência da voz em forma de grito ou choro.

Para acalmar o grito e o choro, a mãe se comunica com seu bebê com uma voz sedutora, embalando-o com as belas melodias dos acalantos, envolvendo-o na dominação da linguagem. As cantigas de ninar, os versos reproduzidos pelos embalos maternos, a palavra carregada de afeto e júbilo endereçada à criança são os primeiros contatos do sujeito com os textos vinculados à função poética que, a partir da voz do outro, já enraízam uma rede de memória capaz de servir como porta de entrada para o mundo da cultura e da tradição oral, o que seria, enfim, a transmissão simbólica da última expressão referida no mito das sereias. Junto a ela estão as imagens mnêmicas geradas pela necessidade, servindo de mecanismo para o sujeito seguir atrás das experiências de satisfação já vividas com as quais ele deseja gozar novamente.

A voz está metaforicamente representando a origem, o início da civilização e da evolução humana em muitas tradições orais. A voz é suficiente em si e basta para impor ordem e comando, para acalmar um neném que chora e ainda está excluído do discurso, para seduzir e encantar, para dar origem ao pecado (como na tradição bíblica), para curar e dirigir um povo, para quebrar o silêncio e dar início a articulações e aproximações entre um e outro 
indivíduo. Podemos reconhecer na reprodução social da voz dois tipos de efeito da oralidade, aquela que se baseia na experiência individual do enunciador e aquela que parte de uma tradição oral, gerando conhecimento mediatizado ou discurso para assegurar a perpetuação de uma sociedade, em geral, de maneira difusa e coletiva.

Assim, a linguagem em forma de discurso pode até ser impensável sem a voz e sem a enunciação da palavra. É com a voz que a palavra ganha valor de ato simbólico e pode representar as ideias sobre o mundo, além de estabelecer relações profundas entre os indivíduos, mesmo sem ser possível controlar o que os outros compreendem daquilo que falamos:

\footnotetext{
Os valores ligados assim à existência biológica da voz se realizam simultaneamente na consciência linguística e na consciência mítica e religiosa, a ponto de ser difícil distinguir nisso duas ordens. Mas eles permanecem aí não apropriados, moventes, ricos em conotações ambíguas, por vezes contraditórias, focalizamos num bem pequeno número de esquemas que fogem à interpretação (ZUMTHOR, 2010: 15).
}

Enquanto que para Zumthor a voz tem lugar fundamental no discurso, para Lacan, o discurso não necessariamente precisa da voz, mesmo se o sentido dessa for mais amplo que a fala (a manifestação ativa da expressão humana). Para o psicanalista, o discurso é o fundo silencioso das manifestações do ser, faz que as pessoas falem, até mesmo dando a entender outros sentidos diferentes daqueles que pretendiam falar. Sobre isso, Zumthor e Lacan dizem algo semelhante ao tratar da questão que está por trás das conotações ambíguas e contraditórias: mesmo com todo aparato da voz e toda tentativa de consciência da linguagem, não somos donos dos nossos próprios dizeres ou nem sempre temos condições de representarmos em palavras exatamente aquilo que pensamos e sentimos. Assim como Pirandello escreveu em seu romance "Um, nenhum e cem mil", as palavras são vazias e nós as preenchemos com o sentido que bem nos cabe. Ao dizê-las para outra pessoa, as palavras serão inevitavelmente preenchidas com o sentido que o outro lhes der: "Mas todo o mal está nisso! Nas palavras. Todos trazemos dentro de nós um mundo de coisas: cada qual tem o seu mundo de coisas! E como podemos entender-nos, senhor, se nas palavras que eu digo, coloco o sentido e o valor das coisas como são dentro de mim, enquanto quem as ouve lhes dá, inevitavelmente, o sentido e o valor que elas têm para ele, no mundo que traz consigo? Pensamos que nos entendemos, mas não nos entendemos de modo nenhum" (2015: p. 55), diz o personagem do romance em sua eterna reflexão sobre a concepção que cada um tem de si mesmo, depois que sua mulher apresenta uma imagem dele bem diferente da que ele tinha de si. Reconhecendo seu conflito com a linguagem e com o produto de que somos feitos, fruto da 
imaginação de cada um que está fora de nós, o personagem reconhece que somos diferentes para cada um, que somos nenhum ou cem mil. Por mais que usemos um mesmo léxico de uma mesma língua, o sentido das palavras está fora do nosso controle, há uma barra de significação nos separando do discurso e de seu significado. Além disso, nós atravessamos o discurso que nos é dirigido e retemos na memória apenas o que nos convém, elementos aleatórios ou enganadores, dependendo, é claro, do que o interlocutor quis deixar de pistas em suas palavras.

Isso porque, nos três registros da linguagem, Lacan articula o desejo no simbólico, enquanto o gozo está no real, no Outro que torna impossível o comando da ordem significante. Desejamos gozar com o corpo capaz de expressar a linguagem dos signos, mas o gozo, diferentemente do gozo fálico, está fora da linguagem, está na impossibilidade de atingir o saber do Outro, é um gozo expresso na falta, num saber que não se sabe, na ausência do objeto de desejo. O real impossível move as pulsões humanas e se inscreve no corpo através da memória. Nesse sentido, se a memória carrega uma escrita psíquica que se move em torno do campo da linguagem e das imagens, antes de nos aprofundarmos na ideia da escrita alfabética e das possibilidades de leitura que estão também inscritas em nosso corpo, devemos, por ora, ainda nos debruçar sobre a ideia da palavra e da poesia no campo da oralidade, a fim de explorar melhor a ideia de performance, subjetividade e estética.

\section{A oralidade poética}

"No princípio era o verbo" é a frase que inaugura o Evangelho de João no Livro do Gênesis. De acordo com a profecia cristã, depois que Deus criou o tempo, o céu e a Terra, deu ao primeiro homem o poder de nomear todos os seres vivos e todas as coisas, reconhecendo a verdadeira natureza do mundo: a essência da linguagem. O poder de nomear e preencher de sentido as coisas do mundo vem do "fundamento da linguagem, e, por extensão, o fundamento da poesia" (BOSI, 2010: p. 164), a forma inaugural da expressão humana carregada de sentido. "O poeta é o doador de sentido", é aquele capaz de conceber em figuras, imagens e ritmo os seres e as coisas. Não é à toa que "na Grécia culta e urbana, as crianças ainda aprendiam a escrever frases assim: "Homero não é um homem, é um deus"” (idem).

Na recusa às concepções puramente lógicas da linguagem, a teologia buscou atribuir à origem divina a criação da palavra, no entanto, atribuiu ao ato poético a vocação e competência de fazer firmar e perdurar o sentido das palavras que consagram a vida e a 
natureza, que marcam os corpos, as gerações e toda uma sociedade, que percorre os séculos, que dura milênios e que carrega na cadeia significante uma força de expressão capaz de fornecer ao ser humano condições para contemplar a vida e a natureza de forma singular e memorável. Por isso que, para Lacan (1999), a estrutura do real é a estrutura do ato poético, em razão da poesia produzir algo similar à ideia da verdade como algo impossível materialmente, aquilo que não pode ser capturado ou traduzido, pois as palavras por si só não bastam. Na poesia, as palavras necessitam de uma figurabilidade, efeitos de ressonância capazes de ressoar analogias e homofonias verbais, de condensar pensamento-som-imagem em um só verso. O que é real é o que está entre as realidades que criamos, é um hiato na dualidade entre a harmonia que queremos acreditar existir e o caos que de fato nos rege. A poesia também está nesse ato efêmero, ela é capaz de clarificar um extenso cosmos nebuloso.

Assim como muitos outros filósofos e pensadores, Heidegger, em sua obra $A$ caminho da linguagem (2011), vale-se de um poema com o propósito de refletir sobre a concepção de linguagem, expressão e fala. Após a leitura dos versos de Georg Trakl, Heidegger esclarece que a linguagem se encontra em toda parte, mas, para compreendê-la, é preciso, antes de mais nada, penetrar na fala da linguagem, não na nossa fala, mas sim na fala que não se esvai após uma simples enunciação, que não se perde em meras palavras e que não ressoa em poucos sons. Para o filósofo, falar não é apenas a expressão e comunicação dos seres humanos, mas sim uma experiência estética que se encontra na poética do que se diz, na plenitude do dizer genuinamente. Nesse sentido, a primeira função da fala é nomear. Mas, segundo Heidegger, nomear não é apenas distribuir títulos ou atribuir palavras às coisas e aos seres. Nomear é evocar com o objetivo de firmar aquilo que se evoca, é submeter o ser ou a coisa ao âmbito imediato das experiências vigentes. E mais, a evocação da nomeação convoca o objeto aproximando-o da sua vigência e invocando sua ausência. Uma vez pronunciado seu nome, a evocação nomeadora convida as coisas a concernir e pertencer aos seres humanos, a penetrar no nosso corpo e se tornar técnica da nossa linguagem.

Exemplificando todo esse movimento de nomeação, evocação e convocação da linguagem a partir dos versos do poema "Uma tarde de inverno" - o qual o filósofo julga ser um poema simples, sem palavras desconhecidas ou obscuras, ele diz que "a evocação que nomeia as coisas invoca e provoca também a saga do dizer que nomeia o mundo. O dizer confia o mundo para as coisas, abrigando ao mesmo tempo as coisas no brilho do mundo. $\mathrm{O}$ mundo concede às coisas sua essência. As coisas são gesto de mundo. $\mathrm{O}$ mundo concede coisas" (p. 19) e essa saga da linguagem só é possível de ser compreendida nos versos de um 
poema ou mesmo antes, quando está imersa nos ritos da oralidade poética. Em outras palavras, sem a poesia não seria possível compreender a linguagem em sua essência, pois não adianta procurar em um dito qualquer, em uma fala prosaica a resposta para as provocações da linguagem. A linguagem fala e a fala da linguagem se mostra nos ditos genuínos: "Dizer genuinamente é dizer de tal maneira que a plenitude do dizer, própria ao dito, é por sua vez inaugural" (p. 12) e o que se diz genuinamente é o poema, a hesitação prolongada entre som e sentido (Valéry, 1991), de potência intersubjetiva, na forma mais condensada das expressões verbais.

Na tentativa de responder a sua própria provocação, se é a linguagem que fala ou o ser humano, Heidegger explica que é preciso buscar no poema o que é o falar da linguagem, pois o que procuramos está na poética do que se diz e não em qualquer fala, escolhida de qualquer modo. A fala genuína e inaugural está, como Rousseau e Bosi também afirmaram, no ato poético, na poesia, nos versos que evocam e convidam as coisas a estarem presentes e vigentes no mundo. A linguagem fala e evoca as coisas pelo nome, chamando as coisas e o mundo para virem e estarem em nós. Assim, “(...) o dito do poema é puro chamado. Poesia nunca é propriamente apenas um modo mais elevado da linguagem cotidiana. Ao contrário. É a fala cotidiana que consiste num poema esquecido e desgastado, que quase não mais ressoa" (p. 24).

Então, podemos afirmar que no princípio era o verbo existente e contido na oralidade poética e quem primeiro deu nome aos seres e as coisas foi o poeta, o doador de sentido (e aqui pretendemos usar "nome" não apenas como ideia significante, mas também como ferramenta de atribuição de sentido ao nomear, evocando e convidando as coisas e os seres para o mundo). Quando o poeta fala, a fala da linguagem não é a do senso comum, não é a da ideologia e da ordem do discurso político. É a fala que ficou na memória, que sobreviveu ao tempo e ao conceito do antigo e do novo, que foi refinada ao longo dos séculos e fornece até hoje imagens e figuras do "mundo-da-vida", tal como Husserl definia o estado pré-categorial da existência (Bosi, 2010: p. 132). A obtenção do efeito poético se dá nessa relação do poeta entre linguagem e mundo, na criação de um mundo seu. Na unidade indissolúvel entre ritmo, sonoridade e significado, as palavras são capazes de ativar a sensibilidade dos sujeitos envolvidos na tradição oral, tornando-a memorável e duradoura. Isso porque as realizações expressivas do discurso poético atribuem à poesia oral a qualidade de expressar o máximo de sentimentos, tradições, símbolos e crenças com relativa brevidade, condensando forma e conteúdo em uma unidade de som e sentido a partir das rimas, das associações e metáforas 
exploradas no poema. Como apontamos no mestrado (Joaquim, 2016: p. 67), a aproximação entre poesia e condensação de sentidos se dá na "estrutura de superposição dos significantes em que ganha campo a metáfora, e cujo nome, por condensar em si mesmo a Dichtung, indica a conaturalidade desse mecanismo com a poesia, a ponto de envolver a função propriamente tradicional desta" (Lacan, 1999: 515). Foi Lacan que aproximou ao conceito de condensação da poesia à figura da metáfora ${ }^{10}$, fórmula esta que, segundo o psicanalista, é função primordial do significante e se caracteriza como uma palavra que pode ser substituída por outra, assim dizendo: “caso seja você poeta, produzirá, para fazer com ela um jogo, um jato contínuo ou um tecido resplandecente de metáforas" (1998: p. 510). Isto é, ao poeta pertence o exercício de atribuir às palavras o máximo de carga semântica possível, sobrepondo significantes, fazendo associações, substituindo seus sentidos por outros totalmente inesperados.

A linguagem da poesia é uma espécie de efeito mágico que torna a palavra viva, dinâmica e resistente, o que podemos bem ilustrar com os textos épicos e líricos de três mil anos atrás que ofereceram estruturas estéticas e mnemônicas, que estão presentes até hoje nos complexos sistemas de recorrências e figuras que dão lugar a novas criações literárias: "A épica e a lírica são expressões de um tempo forte (social e individual) que já se adensou o bastante para ser reevocado pela memória da linguagem” (p. 132). E é isso que chamamos de oralidade poética: o que está na ausência ou sem proximidade com a fala cotidiana ou com outros gêneros discursivos próprios da fala pragmática. Segundo Otero (2011: p. 58), junto à oralidade opera a teoria formular da poesia, um suporte da memória, cuja reprodução não é uma cópia ou automatização, mas sim "uma contínua recriação do canto original, matriz identificatória que enlaça o corpo social". Na oralidade poética, efetua-se a ritualização da palavra, dos gestos e do timbre da voz, não havendo espontaneidade nesse percurso de enunciação, pois essa é uma característica da fala prosaica. Logo, o que está em jogo é um trabalho de mnemotécnica fundado nos padrões formulares e no funcionamento de diversos tipos de paralelismos (sonoro e sintático), que será exposto adiante ao abordar a teoria da função poética de Jakobson.

\footnotetext{
${ }^{10}$ Vale lembrar que Jakobson já havia sugerido aproximação parecida em sua obra "Linguística e Comunicação" (2010) e Lacan se beneficiou de seus estudos sobre a função poética da língua para se apropriar do esquema freudiano, usando a metáfora e a metonímia para recobrir os conceitos de condensação e deslocamento.
} 
A oralidade poética é, portanto, a linguagem que fala e cria efeitos de performance e memorização. Retomando Heidegger, é a partir dessa linguagem que fala que nós somos capazes de nos expressar e de nos colocar no mundo à medida que correspondemos a essa linguagem. A expressão singular do ser só é possível quando aprendemos a morar na fala da linguagem, quando aprendemos a nos posicionar a partir da linguagem que fala, pois é ela que nos convoca e nos subjetiva diante do mundo e da existência das coisas e dos seres e que "permite vencer a inércia das memórias individuais e o esquecimento coletivo" (Zumthor, 1997: p. 31). Partindo dessa hipótese, torna-se fácil conceber que a poesia é uma manifestação fundante da linguagem e sua essência carrega os mesmos elementos primordiais da expressão humana: o ritmo e a figuração, a cadência e a imagem, os efeitos de acumulação e a repetição.

De acordo com Zumthor (2010: p. 61), "pode-se duvidar de que tenha existido algum dia uma cultura desprovida de poesia oral”, pois esta foi a arte que esteve presente desde os primeiros traços da cultura humana, tendo em vista a representação de um grupo capaz de produzir signos, identificá-los e interpretá-los da mesma maneira. Havelock (1996: p. 90) também afirma algo similar quando diz que "foi assim o nascimento daquilo que se chamou poesia, uma execução hoje relegada sob a literacia para o estatuto de passatempo, mas originalmente o instrumento operativo de armazenamento de informação cultural para reutilização, ou, em termos mais familiares, o instrumento para o estabelecimento de uma tradição cultural".

Como exemplo de riqueza incomparável nas tradições orais, Zumthor caracteriza as culturas africanas como culturas do verbo, culturas que rejeitam tudo que quebra o ritmo da voz viva (2010, p. 66). A força do verbo não está em qualquer palavra, em expressões banais ou comuns, mas se encontra na "palavra-força", que em algumas sociedades só cabe a "pessoas da palavra", como aos griôs da África ocidental. Ela produz o que Zumthor chamou de memória viva (e adiante estabeleceremos vínculo com a ideia de memória na obra de Freud), cuja manifestação está tanto para o indivíduo "para quem a imposição de seu nome deu forma" (idem), quanto para a sociedade que se organiza em torno da linguagem e de seus gêneros poéticos. Da mesma forma, observamos aqui no Brasil os repentistas e cancioneiros que sobrevivem desde as entoadas poesias narrativas dos romanceiros ibéricos, os quais, há pouco tempo, ainda eram identificados nos versos dos folhetos de cordel nordestino. Dos griôs africanos aos poetas sertanejos, reconhecemos a qualidade dos gêneros e diversidade dos métodos da literatura oral. 
Em quase todas as culturas estudadas no mundo, foi possível identificar uma poesia oral que deu espaço e vazão a diversos sentimentos investidos em poemas coletivizados, em canções entoadas por casais apaixonados, soldados à beira da morte, crianças em brincadeiras de roda, camponeses lavrando a terra, chefes e líderes impondo ordem e respeito. As sociedades são marcadas pelas tradições orais em suas ricas formas, diferentes durações históricas, miscigenações e disseminações.

A poesia oral é um recurso da sociedade para falar de si mesma e conservar sua cultura e tradição, no entanto, o advento da escrita provocou uma mutação profunda de ordem mental, econômica e institucional e "implicou uma disjunção entre o pensamento e a ação, um nominalismo natural ligado ao enfraquecimento da linguagem como tal, a predominância de uma concepção linear do tempo e cumulativo do espaço, o individualismo, o racionalismo, a burocracia..." (Zumthor, 2010: p. 35). Inicialmente, a poesia oral cumpria uma função clara na sociedade, mas hoje ou se encaixa no status de sobrevivente ou de relíquia de uma cultura obsoleta.

Pois é aqui que devemos suspender a introdução sobre a oralidade poética em uma perspectiva histórica para chegar mais rápido à questão que nos cabe agora refletir: o que ocorre hoje com nossa cultura oral, tendo em vista a dominação das mídias e a tecnologização da palavra? Aparentemente, a palavra no mundo das mídias parece assegurar um lugar exato e permanente na tradição oral, ela adentra ao mesmo tempo várias casas, em diversas cidades, perpetuando-se como verdade. O rádio, a televisão, os CDs, DVDs e aplicativos de celular são atualmente máquinas responsáveis pelo impacto dos meios sobre a vocalidade e a oralidade poética. Em suas transmissões já não é mais possível reconhecer a presença de quem traz a voz, o tempo em que ela se propaga ou o espaço onde é veiculada, uma vez que sua composição se dá artificialmente, é uma voz que se faz ouvir mas se tornou abstrata. Segundo Zumthor (2014: p. 19), o que se perde com as mídias e os meios eletrônicos “é a corporeidade, o peso, o calor, o volume real do corpo, do qual a voz é apenas expansão. Daí, naquele ao qual o meio se dirige (e talvez naquele mesmo cuja voz é assim transmitida), uma alienação particular, uma desencarnação, da qual ele provavelmente só se dá conta de maneira muito confusa, mas que não pode deixar de inscrever-se no inconsciente".

Ainda assim, há uma contradição possível de identificar nas acusações que proferimos contra as mídias, uma vez que acreditamos que elas sejam também responsáveis por isolar ainda mais os indivíduos, afastando-os do princípio de comunidade e coletividade predominantes na tradição oral. Antigamente, os rituais das culturas oralistas reuniam as 
pessoas em torno de um contador de histórias, de um narrador ou, nem tão antigamente assim, em torno de um sujeito letrado para ouvi-lo ler um livro. Hoje, apesar de muitas famílias já terem condições materiais e financeiras para adquirir uma televisão em casa, um carro próprio no qual se conectam ao rádio ou fones de ouvido para se isolarem com seus celulares, ainda encontramos em cidades pequenas e vilarejos, famílias que se reúnem para assistir à novela na casa daqueles que conseguiram comprar uma televisão ou amigos que se encontram no bar onde a antena é mais alta e a transmissão do rádio mais compreensível.

Nas periferias das grandes cidades, também é possível reconhecer o fenômeno da poesia oral e performática em crescimento no mundo contemporâneo: os saraus, slams ${ }^{11}$ e batalhas de poesias fazem ressoar as vozes dos jovens que confrontam a marginalização e a desigualdade social. Apenas como um exemplo dentre vários espaços de performance oral existentes, há quase vinte anos surgia o sarau da Cooperifa na zona sul da cidade de São Paulo, onde muitos poetas, como Sérgio Vaz e Ferréz, hoje consagrados pela crítica literária, apresentaram seus poemas, canções e performances para um público ativo e produtivo na enunciação do discurso poético. Isso porque havia a demanda de um espaço como aquele, a necessidade de conservação de uma tradição de sujeitos ansiosos e desejosos pela tomada da palavra poética, a fim de significar o mundo de uma forma sensível que não lhes era permitida. Assim, na ordem da palavra poética que significa o mundo, o corpo é ponto de partida e referente do discurso poético. Através da voz que declama a poesia pela ordem do sensível, o corpo se torna capaz de sentir as palavras, atribuir novos sentidos não expressos pela língua normativa e se colocar subjetivamente no mundo. Esse era o objetivo e tarefa fundamentais dos espaços de oralidade poética das periferias desde as décadas de 80 e 90 . Nessa mesma época surgiam grupos de rappers como Racionais MC's, Sabotage, MV Bill, GOG, entre outros, cuja palavra cantada manifestou um novo gênero de linguagem intermidial convergindo poesia, ritmo, performance, música e discurso antissistêmico. Mais adiante, discorreremos novamente sobre esse gênero da poesia oral explorado nas periferias

\footnotetext{
11 “A palavra slam é uma onomatopeia da língua inglesa utilizada para indicar o som de uma "batida" de porta ou janela, seja esse movimento leve ou abrupto. Algo próximo do nosso "pá" em língua portuguesa. A onomatopeia foi emprestada por Marc Kelly Smith, um trabalhador da construção civil e poeta, para nomear o Uptown Poetry Slam, evento poético que surgiu em Chicago, em 1984. (...) Smith nomeou de slam os campeonatos de performances poéticas que organizava e no qual os slammers (poetas) eram avaliados com notas pelo público presente, inicialmente, em um bar de jazz em Chicago, depois nas periferias da cidade." (NEVES, 2017: p. 93).
} 
ao longo das últimas décadas, uma vez que nosso campo da pesquisa foi a comunidade de Paraisópolis, reconhecidamente ocupada por saraus e grande difusora das performances da poesia periférica e do rap.

Conforme preconiza Otero (2011: p. 44), esse fenômeno transnacional que é o rap pode ser compreendido como

\begin{abstract}
uma sobrevivência do fato épico oral na contemporaneidade, narrando justamente, na saga do homem pobre, essa rivalidade entre a cultura dominante da elite econômica e a cultura dos dominados que o RAP ilumina. É evidente que esse fenômeno cultural está intimamente ligado aos modos de produção da sociedade de massas possibilitados pela indústria cultural. No outro polo das manifestações culturais, a despeito da indústria cultural, observamos a multiplicação dos saraus poéticos nas periferias da capital paulista na década de 1990. O sarau é um agrupamento em torno da declamação de poesia, do qual o RAP também participa, como mobilização reivindicativa, maneira de desestabilizar ou subverter relações de poder e dominação estabelecidas. Assim, revela uma função social e histórica do fazer poético e oral.
\end{abstract}

Os poemas declamados nos saraus e slams são em sua maioria de autoria própria, acompanhados de uma performance que torna os significantes mais evidentes. A produção artística experienciada nesses espaços se preocupa não apenas com a harmonização dos versos por meio das rimas, aliterações, paralelismos e repetições - recursos mnemônicos da oralidade poética, mas também com a expressividade do corpo, da memória, do alcance da voz e do gozo pela liberdade. Nessas performances orais, há certa teatralidade e respeito à tradição ritualística da oralidade, possíveis tentativas de retorno forçado ou de reparação pelo avanço da tecnologia midiática que tende a tomar mais atenção dos ouvintes que a cena poética da voz humana. Para isso, é preciso, mais do que nunca, um engajamento do corpo e da memória, uma corporalidade, cujo apoio não deve ser o suporte gráfico ou eletrônico, mas sim a performance oral da voz e dos gestos. As declamações poéticas pela via da memória criam laços de transmissão entre o poeta e o ouvinte, entre a fala, a voz do outro e o corpo que ouve e sente tornando a poesia capaz de invadir tudo, todos os nossos sentidos de ordem biológica e psíquica, fenômeno que muitas vezes não é perceptível quando temos um suporte em mãos.

Nesse caso, a oralidade também é capaz de espacializar as palavras. A voz se estende a nossa memória inscrevendo-se no corpo. Ou seja, não é apenas a escrita que sabe deixar marcas no espaço, como na superfície de um texto. É claro que a partir da concretude das páginas escritas podemos ler, reler, compartilhar, no entanto, a partir da performance, 
podemos sentir intensamente a voz que vibra originalmente em sua escritura própria, interior, que ao se transformar em matéria nos dá a impressão de que já exigia desde sempre ser pronunciada.

Isso não significa que o registro de um poema oral prejudique sua forma, mas um desdobramento ocorre: "doravante tem-se um texto de referência, apto a gerar uma literatura; e, às vezes sem contato com ele, as séries continuam das versões orais que se sucedem no tempo" (Zumthor, 2010: p. 37). Além disso, há a presença de uma intertextualidade mais aflorada que um registro pode passar para outro, assim como um poema composto por escrito, mas performatizado oralmente se transforma formalmente ao ser declamado por outras vozes.

No mundo contemporâneo, "é preciso um esforço de imaginação para reconhecer entre nós a presença de uma poesia oral bem viva" (idem, p. 8), pois não é mais óbvio e evidente o papel da oralidade poética em uma realidade em que os discursos estão atravessados por dezenas de mídias, modos pré-fabricados de enunciar, por um falso estranhamento do discurso de ódio promovido pelas redes sociais, pela inautenticidade de um mundo em que a gramática do dizer já está produzida e nos moldando, pela avalanche de fake news, pela falação de palavras que não nos transformam e só nos ocupam e nos preenchem para nos fazer esquecer nossos reais desejos. Dessa forma, é tarefa nossa buscar compreender os aspectos causados pela introdução da tecnologia da escrita e pelas transformações da escrita manuscrita para a impressa, bem como a difusão das mídias, uma vez que nossa tese tem o compromisso de investigar o atual contexto da oralidade midiatizada em que as técnicas de escrita ainda não foram amplamente difundidas em alguns grupos sociais periféricos, como o analisado no corpus desta pesquisa. Há uma camada social ampla que foi brutalmente marginalizada nos processos de disseminação da escrita e, não apenas por isso, também se encontra expulsa da oralidade primária, agora vazia de conteúdo. Ao mesmo tempo, essa mesma camada social excluída e fora do debate anseia por um espaço de visibilidade de suas vozes e pela repercussão de suas manifestações artísticas. Em uma transição mal consolidada entre a oralidade e a escrita, a periferia planta espaços de resistência em seus canais e adentra a conversa com o mundo hostil a partir de um dos predicados do real: a diferença.

\section{A cultura da escrita}

Quando a cultura oral se tornou cultura escrita em diversas sociedades ocidentais e orientais, a consciência humana passou por processos de radicais transformações culturais e, 
no âmbito coletivo, passou, consequentemente, por mudanças no campo político-social. No Ocidente, a escrita alfabética foi introduzida na Grécia por volta do século VIII a. C. e "o aparecimento, entre outras coisas, do pensamento lógico-empírico e filosófico, a formalização da história e da lógica enquanto disciplinas intelectuais, e a própria democracia grega têm íntima relação com a expansão e solidificação da escrita fonética na Grécia e Jônia" (Tfouni, 2010: p. 15). Essas transformações foram tão profundas na sociedade grega, principalmente porque, ao contrário de outras civilizações de seu tempo, não havia um monopólio dos livros sagrados por parte da alta camada social. As ideias reproduzidas na vasta difusão escrita da época não eram segredos dos governantes e dos escribas, eram de domínio comum da população.

\footnotetext{
Em resumo, a escrita pode ser tomada como uma das causas principais do aparecimento das civilizações modernas e do desenvolvimento científico, tecnológico e psicossocial da sociedade nas quais foi adotada de maneira ampla. Por outro lado, não podem ser esquecidos fatores como as relações de poder e dominação que estão por trás da utilização restrita ou generalizada de um código escrito. (TFOUNI, 2010: p. 16).
}

Para nós, retomar a história da escrita é poder refletir sobre como essa nova forma de comunicação afetou o sentido e o conteúdo dos textos e é também compreender o letramento de forma mais ampla, partindo das relações entre culturas oralistas e culturas de escrita. A partir dos estudos de Havelock (1996) e Ong (1998), temos como objetivo compreender como o campo da poética se moveu e se identificou em uma nova situação no campo das artes que muito se transformou desde a Antiguidade Clássica, que é também acompanhada de uma nova filosofia do sujeito, colocando-nos outros desafios para a educação contemporânea. Sobre o nosso papel de educadores inseridos na área do letramento, podemos enxergar semelhanças tanto na figura dos rapsodos gregos, quanto na figura do narrador benjaminiano, representantes da transição histórica de duas antigas tradições que vemos se apagando na sociedade tecnologizada e sendo pulverizadas nas reformas educacionais do atual governo federal.

Assim, reconhecemos a necessidade de também retomar a pesquisa anterior do mestrado (Joaquim, 2016) no que se refere à investigação da história da escrita vinculada aos estudos de culturas oralistas. Com as descobertas de Parry e Lord, Havelock partiu para os estudos sobre a reestruturação do pensamento grego com o advento da escrita. Ao analisar a República de Platão, o autor explica que a rejeição aos poetas, à mimesis e ao estilo do pensamento oral perpetuado em Homero, seria, em suma, uma rejeição à forma e à essência 
do discurso poético oral. Segundo Havelock, Platão não criticava apenas os maus poetas, mas a experiência poética como tal, sua forma de expressão diante o público, sua performance envolvente e seu poder de atração:

\begin{abstract}
Desse modo, o poeta, diz ele [Platão], consegue colorir seus enunciados mediante o uso de palavras e frases e embelezá-las pela exploração dos recursos do verso, do ritmo e da harmonia. Estes são como cosméticos aplicados à superfície, que ocultam a pobreza do enunciado subjacente. Assim como os desenhistas empregam a ilusão ótica para nos enganar, os efeitos acústicos empregados pelo poeta confundem nossa inteligência (HAVELOCK, 1996: p. 21).
\end{abstract}

A reeducação proposta por Platão visava, portanto, superar a imitação dos poetas que atraíam o público com suas vozes rítmicas e encantadoras e implementar um método de ensino com características não poéticas, a fim de que, segundo Havelock, não houvesse identificação pessoal entre o público espectador e os poetas imitadores, mediante a empatia que a representação poética é capaz de suscitar. Platão percebeu que essa identificação, essa empatia, retirava do público a autonomia para se relacionar com o conhecimento e o objeto de saber. Para o filósofo, deveria haver uma doutrina psíquica autônoma que separasse o sujeito que pensa do objeto sobre o qual se pensa, favorecendo a desidentificação entre a plateia e a representação mítica, provocando assim o distanciamento da palavra pronunciada no fato poético do corpo que ela é capaz de tocar: a filosofia. Não por outro motivo, Platão propunha como governo ideal de sua república uma oligarquia de filósofos, que comandariam uma cidade voltada para o Bem, purificada da má influência dos poetas.

Havelock acredita que a implantação dessa nova metodologia de ensino promovida por Platão foi possibilitada também pelo progresso do uso da escrita na época, por uma "nova organização da linguagem", baseada em conceitos lógicos, em um sistema fechado e um novo suporte capaz de mudar o estatuto da linguagem. Com o instrumento do alfabeto, foi descoberto um novo meio de armazenamento capaz de estender a eficiência da memória. Já não era mais preciso o esforço da recordação de Homero, pois este foi substituído pela invenção do discurso textual de Tucídides e Platão, escancarando o destino obsoleto da oralidade. "Aqui estava, na verdade, um paradoxo do processo dialético, da mudança transformadora. A musa que cantava traduz-se num escritor: ela, que requeria pessoas para a ouvirem, convida-as agora a ler" (Havelock, 1996: p. 79).

Para a sociedade da época (e até hoje para o nosso funcionamento enquanto grupo social com traços linguísticos comuns), foi preciso, através da voz coletiva, codificar o corpo 
de linguagem para que este pudesse carregar as instruções necessárias rumo à civilização em progresso. Para isso, as instruções deviam possuir uma estabilidade e serem repetidas de geração em geração, a fim de que uma cultura civilizatória pudesse se perpetuar sem perder a coerência, adquirindo, assim, caráter histórico.

Desse modo, a língua passou a exigir de sua materialidade mais estabilidade para além das fórmulas orais bem metrificadas. Era preciso documentar as leis, os textos religiosos, a filosofia, a história e a literatura, fazendo ocultar-se a improvisação e mobilidade do discurso oral. As palavras inscritas em um texto documentado garantiram aos poucos a estabilidade da ordem e a permanência de um instrumento capaz de sustentar a tradição de uma sociedade que almejava o progresso civilizatório.

Porém, Rancière (2009: p. 34) atenta que não é a escrita, como suporte gráfico de mensagens e do conhecimento, que modificaria o estatuto da palavra, da língua, do pensamento e das mentalidades, enfim, da capacidade cognitiva. É verdade que, com o surgimento da escrita, fomos nos tornando mais presos à letra e as palavras foram se fechando no código escrito, tomando formas rígidas. Para as imagens abstratas, criaram as letras, símbolos concretos. Mas, como nos alerta Rancière, para Platão "a escrita não é simplesmente a materialidade do signo escrito sobre um suporte material, mas um estatuto específico da palavra” (idem), a escrita é um logos mudo e ao mesmo tempo vivo, está relacionada no pensamento e no não pensamento.

Além do mais, Rancière diz que essa escrita muda é a potência de significação inscrita nos corpos, tanto dos seres humanos como dos objetos da natureza, cada um carrega sua marca. Como dissemos acima, a decifração dessas marcas presentes nos corpos se dá por meio da escrita literária, do fato poético que permite possíveis identificações entre obra e público, dos textos da tradição oral capazes de encantar e mobilizar o sensível, o irracional. Assim, o autor compara os escritores com os geólogos ou arqueólogos, que recolhem os vestígios deixados pela história dos homens e de suas marcas e transcreve em signos, decifrados dos fósseis, a materialidade sensível da palavra.

Ong (1998: p. 96), ao analisar inúmeras referências à escrita em citações bíblicas e obras de autores como Horácio e Browning, capta uma associação íntima da mesma com a morte. Para muitos pensadores, suas formas rígidas e conservadoras não poderiam acompanhar a vivacidade da palavra poética. Lord, ao pesquisar os poetas balcãs, descobriu que o aprendizado da leitura e da escrita incapacitava suas habilidades de composição, memorização e improvisação dos textos por introduzir elementos controladores e regrados. 
De fato, a escrita sempre foi analisada de maneira dialética: ela é capaz de minar a primazia da memória e da narrativa oral na transmissão do conhecimento, ao mesmo tempo que possibilita sua conservação e reprodutibilidade precisa, apoiada em um aparato externo ao sujeito que funciona como extensão artificial da memória.

Devemos pensar, conquanto, que a entrada no mundo escrito, ou seja, a transição da imagem para a letra, assim como o som e o sentido da poesia, ocorre moëbianamente ${ }^{12}$. São diferentes suportes em uma mesma manifestação da linguagem humana, do funcionamento Simbólico (termo cunhado por Lacan, a partir dos estudos de Freud), da passagem da palavra muda para a palavra viva.

Para Lacan (2003), a escrita é uma decorrência do próprio funcionamento do psiquismo e, se tomarmos em seus fundamentos, não se poderia dizer com tranquilidade que ela suceda cronologicamente a fala [...]. Deixar marcas em superfícies externas ou mesmo internas ao corpo e retomá-las mais tarde como significantes que podem ser relidos é característica geral do ser humano (BELINTANE, 2013: p. 44).

Segundo Belintane, as habilidades de leitura e escrita que se desenvolvem no corpo dos sujeitos em letramento estão no jogo entre oralidade e fala cotidiana. Assim, compreender o processo de confluência entre a memória oral e aquelas que estão no escrito é uma estratégia importante para lidar com os esforços de decifração e elaboração escrita dos alunos. Para o autor,

se a escrita é uma tecnologia que expande a memória e a expressão humana, a corporalidade não deixa de ser também uma tecnologia, um recurso estético que os povos ágrafos usavam para lutar contra o esquecimento (Mnemosine e suas nove filhas $\mathrm{x}$ rio Lete). Notamos também que a corporalidade do passado deu origem à escrita de grande volume (as epopeias, os livros sagrados, as grandes narrativas, etc.). Nesse sentido, recomendamos que a função narrativa e a função poética da linguagem sejam os elementos-alavanca da escrita e da leitura de grande volume como aconteceu na história! (BELINTANE, 2017: p. 189).

\footnotetext{
12 O matemático alemão August Ferdinand Moëbius (1790-1868) criou a faixa de Moëbius, uma superfície uni(bi)lateral que representa um caminho onde se pode percorrer toda a superfície sem notarmos sua borda, sem percebermos a transição de um lado para o outro, de maneira que o que é paralelo é, ao mesmo tempo, simultâneo.
} 
Tendo como ponto de partida o par corporalidade e escrita, devemos agora refletir sobre a memória viva e sua relação com o prazer e o desejo que nos instigam a permanecer no simbólico e em busca da decifração das diferentes escritas no mundo, para em seguida refletir sobre o letramento escolar.

\section{O papel da memória diante de uma escrita}

A memória é uma dimensão essencial na teoria psicanalítica, uma vez que para Freud o aparelho psíquico nada mais é do que um aparelho da memória e da linguagem. O modelo de memória que Freud apresentou ainda no final do século XIX, cuja organização se dava a partir de signos perceptuais, inconscientes e pré-conscientes, foi melhor desenvolvido em sua pesquisa sobre a interpretação dos sonhos e em seu artigo intitulado "Uma nota sobre o bloco mágico", de 1924. Neste momento de sua construção teórica, Freud expõe a analogia que explicita o mecanismo da memória, com a qual o bloco mágico pode ser comparado à concepção e ao funcionamento do aparelho psíquico.

Segundo Freud, o bloco mágico é uma prancha de resina ou cera sobre a qual está colocada uma folha fina e transparente com duas camadas. A camada de cima é transparente, de celuloide, enquanto a camada debaixo é de papel fino e encerado. Para registrar no bloco mágico é preciso um estilete ou outro instrumento pontiagudo para pressionar a superfície marcando traços de escrita. Para eliminar as marcas produzidas pelo estilete e fazer desaparecer os traços de escrita, é necessário destacar a primeira camada da folha colocada sob a prancha de cera, assim o bloco mágico estará limpo para novas escritas. O que ocorre com a prancha de cera, no entanto, é que apesar da escrita desaparecer com a retirada da primeira camada de folha, suas marcas permanecem perfuradas no bloco. Com determinada incisão de luz, as marcas podem se tornar legíveis.

Assim, Freud relaciona a prancha de cera ao inconsciente, capaz de preservar permanentemente os traços mnêmicos ali inscritos, fundamentando assim a memória, enquanto a primeira camada de folha que pôde ser destacada serve de referência para a capacidade descontínua do funcionamento de investimento do inconsciente, ou seja, seria uma alusão ao sistema percepção-consciência e seu escudo protetor (sendo este último comparado à segunda folha transparente). Assim, notamos a presença de duas camadas: "um escudo protetor externo contra estímulos, que procura diminuir a intensidade das excitações que estão ingressando; e uma superfície por trás desse escudo, que recebe os estímulos" (Carreira, 2010: 
p. 20). A folha de celuloide funciona de modo semelhante ao que Freud chamou de escudo protetor do aparelho psíquico, uma vez que ela impede que o estilete perfure o papel fino transparente que está na segunda camada, permitindo apenas que nela fique temporariamente os registros marcados até serem descartados, dando lugar, assim, a outros registros.

$\mathrm{Na}$ base de todo esse sistema está a prancha, referência ao sistema que possui memória e transforma as excitações momentâneas em traços permanentes, ou seja, "traços mnêmicos responsáveis por registrar e manter as associações, pois as percepções estão mutuamente ligadas na memória, podendo tornar-se conscientes, mas que produzem seus efeitos quando em estado inconsciente" (Magalhães, 2004: p. 112).

Os traços mnêmicos do aparelho psíquico que produzem a memória podem ser compreendidos, assim como nos sonhos, como um texto a ser decifrado, uma articulação entre a escrita e a memória, e não apenas no sentido da escrita alfabética, mas principalmente no sentido da escrita psíquica que se inscreve em forma de reminiscências. Mas a escrita do inconsciente, segundo Freud, "caracteriza-se por não possuir qualidades, não reconhecer o não e, por isso, não comportar a contradição, apresentando uma lógica própria e atemporal. Tal lógica é regulada pelo princípio do prazer, que visa restabelecer pelo caminho mais curto a identidade da percepção, ou seja, ler o atual a partir do atemporal, configurando uma compulsão à repetição" (Carreira, 2010: p. 21). Tal asserção nos remete à força da palavra, sobre a qual tratamos no item anterior, ao dizer que na memória viva identificamos a poesia, a arte da palavra que marca a cultura dos seres humanos e estabelece discursos comuns a determinados grupos. Dessa memória viva oriunda da palavra poética é que surge o trabalho do ser em sua eterna repetição (Heidegger, 2010). Quando, no subcapítulo anterior referente à oralidade poética, associamos a teoria de Rousseau sobre o aspecto passional do entendimento com a teoria de Havelock sobre a repetição ligada ao sentimento de prazer, fator de importância primária na compreensão do encantamento da poesia oral, discorremos a respeito do ritmo ser o fundamento de todos os prazeres do ser humano, isso porque ritmo é repetição.

No entanto, a história da civilização nos mostra que o ritmo e os recursos mnemônicos não nos foram suficientes no desenvolvimento da linguagem. Desde antes da Antiguidade, o ser humano tinha como necessidade deixar gravado aquilo que julgava importante para o conhecimento de sua história e para o gozo estético das artes. Reter apenas na memória não parecia o bastante, pois a mera repetição de um conteúdo idêntico não nos levaria muito longe, logo, era preciso materializar a palavra. Por meio de sua tecnologização, foi possível à humanidade decolar rumo a outras dimensões do saber e do prazer. Desde os hieróglifos e os 
diagramas, em argilas ou em placas de cera, registros de pergaminhos ou papel, uma memória artificial vem tomando o lugar da memória natural, viva e em movimento. Com o avanço dos recursos de gravação no passar dos séculos, fomos transformando nosso modo de lidar com nossas lembranças e nossos esquecimentos, confundindo o que de fato conseguimos reter na memória com aquilo que temos impresso por meio da memória estendida (cartas, fotografias, vídeos, CDs). Mesmo assim, essas imagens, materiais ou não, podem se configurar como uma escrita capaz de ser acessada de maneira consciente ou, quando composta por restos diurnos, podem reproduzir a forma dos objetos do mundo em nosso inconsciente, através dos sonhos, dos atos falhos, chistes ou de livres associações. De uma maneira ou outra, a ligação entre memória e escrita é profunda, principalmente por esta ser o auxílio mais antigo daquela. Além disso, valemo-nos de uma concepção mais ampla de escrita, isto é, daquela preconizada por Lacan: uma escrita que já estava em nós esperando ser fonetizada, uma escrita que representa tudo aquilo que pode ser retido da perda e do esquecimento, submetido a uma releitura. Isso porque a escrita é efeito da metáfora e da metonímia, ou seja, da capacidade humana de tomar uma coisa pela outra e/ ou a parte pelo todo.

Na história da cultura ocidental, desde a época de Platão, essa ligação entre memória e escrita já se notava, inclusive devido ao uso em desenvolvimento das pranchas de cera para anotações e desenhos. Segundo Draaisma (2005), em seu livro "Metáforas da memória: uma história das ideias sobre a mente", na época de Platão, as placas de cera já estavam em uso há vários séculos e sua particularidade era que, diferentemente das placas de barro que se endureciam, as placas de cera podiam ser apagadas e reutilizadas. No diálogo Teeteto, escrito por Platão, Sócrates afirma que a placa de cera era uma dádiva da mãe das musas, a Mnemosine, e que ela poderia ser comparada com aquilo que carregamos de recursos da memória em nossa alma, pois "sempre que queremos recordar algo visto ou ouvido, ou mesmo imaginado, sujeitamos o bloco à percepção ou à ideia e gravamos nele a impressão (...) Recordamos e conhecemos qualquer coisa impressa, enquanto persiste a imagem no bloco; mas esquecemos e desconhecemos tudo que é apagado ou não pode ser impresso" (Platão, 1987: p. 99, apud Draaisma, 2005, p. 50). Em seus diálogos, Socrátes já utilizava a placa de cera como metáfora da memória e do esquecimento, transformando-a em figura retórica para representar a memória como uma superfície para a escrita. Para o filósofo, alguém com boa memória tinha a cera mental profunda, abundante e macia, já alguém com memória fraca estava trabalhando com uma cera mole demais, sem "impressionabilidade". Era preciso que a cera tivesse a consistência certa, pois uma cera muito dura também não era 
ideal, já que as impressões não poderiam alcançar a profundidade suficiente para deixar suas marcas na memória.

Com Aristóteles, a metáfora do bloco de cera se aproxima (ou antecipa) ainda mais da teoria psicanalítica de Freud sobre a existência do inconsciente, principalmente quando o filósofo grego discorre sobre o substrato físico dos vestígios da memória. Ele afirma que a experiência absorvida pelos sentidos deixa uma imagem na memória, isso porque, a partir da visão e da percepção das coisas no mundo, algo fica impresso no corpo, um vestígio material que costuma permanecer submerso, assim como as marcas no bloco de cera. Logo, a imagem deixa de ser simples captação instantânea visual de objetos dispostos a nossa frente e se torna imediatamente signo de uma interpretação eminentemente subjetiva, ou seja, imaginária. Segundo Freud, a imagem se encontra na raiz do verbal, logo, uma representação do pensamento só se torna consciente por meio da representação das palavras, que, quando investidas pelo desejo, desencadeiam-se de acordo com as leis da linguagem e se tornam imagens visíveis, matéria sensorial e corporal.

Dessa forma, o sujeito do inconsciente é constituído, de um lado, pelas pulsões e desejos que se expressam em objetos fantasiados e representações manifestadas no Imaginário, e de outro, pela linguagem originada no Simbólico. São várias as imagens criadas por nossa imaginação ativa que permitem a manifestação dos desejos, da fantasia e do passo inicial da criação poética, caracterizado pelo devaneio, no qual depositaremos maior interesse ao analisar o corpus de nossa pesquisa no quarto capítulo da tese. Essa demonstração de imagens que se entrelaçam em nosso Imaginário é apresentada na obra de Freud, Interpretação dos sonhos, em que ele se utiliza dos conceitos de condensação e deslocamento para realizar a leitura da linguagem inconsciente que se expressa enquanto dormimos. Uma vez que a condensação, como a cadeia associativa do eixo metafórico, é a síntese das ideias e imagens do sonho, que se relacionam e são análogas entre si e no processo de deslocamento, substituímos uma ideia por fragmentos constituintes do sonho, que evidencia ou foca um detalhe de algo representado, como ocorre na cadeia combinatorial ou metonímica, em que as unidades linguísticas servem de contexto para unidades mais simples ou encontra seu próprio contexto em unidades mais complexas. A seguir, relacionaremos esses conceitos ao fato da criação poética, aproveitando também a teoria do princípio do prazer de Freud e seu papel desempenhado na produção artística e literária, ao compreender a presença de uma compulsão à repetição de situações que sobrepuja o princípio de prazer, característica intrínseca ao movimento de toda pulsão e de todo ato criativo. Veremos, portanto, como a experiência 
artística e literária e suas inscrições num corpo que escreve, que exterioriza as pulsões de forma intensa, estilizada e singular, são capazes de constituir novos registros da simbolização e de instaurar novas realidades.

\section{As marcas inscritas no corpo que frui}

A partir da teoria das pulsões de Freud, podemos defini-las como estímulos que se originam no interior do corpo e possuem como meta sua satisfação. Segundo a Psicanálise, as pulsões não são possíveis de serem eliminadas (e isso nem é desejável), em contrapartida, é possível diminuir a intensidade de suas exigências. A busca pelo equilíbrio entre a exigência de satisfação das pulsões e a necessidade de compromisso com a realidade e a civilização estão na base da história dos indivíduos e de suas relações intersubjetivas com a linguagem e o Outro. Em 1905, em Três ensaios sobre a teoria sexual, Freud utiliza o conceito de pulsão como o conceito fundamental [Grundbegriff] da Psicanálise para afastar o conceito da sexualidade humana do campo da biologia e inseri-lo nessa nova disciplina que surgia, tendo em vista as pulsões como parte do aparelho da psique e não mais como mero resultado de mecanismos do corpo.

Dessa forma, a origem dos conceitos princípio de prazer e princípio de realidade procurou elucidar o funcionamento do aparelho psíquico regido por dois processos dominantes. O princípio de prazer é de satisfação imediata, em que há uma ausência de repressão que deve ser adaptada à satisfação adiada e à restrição do prazer para que o homem possa se civilizar. Já o princípio de realidade implica no controle do instintivo para a compatibilidade às normas e relações estabelecidas na sociedade. Em outras palavras, o princípio de realidade controla a manifestação livre dos prazeres desde os primórdios da civilização e desde os primeiros anos da vida humana, constituindo-se na condição básica para a existência da civilização.

Assim, no aparelho psíquico, decorrem dois processos: o processo primário, que é fruto do inconsciente e busca proporcionar prazer e evitar o desprazer, ou seja, a dor, a frustração ou qualquer sentimento negativo provocado pelo recalque; e o processo secundário, que regula o processo primário e a busca pela satisfação, considerando as condições impostas pelo mundo externo. Tal regulação entre prazer e desprazer é citado na Interpretação dos sonhos: "algumas reflexões importantes decorrem disso, se considerarmos as relações existentes entre a inibição de descarga efetuada pelo segundo sistema [consciente] e a 
regulação efetuada pelo princípio do desprazer" (Freud: 1987, p. 638). Os sentimentos de prazer e desprazer e sua autorregulação, para esse momento da obra de Freud, movimentamse e realizam transposições de energia no interior do aparelho psíquico.

No entanto, em 1915, Freud enxerga a falta de exatidão nesta suposição, pois analisa que as imposições do princípio de realidade produzem transformações no ego no momento em que recalcam a realidade dos desejos inconscientes. Na tentativa de compreender a significação ética desses desejos recalcados, Freud percebe a existência de um ego dominado pelo prazer e um ego dominado pela realidade: "tal como o ego-prazer nada pode fazer a não ser querer, trabalhar para produzir prazer e evitar o desprazer, assim o ego-realidade nada necessita fazer a não ser lutar pelo que é útil e resguardar-se contra danos." (Freud, 1996: p. 241). Mesmo que o sujeito seja capaz de recalcar as necessidades do princípio de prazer, elas não são suprimidas ou depostas, uma vez que continuam trabalhando na instância inconsciente, a qual funciona de acordo com as leis dos processos primários e apresenta uma outra realidade, isto é, as fantasias.

De um ponto de vista, temos implicado nos fenômenos psíquicos a realidade do pensamento em fantasias e desejos da imaginação nos processos inconscientes; e de outro, a realidade material aplicada aos padrões das estruturas psíquicas recalcadas que, por sua vez, não menosprezam as fantasias, mas tendem a controlá-las. De acordo com Freud, "se olharmos para os desejos inconscientes reduzidos a sua mais fundamental e verdadeira forma, teremos de concluir, fora de dúvida, que a realidade psíquica é uma forma especial de existência que não deve ser confundida com a realidade material” (1987: p. 658).

A compreensão do dinamismo do aparelho psíquico leva Freud a concluir que os princípios de prazer e de realidade estão baseados no impulso sexual e no impulso de autoconservação. Ele irá, portanto, conceber o conceito de impulso sexual para pensar o surgimento do pensamento, da linguagem, da capacidade de figurar nossas fantasias e de perceber as formas dos objetos. Em seu artigo Impulso sexual: impulso lúdico e impulso estético, Corrêa (2016: p. 94) apresenta a característica de autoestimulação do impulso sexual desenvolvida por Freud para compreender como as relações da sexualidade com o desenvolvimento do eu capacitam os sujeitos para uma disposição estética, relacionando o impulso sexual ao impulso lúdico, conceito anteriormente formulado por Schiller ${ }^{13}$,

\footnotetext{
${ }^{13}$ Retomaremos este conceito no terceiro capítulo da tese, ao analisar algumas passagens da obra "A educação estética do homem", de Schiller.
} 
apontando para uma aproximação dos conceitos de Freud sobre sexualidade, ludicidade e arte às concepções estéticas que o filósofo alemão traçou um século antes:

\begin{abstract}
A aproximação entre o papel exercido pela autoestimulação no desenvolvimento da sexualidade e o papel exercido pelas imagens de movimento no desenvolvimento do eu, no Projeto de uma psicologia, é esclarecida pela concepção de gestos mágicos, apresentado por Ferenczi, um dos principais interlocutores de Freud (...). Os gestos mágicos são as ações intermediárias entre a sexualidade infantil alucinatória e os processos secundários (o pensar, possibilitado pela linguagem, que leva em conta o princípio da realidade). Ferenczi ainda nos possibilita relacionar o impulso sexual com o impulso lúdico. Voltando a Freud e analisando o que ele concebeu sobre a magia e a arte, podemos compreender, então, o impulso sexual como impulso que as possibilita, podemos considerar o impulso sexual como o impulso que instaura o campo do estético, capaz de figurar a fantasia e a diversidade do mundo campo do estético como o concebido por Schiller em A educação estética do homem (Corrêa, 2016: p. 94, grifo nosso).
\end{abstract}

Não nos interessa aprofundar aqui os conceitos de gesto mágico e a tentativa de Ferenczi (1990) em utilizar o surgimento de uma experiência psicanalítica para compreender o desenvolvimento do eu. A partir desta citação, cabe a nós perceber a relação entre o impulso sexual e o impulso lúdico como formas de aproximação do eu com a arte. Assim, resumiremos o diálogo que Ferenczi estabeleceu com a teoria de Freud ao explicitar apenas os distintos períodos do desenvolvimento do eu, a partir do segundo período denominado onipotência alucinatória mágica, quando a criança percebe o prazer, e do terceiro período, o da onipotência com a ajuda de gestos mágicos, quando se manifestam traços da sexualidade infantil, como o sugar, proporcionando satisfação à criança. Esse gesto servirá de representação do mundo e se torna mágico ao sujeito, por ter significado de uma ação que realiza o desejo da criança.

Neste momento dos gestos mágicos, os impulsos sexuais se deslocam no corpo da criança e se expandem para outras zonas erógenas, diversificando as vivências do prazer. Do sugar, a criança passa a ter prazer por manipular, emitir sons, ver, lembrar, tocar-se, e, segundo Freud e Ferenczi, todos esses gestos, caracterizados também pelos impulsos sexuais, são realizados de maneira lúdica e repetitiva. Por isso, interessou-nos aqui compreender o que Schiller já havia elaborado em sua teoria sobre a estética no que diz respeito aos impulsos do ser humano. Sua concepção dos impulsos foi desenvolvida a partir dos conceitos do gosto e do belo, em que há a explicação de uma força sensível no meio da liberdade dos fenômenos. Segundo Schiller, cabe ao homem exercer uma dupla tarefa para realização de seus objetivos: dar realidade ao que nos é necessário e submeter a realidade que está fora de nós à lei das 
necessidades. Para isso, é preciso compreender que nessa tarefa há duas forças opostas as quais Schiller nomeou de impulso sensível, que parte da existência física do homem, ou seja, a origem do impulso sensível coincide com a origem do homem; e de impulso formal, que parte da existência absoluta do homem, ou seja, de sua natureza racional, que surge com a lei e os conceitos de justiça e verdade. Para Schiller, a existência do homem somente é possível a partir da ação desses dois impulsos, porém, apenas se o impulso sensível, que atua evidenciando as necessidades, puder ceder seu lugar para o uso da razão e para o exercício da necessidade lógica ou moral: "o homem não pode passar imediatamente do sentir para o pensar; ele tem que retroceder um passo, pois somente quando uma determinação é suprimida pode entrar a outra que lhe é oposta" (Schiller, 2017: p. 106).

Assim, o filósofo caracteriza o impulso sensível pela manifestação dos sentidos, pois é dominado pela sensibilidade e está ligado ao tempo e aos instintos. É um estar fora de si: "estar fora de seu eu, embora esse modo de dizer só ocorra quando a sensação se torna afeto e esse estado seja mais perceptível por sua maior duração" (2017, p. 59). Este impulso, Schiller chama de vida e diz que está empenhado em transformar o homem em matéria.

Para Schiller, os sentidos, a sensibilidade e as leis de determinações naturais também estão ligadas a necessidades materiais e realidades concretas que, segundo ele, são modificações que devem preencher o tempo, já que o estado de tempo é a sensação da qual se manifesta a existência física, ou seja, o tempo exige um conteúdo real. Ter domínio deste impulso é a finalidade da existência humana, pois é nele que constituímos nossa subjetividade e agimos diante das leis naturais da vida. Já o impulso formal é caracterizado como a forma que garante a existência do indivíduo apesar do estado e a permanência da essência e apesar das modificações impostas pelo impulso sensível. O impulso formal outorga leis e tem a função de reger a moral e a ética do homem, facilitando sua vida em sociedade, uma vez que é capaz de fornecer as regras para todos os juízos no que se refere a conhecimentos, e para todas as vontades no que se refere a ações. Para Schiller, essa busca pela compreensão da forma e da razão dos objetos e das sensações propiciada pelo impulso formal tem como pressuposto a libertação do homem e a harmonização das diferenças, porém ele diz que isso só é possível ao reestabelecer a unidade da qual ambos impulsos, da vida e da forma, carecem na natureza humana. Para essa unidade, é necessário compreender a existência de um terceiro impulso fundamental: o impulso lúdico [Spieltrieb].

Segundo Schiller, o homem só é capaz de se elevar moralmente, racionalmente, se for capaz de elevar sua sensibilidade. Para tanto, o homem deve conseguir encontrar algo que 
possa agregar as forças moral e sensível e estabelecer um estágio transicional que permita que a razão e a sensibilidade atuem juntas em favorecimento da liberdade e emancipação do homem. Assim, Schiller elabora o conceito de jogo, claramente influenciado pela ideia de Kant a partir do juízo estético, do jogo entre imaginação e entendimento, que "suportará o edifício inteiro da arte estética e da bem mais dificultosa arte de viver" (Schiller, 2017: p. 16).

De um lado, o impulso sensível exige modificação e controle, do outro lado, o impulso formal necessita de permanência e identificação, assim,

\begin{abstract}
os limites de cada um dos dois impulsos é tarefa da cultura, que deve igual justiça aos dois e não busca afirmar apenas o impulso racional contra o sensível, mas também este contra aquele. Sua incumbência, portanto, é dupla: em primeiro lugar, resguardar a sensibilidade das intervenções da liberdade; em segundo lugar, defender a personalidade contra o poder da sensibilidade. A primeira ela realiza pelo cultivo da faculdade sensível; a outra, pelo cultivo da faculdade racional (SCHILLER, 2017: p. 64).
\end{abstract}

Ao impulso lúdico cabe, portanto, a tarefa de harmonizar os impulsos sensível e formal, conciliando o dinamismo das paixões aos constrangimentos da razão. Segundo Schiller, o impulso lúdico é necessário para estabelecer a plenitude e liberdade do homem, uma vez que as forças opostas de cada impulso disputam interesses distintos. "O impulso sensível quer que haja modificação, que o tempo tenha conteúdo; o impulso formal quer que o tempo seja suprimido, que não haja modificação. O impulso em que os dois atuam juntos (...) seria direcionado, portanto, a suprimir o tempo no tempo, a ligar o devir ao ser absoluto, a modificação à identidade" (p. 70), ou seja, o impulso lúdico deve se empenhar no estabelecimento de um elo harmonioso, tornando contingentes tanto nossa índole formal quanto a nossa índole material. Assim, "o homem é como que recriado em todas as suas potencialidades e recupera sua liberdade tanto em face das determinações do sentido quanto em face das determinações da razão" (Schiller, 2017: p. 17), de modo que o homem pode de fato experimentar um estado de liberdade.

Ao ter condições de harmonizar as duas qualidades, da sensibilidade e da razão, sem que uma se sobreponha ou se submeta a outra, o homem se torna capaz de jogar com a imaginação e a fantasia não com o objetivo de desfrutar da liberdade moral stricto sensu, mas de uma liberdade em meio ao mundo sensível. O jogo ocorre, portanto, entre a imaginação e o entendimento, uma vez que o impulso lúdico permite ao homem não ser dominado nem pela sensibilidade, nem pela razão e sim ter condições de transitar livremente entre essas suas esferas subjetivas. 
Assim, a proximidade entre o impulso erótico, ou sexual, formulado por Freud e o impulso lúdico formulado por Schiller ocorre no sentido de que ambos simulam uma tensão entre o prazer e o desprazer, entre o desfrutar da conquista do gesto e, ao mesmo tempo, já almejar a próxima etapa de superação e nova descoberta, uma mistura de satisfação e insatisfação. Nesse jogo de repetição e descoberta de novos prazeres, há uma excitação pela superação do prazer recém-conhecido, pois a criança rapidamente é tomada pelo desejo de eliminação do prazer descoberto, devido a sua autoestimulação e repetição incessante, até ser atingida por uma nova etapa do desenvolvimento. É devido a esse movimento de busca por novos prazeres que a criança, inconscientemente, torna-se capaz de figurar as diversidades do mundo e estabelecer novas metas para seu desenvolvimento.

Como vimos, o impulso sexual apresenta certa característica de provocar excitação e estímulo para o conhecimento de novos prazeres e, ao mesmo tempo, procura eliminá-los para que esse movimento possa acontecer mais vezes. Se o mesmo prazer fosse capaz de gerar sempre prazer, a criança não precisaria buscar novos prazeres, por isso é tarefa do impulso sexual subtraí-los para que o desejo seja passível de renovação. Essa tendência pode ser correspondida ao impulso lúdico, uma vez que se assemelha ao jogo de repetição da angústia de querer alcançar determinado prazer até o momento em que o objetivo dos movimentos, inconscientes ou conscientes, seja atingido. O impulso sexual e lúdico "repete o desprazer, em uma dosagem conhecida, para, em certa medida, superá-lo. Nisto está a fruição, (...) ele [o impulso] próprio suscita um desprazer com o intuito de desfrutar de sua interrupção e o desprazer só é permitido em certa medida" (Corrêa, 2016: p. 101).

Dessa forma, retomamos o que Freud descreve sobre o ato de brincar e jogar da criança, que, assim como a ideia de magia dos povos primitivos, tem o reestabelecimento da vivência de satisfação como capaz de deslocar o acento psíquico do motivo de se buscar o prazer para os meios com os quais pretende alcançá-lo, ou seja, para a própria ação de prazer. Assim, Freud (2010) acentua que nos jogos infantis, as crianças substituem a técnica puramente sensorial de satisfação para colocar no lugar do desejo uma satisfação motora, que se evidencia por meio da superestimação de seus atos psíquicos. Quando as ações mágicas, alucinatórias, já não as satisfazem mais, a criança busca ter prazer em suas brincadeiras por meio de suas próprias ações, de movimentos e gestos determinados. É como se, aos poucos, o objeto de desejo alucinado, por exemplo, o seio da mãe, fosse perdendo importância e cedendo lugar para a ação (os meios) que se liga a ele, por exemplo, o movimento da boca indo sugar o seio da mãe. Em outras palavras, mais importante que a ideia sensorial do objeto 
é a realização da ação que imita o objeto.

Nesse sentido, Freud aproxima a arte e a criação literária como o campo da cultura que ainda se preserva por meio da alucinação motora, ou seja, pelas ações que imitam o objeto alucinado: "unicamente na arte ainda sucede que um homem consumido por desejos faça algo semelhante à satisfação, e que esse jogo provoque - graças à ilusão artística - efeitos de afeto como se fosse algo real" (2010: p. 142). As obras de arte e o valor que atribuímos a elas, por meio do efeito estético que produzem em nós, comprovam que somos capazes de ter uma compreensão artística e mimética do mundo. A arte, segundo Freud, esteve originalmente a serviço de supor várias intenções mágicas e a magia implica a cópia de ações do que é desejado.

O psicanalista também aproxima a arte e a criação literária com o brincar infantil a partir da perspectiva de que tanto o artista como a criança criam um mundo de fantasia repleto de emoções e prazeres, como recursos do funcionamento psíquico, sendo ambos, tanto a criança como o adulto, capazes de distinguir nitidamente a fantasia da realidade. A maneira como a criança brinca a partir de um mundo irreal e fantasioso se aproxima, portanto, do fazer artístico e literário do universo adulto. A imaginação desenrolada na mente de um artista pode ser considerada uma herança da irrealidade do mundo infantil, proporcionando fantasias e prazeres que tendem a romper com a seriedade e a imposição da realidade no mundo adulto. Esse movimento de buscar o prazer no fazer artístico é interpretado por Freud como um devaneio, uma forma de continuar fantasiando mesmo depois da renúncia (ou tentativa de renúncia) à brincadeira para enfrentar a "vida séria". Na realidade, nunca renunciamos nada; apenas trocamos uma coisa por outra. A cada fantasia da criança e do adulto há a realização de um desejo insatisfeito na vida real.

Assim, Freud considera a arte como passagem do princípio de prazer para o de realidade, quando se figura a fantasia em um tipo de realidade:

a arte consegue por um caminho peculiar uma reconciliação entre os dois princípios [de prazer e de realidade]. O artista é originalmente um homem que se afasta da realidade, pois ele não pode aceitar a renúncia à satisfação dos impulsos que ela a princípio exige, e consente na vida de fantasia seus desejos eróticos e ambiciosos. Ele encontra, porém, o caminho de volta deste mundo de fantasia para a realidade, na medida em que, devido a dons especiais, ele figura suas fantasias em um novo tipo de realidade, que são valorizadas pelos homens como reflexos preciosos do real (FREUD, 2010: p. 117).

A fantasia, imprescindível para a criação artística e para a brincadeira infantil, surge, 
segundo Freud, por meio dos mesmos deslocamentos do impulso sexual e lúdico: a alucinação de seu movimento se desloca para o restabelecimento de uma nova ação, capaz de representar o mundo e de transformar a realidade percebida na realidade desejada, ou seja, é como se antes, aquilo que era apenas alucinado, agora se torna possível de ser encenado, representado com a arte e, por tanto, apreendido esteticamente. Dessa forma, a capacidade de fantasiar não deixa de fazer parte dos impulsos sexual e lúdico, condicionando um espaço psíquico para a sensibilização e para as formas de fruição estética. A criança se torna capaz de brincar e de fantasiar representando as diferentes vivências de prazer sobre o mundo, estabelecendo uma ação sobre a realidade, assim como o artista, ao produzir o objeto artístico, é capaz de compor desejos e fantasias de forma figurativa. Tal compreensão da disposição estética do homem para além da satisfação da necessidade está tanto na psicanálise de Freud como na filosofia de Schiller, cujas teorias afirmam que a imaginação e a fantasia constituem um jogo capaz de enobrecer o ser humano com aquilo que é belo e propiciar o gozo do prazer e da fruição das obras de arte. No entanto, se para Freud a civilização requer não só a repressão dos impulsos, mas também sua capacidade de sublimação e criação, ou seja, sua característica lúdica e estética, para Schiller, a ideia de civilização tem a arte como papel formador e educador, servindo a uma finalidade que a transcende e a eleva como condição para a libertação e emancipação do homem reconciliado com o mundo e seus sentimentos.

Mesmo com as diferentes concepções de civilização acima apresentadas, sabemos que o marco do pensamento estético em Freud decorre de múltiplas referências filosóficas, no entanto, sua fonte está fundamentalmente no idealismo transcendental de Kant, Schiller e do romantismo alemão. O psicanalista estudou o juízo estético kantiano como mediador do conhecer e do desejar que tornou possível a compreensão do livre jogo das faculdades psíquicas, da associação da arte com a fantasia e a imaginação e suas formas de manifestação dos impulsos sexuais. A vertente subjetiva da estética se encontra presente na base da psicanálise e de todo o pensamento da modernidade. Freud recorreu à ideia de Kant sobre as representações estéticas como aspectos sobrenaturais, transcendentais e divinos, sendo eles dificilmente encontrados na experiência do real. Ou seja, uma representação estética implica uma multiplicidade de facetas ou imagens interrelacionadas que a mente não pode conhecer em sua totalidade, da mesma maneira que se escapa o conhecimento absoluto do divino ou do transcendental. Para Kant, a profusão de imagens interrelacionadas seria o modo como nossa mente é capaz de projetar ideias para além do sensível, no entanto, para Freud, a profusão de imagens constitui o meio pelo qual as ideias acessíveis são organizadas de tal maneira que 
certos pensamentos devem ser recalcados e impossibilitados de penetrar na consciência. Esses pensamentos são indicativos de que há algo dentro de nós que não pode ser totalmente conhecido. Segundo Kant, a realidade aspirada por nosso conhecimento se refere a algo externo, já na teoria de Freud, tal realidade é derivada do princípio de prazer, das nossas necessidades e desejos mais emergenciais.

A aproximação de Freud com o campo da estética ocorre justamente na descrição das atividades artísticas frente aos impulsos sexuais como forma de manifestação dos processos primários. Em Interpretação dos sonhos, quando Freud compara os processos oníricos com quadros e pinturas, ele afirma que a arte constitui uma via de expressão do inconsciente reprimido. Ao interpretar os sonhos e as narrativas das quais eles são munidos, o psicanalista procurou fugir das analogias e alegorias mais óbvias para pensar suas imagens como um código escrito, passível de ser decifrado. Para ele, os sonhos são formulações do que nosso inconsciente produz relacionado a desejos reprimidos, a impulsos de ordem sexual ou moral, castrados em nossa sociedade. O artista, mediante suas obras, conseguiria, portanto, representar conteúdos reprimidos de seu psiquismo e, dessa forma, os fazer retornar a sua consciência. As formações substitutivas criadas pela repressão são consideradas atividades psíquicas dedicadas à satisfação dos desejos reprimidos e, a arte, assim como o mito ou a poesia, pode ser considerada como parte dessas formas substitutivas. A partir desse ponto de vista, a psicanálise lançou mão da palavra poética para abordar aquilo que não conseguimos nomear ou sobre o qual não conseguimos falar, contudo, tanto a poesia como a psicanálise estão em busca de vestígios, de vazios e objetos perdidos, de contornos ao indizível e inacessível.

Diante do ato poético e da análise subjetiva de nossas ações, resta-nos o desafio das leituras impossíveis. Isso porque, ainda que em diferentes escrituras, podemos aproximar a escrita dos sonhos à escrita poética e artística, uma vez que ambas carregam um substrato inconsciente, enraízam-se no inconsciente e se manifestam como desejo pulsional. Tanto na leitura de poesia, por exemplo, quanto na leitura dos sonhos, os significantes emanam no sujeito uma carga psíquica de tipo complexa. Decifrar a linguagem artística e a linguagem dos sonhos constitui um dos caminhos para a interpretação do nosso mundo interior, dos nossos desejos, anseios e frustrações. Nesse sentido, veremos mais adiante como a poesia, nosso objeto de pesquisa vinculado ao letramento contínuo de jovens do Ensino Médio de Paraisópolis, apresenta-nos a capacidade de articular o que há de mais obscuro em nós com a nossa realidade circundante. 


\section{Os traços escritos da palavra poética}

Em “Recordar, repetir e elaborar", de 1914, Freud afirma que aquilo que não pode ser recordado é repetido em um movimento antagônico ao princípio de prazer. Aquilo que já conhecemos como objetos de prazer é revisitado, reproduzido e refeito como forma de evitar situações inusitadas que podem nos causar dor, sofrimento ou traumas e como forma de seguir buscando a satisfação, pela via imaginária, supondo alcançar o gozo que vislumbra plenitude. Assim, lutamos por manifestar as mesmas ações (por meio da repetição), impedindo a evidência e rememoração do material reprimido ou daquilo que julgamos já ter esquecido, como se a repetição pudesse ser também um escudo protetor, a folha de celuloide da placa de cera. E, da mesma forma que a poesia se mantém nas rimas e cadência próprias para manter o ritmo (a repetição), nós seguimos refazendo, em ato, a busca do objeto perdido da primeira experiência de satisfação. Para Lacan, a repetição nesse caso consiste em não ser de todo uma repetição, pois ela só existe e persiste por conta do fracasso de reencontrar e fazer surgir a "coisa" (das Ding) e pela impossibilidade de alcançar a origem do desejo. O movimento da repetição só pode tornar a ocorrer não apenas pelo fato de ele não ser capaz de atingir seu objetivo, mas também pela existência de uma diferença entre o que ocorreu no passado com o que ocorre no presente, pois sem ela não é possível destacar o caráter repetitivo de um determinado elemento.

Nesse texto de 1914, Freud expõe os dois modos de tratamento experimentados em sua prática por meio das recordações e associações livres, respectivamente, a hipnose e a clínica propriamente analíticas, e explica que, com a descoberta do fenômeno da resistência da repressão, o método da hipnose não mais correspondia aos objetivos que pretendia alcançar com a psicanálise. Para ele, o movimento da repetição se contrapõe ao da recordação, pois o analisando apresenta um bloqueio, uma proteção, uma resistência que o impede de recordar o que recalcou, expressando-o não por meio da lembrança de um fato esquecido através da técnica de hipnose, mas sim por meio de uma ação repetida:

\footnotetext{
Aprendemos que o paciente repete ao invés de recordar e repete sob as condições de resistência. Podemos agora perguntar o que é que ele de fato repete ou atua (acts $o u t$ ). A resposta é que repete tudo o que já avançou a partir das fontes do recalcado para sua personalidade manifesta — suas inibições, suas atitudes inúteis e seus traços patológicos de caráter. (FREUD, 1996: p.167)
} 
Dessa forma, Freud passa a se debruçar sobre o trabalho analítico da clínica, buscando captar por meio das livres associações do analisando traços de repetição em seu posicionamento subjetivo. Alguns anos depois, após observar as brincadeiras de uma criança, Freud se surpreende com a compulsão à repetição e discorre em Além do princípio do prazer, de 1920, sobre a quantidade de excitação presente no aparelho psíquico na relação do prazer e do desprazer, concluindo que, nas sessões analíticas, é possível compreender as marcas daquilo que foi recalcado ou esquecido na infância ou em situações traumáticas. Complementando a teoria freudiana, Lacan caracteriza a diferença essencial para o fenômeno da repetição como um aspecto de temporalidade retroativa, pois algo se repete no presente em direção a um passado.

O que Freud nomeou de compulsão à repetição (Wiederholungszwang) foi apresentado por Lacan como "a insistência da cadeia de significantes". A escrita presente no inconsciente não é fonética, ela se configura como uma escrita composta por imagens, mas, para decifrá-la é preciso transpor as imagens para a faceta sonora das palavras, ou seja, para aquilo que Saussure chamou de significante. Assim, Lacan se apoia na linguística de Saussure para explicar que o inconsciente é estruturado como a linguagem e não pela linguagem. Não é a linguagem que encontramos no inconsciente, mas sua estrutura.

Primeiramente, Lacan deixa claro que, para a psicanálise, entre as ordens do significante e do significado há uma barra de resistência à significação, ou seja, a linguagem não responde à necessidade de representar o significado, as palavras faltam ao sujeito que tenta dizer e, no entanto, depara-se com o ponto limite, o vazio. Assim, diferentemente do signo linguístico, em que há a prevalência do significado, o signo da psicanálise lacaniana tem como prevalência o significante, uma vez que ele só pode operar por estar presente no sujeito e ser utilizado para expressar algo que pode acabar sendo completamente diferente do que ele diz, comportando na estrutura da língua o conceito de subjetividade (Joaquim, 2016). Logo, é nas lacunas presentes nos textos oníricos ou nos restos diurnos dos sonhos que podemos localizar o recalcado ou a possibilidade do acesso ao desejo, mas esses pontos lacunares do inconsciente estão inscritos na camada mais profunda da placa de cera, remetendo a uma escrita que só pode ser lida parcialmente, entre as lacunas e os significantes.

Ou seja, a psicanálise compreende o processo de busca incessante do sujeito por se identificar por meio de sua linguagem e de seu discurso, e esse processo é, para além dos conteúdos manifestos e latentes dos sonhos e da imaginação, uma identificação de significante (dos sinais dos desejos subjetivos). Assim, Lacan inverte a relação do signo 
saussuriano em que significado (conceito, sentido) corresponde a um significante (a uma imagem acústica), para a relação não fixa entre ambos, já que a imagem acústica nem sempre levará ao significado correspondente e esperado. Para Saussure, o signo linguístico é uma entidade dupla, produto da aproximação de dois termos, ambos psíquicos e unidos pelo laço da associação. Ele une não uma coisa a um nome, mas um conceito a uma imagem acústica (não o som material, mas a impressão psíquica deste som). Nesse sentido, o algoritmo saussuriano é representado por significado, barra, significante, sendo os dois aspectos formais do enunciado complementários e indissociáveis da unidade do signo. Lacan, transformando o algoritmo da linguística em campo analítico, separa o significante do significado, destacando o status significativo do significante, ou seja, seu poder de produzir efeitos de significado. Assim, o algoritmo passa a ser representado como:

SIGNIFICANTE: S1, S2, S3 ...

SIGNIFICADO: $\$$

\section{FIGURA 2. INVERSÃO DO ALGORITMO DE SAUSSURE}

De forma que o significante não se atrela a um significado único, seu valor só pode se dar em termos relativos, a partir do deslocamento e da substituição dos termos na relação binária da cadeia significante $\left(\mathrm{S}_{1}-\mathrm{S}_{2}-\ldots\right)$. Na teoria lacaniana, o discurso se estabelece, portanto, na repetição da articulação dos significantes e na possibilidade de recortá-los pela sua diferença, deixando como resíduo o desejo do não dito. Ou seja, o sujeito em compulsão à repetição se encontra como produto desta cadeia de articulação dos significantes, deparandose, além disso, com o objeto causa $a$, isto é, a busca pela identificação e acesso à linguagem, o elemento que proporciona o movimento de concatenação ou a própria compulsão à repetição, pois não há identidade entre significantes, eles existem somente a partir da diferença. $\mathrm{O}$ sujeito só retoma o movimento porque ele segue em busca do objeto perdido, da satisfação inalcançada. No entanto, somente é possível identificar a repetição dentro do sistema 
simbólico, pois não é um acontecimento que se repete, e sim um elemento significante dentro de um sistema. Deste modo, o que determina a tópica do sujeito é basicamente a estrutura do significante, apenas a estrutura formal e simbólica dele, sem a intenção de significação, uma vez que o encadeamento dos significantes produz efeito por si mesmo e não visa corresponder a uma significação preestabelecida. O sujeito se vê, assim, atravessado pela linguagem, em uma posição condicionada pelo significante.

Já que, para Lacan, o significante constitui o elemento que se sobrepõe ao significado, uma vez que, ao ser representado em uma cadeia de significantes, é a subjetividade do falante e do receptor que está em jogo, há primeiro uma alteridade de discurso fundada na materialidade da letra, em seu aspecto fônico e gráfico. Em seguida, há um discurso dissociado de sentido, da intencionalidade consciente do sujeito no ato da enunciação. Portanto, o que ouvimos não é o significado das coisas e sim seu significante, isso se deve também ao fato de que a linguagem não é um código fixo e rígido, e sim um sistema essencialmente ambíguo. "Os semantemas são sempre poli-semantemas, os significantes têm sempre diversas significações, por vezes extremamente disjuntas” (Lacan, 1979: p. 348). A ordem do significado é, então, efeito da cadeia significante, em que S1 (significante um) enlaça outros significantes, S2, S3, no discurso em que se constrói, pois sozinho ele não pode existir, ele só é significante quando se articula a outros significantes.

Para explicar o deslizamento incessante do significado em relação ao significante, Lacan retoma o conceito das massas amorfas de Saussure para ressaltar a ideia de que a língua não é uma representação do pensamento, pois nem mesmo a correspondência entre a palavra e a coisa fogem do corte da massa amorfa, responsável por separar as duas unidades em duas instâncias formais, o que significa que a língua não é uma substância, mas sim uma forma. Para ilustrar essa ideia, Saussure (1996: p. 131) utilizou o seguinte esquema: 


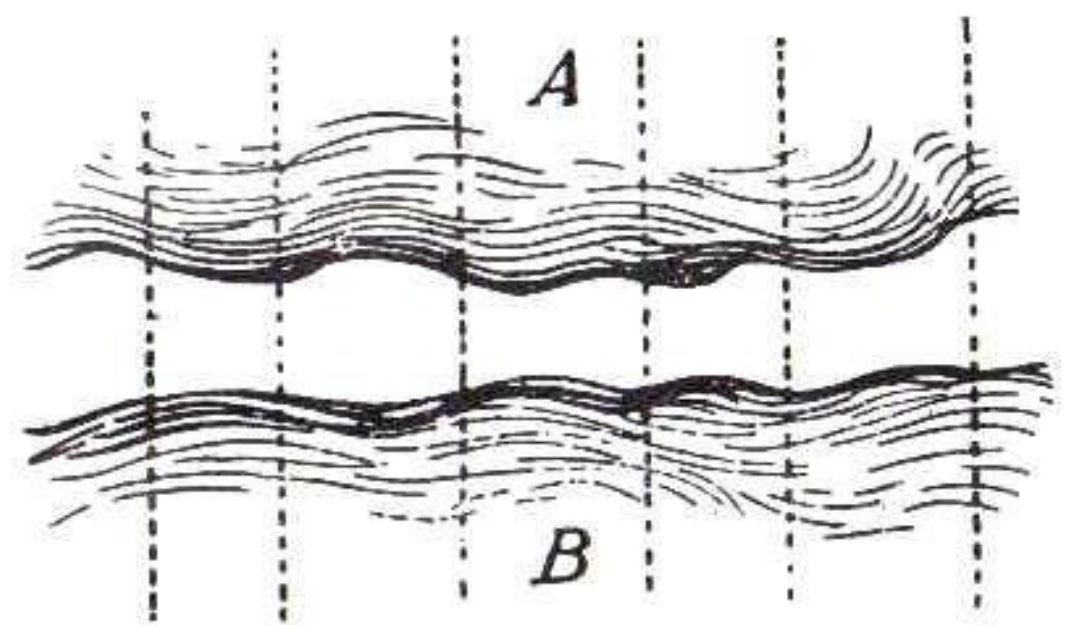

FIGURA 3. ILUSTRAÇÃO DAS MASSAS AMORFAS

Segundo Lacan (1998), há um duplo fluxo que ocorre nessa representação saussuriana das massas amorfas, em que o discurso articulado em forma de palavra (som e sentido) ocorre por meio da separação por recortes e pela introdução da diferença, como já esclarecemos acima, fazendo com que a estrutura do significante se caracterize pela articulação do signo e pela possibilidade de sua redução a puros elementos diferenciais. A partir dessa imagem, Lacan compreende que "as duas sinuosidades das águas superiores e inferiores" e "o marco dos finos riscos de chuva que ali desenham os pontilhados verticais" (p. 506) representam a impossibilidade do discurso de se constituir em apenas uma linearidade. Logo, o discurso é compreendido como uma dimensão horizontal composta por uma estrutura significante que, ao mesmo tempo, ocorre também na vertical, cuja operação tem sua base na metáfora (na dimensão vertical) e pela metonímia (na dimensão horizontal).

Visto dessa forma, a cadeia significante é regida pelas leis da linguagem, ou seja, pelos processos metafóricos e metonímicos que podem ser vinculados aos processos de condensação e deslocamento na interpretação dos sonhos, relação bem justificada nas palavras de Jakobson (2010, p. 75):

O desenvolvimento de um discurso pode ocorrer segundo duas linhas semânticas diferentes: um tema pode levar a outro, quer por similaridade, quer por contiguidade. $\mathrm{O}$ mais acertado seria talvez falar de processo metafórico no primeiro caso e de processo metonímico no segundo, de vez que eles encontram sua expressão mais condensada na metáfora e na metonímia, respectivamente. (...) A 
competição entre os dois procedimentos, metonímico e metafórico, se torna manifesta em todo processo simbólico, quer seja subjetivo, quer social. Eis por que numa investigação da estrutura dos sonhos a questão decisiva é saber se os símbolos e as sequências temporais usadas se baseiam na contiguidade ("transferência" metonímica e "condensação" sinedóquica de Freud) ou na similaridade ("identificação" e "simbolismo" freudianos).

Desse modo, a condensação, bem como o processo metafórico do eixo de seleção, é uma síntese das ideias e símbolos de uma metalinguagem, em um mecanismo de concentração do conteúdo manifesto e das imagens análogas a ele. Já a operação do deslocamento, correspondente ao processo metonímico do eixo de combinação, relaciona ou aproxima um elemento com outro que ele substitui. Logo, na lista paradigmática, vemos operando a metáfora, a condensação e os termos in absentia (conjunto das unidades que, em posição apropriada, podem substituir as unidades utilizadas in praesentia). Por conseguinte, na sequência sintagmática operam a metonímia, o deslocamento e os termos in praesentia, a sequência das palavras que, por sua sucessão, constituem a frase realizada.

Podemos ilustrar essa associação da seguinte forma:

EIXO DE SELEÇÃO - METAFÓRICO

CONDENSAÇÃO

TERMOS IN ABSENTIA

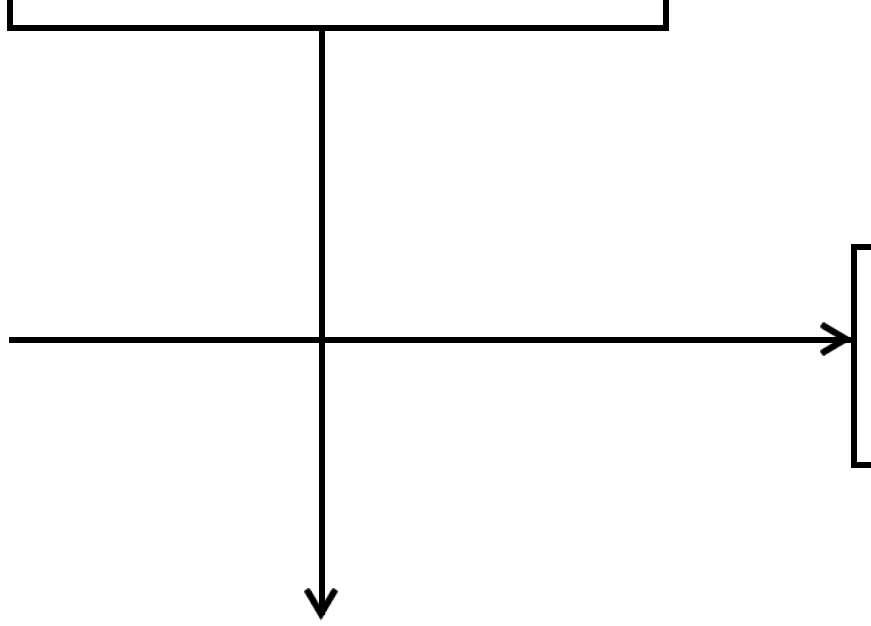

EIXO DE COMBINAÇÃO - METONÍMICO

DESLOCAMENTO

TERMOS IN PRAESENTIA

FIGURA 4. EIXOS METAFÓRICO E METONÍMICO 
As setas no cruzamento do eixo indicam que o deslocamento sintagmático aponta também para a passagem do tempo, pois é diacrônico e a contiguidade ocorre no tempo do enunciado. Já a condensação do eixo paradigmático é sincrônico, conta com termos in absentia, ou seja, latentes, com possibilidades de co-ocorrência, pois um pode tomar o lugar do outro à revelia do sujeito.

Essa proposição se torna ainda mais expressiva, tanto para Freud como para Jakobson e Lacan, quando ilustrada pela linguagem poética: "(...) basta escutar a poesia, o que sem dúvida aconteceu com F. de Saussure, para que nela se faça ouvir uma polifonia e para que todo o discurso revele alinhar-se nas diversas pautas de uma partitura" (Lacan, 1998: p. 507). A dimensão horizontal do eixo de seleção e a vertical estrutura da cadeia significante combinatória ocorrem ao mesmo tempo, a partir da emissão de não apenas uma voz, como ocorre nas pautas de uma partitura, cujas escalas sobrepostas compõem a harmonia da obra unindo o tom e o tempo em um único discurso. Lacan não poderia se valer de outra comparação mais poética como a imagem das pautas de uma partitura para ilustrar o efeito da cadeia significante no discurso e, simultaneamente, aproximar a linguagem poética (e sua essência mnêmica de ritmo e cadência) aos mecanismos do inconsciente por meio da dupla operação da metáfora e da metonímia.

A estrutura da linguagem, a poesia, a música e o deslize incessante do significado em relação ao significante se condensam no discurso lacaniano para suportar sua teoria do inconsciente. Assim, ele explica que "a Verdichtung, a condensação, é a estrutura de superposição dos significantes em que ganha campo a metáfora, e cujo nome, por condensar em si mesmo a Dichtung, indica a conaturalidade desse mecanismo com a poesia, a ponto de envolver a função propriamente tradicional desta" (1998: p. 515). Em alemão, a mesma raiz morfológica para designar as palavras condensação e poesia vem do substantivo Dichtung, que se refere ao ato de versejar, enquanto o verbo dichten significa condensar. É dessa estrutura vertical da condensação operada pela metáfora que a poesia se serve para "expressar algo completamente diferente do que ela diz. Função mais digna de ser enfatizada na fala que a de disfarçar o pensamento (quase sempre indefinível) do sujeito: a saber, a de indicar o lugar desse sujeito na busca da verdade" (p. 508).

Isso se deve principalmente ao fato de que a poesia predomina o estudo dos eixos de enunciação pois visa ao signo, a estrutura da metáfora, enquanto a fala pragmática visa apenas ao referente e ao simples ato de enunciação: 
o princípio de similaridade domina a poesia; o paralelismo métrico dos versos ou a equivalência fônica das rimas impõem o problema da similitude e do contraste semânticos; (...) a prosa gira essencialmente em torno de relações de contiguidade. Portanto, a metáfora, para a poesia, e a metonímia, para a prosa, constituem a linha de menor resistência, o que explica que as pesquisas acerca dos tropos poéticos se orientem principalmente para a metáfora (JAKOBSON: 2010, p. 78).

Os psicanalistas e linguistas consumaram a potência e a eficácia dos significantes tomando por referência exemplos poéticos, pois necessitaram da palavra poética para falar daquilo que nos é inefável. Em nenhum outro fenômeno linguístico, o jogo de condensação metafórica tem tanto êxito quanto no ato poético, é ele que concede à língua a capacidade do indizível. Em "A instância da letra no inconsciente ou a razão segundo Freud”, do livro Escritos (1998), Lacan observou os efeitos de consonância e de combinação dos significantes nos seguintes versos: "Non! dit 1'Arbre, il dit: Non! dans l'etincellement/ De sa tête superbe/ que la tempête traite universellement/ Comme elle fait une herbe" ${ }^{14}$. A primeira motivação do poema é a presença da palavra "arbre" (árvore), mesma palavra utilizada por Saussure para exemplificar a linearidade do signo que em francês tem como anagrama a palavra barre (barra), jogo linguístico utilizado por Lacan para ilustrar um dos aspectos da produção significante. A segunda motivação do poema são as analogias sonora e semântica das palavras "arbre" e "herbe" (erva) que se destacam por apenas dois fonemas diferentes, a rima da palavra-valise "superbe" (soberba) com "herbe" e principalmente a palavra-valise "tempête" (tempestade) que carrega consigo a palavra "tetê" (cabeça). Nesses versos, Lacan nota a ordem do paralelismo que rege o significante e que move a cadeia significante em uma série polifônica, provocando um efeito de sentido passível apenas na construção da linguagem poética. A criação metafórica marcada por uma árvore que fala sobre uma cabeça caracterizada como esplêndida, mas ao mesmo tempo comparada a uma erva, é pura contradição e negação da relação indivíduo - universal, submissa à tempestade. $O$ efeito inédito provocado pela sucessão dos significantes se deve à substituição dos sentidos, à metáfora existente.

\footnotetext{
A metáfora não é a coisa no mundo das mais fáceis de falar. Bossuet diz que é uma comparação abreviada. Todo o mundo sabe que isso não é inteiramente satisfatório, e creio que na verdade nenhum poeta o aceitaria. Quando digo nenhum poeta é porque poderia ser uma definição do estilo poético dizer que ele começa na metáfora, e que ali onde a metáfora cessa, a poesia também (LACAN, 1954: 248).
}

\footnotetext{
14 “Não! diz a árvore, ela diz: Não! No cintilar/ De sua cabeça soberba/ Que a tempestade trata universalmente/ Como se fosse uma erva".
} 
No ato poético, a função primordial do significante é produzir "um tecido resplandecente de metáforas" (Lacan, 1998: p. 510). Diante desse desafio, o poeta escolhe precisamente as palavras, sobrepõe significantes, estabelece associações e provoca recorrências, substitui os sentidos por outros totalmente inesperados, atribuindo o máximo de carga semântica possível. Tomando a poesia como exercício da metáfora, Lacan (1998: p. 519) apresenta a seguinte fórmula:

\section{$f\left(\frac{S^{\prime}}{S}\right) S \cong S(+) s$}

\section{FIGURA 5. ESTRUTURA DA METÁFORA}

O algoritmo pretende expor a relação de substituição dos significantes no eixo metafórico, deixando claro que é na substituição de um significante por outro significante que se produz um efeito de significação. Observamos no ato poético esse advento da significação, da condensação e transferência de sentidos na substituição de um significante por outro, distorcendo seus sentidos. Assim, os "S" maiúsculos são os significantes e o sinal "+" representa um mais de sentido que só é possível por meio da transposição da barra, transposição necessária para a emergência da significação, que se representa na fórmula lacaniana pelo "s" minúsculo. No entanto, o significante somente opera dentro do sujeito, condicionando-o em um encadeamento de sentidos que desliza no inconsciente. A partir de diferentes estudos, Schiller declarou que a poesia é uma força que atua acima do consciente, pois é em outro lugar que o pulsional se intensifica. E não por outro motivo, Lacan compara a estrutura do real com a estrutura do ato poético, pois a linguagem em ambas estruturas não revela ou não corresponde necessariamente o que está sendo dito ao que é compreendido e apreendido no discurso do outro. É também devido a essa compreensão da psicanálise que tomamos a oralidade poética como fenômeno de enunciação em que a poesia, como alimento da fantasia e do desejo, afasta necessariamente o discurso pragmático e a pretensão objetivista da apreensão do real. Podemos, dessa forma, associar ainda mais a estrutura da linguagem 
inconsciente com a estrutura da linguagem poética, uma vez que ambos discursos se estabelecem na repetição da articulação dos significantes e na possibilidade de recortá-los pela sua diferença, deixando como resíduo o desejo do não dito.

Há um discurso intencional que pode ser alterado na ordem significante, fazendo emergir um outro discurso que não estava sob controle do sujeito. Dessa mesma forma opera a realidade, a qual enfeitamos e disfarçamos através de um olhar que a interpreta de maneira organizada e harmônica, quando na verdade ela possui uma estrutura trágica e caótica que não queremos enxergar. Empenhamo-nos em sentir uma totalidade coerente do que acreditamos ser o real, antevendo a lógica de um mundo coeso, dotado de sentido. Isso porque estamos alienados na linguagem que nos permeia e que determina toda nossa subjetividade, fazendo esconder a verdade do nosso desejo. Quando dizemos algo distinto do que queremos dizer, em ocasião dos atos-falhos ou chistes, não somos nós organizando o discurso, mas sim o discurso que está organizando os significantes, deixando-nos de fora dessa ordem, em uma relação de exterioridade, de alienação.

Isso ocorre, como já dissemos anteriormente, pelo fato de que as palavras não são capazes de representar as coisas e nossos pensamentos, pois elas não coincidem com a origem das coisas da natureza, tampouco com a essência do pensamento humano. As palavras estão descoladas da ideia de essência, uma vez que sua forma e o conceito dos elementos que pretendem representar não correspondem à ideia de verdade real, mas simulam uma verdade artificial, o que Nietzsche (1999: p. 55) identificou como "um batalhão móvel de metáforas, metonímias e antropomorfismos". Para o filósofo, o que consideramos verdade não passa de "uma soma de relações humanas, que foram enfatizadas poética e retoricamente, transpostas, enfeitadas, e que, após longo uso, parecem para um povo sólidas, canônicas e obrigatórias". Como instinto de sobrevivência, a fim de preservar o desejo e a paixão de viver, de se expressar e de se relacionar, o ser humano criou uma ideia de verdade que deveria ser ocultada, para, assim, poder se intrigar com o que está escondido e deve ser encontrado, suscitando então a ação que o motiva a seguir na eterna busca enigmática por algo que alimenta seu impulso à verdade. Se as verdades "são ilusões das quais se esqueceu que o são, metáforas que se tornaram gastas e sem força sensível" (Nietzsche, 1999: p. 57), a tentativa de fixar a palavra à coisa que ela pretende representar está fadada ao fracasso. Não é tarefa fácil reconhecer e localizar o que há de estranho nessa linguagem do inconsciente, na verdade oculta nas palavras, no real desejo que nos move. Em uma realidade que automatiza nossos pensamentos e nossas ações, em um mundo caracterizado por máquinas e discursos que se 
apropriam do nosso desejo, essa "verdade" fica ainda mais difícil de ser desvelada. Ao tentar retirar o véu que a esconde, encontramos outro véu, e em seguida outro, e assim sucessivamente, pois estamos atravessados por aparências, vestígios, figurabilidades, ilusões e fantasias provocadas pela linguagem e pela nossa condição social. Os véus que entrecorrem uns sobre os outros podem ser imagens convenientes para simbolizar a cadeia significante, o S1, S2, S3... que sucedem no discurso e reforçam os limites da representação, a impossibilidade de fazer das palavras o enunciado perfeito de nossos pensamentos.

A palavra, quando enunciada, já não é capaz de representar a ideia real como existe em nós ou na natureza, gerando, portanto, um conflito entre o conceito que temos da realidade e a forma em que nos apoiamos para nos expressarmos sobre essa realidade. Os quadros surrealistas da obra "A traição das imagens", de René Magritte, são bons exemplos para ilustrar a contradição que a leitura e interpretação dos diversos discursos no mundo provocam no sujeito. Ao desenhar um cachimbo e afirmar que aquilo não é um cachimbo, o artista nos faz refletir não mais sobre o objeto em si, mas sim sobre sua representação, revelando o óbvio: o cachimbo pintado não é o objeto de verdade, mas apenas uma pintura. A palavra não constitui a coisa, a pintura não constitui o objeto, elas apenas apontam para interpretações variadas, ou seja, para várias verdades possíveis, pois um mesmo texto pode ser lido de formas distintas, desvelando associações e analogias singulares e subjetivas. Na poesia, vimos que essa distância entre palavras e coisas é estabelecida por meio do uso acentuado de metáforas, de abstrações e ilogismos, caracterizando o gênero poético como expressão extremamente disposta a interpretações múltiplas, a um mundo aberto à polissemia. Não por outro motivo defendemos o exercício contínuo e assíduo da palavra poética no ensino e aprendizagem da Língua Portuguesa em sala de aula.

No entanto, esse conflito da representação e da expressão, além da alienação a que a linguagem nos submete podem ser causas de angústia e sofrimento, cujos sintomas decorrem daquilo que o sujeito subtrai da realidade e torna a se manifestar por meio do discurso (fenômeno inevitável, uma vez que o que se deseja ocultar fica inscrito no corpo e se anuncia quando menos se espera). Dessa forma, é relevante a concepção do real para Lacan como a instância composta a partir da subtração de algo que causa angústia e sofrimento, pois fica ainda mais evidente o importante papel da linguagem poética na constituição subjetiva do indivíduo, uma vez que a existência do real está entre duas realidades provisórias e divididas. Somente agimos no real - neste hiato efêmero, em um momento de reconhecimento do desejo e retomada da experiência, a partir do nosso próprio discurso. No entanto, o real também é o 
impossível, aquilo que não é capturável, fazendo-nos lidar constantemente com impossibilidades fundamentais, como a de representar nossos pensamentos por meio de palavras. Logo, se a linguagem poética se realiza a partir de uma torção das palavras e de uma articulação quase que inconsciente ao concretizar jogos linguísticos e fazer ressoar uma harmonia sonora e uma densidade semântica inesperadas, essa articulação da palavra poética com a linguagem inconsciente não deixa de ser também parte de um impossível, de um improvável manifesto na evasão de um desejo não vislumbrado no campo do real.

Esse desejo que não reconhecemos no real é localizado e demarcado em função de uma metáfora (de um sintoma). Se não nos colocarmos no discurso e não escutarmos o que tem sido operado pela falta, a verdade se manifestará em sintoma, cuja estrutura metafórica substitui um determinado significante por outro e só é possível de ser decifrado por meio da experiência. A experiência não está nos dados, nas receitas, nas bulas de remédio da prosa pragmática. Ela está em uma articulação simbólica e em certas formulações do código que geram prazer, que despertam o sensível, como no mito, na poesia e nas artes. São elas que estruturam a experiência e dão materialidade à palavra de forma sensorial, visual e corporal, tornando-a visível e apreensível ao sujeito. A abertura que os textos poéticos e as artes nos oferecem para diferentes leituras são, portanto, a própria razão do desejo de desvelar a verdade em um mundo desprovido de um sentido último, já que não há uma única verdade, mas interpretações e processos inacabados de leituras e escritas do Outro e de nós mesmos.

No entanto, a metáfora não existe no poema de maneira imediata por meio das palavras, como se o poeta já tivesse pré-determinado suas ideias e conseguisse as transpor diretamente em palavras. O poeta cria a metáfora através da letra, da estrutura localizada do significante, nesse jogo da ordem simbólica que produz um efeito de sentido e compromete o sujeito em sua essência. A letra, assim como a pintura que não representa o objeto em si, caracteriza o significante em sua materialidade, invade o sujeito rompido com o centro, domina o indivíduo cindido e dividido, escancarando sua incompletude, pois junto ao seu traço, a letra tentará representar a verdade oculta. Contudo, o sujeito não é um eu, mas sim um lugar relativo ao discurso determinado pelo inconsciente e pelo sentido da letra, logo, ele permanecerá preso à metáfora solidificada em forma de verdade.

Lançando mão desta formulação teórica, Tfouni e Belintane (ambos retomando Lacan) estudaram o conceito de letra e os processos de subjetivação que ela provoca, focando no contexto do ensino e da aprendizagem da leitura e da escrita. À luz de suas teorias e invocando a função poética da linguística, prosseguiremos a dissertação teórica no próximo 
capítulo, aproximando-nos de nossos objetos da pesquisa: os jovens escolares diante de uma decifração impossível e a poesia como dispositivo de estímulo criativo e de fruição estética a partir de uma corporalidade. 


\section{Capítulo 2. A questão do letramento: sob o crivo da subjetividade}

Em seu texto "A instância da letra no inconsciente ou a razão desde Freud" de 1957, Lacan (1998) define a letra como o suporte material que o discurso concreto toma emprestado da linguagem, cuja fórmula se caracteriza numa combinatória de substituição e composição. A fim de esclarecer essa ideia, Lacan retoma o trabalho freudiano de decifração dos sonhos (similar à decodificação dos criptogramas ou hieróglifos), afirmando que são as imagens dos sonhos que permitem uma possível leitura do inconsciente. Se o sonho funciona como um rébus, ou seja, como imagens que podem ser substituídas por seu valor significante, esse valor deve ser considerado como signos pertencentes a um sistema de linguagem cuja significância só pode ser extraída na ação de deslizamento do significado sob o significante. Assim, a possível leitura do efeito de significado no discurso inconsciente é orientada pela condensação e deslocamento, como vimos anteriormente, nos eixos da metáfora e da metonímia, mas deve ser realizada deixando de lado o sentido lógico das palavras, suspendendo momentaneamente o valor semântico que atribuímos às coisas.

A partir desse trabalho de decifração pictográfica, Lacan procura elucidar o conceito de letra, que uma vez estruturada segundo uma mesma lei de linguagem como a do inconsciente, também carrega em si um elemento criptográfico: a letra não tem qualquer sentido em si mesma, mas insiste no sentido que não se esgota, que vai além do que o sujeito se propõe a dizer intencionalmente, que carrega em si, portanto, um enigma a ser desvendado (definição bem próxima da que formulamos sobre a potência da poesia).

Sua estrutura material é compreendida através da diferença, dos elementos diferenciais que estão combinados na articulação sistemática e sintagmática do significante. Dito de outro modo, a diferença é estabelecida segundo leis de uma ordem fechada, ou seja, a partir dos fonemas, que, segundo Lacan (1998), são parte de um sistema sincrônico dos pareamentos diferenciais necessários ao discernimento de vocábulos em uma dada língua. Com o exemplo da própria palavra letra em francês, o psicanalista evidencia que apenas um fonema diferencial é capaz de deslocar o sujeito e colocá-lo em questão sobre a letra que gera o ser e sobre o ser que vai ao outro: "la letre" (a letra), "l'être" (o ser) e "l'autre" (o outro). Nesse caso, o sentido da letra é gerado por substituição e combinação, produzindo efeitos de sentido que divergem quanto ao sentido que ela poderia comportar se estivesse em uma relação biunívoca. Os hieróglifos egípcios, por exemplo, só puderam ser desvendados por 
Champollion e Young após a descoberta da Pedra de Roseta, cujas inscrições não eram apenas em hieróglifos, mas também havia uma versão em grego.

A materialidade da letra está, portanto, baseada em uma literalidade, por fragmentos que por si mesmo não produzem efeitos de significação, mas, quando em uma composição linguística particular, podem gerar efeitos heterogêneos. Por isso, Lacan diz que é preciso tomar o sentido da letra ao pé da letra, através da preponderância do literal, ou seja, através da combinação que articula um discurso que vai além da ordem dos significados previamente tomados como lógicos, podendo, assim, resultar efeitos não esperados.

Assim, à existência do movimento de leitura do inconsciente, destacada por Freud na interpretação dos sonhos como enigmas a serem desvendados, Lacan acrescenta a operação de escrita do inconsciente com base na letra. A instância da letra é, portanto, uma formulação inconsciente que, através da ordem simbólica, questiona e interpela o sujeito com um discurso outro que ele não reconhece de prontidão, com algo que o surpreende. Nesse discurso, localiza-se o recalcado, nossos impulsos reprimidos e também a possibilidade de acesso ao desejo. De volta à metáfora do bloco de cera, esses elementos recalcados fazem parte do texto gravado na superfície da prancha que foram descartados para dar lugar a outros textos. No entanto, esse registro pode voltar a ter lugar e se tornar legível, sendo, assim, caracterizado por uma escrita condicionada pelo retorno do recalcado, uma escrita que só pode ser lida parcialmente entre as lacunas e os significantes (Carreira, 2010: p. 23).

\section{Letramento e função poética}

Logo no início do livro Escritos, Lacan (1998) expõe a leitura que faz do conto "A carta roubada", de Edgar Allan Poe, aproveitando a homofonia do francês entre as palavras carta e letra, para comparar o desvio da carta roubada do conto com os desvios operados por nosso inconsciente. Os rastros e trajetos que a carta desviada sofreu correspondem ao retorno do recalcado, cujos deslocamentos de ambos (da carta e do recalque) só são percebidos após um reviramento. A carta roubada só passou despercebida pelo detetive, pois foi deixada à mostra, mas revirada pelo avesso. "É justamente isso o que ocorre com o recalcado: ele fica à mostra e escondido, pois se encontra revirado por condensação e deslocamento" e para recolocar essa carta/ letra no caminho de seu destino seria preciso ler esse enigma de outra forma, notando que o dentro e o fora constituem uma mesma superfície. Lacan se vale de figuras como a faixa de Moëbius, já citada no primeiro capítulo, para ilustrar esses "desvios e 
reviramentos a que está condicionado o retorno do recalcado, o qual parece ocultar-se dentro, mas está fora" (Carreira, 2010: p. 24). A imagem de Escher (1994: p. 40) facilita a compreensão dessas bordas que não separam um dentro e um fora, as formigas podem circular entre uma superfície a outra sem notar que estão mudando de borda:

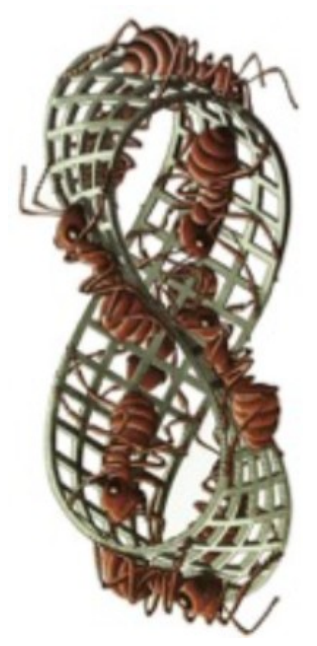

\section{FIGURA 6. DESENHO DE ESCHER, MOËBIUS STRIP II}

Em paralelo ao conceito de letra, Lacan recupera a ideia de identificação em Freud em sua segunda forma, isto é, a caracterização da identificação não simplesmente como uma correspondência biunívoca entre uma coisa e outra, mas uma separação fundada em perda e deslocamento. Ela seria, então, uma identificação regressiva do sujeito reduzida a um traço do outro ou do objeto perdido. Lacan passa a chamá-la de traço unário, tomando a identificação "não como uma cópia ou imitação, mas sim como referente à singularidade, ao que é ímpar", ou seja, "a identificação ao traço unário é a identificação primária do sujeito", um estilo próprio:

Lembremos que o estilo ${ }^{15}$ também é aquilo que escreve. O traço unário, segundo Lacan, também possui essa função, pois ele inscreve o sujeito no campo do Outro (o tesouro dos significantes), marcando a sua existência enquanto sujeito que conta. Trata-se de uma inscrição tal qual o são as marcas verticais e sucessivas cravadas

\footnotetext{
${ }^{15}$ A palavra stilu na língua latina designava uma haste pontuda utilizada para escrever ou marcar na argila, como uma caneta ou um estilete. Metaforicamente passamos a utilizar a palavra estilo para designar o modo de escrever, de falar, de se vestir ou se portar, no geral.
} 
pelos nossos ancestrais, em ossos ou nas paredes das cavernas, as quais serviam para computar cada um dos animais que haviam caçado, independentemente de suas qualidades. Dessa forma, o traço unário escreve (é estilo, pena) e inscreve (é marca). (CARREIRA, 2010: p. 25)

Essa marca singular do sujeito pode ser compreendida como um processo de subjetivação, no qual cada indivíduo pode ser dito como um. Pela cadeia significante, o traço unário comporta a diferença, marcando a existência do sujeito no campo do Outro, e, ao mesmo tempo, alienando-o no momento em que fala sobre seus sintomas e angústias, uma vez que ele não domina exatamente o que vai enunciar e o que pode aparecer em seu discurso.

\begin{abstract}
Nesse sentido, "diferença unária" tem a ver com o não saber do sujeito. Ora, unário é aquilo que pertence a um mesmo conjunto em que as unidades desse conjunto se definem por suas oposições mútuas, pela diferença, por aquilo que não são em relação às outras. A origem saussuriana desta desontologização radical dos significantes é clara: para Saussure, não apenas os fonemas, mas todos os elementos de uma língua se definem entre si pela diferença que marcam em relação aos outros. A própria língua é, para Saussure, um sistema solidário e arbitrário de puras diferenças (Saussure, 1995, p. 166 apud SILVIA \& JUNIOR, 2017: p. 131).
\end{abstract}

A pura diferença do significante no discurso opera de outra forma no campo da escrita, já que não há o caráter fonemático que permite essa propriedade de diferenciação. Assim, quem opera no discurso escrito é a letra, que para Lacan, nessa estrutura, ganha o desvio da rasura, caracterizada tanto por um traço que faz uma letra ou uma palavra inteira tornarem-se ilegíveis ou um risco que pretende substituí-las. Novamente, o traço, a letra, a rasura ou o risco no campo da escrita permanecem condicionados pela cadeia significante e pela compulsão à repetição, pois o que fica implicado é que a relação do signo à coisa seja apagada. Seu apagamento ou substituição representam, portanto, a possibilidade de uma leitura ou decifração apenas por meio das lacunas, no espaço entre dois significantes, no contexto associativo ou no encadeamento em que se unifica, através do código, a pluralidade de elementos discursivos que estão operando em determinada articulação simbólica. Para essa leitura ser parcialmente possível, algo da letra tem de resistir, mas ainda assim há uma barreira significante que a torna incompleta, lacunar. Portanto, nas tentativas de leitura do sujeito, a letra não pode ser toda lida, ela fica sujeita a uma rasura, a qual está representada na imagem abaixo pelo espaço em branco: 


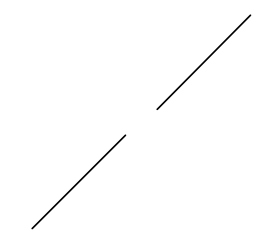

FIGURA 7. RASURA NA LEITURA DO SUJEITO

E é devido a esse espaço em branco, a esses vazios impossíveis de serem lidos que o sujeito persiste nas tentativas de leitura e interpretação de seus desejos e sintomas. Através da sensação de incompletude o sujeito é colocado em uma posição de existência e desejo, por isso é importante que, no processo de subjetivação, apareçam significantes que persistam como aquilo que não se escreve e que não se lê, colocando o sujeito diante de impossíveis, de lacunas, de objetos que o estimulam a seguir decifrando. Ao confrontar os enigmas do texto, o sujeito investe no movimento de decifração e coloca algo de si, de sua marca singular carregada pelo traço unário em sua enunciação (do seu estilo, da sua escrita interior), vendose, assim, instigado a descobrir o que o Outro pretende com o seu discurso. Se um texto fosse todo legível e trouxesse todas as respostas para nossas indagações, não teríamos por que continuar lendo e investigando o mundo e as verdades que ele esconde.

Se é pelos vazios que estabelecemos os sentidos não literais da literalidade da letra, se é pelas falhas e deficiências da linguagem que somos provocados e estimulados a seguir criando enunciados, se é pela compulsão à repetição que buscamos prazer e se é na incompletude que continuamos desejando, nada pode ser mais excitante e desafiador no campo da linguagem que a leitura de um poema na intenção de inserir o sujeito na experiência da ordem simbólica. A poesia tem sua base nos efeitos de ambiguidade, de transmutação dos sentidos das palavras, de semelhanças sonoras e trocas semânticas que mexem com a contextura dos versos, produzem um nonsense, um enigma, um texto que motiva a decifração e interpretação. Assim, acreditamos que, se acessamos de alguma forma um espectro de sentido diante das coisas no mundo, essa compreensão se dá de modo poético, a partir do inesperado da poesia e de seus efeitos estéticos, daquilo que escapa de nós. Logo, nossa intenção com o trabalho poético no curso de Língua Portuguesa aplicado aos alunos do Ensino Médio de Paraisópolis foi principalmente desfocar a lacuna evidente ao sujeito que se instaura no interdito para refletir coletivamente sobre os métodos pelos quais sua 
subjetividade pode ir além dela, ou seja, como é possível reposicioná-la para que o sujeito se veja nas potências para além das lacunas. Por acreditarmos na potência para a criação e subjetivação a partir da análise e inferência da poesia, nosso desafio maior ao longo da pesquisa foi compreender como a potência advém não apenas do reconhecimento da lacuna que mobiliza o desejo do sujeito, mas do modo como lidamos com esse espaço aberto para a imaginação e a criação artística.

À vista disso, defendemos a ideia de letramento que enxergue o ser como efeito de um texto, de uma organização de sentido não significável (de um sentido inconsciente) que esteja implicado a uma condição corporal e sensorial, ao gozo diante das possibilidades ou impossibilidades de leitura e escrita e à transformação de seu lugar social. Não por outro motivo, a metodologia que procuramos pautar para o ensino de Língua Portuguesa (já desde o antigo projeto voltado para o Ensino Fundamental e agora em extensão à pesquisa de campo posta em prática no Ensino Médio) dirige seu olhar para a potência da corporalidade como ferramenta criada para lidar com o esquecimento a partir das modalidades poéticas em uma relação dinâmica (e não dicotômica) entre oralidade e escrita. Isso porque já identificamos em pesquisas anteriores (conforme citamos na introdução) a importante função da corporalidade na constituição de uma subjetividade mais inclinada à diversidade e afeita aos jogos intertextuais (Belintane, 2017), capaz de reter na memória narrativas e experiências poéticas que convocam o sujeito no campo simbólico.

Para nos aprofundarmos sobre esses aspectos, organizamos este item em três eixos: i) o conceito de letramento com relação à dispersão, deriva e autoria; ii) a poesia como dispositivo de letramento mais favorável à apropriação da escrita e à competência leitora dos sujeitos escolares; e iii) o conceito de estilo e técnica de escrita que movimenta e desloca esses sujeitos do lugar da mesmice mecânica e repetitiva de certas formas de ensinar para explorar os textos através do sensível e das paixões.

\section{Dispersão e Deriva}

Ao propor uma pesquisa envolvendo o conceito de letramento, Tfouni (2010: p. 217) nos adverte que o grande desafio está em "ultrapassar a dicotomia entre língua oral e escrita, e atingir um nível de reflexão onde se possa tratar de discursos e sua forma de organização", sem restringir a questão da aquisição da leitura e da escrita a seus usos sociais. Desde que os teóricos da linguagem e da pedagogia passaram a estudar o conceito de letramento, criou-se 
uma vertente que insistiu em tratar apenas das produções e recepções de textos escritos para investigar o domínio de maior ou menor grau das habilidades de leitura e escrita no universo escolar, deixando de lado todos aqueles que estão excluídos dessas práticas hegemônicas.

Em contraposição a esse movimento, Tfouni considerou no centro do debate de letramento não apenas aqueles que tem condições de frequentar a escola, mas também os excluídos do sistema escolar formal, principalmente os não alfabetizados. Na tentativa de ultrapassar a dicotomia entre oralidade e escrita, ela propôs a noção de autoria para tratar da heterogeneidade das práticas letradas, mobilizando os conceitos de dispersão e deriva (2010: p. 220) com base na Psicanálise lacaniana e na Análise do Discurso de Michel Pêcheux. Dessa forma, o sujeito que faz uso da língua escrita ou oral não é considerado como um indivíduo isolado, mas sim em posição de sujeito dentro do continuum ${ }^{16}$ do letramento, ou seja, o sujeito do discurso, condicionado pela cadeia significante e localizado entre-textos e meios diversos e alheios a ele. Isso significa que o sujeito se determina na relação com o Outro e com os outros e carrega consigo marcas do discurso social, histórico e ideológico de seu tempo.

Além de ressaltar a importância do avanço que a concepção de um sujeito excêntrico em posição intervalar trouxe para as práticas pedagógicas, Tfouni propõe, por meio de tal formalização da teoria de letramento, um olhar crítico às injustiças sociais capaz de impulsionar ações transformadoras e combativas e diligenciar medidas práticas que de fato condicionem avanços sociais, econômicos e culturais na vida da classe trabalhadora. Por mais que nossos sujeitos da pesquisa estejam inseridos nas engrenagens do mecanismo educacional formal, as demandas de trabalho e sobrevivência a que estão submetidos restringem o acesso a uma rotina escolar saudável e a oportunidades de promoção intelectual, uma vez que muitos são obrigados a trabalhar nas horas destinadas aos estudos. Outro fator de desigualdade é a conjuntura familiar não-alfabetizada ou de pouco acesso a livros, exposições, filmes e outros meios de propagação cultural e artística. Dessa forma, não podemos perder de vista que a elaboração da concepção de letramento aqui exposta e, por conseguinte, a metodologia a ser apresentada com base nesse aporte teórico caminharam ao lado das análises do contexto

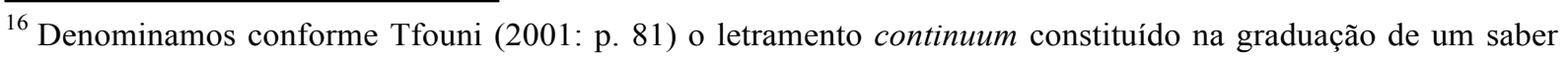
sobre a escrita e sobre seus usos na sociedade que independe de variáveis como alfabetização, grau de escolaridade ou tempo de escolarização.
} 
político da luta de classes frente a uma atual ofensiva reacionária (tanto no campo econômico quanto social).

Dito isto, quando Tfouni discorre sobre a noção de autoria ao tratar da heterogeneidade das práticas letradas, ela se refere não apenas ao fenômeno autoral através do código escrito, mas também através da oralidade, ou seja, um sujeito não alfabetizado pode apresentar traços de autoria em seu discurso mesmo sem dominar o código escrito, pois a ideia de autor é referente a uma posição discursiva. Retomando Lacan e Pêcheux, Tfouni (2002) afirma que quando o sujeito discursa (em um texto oral ou escrito) e retroage sobre o processo de produção de sentido lançado por meio de sua enunciação, ele se torna capaz de controlar a deriva e amarrar a dispersão que está sempre virtualmente se instalando. Nesse movimento de retroação, o sujeito retorna ao enunciado proferido e o analisa de um outro lugar, conseguindo, assim, organizar o conteúdo de seu discurso em uma sequência com começo, meio e fim, ou seja, o sujeito é capaz de estabelecer coerência e coesão ao seu texto.

Como já equacionamos anteriormente, o funcionamento da linguagem se dá na operação dos eixos metafórico e metonímico, assim, o efeito de sentido produzido pelo texto abre espaço para os efeitos de dispersão, de um não-controle do deslocamento do sujeito pela cadeia significante, por exemplo, no caso de um lapso. Se no decorrer do enunciado, o sujeito realizar esse processo de retroação sobre a cadeia metonímica, ele poderá ser capaz de conter a dispersão e corrigir o lapso, seja retomando o discurso oral a partir do significante que agora julga ser mais adequado para representar sua ideia ou efetuando uma rasura no texto escrito, substituindo significantes por outros que façam mais sentido ao seu campo de expressão.

No entanto, mesmo conseguindo conter a dispersão, o autor não consegue controlar o equívoco, fazendo que a deriva sempre se instale no discurso. É um processo inconsciente provocado pelos deslizamentos significantes que quando multiplicados no entrecruzamento dos eixos paradigmático e sintagmático fazem irromper um novo sentido. Nesse sentido, "a autoria de um texto se instaura quando o sujeito do discurso ocupa uma posição que lhe permite lidar com a dispersão e aceitar a deriva que sempre se instala" (Tfouni, 2010: p. 221), ou seja, a formulação do discurso apresenta uma tensão entre um eu que tenta controlar a dispersão e um sujeito que se perde na deriva. Não obstante, ambos procuram se equilibrar por meio dos mecanismos linguísticos e pela sensação de que estão produzindo um texto coeso e coerente, uma vez que passam a acreditar que o que está sendo dito não teria como ser formulado de outra maneira. Assim, se para o sujeito-enunciador a deriva é um processo inconsciente, para o sujeito-autor ela passa ser um ponto de apoio, "seja para criar manobras 
retóricas a fim de evitá-la, como ocorre no texto científico (...), seja para escancará-la como recurso de denegação da equivocidade da língua" (Tfouni, 2010: p. 222).

O movimento de retroação do sujeito que o permite se ver (e se ouvir) de um outro lugar foi denominado por Lacan (1957, apud Tfouni, 2010) de "point de capiton" ${ }^{17}$, ponto com que o tapeceiro une as diferentes partes de um estofado. Essa metáfora foi utilizada para representar a fixação da significação em determinada cadeia de significantes, expressando a ideia de uma unidade de sentido que retroage a partir dos deslizes não intencionais. Ao amarrar as pontas soltas e dispersas, o autor localiza um ponto de ancoragem na significação para seguir unindo e condensando significantes na cadeia do discurso. Esse movimento consiste, portanto, em uma exceção ao deslizamento incessante do significado sob o significante, sendo anterógrados e retrógrados, uma vez que há relações de determinação recíproca entre as palavras na enunciação falada ou escrita. Isso só é possível, pois o sujeito do discurso se situa em algum ponto da rede interdiscursiva do campo simbólico que o constitui enquanto um sujeito de memória capaz de retomar os enunciados já formulados em seu interdiscurso subjetivo, definido pela sua história pessoal e social. As palavras que proferimos não estão desprovidas do conteúdo ideológico que reflete nossa condição de classe (econômica e social), pelo contrário, elas carregam consigo as marcas subjetivas de nossa história e daquilo que apreendemos da heterogeneidade discursiva, da presença do outro em nosso discurso.

Mas, como vimos a partir de Freud e Lacan, não é tudo que nossa memória é capaz de fazer ressurgir e transformar em palavra. Nesse hiato em que o sujeito se encontra, entre a dominação do complexo das formações ideológicas e o discurso do Outro, há algo ainda que lhe escapa e lhe desencadeia um incômodo, uma falta que o governa, e, assim, ele percebe que o que possui no termo real do discurso é, em grande parte, a incompletude e a dispersão.

Como o mecanismo que o sujeito dispõe para recuperar sua sequência perdida à cadeia metonímica não é um mecanismo consciente nem aleatório, "o sujeito se refugia no interdiscurso pelo lado do avesso: ele se refugia no fantasma" (Tfouni, 2010: p. 223). Esse fantasma do qual Tfouni trata é a imbricação de dois registros, Simbólico e Imaginário, na qual o sujeito procura se proteger e domesticar a instabilidade daquilo que lhe escapa "fixando, assim, por metáforas e metonímias, uma nova unidade transitória, que logo também

\footnotetext{
${ }^{17}$ Retomaremos este conceito no final deste capítulo, ao abordar a prática de performance e leitura de textos poéticos como ferramentas de "ponto-de-giro" - termo cunhado por Belintane (2017), a ser explicado adiante.
} 
se dissolverá sob o assédio incessante do real, do retorno do recalcado, daquilo que é impossível de se dizer enquanto tal" (idem).

Como vimos anteriormente, o primeiro efeito do real é o objeto do desejo como lugar de uma falta impossível de ser preenchida, estando à margem da linguagem. O fenômeno da deriva se assemelha, portanto, à irrupção do real, visto que no processo de deriva outras possibilidades de significação irrompem, quebrando a unidade de sentido e deixando a lacuna e a falta no corpo do sujeito. Logo, se o único meio de apreender o real é por intermédio do simbólico, na tentativa de transformar o novo, isto é, o inédito da significação que perturba e se instala enquanto sintoma, cabe ao sujeito procurar retomar sua posição de autor, intentando unir as pontas dispersas de seu discurso em busca de uma verdade que existe, mas passa apesar do sujeito.

Ao enunciar e buscar sua posição de autor do discurso, o sujeito se coloca numa posição de narrador que, mesmo estando assujeitado pela cadeia significante, está, contudo, sujeito a irromper o inesperado e se conhecer, reconhecendo-se em si e no Outro, exteriorizando os lapsos e atos falhos, deixando vir à tona a língua que incomoda e que carrega a verdade sobre si. É a partir do ato discursivo que o sujeito será capaz de se perceber e se posicionar subjetivamente diante do Outro. Essa também é a intenção da prática psicanalítica ao convidar o analisando a elaborar seu discurso por meio de associações livres, narrando suas experiências como forma de lidar com os sintomas. Segundo Tfouni (2010), o resultado dessa batalha discursiva nunca chega a um fim, pois a deriva ameaça constantemente o fluxo do dizer ou do escrever, "visto que a cada escolha lexical possível, no eixo paradigmático, antecede um vazio de significação que ameaça a unidade do texto" (p. 225). Da mesma forma, o sintoma não está sendo enunciado na clínica para ser curado ou para que o analista ofereça um tratamento de transformação radical do sujeito, mas diante de uma escuta analítica, nossa fala ajuda a lidar com as misérias de nossa neurose e nos leva a bordejar o impossível potente que nos acompanha.

Graças ao movimento de separação e repetição do sujeito confrontado pela sua própria linguagem, em um encadeamento retroativo do desejo pela verdade, seguimos interessados pelas narrativas e pela experiência do ato poético, além de tensionados pelos meios para compreender e transformar a realidade a nossa volta, a partir da materialidade da linguagem que o texto desvela. Se não houvesse a insistência da barra do Outro, do vazio que resiste ao significante e não se deixa falar, ler ou escrever, não teríamos mais motivos para explorar os enigmas de nosso universal dividido e de nosso traço unário. Ter condições de suportar as 
angústias nos momentos de entrave da leitura e da escrita e colocar-se no jogo da inferência se tornam, assim, importantes tarefas para o professor em sala de aula diante de alunos que já se veem estigmatizados como aqueles que não sabem ler, não sabem escrever, não sabem narrar e, consequentemente, não se conhecem e se sentem excluídos do processo de subjetivação imprescindível para a fase escolar na lida com textos complexos.

Ainda assim, a prática docente em sala de aula não vem apontando para o reconhecimento de nossos alunos enquanto autores, mas sim enquanto indivíduos enunciadores que devem repetir o discurso escolar sem refletir sobre seus princípios, suas leis e representatividade. Em concomitância, o trabalho com a estética e os textos poéticos vem perdendo cada vez mais força nas escolas, sendo substituído por uma abordagem utilitária de texto que não estimula a compreensão da língua em sua heterogeneidade discursiva. Sabemos que é o nonsense, a magia, a estranheza e o mistério do funcionamento do texto literário que abrem caminhos para o sujeito repensar o mundo e suas formas de comunicação, à vista disso, discorreremos na próxima seção sobre a potência e o alcance da função poética e seus desdobramentos na sala de aula.

\section{O alcance da função poética}

Hoje, no meio acadêmico estudioso de Schiller a Benjamin, de Saussure a Jakobson, de Valéry a Candido, de Freud a Lacan, afirmar que a essência da linguagem está na arte e na poesia se tornou um lugar-comum. No entanto, com o rápido desmonte dos currículos das ciências humanas promovido pelo atual governo, a arte sensível e transformadora vem sendo colocada em um lugar obscuro e abafado, e não nos parece mais redundante resgatar a ideia de que é a arte, as narrativas e os textos poéticos que estão no cerne da cultura e do processo de humanização dos seres. Reconhecemos, assim, a necessidade de continuar enfatizando a importância da linguagem poética nos processos de subjetivação e apreensão dos elementos estéticos da natureza, apesar de já termos avançado muito neste campo. No entanto, há projetos educacionais e práticas docentes que ainda acreditam que a faculdade da linguagem mais importante de ser trabalhada em sala de aula é a mera faculdade de comunicar, de transmitir informações e estabelecer interlocuções do ponto de vista pragmático. Esses projetos não vislumbram que há algo essencial da linguagem que é transmitido por meio do ato poético, cujas funções comunicativas cotidianas e concretas se encontram suspensas para dar lugar à imaginação criadora de efeito catártico. 
Devido à incongruência política e pedagógica de muitos livros didáticos e de outros materiais destinados ao ensino de Língua Portuguesa, notamos a presença de práticas docentes apoiadas em uma premissa pragmática do uso da língua que deixam para trás a diversidade e multiplicidade dos efeitos estéticos da linguagem artística capaz de dinamizar os modos independentes de ver o mundo. Ao se valer apenas de textos do cotidiano, como artigos de jornais e revistas, propagandas e outras produções focadas na função referencial, o professor se apega à ideia de linguagem como meio para comunicar uma informação útil (linguagem como Mittel) e se afasta da ideia de linguagem como meio no qual o ser humano percebe a si e a todas as coisas ao seu redor (linguagem como Medium). Ao nomear as coisas, o sujeito não está falando através da língua, mas é a língua que está falando através dele.

No primeiro capítulo, evidenciamos por meio dos estudos de Heidegger a linguagem com que o mundo se apresenta a nós num determinado modo de nomear discursivo, no qual a essência do espírito se manifesta exteriormente na língua, em uma estrutura mediada por símbolos, e não através dela. Isso porque a linguagem não deveria estar a serviço da comunicação mundana, mas sim a serviço da revelação do ser. É por este aspecto de revelação da nossa verdade interior como tarefa fundamental da linguagem (em vez de simples ato comunicativo) que Walter Benjamin se interessou ao escrever seu ensaio "A tarefa do tradutor" ${ }^{18}$ em 1923. Na tentativa de apontar as características de uma má tradução, o filósofo se indaga:

O que diz uma obra poética? O que comunica? Muito pouco para quem a compreende. $\mathrm{O}$ que lhe é essencial não é a comunicação, não é o enunciado. (...) Mas aquilo que está numa obra literária, para além do que é comunicado - e mesmo o mau tradutor admite que isso é o essencial - não será isto aquilo que se reconhece em geral como o inapreensível, o misterioso, o "poético"? Aquilo que o tradutor só pode restituir ao tornar-se, ele mesmo, um poeta? (BENJAMIN, 2001: p. 102).

A forma como Benjamin descreve o "inapreensível" e "misterioso" da obra poética assemelha-se à categoria do real de Lacan, pois sempre há algo que escapa e não se deixa dominar até mesmo na produção do artista mais consciente sobre os rumos estéticos de sua

\footnotetext{
${ }^{18}$ Este ensaio foi escrito por Walter Benjamin na intenção de compor o prefácio da edição de sua tradução dos Tableaux parisiens de Baudelaire, publicado em 1923 na Alemanha. No entanto, o ensaio não trata da lírica de Baudelaire, tampouco aborda seu trabalho de tradução dos poemas, mas apresenta a essência da filosofia da linguagem de Benjamin.
} 
obra. Ao leitor das obras poéticas impõe-se, então, um movimento de suspensão dos sentidos costumeiros das palavras que o desloca para diferentes formações discursivas com as quais não está acostumado, forçando, assim, uma experiência singular e memorável a partir de mundos contingentes concedidos pelo lirismo da linguagem (Candido, 2004). A revelação com a qual Benjamin se ocupa é resultado deste deslocamento do sujeito, que em busca da verdade que o real não o deixa ver, sai à procura do que o filósofo chamou de língua pura, que é, para nós, o impossível potente da linguagem poética, um lugar em que o excesso e a intensidade do que sentimos se estruturam em uma forma condensada de som e sentido, abrindo novos caminhos para o registro do Simbólico.

Em "Sobre a linguagem em geral e sobre a linguagem humana", Benjamin situa a revelação do ser guiada pela linguagem não a partir de um acúmulo de conhecimento ou de experiências científicas comuns aos sujeitos modernos, questionadores e investigativos. Ele atribui a possibilidade da revelação libertadora (a caminho da verdade) à origem da palavra, que, nesse caso, parte de uma conotação divina, mas, similarmente, podemos compreender também como a origem do dizer - genuíno e singular, como Heidegger costumou definir. Afinal, conforme revelou o Livro do Gênesis, "no princípio era o verbo", ou seja, a palavra poética sempre esteve na origem e essa questão sempre intrigou o ser humano.

O mistério que a origem provoca serviu de motivação para a criação da maioria dos mitos ocidentais e orientais, uma vez que, da mitologia grega à indígena, as narrativas buscaram explicar de onde vieram ou por que existem os cosmos e os seres do universo. Diversas obras, não apenas as mitológicas, valeram-se das inquietações sobre a origem, o novo, o desconhecido e o ininteligível. A título de exemplo, o campo das narrativas orais indígenas oferece um conjunto denso de mitos de origem, como a lenda da mandioca, do guaraná, do fogo, do uirapuru, entre outras histórias mágicas que firmam um sentido para o inefável. A partir de suas indagações e desconfortos, o ser humano transformou a angústia em linguagem poética, bem como evidenciou Lacan (1993) ao dizer que a mesma operação que mortifica a carne também vivifica o corpo, isto é, o efeito mortificante do Simbólico cria caminhos para que o significante motive o gozo e se manifeste na corporalidade, no mistério do corpo vivo. Logo, a origem da palavra está na poesia, na escrita do que não acontece ${ }^{19}$, na descoberta das coisas que nunca vimos ${ }^{20}$, na leitura do que nunca foi escrito ${ }^{21}$. A poesia está

\footnotetext{
${ }^{19}$ Segundo Manoel de Barros, “escrever o que não acontece, é tarefa da poesia” (2010, p. 31).

${ }^{20}$ No poema "3 de maio", Oswald de Andrade (1990) escreve: "Aprendi com meu filho de dez anos/ Que a
} 
no real da língua, no real do corpo. É aquilo que eleva nossa percepção diante das obras e das experiências do mundo, mesmo não sendo possível apreender sua totalidade, mesmo que ela perturbe e desconcerte, a poesia traz à tona nossa subjetividade. Isso porque os significantes ali compostos emanam no sujeito uma carga psíquica que supera o signo, o sentido e a própria linguagem, uma vez que a linguagem comum (como a julgamos conhecer no dia a dia) não é capaz de alcançar os efeitos que a poesia produz.

A poesia carrega consigo uma fórmula exata, como se o poeta fosse capaz de acessar o real e calcular precisamente a ordem e disposição das palavras nos versos. Como inspiração desse cálculo, por vezes, os poetas voltam a sua própria origem, às reminiscências da infância, às matrizes de textos orais que enredaram sua corporalidade, para seguir em busca da unidade entre som e sentido. Assim, na poesia, a palavra toma um rumo próprio e ganha caráter polifônico, com múltiplos sentidos, em um percurso de figurabilidade e de associação por metáforas e símiles que já não cumpre mais a função de simplesmente nomear as coisas do mundo. A palavra se torna mágica, pois na criação dos versos há a possibilidade de retirá-la de seu legado histórico, que a enfraqueceu enquanto matéria, fazendo-a delirar e se subordinar às leis da analogia. A esse fenômeno linguístico Jakobson (2010) deu o nome de função poética, cuja definição já conhecemos bem: a projeção do princípio de equivalência do eixo de seleção sobre o eixo de combinação. Quando a projeção das semelhanças e dessemelhanças (sonoras e semânticas) do eixo paradigmático se projeta sobre o eixo sintagmático, a combinação que normalmente ocorre por contraste se dá, na função poética, por similaridade, causando uma ruptura inesperada nesses dois modos básicos de organização da linguagem (Barros, 2014: p. 30). Formulando de outro modo, na estrutura linguística poética, as equivalências semânticas e fônicas ocorrem em posições sintagmáticas também equivalentes e operam como princípio organizador e recurso constitutivo da sequência do verso, constituindo, assim, tipos especiais de paradigmas.

Em sua ciência poética, Jakobson insistiu que o princípio de similaridade domina a poesia principalmente de duas maneiras: i) através do paralelismo métrico dos versos e da equivalência fônica dos termos, seja por meio de rimas, paronomásias, aliterações ou

poesia é a descoberta/ Das coisas que eu nunca vi".

${ }^{21}$ BENJAMIN, Walter. (1989, p. 1238): "Die historische Methode ist eine philologische, der das Buch des Lebens zugrunde liegt. 'Was nie geschrieben wurde, lesen' heißt es bei Hofmannsthal. Der Leser, an den hier zu denken ist, ist der wahre Historiker". 
assonâncias e ii) através da escolha e combinação de palavras próximas a um mesmo campo semântico, seja por sinônimos, antíteses, sinédoques ou símiles. No entanto, tais equivalências somente ocorrem em uma convergência de som e sentido, isto é, a partir de um processo em que o componente semântico é condensado no componente posicional, fundindo forma e significado, mas não entrelaçando apenas algumas formas linguísticas equivalentes no poema, mas sim unificando os versos como um todo. Não por outro motivo, Nancy (2016: p. 113), ao caracterizar a essência do poeta, diz que ele tem "uma consciência absoluta e constantemente determinada, completa e unificada, sem resto, que não retém nada em si e se dá toda ao seu olhar. (...) O alcance desse olhar atinge um todo: a totalidade desse todo é assim tocada para além — ou no além de — toda composição ou síntese, no centro, no coração, na junta que não totaliza, mas que é o todo".

A partir dessa ideia de totalidade e condensação, Jakobson se preocupou em esclarecer que não seria proveitoso confinar convenções poéticas como metro, aliteração ou rima ao plano simplesmente sonoro das palavras, uma vez que a projeção do princípio de equivalência na sequência do verso tem um significado muito mais profundo que o mero som que ela produz. Tomemos o conceito de rima para exemplificar esse fenômeno de unidade, uma vez que ela não deve ser tratada meramente sob o ponto de vista do som. Segundo o linguista, a rima implica necessariamente uma relação semântica entre unidades rímicas, máxima sintetizada ironicamente nos versos de Drummond em seu "Poema de sete faces": "Mundo mundo vasto mundo,/ se eu me chamasse Raimundo/ seria uma rima, não seria uma solução" 22 , sendo que, em seguida, Drummond rima "solução" com "coração" nos versos decorrentes: "Mundo mundo vasto mundo/ Mais vasto é meu coração". Assim, a equação que compõe a poesia não se dá apenas pela sequência fonológica já que ela implica inevitavelmente uma equivalência semântica que gera o efeito de hesitação entre som e sentido, comunicando, por consequência, uma "linguagem carregada de significado até o máximo grau possível" (Pound, 2006: p. 32).

Ao aprofundar as teses sobre as funções da linguagem formuladas pela Escola de Praga, Jakobson criticou o caráter mecanicista da teoria da informação uma vez que ela desconsiderava o contexto sócio-histórico e cultural da interação entre os seres humanos. Para ele, era urgente inserir os estudos linguísticos na multidisciplinaridade dos estudos da

\footnotetext{
${ }^{22}$ In: Alguma Poesia, 2006.
} 
linguagem, incluindo a teoria literária e a antropologia no diálogo com a linguística. Por estudar intensamente a poética, Jakobson pautou a importância das funções emotiva e apelativa para evidenciar na nova vertente do estruturalismo linguístico que, para além da racionalidade da interação, há fortemente presente na comunicação humana um caráter de manipulação passional e sensorial da linguagem. Por isso que seus estudos nos são tão caros para aproximar a função poética e o conceito de deriva exposto anteriormente na intenção de salientar o trabalho com poesia em sala de aula.

O esquema das funções da linguagem e a teoria da comunicação traçados por Jakobson indicou que, para ele, não existe um uso da língua meramente referencial, mas há numerosas interferências num texto determinado, inclusive interferências da função poética e de seu caráter passional, sensorial e estético devido às organizações inusitadas na fala ou em um texto, provocando equívocos ou desvios que, do ponto de vista literário, podem gerar riquezas de forma estilizada e singular, constituindo novos registros psíquicos no sujeito. Desta forma, Jakobson ressalta que a função poética não está restrita à poesia ou à literatura, mesmo sendo textos nos quais ela é predominantemente analisada. A função poética aparece também em propagandas, artigos jornalísticos ou religiosos, na nossa fala cotidiana e entre outros usos referenciais da comunicação, isso porque as funções da linguagem ocorrem ao mesmo tempo, no entanto há sempre uma que mais se destaca e influencia a interpretação do texto.

A partir desta teoria, é possível afirmar que a poesia é parte dos mecanismos da comunicação e está presente em nossos textos não apenas como valor literário e artístico, mas também em outros processos comunicativos que evidenciam o foco sobre a mensagem, cujo modo de pronunciar transcende a linearidade para a simultaneidade. Dito de outro modo, o efeito paronomástico da linguagem transracional e seus jogos de palavras comprovam a indivisibilidade da forma e do conteúdo.

Essa concepção do alcance da função poética foi um dos desafios do nosso curso de Língua Portuguesa com os alunos de Paraisópolis, principalmente no que diz respeito à corporalidade de jovens que já não se deixam levar ou experimentar espontaneamente os jogos linguageiros e as possibilidades lúdicas da língua como fazem as crianças em processo de alfabetização. Por ser capaz de tratar as palavras como objetos lúdicos, a criança tem facilidade para experimentar novas linguagens (a língua do p e o revestrés, por exemplo) e formas sintáticas artificiais - o que Freud (1974) chamou de truques linguísticos infantis. Diferentemente dos adolescentes que se envaidecem com frequência, as crianças não estão 
preocupadas se as brincadeiras com o nonsense da língua podem soar ilógicas, risíveis ou excêntricas demais, pois, muito pelo contrário, o gozo da criança se encontra exatamente nesse estranhamento que o adolescente tem medo de expor.

Ao ensaiar alguns exercícios com a linguagem poética ${ }^{23}$, descobrimos um tema motivador que despontou na performance oral da maioria dos alunos que não se sentiram acoados pelo fato inusitado da brincadeira ritmada: os temas que se sobressaíram foram a paixão e a desilusão amorosa. Foi interessante notar a associação direta que os jovens do primeiro ano do Ensino Médio realizaram a partir do trabalho com a função poética, vinculando-a estreitamente aos efeitos de sentido passionais. Para eles, a poesia estava aliada às paixões e às dores da desilusão amorosa, já que o contato que haviam tido com os textos poéticos demonstrava a alusão aos desejos inconcebíveis do sujeito do discurso (como o do eu-lírico de um poema) e a frustração decorrente de um amor não correspondido. Com base nessa asserção coletiva dos alunos, prosseguimos com a discussão sobre a função poética da língua, tomando cuidado para não a reduzir à poesia ou simplificá-la às produções versificadas, numa tentativa de extrapolar a concepção restrita que os alunos tinham do papel dessa função na comunicação.

Se tomarmos a paixão como efeito de uma intensidade que pode ser sentida por meio de um arranjo de palavras ou de uma combinação sintagmática presente no discurso emotivo, devemos considerar, portanto, que esses procedimentos linguísticos ocorrem não apenas no nível da enunciação, mas também no nível do enunciado. Essa complexidade do comportamento verbal da função poética é captada pela condensação de sentido orientada para o plano de expressão, isto é, a inclinação da mensagem poética está dirigida ao sistema significante, a sua massa fônica ou gráfica, tanto no nível fonemático como morfemático. Além disso, tal comportamento verbal é governado por leis imanentes, intrínsecas ao ritmo. A fim de formular a teoria da função poética de maneira acessível aos alunos do Ensino Médio, ativemo-nos no início do curso de Língua Portuguesa a uma dessas leis, especificamente, a lei do paralelismo entre as organizações da expressão e as do conteúdo.

A partir de produções dos próprios alunos ou de exemplos que trouxeram da experiência com a linguagem poética, elucidamos a ideia do paralelismo entre a organização por similaridade do som e a organização por semelhança ou dessemelhança do conteúdo. A

\footnotetext{
${ }^{23}$ Os exercícios supracitados serão melhor detalhados na exposição da sequência didática do curso de Língua Portuguesa presente no quarto capítulo da tese.
} 
ideia inicial foi estimular os alunos a reconhecer a tendência dos textos poéticos de seguir uma simetria sintática e semântica pautada pelas repetições, não apenas por meio do recurso da rima, mas também por meio de anáforas, paronomásias e outras figuras do som e da sintaxe que antes passavam despercebidas por eles ao lidar com a função poética em uma perspectiva menos abrangente. Inicialmente, a primeira identificação do verso se dava unicamente pela presença de rimas ou por uma intuição métrica de alternância das sílabas fortes e fracas, motivando a percepção de uma cadência peculiar. Contudo, ao longo do curso de Língua Portuguesa, os alunos foram ganhando repertório para constatar uma riqueza maior do simbolismo sonoro correlacionado ao seu aspecto conceitual, experimentando diferentes modos sensoriais e metafóricos.

Quanto mais os alunos puderam descobrir relações analógicas a partir do contato com a linguagem organizada em discurso poético, mais condições eles tinham de desvelar outros sentidos na dimensão do sensível. Para isso, a compreensão da metáfora e da metonímia cumpriu um papel fundamental nos exercícios da corporalidade em curso, isso porque:

\footnotetext{
em poesia, não apenas a sequência fonológica, mas, de igual maneira, qualquer sequência de unidades semânticas, tende a construir a equação. A similaridade superposta à contiguidade comunica à poesia sua radical existência simbólica, multíplica, polissêmica (...). Em poesia, onde a similaridade se superpõe à contiguidade, toda metonímia é ligeiramente metafórica e toda metáfora tem um matiz metonímico. (JAKOBSON, 1960 [1999a, pp. 149-150] apud TFOUNI, MARTHA, CARREIRA, 2014: p. 78)
}

Em nossa perspectiva metodológica cuja corporalidade do texto poético nos guia em sala de aula, é impossível separar a metaforicidade da linguagem figurada daquilo que captamos de maneira sensível, emotiva e cognitiva. A realidade que a poesia pretende exteriorizar nos leva a analisar a sociedade em que vivemos, nos faz refletir sobre nossa cultura e nossas tradições e nos permite, para além de ressignificarmos aquilo que já experienciamos, ter contato com outras realidades possíveis, a realidade de um outro mundo, fictício e mágico, inusitado e excêntrico, que nos desestabiliza por desconhecê-lo e ao mesmo tempo nos motiva a buscar as "verdades" do nosso próprio mundo. Ao ler o que nos é estranho, desencostamo-nos de nosso apoio confortável para encarar um outro ponto de vista por vezes doloroso, já que esse deslocamento atesta a presença da alteridade e da possibilidade de enxergarmos nosso modo de estar no mundo interpretado de um outro lugar, um movimento subjetivo que, mesmo podendo vir carregado de angústia e autonegação, suscita o autoconhecimento. 
A unidade da qual desfruta a mensagem poética transforma a palavra em matéria memorável, sobretudo devido ao fato de que a performance contida no lirismo da palavra nos faz experimentá-la enquanto palavra do real. Sua ordem engendra em nós um tipo especial de raciocínio, como um instrumento que "inspira a reflexão das tensões para além da poesia de nossa sociedade, seja sobre a sociedade, seja sobre o inconsciente estruturado como uma linguagem" (Tfouni, Martha, Carreira, 2014: p. 82). O paralelismo fonológico, sintático e semântico da função poética recria a fala cotidiana e revela o caráter substancial da metáfora, possibilitando deslocamentos e deslizes fundamentais no processo de subjetivação no que diz respeito à leitura tensiva e plural das sociedades contemporâneas. Diante desse desafio, o sujeito se vê obrigado a esvaziar o sentido ordinário das palavras para deixar surgir o inesperado, o nonsense do arranjo inusitado da linguagem poética, dando espaço para que a deriva se instale no discurso, para que a palavra que falta incomode e o movimento de alteridade aconteça. Afinal, "literatura é novidade que permanece novidade" (Pound, 2006: p. 33), dela sempre surgirá algo inédito no corpo do sujeito que a frui. É nessa intensa cinesia que o alcance da função poética se legitima como a arte do indizível, como a resistência da linguagem como medium e a experiência de outros mundos contingentes dentro e fora das salas de aula.

\section{Alteridade, autoria e estilo}

Para que esses sistemas falados cessem de enlouquecer ou incomodar, não há outro meio exceto habitar um deles. Senão: e eu, e eu, o que é que estou fazendo no meio disso tudo? - R. Barthes, "O prazer do texto", 2010:

No conto "O afogado mais bonito do mundo" ${ }^{24}$, de Gabriel García Márquez, lido no curso de Língua Portuguesa com a turma do primeiro ano do Ensino Médio, o narrador observador descreve a chegada de um corpo morto na beira da praia, avistado pela primeira vez por crianças que brincavam na areia. $\mathrm{O}$ defunto chegou a uma vila de pescadores onde pouca novidade existia e com a qual o resto do mundo pouco tinha contato. Quando os adultos se confrontaram com aquele homem afogado, surpreenderam-se com suas características completamente díspares e não puderam reconhecer naquele homem nenhum

\footnotetext{
${ }^{24}$ In: A incrivel e triste história de Cândida Eréndira e sua avó desalmada. Tradução de Remy Força Filho. Rio de Janeiro: Record, 2009, pp. 46-55.
} 
traço semelhante ao deles. Notaram que era muito maior, mais forte e pesava bem mais do que todos os homens da aldeia, tinha um rosto bonito que não expressava o semblante solitário de outros afogados e transmitia uma virilidade jamais vista pelas mulheres do povoado. Concluíram, então, que pela sua aparência serena deveria se chamar Estevão.

Naquele lugar esquecido e isolado do mundo, até um corpo morto era motivo de festividade. Pela tradição, as mulheres deveriam limpar e enfeitar o afogado para enterrá-lo em um longo ritual pitoresco. Nesse processo de despedida de Estevão, a vila e seus moradores nunca mais foram os mesmos. Com a chegada daquele corpo estranho, eles passaram a olhar desconfiados para suas próprias casas, seus familiares e suas tradições. Se Estevão tivesse sido morador da vila, pensaram as mulheres enquanto retiravam os resíduos do mar de seu corpo,

\footnotetext{
sua casa teria as portas mais largas, o teto mais alto e o piso mais firme, e o estrado de sua cama seria de cavernas mestras com pernas de ferro, e sua mulher seria a mais feliz. Pensavam que tivera tanta autoridade que poderia tirar os peixes do mar só os chamando por seus nomes, e pusera tanto empenho no trabalho que fizera brotar mananciais entre as pedras mais áridas, e semear flores nas escarpas. Compararam-no, em segredo, com seus homens, pensando que não seriam capazes de fazer, em toda uma vida, o que aquele era capaz de fazer numa noite, e acabaram por repudiá-los, no fundo de seus corações, como os seres mais fracos e mesquinhos da terra. (MÁRQUEZ, 2009: p. 50)
}

$\mathrm{Na}$ imaginação daquelas mulheres, Estevão havia sido um herói, um homem muito melhor do que seus maridos e, então, ocorreu-lhes de desejar o afogado secretamente e de, pelo menos naquelas horas, fantasiar uma vida possível ao seu lado. Os pescadores, que naquele dia não foram ao mar trabalhar, observavam de fora os olhares ternos e entristecidos de suas mulheres frente aquele homem corpulento e exuberante e sentiram ciúmes e inveja da autoridade que Estevão transmitia mesmo enquanto morto, poder este que eles em vida nunca tiveram.

É admirável a poeticidade com a qual Gabriel García Márquez narra o ritual de despedida nas linhas finais do conto, autorizando o movimento que a vinda daquele corpo provocou no olhar de cada um sobre si mesmo. Este foi o trecho que mais chamou a atenção dos alunos durante o exercício da leitura:

Enquanto se disputavam o privilégio de carregá-lo nos ombros, pelo declive íngreme das escarpas, homens e mulheres perceberam, pela primeira vez, a desolação de suas ruas, a aridez de seus pátios, a estreiteza de seus sonhos, diante do esplendor e da beleza do seu afogado. Jogaram-no sem âncora, para que voltasse se quisesse, e 
quando o quisesse, e todos prenderam a respiração durante a fração de séculos que demorou a queda do corpo até o abismo. Não tiveram necessidade de olhar-se uns aos outros para perceber que já não estavam todos, nem voltariam a estar jamais. Mas também sabiam que tudo seria diferente desde então, que suas casas teriam as portas mais largas, os tetos mais altos, os pisos mais firmes, para que a lembrança de Estevão pudesse andar por toda parte (...) (MÁRQUEZ, 2009: 55).

Ao final da leitura, iniciamos a discussão sobre o percurso de Estevão na vila de pescadores, sobre o desvio do corpo de um defunto afogado para que os moradores pudessem reconhecer sua própria essência. Devido ao encontro com Estevão e seu universo emudecido, as mulheres, os homens e as crianças daquele povoado experimentaram a força do diálogo e a escuta de suas próprias falas. Segundo a análise de Cézar e Santos (2010), o afogado que vem de fora se apresenta à vila como o "duplo exterior". Com sua chegada e com o estranhamento que causou na comunidade, as mulheres e os homens passam a refletir sobre seu aspecto e compará-lo ao seu próprio comportamento, reconhecendo os traços distintivos, as diferenças que os separam. Tal excentricidade se torna, ao final, um estranho familiar, revelando a possibilidade de identificação do sujeito a um traço do outro, a uma realidade que antes lhes era desconhecida. Esse movimento é similar à existência do traço unário da qual discorremos anteriormente, pois ele ocorre não como uma imitação daquilo que identificamos como traço do outro, mas como referente à singularidade, ao que é ímpar. Com a leitura deste conto, tivemos a intenção de despertar o espírito crítico dos alunos a partir da experiência de poder pensar de um outro lugar, vivida tanto pela trama dos personagens quanto pela própria realização do ato de ler, com a possibilidade de um distanciamento, uma descontextualização que nos leva a novas sociabilidades, a outros círculos de pertencimento e a construção de uma identidade singular.

Em seu artigo "Das unheimlich", de 1919, Freud trata do conceito do "estranho familiar", do "inquietante" causado pelo mal-estar na civilização, ou, em outras palavras, de algo que suscita uma sensação de desequilíbrio da ordem que julgávamos conhecer, originado pelo aspecto misterioso e ao mesmo tempo íntimo do que nos é estranho, sentimento recorrente na adolescência, fase em que nossos sujeitos da pesquisa se encontram. A palavra alemã "unheimlich" não tem significante correspondente na língua portuguesa, mas foi traduzida recentemente por "infamiliar" na tentativa de se aproximar à ideia de algo ou alguém que desconhecemos em nossa intrinsecidade, aquilo que não é inerente e próprio do sujeito, ou seja, que é procedente do exterior. Para explicar o significado de "unheimlich", Freud recorre ao conceito romântico que Schelling atribuiu à palavra: "Unheimlich seria tudo 
o que deveria permanecer secreto, oculto, mas apareceu" (Freud, 2010: p. 338). A angústia que os homens e mulheres do conto de Gabriel Garcia Márquez sentem ao se confrontarem com o corpo morto de Estevão faz parte do retorno do que estava recalcado, da elaboração confusa diante da presença de um estranho que se torna familiar, de um duplo exterior que passa a compor um duplo interior e impulsiona um reposicionamento subjetivo diante do outro. Em nossas discussões após o exercício da leitura, aproximamos a angústia das personagens ao processo de busca de identidade na fase adolescente, desafio atual de nossos alunos. Por um lado, eles se identificam com sua tradição familiar, sentem-se pertencentes aos posicionamentos éticos, religiosos e sociais estruturados pela família. Por outro lado, reconhecem o desejo de romper com a tradição, de se abrir a novas culturas, a outras verdades, mas se veem barrados por um mundo hostil que já está tomado de ideologias preestabelecidas que ditam as formas de consumo e de comportamento dos jovens. Eles se encontram em um impasse entre um mundo exterior afrontoso e um mundo interior inquietante, repleto de sentimentos contraditórios.

Antes de Freud, esse fenômeno de exteriorização para uma "reinteriorização" do sujeito foi explicado por Hegel a partir do conceito de Innerlichkeit (intrinsecidade absoluta). Conforme já exposto na pesquisa de mestrado (Joaquim, 2016), o sujeito romântico se vê diante de uma ruptura com a bela unidade do ideal clássico e lida com formas de superação de suas limitações quanto à relação sujeito-objeto. O sujeito não se encontra mais atado à exposição sensível, no entanto, devido à necessidade de realizar o percurso da autoconsciência, ele não está livre de ter de passar pela exterioridade, "que deve ser estabelecida, superada e refletida negativamente" (Hegel, 2001: 95). Em um movimento reflexionante, o sujeito se vê determinado a fazer um percurso por onde deve passar por si e pelo exterior para se materializar e retornar para o interior, buscando conquistar o seu absoluto. Este absoluto não incorpora a parte material da exterioridade, ignorando-a e provando a independência da sua interioridade, visto que o sujeito não será determinado pelo que encontrou lá fora. Ao mesmo tempo em que prova sua independência, o movimento absoluto se mostra contraditório, dialético, uma vez que um pedaço inteiro (aquilo que está na exterioridade e fora comprovado pelo sujeito) não lhe pertence e é por ele ignorado. Desta forma, mais uma vez, a autoconsciência do sujeito marca sua expressividade: "A interioridade comemora seu triunfo sobre a exterioridade e faz com que esta vitória apareça no próprio exterior e por intermédio dele, fazendo com que o fenômeno sensível desapareça na falta de valor" (idem). 
O contato que os moradores da vila tiveram com Estevão provocou uma saída inevitável para a exterioridade, para aquilo que não lhes era inerente, gerando, assim, uma sensação de incompletude, sentimento análogo ao descrito por nossos alunos. Na busca por melhor entendê-los, a nova filosofia do sujeito concedida pelos estudos hegelianos nos auxilia no modo de pensar a impossibilidade do sujeito de se manifestar completamente, pois ele carrega apenas a aparência de totalidade, no entanto, o que de fato ocorre é uma cisão, um conflito entre o absoluto e as manifestações corpóreas da linguagem. Graças a essa cisão, o sujeito pode ser capaz de "realizar uma pacificação mais profunda num mais íntimo acordo com o seu próprio domínio interior" (Hegel, 2001: 96). Ainda assim, permanece o conflito com a linguagem e a insatisfação devido à fragilidade e à incompletude de sua exteriorização, uma vez que a linguagem é o veículo e a matéria da manifestação do exterior, e, não havendo acordo entre o interior e o exterior, o ser humano e sua expressão também não estarão de acordo.

Ao passo que o sujeito se utiliza da linguagem para expressar sua subjetividade, ele a afirma, mas percebe que não está completamente presente e que esta expressão não faz parte da sua interioridade. Deste modo, o sujeito não se reconhece em sua manifestação, rejeitando a linguagem, porque o absoluto nunca estará inteiramente ali expresso. Dessa forma, a expressividade sempre será imperfeita e o sujeito não poderá escapar das trapaças da linguagem, tanto verbal quanto a linguagem presente em um corpo afogado, por exemplo, que, na obra de Gabriel García Márquez, foi capaz de retirar inesperadamente a máscara que escondia a verdade tida como absoluta pelos moradores da vila. Logo, como afirmou Barthes (2016), resta-nos assumir o desafio de trapacear com a língua, deslocá-la do controle dos signos e preenchê-la com nossos próprios desejos.

Nesse sentido, os movimentos de alteridade e de identificação do traço unário se tornam fundamentais para marcar a existência do sujeito no mundo e no campo do Outro no qual se enuncia. Antes mesmo de nascer, os desejos parentais do Simbólico estabelecem ao sujeito uma cadeia de significantes que lhe dão nome e destino, originando um dos primeiros efeitos do conflito com e em meio à linguagem. Diante de um outro, o sujeito será desafiado a expor sua interioridade por meio de mecanismos que ele não consegue controlar totalmente e buscará, portanto, compor uma marca singular, um estilo próprio de manifestação.

$\mathrm{Na}$ análise das relações entre sujeito e linguagem, o estilo se caracteriza como a expressão singular ou idiossincrática que remete a um escrevente ou locutor ao seu modo de compor o discurso, ou seja, é sua marca identificatória, seu rastro de presença ou sua 
subjetividade que estão em jogo (Signorini, 2010, p. 198). No entanto, já que o sujeito se encontra dividido entre a ilusão do controle de suas manifestações e a deriva do sentido imposta pelo inconsciente, esse traço singular que ele acredita encontrar não deixa de ser uma outra ilusão de ter se identificado em seu próprio discurso, de ter reconhecido um estilo que aparentemente lhe garante a plenitude de sentido, um preenchimento daquele vazio devido à conquista de novos significantes. Mesmo sendo uma ilusão, esse movimento é importante na medida em que possibilita um deslocamento do sujeito do lugar da mesmice mecânica e repetitiva do discurso ideológico (ou daquele proferido pelo neurótico), abrindo novos caminhos para um discurso contínuo, coerente e coeso cujo conteúdo pode representar a própria história do sujeito.

O conceito de estilo pode estar atrelado, portanto, à ousadia do sujeito em extrapolar as velhas formas do discurso para, então, explorar os textos por meio das paixões do campo sensível e estético, a título de exemplo a partir de nossas experiências em sala de aula. Deste ponto de vista, o domínio da escrita e de suas regras gramaticais possibilitam ao sujeito maior poder e confiança para se colocar nas práticas discursivas dominantes e disputar ideologicamente seu espaço na sociedade. Nesse caso, ao sujeito da escrita fica vinculada outra perspectiva de ilusão, a de controlar ou de precisar os significantes no processo de deriva, uma vez que o espaço-tempo da produção do discurso gráfico é maior e mais fácil de administrar comparado ao discurso oral. A sensação que a escrita nos dá é a de ser capaz de nos manifestar com exatidão, de encontrar palavras que correspondam perfeitamente às nossas ideias e, por conseguinte, de garantir ao nosso leitor uma compreensão completa daquilo que pretendemos expor, como se essa compreensão dependesse somente da nossa capacidade de traduzir impecavelmente nossos pensamentos a partir da escolha de um léxico correto.

O lado positivo desse movimento é que a ilusão é própria da arte e da literatura. As lacunas e os espaços em branco que ficam no interdito promovem ao fato ilusório uma energia que resiste ao obscurantismo das palavras e segue à procura do preenchimento, da fixação e do gozo da liberdade de se enunciar e se colocar como interlocutor. Segundo Barthes (2010: p.15), esse é o prazer que o texto gera, na intermitência entre algo que se mostra e se esconde, que está nas bordas, encenando um aparecimento e um desaparecimento, logo, o sujeito diante de uma escrita fica à margem de uma indecisão, de um prazer edipiano em busca da origem, da verdade e do fim. Mesmo que o sujeito tente controlar a deriva no ato de escrita, o prazer que o texto gera, segundo Barthes (2010: p. 26), pode muito bem assumir 
a forma da deriva. A linguagem arrasta o sujeito para experimentar as ilusões, seduções e intimidações que provoca, deixando-o levar pela deriva toda vez que o todo não é respeitado, toda vez que a linguagem social lhe falta.

Contudo, seguir em busca de um estilo pressiona o sujeito a executar uma outra missão referente às habilidades do uso do código que não se estabelecem apenas pelo conhecimento da língua em sua dimensão oral, já que ela está a serviço de um poder e corresponde a uma legislação. $\mathrm{Na}$ ordem do discurso da sociedade estratificada, é preciso também ter competência para lidar com os instrumentos de poder da classe dominante que impõe as normas de prestígio e de valor do saber linguístico. Como na sociedade capitalista tudo é transformado em mercadoria, o estilo também é vendido como tradições de escolas literárias, como marcas que identificam um autor específico, como o discurso da retórica e da ciência, e aqui cabe até mencionar sua acepção mais superficial como o estilo nos modos de se vestir e portar. No que se refere aos estudos literários e do discurso, essas tradições moldaram as práticas escolares de ensino da leitura, interpretação de textos e da produção escrita, cuja abordagem do estilo se tornou vulgar e sem vínculo entre o sujeito e o texto.

Dessa forma, o movimento de deslocamento do sujeito em busca do estilo e da autoria diante tantas adversidades, subjetivas e ideológicas, tanto por parte dos mecanismos inconscientes, quanto dos mecanismos sócio-históricos, depende da alteridade:

\footnotetext{
Uma das consequências importantes da codificação do saber linguístico nas gramáticas e dicionários foi o aparecimento da alteridade. Segundo Auroux (1992, p. 22) "o florescimento do saber linguístico (...) tem sua fonte no fato de que a escrita, fixando a linguagem, objetiva a alteridade e a coloca diante do sujeito como um problema a resolver. Nesse sentido, os trabalhos de Eni Orlandi sobre o discurso fundador (v.g., 1991), que mostram como somos construídos como outros de nós mesmos e para nós mesmos dentro do discurso (escrito) dos "descobridores", são importantíssimos para mostrar essa relação entre o poder da escrita (ou de quem escreve) e a submissão à qual é submetido o iletrado (TFOUNI, 2010: p. 95, grifos nossos).
}

Para que o sujeito se afirme em uma posição discursiva e produza efeitos de estilo que se refiram ao seu modo de inscrição no discurso (constituindo assim seu papel de autor na sociedade) é necessário que ele tenha acesso a uma rede de textos que possam compor sua corporalidade e intertextualidade. Assim, em uma relação moëbiana e constitutiva da transição da oralidade para a escrita, compreendemos que é imprescindível ao sujeito uma imersão profícua nos tipos de produção literária e artística, em que o estilo como agenciamento de formas e forças linguísticas se sustente em um "estado de tensão" que, 
segundo Deleuze (1992 apud Signorini, 2010), seja uma tensão que direcione o sujeito para fora da linguagem. Com essa expressão, o autor explica que estar fora da linguagem é deixar que perceptos e afetos constituam o estilo como singularidade de uma visão de mundo, um conjunto de experiências não propriamente individuais ou subjetivas, mas que possam transbordar e exceder a intensidade da prosa e da poesia, das narrativas e da função poética. "Desse modo, o que vem "de fora" não é alheio ao escrevente, pois o afeta e é pelas/ nas ações do escrevente que se concretiza como texto" (Signorini, 2010: p. 202) as percepções e os afetos, "devires que transbordam aquele que passa por eles (tornando-se outro)" (Deleuze, 1992: p. 171 apud Signorini, 2010: p. 202).

Como educadores e professores de Língua Portuguesa, a questão da produção de texto dita criativa e a leitura de obras dita retroativa e significativa nos coloca um grande desafio: pensar uma metodologia de ensino e uma prática docente que retirem os sujeitos enunciadores da posição de meros reprodutores do discurso escolar mecanizado e atrofiado, que transformem o olhar para as produções dos alunos que hoje está restrito às regras institucionais, às correções ortográficas e gramaticais, impulsionando-os a enxergar para além do código, a fruir e experimentar mais o estilo da função poética, do lugar de fora da estrutura colonial, de fora da linguagem, recriando aquilo que nos escapa, retomando a ideia de que a literatura "é a Terra Prometida em que a linguagem se torna aquilo que na verdade deveria ser" (Calvino, 1990: p. 72).

Embora seja fundamental que a escola cumpra com as exigências do ensino da gramática e do domínio culto da língua, ela carece de uma visão de estilo como "processo heterogenético de atualização e (re)contextualização sócio-histórica dessas formas e fórmulas em função de um "fora" que as atravessa, contorce, rompe e até vira do avesso" (Signorini, 2010: p. 207), ou seja, temos observado a insuficiência do trabalho com a função poética capaz de provocar outros sentidos para as exigências do estilo. Além disso, cabe-nos também a análise da heterogeneidade de nosso grupo-classe para pensar as ações mais relevantes e significativas para o aqui e o agora na situação de produção de texto dos alunos envolvidos, refletindo sobre o que é possível e desejável de realizar diante daquele contexto. Retomaremos essa questão no quarto capítulo ao expor as produções autorais dos alunos do Ensino Médio.

Evocando mais uma vez Jakobson para concluir a consideração acerca do papel da alteridade, do estilo e da autoria no processo de letramento, vale retomar que a linguagem é um meio essencialmente figurativo da expressão humana e, por isso, "os processos 
metafóricos e metonímicos estão constantemente em ação, mas estão também sob influência dos modelos culturais, da personalidade e do estilo verbal, ora um, ora outro processo goza de preferência" (2010: p. 70). Na constituição de uma subjetividade que escreve e se inscreve no mundo, o estilo e a singularidade de cada indivíduo operam na manipulação desses tipos de conexão (da similaridade e da contiguidade), tanto no aspecto posicional como semântico, selecionando, combinando e hierarquizando os significantes em cadeia, revelando assim, seu estilo pessoal, seus gostos e preferências verbais. Vale lembrar também que, na poesia, a interação desses dois elementos é particularmente marcante e, por isso, defendemos que ela esteja em sala de aula como forma de descobrir o desconhecido, ultrapassando as barreiras da linguagem.

Os linguistas da Escola de Praga reconheceram a importância do estilo na linguagem poética devido à desautomatização dos elementos linguísticos posicionados de forma não ordinária. Na linguagem comum, os elementos automatizados não chamam a atenção para si, eles simplesmente comunicam, enquanto que na função poética eles são postos em primeiro plano e sua seleção gera um estranhamento que deve ser analisado na mensagem conduzida pelas distribuições de frequências e pelas probabilidades transicionais de seus traços linguísticos. Essa característica enriquece o exercício de interpretação diante de um texto poético, pois o aluno se vê obrigado a lidar com o descontrole do devaneio poético, com um enigma nas entrelinhas, com palavras que extraem imagens insólitas, subvertendo o sentido habitual do enunciado.

Essa lida não é tarefa nada fácil, por isso, defendemos que, em sala de aula, o professor cumpra um papel fundamental de estímulo à decifração e de mediação (mesmo que sutil e discreta) entre o texto e o leitor na tomada consciente do poder ambíguo da palavra. Por mais solitária que seja a atividade da leitura, ela implica uma abertura para a linguagem do outro e a possibilidade de se reinventar em mundos inexistentes, impossíveis e irreais. Aprofundaremos a seguir a importância da leitura e da apreensão do efeito estético na formação dos sujeitos e na resistência à exclusão social. 


\section{A leitura e o efeito estético}

Tomar o texto para si, a nosso ver, é ativar a corporalidade imbricada na constituição subjetiva, que, quando bem formada entre os textos da tradição oral, impulsiona o desejo pela leitura e pelo contato com as produções literárias escritas. Acreditamos, portanto, que a oralidade está na origem do gosto pela leitura, e que esta, por sua vez, não deixa de ser uma performance do corpo, de um corpo que se aquieta, recolhe-se e se deixa impregnar pela polifonia das vozes de um outro. Ao transmitir a obra pelo texto escrito, sua recepção não é mais coletiva como na transmissão oral, mas está concentrada no sujeito, em uma entidade de fenomenologia psicológica. Nessa troca dinâmica entre obra e a consciência do leitor, a leitura ocorre em uma performance de tomada da linguagem que fala por meio de traços e sinais, cuja percepção se dá em uma situação transitória e única, da expressão e da elocução juntas (Zumthor, 2016: p. 57).

Com a Escola de Constança aprendemos que a obra literária só passa a existir de fato depois de ativada pelo leitor, como definiu Wolfgang Iser em seu livro $O$ ato da leitura: uma teoria do efeito estético (1996), ao dizer que a obra é o ser constituído do texto na consciência do leitor. Iser propõe em sua teoria que o efeito estético de uma obra deve ser analisado na relação dialética entre texto, leitor e sua interação, pela qual o leitor "recebe" o sentido do texto ao constituí-lo. Devido a esse ponto de vista, Iser e Jauss se tornaram os autores alemães mais representativos da estética da recepção, cuja análise do fato artístico enfoca a relação dinâmica entre autor, obra e leitor, constituindo, assim, um novo paradigma da investigação literária e discursiva, voltado para as condições sócio-históricas das diversas interpretações textuais.

Por aproximarmos a atividade da leitura aos conceitos de performance e recepção, devemos logo no início da discussão distinguir suas abordagens, uma vez que, segundo Zumthor (2016), a performance é parte de um momento da recepção, em que um enunciado é realmente recebido pelo leitor, mas não pode ser caracterizada como um mesmo fenômeno. Enquanto que a performance carrega uma conotação antropológica e não histórica, relativa às condições de expressão e percepção, a recepção se dá em uma compreensão histórica, implicando um processo de extensão imprevisível, mas podendo durar bastante tempo. A performance designa um ato de comunicação referente a um momento tomado como presente, cuja mensagem recorre imediatamente à presença concreta dos participantes no ato enunciativo. Já a recepção, através da existência real do texto, expande-se no corpo, no espaço 
e na sociedade onde o texto produz seus efeitos. Ela se concentra no sujeito e se produz em circunstância psíquica privilegiada, intermediada pela performance. Zumthor acrescenta ainda que o fato de a performance compor o ato de leitura expande o alcance e sentido da teoria de recepção para a ideia aristotélica de catarse. Ao se comunicar por meio de um texto, o sujeito não pretende apenas transmitir uma informação, mas intenta mudar, transformar aquele a quem se dirige. Não é possível saber de prontidão em que medida o ato da leitura literária é capaz de modificar o conjunto de sensorialidade do ser humano, mas é sabido que essa leitura reconstrói o sentido das experiências e cumpre um papel fundamental no engajamento do corpo:

\footnotetext{
Tal é, em nossa civilização, o meio natural de toda "literatura"; poesia desde o instante em que ela se forma até aquele em que é "recebida". A leitura se desenrola sobre o pano de fundo do barulho de voz que a impregna. Para o homem do fím do século XX, a leitura responde a uma necessidade, tanto de ouvir quanto de conhecer (...). É uma voz que ele escuta e ele reencontra uma sensibilidade que dois ou três séculos de escrita tinham anestesiado, sem destruir (ZUMTHOR, 2016: p. 60).
}

Nesse sentido, a leitura exige uma intepretação e não se dá separadamente à análise e tampouco é uma operação abstrata. Ela é inevitavelmente particular, um confronto pessoal e um diálogo muitas vezes regido por nós mesmos, no qual nosso corpo deve lidar com a materialidade do texto, evocando uma voz que é internamente nossa, mas externamente de um outro. Essa contradição chamou a atenção de Barthes (2010: p. 24) ao formular o que seria o prazer oferecido pelo texto, que, segundo ele, ocorre exatamente nesse momento em que o corpo segue suas próprias ideias, pois o corpo não tem as mesmas ideias que julgamos possuir. $\mathrm{O}$ autor distingue o texto de prazer do texto de fruição como aquele que contenta, enche, dá euforia, mas vem da cultura, não rompendo com ela, mas conectando-a aos sujeitos em uma prática confortável de leitura. Já a fruição do texto põe em jogo o estado de perda, aquele que desconforta, faz vacilar as bases históricas, culturais e psicológicas do leitor, pondo em dúvida a consistência de seus gostos, de suas lembranças, provocando uma relação conflituosa com a linguagem (idem, p. 20). Na leitura, as regras do jogo são de fato dialéticas, reguladas entre o prazer cultural e a fruição incultural, o jogador, sujeito histórico que deve ocupar seu lugar no espaço vazio do texto onde foi arremessado, necessita articular a voz do corpo com a letra do sentido para que a leitura seja "recebida".

A execução desse jogo se aprende com a experiência, com a prática de recepção, e exige esforço, concentração e constância. Por isso defendemos que as metodologias do ensino 
de Língua Portuguesa devem ser investigadas e reformuladas de acordo com o avanço das tecnologias e as mudanças sócio-políticas na sociedade. Não é de se espantar quando o jovem escolar desacredita e autoestigmatiza sua força e persistência na lida com os textos literários, uma vez que a literatura exige muito do corpo e da subjetividade para que o sujeito possa entrar no jogo e participar dele até o fim. Nesse direção, as desistências e evasões se tornam frequentes. Ao mesmo tempo, é preciso desescolarizar a leitura e superar a concepção que o aluno tem do texto como mera ferramenta pedagógica, provando o valor do texto literário junto ao deleite e à fruição que o ato da leitura proporciona.

Logo, a leitura de poesia pode ser um pontapé inicial nesse jogo, já que os sons que ecoam no texto estão fortemente ligados ao sentido que estabelecem, constituindo vias de unidade entre expressão e conteúdo que podem estimular os leitores a desvendar seus mistérios. A leitura da poesia explora a escrita de uma maneira não-linear, capacita o sujeito a estabelecer retroações necessárias para a apreensão do todo do texto, busca decodificar as entrelinhas e interpretar imagens instigantes. Segundo Belintane (2017: p. 188), a leitura auxilia no exercício retroativo de apreensão, ressignificação e reorganização do conhecimento, de tudo o que aprendemos com os ouvidos e os olhos. "Antes, nas comunidades ágrafas, isso era feito por meio da repetição, que nunca era uma retomada exata do texto dito antes, mas um novo parafraseamento e, claro, com um posicionamento subjetivo de quem quer mesmo o texto para si." Nessa performance de repetição de um discurso, a poesia se tornou objeto fundamental para a memória e se converteu em um fato de ritualização da linguagem. No entanto, com o advento da escrita, o ser humano experimentou a insurgência contra o tempo, contra o esquecimento, conservando em palavras sua história e se sentindo poderoso por ser capaz de arquivar em suportes conhecimentos e tradições milenares. Todavia, a poesia não perdeu o seu valor e se assemelhou à escrita por fazer parte dessa luta contra o passar dos séculos, já que, por meios não comparáveis, ela garantiu um outro tipo de reflexão sobre a linguagem, um tipo de esforço radical que não permitiu sua estagnação e banalização.

Mesmo com o avanço da escritura e das tecnologias, a poesia resistiu não apenas sob a forma dos livros, mas também na corporalidade, mesmo porque a "materialidade do livro pode, pois, ser vista como metáfora da corporalidade da escritura que, ao inscrever-se em nosso imaginário, funda novos conceitos e nos obriga a mudar de posição diante do mundo e de nós mesmos" (Toneto, 2010: p. 54). A existência do livro como objeto de valor na 
sociedade ocorre apenas na presença de um leitor e na profundidade de seu olhar sobre o texto, o livro se torna a extensão de sua memória, a continuidade de seu domínio linguageiro.

\section{O suporte material para a leitura}

Desde a Idade Média o livro era visto como símbolo de prestígio e como metáfora para representar sabedoria, sobriedade e sensatez (naquela época, a sociedade ainda desconhecia a história de Dom Quixote e seu enfrentamento contra os moinhos de vento). Com o objetivo de comportar os tesouros da memória humana, o livro apresentava à nobreza daquele tempo a experiência de muitas gerações, o que correspondia a um dos grandes valores do registro, já que raramente as pessoas viviam anos suficientes para ver seus netos nascerem e seu legado se difundir entre as novas gerações. Carregar um livro nas mãos significava transportar de forma segura e fiel a tradição de um povo, cujo progresso era inegável pela qualidade dos pergaminhos, pelo avanço das técnicas de escrita, pela execução de cópias dos textos sagrados feitas para durar para sempre. Do registro das escrituras sagradas, composto pelas liturgias, o ser humano passou a reproduzir graficamente as leis, a gramática e a poesia. Segundo Draaisma (2005: p. 64), nos séculos XII e XIII, a tradição de livros escolásticos evoluiu gradualmente em comparação aos livros monásticos, devido ao surgimento das primeiras universidades e dos cursos de Teologia. Já não era mais possível realizar leituras em voz alta, como se fazia antes nos monastérios, uma vez que o tempo das aulas era limitado e não havia exemplares suficientes para todos os alunos. Somente no século XIII a Bíblia se tornou portátil e graças às letras menores e ao pergaminho mais fino, passou a ser copiada em um só volume, permitindo seu transporte em viagens. Com o passar dos séculos, os livros ganharam novas concordâncias, índices, tipografias, organização em seções, mais cores, materiais mais leves e versáteis.

No início do século XV, o consumo dos livros estava no auge, no entanto, antes mesmo da invenção da prensa para suprir uma demanda de mercado, os livros passaram a ser copiados por escribas não profissionais e sua qualidade diminuiu o suficiente até o respeito pela palavra escrita ser colocado em questão. Após a invenção da prensa, surgiram grandes gráficas que substituíram os livros de pergaminho por papel e a sociedade começou a viver uma era em que os livros deixaram de ser raridade e se transformaram em um instrumento prático do dia a dia. Com a proliferação do mercado de livros e com uma pequena democratização do acesso à leitura, a polêmica em torno de seu prestígio aumentou. No início 
do século XVII passaram a questionar sua utilidade, os sintomas que a leitura incessante acarretava, sua durabilidade, e, aos poucos, os livros não estavam mais associados com a memória que possibilita a permanência de um legado, mas sim com a finitude e a futilidade do que é mundano (Draaisma, 2005: p. 68). No século XVIII o poeta holandês Jan Luyken escreveu os seguintes versos: "um livro impresso na cera do coração/ vale mil livros no porão" (idem, p. 69), aludindo a ideia de que era preciso valorizar o que reter na memória expandida. Para alguns artistas da época, o bloco de cera de Platão e o coração de Aristóteles ainda faziam mais sentido para a intenção da escrita, do que um calhamaço de papel.

Logo, "o amor e a reverência pelos livros como tais, próprios de uma época em que nenhum livro era duplicado até que alguém se desse ao trabalho de copiá-lo a mão, não respondem mais, obviamente, 'às necessidades da sociedade' ou à preservação do saber. Precisa-se com urgência de uma boa poda, se é que o Jardim das Musas pretende continuar a ser um jardim" (Pound, 2006: p. 23). Hoje, vivemos na era das memórias externas e artificiais, em que a pesquisa eletrônica, os livros eletrônicos, os computadores portáteis fizeram diminuir a necessidade de impressão de livros ao ponto de provocar o fechamento de várias livrarias e editoras que não se sustentaram em seus negócios. Vivemos em uma época de avanços tecnológicos tão dinâmicos que a cada ano surgem novas formas de uso do suporte eletrônico mediados pela internet. Por mais que os textos não se modifiquem ao serem transmitidos por um ou outro determinado suporte, a dinâmica do ato de leitura pode se diferenciar, bem como a relação do leitor com a obra. Por mais instigante que seja essa questão de como os diferentes suportes podem alterar as dinâmicas de leitura, não nos cabe agora aprofundá-la, mas a citamos aqui como um aspecto relevante a ser considerado nas práticas docentes. Ainda assim, em sala de aula, o livro continua a ser um dos principais e mais utilizados suportes de escrita, mas é sabido que as telas disputam a atenção dos alunos de maneira intensa e frequente.

Dessa forma, é preciso compreender que, independentemente de em qual suporte a escrita se encontre, a ideia de portar um texto, de haver um lócus físico ou virtual para fixar a materialidade da escrita (Marcuschi, 2003) fornece ao texto escrito um status de não objeto, pois é o seu suporte que o distingue em relação ao seu tipo de reprodução. Se o texto é inseparável do modo de existência material, ele se estabelece somente na medida em que seu suporte garante sua comunicação, seu transporte, reprodução, recepção e, por fim, sua memorização. A impressão material do texto lhe permite uma característica particular de ocupar um lugar isoladamente, uma posição física única, diferenciando-se dos suportes 
virtuais que fixam os textos em um sistema de dados com vários outros textos presentes em uma pasta de memória virtual. Assim, acreditamos que o contato com o volume do texto a partir do suporte físico de um livro representa ainda um valor fundamental para o exercício da leitura. Folhear as páginas, tocar o livro e marcá-lo com seu manejo, abrir e fechar sua capa, desenvolver estratégias para demarcar a página em que a leitura foi interrompida, visualizar o percurso da leitura em seu volume, o quanto já foi lido, o quanto falta para terminar são aspectos que mantém o livro ainda como suporte privilegiado, mais dinâmico e vivo se comparado a outros suportes, além de não depender de conexões, baterias ou eletricidade. Não pretendemos nos posicionar contra o avanço das tecnologias e nem desconsiderar sua relevância, pelo contrário, buscamos cada vez mais utilizá-las a nosso favor. Sabemos, também, que essa descrição da relação com o livro pode ressoar um tanto romantizada, mas a ideia que pretendemos transmitir é que essa experiência evoca um empenho do corpo que é diferente do contato com as telas. Acreditamos que a performance de leitura diante de um livro tradicional pode facilitar a "corporização" do prazer literário e poético devido ao seu caráter mais palpável, no entanto, reconhecemos a praticidade do livro eletrônico e a pluralidade de sua existência. Retomaremos esse assunto no item a seguir ao tratar da escolha feita pela escola-campo em não investir amplamente em uma biblioteca (no momento em que a pesquisa foi aplicada), mas concentrar todo o material escolar na plataforma eletrônica do moodle.

\section{O empenho do corpo na leitura poética}

Zumthor (2014), em seu livro "Performance, recepção, leitura", desenvolve seis teses sobre o efeito da voz no corpo a partir da leitura do texto poético. Estudioso da performance da poesia oral, o autor ressalta que a estrutura de sentido do texto se transforma da performance à leitura, uma vez que o texto escrito deve ser interpretado também como objeto semiótico, não se tratando necessariamente de um processo global de significação. Já na performance, o gesto, a entonação, o tempo, o lugar e o cenário transbordam o signo e devem ser analisados como um todo. Ainda assim, nos dois casos, há sempre algo que escapa da interpretação, elementos marginais, múltiplos significantes, sistematizados ou não no contexto cultural, o que Zumthor denominou de "barulho de fundo existencial (as conotações, condicionadas pelas circunstâncias e o estado do corpo receptor, do texto e dos elementos não 
textuais)" (p. 74).

Dessa forma, o corpo é elemento central na percepção do discurso, é por meio dele que o mundo toca o sujeito, em uma ação dupla, em que o corpo dá a medida e as dimensões do mundo e o mundo as devolve ao sujeito à luz de uma nova experiência subjetiva. O corpo é "ao mesmo tempo o ponto de partida, o ponto de origem e o referente do discurso" também no ato dinâmico da leitura, em que o leitor, na escuta de uma voz, refaz e reconstrói a comunicação que se estabelece em seu corpo e em seu espírito ao compreender a mensagem do poeta. Dito de outra maneira, é através da voz introjetada na mente, a partir da ordem do sensível e da leitura retroativa, que o corpo sente as palavras, estabelece novos sentidos a elas e se posiciona subjetivamente no mundo.

Diante da leitura de textos poéticos, esses significantes que tocam o corpo se tornam mais evidentes. A harmonização dos versos por meio das rimas, das aliterações, dos paralelismos e repetições causam sensações tanto de ordem biológica como de ordem psíquica. Podemos nos emocionar com a combinação de palavras e também convocar de memória algo que já nos era conhecido através de sons, imagens e sentidos que estão inscritos em nossa memória corporal. A experiência poética aflora essa expressividade do corpo, a poesia "invade tudo", faz com que algo se passe em nós.

\footnotetext{
É por isso que o texto poético significa o mundo. É pelo corpo que o sentido é á percebido. O mundo tal como existe fora de mim não é em si mesmo intocável, ele é sempre, de maneira primordial, da ordem do sensível: do visível, do audível, do tangível. O mundo que me significa o texto poético é necessariamente dessa ordem; ele é muito mais do que o objeto de um discurso informativo. O texto desperta em mim essa consciência confusa de estar no mundo, consciência confusa, anterior a meus afetos, a meus julgamentos, e que é como uma impureza sobrecarregando o pensamento puro... que, em nossa condição humana, se impõe a um corpo (...) (ZUMTHOR, 2014: p. 76)
}

Como vimos a partir dos estudos da psicanálise lacaniana, o sujeito insiste no desafio de decifração da leitura justamente por constatar a falta de firmeza desse pensamento puro como mencionado por Zumthor, já que o texto poético se faz no real, no que está sempre fora, na exterioridade da presença de um sentido suspenso, de uma busca pelo objeto perdido. A recepção do texto poético se dá essencialmente nessa busca e nessa presença suscitadas pela leitura, no entanto, elas não são busca e presença plenas, mas misteriosas e ameaçadoras. Isso porque as vozes de um texto literário implicam no sujeito leitor um movimento de alteridade, de confronto com o estranho, decorrentes de seis principais evidências postuladas por Zumthor (2014, p. 80): 
1. A voz do texto é o lugar simbólico por excelência, cuja relação e articulação entre sujeito e objeto ocorre apenas na relação entre o objeto e o outro, isso porque essa voz é inobjetivável;

2. Dessa forma, a voz do texto estabelece ou restabelece uma relação de alteridade, que funda a palavra do sujeito leitor, junto a seu traço unário, a seu estilo e à intertextualidade;

3. Quando vocalizado, todo objeto adquire uma dimensão simbólica e, nos textos reconhecidamente poéticos, essa voz é interiorizada de maneira mais intensa pela unidade entre som e sentido;

4. Na leitura de textos poéticos, a linguagem não cessa de trapacear, ela se manifesta através de uma voz subversiva, rompendo a clausura do corpo, sem romper seu limite, suas bordas. Esse processo ocorre, como já vimos, moëbianamente, em que subjetividade e alteridade transitam pelo corpo mutuamente. A voz do texto significa o lugar de um sujeito que não se reduz a sua individualidade, pois ela se aloja no seu corpo, revelando um limite e uma liberdade. Quando o sujeito fala, já não é apenas a sua própria voz que está presente no discurso e que habita sua linguagem, mas a voz de um outro, de um interdiscurso.

5. A voz do texto não é especular, ou seja, não tem um espelho, não reflete o que está diante de si, mas tende a refletir sua própria realidade.

6. Escutar a voz de um outro dentro de si, em silêncio, é escutar a sua própria voz que vem de outra parte. A voz que ressoa do texto se dirige ao leitor e exige dele uma atenção que se torna o lugar em que ele deve se posicionar, onde seu corpo se empenha e se desloca subjetivamente enquanto a escuta ocorre.

De acordo com o autor, esses valores da voz e de seu reconhecimento é independente do fato de que o texto seja apreendido interiormente, compreendido e interpretado, pois esses são os valores da própria linguagem e do próprio fenômeno poético. À vista disso, já no primeiro contato dos alunos com os textos poéticos, um movimento de reposicionamento subjetivo já deve ocorrer nos corpos daqueles que deixaram ao menos uma voz se introjetar e a articulação de sons se adensar na sensorialidade dos sentidos. No entanto, a experiência que obtivemos nos dois anos da pesquisa de campo demonstrou que a leitura solitária, em silêncio, tal como conhecemos como prática escolar nas gerações passadas, não é mais tão recorrente na sala de aula. Investigamos a frequência dessa prática por meio das atividades propostas pelo conjunto de professores da escola-campo e descobrimos que os exercícios de leitura 
silenciosa se encontram limitados aos momentos de aplicação de avaliações, quando os alunos devem ler sozinhos os enunciados e os textos das questões da prova para em seguida elaborar suas respostas escritas. Se o exercício da leitura silenciosa e individual se encontra restrito às provas e aos diagnósticos, como é possível avaliar as habilidades de interpretação e inferência dos alunos que não desenvolvem essa prática, tampouco a exercitam em outros espaços para além do contexto escolar?

Ao levantar essa questão em reuniões pedagógicas com o grupo docente, as justificativas para a ausência desse espaço de leitura vinham acompanhadas de argumentos como a fragmentação do currículo das disciplinas da área de ciências humanas e a diminuição da carga horária semanal dos professores para lecionar em cada turma, o que acarretou a necessidade de um replanejamento do tempo da aula. Diante desse replanejamento, os momentos de leitura silenciosa foram substituídos por leituras mais dinâmicas a fim de ganhar tempo para realizar outras atividades orais e escritas. No curso de Língua Portuguesa, também tivemos que acelerar algumas propostas previamente elaboradas no currículo para que fosse possível abarcar todas as exigências de conteúdos a serem trabalhados no Ensino Médio. Diante desse desafio, sentimos que o imediatismo que o sistema econômico exige das produções sociais reflete diretamente na estrutura escolar, que hoje ganhou outro ritmo, deixando de lado o tempo que os processos socioculturais demandam. O projeto políticopedagógico neoliberal, o impacto da globalização tecnológica e o tempo imediato da produção capitalista fizeram da escola prisioneira a esse ritmo que não respeita o que é próprio da cultura. Narrar, ler, fruir esteticamente, escrever, interpretar as artes são competências que necessitam de tempo para elaborar o pensamento, a crítica, o ponto de visa, o erro e o acerto diante de um texto. Além disso, percebemos que o discurso de que a leitura silenciosa não corresponde mais à realidade dos alunos se introjetou como demanda deles próprios, uma vez que, em nosso curso, surgiram contínuos pedidos para que substituíssemos a leitura silenciosa por atividades de leitura em voz alta (em variadas dinâmicas), pois alguns alunos alegavam não conseguir se concentrar estando sozinhos diante do desafio de ler o texto, principalmente por se sentirem pressionados a concluir a leitura em um determinado tempo, já outros diziam que ler silenciosamente dava dor de cabeça, enquanto que ouvir uma outra voz lendo e apenas acompanhar com os olhos era um movimento mais prazeroso.

O fluxo de informação na sociedade contemporânea tem transformado a postura e o empenho do corpo diante do ato da leitura. O leitor jovem parece não encontrar fôlego suficiente para leituras mais extensas, ele lê de forma fragmentada, desconcentra-se 
facilmente, interrompe inúmeras vezes a leitura para checar o celular ou outro aparelho eletrônico. Logo, uma vez que a tecnologia disseminada no cotidiano e o progressivo desenvolvimento da informação audiovisual têm alterado profundamente as práticas de leitura dos jovens, vemos com urgência a necessidade de se debruçar sobre a situação e a não situação dessas práticas fora e dentro das salas de aula.

Ainda estamos em um tempo em que a escola é a principal via de acesso aos bens culturais e carrega (por vezes, exclusivamente) a responsabilidade de promover e estimular espaços para a prática de leitura como atividade intelectual, não de mera decifração, mas visando sua dimensão subjetiva, política e emancipatória. Ao mesmo tempo, consideramos insatisfatório abordar a questão da leitura considerando apenas sua prática a nível escolar (muitas vezes tecnicista), pois é preciso compreender sua realidade social, em que a leitura se tornou um privilégio. Em um país como o nosso, em que a taxa de analfabetismo das últimas décadas ainda se mostra alta, observamos como os últimos governos federais se focaram na elaboração e implementação de diversos programas que determinam os meios e as formas de disseminar a alfabetização. A prioridade se tornou atingir números mais elevados nos diagnósticos das habilidades e competências de leitura e escrita de nossas crianças nos anos iniciais da alfabetização, deixando de lado importantes considerações acerca do desenvolvimento contínuo da capacidade de ler em idade escolar mais avançada, como a dos pré-adolescentes e adolescentes do ensino fundamental e médio.

Na fase da adolescência, em que o discurso repressivo e a formação identitária são aspectos frágeis na constituição da personalidade do jovem, o jogo de construção de si mesmo a partir do ato da leitura é muito significativo e potente e deveria ser melhor investigado, estimulado e representado pelas políticas públicas. Se a escola pública se colocar como mero instrumento de alfabetização para garantir capacitação de decifração e decodificação dos alunos, a leitura inferencial e crítica continuará sendo privilégio de uma minoria que domina os meios de informação e subjuga sua verdade a maioria da população. As formas de transmissão dos saberes operadas nas escolas têm as transformado em instrumentos úteis à sociedade mercantilizada a tal ponto que os saberes não se encontram mais na cultura, mas sim como valores de troca, simples produtos a serem reproduzidos no mercado de trabalho. Para os jovens de 15 a 17 anos, preocupados em se firmarem no meio social em que desejam atuar, aflitos para marcar seu lugar em um mundo aparentemente cheio de ideias préestabelecidas, retomar o gosto pela leitura e marcar o seu lugar em um texto parecem desafios impossíveis, ações impraticáveis, ainda mais se estiverem confinados a um espaço como a 
escola tecnicista e neoliberal que pouco os compreende. Nela, os jovens são vistos como rebeldes, incontroláveis e aventureiros demais para o regimento que se pretende impor. Talvez, devido a essa percepção reducionista sobre uma fase cheia de pulsões e ideais, vemos a crescente falta de investimento por parte dos projetos político-pedagógicos das redes em elaborar e aplicar programas voltados para a leitura e suas performances, para bibliotecas e outros laboratórios que propiciam experiências com a leitura literária, por exemplo.

No Ensino Médio, as escolas reproduzem o currículo de Língua Portuguesa voltado para os exames vestibulares, distribuindo fichas e resumos das obras literárias que serão cobradas nas provas, escolhendo trechos já acompanhados de interpretações prenunciadas pelos avaliadores, não deixando nenhum espaço para que os alunos apreciem, analisem e discutam outras possíveis interpretações. Com sorte, os jovens leitores podem ter a chance de ler as obras integralmente, no entanto, o que geralmente ocorre, é a disseminação de um conteúdo mastigado e engessado das escolas literárias e um breve compêndio de suas obras. $\mathrm{O}$ que parece estar por trás dessa prática mecanizada da leitura, para além dos resultados que a escola espera obter para poder vender os alunos como produtos prontos ao mercado de trabalho, é o medo de deixá-los a sós com os contos, os romances, as crônicas, os poemas. As autoridades parecem temer as interpretações que podem emergir das leituras silenciosas realizadas por sujeitos na fase adolescente, na qual, segundo o que se desenha na sociedade, já é uma fase essencialmente incontrolável e enigmática. Se, aliada a ela se aproxima a possibilidade da prática da leitura crítica, de apropriação de textos teóricos, filosóficos, artísticos, revolucionários, o ensejo de transformação social pode crescer, ganhar força e ressignificar valores impostos, afinal, não se pode controlar o modo como o texto é compreendido e interpretado diante do exercício da leitura silenciosa e inferencial. Não à toa, estamos vivendo em um tempo de crescimento da censura, de proibição de programas culturais, apresentação de peças em teatros, exibição de filmes nos cinemas, adoção de certos livros nas escolas. Isso porque a leitura de textos literários e poéticos pode ser capaz de canalizar a "rebeldia" para um sentimento de liberdade e de emancipação resultante de um maior domínio do código, devido a um processo de subjetivação inerente.

Para Lacan (1970, p. 144), toda determinação de sujeito, portanto, de pensamento, depende do discurso. Ser é uma questão de dizer, é efeito de um texto e de uma escrita que produza sentido não significável no inconsciente, mas que o demarque numa condição corporal. Ser depende de um Outro, enunciante, que ao sujeito enderece a palavra e o reconheça enquanto ser (Bairrão, 2010). Nesse sentido, a experiência da leitura literária 
desperta o espírito crítico e abre espaço para o devaneio, auxiliando no reconhecimento do estado pelo qual se passa o jovem, estimulando o autoconhecimento, a partilha do sensível, e até a tirar vantagem das trapaças da linguagem. Para Barthes (2004: p. 16), "essa trapaça é salutar, essa esquiva, esse logro magnífico que permite ouvir a língua fora do poder, no esplendor de uma revolução permanente da linguagem, eu a chamo, quanto a mim: literatura (...)". Nessa etapa de subjetivação entre a infância e a fase adulta, o adolescente reestrutura sua vida social em torno da pressão e da demanda por uma postura de responsabilização e de tomada de decisões. Ele precisa vir a ser um sujeito de ação e, para isso, tornar-se leitor pode evidenciar um sentimento de pertencimento e de poder por capacitá-lo a atuar como interlocutor daquilo que é produzido por autores, daquilo que é discutido na sociedade. Ter acesso direto ao que está sendo escrito e divulgado pelos "detentores do saber" pode ser uma atividade transgressora por excelência.

Como afirmou o historiador francês Michel de Certeau (1994), o ato da leitura é uma peregrinação por um sistema imposto, uma operação de caça furtiva em reservas alheias. Ler é invadir outros saberes, é se ocupar de novos conhecimentos. Para isso, é preciso estruturação psíquica para adentrar campos não escritos por nós mesmos, pois neles os jovens se distanciarão dos fatos e de suas certezas e serão guiados para outros lugares que desconhecem, por meio de sentidos que lhes escapam. Perscrutarão conhecimentos transmitidos por outros, conhecendo o que se passa em outras cabeças, o que pode os levar a compreender melhor o que se passa em sua própria imaginação. Além disso, para operar essa caça furtiva, é conveniente dispor de diversas outras estruturações, como espaços propícios para a leitura, mediação para o encontro com a literatura, implicações governamentais para melhores contextos socioeconômicos, entre outros fatores que colaboram com um cenário favorável para os jovens leitores, os quais, infelizmente, não vem sendo colocados em prática de forma contínua e sistemática na rede pública.

No caso da escola-campo onde realizamos a pesquisa, a ausência de um ambiente adequado para a leitura também dificultou o acesso e assiduidade dos jovens no contato com os livros. Não havia biblioteca, apenas uma caixa de papelão com livros didáticos descartados e alguns livros que os alunos não queriam mais, dispostos sem qualquer organização. $O$ material didático da escola era todo compartilhado através da plataforma moodle, os alunos tinham acesso aos computadores e tablets para realizarem a leitura dos textos referentes a cada curso, além de, em alguns casos, receberem textos ou apostilas impressas pela gráfica da escola. Quando algum professor pretendia trabalhar com uma obra completa em seu curso, os 
livros eram comprados pela coordenação e distribuídos no momento da aula. Depois do curso, os livros ficavam guardados em uma pequena sala onde se encontravam a gráfica e a mesa de trabalho do secretário da coordenação. Essa prática de dispor os livros adotados para os alunos apenas durante o momento da aula ou do curso também é comum nas escolas públicas, mas prejudica o engajamento do sujeito com a leitura da obra. Neste caso, o livro é aproveitado pelo aluno apenas provisoriamente em um período pré-determinado pelo tempo da aula e pelo espaço da sala onde o curso ocorre. Se houvesse a possibilidade de empréstimos de livros como ocorre com a existência de uma biblioteca na escola, o aluno poderia ao menos levar o livro para casa e se avir com ele de modo privado e descontraído, em seu tempo e a seu modo, fora do contexto escolar. Além disso, sabemos que a biblioteca é um lugar privilegiado para as várias facetas da leitura e para a realização de atividades que propõem um contato mais profundo com a literatura. Procurar por um livro guardado fisicamente em uma estante em que há conexão com outras obras pode despertar e estimular a curiosidade do aluno, propiciando descobertas improváveis, outras visitas à biblioteca para novas pesquisas, percursos singulares pelas prateleiras que, para este sujeito, deixarão de ser complementos meramente didáticos e passarão a ser compreendidos como um ambiente potencialmente cultural e educativo. O deslocamento do corpo pelos corredores de livros em uma biblioteca contribui para a percepção da grandeza da tradição literária. Diante de um arsenal de obras, o corpo se encontra perplexo com a variedade e multiplicidade da cultura escrita, motivando-o a se inserir nessa realidade e buscar conhecimento. A biblioteca cumpre o papel de representar o espaço onde as pessoas cultivam a cultura e se transformam socialmente, onde há o encontro com um mundo próprio e com as nuances da língua, além do acesso a uma reflexão própria, que é, ao mesmo tempo, individual e coletiva.

No entanto, o que tínhamos na escola-campo durante os anos de aplicação da pesquisa era uma caixa de papelão na qual descartavam-se livros. Ela ficava ao lado do micro-ondas utilizado pelos alunos para esquentar a marmita nos dias de grade-horária integral (às terças e quintas-feiras, nos anos em que a pesquisa foi realizada). Este espaço continha também uma mesa para o almoço e para o convívio dos alunos no período fora das aulas, além dos armários nos quais os alunos guardavam seus cadernos e outros materiais. Neste local, também exibíamos com frequência as produções escritas e fotos dos saraus que realizávamos semestralmente, como ilustrado na imagem ${ }^{25}$ abaixo: 


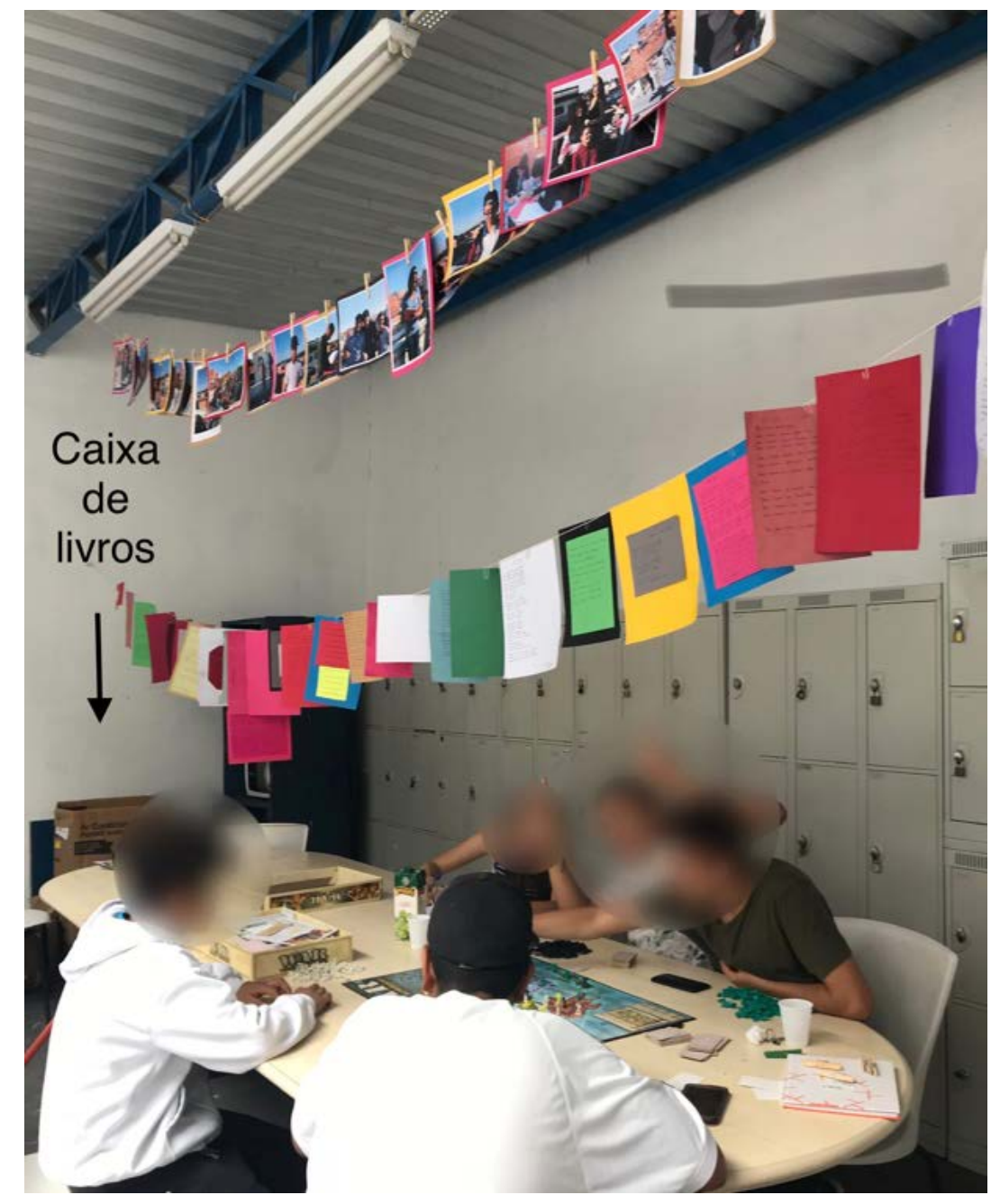

FIGURA 8. FOTO DO ESPAÇO DE CONVIVÊNCIA DOS ALUNOS NA ESCOLA ALEF PERETZ - PARAISÓPOLIS

A falta de biblioteca na escola gerou obstáculos para algumas atividades que foram propostas no curso de Língua Portuguesa, uma vez que, além do laboratório de informática, o único espaço fora da sala de aula em que os alunos poderiam estudar e realizar suas leituras

\footnotetext{
${ }^{25}$ De acordo com os termos de autorização para coleta de dados (Anexo 5), todas as fotos apresentadas na tese estão com os rostos dos sujeitos da pesquisa desfocados a fim de preservar a identidade dos alunos e assegurar as disposições éticas da pesquisa.
} 
era nesta mesa compartilhada com aqueles que almoçavam, jogavam cartas, conversavam alto, trabalhavam em grupo ou viviam qualquer outra situação que não a leitura silenciosa (retomaremos essa questão no quarto capítulo da tese). Agora ainda vale lembrar que, por estarmos tratando do empenho do corpo para o amadurecimento do hábito e da prática da leitura, não nos adianta esperar que o engajamento do aluno venha somente por influxos próprios. Pelo contrário, é preciso trabalhá-lo em todos os níveis: no processo de subjetivação do aluno, em sua relação de alteridade e de pertencimento, no conjunto da comunidade e da recomposição do tecido simbólico, de forma institucional e pública, interna e externa, refletindo tanto sobre o espaço disponível para as práticas de leitura, quanto sobre o programa curricular e cultural a que o aluno está vinculado. No contexto escolar, temos reivindicado das políticas pedagógicas da escola que bibliotecas, laboratórios e salas de leitura sejam multiplicadas, sistematizadas e organizadas em meios prazerosos e convidativos, já que acreditamos que esses espaços podem contribuir consideravelmente para incentivar o acesso a novas ordens imaginárias que os livros proporcionam, apresentando aos alunos, portanto, possibilidades de se reinventarem após a leitura de um texto literário e se envolverem com os desafios dos limites e dos poderes da linguagem poética. Por isso nos interessa tanto as diferentes maneiras pelas quais a literatura é capaz de ordenar o caos interior, além de poder se tornar instrumento de resistência e emancipação. Outras práticas de leitura realizadas com os alunos do Ensino Médio de Paraisópolis serão melhor analisadas à luz das teorias de performance, corporalidade e do efeito estético e da recepção a ser ainda aprofundada no item a seguir.

\section{A teoria do efeito estético e da recepção}

Iniciamos a tese apresentando nossa premissa central sobre como cultivar sentimentos estéticos por meio da linguagem poética pode ser um caminho perspicaz para reposicionar subjetivamente os jovens escolares diante dos desafios da leitura e da escrita, bem como diante da consciência cindida e da alienação agravada pela sociedade contemporânea. A partir dessa hipótese, desenvolvemos uma metodologia de ensino de Língua Portuguesa visando um trabalho com a literatura, principalmente com o gênero lírico, que desenvolvesse a oralidade poética e a performance da corporalidade com foco no letramento inferencial e autoral, buscando potencializar o desejo por emancipação social através do efeito estético e da fruição poética. Para isso, elaboramos uma intervenção de pesquisa-ação com propostas de 
transformação do currículo de Língua Portuguesa em uma unidade filantrópica da Escola Alef Peretz na comunidade de Paraisópolis, visando mudanças não apenas curriculares, mas também no espaço escolar, na formação dos jovens no que diz respeito às habilidades e competências de leitura e escrita, respeitando as necessidades da comunidade e do grupo de alunos implicados no cotidiano da pesquisa. Dessa forma, a metodologia não se pautou em mera extração de dados, mas voltou-se para as necessidades da comunidade, pensando nas transformações urgentes que se faziam evidentes naquele contexto. Dito isso, justificamos a necessidade de abordar a teoria do efeito estético, principalmente a partir dos estudos de Iser, para compreender a complexidade do trabalho com a literatura em sala de aula, uma vez que, diante da situação em que se configurou a pesquisa (em um espaço em que a leitura não é mais vista como socialmente evidente), revelar as condições culturais, históricas e econômicas dos receptores do texto se tornou elemento importante para tratar da interpretação da literatura. No entanto, isso não foi suficiente para analisar a relação dialética entre texto, leitor e sua interação, orientada pela estética do efeito no contexto da sala de aula, já que, ao longo do estudo de campo, para além de definir historicamente os leitores sujeitos da pesquisa, foi preciso refletir, antes de mais nada, sobre as atividades imaginativas e perceptivas que os textos deveriam requerer de seus leitores e quais resultados de efeito poderiam decorrer de sua performance no processo de leitura.

Logo, a elaboração de uma metodologia de ensino de Língua Portuguesa com foco na leitura, inferência, interpretação, fruição, ludicidade e escrita de textos poéticos procurou se questionar sobre os três problemas básicos da estética da recepção: i. como os textos são apreendidos?; ii. como são as estruturas que dirigem a elaboração do texto naquele que o recebe?; e iii. qual é a função de textos literários em seu contexto? Não obstante, para além de explorar os efeitos do texto em sua recepção, não se esquecendo de que a obra poética não deveria ser vista como uma mera alegoria da sociedade, foi preciso debruçarmo-nos também sobre os interesses da teoria do efeito estético, isto é, sobre o modo como os textos liberam um acontecimento. De acordo com as preocupações da Escola de Constança sobre a interação entre texto e contexto, outras questões foram formuladas: i. em que medida o texto literário se deixa apreender como um acontecimento?; e ii. até que ponto as elaborações provocadas pelo texto são previamente estruturadas por ele? O que temos e o que muito nos interessa, portanto, são dois caminhos complementares de lidar com a obra literária: a teoria da recepção atenta a leitores historicamente definíveis, cujas reações evidenciam algo sobre a literatura, e a teoria do efeito estético, apoiada na relação dialética entre texto, leitor e sua 
interação (Iser, 1996: p. 10). De um lado, temos uma preocupação com os juízos históricos dos leitores e do outro, com o texto literário e o efeito que ele suscita no leitor.

Antes de enfrentar tais questões, é preciso esclarecer que, segundo a teoria de Iser, o texto se mostra como um potencial de efeitos que se atualiza no processo de leitura, visando, assim, por meio da práxis da interpretação, um acontecimento da formação de sentido. Resumidamente, a estética do efeito compreende o processo de interpretação da literatura em um movimento que busca lidar com três aspectos fundamentais para que ela de fato ocorra: a função do texto nos diferentes contextos em que ele atua, sua comunicação, por meio da qual ele transmite experiências, intervêm no mundo e nas estruturas sociais dominantes e, por fim, sua assimilação, através da qual se mostram as habilidades e competências do leitor que foram estimuladas no ato da leitura. Nesse processo temos, de um lado, o leitor, ou seja, o verdadeiro receptor dos textos e, de outro, temos a obra que foi pensada e elaborada pelo autor. Assim, Iser (1996: p. 49) nos adverte de que nada adiantaria aos teóricos continuar discursando sobre a intenção do autor se não considerassem que a significação contemporânea, psicanalítica e histórica da obra só tem sentido se os textos fossem de fato lidos e interpretados pelos seus leitores. Por mais óbvia que seja essa constatação, segundo Iser, a evidência da leitura das obras não foi amplamente estudada pelos críticos literários na época em que fundava sua teoria sobre o efeito estético, no entanto, passou a ser devidamente considerada com a teoria fenomenológica da arte ao enfatizar que o estudo de uma obra literária não pode dedicar-se apenas à configuração do texto, mas deve, na mesma medida, dedicar-se aos atos de sua apreensão.

Nesse sentido, diante de uma obra literária, temos dois polos, o artístico e o estético. $\mathrm{O}$ polo artístico designa o texto criado pelo autor, enquanto o polo estético caracteriza a concretização da obra produzida pelo leitor, significando assim, que a obra é mais que o texto, pois ela se realiza apenas na sua concretização enquanto objeto de leitura nas mãos e na mente de um leitor capaz de interpretá-la. Nas palavras de Iser (1996: 50),

\footnotetext{
A concretização por sua vez não é livre de disposições do leitor, mesmo se tais disposições só se atualizam com as condições do texto. A obra literária se realiza então na convergência do texto com o leitor; a obra tem forçosamente um caráter virtual, pois não pode ser reduzida nem à realidade do texto, nem às disposições caracterizadoras do leitor. Dessa virtualidade da obra resulta sua dinâmica, que se apresenta como a condição dos efeitos provocados pela obra. O texto, portanto, se realiza só através da constituição de uma consciência receptora. Desse modo, é só na leitura que a obra enquanto processo adquire seu caráter próprio. (...) A obra é o ser constituído do texto na consciência do leitor. (grifo nosso)
} 
A partir dessa perspectiva, ao trabalhar com textos poéticos, procuramos não isolar o polo artístico do estético, ou vice-versa, pois isso significaria reduzir a obra à técnica de representação do texto (desconsiderando o momento de fruição estética) ou à interpretação singular e subjetiva dos alunos (pautando-nos apenas pela sua consciência enquanto leitor). Se na interação com obras literárias o leitor "recebe" o sentido do texto ao constituí-lo, as condições para a interpretação se fundam nas estruturas do texto, na medida que os efeitos mnemônicos e estéticos afetam o leitor a partir de uma função dupla: a estrutura verbal e a estrutura afetiva a ser penetrada no leitor concomitantemente. O aspecto verbal da obra, que no contexto de nossa pesquisa é, na maioria das vezes, referente ao gênero poético, dirige a reação do leitor e impede a arbitrariedade da leitura e da interpretação do poema, enquanto o aspecto afetivo se vincula ao cumprimento do que é pré-estruturado verbalmente pelo texto (Iser, 1996: p. 51). No decurso das propostas apresentadas aos alunos na escola-campo, essa interação se fez ainda mais evidente, uma vez que, nos textos reconhecidamente poéticos, a construção rítmica dos versos obriga o leitor a lidar com fatores não-psicológicos que estimulam uma reação estética, baseada em figuras bastante objetivas como a aliteração e a assonância, ao mesmo tempo que a condensação da estrutura verbal, por meio de metáforas e metonímias, e a polissemia das palavras selecionadas e dispostas de maneira singular pelo poeta em seu poema produzem uma reação subjetiva e singular, confirmando, assim, a essência da estrutura afetiva do texto poético.

Como exemplo desse fenômeno sucedido pela leitura poética, valemo-nos da experiência dos alunos do primeiro ano durante uma de nossas aulas de Língua Portuguesa, cuja intenção foi aprofundar os conceitos de sonoridade, ritmo e métrica a partir da leitura e fruição do poema de Manuel Bandeira (1996), "Canção do Vento e da minha Vida": 
O vento varria as folhas,

$\mathrm{O}$ vento varria os frutos,

$\mathrm{O}$ vento varria as flores...

E a minha vida ficava

Cada vez mais cheia

De frutos, de flores, de folhas.

$\mathrm{O}$ vento varria as luzes,

$\mathrm{O}$ vento varria as músicas,

$\mathrm{O}$ vento varria os aromas...

E a minha vida ficava

Cada vez mais cheia

De aromas, de estrelas, de cânticos.

$\mathrm{O}$ vento varria os sonhos

E varria as amizades...

$\mathrm{O}$ vento varria as mulheres...

E a minha vida ficava

Cada vez mais cheia

De afetos e de mulheres.

$\mathrm{O}$ vento varria os meses

E varria os teus sorrisos...

O vento varria tudo!

E a minha vida ficava

Cada vez mais cheia

De tudo.

O poema é constituído de uma canção paralelística composta pelo recurso da melopeia, como utilizado na linguagem de Pound. O extrato gráfico do poema é particular: observam-se quatro estrofes de sextilhas, em versos que, apesar da ausência de rimas, possuem uma admirável melodia. A ausência de rimas é compensada pela repetição anafórica de "O vento varria..." no princípio das orações, procurando recuperar a sensação de simultaneidade das ações do tempo (metaforizado pela imagem do vento). A repetição paralelística no poema de Manuel Bandeira possibilitou sua composição com o mínimo de vocabulário, com simplicidade, pureza e musicalidade características do poema lírico, muito próxima às canções provençais.

Primeiramente, o poema foi declamado de memória por mim, a partir da minha leitura e interpretação e da minha performance corporal. Os alunos foram então questionados sobre 
suas primeiras impressões ao ouvir o poema e em seguida, uma cópia impressa foi entregue e dois tipos de leitura em voz alta foram realizadas: um aluno se voluntariou para ler o poema individualmente e depois de discutir sobre seu aspecto gráfico (o vai e vem dos versos simulando o movimento do vento), a própria turma propôs uma leitura performática em forma de jogral ${ }^{26}$, em que duas fileiras leram juntas os três primeiros versos de cada estrofe, enquanto as outras duas fileiras deram sequência à leitura com os três últimos versos. A performance dessa segunda leitura se assemelhou a um jogo de perguntas e respostas, que seriam nesse caso, constatações e análises, como se os primeiros versos fossem a declaração do ocorrido e os últimos a apreciação dos fatos.

A partir da oralização do poema, foi observado com os alunos que a repetição dos fonemas /f/ e /v/ explora a figura sonora da aliteração que intensifica o ritmo do poema e produz efeito sonoro significativo. Nesse caso, pudemos aferir que tal efeito sonoro nos remetia ao ruído do vento, à ideia da força arrasadora do vento que leva tudo embora. Não é à toa que boa parte das línguas, tanto latinas como germânicas, carregam tal significante com os sons de V, próximo ao som emitido pelo vento. Os elementos "folhas", "frutos", "flores", "luzes", "sonhos", todos no plural, realçam a sonoridade do /s/ e causam o efeito de algo que se prolonga, que se estende. Voltamos a atenção para a notável sibilante no fim dos versos e para o uso de reticências que produzem o efeito de uma ação inacabada, dos elementos varridos pelo tempo, das coisas da vida indo embora aos poucos. Ao levantarmos a questão de que o vento varria os elementos importantes da vida do eu-lírico, os alunos foram confrontados por uma possível ambiguidade ou contradição, devido à presença constante da palavra "cheia". Eles se perguntaram se o vento estava varrendo tudo para longe ou para perto da voz central do poema. Uma aluna então perguntou por que a vida do eu-lírico ficava cada vez mais cheia de tudo, se o vento estava levando tudo embora. Ela indagou: "a vida dele está mais cheia, lotada de tudo, ou ele está de saco cheio de tudo?". A discussão fluiu no grupo e alguns alunos interpretaram os versos como um abandono da vida, uma aproximação com a

\footnotetext{
${ }^{26}$ A palavra jogral vem da substantivação do adjetivo joculáris que em Latim significa jocoso, divertido, risível. Antes mesmo da lírica medieval e trovadoresca, havia a tradição de uma figura assumir o papel de bufão para entreter o povo nas praças e a realeza nos palácios. Como os antigos aedos, os jograis representavam a cultural oral da Península Ibérica se valendo de sátiras, mágicas, acrobacias e mímicas para divulgar a poesia declamando-a com ou sem o acompanhamento de algum vielas, alaúdes ou cistres. Hoje o jogral é considerado uma técnica de declamação de poesia em coro, alternando partes individuais e coletivas, conferindo musicalidade e ritmo aos textos literários.
} 
morte, pois o eu-lírico se demonstrou cansado, saturado de tudo, enquanto outros disseram que a partir dos versos, eles sentiram uma sensação de plenitude, de uma vida repleta e satisfatória.

Assim, o poema foi capaz de mobilizar os alunos para a fruição dos dois polos apresentados por Iser: o artístico e o estético. Enquanto a combinação de sons do poema despertou sensações de ordem física e objetiva, plásticas ou auditivas, a polissemia das palavras carregou os alunos de sensações e emoções de outras naturezas, psicológicas e individuais, mas apenas depois de lidarem com seus aspectos mnemônicos. Logo, a reação estética reproduzida pela forma do poema é aqui verificada pela sua integridade, uma vez que não se confunde com processos aleatórios, que permeiam a psique individual. Segundo Iser, essa experiência com o som e a forma do poema sempre antecede a significação atribuída às obras, pois esta se funda naquela. Nesse caso, todos os recursos sonoros e as suas combinações utilizadas pelo poeta estão interligadas ao fenômeno do ritmo poético. A ideia de ritmo vem de muitas vertentes artísticas, e todas exprimem o conceito de regularidade que toca nossos sentidos (geralmente de forma agradável e harmônica) e em todas elas o ritmo não pode estar dissociado do tempo e espaço em que os sons se manifestam. Candido (2006) definiu o ritmo na poesia como a alternância de sonoridades mais fracas e mais fortes, mais longas e mais breves, formando uma unidade configurada e coesa. No poema "Canção do vento e da minha vida", percebemos a modulação das unidades sonoras dentro de um sistema de ritmo ternário ascendente (acentos fracos seguidos de um acento forte): o vento varria as fôlhas - os acentos fortes estão na segunda, quinta e sétima sílabas, lembrando que em "varria as" ocorre a chamada elisão. O uso das vogais em vento e varria se contrapõe, uma vez que [IA] (de varria) apresenta vogal alta, aberta e [EN] (de vento) apresenta vogal nasalizada, fechada. A composição rítmica do poema se mostra adequada ao seu significado. Quando os versos apresentam ritmo ternário (segunda, quinta e sétimas sílabas fortes, estrutura 2 - 5 - 7), o poeta retrata três elementos "varridos pelo vento" (folhas, frutos, flores), e quando os versos apresentam ritmo binário (segunda e sétima sílabas fortes, como no verso de afetos $e$ de mulheres - estrutura 2 - 7), ele retrata dois elementos (afetos, mulheres). Portanto, a tessitura sonora do poema estabelece seu contraponto (seu ritmo) na alternância de sílabas fracas e fortes e também no jogo de vogais, abertas e fechadas, sibilantes e fricativas, instaurando o sentido geral do poema e colaborando para a criação da imagem presente e recorrente em todas as estrofes: as experiências que preenchem a vida a despeito da passagem do tempo.

Ao tratar do ritmo e da melopeia do poema, fez-se necessário verificar a divisão 
métrica dos versos, quando ela existe, como no caso do poema em questão. A análise da métrica foi realizada pelos segmentos rítmicos do poema, não pela divisão silábica padrão das normas gramaticais. A contagem das sílabas nos versos poéticos varia no tempo e no espaço, e a tradição luso-brasileira considera até a última sílaba tônica. Portanto, os quatro primeiros versos do poema, $O$ vento varria as folhas, / $O$ vento varria os frutos, / $O$ vento varria as flores... E a minha vida ficava, temos versos em redondilhas maiores (composto por até sete sílabas). Os versos das outras estrofes apresentam composições métricas variadas (ora em redondilhas menores, ora em octassílabos), mas se adequam à composição rítmica do poema, já que, "a alternância das sílabas em si nada significa, mas sim a alternância de tonicidade e atonicidade dentro de grupos silábicos que formam unidades rítmicas" (Candido, 2006: p. 82). Contudo, para nós interessou mais pensar na unidade entre som e sentido, entre ritmo e significado poético, do que nas regras de divisão métrica. Inclusive porque o metro nada mais é do que um recurso do efeito rítmico do poema, podendo ou não fazer parte de sua composição. Versos sem métrica evidenciam modulações expressivas e significativas tanto quanto os versos metrificados. Ao longo da história do fazer literário, o metro cedeu lugar ao ritmo e "quando se voltou ao desejo de regularidade silábica esta se fez [...] segundo rumos novos. Surge um universo formal de extrema liberdade, no qual os ritmos se constroem à vontade, e se esbate ou anula a noção de melodia do verso" (idem, p. 93).

Considerando a riqueza dos efeitos rítmicos e sonoros do poema, a criatividade discente na interpretação dos versos possibilitou releituras envolvendo aspectos subjetivos, uma vez que, após a experiência com o efeito estético do poema, os alunos puderam se indagar sobre o modo como o tempo manipula a vida, como nossa presença no mundo é frágil e efêmera e, por fim, como o eu-lírico descreveu sua impotência com relação ao vento que tudo arrasta. Assim, "compreender essa experiência significa ter a consciência dos atos que originam nossos juízos sobre a arte e que se atualizam em sua experiência. Caracteriza a natureza do efeito estético o fato de que ele não se cristaliza em algo existente" (Iser, 1996: p. 52), mas sim no que advém ao mundo em decorrência dele. O efeito estético é, então, "o nãoidêntico ao de antemão existente no mundo" (idem).

Uma questão controvérsia se dá ao buscar relacionar o não-idêntico a algo familiar e compreensível, pois, quando isso ocorre, o efeito estético desaparece, uma vez que ele só é efeito, enquanto o significado que dele decorre não se funda em nada senão nele mesmo. Por isso, Iser nos adverte que devemos substituir a velha pergunta sobre o que significa esse poema pela pergunta sobre o que sucede com o leitor quando sua leitura dá vida aos textos 
literários. Isso porque a significação é um acontecimento que existe graças ao efeito estético que estimula nossas leituras, ou seja, a significação é produto dos efeitos experimentados. Nesse sentido, a interpretação do poema não visa decifrar o seu sentido, mas sim evidenciar o potencial de sentido proporcionado pelo texto, abrindo espaço para diferentes significações, como essas colocadas pelos alunos após a leitura da "Canção do vento e da minha vida".

Posteriormente à leitura do poema, surgiu uma situação conflitiva na recepção dos alunos, derivada de um elemento central da obra: a ambiguidade do tempo que, de um lado aprofundava as experiências do eu-lírico e sua sabedoria diante de tudo que já pôde viver aos longo dos anos, e, da mesma forma que a vida avançava no tempo lhe garantindo experiência, ele fazia desaparecerem suas conquistas, seus prazeres, seus sentimentos com a aproximação da morte. Assim como no contato com outros textos literários, a solução desse conflito apenas se cumpre na experiência do leitor, que consiste menos em solucionar o conflito do que em reagir à solução possível representada nos versos do poema. Segundo Iser (1996: p. 93), se o leitor é capaz de identificar um conflito e buscar uma solução na obra poética, esse fenômeno "não se desenrola diante do leitor, mas sim o ocupa internamente e o obriga a trabalhar a excitação que o texto produz". Com esse argumento podemos, mais uma vez, expandir a importância do trabalho com poesia em sala de aula, pois o gênero lírico é, por excelência, capaz de lançar o leitor através da estrutura das perspectivas e suas divergências no terreno da excitação em busca de solução de conflitos, imerso em um processo de subjetivação e alteridade. Ao mesmo tempo que o texto provoca o leitor com seus conflitos, ele o guia para superar o seu envolvimento, distanciar-se do eu-lírico em um efeito catártico e participar, assim, da solução que não é aquela previamente formulada, pois o texto poético não a desvela ao leitor, mas sim uma solução como efeito de descoberta própria a partir da recepção individual e experiência singular. Ou seja, a leitura poética não pressupõe um leitor passivo, pelo contrário, exige dele um trabalho produtivo de distorcer os sentidos e de estar aberto ao inesperado.

Sabemos que esse potencial de sentido suscitado pelo poema a partir da leitura dos alunos não pôde ser completamente constatado em nossas aulas, pois, como já discorremos anteriormente acerca dos conflitos da linguagem, o sentido nunca se manifesta plenamente, há sempre algo que nos escapa e não é possível transformar em palavras. Além disso, em cada aluno engajado na leitura do poema constituíram-se nuances de sentido, realizações individuais dos textos, pois elas carregam fatores intersubjetivos. Devemos, portanto, considerar o caráter de evento da produção de sentido na experiência de cada leitor, podendo, 
é claro, analisar sua interpretação de forma crítica a fim de estimular novas leituras, mas não se esquecendo do fato de que a significação de uma obra poética tem um caráter discursivo, ou seja, ao referenciar sua interpretação, o aluno deixa em segundo plano seu caráter estético e passa a discorrer sobre os resultados do texto em um sentido constituído.

Em princípio, esse sentido carrega um caráter estético, "pois significa a si mesmo; pois por ele advém algo ao mundo que antes nele não existia" (Iser, 1996: p. 54), no entanto, ele se manifesta enquanto efeito estético, sendo reconhecido pelo aluno após a leitura do poema, antes de mais nada, enquanto experiência estética. Essa experiência já é uma interpretação e ela não precisa recorrer a nenhuma referência ou padronização das interpretações tradicionais do poema para se justificar e validar sua existência. O puro ato de se deixar levar pela experiência estética da leitura poética já constitui o sentido que acontece na leitura, principalmente porque a poesia tem uma organização própria de condensação e deslocamento de sentidos que são somente ativados pela presença ativa do leitor, que insiste em preencher os vazios deixados pelos versos.

$\mathrm{O}$ efeito que surge dessa carência de sentido da obra poética indica rasuras e impossíveis leituras (conceitos compreendidos pelo estudo do traço da letra e do significante lacaniano) que formulam algo em nós. Assim considerando, o leitor não é um mero decodificador que se mantém fixo nos significantes que lê, como se o texto o conduzisse de acordo com suas próprias exigências. Perante à obra poética, o leitor se vê tensionado pela ambiguidade e transmutação dos sentidos das palavras, pelas semelhanças sonoras e trocas semânticas que mexem com a contextura dos versos, pelo nonsense e enigmas que ele procura decifrar e interpretar. Nesse movimento, o leitor não só cria um horizonte de sentido, formulando o não formulado, como alcança a possibilidade de se reformular, descobrir-se e desvendar o que até aquele momento parecia se subtrair em sua consciência (Iser, 1999: p. 13), sendo essa a maneira como se estabelecem os atos de apreensão do texto poético quando bem sucedidos.

Em contra partida, no contexto escolar, a experiência decorrente do efeito estético quando não manifestada de forma discursiva é muitas vezes vista como insuficiente, como ilegítima, pois para a escola o que têm sido valorizado são os resultados de como as habilidades e competências da leitura e da escrita dos alunos progrediram na forma de textos práticos e concretos. Nesse contexto, o caráter estético fica constantemente ameaçado por uma referencialidade discursiva, vestida de questionamentos como "o que significa o poema?", "o que o autor quis dizer com tal obra?" ou até mesmo "qual é a interpretação 
correta para esse texto?". Tendo isso em vista, a intenção do trabalho com a poesia em sala de aula não é desenvolver uma ideia de padronização da interpretação, uma análise ideal do poema, adequando os modos de compreensão dos alunos, e sim estimular a experiência suscitada pelo efeito estético e a evidência dos múltiplos sentidos, orientadas pela estrutura singular do texto poético, uma vez que eles constituem seu próprio objeto e não copiam objetos já dados. Além disso, os textos poéticos carregam elementos indefinidos, nonsense, jogos linguísticos complexos que possibilitam que o leitor participe na produção de sentido e da intenção dos versos, como se as palavras ali compostas estivessem abertas para ganhar novos significados, não de modo aleatório, mas em uma interação entre texto e leitor, fundada nos aspectos estéticos da obra. Voltando ao exemplo do exercício de leitura efetuado com o poema de Manuel Bandeira, os alunos refletiram sobre os recursos estilísticos e sobre as figuras de linguagem da obra, incorporando a experiência da leitura a suas próprias experiências coletivas e individuais, fundamentando, assim, juízos subjetivos, baseados em critérios objetivos. Isso porque os textos poéticos ativam processos de realização de sentido por meio de suas qualidades estética e mnemônica, produzindo algo no leitor que, por vezes, eles próprios não são, ou não tinham a intenção de ser. Uma vez que a leitura de poesia não exige apenas capacidades cognitivas do leitor, mas também capacidades emotivas, precisamos explorar o efeito e a recepção que vão para além das questões sobre "o que esse poema significa", enfatizando nosso interesse em pontos como a questão "o que o texto suscitou no leitor".

Ainda assim, na tentativa de retomar as questões colocadas no início deste item, outros aspectos devem ser elucubrados. Em uma turma heterogênea, como todas as turmas de alunos, tivemos que considerar que ali estavam presentes diversos tipos de leitores, aqueles que evidenciavam mais a construção de sentido, outros que se apoiavam no substrato empírico do texto, mas, para além disso, vimos como tarefa importante avaliar e compreender que, no geral, estávamos diante de leitores contemporâneos, atravessados por diversos meios e discursos. Antes de ter a chance de refletir se era o efeito ou a recepção da literatura que se tornava foco do exercício de leitura poética por parte de nossos alunos, víamo-nos diante do desafio de desviar sua atenção flutuante para as mídias que apitavam em suas cabeças. Além do aspecto da interferência das redes, é importante relembrar o contexto escolar onde o texto literário era abordado, no qual os alunos tinham que lidar com a preocupação com notas, rendimento do boletim, possibilidade de reprovação, vestibular, resultados quantificáveis, avaliações internas e externa, ou seja, com a obsessão de nossa sociedade por metas, efeitos 
imediatos e padronizações. Como forma de se desviar dessas demandas e bordejar os sintomas em tempos de crise, os alunos organizavam os saraus na tentativa de se libertar minimamente da rotina maçante da escola. Ali os alunos se viam em um terreno de aventura, de devaneio, no qual cada sujeito era potência para uma escuta singular da dor, do amor, da desilusão ou da raiva do outro. Nesses momentos, ficava ainda mais clara a necessidade de mudar nosso ponto de vista quando tratamos do trabalho com poesia e concentrar o interesse da leitura e da fruição de obras literárias mais nos atos estimulados pelos efeitos do que nos seus resultados. Aprofundaremos essa tentativa de mudança de perspectiva diante do ato da leitura e de sua apreensão no item a seguir.

\section{Interação entre o desejo do sujeito leitor e o texto poético}

Como vimos acima, a doação de sentido por meio do efeito estético produzido pelo poema não está previamente dada e tampouco é arbitrária, pelo contrário, ela é concebida a partir de uma relação dialética entre texto, leitor e sua interação dinâmica e intersubjetiva. Partindo do pressuposto de que todo texto poético oferece determinados papéis a seus possíveis receptores, a depender de sua estrutura e da estrutura do ato de leitura, cabe aos leitores, portanto, atualizar o potencial do texto para construir para si (e, consequentemente para o mundo) o objeto estético que a obra carrega. Contudo, sabemos que o processo de leitura não é uma via de mão única, ou melhor dizendo, sabemos que a transferência do texto para a consciência do leitor não deve ser compreendida apenas como algo resultante somente do texto, pois o que também vemos em jogo são as condições da capacidade de apreensão e de processamento dos jovens leitores de poesia (para atermo-nos desde já aos sujeitos da nossa pesquisa). Dessa forma, há de se avaliar o comportamento subjetivo dos alunos ao se verem confrontados com as diferentes perspectivas de mundo criadas pelos autores das obras, uma vez que o texto literário não é mera cópia do mundo em que vivemos, mas constitui um mundo contingente, que pode ou não lhe ser familiar. É nas estruturas mnemônicas e verbais da elaboração poética que a perspectiva do autor se manifesta, não permitindo, portanto, que o leitor escolha livremente seu ponto de vista, já que este só pode existir a partir de uma perspectiva interna ao texto, ou seja, a partir das figuras e dos sons que originam a percepção de amplos sentidos. Logo, a percepção do leitor é composta por uma estrutura do texto e uma estrutura do ato da leitura, aspectos subjetivos e materiais, enlaçados por um complexo objetivo e desejo: apreender o conteúdo da enunciação. 
Em nossa perspectiva de sujeito, vimos anteriormente que ele é compreendido em sua relação com o desejo (tal como indica a hipótese da fundação do aparelho psíquico em Freud) e, se o desejo é erigido a partir do que se apresenta em relação ao Outro, então o sujeito do qual aqui tratamos é, sobretudo, um efeito da linguagem que ele apreende e pela qual é apreendido, na medida em que se fala e pode ser expresso pelo Outro. Além disso, compreendemos que o modo como acessamos o mundo é sempre de natureza perspectivística por meio de significantes, por isso, na intenção de analisar a interação dos adolescentes com o texto poético, tomamos como ponto de partida a ideia de que a estrutura do texto estabelece o ponto de vista para o leitor e, consequentemente, seu ponto de vista o situa no texto e no discurso do Outro, tornando-o capaz de constituir um horizonte de sentido para si. No entanto, alicerçado nos estudos de Lacan e com base nas leituras de Iser, compreendemos que esse horizonte de sentido é desprovido de reproduções da realidade, devendo, assim, ser imaginado pelo leitor: "apenas a imaginação é capaz de captar o não-dado, de modo que a estrutura do texto, ao estimular uma sequência de imagens, se traduz na consciência receptiva do leitor. $\mathrm{O}$ conteúdo dessas imagens continua sendo afetado pelas experiências dos leitores" (Iser, 1996: p. 77). Lacan (1998), por sua vez, ao tratar do princípio da realidade, enfatiza a imagem como elemento fundamental da experiência de significação real, como matéria-prima das identificações e representações. Mesmo que essa experiência possa ser apenas uma ilusão de autonomia da consciência, ela é resultado do desejo do sujeito de entrar no discurso do Outro, um desejo do desejo do Outro.

A prática da leitura se desempenha nessa dinâmica desejante, o que Iser (1998: p. 10) denominou como "jogo de fantasia" entre o autor e o leitor, cuja dinâmica consiste em ceder espaço para a imaginação do leitor para que ela também favoreça o reconhecimento do texto enquanto objeto estético e literário, afinal, como afirmou Sartre (1985, p. 35 apud Iser, 1998: p. 11)

(...) o processo de escrever, enquanto correlativo dialético, inclui o processo da leitura, e estes dois atos dependem um do outro e demandam duas pessoas diferentemente ativas. $\mathrm{O}$ esforço unido de autor e leitor produz o objeto concreto e imaginário que é a obra do espírito. A arte existe unicamente para o outro e através do outro (grifo nosso).

Dessa forma, ao tratar da relação leitor-texto, valemo-nos de uma relação peculiar entre sujeito-objeto, pois o ponto de vista do leitor se movimenta por dentro do objeto que deve apreender, envolvendo-se diretamente com a obra, transcendendo-se e transformando-se 
a partir dela. "Daí a necessidade de a fenomenologia da leitura esclarecer os atos de apreensão pelos quais o texto se traduz para a consciência do leitor" (Iser, 1998: p. 11).

Pode parecer suspeita a aproximação manifesta neste item entre o campo da fenomenologia (no qual Iser se apoiou) ao campo psicanalítico de Lacan. Todavia, nossa intenção com tal aproximação é aproveitar os estudos sobre o modo de apreensão do texto na consciência cognoscente, já que nos interessa refletir sobre a disposição dos nossos jovens da pesquisa perante ao ato de leitura, como movimentaram seus pontos de vista e sob quais condições o fizeram. Mesmo assim, nessa reflexão, não deixaremos de levar em conta a noção de sujeito e de desejo oriundas da psicanálise lacaniana. Por mais que a fenomenologia de Husserl tenha feito parte dos estudos de Lacan e embora ambas metodologias de análise do sentido oculto da existência tomaram como centro o mesmo objeto, o conceito de intencionalidade da consciência não parecia nem um pouco suficiente ao psicanalista francês para investigar os movimentos do inconsciente. E, não por outro motivo, ao abordar o Estádio do Espelho, Lacan declara sua posição completamente oposta ao cartesianismo e ao existencialismo da fenomenologia. Por mais que essa oposição não tenha sido tão simples e direta como pareceu na época, foi somente com a Fenomenologia da Percepção, de MerleauPonty, que Lacan passou a se aproximar novamente desta teoria, principalmente por concordar que a experiência vivida deveria ser considerada antes de qualquer objetivação.

Assim, evidenciando mais uma vez a teoria lacaniana das imagens, sabemos que por meio delas o sujeito e sua própria realidade são constituídos, uma vez que o conhecimento humano se encontra ancorado nas imagens e no processo de retroação de seu efeito de sentido para a compreensão do discurso do Outro. Essa relação é fundante para que o sujeito organize suas formas de experiência e se identifique com as imagens representadas a sua volta. Em situação análoga a esse movimento de representação e retroação, encontra-se o ato de leitura de textos poéticos: neles o leitor se move constantemente em um fluxo temporal determinado por etapas ou fases que requerem sínteses para a compreensão total de sentido. Segundo Iser (1998), essas sínteses ocorrem em cada fase em que se move o ponto de vista do leitor, traduzindo, assim, o texto para sua consciência. Para ilustrar esse movimento retroativo imprescindível tanto para o processo de subjetivação quanto para a inferência da leitura, utilizaremos o grafo do desejo de Lacan (1969, Seminário 16): 


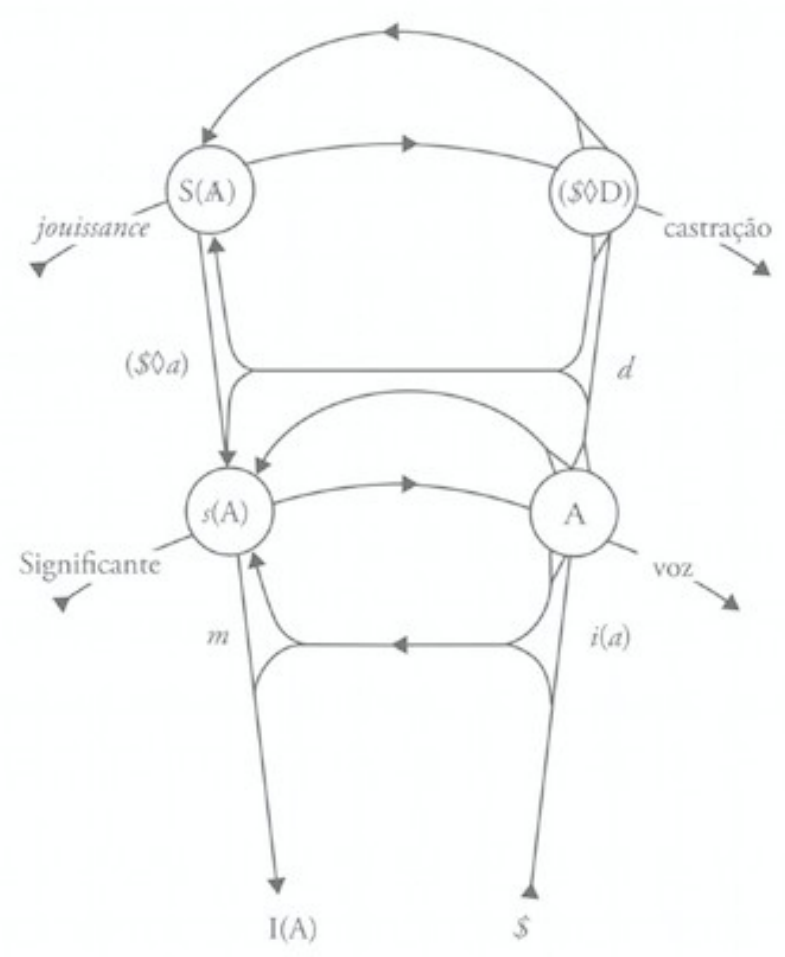

FIGURA 9. GRAFO DO DESEJO

Nesse modelo de topologia combinatória, Lacan se serve de vetores e lugares conectados para expor as relações subjetivas que condicionam o processo de constituição do sujeito e os processos que ocorrem na análise do sujeito por meio do exercício da memória. Partindo da representação do sujeito barrado (\$ localizado à direita), lemos o grafo do desejo de Lacan como o desejo do sujeito de reunir condições para aceder à totalidade de sua expressão, mas encontra obstáculos e limitações, pois depende dos sentidos que o Outro lhe atribui, como, por exemplo, a mãe (o Outro absoluto) e a forma como ela nomeia a criança desde sua posição fora da linguagem, colocando-a no Simbólico a partir de seu discurso.

Dentro do corpo simbólico o sujeito se vê rodeado de leis que condicionam as posições intermediárias pelas quais deve percorrer na transição de um lugar para o outro, conforme apontam os vetores em direções opostas. Essa primeira transição entre o sujeito barrado (\$) e o grande Outro (A) foi denominada por Lacan como Estádio do Espelho, em que o Eu (m), em sua relação com a imagem (i(a)), se reconhece finalmente como sujeito, o que pode ser relacionado aqui à primeira fase da leitura em uma perspectiva ainda imaginária. Após estranhar a imagem que está diante dele, o sujeito é capaz de reconhecer que ela o representa e que ela determina o seu lugar com relação ao discurso do Outro. Diante dessa primeira fase da linguagem (a linha diacrônica da estrutura da fala), o leitor, segundo Iser, 
pode constituir um correlato intencional de um complexo de enunciações, ativando a interação entre sujeito e texto.

Nesse movimento de retroação do sujeito para o Outro, temos o point de capiton (ponto de estofo), no qual o significante se associa ao significado na cadeia do discurso, adiantando a conclusão da significação. É um movimento de abertura e fechamento da significação, uma exceção ao deslizamento incessante do significado sob o significante, que se remete à manifestação de significantes no discurso sem um ponto de ancoragem na significação. Isto é, o movimento de retroação é o momento de atribuição de sentido, de significado ao que foi lido. Quando o leitor conclui a leitura do último elemento do verso, ele está pronto para interpretar o sentido dos primeiros termos, isso porque, o verso só tem seu sentido completo se o leitor for capaz de fazer a retroação, esvaziando o sentido previamente estabelecido para dar lugar a poeticidade da língua, repleta de figuras de linguagem, contradições e ambiguidades. Conforme indica a primeira seta horizontal (debaixo para cima) que atravessa o significante, o movimento retroativo do sujeito em direção ao Outro dá lugar ao significado (ao compartilhamento de signos por meio de uma tradição).

Essa resposta que o Outro (a língua, o texto, a cultura) anuncia ao sujeito é também vista por Lacan como o sintoma, elemento que relocaliza o sujeito no seu lugar submisso à linguagem e ao inconsciente, revelando a significação que o perturba, pois o determina e o identifica. É a significação que o sujeito atribui para o desejo do Outro e a partir do desejo do Outro, o que pode ser caracterizado por nós na analogia com o processo de leitura como a segunda fase após a perspectiva imaginária, a etapa de esvaziamento dos sentidos triviais para a entrada de um novo sentido, um sentido outro que só se revela após a leitura percorrer todos os elementos do verso e realizar o seu retorno para o primeiro significante. Em um processo de deslocamento pela cadeia significante, em que os elementos do verso vão se deslizando pelas associações do leitor, o efeito estético do ato da leitura permite a suspensão dos sentidos não poéticos para que o leitor possa condensar um novo sentido com auxílio da inferência de metáforas e metonímias presentes no poema. Iser (1998: p. 16), por sua vez, explicou esse movimento retroativo de inferência de sentido no processo da leitura da seguinte forma:

Se as representações vazias dos correlatos despertam a atenção para o que virá, a modificação da expectativa causada pela sequência das enunciações certamente terá um efeito retroativo sobre o que antes fora lido. Com efeito, o que foi anteriormente lido é, em vista dessas modificações, um pouco diferente do que parecia no momento da leitura. O que temos lido se afunda na lembrança, corta suas perspectivas, empalidece de modo crescente e acaba dissolvendo-se num horizonte 
vazio, não oferecendo mais do que um padrão bastante geral para o que fixamos na retenção. Porém, no desenrolar da leitura, despertam-se múltiplas facetas daquilo que possuímos somente na retenção, e isto quer dizer que o que lembramos é projetado num novo horizonte, que ainda não existia no momento em que foi captado (ISER, 1998: p. 16).

A aproximação entre as duas teorias pode, portanto, indicar que ambas valorizam o efeito retroativo para a compreensão da perspectiva do sujeito sobre si e sobre o mundo. Enquanto Lacan analisa a operação de retroação visando o efeito do desejo no sujeito, Iser a investiga visando o efeito estético da leitura na constituição de pontos de vista do leitor em movimento (o que não deixa de ser consequência do desejo de decifração e interpretação do sujeito diante da estrutura hermenêutica elementar da leitura). Com a obra poética, o leitor modifica suas expectativas e transforma o sentido antes lembrado para conseguir traduzir o texto num correlato de consciência, o que para a circulação da fala em uma sessão de psicanálise pode se assimilar à ressignificação necessária para a interpretação e a reformulação da posição sintomática do sujeito.

Na operação de retroação ao desejo e à palavra do Outro (nesse caso, o texto poético), o leitor se estabelece em uma posição simbólica do seu Eu ideal (I(A)) que produz efeitos imaginários, produto este representado no segundo "degrau" do grafo de Lacan. Na lida das demandas do sujeito em busca de se estabelecer na relação com o Outro, surge um redobramento da demanda, resultando na necessidade do sujeito de ir além de si mesmo e, consequentemente, no desejo (d) de mover o significante para a realização da demanda (representada no grafo como $\$ \diamond \mathrm{D}$ ). A relação entre demanda, necessidade e desejo pode ser compreendida pela estrutura da faixa de Moëbius vista anteriormente (representada pelo desenho de Escher - figura 6, p. 97). Assim como o significante não cessa ao deslizar pela superfície unilátera da faixa sem perceber suas bordas, assim como o som e o sentido da poesia transitam condensadamente no inconsciente do leitor, a demanda como torção da faixa coloca a necessidade do sujeito em circulação estreita com o seu desejo nas bordas da mesma superfície. É a necessidade do significante do desejo do desejo do Outro.

Como indica o grafo, o sujeito, operado por essa torção, caminha do lugar da demanda para o lugar da castração, do significante da falta do Outro, gerando a demanda castrada (\$ seguido de A barrado) pela impossibilidade deste Outro ser completo. Temos, assim, no trecho inferior do grafo, o produto da ressignificação, do Imaginário, da posição do sujeito, do ideal do Eu preocupado com o conteúdo do que se diz, enquanto que no trecho superior 
vemos o poder da enunciação, a operação de onde fala o inconsciente, de onde o inconsciente se articula com a pulsão e pela qual ao sujeito é lançada a questão: "O que quer? O que deseja?".

Nesse momento de constituição do sujeito, a preocupação passa a ser com o ato de dizer e com o lugar no qual o sujeito se localiza no dizer. Na leitura, esse é um momento crucial para a compreensão e apreensão do texto, pois é o momento em que o leitor deve tomar o texto para si, reposicionando-se subjetivamente como chave determinante para operar os horizontes de sentido que devem ser esvaziados e preenchidos continuamente no ato da leitura. "Desse modo, o ponto de vista em movimento do leitor não cessa de abrir os dois horizontes interiores do texto [o vazio e o já preenchido], para fundi-los depois" (Iser, 1998: p. 17), fixando o point de capiton, isto é, impondo uma amarração de unidade de sentido, uma formação de coerência aos correlatos de consciência produzidos pelo ponto de vista em movimento.

No entanto, esse movimento de amarração e de compreensão da consciência leitora é altamente complexo e muitas vezes não se conclui. Como mostra o grafo lacaniano, o sujeito se depara com a angústia e a dificuldade de compreender sua própria existência, pois percebe que a existência do Outro já está dada e determinada, mas a sua própria não depende apenas do discurso do Outro, mas também da constituição de seu próprio discurso e desejo, de um reposicionamento subjetivo que exige muito engajamento e introspecção. Na tentativa de encontrar resposta para essa questão e ao mesmo tempo preso a essa torção da demanda, o sujeito leitor reformula a questão: "o que o Outro quer de mim?", "o que o texto quer que eu interprete?". Ao endereçar sua questão ao Outro, ele se oferece como objeto para a demanda e desejo do texto, pois não consegue identificar o seu próprio desejo e tampouco se desarticular dos significantes da demanda do Outro. Logo, o sujeito recebe como resposta primeira um filtro da castração, e, em seguida, como seu desejo deve ir além da demanda particular do Outro, ele se encontra no lugar da fantasia $(\$ \diamond$ a) que o remete ao sintoma $(\mathrm{s}(\mathrm{A}))$ devido à falta do objeto de desejo. A relação de sua fantasia com a busca pela verdade do seu desejo produz sintomas que constituem impasses ao sujeito e fazem parte de seu processo construtivo de desassujeitamento do Outro. Ele deve se haver com o texto a partir de sua própria perspectiva e de sua própria experiência.

Diante dessa primeira experiência do desejo (que é desejo do desejo do Outro e se situa na fantasia), o sujeito pode ser tomado por um tormento ao perceber como esse objeto está entre fissuras e cortes difíceis de acessar. A leitura da poesia, do Real de sua fala, coloca 
o sujeito para além do seu conhecimento, em um intervalo de ressignificação que sem o efeito retroativo não é possível apreender o sentido ilógico dos significantes contidos nos versos. Não por outro motivo nos beneficiamos do grafo do desejo de Lacan para avançar na compreensão de um fenômeno subjetivo tão enigmático e enriquecedor como a leitura poética.

Em suma, do Estádio do Espelho representado no "degrau" inferior do grafo à entrada do sujeito na linguagem e da formação e fixação da fantasia à circunscrição do gozo, a constituição do sujeito no ato da leitura é representada por uma demanda que encontra no Simbólico um furo, um ponto de inserção do Real. Logo, estar diante da escrita poética é também confrontar-se com uma rasura no sentido provocada pelo Real, uma vez que sua estrutura condensada intenta representar o inefável, o vazio do não-dito, suscitando uma suspensão dos sentidos habituais da cadeia significante. Nesse sentido, o que estão de antemão ao alcance do sujeito para a lida com a demanda da poesia são elementos materiais como sua voz, seu artifício gramatical e o empenho de seu corpo na leitura, bem como o estímulo (muitas vezes externo) para o desejo de decifração e inferência, que deverão ser aproveitados para seu reposicionamento subjetivo diante dos desafios do letramento. Para que essa lida suceda, a interação entre leitor e texto deve ocorrer moëbianamente, transformando a relação de distanciamento entre eles em um engajamento polifônico, tanto de identificação com uma voz externa que o provoca, quanto de reconhecimento de uma voz interna capaz de ocupar as lacunas com suas projeções. Assim como é impossível distinguir na faixa de Moëbius uma superfície da outra, em um cenário de leitura inferencial, as vozes do autor e do leitor se confundem, deixando este livre para circular pelo texto, em um movimento de ida e vinda entre os contornos das bordas pulsionais, das fantasias e dos devaneios, dos cortes do Real e das rasuras e enigmas do texto poético e os contornos das bordas do Simbólico, da tradição, da cultura e do discurso do Outro. A leitura de poesia dissolve a cisão entre sujeito e objeto e impõe um novo lugar ao sujeito-leitor, pois agora ele foi tomado por pensamentos que não o pertencem, no entanto, o condicionam a deslocar a cisão para dentro de si mesmo. Ele se torna sujeito efeito do discurso de um outro, suspende momentaneamente suas disposições individuais e se ocupa de algo que até então desconhecia.

Logo, o sentido do texto apenas é constituído pelo leitor se ele se reposiciona subjetivamente em um lugar não de mero decodificador, mas de explorador de seu próprio ponto de vista. Isso ocorre na medida em que o texto exerce influência sobre a posição que o sujeito ocupa, "pois a constituição de um sentido não representa uma exigência unilateral por 
parte do texto ao leitor; ao contrário, o sentido só vem à tona se algo sucede ao leitor" (Iser, 1998: p. 82). É devido a essa perspectiva que afirmarmos que esse processo ocorre moëbianamente, já que ao mesmo tempo em que o ponto de vista do leitor se movimenta e ocupa seu lugar no texto, ele age sobre o sujeito, transcendendo-o para outras leituras e formas de interpretar o mesmo texto: um novo horizonte de sentido se abre, novos aspectos textuais se evidenciam ao leitor e suas próprias experiências não são mais suficientes para instituir seu ponto de vista. É preciso se entrelaçar nos aspectos textuais para que lhe suceda algo, pois a poesia não precisa do sujeito por sua própria causa senão para desenrolar-se nele (idem). O aspecto "unheimlich" (infamiliar) da poesia pretende abrir ao leitor uma extensão de seu horizonte de sentido, introduzindo concepções em geral opostas às do leitor, quebrando paradigmas e causando estranhezas por revelar possibilidades que até então o sujeito leitor não acreditava ser possível existir em outro contexto.

Quando uma poesia estimula outros hábitos de leitura do sujeito, deslocando-o de seu lugar confortável enquanto decodificador, ela exerce seu papel de agir sobre ele, modificandoo, pois sua leitura não se deu apenas por meio de suas disposições e experiências individuais enquanto leitor, mas também pelas condições do texto que o fizeram trabalhar na constituição de sentido que vai além de si (na busca pelo desejo do Outro - $\$ \diamond \mathrm{D}$ ). Essa cisão interna no leitor não significa que sua singularidade ou orientação própria foram barradas por completo quando ele se aventurou a pensar no lugar de um outro. Sua experiência subjetiva forma um pano de fundo para a dominação do pensamento do autor e para o movimento do seu ponto de vista, por isso, cada poema se organiza e se traduz de maneira heterogênea na consciência dos mais diversos sujeitos leitores.

Nesse sentido, junto ao grupo de jovens escolares, coube a nós, professores, encorajarmos os atos de apreensão dessas experiências estranhas que ocorrem no contato com a poesia e não deixam de ter efeitos retroativos sobre suas próprias experiências prévias ao ato da leitura, pois delas depende o processo de subjetivação e de reposicionamento diante dos desafios do letramento. Tal responsabilização do nosso papel de professor nos coloca em um posicionamento diferente do tradicional, que não se pauta "pela intenção estritamente apegada à ideia de transmitir conteúdo sem levar em conta as singularidades do aluno que apresenta dificuldades" (Belintane, 2017: p. 35). Preocupado com as demandas específicas da alfabetização brasileira e propenso a colocar em relevo a lida com as singularidades dos alunos a fim de evitar sua marginalização ou exclusão do processo de letramento, Belintane desenvolveu uma estratégia de manejo da heterogeneidade do grupo-classe, instruindo o 
professor a enredar a subjetividade entre-textos a partir de um posicionamento cunhado como "ponto-de-giro", próximo ao point de capiton da Psicanálise, situado no escopo da escuta e da transferência (idem). A ideia com o desenvolvimento desta estratégia não foi transferir os conceitos exclusivos da clínica para a o ensino e a sala de aula, mas considerar que uma escuta acurada das demandas singulares dos alunos pode fazer parte do cotidiano escolar e das pesquisas ali desenvolvidas, principalmente por contribuir para a inclusão daqueles que evidenciam descompassos em relação à performance geral da turma, democratizando seu acesso ao conhecimento, estimulando sua permanência na escola e impulsionando um letramento contínuo com foco na leitura inferencial e na escrita criativa. Por isso, uma escuta sensível é parte constitutiva dessa metodologia que defendemos, tanto da pesquisa como de ensino, quando abordada pela interlocução com o aluno a partir de uma relação permeada por textos literários, pela função poética sobre a qual discorremos até agora. Ou seja, nós professores não pretendemos de forma alguma nos portar como psicanalistas, mas sim como educadores intencionados a colocar o sujeito em movimento, em processo de descobrimento do mundo e da cultura.

Com a palavra poética endereçada ao aluno, de maneira que se possa estabelecer um vínculo efetivo e afetivo, a mediação do professor na relação aluno/ Outro pode alentar a emergência de desejos, fantasias ou até impasses e angústias que muitas vezes só conseguem se manifestar em momentos de associações livres e falas não intencionais. Mesmo nos diferenciando conceitualmente da escuta psicanalítica, a escuta pedagógica se estabelece por meio de relações intersubjetivas que, em nosso entendimento, dependem da compreensão de conceitos da Psicanálise, como a noção de transferência e a necessidade do deslocamento de uma posição narcísica para uma posição de reconhecimento da alteridade como lugar do saber. Tendo isso em vista, seguiremos com essas questões no próximo item.

\section{O professor como ponto-de-giro para o reposicionamento subjetivo do aluno}

\section{diante dos desafios da leitura}

Em uma roda de conversa sobre os hábitos de leitura dos alunos do primeiro ano do Ensino Médio, ouvimos mais objeções e queixas vinculadas à obrigação e à pressão que a escola decretava em seu discurso sobre a importância de ler, do que comentários e análises positivas das relações dos alunos com os livros. A maioria dos alunos alegou sentir-se entediado ao ter que ler um livro, pois era uma atividade solitária, sem interação ou 
comunicação com outras vozes reais. Alguns afirmaram que a leitura os colocava em uma posição humilhante por não se sentirem capazes de se concentrar suficientemente para compreender o conteúdo do texto ou pela dificuldade de acompanhar a estrutura sintática ou a complexidade lexical de algumas obras. Quando questionamos quais obras relacionadas a esse sentimento de humilhação vinham à lembrança, uma aluna citou $O$ quinze de Raquel de Queiróz, outro aluno retomou parte do nome da peça de Gil Vicente $O$ auto da barca do inferno e uma aluna ainda comentou ter tentado ler um livro da Clarice Lispector, cujo título não se lembrava. Nesse esforço de recordar nomes de livros abordados no curso do nono ano das antigas escolas de onde vieram, quatro alunas apresentaram outros títulos de livros de que gostaram, como a saga "Crepúsculo", "Diário de uma adolescente" e "Por treze razões", bestsellers americanos que se tornaram filmes ou séries. Dos trinta e dois alunos presentes na sala durante a roda de conversa, escutamos o título dessas obras, ora como exemplo de fracasso, ora como conquista pelo interesse e capacidade de concluir a leitura de um livro.

A discussão prosseguiu com mais três intervenções que apontavam para a vinculação da leitura à obrigação, humilhação, tédio e fracasso, até que surgiu uma polêmica. Um aluno, claramente líder da turma dos meninos "populares" da escola, afirmou: "só os nerds leem, 'profi', quem quer perder tempo lendo fora da escola se a gente pode dormir, dar rolê, fumar e ficar de boa, pegar as mina... essa galera aí que fica lendo depois da aula tá sem amigos". Inspirada nas aulas de Belintane e antes que a risada se generalizasse e implodisse a conversa, eu concordei com o aluno: "é verdade, ler pode ser bem entediante mesmo, por isso eu só leio o que me dá prazer, o que me deixa sem vontade de dormir, o que me faz querer encontrar meus amigos o mais rápido possível para eu poder contar o que li, o que aprendi. Se a literatura não for boa, ler fica mesmo nada a ver... eu leio também porque vejo meus amigos gostando de algo que leram ou porque me interessei por alguém que comentou sobre um livro... uma vez, para fazer charme fui lá e li o tal livro que o cara tinha comentado só para ter o que falar com ele... quem aqui já leu algo para impressionar uma menina ou um menino?"27. Em resposta, várias mãos levantadas e alguns comentários sobre leitura de poemas, romances e outras referências que vieram de pessoas de quem gostavam ou por quem se interessavam. Inclusive o aluno que afirmou que quem lê não tem amigos se lembrou de ter copiado um poema longo para escrever um recado de amor. Por mais que os livros gerem desconfiança e a

\footnotetext{
${ }^{27}$ Relatei o episódio aos alunos de um jeito caricatural para eles poderem captar de maneira mais clara a mensagem que estava por trás.
} 
cultura escrita possa muitas vezes representar um instrumento de humilhação para esses jovens, cultura que vem do poder de cima, de uma ordem estabelecida e controladora, sempre tem algo da escrita e da leitura que nos faz desejantes, que nos move em busca de mais conhecimento.

Diante de tal alegação provocativa do aluno, era possível que a turma esperasse uma reação diferente de minha parte, como uma aceitação e resignação expressa em frases como "pois é, hoje em dia ninguém mais gosta de ler" ou "vocês jovens não sabem valorizar a importância da leitura". Segundo Belintane (2017: p. 36), essa reação seria fruto de uma conjunção entre o desejo provocador, mas ainda não sedimentado dos adolescentes em dizer que não gostam de ler e um imaginário do professor que expandiria essa provocação como uma verdade. No entanto, "um não reiterativo poderia significar exatamente o seu contrário, um sim apaixonado, ambíguo" (idem), e foi a partir desse ponto de vista que a reação à fala denegativa do aluno se deu por meio de uma recepção enviesada, que em vez de permanecer no solo firme e racional dos sentidos diretos de sua afirmação sobre a leitura, fisgou apenas o tema da amizade e do prazer para afirmar exatamente o contrário.

Belintane, retomando o conceito de escuta psicanalítica de Freud, explica que a escuta pedagógica também pode se valer dessa técnica não tão centrada e amparada por um saber prévio e estruturador para, em vez de se fixar nos sentidos e no alinhamento dos significados consensuais, dar mais valor ao jogo significante e a sua flutuação de sentidos, o que resultaria em uma escuta mais produtiva em termos de busca das singularidades. Ao escutar o aluno, o sentido da falta de prazer e desejo pela leitura se tornou um elemento flutuante e a resposta não se pautou por um discurso moralista sobre a importância de ler (o que era esperado pela turma), mas engatou um novo sentido de leitura como forma de prazer (tanto em relação a si mesmo quanto na conquista de um prazer vindo do outro). Com a ambiguidade da leitura como prazer intelectual (em busca de conhecimento) e sexual (em busca do flerte) exposta aos alunos, um vazio desconcertante se abriu e ajudou a desfazer as polaridades (entre gostar ou não de ler), instigando os alunos a refletir se eles já utilizaram a leitura para conquistar alguém. Nesse ponto-de-giro, os alunos suspenderam por um momento o lugar humilhante e entediante no qual inseriram a leitura e relembraram situações em que o ato de ler tenha sido positivo e agradável.

Infelizmente, em uma sala de aula com trinta e dois alunos e uma única professora acompanhando a turma, essa escuta pedagógica, sensível e que movimenta os sentidos não ganhou tanto espaço para se desenvolver em momentos particulares. No curso de Língua 
Portuguesa, ampliamos a estratégia em busca de uma melhor compreensão das singularidades dos alunos em momentos mais coletivos, de conversa ou discussão com o grupo-classe a partir da leitura de poesia ou de outro texto literário. No entanto, pudemos vivenciar diversas situações dessa escuta acurada nos momentos de orientação dos trabalhos monográficos, chamados de Projeto de Síntese que ocorriam uma vez por semana, em reuniões de uma hora e meia com os alunos orientandos distribuídos em núcleos de pesquisa. Em nosso caso, eu e uma professora de Artes atuávamos no núcleo de "Linguagens e Expressões Artísticas" com a orientação de vinte e oito alunos. A cada encontro trabalhávamos em duplas ou trios para discutir o andamento dos trabalhos monográficos e, nesses momentos reservados, tínhamos mais condições de exercer essa escuta sensível e ir além do lugar estigmatizado do "eu não sei" e "eu não consigo" em que os alunos muitas vezes se colocam ou são colocados pelo sistema. A orientação das sínteses era um momento privilegiado para abrir novas associações, novos caminhos que constituem a técnica e a ética docente. No quarto capítulo, elucidaremos outros exemplos desse processo de escuta e estratégia de ponto-de-giro, em que outros sentidos foram enlaçados a partir de leituras e enredamentos subjetivos e novas predisposições surgiram na apreensão dos textos.

Com o modelo do grafo do desejo de Lacan, vimos que o efeito retroativo de amarração e unidade de sentido é essencial para que o sujeito se reposicione no Simbólico e na demanda do outro. Logo, na relação transferencial dos professores com seus alunos, Belintane (2017: p. 43) alerta para a importância de prevalecer certa precaução para que os sentidos vindos do outro não caiam em uma rede preestabelecida pelo imaginário do professor, sobretudo porque esse modo de lidar com o diferente, com a alteridade ancha, está na tentativa de não recobrir os significantes e sentidos do outro com os nossos significantes e com os nossos sentidos, mas sim de abrir espaço para manifestações mais singulares:

\footnotetext{
em nosso campo, não nos interessamos por sintoma, mas sim pela relação educadoreducando; o que está em jogo, portanto, é a habilidade de o professor ir além de possíveis giros e conceituações em torno de um núcleo persistente e repetitivo. Abrir novas associações, novos caminhos, é sua técnica e sua ética. De vez em quando, é sempre possível fazer uma síntese, elaborar unidades de compreensão juntamente com o aluno, assumir um diagnóstico (que é o nosso "ponto de basta", nosso "pontode-giro"), mas sempre com a certeza de que ele é provisório, de que é produto de nossa interpretação (BELINTANE, 2017: p. 42).
}

Para isso, devemos procurar suspender momentaneamente os sentidos que aparentemente figuram como os mais importantes para valorizar um pormenor, um nonsense, 
um lapso, um indício (p. 43). Portanto, a atuação como ponto-de-giro através de uma escuta pedagógica acurada e de uma posição intervalar do professor, constitui uma ética pedagógica que se predispõe a valorizar os indícios do falante em vez de se prender aos significados já preestabelecidos e às interpretações diretas das coisas, como taxar os alunos mais dispersos como hiperativos e encaminhá-los rapidamente à medicação, por exemplo, sem ouvi-los, sem percebê-los. Procuramos expor aqui a preocupação em não nos prender à "primeira impressão" e rotulação com a qual nós, professores, acabamos classificando os alunos, como “aquele que não lê", "aquele que não senta", "aquele que não sabe”. O estigma previamente determinado coloca os alunos nessa posição relutante, que dificulta muito a superação de seus entraves. Esse discurso e o lugar onde o aluno é colocado devem ser removidos para que uma nova predisposição se instale e para que haja a possibilidade do professor se colocar como ponto-de-giro e dialogar com as mais complexas singularidades encontradas dentro das salas de aula.

Portanto, podemos relacionar essa atuação do professor como ponto-de-giro com a leitura de poesia e sua necessidade de esvaziamento dos sentidos triviais das palavras, reposicionando-as em um jogo de significantes. A escuta pedagógica e a poesia se encontram nesse processo intrínseco de efeitos retroativos para compreender o que está "escrito" nas entrelinhas e, assim como tentamos ensinar nossos alunos sobre a torção dos sentidos das palavras em um poema, podemos repensar nossa disposição para ouvir e ler os alunos também pelas técnicas da poesia. O exercício de retroação cabe tanto ao professor no cuidado com a forma de se relacionar com o aluno e de ajudá-lo a superar suas dificuldades, como ao próprio aluno ao se deparar com a leitura de poesia, que, por sua vez, também retoma o ponto de partida de toda proposta metodológica em questão: a reimersão na oralidade poética e o aprofundamento do trabalho com textos literários no avanço de um ponto-de-giro e de sua formação como leitor fluente, capaz de compreender criticamente o mundo em sua volta por meio de palavras espertas.

Por não me impressionar com os significantes denegatórios do aluno ao dizer que a leitura é perda de tempo e só serve para aqueles que não tem amigos, pude me posicionar em permeio para novos laços que trouxeram à memória da turma outras experiências com o ato de ler. Parodiando Belintane (2017: p. 45) que emprestou o verso "...o esplendor da manhã não se abre como faca" ${ }^{28}$, de Manoel de Barros, para dizer sobre a relação do professor

\footnotetext{
${ }^{28}$ Do poema "Uma didática da invenção" (Barros, 2010: p. 299 apud Belintane, 2017: p. 45).
} 
ponto-de-giro com as crianças, favoreço-me de suas palavras para falar dos adolescentes: o esplendor de cada jovem não se abre com falatórios e com interpretações genéricas, baseadas nos sentidos denotativos do que diz um adolescente. É preciso torcer tais indícios para poder encontrar uma porta aberta à tomada entusiasmada da palavra poética. 


\section{Capítulo 3. A tomada entusiasmada da palavra poética}

O melhor da história é o entusiasmo que ela suscita. - J. W. von Goethe. ${ }^{29}$

De origem grega, a palavra entusiasmo vem de entheos, que significa ter um deus dentro de si, uma inspiração divina. Essa "exaltação do espírito" no processo de letramento contínuo é, muitas vezes, condição sine qua non para mover subjetivamente o aluno aos estímulos do ensino e aprendizagem. Retomando nossas premissas, professores e educadores tendem a perceber que o aprendizado efetivo e afetivo da/ pela leitura e escrita neste processo depende muito da sua capacidade de despertar desejo e interesse nos alunos que chegam à sala de aula. E o que desperta a curiosidade ou o que motiva o jovem a buscar decifrar, compreender e analisar os códigos ao seu redor?

Como já acentuado anteriormente, contrapomo-nos às concepções pedagógicas dominantes nas diretrizes governamentais, que tanto valorizam os gêneros discursivos do cotidiano (bulas, receitas, logomarcas e outros gêneros do mercado) e acreditamos que o trabalho com os textos narrativos e poéticos (os mitos, fábulas, romances, poesias) forma uma rede de memória oral que já enraíza potencialidades para o gosto literário do aluno. Assim, permanece ainda a dúvida sobre a real intenção dos livros didáticos em substituir a literatura e a arte por gêneros do cotidiano prosaico ou confinar os exercícios de leitura e interpretação de texto ao gênero jornalístico com artigos e editoriais. Qual é o estímulo à formação subjetiva e cultural que a escola se propõe a oferecer quando apresenta apenas atividades com propagandas e logomarcas e pede para que o aluno identifique sua mensagem? Onde estão a fruição e percepção estética de textos da nossa cultura que são inerentes ao universo formador da linguagem humana e da oralidade primária?

A escola do século XXI está cada vez mais orientada à competitividade e à eficácia, abandonando gradativamente a ideia de que ensinar pela arte é poder acionar uma rica comunicação humana para melhor desenvolver outros tipos de expressão, habilidades e competências que não são estimuladas quando ficamos presos às imposições do mercado. Quando nos sensibilizamos com o entusiasmo do aluno ao escutar versos de uma poesia, ao se encantar com a polissemia das palavras, ao abrir as páginas de um livro e contemplá-lo como quem quer penetrar nas aventuras dos personagens, motivamo-nos para que a literatura tenha um amplo espaço e presença garantida nas salas de aula. É a partir da resistência e da crença

\footnotetext{
${ }^{29}$ In: Máximas e reflexões, 2001.
} 
de que o gênero literário não pode ser substituído por artigos de jornal que nos propusemos a refletir sobre a importância de despertar o entusiasmo dos alunos em buscar compreender o mundo a nossa volta a partir da literatura e da sua capacidade estética de encantar, intrigar, aprofundar a curiosidade sobre o desconhecido e fortalecer a disposição para a emancipação intelectual e subjetiva. Nessa direção, deparamo-nos com muitas contrariedades, que, apesar de austeras, não nos detiveram em nossa travessia.

\section{Primeiros obstáculos: o conceito de escola e ensino no atual governo}

Em tempos de Ritalina, até mesmo a curiosidade dos alunos vem sendo cerceada nas escolas, já que, diante da estrutura que as rege e da organização que lhes é imposta, o entusiasmo e a excitação provocadas pela curiosidade causam barulho e alvoroço em demasia para a ordem disciplinadora. Diante desse entrave, logo compreendemos que o contexto político é desfavorável, mas aprendemos a enfrentar suas contradições e a enxergar que sua transformação não é impossível.

O aluno curioso é inquieto, é investigador, é ativo e sua postura é desafiadora. Não é de hoje que a escola não tem tempo, nem paciência para guiar a curiosidade dos jovens para o caminho da criatividade e da transformação, uma vez que ela é reflexo do mundo neoliberal que a conduz. Ao se deparar com essa ordem uniformizadora que desrespeita as diferenças, o aluno passa a enxergar a escola como adversária, pois ele não se identifica com o regimento imposto e nem avista brechas para transcender a estrutura engessada dos currículos. Nesse ciclo de enfrentamento, os professores e a equipe pedagógica necessitam encontrar estratégias para responder aos ataques do projeto tecnicista do governo que visa uma educação mercantilista e militarizada e, ao mesmo tempo, buscar afirmar o desejo dos alunos de se envolver com o ensino e o aprendizado pela via da fruição estética, cuidando para que esse desejo não se desfaça diante de tanta hostilidade. Correr atrás de alternativas inventivas e afetivas para lidar com o sentimento de rejeição e de não-identificação dos alunos tem nos parecido uma ação e responsabilização isoladas do corpo docente e da equipe pedagógica, uma vez que os órgãos institucionais não apontam para nenhuma medida coletiva ou colaborativa que pretende refletir sobre os valores de uma educação humanizada, democrática, emancipatória e sensível às artes.

A linguagem artística, como vimos anteriormente ao estudar a função poética da língua, permite atravessar um mundo que, na realidade não artística, não conseguimos atravessar, 
pois nesta realidade falta o mistério, falta um enigma para despertar o desejo de explorar e decifrar o que está por trás das imagens, das metáforas, nas entrelinhas. No entanto, o fomento ao exercício de inferência e interpretação da linguagem poética não é do interesse do atual Governo Federal e do Ministério da Educação, muito pelo contrário. A poesia lhes parece assustadora, - os devaneios do poeta, os arranjos complexos e inusitados das palavras, suas figuras enigmáticas, - eles a temem por não poderem controlar seus sentidos. A literatura carrega consigo a ameaça de um mundo insurgente, livre dos modos preestabelecidos de atribuir sentidos, o que incomoda e estremece os determinismos sociais e culturais ditados pelos reacionários que compreendem a língua a partir de uma concepção instrumentalista, como se ela servisse apenas para o trânsito de informações. A poesia não permite que a língua se empobreça ou se aprisione em linhas rígidas, ela transforma os signos em elocuções vigilantes e irrequietas, que, quando se sentem engessadas, logo se atrelam a outras constelações de signos capazes de subverter mais uma vez a imposição dos sentidos. Não à toa, muitos livros foram censurados ou impossibilitados de circularem nas escolas desde que o atual presidente moveu um projeto de restauração de uma suposta coesão social que teria sido aniquilada anteriormente a seu governo por políticas de esquerda. Acompanhado de um discurso de ódio, o atual presidente expôs desde o início de seu mandato a ambição de uma doutrina na qual a família brasileira deve se reconciliar com a religião cristã e com o princípio da tradição patriarcal e heteronormativa, e, para isso, as escolas deveriam cumprir um papel fundamentalista na reeducação religiosa e tradicional dos jovens. Para o governo, seria preciso, portanto, que a escola enquadrasse os alunos em programas curriculares que não despertassem dúvidas ou contraposições sobre a máquina de reprodução da ordem social. Não por outro motivo, disciplinas como História, Sociologia e Filosofia foram retiradas do currículo de diversas instituições de ensino, além do fato de que os cursos de Língua Portuguesa estão cada vez mais pasteurizados para corresponder às demandas do vestibular.

Enquanto isso, o país ainda enfrenta grandes dificuldades em manter os jovens nas escolas, principalmente na faixa etária dos 15 e 17 anos, no entanto, este grave problema de evasão escolar não é combatido pelas medidas governamentais, sequer há propostas para reverter este cenário. Muitos alunos abandonam os estudos no final do Ensino Fundamental para auxiliar nos negócios da família e contribuir para a renda mensal dos pais. Segundo o Anuário Brasileiro da Educação Básica, em 2018, 8\% dos jovens não continuam os estudos 
após abandonar a escola ${ }^{30}$. Os números de abandono da escolarização crescem não apenas no final do Ensino Fundamental, mas ao longo de todos os anos da Educação Básica. Das 48,5 milhões de matrículas em 2017 em toda Educação Básica, 3,5 milhões de alunos foram reprovados ou abandonaram os estudos, segundo a pesquisa divulgada pela Unicef em 2019 com base nos dados do Censo Escolar 2018. Com isso, cresceu o atraso escolar com relação à faixa etária prevista para cada série, resultando em 6,4 milhões de crianças e adolescentes que estão fora do período escolar esperado para sua idade. O relatório da Unicef também mostra que o período escolar que mais reprova e naturaliza a cultura do fracasso escolar na vida dos alunos brasileiros é o Ensino Médio ${ }^{31}$ : em 2018, 460 mil alunos abandonaram os estudos nessa etapa da escolarização. Em Paraisópolis, durante o estudo de campo, seis alunos dentre as duas turmas do primeiro e segundo ano do Ensino Médio que participaram de nossa pesquisa também abandonaram os estudos por não conseguirem acompanhar as exigências da vida de estudante em concomitância com empregos e trabalhos informais aos quais eram submetidos pelas necessidades da família.

A perspectiva para a continuidade dos estudos após a formação no Ensino Médio é ainda mais decrescente. Em 2019, quase 30\% dos formandos no Ensino Médio público no Brasil não se inscreveram para a realização da prova do ENEM, principal acesso às instituições federais do Ensino Superior. Desde 2017, o ENEM vem perdendo inscritos tanto de alunos oriundos das escolas públicas quanto das privadas, o que aponta para o fato de que muitos formandos não vislumbram um futuro acadêmico, possivelmente devido às demandas precoces de contribuição da renda familiar, ou seja, à necessidade de um rápido ingresso no mercado de trabalho, quando analisamos os casos dos alunos oriundos de escolas públicas. Além disso, há uma ideologia por trás das políticas públicas voltadas ao ensino técnico e especializado com formação a curto prazo que estimula os jovens a não cursarem o ensino superior para que sirvam rapidamente de mão de obra barata, principalmente nos setores da construção civil e da tecnologia da informação.

Os dados e indicadores sociais divulgados nos últimos três anos apontam mais uma vez para um movimento retrógrado da qualidade de vida, inclusive no que toca o acesso

\footnotetext{
30 Dados extraídos em 04/11/2019 do site: https://www1.folha.uol.com.br/educacao/2019/11/quase-30-deformandos-de-escola-publica-nao-se-inscrevem-no-enem.shtml

31 Dados extraídos em 04/11/2019 do site: https://educacao.uol.com.br/noticias/2019/10/31/35-milhoes-dealunos-reprovaram-ou-abandonaram-estudos-em-2018-diz-unicef.htm
} 
democrático e de qualidade à educação, moradia e saúde. Os jovens que acompanhamos ao longo desta pesquisa expunham frequentemente um sentimento de anomia social, de desesperança em um futuro transformador e libertário. A escola poderia estar na linha de frente da promoção de uma educação que se atrela à cultura, à ciência e à tecnologia de forma a nos aproximar também das artes. No entanto, essa missão recai somente nos ombros dos profissionais que estão no chão da escola, lidando com salas de aula lotadas e falta de estrutura e material e, mesmo assim, se mantêm na busca por viabilizar o possível para enriquecer a relação dos alunos com o conhecimento, ativando o mundo simbólico e as potências de nosso imaginário. Isso porque, se deixássemos as iniciativas governamentais subjugarem nosso trabalho, estaríamos sufocados pela ideologia de uma educação focada na instrução profissional, reduzida ao papel subalterno de preparação de mão de obra e adestramento para a produção do mercado.

Se tomarmos como exemplo a forma como o ensino da língua deveria ser promovido segundo as diretrizes do atual governo, compreendemos o grau de afastamento drástico entre educação e cultura nos programas curriculares. A reforma proposta na nova BNCC se preocupou mais com dados quantitativos do que com a qualidade emancipatória da leitura e escrita no ensino da língua, uma vez que acrescentou ainda mais o uso pragmático da gramática e dos gêneros textuais que devem ser reconhecidos pelos alunos (apenas a identificação de qual regra ou gênero se trata o texto já é considerada satisfatória, ou seja, uma interpretação do texto e de sua formulação gramatical não seria de fato avaliada).

Além do corpo que vem se engessando em uma ordem disciplinadora, o ensino da língua em sala de aula segundo tais diretrizes também deve se instrumentalizar e introjetar um modo correto de pronunciá-la, manejá-la e (não) fruí-la. Segundo essa concepção instrumental, a língua deve manter sua estrutura colonial, afastada da cultura popular, vigiada pela política elitista que impõe uma habilidade desigual para se servir da linguagem. Enquanto os de cima são reconhecidos por expor "corretamente" seus discursos, os debaixo são excluídos da apropriação da língua apta a dar sentido ao que sentimos e vivemos. Quanto menos o jovem se sentir capaz de nomear e simbolizar o que está a sua volta, mais dificuldades ele enfrentará para transformar o mundo injusto e desigual que o domina. Por isso, a nosso ver, a escola ainda deve ser o lugar de resistência e de oposição à escalada conservadora. Nela, a educação deve ganhar o seu significado mais profundo, não apenas de formação racional, mas também de formação sensível às experiências humanas, à estética da poesia e à emancipação intelectual. 


\section{Seguir em frente em busca da educação estética}

Em acúmulo com o que já discutimos sobre i) o campo da oralidade poética à luz da história da escrita, da importância do ritmo e da poesia como elemento fundante da língua e da teoria sobre a poesia como núcleo de toda atividade humana, concebida como linguagem originária e dotada de um status mitológico; sobre ii) os conceitos de letramento contínuo e corporalidade desenvolvidos por Tfouni e Belintane, a partir de um embasamento teórico nas obras de Lacan, a fim de traçar uma perspectiva do trabalho com a poesia como forma de organização do universo cultural e escolar; sobre iii) o entendimento psicanalítico do funcionamento do inconsciente como linguagem, o que nos auxilia a compreender o modo de pensar do sujeito excêntrico, que, ao se colocar diante dos textos, torna-se efeito da intertextualidade (da metáfora e da metonímia) e do inconsciente (de livres associações). Essa identificação da nova situação do campo das artes, acompanhada de uma nova filosofia do sujeito, recusa a adesão identitária imediata do sujeito autoconsciente e completo em sua corporeidade e caracteriza-o como sujeito excêntrico, cindido, que não escapa das trapaças da linguagem, dos lapsos e dos chistes que manifestam o desejo antes oculto e recalcado; e, sobre iv) os conceitos de performance e da estética do efeito e da recepção nos atos de leitura, buscaremos respaldar nossas hipóteses metodológicas de um ensino da leitura e escrita desenvolvido por meio das narrativas poéticas, da fantasia, da tradição oral, da poesia e do ludismo da língua, expondo neste capítulo novas leituras de autores situados nos campos da Teoria Literária e da Filosofia.

Ao defender a literatura como um direito humano, assim como a alimentação, a moradia e o emprego, Antonio Candido (2004) apresenta-nos um conceito preciso de literatura como forma de ordenação do caos no mundo, como objeto artístico e estético indispensável ao ser humano e à formação de cultura e comunidade. A literatura, por meio de metáforas e de narrativas fantásticas, é capaz de formular elementos aceitáveis em resposta às indagações sobre a vida e a morte que nos atormentam a mente, sobre questões e explicações que, sozinhos, não somos capazes de elaborar, aceitar ou com as quais não conseguimos conviver. Por isso, quando falamos de literatura em sala de aula, é importante tomar cuidado para não reificá-la, esquecendo-nos de seu caráter subjetivo e estético e, ao mesmo tempo, é importante contextualizar as obras literárias a nossa realidade.

Em nossa abordagem sobre a literatura em sala de aula, buscamos pensá-la, portanto, como um direito dos jovens à fruição de todas as criações de toque narrativo e poético, já que 
a forma como nos organizamos e vivemos nos impulsiona a buscar tentativas de escape da realidade e do princípio de desempenho, que são muitas vezes duros e sufocantes. Nesse sentido, Candido (2004: 172) afirma que "se ninguém pode passar vinte e quatro horas sem mergulhar no universo da ficção e da poesia, a literatura (...) parece corresponder a uma necessidade universal, que precisa ser satisfeita e cuja satisfação constitui um direito".

É por meio desse apelo à ficção que o aluno se torna capaz de reconstruir o sentido de sua vida de maneira mais próxima a seu universo, é por meio da cultura que o sujeito se coloca no mundo, estabelece laços profundos com sua realidade circundante. Em sala de aula, percebemos claramente a capacidade da literatura em reposicionar subjetivamente os alunos no estabelecimento de vínculos, em sua compreensão subjetiva consigo mesmo e com os outros. Sem a ficção, sem a literatura como formação dos seres humanos, não damos conta de compreender a complexidade da vida, isso faz com que ela se torna um direito e por isso lutamos em resistência às imposições da sociedade de consumo. A tendência crescente das imposições neoliberais às práticas educativas é uma questão preocupante. O mercado, com ajuda dos gêneros publicitários, procura cada vez mais, de maneira ardilosa, convencer educadores de que as propagandas são textos mais eficazes para o letramento, pois estão no cotidiano de nossos alunos. Ora, justamente por acreditarmos que a escola pode ser um lugar de excelência para o ensino de nossa tradição cultural, não devemos abrir mão de nosso patrimônio literário, tanto oral como escrito, para pensarmos a prática docente e a elaboração dos planos curriculares.

Compreendido isto, buscamos explorar e valorizar as contribuições do campo da literatura para a formação de professores do ensino básico e seu trabalho em sala de aula, principalmente por estarmos caminhando na contramão dessas premissas, em que as diretrizes governamentais, em detrimento às artes, impõem às escolas por meio do Programa Nacional do Livro Didático (PNLD), o uso de textos do cotidiano e gêneros publicitários para o ensino da leitura e escrita, deixando de financiar outras pesquisas e publicações na área da literatura e da estética. A ideia de que a poesia deve estar presente no ensino da Língua Portuguesa e ser agente de conhecimento tem deixado de ser difundida entre nossos pares, diretores e coordenadores que pensam o projeto político pedagógico das escolas. Outra dificuldade que enfrentamos no contexto escolar é desvencilhar a literatura de um arcabouço tão somente pedagógico no qual ela se encontra (junto a uma finalidade instrumental) e passar a lidar com os textos literários valorizando-os enquanto arte.

O entendimento do caráter subjetivo da literatura e do direito de todos os alunos terem 
relação de fruição com a arte é condição para que consigamos romper com a tendência escolar de instrumentalizar a literatura e didatizar as experiências dos jovens com a estética literária. Além de se pensar a literatura em sua função de construir objetos autônomos com estrutura e significado e de se pensar a literatura como manifestação de emoções e visões de mundo dos indivíduos e grupos, Candido (2004: p. 176) explicita uma terceira função da ficção criada pelo e para o homem: a literatura como forma de conhecimento (do mundo, do outro, de si mesmo), inclusive como incorporação difusa e inconsciente, e isso vale também para o jovem escolar. Isso não significa que devemos afastar a literatura e as artes da sala de aula já que não queremos instrumentalizá-la, pois, quando compreendemos a literatura e a poesia em sua função formadora, muito diferente de uma suposta "missão pedagógica", conseguimos pensar em uma aproximação não doutrinária e sim emancipatória entre sujeito e arte.

Com base nessa terceira face da poesia e das artes, podemos pensar na apropriação que os jovens fazem da literatura que trazemos para a sala de aula. A escolha que fazemos dos textos que irão compor o repertório da turma deve ser cuidadosa e responsável, já que é também na literatura e nas histórias ouvidas que o aluno busca se identificar e compreender sua existência. Ele precisa não só se reconhecer no outro pela diferença (na relação de alteridade), mas também precisa se reconhecer pela semelhança e, quando não se sente representado nas narrativas dos textos literários e/ou na composição do material didático e de suas propostas, não se encontra e não se sente parte desse processo. Por isso, acreditamos ser de suma importância a diversidade de literaturas que serão apresentadas e trabalhadas em sala de aula, para que se contemple a diversidade cultural e social de nossos alunos, bem como as regionalidades de nosso país.

Defenderemos, a seguir, a permanência da poesia e do trabalho com seus elementos estéticos durante o processo de letramento contínuo, a partir de conceitos do campo filosófico e político em diálogo com a Psicanálise, para aprofundar os assuntos pertinentes ao tema da poesia enquanto ponto de partida para o ensino e aprendizagem da leitura e escrita nos anos finais do ensino básico.

Portanto, a fim de compreender a dimensão estética na vida do ser humano a partir de uma perspectiva social, histórica, cultural e política, acreditamos ser importante perceber as relações entre prazer, sensibilidade, beleza, verdade, arte e liberdade (Marcuse: 2010, p. 156) na história filosófica do termo estética e nos desdobramentos da teoria de Freud sobre a civilização e a repressão cultural. Essa associação nos interessa para a reflexão sobre a educação contemporânea e sobre os sujeitos em processo de letramento, uma vez que 
defendemos a poesia e a cultura estética como pontos de partida para uma possível emancipação intelectual dos jovens escolares e acreditamos ser de suma importância ampliar o aporte teórico nos campos da Filosofia e da Psicanálise, uma vez que atrelado a nosso objetivo da tese está também a capacidade da poética e da estética em impulsionar reposicionamentos subjetivos diante dos desafios da leitura e escrita.

\section{Elementos de uma possível cultura não-repressiva}

No campo da filosofia, quem se preocupou em aliar uma educação estética a uma conscientização política foi Schiller (2017), cujo diagnóstico de época foi feito de maneira impetuosa, escancarando um problema instaurado na formação do estado burguês que decorre até os dias de hoje. Por já termos avançado na discussão a partir da contribuição teórica de outros filósofos mais próximos a nosso tempo, faremos apenas uma breve revisão do que tratou a obra de Schiller para logo estarmos mais perto da Escola de Frankfurt com Marcuse em diálogo com Freud. A fim de compreender o surgimento do conceito de cultura estética e de uma proposta de educação em que o belo artístico se mostra como a via capaz de propiciar harmonia no indivíduo e na sociedade ao mesmo tempo, compreendemos como necessário, portanto, identificar brevemente como o desenvolvimento de sua teoria a partir de uma visão sobre sua época, Schiller pôde pensar nos princípios de sua superação.

O movimento proposto por Schiller, consistia em partir da cultura estética para formar o homem para sua liberdade, de acordo com a expectativa de retirá-lo da mera luta pela existência para movê-lo em direção a uma luta por emancipação política. Este movimento, no entanto, passava antes pela tentativa de compreender o belo, o gosto e a constituição subjetiva da classe. Em A educação estética do homem, Schiller (2017) reúne cartas destinadas ao príncipe da Dinamarca que podem ser consideradas um tratado sobre o belo e a arte. No final do século XVIII, período em que se iniciava um novo modo de pensar a arte e sua relação com o sujeito, Schiller se vale dos conceitos da filosofia kantiana e atribui à cultura estética um papel social e revolucionário para a modernidade da época, cindida entre uma razão pura, voltada para a ciência e uma razão prática, voltada para a moral. Para ele, a arte seria a mediação perfeita para o ser humano alcançar a verdadeira liberdade política de maneira coletiva e totalizadora, trocando o que chamava de Estado da privação pelo Estado da liberdade a partir do caráter público da arte. 
Não há dúvidas de que os tempos de hoje são bem distintos daqueles dos póskantianos, que buscavam compreender a revolução no mundo filosófico imposta pela Crítica da razão pura (2012) e tentavam estabelecer uma teoria estética e inovadora. No entanto, acreditamos que a defesa que Schiller faz da arte como um instrumento de emancipação universal e de liberdade pode ser revisitada, uma vez que, em nossa opinião, a reflexão sobre a teoria do belo como capaz de unificar sensibilidade e entendimento, e propiciar harmonia ao indivíduo e à sociedade, deve contribuir para a discussão atual sobre educação e cultura estética. Logo, por nos posicionarmos contra as políticas públicas do Estado de nossa época e contra as regressões sofridas no que diz respeito à democracia e à falta de valorização à cultura e à estética nas escolas, acreditamos que retomar esse conceito de educação estética pode contribuir para o diagnóstico sobre a importância do papel da poesia na escola.

Como vimos no capítulo anterior, a utopia estética do pensamento de Schiller procurava restabelecer a unidade e a harmonia que foram fragmentadas pelas imposições do mundo moderno e a arte deveria ser a mediação na busca do ser humano por sua totalidade. Freud retoma essa linha de pensamento, principalmente por compreender a arte como mediação da fantasia e da realidade, compreensão similar a de Schiller, quando o filósofo afirma que a mediação estética decorrente do impulso lúdico é capaz de conciliar o que é sensível e o que é formal. A grande diferença entre essas duas concepções é a importância que Schiller deu ao papel revolucionário da arte por meio da educação estética, enxergando-a como possível solução para o homem recuperar a totalidade perdida, enquanto que para Freud, o papel mediador da arte não pode representar uma possível solução para os problemas sociais, uma vez que, para a psicanálise, não há formas de solucionar os sintomas ou curá-los, mas sim há métodos para bordejá-los, amarrando suas pontas de forma que se torne possível lidar com eles.

No início do texto O mal-estar na civilização, Freud (2010) apresenta alguns métodos pelos quais os homens se esforçam para conseguir a felicidade e manter afastado o sofrimento, atribuindo um valor à arte e à criação como uma das possibilidades de sublimação das pulsões destrutivas, mas, ao mesmo tempo, alerta quanto aos seus limites. Ele diz que a ilusão e imaginação oferecidas pela arte condicionam os sujeitos a satisfações que podem substituir o sofrimento, graças ao papel que a fantasia assumiu na vida mental, reorientando as pulsões e as frustrações para fontes do trabalho psíquico e intelectual, como a criação artística ou as descobertas científicas. Freud considera tais satisfações como 'mais refinadas e mais altas', mas alerta que elas podem ser desintensificadas quando comparadas às satisfações das 
pulsões primárias e mais "grosseiras". No entanto, dentre as satisfações originadas pela fantasia, Freud destaca a fruição das obras de arte, que, por intermédio do artista, é acessível inclusive àqueles que não são artistas. A arte para Freud pode ser vista como uma forma de libertação, mas, pela sua teoria, os delírios da criação e da imaginação mantêm a arte ainda figurada na pulsão não domesticada do homem.

Além da diferença com relação ao papel da arte na constituição subjetiva do homem, ao teorizar sobre o mal-estar na civilização, Freud compreende a civilização como a subjugação e destruição do homem pelo homem e vê a repressão como a mais necessária ação da humanidade para o convívio possível em sociedade. Já Schiller acreditava no caráter libertário do ser humano, que, por meio da arte, seria capaz de se desvencilhar das amarras da dominação e se emancipar politicamente e intelectualmente. Próximo a esse pensamento encontramos Herbert Marcuse (2010), representante da Escola de Frankfurt, cuja obra Eros e Civilização: uma interpretação filosófica do pensamento de Freud traz inúmeras contribuições para o nosso debate. Seu ensaio teve como objetivo resgatar as ideias de Freud acerca do problema dos impulsos humanos na civilização e criticar as contradições supostamente insolúveis para o psicanalista com a teoria do mal-estar na civilização entre as exigências das pulsões e as exigências da vida em sociedade. A partir de um viés marxista de sua reflexão filosófica, Marcuse procura refutar a teoria de Freud de identificar a ideia de civilização como unicamente sintoma da repressão, e, assim como Schiller, também influenciado por Kant, acreditava na possibilidade de libertação do homem por meio da arte e da beleza. Seguia na busca moderna pelo retorno à unidade do homem e apontava para uma dimensão estética da existência humana, não apenas como uma "função" estética, mas sim como objeto revolucionário. A influência estética marxista em Marcuse propõe uma reflexão da arte como forma de rompimento da realidade reificada e representante da subversão das formas dominantes de percepção do mundo.

Nesse mesmo livro, Schiller foi também uma das grandes influências filosóficas para Marcuse a partir da crítica pioneira ao processo moderno de formação de um homem cada vez mais unidimensional e do caráter mercantil dos bens culturais. Como aponta Habermas (2008, p. 61): "Herbert Marcuse definiria mais tarde a relação entre arte e revolução em termos similares ao de Schiller". Deste modo, devemos compreender as relações que sua obra estabelece no contexto da dimensão estética e das possíveis reconciliações entre prazer e liberdade, entre impulso e moralidade.

Em seu livro, Marcuse propõe esclarecer que a própria teoria de Freud sobre as 
condições humanas para a produção de cultura fornece-nos razões para rejeitarmos a sua identificação de civilização estreitamente ligada à ideia de repressão, dominação, castração e destruição. A pesquisa do filósofo aponta para a possibilidade de se pensar o conflito entre o princípio de prazer e de realidade como algo reconciliável, contrariando a necessidade de transformação repressiva colocada por Freud, num grau que atingisse a estrutura de pulsões do homem. O impasse colocado por Marcuse reabre a discussão iniciada um século atrás, uma vez que tal conflito poderia permitir o desenvolvimento de um conceito de civilização nãorepressiva, baseada principalmente nas formas de libertação e emancipação já intentadas e alcançadas por sociedades dominadas e reprimidas na história da humanidade.

A questão do mal-estar na civilização trazida por Freud colocava em dúvida os benefícios que a cultura poderia fornecer para a felicidade dos homens, pois, segundo ele, a civilização se baseia permanentemente na subjugação das pulsões que geram prazer. A aceitação axiomática desta preposição no meio acadêmico incomodou Marcuse décadas depois da publicação de $O$ mal-estar na civilização, incômodo este que deu origem ao ensaio que nos auxiliará na compreensão da cultura estética como forma de libertação do homem, cuja principal premissa se encontra na possibilidade concreta de uma civilização nãorepressiva, do ponto de vista da opressão dos povos dominados. Nela, a experiência estética pode ser um fator de conhecimento e de transformação da realidade estabelecida.

$\mathrm{Na}$ introdução de Eros e Civilização, Marcuse reconhece o avanço da ciência e da tecnologia da civilização ocidental como favorável à satisfação de muitas necessidades dos povos e de uma promessa de vida materialmente melhor comparada àquela pré-industrial. Contudo, tanto para Freud como para Marcuse, o progresso intensificado apontava para uma igualmente intensificada ausência de liberdade, de dominação do homem pelo homem (2010: p. 27), levando a sociedade moderna a um novo patamar civilizatório.

Já no prefácio político do livro, escrito em 1966 como um revisionismo a sua própria teoria, Marcuse utiliza o conceito freudiano do princípio de realidade para explicitar que a administração científica das necessidades (dos prazeres) converteu-se em fator vital na reprodução do sistema. O capitalismo se aproveitou do controle propiciado pelo domínio das razões, aquele que a filosofia moderna já havia esclarecido: o uso da razão em detrimento da sensibilidade, como meio de ocultar as paixões. Isso foi visto mais à frente pelos filósofos contemporâneos como parte da história da repressão, como a lógica para a dominação e progresso da civilização. Com o controle dos impulsos, o sistema procura provar aos homens que sua liberdade está no domínio das aquisições materiais necessárias para uma vida 
saudável e plena, além de sua participação nos benefícios que ele proporciona. Essa estratégia do capitalismo, de mover a libido do homem para a mercadoria desejada e consumida, seria o que Marcuse chamou de um novo princípio de realidade:

\begin{abstract}
A ideia de um novo Princípio de Realidade baseou-se no pressuposto de que as precondições materiais (técnicas) para o seu desenvolvimento estavam estabelecidas ou podiam ser estabelecidas nas sociedades industriais mais avançadas do nosso tempo. Entendia-se implicitamente que a tradução das capacidades técnicas em realidade significava revolução. Mas o próprio escopo e eficácia da introjeção democrática suprimiu o sujeito histórico, o agente de revolução: as pessoas livres não necessitam de libertação e as oprimidas não são suficientemente fortes para libertarem-se (MARCUSE, 2010: p. 16).
\end{abstract}

A civilização industrial de hoje conduz a um princípio de realidade com características específicas de repressão e dominação, como a divisão hierárquica do trabalho, o controle público da existência privada, a falsa democracia e a falsa sensação de participação do povo nas decisões políticas e nos benefícios concedidos como privilégios, entre outras especificidades do capitalismo atual. Considerando que os elementos do princípio de realidade são marcadamente históricos, Marcuse denomina este novo fenômeno como princípio de desempenho, que intensifica o caráter repressivo nas instâncias não apenas políticas, mas também culturais e sociais.

Tendo em vista as modificações históricas sofridas no decorrer do progresso da civilização industrial com relação às formas de repressão das pulsões, uma vez que o que está em jogo não é mais a sobrevivência da espécie humana, e sim o assujeitamento às sociedades de controle, a interpretação filosófica de Marcuse pretende "mostrar que a dominação e alienação, derivadas da organização social predominante do trabalho, determinaram em grande medida as exigências impostas aos instintos [pulsões] por esse princípio de realidade" (2010, p.123).

A ocorrência de novos modos e padrões de controle social já não corresponde àqueles padrões originalmente necessários para a adaptação do homem à sociedade. Assim, da mesma forma que o princípio de realidade e suas instâncias de controle se transformam historicamente, as forças que se opõe ao controle também são capazes de conduzir historicamente as transformações subjetivas necessárias ao povo oprimido e podem ser consideradas forças conscientes que se mantêm livres do princípio de realidade. Em outras palavras, Marcuse visa elucidar que há fenômenos do princípio de prazer não controlados pelo 
princípio de realidade, como forças intelectuais, artísticas, culturais que serviriam para transformar a sociedade em uma possível civilização não-repressiva.

Para chegar a essa premissa, a primeira parte do livro Eros e Civilização procura identificar as tendências básicas da estrutura de controle dos impulsos como forma civilizatória e procura definir qual é esse novo princípio de realidade que governa o progresso da civilização ocidental. Por conseguinte, na segunda parte do livro, Marcuse explora as precondições necessárias para que este novo princípio de realidade seja visto de forma diferente e não-repressiva, partindo de tendências históricas básicas do progresso cultural do homem. São elas:

1) O progresso de civilização atinge um nível de produtividade cujas exigências sociais passam a ser reduzidas para a garantia de um consumo e de uma produção alienada, ou seja, a organização repressiva dos impulsos se torna menos necessitada pela "luta pela existência", já que agora não necessitamos mais da repressão dos impulsos para sobreviver, para garantir a existência da humanidade de forma civilizatória. Quem necessita dessa organização repressiva é o sistema, o Estado, que apresenta interesse nas formas de controle para dominar a sociedade.

2) A filosofia que representa a civilização ocidental passou a seguir o atual princípio de desempenho, após estabelecer a forma superior da razão não apenas como a subjugação dos impulsos sexuais e do livre gozo, mas também como forma de servir às paixões, não se opondo a elas, mas sendo útil, apontando os meios suficientes para alcançar os objetos da paixão e da sensibilidade. Marcuse nomeia tais características presentes na razão, e que são também sua própria negação, como receptividade, contemplação e fruição do prazer.

Em suma, as transformações históricas que nos capacitam pensar em uma civilização não-repressiva estão no povo, que não mais necessita das organizações de controle das pulsões para sobreviver à selvageria instintiva do homem, no entanto, estão assujeitados pela sociedade que ainda as utiliza para dominar e alienar. De um ponto de vista marxista, tanto as transformações têm respaldo na materialidade da sociedade ou na reprodução da vida social (na civilização) quanto, por um lado subjetivo, a própria filosofia já tem maturidade conceitual para dar conta de equalizar razão e pulsão e empoderar a sociedade para uma 
emancipação política e intelectual.

\section{Fantasia e realidade}

Diante deste novo cenário em que é possível pensar um novo princípio de realidade não-repressivo, cuja ordem não se baseia na dominação, Marcuse acentua a importância da fantasia como uma atividade mental que retém um elevado grau de liberdade em relação ao princípio de realidade, assim como já havia apontado Freud em sua obra Além do princípio de realidade. Como já conceituamos no item anterior ao tratar da relação dos sonhos e da criação artística do ponto de vista psicanalítico, "a fantasia desempenha uma função das mais decisivas na estrutura mental total: liga as mais profundas camadas do inconsciente aos mais elevados produtos da consciência (arte), o sonho com a realidade; preserva os arquétipos de gênero, as perpétuas, mas reprimidas ideias da memória coletiva e individual, as imagens tabus da liberdade" (Marcuse, 2010: p. 132). A fantasia, junto à imaginação e à dimensão estética, assume, portanto, uma nova dignidade diante da razão ao procurar a liberdade. No entanto, Marcuse diz que tal faculdade mental constitutiva não pode validar um princípio de realidade, pois é essencialmente "irreal". O reino da estética conservou a sua liberdade, em face do princípio de realidade, à custa de sua ineficiência na realidade (p. 156).

É a partir desta afirmação que Marcuse se aproxima de Schiller, também por meio da crítica do juízo de Kant, defendendo uma nova sensibilidade a ser revelada com a arte e sua manifestação estética, sendo ela capaz de conter uma força política e libertária. Para Marcuse, o potencial revolucionário da arte independe da classe social do artista ou da "presença ou ausência da classe oprimida nas suas obras" (2010, p. 28). O potencial revolucionário da arte é visto na obra como um todo, ou seja, na sua dimensão estética e na transgressão aos controles das formas políticas e das organizações sociais. Segundo o filósofo, a arte é representação de uma consciência coletiva e figura necessidades universais de libertação, não sendo capaz, no entanto, de por si só transformar o mundo e o sistema, mas se constitui por meio de características capazes de mudar a consciência e os impulsos dos homens e mulheres engajados na transformação social. A sublimação estética de que os engajados dispõem pode libertar e validar os sonhos de felicidade e tristeza da infância e da idade adulta, à medida que permite modificar os padrões do princípio de realidade e, assim, tornar possível experimentar o mundo desmistificado.

$\mathrm{Na}$ intenção de encontrar saídas políticas para a ausência de liberdade em uma 
sociedade de hierarquização social do controle e da dominação de classes, Marcuse se utiliza das investigações dos processos cognitivos e da linguagem inconsciente realizadas por Freud para compreender a apropriação da forma estética e das artes pelas instâncias de poder na civilização e como elas poderiam ser apropriadas pela sociedade em busca de emancipação e felicidade. A questão central para ele é, portanto, investigar sobre a questão do processo emancipatório humano, tomando como ponto de partida a dimensão estética como uma nova práxis política.

Para além da ideia marxista de revolução das massas trabalhadoras e da destruição do modo de trabalho capitalista, Marcuse percebe que a nova forma de dominação implantada uniformizou relativamente as classes sociais, tornando mais difícil o processo de revolução universal. Nesse sentido, ele propõe aprofundar a crítica marxista contra os modos de produção capitalista, analisando as possibilidades de subversão de todas as estruturas sociais, inclusive no meio artístico e cultural. Para tanto, seria preciso acrescentar às ideias marxistas a dimensão lúdica, estética e erótica de forma que uma autêntica emancipação da humanidade pudesse ser alcançada.

Nessa perspectiva, Marcuse procurou compreender as raízes do fenômeno da produção e recepção estética através da apreensão do belo e do conceito de fantasia. Para ele, a percepção estética é acompanhada do prazer que deriva da percepção da forma pura de um objeto, ou seja, de sua beleza. O prazer que sentimos ao ver a beleza de uma obra é de caráter essencialmente subjetivo, todavia, ao passo que esse prazer é constituído pela forma pura do próprio objeto, a sensibilidade se torna também universal. A imaginação estética proveniente do prazer pelo objeto artístico é criadora e gera princípios universalmente válidos para uma ordem objetiva, que para além do contexto kantiano, a essência dessa ordem pode ser verdadeiramente não-repressiva: "na obra de arte, o belo fala a linguagem libertadora, invoca as imagens libertadoras da sujeição da morte e da destruição, invoca a vontade de viver. Este é o elemento emancipatório na afirmação estética" (2010, p. 159).

As reflexões kantianas auxiliaram Marcuse no entendimento das virtudes da experiência estética e suas possíveis consequências éticas, morais e na capacidade de julgamento. Primeiro, retoma o conceito da imaginação estética, em que o objeto é representado como inteiramente livre de termos úteis ou propósitos a que possa talvez servir, sendo analisado por meio do livre jogo da imaginação, capaz de tornar sujeito e objeto livres em um novo sentido de prazer. A forma pura do objeto "sugere uma unidade da multiplicidade, uma harmonia de movimentos e relações que opera segundo suas próprias leis 
- a pura manifestação (...) de sua existência. É esta a manifestação da beleza" que é governada pelo jogo da imaginação e experiência estética que ligam o belo com o lúdico, a natureza com a liberdade, o prazer com a moralidade.

Marcuse afirma que, para Kant, a dimensão estética é o meio onde os sentidos e o intelecto se encontram e complementa dizendo que é também o meio onde natureza e liberdade se encontram. No entanto, este encontro não se dá sem conflitos, já que o progresso da civilização se reafirma com a subjugação das faculdades sensíveis à razão e através de sua utilização repressiva para as necessidades sociais (2010, p.161). A produção artística ou a recepção da forma estética, de um modo autônomo, representariam uma tentativa de reconciliação da sensibilidade e razão, duas dimensões da existência humana que foram separadas pelo primado do princípio de realidade estabelecido. Assim, a faculdade estética como reconciliadora implica um fortalecimento da sensibilidade "contra a tirania da razão" e, em última instância, exige a libertação da sensibilidade frente à dominação repressiva da razão (idem).

Nesse movimento, a disciplina da estética instala a ordem da sensibilidade contra a ordem da razão, operando através de um impulso considerado por Marcuse como básico e vital: o conceito de impulso lúdico desenvolvido por Schiller. A partir dele a função estética ganha condições para harmonizar os sentimentos e afeições com as ideias da razão e para colocar o homem, moral e fisicamente, em liberdade. Isso só é possível de ser condicionado porque a beleza e a fantasia cumprem um papel fundamental na vinculação da arte ao princípio de prazer.

A contemplação e o devaneio são faculdades que possibilitam as inspirações estéticas mais subjetivas, capazes de acessar camadas profundas do inconsciente, conectando-as com as representações sublimes da consciência. Esta capacidade mental do devaneio e da fantasia manifestada pela forma estética prepara a compreensão de nossa própria realidade e história. Os substratos inconscientes aproveitados pela fantasia denunciam também tensões e prazeres gerais, frutos de memórias sociais e coletivas condicionadas pela aproximação das representações artísticas aos traços da realidade. É bem sabido que, embora a arte seja despertada por um lugar fantasioso, ela não está desconectada da realidade concreta, justamente porque a fantasia é a expressão de desejos reais e permite que o sujeito transite entre a dimensão real e imaginária.

Em suma, a fantasia está diretamente ligada ao princípio de prazer e, como já dito, consegue se manter mais distante dos controles do princípio de realidade, sofrendo pouca 
influência da repressão. Freud já salientava a necessidade da livre expressão das fantasias para a existência das brincadeiras infantis e até mesmo para o devaneio necessário para a criação poética e artística. Ou seja, graças à liberdade da fantasia, o universo lúdico e artístico podem se desenvolver e suspender a experiência do real em nome do imaginário. O que a arte é capaz de criar com os elementos do irreal e do real, da fantasia e do devaneio, move-se a partir da ordem sensível. Segundo Marcuse, a forma estética da arte cria uma verdade não conceitual dos sentidos na qual é reconhecida uma realidade com padrões muito diferentes, uma realidade "livre" de sublimação ${ }^{32}$. "A tentativa de Schiller de eliminar a sublimação da função estética inicia-se a partir da posição de Kant: só porque a imaginação é uma faculdade central da mente, só porque a beleza é uma condição necessária da humanidade, a função estética pode desempenhar um papel decisivo na reformulação da civilização" (Marcuse: 2010, p. 165). Nesse sentido, o contato com as obras de arte devem aguçar a nova sensibilidade que tanto Schiller como Marcuse enxergavam como condição para a reformulação da civilização. No entanto, o deleite e prazer que a arte poderia proporcionar aos indivíduos dependem de um tempo livre que a sociedade capitalista não cede aos trabalhadores. O tempo livre é essencial para o prazer e para a fruição estética, mas o tempo dedicado às dimensões estéticas não é interessante para o sistema dominante que rege a sociedade e, por isso, o capitalismo domina o pouco tempo livre concedido ao trabalhador por meio das mídias e das redes que se tornam formas de controle das produções artísticas e da regulação do gozo e das fantasias.

A proposta radical de Marcuse a fim de aproximar os trabalhadores ao tempo de fruição estética do qual todos têm direito é a eliminação dos conteúdos repressivos, substituindo o princípio de desempenho por um princípio de realidade que libera espaço para o princípio de prazer. No entanto, ele não expõe exatamente como isso seria possível acontecer, ou seja, ele não deixa claro quais meios e ferramentas são necessárias para a sociedade romper com a lógica repressiva, ainda mais em tempos como o nosso, em que a maior parte das produções artísticas já está dominada pela indústria cultural. Inclusive, em sua obra One-dimensional man (o homem unidimensional, traduzida como Ideologia da sociedade industrial) escrita quase uma década depois de Eros e Civilização, Marcuse afirma,

\footnotetext{
32 Para Freud, o conceito de sublimação refere-se ao destino da sexualidade sob um princípio de realidade repressivo. Ou seja, a realidade reprime a sexualidade e assim se altera o objeto e a finalidade da pulsão. Em nossa civilização, a sublimação naturalmente recai no princípio de desempenho e se volta para o trabalho.
} 
contrariando sua teoria anterior, que o princípio de prazer absorve o princípio de realidade pelas vias da apropriação completa do sistema capitalista de todas as tentativas de libertação do homem. Então, em vez de promover uma repressão libidinal, o capitalismo promove uma satisfação libidinal administrada.

Mesmo assim, ao defender a luta por uma sociedade não-repressiva pelo intermédio da dimensão estética na obra Eros e Civilização, Marcuse não está dizendo que a arte é capaz de transformar uma sociedade com grau zero de repressão, mas é capaz de libertar a sensibilidade e sexualidade reprimidas, ou, nas palavras do filósofo, de "libertar o Eros". Tal libertação libidinal seria possível a partir da disponibilidade de tempo livre longe das forças opressoras do capital e da necessidade de trabalho incessante, para que os indivíduos pudessem se voltar às experiências estéticas, no entanto, sabemos que essa é uma visão ingênua, uma vez que o tempo livre é também absorvido pela ideologia capitalista, pois, nesse tempo, consumimos o que ela produz. Ainda assim, em Eros e Civilização, Marcuse acreditava que os impulsos, uma vez libertos das repressões ancoradas no princípio de desempenho, poderiam voltar-se para uma sublimação não repressiva, uma sublimação capaz de despertar a dimensão irreal da pura fantasia. "À luz da ideia da sublimação não-repressiva, a ideia de Eros como sendo a luta "para formas a substância viva em unidades cada vez maiores, para que a vida possa ser prolongada e levada a um desenvolvimento superior", adquire ainda um maior significado. O impulso biológico converte-se em um impulso cultural" (Marcuse, 2010: p. 184).

A contradição que Marcuse propõe desfazer em sua obra está baseada nas imposições atuais do sistema capitalista: se a sociedade industrial não tivesse como grande tarefa desenvolver ao máximo a alienação humana para manter o princípio de desempenho e a dominação, e se a disponibilização do tempo do trabalhador não estivesse voltada meramente às forças produtivas do capital, poderíamos pensar que a dimensão estética teria condições de servir de base para uma práxis política emancipatória. No entanto, a concepção sobre as experiências estéticas na sociedade contemporânea já é resultado de uma repressão cultural cujos valores da arte são privilégios de poucos ou adorno dos "boêmios decadentes" (p. 156). Por isso, mesmo em meio à grande contradição, Marcuse retorna a Kant e ao idealismo alemão com o intuito de resgatar a dimensão política e revolucionária da estética e sustentar a possibilidade de uma sociedade emancipada.

Marcuse fundamenta sua teoria baseada em uma sociedade não-repressiva na necessidade do impulso lúdico de Schiller, procurando unir o que a sociedade industrial 
fragmentou ao máximo: o prazer, o trabalho, o lazer e o conhecimento. Ele se utiliza da conclusão de Schiller, de que a barbárie da civilização moderna é o conflito entre duas dimensões polares da existência humana (o impulso sensível e o impulso formal) e que a tarefa é a reconciliação entre os dois impulsos, libertando a sensibilidade e a sexualidade das amarras do sistema: "o que se procura é a solução de um problema "político": a libertação do homem das condições existenciais inumanas. Schiller afirma que, a fim de solucionar o problema político, "tem de se passar através da estética, visto ser a beleza o veículo dessa libertação" (Marcuse: 2010, p.167). Todavia, tanto na obra de Schiller como na obra de Marcuse não há clareza prática e metodológica de como essa revolução seria possível.

Assim, ao final do capítulo sobre a dimensão estética, Marcuse (2010, p. 171) procura sistematizar as direções da mudança proposta para uma ordem não-repressiva em três principais elementos: i) a transformação do trabalho como atividade lúdica e a superação da ideia de que o trabalho realizado nos dias de hoje serve de fato para suprir necessidades básicas de sobrevivência e civilização, uma vez que, na sociedade atual, o trabalho da massa dominada serve para alimentar um sistema econômico de privilégios para poucos; ii) a autossublimação da sensibilidade e a des-sublimação da razão, a fim de reconciliar os dois impulsos antagônicos básicos e iii) a conquista do tempo, da tomada de horas livres e de possibilidades de deleite e fruição.

Marcuse esclarece que esses elementos são praticamente idênticos aos de uma reconciliação entre o princípio de prazer e o de realidade. Por fim, recorda-nos do "papel constitutivo que se atribui à imaginação (fantasia) no jogo e na exibição; a imaginação preserva os objetivos daqueles processos mentais que se conservaram livres do princípio de realidade repressivo; em sua função estética eles podem ser incorporados na racionalidade consciente da civilização madura. O impulso lúdico representa o denominador comum dos dois processos e princípios mentais opostos” (p. 172). É provável que se Freud tivesse lido a obra de Marcuse, ele seria levado a apontar para o paradoxo contido no conceito de civilização não-repressiva, uma vez que para a psicanálise freudiana, não há relaxamento possível na sociedade: todas as leis, todas as normas e regras de convívio reprimem a cultura de algum lado da tradição. Acreditamos, no entanto, que o conceito desenvolvido por Marcuse, apesar de suas contradições, caminha em defesa dos trabalhadores e dos povos oprimidos que, além da necessidade do controle pulsional físico e psíquico impostos pela civilização, são submetidos ao controle do Estado, da religião e das classes dominantes. Justamente devido a essa defesa que nos valemos do aporte teórico filosófico embasado nas 
obras de Schiller, Freud e Marcuse para compreender o papel formador e educativo da arte na construção de uma sociedade reconciliada com seus sentimentos, com a imaginação e fantasia, em que a poesia e a vida sejam impulsos e criações emanadas do íntimo profundo da natureza.

A tese aqui apresentada propõe também refletir sobre a poesia e sua possível dupla potência, escolar e política. Assim, pareceu-nos importante dar continuidade à reflexão retomando as teorias desenvolvidas pelo idealismo alemão, que tomou a poesia como maior criação humana e também não seria possível refletir sobre as condições de emancipação como foi vislumbrado pelos filósofos pós-kantianos sem antes compreender a natureza psíquica e subjetiva do ser humano que hoje se encontra ameaçado pela tentativa de alienação e dominação do sistema neoliberal. O percurso teórico exposto até então teve por objetivo apresentar as possíveis soluções para o problema da civilização repressiva (Marcuse) à luz da teoria dos impulsos/ pulsões (Schiller e Freud) já apresentadas no primeiro capítulo da tese, cuja saída se encontra nas faculdades estéticas, indicando também suas contradições. Tentamos não ser apressados e simplórios no diagnóstico de época da era capitalista ao apresentar as possíveis soluções indicadas por Marcuse, principalmente porque estamos mais propensos a concordar com Freud e com sua teoria do impossível em meio aos problemas da repressão, do que acreditar que há possibilidades de libertação dentro das formas de vida estabelecidas pela vigência capitalista. Nesse sistema, as possíveis dessublimações da repressão são absorvidas pela produção neoliberal, uma vez que estamos entregues à mercadoria. No entanto, acreditamos que há formas de ressignificar a repressão em instâncias de organização coletiva, como uma sala de aula, a partir do trabalho sensível e humanizador proporcionado pelas artes. A partir de Freud, sabemos não ser possível curar os sintomas da repressão, mas que é possível trabalhá-los pelas bordas do sistema, contornando as angústias, os traumas, as frustrações para que possamos lidar com esses sentimentos de maneira mais autônoma, contínua e progressiva. Veremos a seguir como aprofundar esse pressuposto a partir de uma perspectiva político-pedagógica.

\section{"A arte é uma filha da liberdade" 33}

Mas, afinal, a que serve a cultura estética na perspectiva político-pedagógica? Vimos

\footnotetext{
${ }^{33}$ SCHILLER, 2009, p. 71.
} 
com Marcuse, em diálogo com Freud, que é possível pensar em um elo que aproxime os impulsos sexuais, do prazer, às questões políticas, em uma reconciliação erótica do homem e da natureza na atitude estética, na qual a beleza gera a ordem e o trabalho artístico a ludicidade. Assim, o homem "não só pode, mas também deve unificar prazer e dever; ele deve obedecer a sua razão com alegria" (Schiller, 2017: p. 22). A cultura estética ocupa, portanto, uma posição central na tarefa de unir sensibilidade e moralidade, os dois polos da existência humana. Ela é aquilo que deve conduzir a natureza humana à plenitude de seu desenvolvimento, à conjunção de suas forças sensíveis e racionais, enfim, à união de dignidade moral e felicidade: "é próprio do homem conjugar o mais alto e o mais baixo em sua natureza, e se sua dignidade repousa na severa distinção entre os dois, a felicidade encontra-se na hábil supressão dessa distinção. A cultura, portanto, que deve levar à concordância de dignidade e felicidade, terá de prover a máxima pureza dos dois princípios em sua mistura mais íntima" (idem).

O que está em jogo nessa tarefa de buscar a felicidade e o pleno desenvolvimento da cultura é ter condições para promover e tornar relevante a ludicidade prevista na arte poética, o que pode ser possível de construir em um projeto político pedagógico que considere as faculdades estéticas como forma de sensibilização e humanização. A poesia é vista, desde os primórdios da civilização, como a arte que possibilita a emancipação da imaginação a partir da conquista de um percurso de libertação da palavra. A palavra poética tem a habilidade de explorar o ritmo e a melodia, os equívocos que geram ambiguidade e estranhamento, as metáforas, metonímias, as hipérboles, as figuras e semelhanças sonoras, ou seja, nela encontramos a ludicidade da língua.

Anteriormente, ao falarmos sobre fantasia e processos oníricos na Interpretação dos Sonhos de Freud, citamos brevemente a importância de buscar decifrar os substratos inconscientes que se enraízam em nós a partir de uma leitura poética, metafórica e figurativa da cultura. Assim, a palavra poética pode ser reconhecida como recurso capaz de fazer sentir as faculdades estéticas livres, espontâneas e condicionadas a distorcer os sentidos estanques das palavras e imagens comuns. O nonsense poético permite subverter os sentidos das coisas, ou mesmo fantasiar como em uma brincadeira, sendo capaz de deixar restos e vazios preciosos a serem dinamizados por significados que nem sempre estão explícitos. Esvaziar o sentido consensual das palavras poéticas é uma operação fundamental da linguagem e da leitura, uma operação lúdica, e é por este viés do 'esvaziamento', da permuta de formas e sentidos, que compreendemos os textos poéticos como matrizes textuais da leitura e da 
própria literatura, sendo, portanto, essenciais ao processo de letramento. Até mesmo antes desse fenômeno, a operação de fruição poética é principalmente um apelo às emoções e à sensibilidade, imprescindíveis para nossa saúde mental e nossa sobrevivência em sociedade.

Todo esse discurso sobre a importância de uma educação estética da humanidade como forma de harmonizar e reconciliar as rupturas impostas pela civilização repressiva pode parecer um tanto ingênuo. Mesmo assim, negar todo o fundamento da dimensão estética que esteve há séculos por trás das teorias do conhecimento e desenvolvimento humanos seria um grave erro. Tomar a cultura estética, principalmente a poesia, no nosso caso, como objeto de estudo para o letramento e a possível emancipação política e intelectual dos sujeitos escolares também não quer dizer que atribuímos generosas esperanças revolucionárias à arte e a suas funções essenciais, inclusive porque os valores estéticos já estão dominados a outros valores na sociedade do consumo, em que o capitalismo se apropria de qualquer objeto para mercantilizá-lo, inclusive dos objetos artísticos. Acreditamos, contudo, que a poesia no contexto da sala de aula deve ser capaz de cumprir uma dupla função de letramento e emancipação a partir de sua forma condensada, de som e sentido, e de seu conteúdo e expansão de sentido imersos no tecido da realidade social.

Essa crença se deve principalmente ao fato de que é na poesia que os valores estéticos podem se realizar em toda a sua plenitude, revelando sua força e expressividade. A poesia articulada é a "linguagem que combina arranjos verbais próprios com processos de significação pelos quais sentimento e imagem se fundem em um tempo denso, subjetivo e histórico" (Bosi, 2000: p. 9). A linguagem poética é, portanto, memorável e traz consigo uma potência intersubjetiva e política.

De modo a compreender a dupla ação que o trabalho escolar com a poesia pode realizar nos sujeitos aprendizes, tanto no desenvolvimento de um letramento contínuo inferencial e intersubjetivo, como nos estímulos para o domínio da linguagem e dos códigos em busca de uma possível emancipação intelectual e política, devemos pensar que há uma interpenetração dos recursos disponíveis por meio da fruição de textos poéticos que ocorre de maneira subjetiva e histórica, isso porque o ser humano é um ser de linguagem e essencialmente poético. Como expusemos nos primeiros capítulos, à luz do conceito de corporalidade, os textos poéticos devem ser explorados no contexto pedagógico tendo em vista sua interpenetração dos múltiplos valores e recursos de que dispõem: a ludicidade, o deleite, a condensação de som e sentido, o processo de ressignificações e a interpretação da realidade material e imaterial são possibilidades que encontramos na linguagem poética. 
Se, então, assumimos que a poesia deve cumprir a dupla função de letramento e contribuir para o processo de emancipação, devemos definir agora o significado deste segundo conceito, já que o primeiro foi desenvolvido a partir do conceito de oralidade, performance e subjetividade no capítulo anterior. A emancipação como possibilidade de transformação social será pensada agora a partir do conceito de Maioridade desenvolvido no contexto filosófico do idealismo alemão. Em seguida, este conceito será retomado pelo princípio de igualdade de Rancière.

\section{"Sapere aude!" - Ousa saber! ${ }^{34}$}

Voltemos brevemente ao fim do século XVIII, no qual o desmoronamento do Antigo Regime preparou a sociedade para a modernidade e para uma revolução moral, a fim de esclarecer o conceito de Maioridade e o porquê ele nos é estimado. O Idealismo alemão germinou em um cenário sócio-histórico em que a reforma política que ocorria era colocada, simultaneamente, como uma reforma do espírito. Por isso a extrema importância de Kant para a filosofia da época, que se estabeleceu a partir dos princípios da subjetividade e liberdade do pensamento, expressas no conceito de crítica. As críticas de Kant podem ser vistas, portanto, como a análise das possibilidades que o sujeito tem de questionar as verdades da ciência, do conhecimento, da moral e da estética e de se mover a partir desses campos.

Tal novidade no campo filosófico, baseada na compreensão da centralidade do sujeito, levou a filosofia kantiana a elaborar a noção de um eu cindido, noção que também será explorada por Freud e Lacan, ainda que de maneira radicalmente diferente de Kant, apenas quando, já em pleno século XX, desenvolvem a teoria da psicanálise por meio dos conceitos do aparelho psíquico e inconsciente. Mesmo assim, tanto a filosofia kantiana quanto a teoria psicanalítica compreenderam que há uma cisão no sujeito que deveria ser investigada. $\mathrm{O}$ sujeito de Freud é marcado por uma falta constitutiva, no qual o próprio aparelho psíquico, em sua totalidade, tem uma dimensão desconhecida. Já para Kant, é o sujeito que chega à clareza das limitações do uso de sua própria razão por meio da autorreflexão. É um sujeito marcado pela consciência, que por um lado conhece e por outro age. Ou seja, a cisão estaria

\footnotetext{
${ }^{34}$ Dito de Horácio (Epístolas, I, 2, 40) evocado por Schiller ao retomar o texto de Kant sobre o conceito de esclarecimento [Aufklärung] como a máxima da atitude esclarecida.
} 
entre um campo teórico e outro prático, de um lado o conhecimento científico e do outro a ação moral.

Tal cisão, no entanto, incomodou os jovens pensadores pós-kantianos, que procuraram unificar essas dimensões separadas no final do século XVIII, com um esforço que se deu principalmente nas teorias de Fichte, Hegel e Schelling, que, com muito entusiasmo, intentaram aprofundar e radicalizar o projeto kantiano. Em seus escritos programáticos sobre a revolução do pensamento moderno, há o desenvolvimento da ideia de uma subjetividade também colocada na dimensão do real, a ideia de uma liberdade do eu não submetido a um Estado e seus mecanismos, e, sobretudo, o desenvolvimento da dimensão estética, ou seja, de um conceito de beleza que poderia unificar todas as outras ideias.

Assim, o cerne de toda revolução estava na necessidade de unificação da razão por meio do ato estético. O fenômeno artístico possibilitaria, portanto, unificar teoria e prática, tornando os objetos da razão objetos sensíveis e acessíveis a todo povo. Para isso, a arte deveria assumir uma posição central neste novo projeto, em que a razão teria uma função fundamental para compreender a dimensão subjetiva, mas que, ao mesmo tempo, deveria abarcar temas mais amplos como a natureza, a religião, a história e a filosofia política.

Nesse sentido, a preocupação de Schiller com uma “educação estética” que é, a um só tempo, estética e política, dá-se exatamente no momento posterior a duas grandes revoluções: no campo filosófico, Schiller deve responder ao aparecimento do projeto crítico de Kant e, por outro lado, lidar com um dos maiores acontecimentos da história da humanidade - a revolução francesa. À época, os salões da intelectualidade abordavam a temática da política e da filosofia a partir do conceito de esclarecimento [Aufklärung]. Se quisermos, assim, entender qual era o horizonte de Schiller ao pensar emancipação humana através do ato estético, devemos nos reportar a esse conceito.

Se não foi o criador da noção de esclarecimento [Aufklärung], foi Kant (1985) que concedeu cidadania filosófica ao conceito, e foi em resposta à Kant que se deram todos os debates subsequentes. A fonte desta definição aparece já nas primeiras linhas de seu conhecido texto "Resposta à pergunta: o que é o esclarecimento?":

Esclarecimento [Aufklärung] é a saída do homem de sua menoridade da qual ele próprio é culpado. A menoridade é a incapacidade de fazer uso de seu entendimento sem a direção de outro indivíduo. O homem é o próprio culpado dessa menoridade se a causa dela não se encontra na falta de entendimento, mas na falta de decisão e coragem de servir-se de si mesmo sem a direção de outrem. Sapere aude! Tem coragem de fazer uso de teu próprio entendimento, tal é a palavra de ordem do esclarecimento (KANT, 1985: p. 63). 
A partir daí, o principal objetivo da filosofia moral e política passa a orbitar em torno da necessidade da emancipação intelectual, que se fundamentava na necessidade do desenvolvimento da autorreflexão e da autonomia dos indivíduos. Nas palavras de Kant, devemos apontar esforços de nosso pensar em direção à maioridade [Mündigkeit]. Maioridade, aqui, descreve a capacidade interna e externa de autodeterminação e responsabilidade pessoal. O indivíduo esclarecido é aquele que se emancipa, que assume sua maioridade falando publicamente por si mesmo. A maioridade é um estado de independência e, para além disso, uma capacidade de ação, de tomar a própria voz e dizer o que pensa de modo autônomo. Essa capacidade de pensar por si próprio e defender suas próprias ideias libertando-se da dominação política e intelectual de um tutor se tornou uma meta para Schiller em seus estudos e no desenvolvimento de sua teoria.

A libertação social aparece em Kant como uma capacidade de autorreflexão e autonomia do pensar definido como Maioridade. E, como sabemos, frequentemente a fecundidade filosófica de um conceito pode ser medida por sua permanência e reprodução do decorrer do tempo. Nesse sentido, podemos ver como, quase duzentos anos após o aparecimento deste conceito neste sentido específico, Habermas (2014) é capaz de apropriá-lo com o objetivo de desenvolver sua própria teoria da emancipação em seu conhecido texto “Conhecimento e interesse”. Dirá ele:

\footnotetext{
O interesse pela maioridade [Mündigkeit] não é meramente vislumbrado, mas pode ser admitido a priori. Aquilo que nos distingue da natureza é a única coisa que podemos conhecer segundo a sua natureza: a linguagem. Com a estrutura da linguagem é posta para nós a maioridade. Com a primeira posição é exprimida, de modo inequívoco, a intenção de um consenso universal e isento de coerções. A maioridade é a única ideia com a qual nos empoderamos no sentido da tradição filosófica. (...) Na autorreflexão, um conhecimento que se quer pelo próprio conhecimento corresponde ao interesse na maioridade. $O$ interesse emancipatório do conhecimento se dirige à realização da reflexão como tal (HABERMAS, 2014: p. 195, grifo nosso).
}

A citação é esclarecedora pois, além do interesse emancipatório do conhecimento como produto da autorreflexão, que compartilha do mesmo estofo dos pressupostos do esclarecimento de Kant e Schiller, Habermas acentua a presença de um outro elemento: a linguagem. Infelizmente, a tradução do conceito de Mündigkeit para o português deixou de lado o aspecto etimológico de "maioridade" como uso da linguagem. Em alemão, a raiz de Mündigkeit é Mund, que significa "boca", assim como o adjetivo mündlich tem o significado 
de "oral". No texto kantiano, aquele à quem alienamos nossa capacidade intelectual é chamado de tutor [Vormund], palavra que em alemão é composta pelo prefixo Vor- (pré, ante) e, novamente, pela raiz - Mund (boca). Assim, o tutor é aquele que toma nossa razão de nós mesmos (ou a quem vendemos nossa razão), é uma "anteboca", uma pré-voz que se antecipa, que se coloca em frente a nossa, fazendo que toda a linguagem do pensamento seja mediada e transmutada pela figura de nosso dominador. Segundo Habermas, portanto, a humanidade só pode se mover no solo de uma compreensão emancipada socialmente se reconhecer e potencializar a capacidade de universalidade intersubjetiva da linguagem. A autorreflexão libertadora, portanto, só pode se dar em meio à linguagem e, assim, reafirmamos aqui que este meio que defendemos para uma possível emancipação é através da linguagem poética.

Ainda que Habermas, posteriormente, venha fundamentar uma teoria da linguagem nos termos de uma linguística pragmática, esse não é o caso de Conhecimento e Interesse, o que nos permite, a partir deste sentido alargado de linguagem, reportar-nos ao conceito de esclarecimento de Kant e à educação estética de Schiller sem precisar assumir os pressupostos da teoria dos atos de fala. Assim, podemos pensar, a partir do conceito de corporalidade defendido como princípio metodológico do letramento, como podemos passar à defesa da poesia como texto fundamental da expressão deste princípio e defendê-la também como ponto de desenvolvimento de uma consciência política. A emancipação almejada no contexto escolar tem em vista o desenvolvimento da capacidade do aluno de pensar por si próprio, de tomar a palavra como experiência de autorreflexão e subjetivação. Logo, para melhor compreender o que significa essa tomada de palavra e o papel da função poética no movimento de emancipação, avançaremos com os conceitos de Jacques Rancière que se propôs a discutir a educação como prática social e política.

\section{A política da literatura}

Após conhecer a experiência de um professor exilado, sem conhecimentos do idioma local e que, mesmo assim, pôde não só continuar sua função, mas ir além do que na época e até hoje se entende por professor, Rancière passou a defender a seguinte premissa: "quem ensina sem emancipar, embrutece" (2015: p. 37). Com a obra "Mestre ignorante: cinco lições sobre a emancipação intelectual”, a história de Joseph Jacotot, contada por Rancière, provocou e causou estranheza às concepções pedagógicas modernas e contemporâneas, pois o professor francês exilado procurou emancipar seus alunos holandeses da ordem explicadora, 
fazendo que eles aprendessem sua língua materna apenas com um livro bilíngue (o original em francês com a tradução em holandês). Os alunos de Jacotot escolheram um método para aprender e foram capazes de, sozinhos, com apenas um livro traduzido, compreender a língua francesa e a história de Telêmaco. Muitas dúvidas surgiram: compreender as inteligências seria, portanto, nada além de traduzir os escritos de um livro? A explicação do mestre não significaria muito mais que impor aos alunos a sua maneira de compreensão do mundo? É possível, com a tensão do desejo pelo conhecimento, aprender sem a ordem explicadora?

Há tempos já se admitiam as contradições do ato de ensinar, em que tanto a preservação da ordem disciplinadora dos corpos, como as expectativas de um rápido progresso intelectual e autônomo dos alunos foram, por muito tempo, capazes de caminhar em uníssonos passos pelos corredores de uma escola, sem provocar ruídos. Pois, foi somente após a Era das Revoluções, que a sociedade ocidental passou a pensar a educação como forma de redução das desigualdades e espaço de desenvolvimento da autonomia dos sujeitos. Antes, a formação intelectual era restrita a uma minoria de aristocratas, sendo privilégio de poucos, com o objetivo de manter as castas sociais e a hierarquia dos saberes. Esse fator fez que, historicamente, no campo pedagógico, aumentassem as dificuldades de ruptura com o modelo conservador, bem conhecido por doutrinar em vez de emancipar os jovens, ainda mais porque, na sociedade de classes, o saber e o conhecimento que a escola pretende ensinar, por si só, não são igualitários.

Com a experiência de Jacotot, Rancière enxergou a possibilidade de partir do princípio da igualdade das inteligências para incitar uma transformação nas práticas pedagógicas. Ele não afirma que o método do Jacotot é uma alternativa aos problemas do embrutecimento da ordem explicadora, mas que, ao permitir que os alunos descobrissem uma forma de compreender a história do livro, sem que Jacotot precisasse traduzi-la, foi possível que os próprios alunos verificassem sua inteligência, sua condição de compreender o livro, sua vontade de se expressar, que, por sua vez, nada mais é que a própria vontade de traduzir. Assim, eles partiram do que era comum a todos: as letras e os signos, a fruição estética das artes, a capacidade de combinar, comparar e analisar diferentes leituras.

A partir deste mesmo princípio, as crianças aprendem a falar e a se expressar. Elas traduzem a fala adulta para significantes memorizados e reproduzidos em contextos próprios com o intuito de se fazer entender. Ao se apropriarem da linguagem, as crianças passam a ser capazes de imaginar, criar e aperfeiçoar sua capacidade de fruição estética. Os livros que uma mãe lê para seu filho, as cantigas que canta ou os acalantos que cede, são verificados pelos 
sentidos da criança, pela sua própria inteligência. Quando isso ocorre, a criança se demonstra capaz de criar hipóteses sem mediação, de comparar outras hipóteses que já formulou, tudo a partir da "coisa" comum, do Simbólico (a linguagem maternal, os gêneros textuais da maternância), que aqui se apresentam como situações da infância que possibilitam um caução da igualdade, da ligadura de um espírito a outro espírito, de um mesmo ponto de partida. Todos partiram do mesmo processo de aquisição da linguagem e do mesmo percurso de decifração dos significantes. Mas, para Rancière, a diferença está em como o mestre, aquele que assume o papel de educar, irá estimular a emancipação intelectual do aluno. O mestre deverá saber identificar o que o aluno pode comparar, compreender, traduzir e verificar com seus próprios sentidos, reconhecendo, assim, sua capacidade intelectual. Mesmo sem saber ler, a criança já poderá, assim, ser capaz de ler o mundo através de suas próprias lentes.

Nesse sentido, a relação do mestre com o aluno que ignora certos saberes pode ser compreendida por meio dos conceitos de tradução e contra-tradução, ainda na perspectiva da igualdade das inteligências. Esses conceitos nos ajudarão a assimilar o papel da literatura em sala de aula. Rancière afirma que, no ato de aprender um novo saber, há o movimento de traduzir e contra-traduzir os pensamentos em palavras e as palavras em pensamento. Esse movimento é condição para que nos façamos entender e para que compreendamos aquilo que nos comunicam. É fruto de um esforço que naturalmente fazemos para nos inserimos nas relações humanas que são sempre permeadas pela linguagem, portanto, todos são capazes de se colocar na realização deste movimento, já que sem ele, não há possibilidade de interação social. Qualquer ato de comunicação, seja entre dois falantes, seja entre o leitor e um livro, a tradução e a contra-tradução deverão acontecer, como já apontado por Iser (1996) a partir da teoria do efeito estético. Traduzimos a recepção de um discurso ou a leitura de um poema em nossos pensamentos e contra-traduzimos o conhecimento adquirido em palavras, significantes próprios. Assim, “toda palavra, dita ou escrita, é uma tradução que só ganha seu sentido na contra-tradução, na invenção das causas possíveis para o som que ouviu ou para o traço escrito: vontade de adivinhar que se apega a todos os indícios, para saber o que tem a lhe dizer um animal racional que a considera como a alma de um outro animal racional" (Rancière: 2015, p. 95).

Ensinar e aprender são ações que não se diferenciam dos atos de traduzir e contratraduzir. Não seria correto assumir que a nossa função, enquanto professores presentes em uma sala de aula repleta de jovens naturalmente investigadores, é a de transmitir os conhecimentos que nos foram anteriormente ensinados como uma verdade. $\mathrm{O}$ ato de ensinar é 
uma prática social que parte da experiência dos indivíduos. Assim, a educação, qualquer que seja ela, é sempre uma teoria do conhecimento posta em prática. No entanto, não parte de uma verdade e sim de uma experiência - experiência de traduzir e contra-traduzir os conceitos do mundo. Educar é impregnar de sentido as experiências que traduzimos e contra-traduzimos e, assim, as palavras, os signos e imagens são responsáveis por mobilizar os saberes, as relações, as culturas, as aprendizagens em tempos históricos e sociais, politicamente condicionados e eticamente impregnados.

E, afinal, qual é o papel da escola, senão praticar a educação como possibilidade de revelação das diferentes culturas, da criatividade por meio da fruição das artes e da emancipação intelectual? Rancière (2015: p. 100) reitera que é preciso aprender e que cada ser humano tem em comum essa capacidade de experimentar o prazer e a pena de aprender. Mas cabe a cada aprendiz verificar suas inteligências para aprender e cabe a cada mestre facilitar as condições para que isso ocorra. No exercício de declamação de um poema, por exemplo, o aluno pode ser instigado a exercer a virtude de verificar suas inteligências para compreender sua forma e conteúdo. Ao apresentarmos a riqueza do gêneros literários e o vasto repertório de nossa tradição oral, estamos impulsionando nossos alunos para a lida com uma matriz de textos que irão compor suas inteligências e, com eles e por meio deles, poderão colocar em prática seu discurso, poderão se fazer claros e se expressar com mais domínio. Como já dissemos algumas vezes, a bagagem que se organiza no pensamento do aluno a partir de histórias - de fantasia, com metáforas e alegorias que são capazes de formular elementos aceitáveis em resposta às indagações sobre a vida -, instigam-no a se posicionar subjetivamente no mundo, a buscar os sentidos ocultos da arte e da cultura e a fugir da realidade que muitas vezes o aprisiona. As histórias que os jovens gostam de ouvir geralmente têm um enigma, uma demanda diferenciada de tradução e contra-tradução. $O$ desafio do "decifra-me ou devoro-te" é um mergulho na imaginação criadora, diferentemente dos elementos da realidade, como uma notícia de jornal que exige uma mera tradução funcional e pragmática da língua. Os alunos não aprenderão as técnicas mais rebuscadas da tradução e contra-tradução com os gêneros textuais do cotidiano e da publicidade. O ideal para nós é "aprender com aqueles que trabalharam o abismo entre o sentimento e a expressão, entre a linguagem muda da emoção e o arbitrário da língua, com os que tentaram fazer escutar o diálogo mudo da alma com ela mesma, que comprometeram todo o crédito de sua palavra no desafio da similitude dos espíritos" (Rancière, 2015: 101). Ou seja, aprender com os poetas, com os trovadores, com as culturas dos mitos, das lendas, das fábulas e dos contos ocidentais 
e orientais, universais e regionais, canônicos e populares, pois todo o poder dos textos literários se concentra na tradução e contra-tradução de buscar o desconhecido, o imprevisível.

A escrita literária é um trabalho de artesão, de composição árdua das palavras que são testadas na tradução e contra-tradução dos próprios poetas e escritores. A escolha minuciosa das palavras e dos recursos estilísticos e mnemônicos das narrativas e da poesia provocam no leitor o esforço da decifração. Os poetas distorcem o sentido das palavras e das imagens e o aluno, ao se deparar com tamanho enigma, busca identificar a subversão dos sentidos, busca investigar os restos preciosos que são deixados para atribuir significados e inferir elementos que nem sempre estão explícitos. A leitura nas entrelinhas é um desafio lúdico e prazenteiro.

Conforme acentuado anteriormente, o movimento de domínio do código e da sensibilidade às possibilidades poéticas, de esvaziar as palavras do seu sentido consensual - o que podemos igualar ao movimento da tradução e contra-tradução, são operações fundamentais da linguagem e da leitura. São por meio das grandes obras literárias que a transmissão de uma mensagem pode ser dotada de não apenas um único sentido evidente, mas de vários, pois, o que o artista faz é utilizar as palavras que estão presentes em nosso dia a dia a partir de uma organização completamente diferente, inédita e excêntrica. Ao lidar com essa certa maneira de reunir as palavras, evocamos a polissemia das coisas, o nonsense, o lúdico, os chistes, as figuras de linguagem.

Logo, a tradução e contra-tradução de uma obra artística, literária, são movimentos que possibilitam também a dissimetria do entendimento presente entre os textos e seus autores, o que eles gostariam de expressar com suas obras e o que os espectadores e leitores compreendem nem sempre são conteúdos consonantes. Essa dissimetria na tradução e contratradução de uma obra é o que provoca os efeitos mais incríveis de sentido e de mobilização simbólica e estética em uma cultura. Vimos também no segundo capítulo como ela possibilita um movimento de alteridade, de ver no outro a possibilidade de se expressar da forma mais intensa e carregada de sentido possível, e, a partir de uma obra, poder lançar mão da sua criação para ser capaz de se colocar no mundo. É uma troca, pois a língua não é capaz de dizer tudo e é nas artes que procuramos dinamizar e mobilizar nossos vazios, nossa incompletude. A dinâmica em si, de lidar com os vazios que a poesia proporciona, é um processo muito importante para a constituição subjetiva dos alunos. Os vazios não devem ser rapidamente preenchidos com significados pré-estabelecidos, pois isso significaria apenas o preenchimento do gozo e não o alimento do desejo pelo processo de buscar os sentidos da 
cadeia significante.

Com Lacan (1998) e sua teoria sobre o inconsciente estruturado como linguagem, sabemos que esta se apresenta em uma cadeia de significantes que se repetem, mas que não provêm necessariamente de significação. É essa mesma cadeia significante do inconsciente que organiza o gozo recalcado e se aproveita das brechas do discurso consciente para aparecer e deixar suas marcas. Sem a literatura, nossas possibilidades de expressão e de busca pela identificação dos significantes diminuem, e, sem os leitores da literatura, as possibilidades de expressão dos poetas não se implicam em se fazer comunicar. Precisamos dos poetas e eles precisam de nós, como já afirmou Iser (1996) em sua teoria do efeito estético, pois a expressão do poeta só se completa com a nossa contra-tradução e a nossa tradução só se enriquece com as artes e a tradição literária. É uma relação curiosa, pois o poeta não sabe qual uso o leitor fará de sua criação, ele nunca saberá em quais tipos de interpretação sua obra se desdobrará e como será a relação dos leitores com suas composições. Cada poeta criará sua obra conforme suas experiências de vida, assim como cada leitor interpretará tal obra a partir das possíveis traduções que a vida lhe permitir. Segundo Rancière, portanto, não cabe ao mestre refutar as condições do saber e da ação de cada aluno ou de se esforçar em transformálo em um intelectual. Ao mestre cabe reconhecer tal saber em ação. Quando existe o livro - a obra literária em sala de aula -, existe, portanto, um objeto importante para a relação entre professor e aluno, pois o livro os coloca em pé de igualdade, já que ambos estão se relacionando com o mesmo objeto e ambos têm condições de exercer a tradução e contratradução dos saberes em movimento.

Em diálogo com esses conceitos, podemos retomar novamente Lacan e o par alienação e separação, processos fundamentais para a constituição e emergência da subjetividade. $O$ processo de alienação pode ser compreendido como um movimento do sujeito em reconhecer o Simbólico, constituído pela linguagem, movimento similar ao que Rancière propõe com o processo de tradução em busca pela emancipação intelectual. Esta entrega ao Simbólico é um mecanismo de troca que faz com que o aluno saia da corporalidade em si fundada no puro ego. Já o processo de separação se dá a partir de uma cisão entre o sujeito que emerge no Simbólico e o Imaginário. Antes, esse sujeito estava preso ao Imaginário, à situação de relação dual e especular entre mãe e filho. Agora, nessa alienação na linguagem do Outro, o Imaginário é atravessado por um terceiro elemento, que representa a corporalidade da cultura e da linguagem, como no processo de contra-tradução. Por isso, podemos tomar para nós que o texto poético pode ser compreendido neste segundo processo, que atravessa a relação do Eu 
com o Imaginário e impõe uma relação entre a subjetividade e a linguagem cristalizada no texto poético, processo que caracterizamos como leitura.

Assim, em termos gerais, o processo de alienação decorre do encontro do indivíduo com a linguagem, que já estava ali antes mesmo de ele nascer. Ainda na barriga da mãe, o bebê já é assimilado por essa linguagem que o precede. Quando cresce, a criança deve se alienar na linguagem do outro para romper com o apelo ao corpo e poder se aproximar do universo da linguagem, do Simbólico. Ao se encantar pelas cantigas, brincadeiras de roda e contações de histórias, a criança passa a ansiar menos o colo da mãe ou do Outro ali presente, para ansiar a palavra poética do Outro. Mesmo na modalidade escrita, podemos observar o processo de alienação do indivíduo que se fixa à demanda de um outro para, a partir de suas memórias e de seu repertório, no movimento de separação, poder criar seu próprio texto. Então, o aluno parte daquilo que lhe é mostrado e se apoia em um molde bem estruturado para evocar sua própria criação e, assim, ser capaz de colocá-la no papel, como veremos em um exemplo de atividade com paródias do poema "José", de Carlos Drummond de Andrade, elucidado no próximo capítulo, item 4.1 .

Para Lacan (1993), o par alienação e separação no campo analítico funciona "como correlatos da metáfora e da metonímia: o efeito de semelhança pode sustentar a alienação, já a mobilidade da metonímia faria o efeito da separação" (Belintane, 2013: p. 29). Na linguagem poética, a metáfora e a metonímia são as figuras que mais se evidenciam em sua forma expressiva, pois são capazes de condensar uma plurissignificação de imagens, palavras e sons que o poeta procura evocar em seus versos e deslocá-las de seu sentido primário, concedendolhes novos sentidos. Sabemos que a poesia é tida como obra mais subjetiva, em que há uma intensidade expressiva da voz de um "eu". As realizações expressivas do discurso poético possuem a qualidade de condensar efeitos de significação por meio de metáforas - no eixo de seleção -, e de deslocar os sentidos por meio de metonímias - no eixo de combinação -, segundo a teoria da função poética de Jakobson. Nesse movimento metafórico e metonímico presente na construção do discurso poético, encontramos também os processos de alienação e separação para fazer emergir o sujeito entre-textos. A torção dos sentidos das palavras utilizadas pelo poeta, do nonsense e dos equívocos permitidos na leitura de cada um são capazes de provocar esse ato de esvaziamento e de abertura de um espaço fundamental para a entrada na linguagem simbólica e para o processo de leitura.

O trabalho poético da tradução também é explorado em outra obra de Rancière, intitulada $O$ espectador emancipado (2007), na qual ele diz que qualquer um pode aprender o 
que pretende aprender por meio deste movimento:

\begin{abstract}
Se a pessoa 'ignorante' que não sabe ler só sabe uma coisa de cor, mesmo que seja uma simples oração, ela pode comparar este conhecimento com algo que ela ainda ignora: as palavras da mesma oração escritas num papel. Ela pode aprender, signo por signo, a semelhança daquilo que ela desconhece com aquilo que ela conhece. Ela pode fazer isso se, a cada passo, observar o que está à sua frente, dizer o que viu, verificar o que lhe disseram. Entre a pessoa ignorante e o cientista que constrói hipóteses, é sempre a mesma inteligência que está trabalhando: uma inteligência que cria formas e faz comparações para comunicar suas aventuras intelectuais e para entender o que outra inteligência está tentando comunicar-lhe de volta (RANCIÈRE, 2007: p. 113).
\end{abstract}

Para Rancière e Jacotot, o trabalho de um cientista e de um aluno parte do poder igual de tradução e contra-tradução, de comparação dos saberes prévios com o que se quer aprender. Assim, o mestre que faz o aluno aprender somente aquilo que ele pretende ensinar não favorece o caminho de tradução e contra-tradução, ou de alienação e separação, na perspectiva da emancipação intelectual e da constituição da subjetividade, mas embrutece o conhecimento e as práticas de ensino. Apresentar textos do cotidiano, como os já citados, em detrimento dos textos literários é impor uma única lógica de tradução que restringe o acesso à cultura e à fruição estética, princípios estes que deveriam guiar as práticas escolares.

Em discussão com um jornalista na Espanha de 1920, Ortega y Gasset (1993) divulga um texto que se aproxima muito com o que aqui defendemos. "El Quijote en la escuela" combate a corrente "funcional" do ensino da leitura e escrita que dominava o campo de Linguagem e Educação na Espanha do século XX. O jornalista Antonio Zozaya escreveu um artigo que criticava a adoção de livros canônicos nas escolas, como o Dom Quixote, pois, para ele, a escola deveria se ocupar de técnicas de leitura que preparariam os alunos para a vida prática e profissional. Ele sugeriu, portanto, que a leitura dos clássicos fosse deixada de lado para dar lugar à leitura de jornais e revistas que abordassem temas mais pertinentes às crianças em formação para o mercado. Esse pensamento de que a escola deve preparar os alunos para o mercado já é antigo e vem se disseminando com força. A partir dos mesmos princípios humanistas do qual nos valemos, Ortega y Gasset defende a literatura a partir da ideia do que seria "mais vital" para o psiquismo da criança e do jovem. Educar para a vida seria, para ele, proporcionar um repertório em que prevaleçam a arte, a cultura, os valores humanos e libertários.

Ainda na perspectiva da igualdade e da emancipação, Rancière empenha-se em desenvolver uma ideia de literatura portadora de um princípio igualitário a respeito dos 
sujeitos, das palavras e dos temas. Com a literatura, há um encontro das percepções individuais possível de aproximar aqueles que tem o direito à palavra daqueles que não têm o direito à palavra, caracterizando-se, assim, como um encontro democrático. Rancière (2007), dessa maneira, defende a literatura como política de todos:

\begin{abstract}
(...) a literatura põe em prática a democracia da letra errante denunciada por Platão: a palavra que vai falar a qualquer um, não controlando seu trajeto e não selecionando seus destinatários. A democracia literária faz qualquer pessoa sentir formas de sentimento e de expressão reservada às pessoas escolhidas. Ela contribui, assim, a uma democracia que é a da circulação e da apropriação aleatória das formas de vida e de experiência vivida, das maneiras de falar, de sentir e de desejar.
\end{abstract}

Nessa concepção de literatura enquanto força democrática, Rancière diz que ela pode, portanto, fazer política, intervindo na divisão das classes, na divisão dos mestres e dos ignorantes e na divisão do que é nobre e do que é banal da vida de cada um. Como dissemos acima, ela pretende se aproximar de cada leitor a partir da ideia de um acesso universal, de ser para todos e por todos compreendida. Com isso, o filósofo desenvolve o conceito de política da literatura, em que política, no entanto, não é tratada como a prática do poder e da organização das leis que regem a vida coletiva. Em seus termos, a política da qual aqui tratamos é "a constituição de uma esfera de experiência específica na qual certos objetos são colocados como comuns; e certos sujeitos, tidos como capazes de designar esses objetos e de argumentar a respeito deles" (2016: p. 110).

A partir do conceito de política literária podemos repensar as relações de poder entre professor e aluno. A palavra que é compreendida pelo aluno em um livro continua sendo uma palavra submissa, pois, por mais que ele compreenda e saiba discorrer sobre a experiência da leitura, sua palavra não é ouvida, não é emancipada, já que, nessa relação hierárquica, ele será sempre verificado pela expectativa da tradução do professor com relação a tal palavra e não pela sua própria inteligência e contra-tradução. As experiências que a literatura nos proporciona devem dar lugar a palavras partilhadas em pé de igualdade, mas isso não quer dizer que o professor não deva interferir nas análises e traduções feitas pelos seus alunos. Ter um professor para nos ensinar e nos apresentar as várias referências da sabedoria dos outros é fundamental para a aprendizagem escolar. Mesmo assim, as traduções de cada aluno podem ser compreendidas como uma troca de traduções e não como uma verificação de uma verdade, ou seja, se há uma tradução correta e uma incorreta. Nessa perspectiva de rompimento com a causa e efeito da análise literária nas salas de aula, a literatura se torna 
capaz de abrir portas para a partilha do sensível, a partilha das fruições estéticas. Esse movimento de partilha também é caracterizado dentro do conceito lato de política difundido por Rancière. Não cabe apenas ao professor identificar quais são as possíveis interpretações da arte, ou seja, não há uma hierarquia da percepção e do sentido da arte. O que podemos passar a conceber em sala de aula é uma instância de enunciação coletiva, em que todas as vozes sejam ouvidas e todas as traduções sejam colocadas de forma igualitária. Com essa possibilidade democrática de recepção estética, a arte abre uma perspectiva para a emancipação intelectual ao trazer à tona o dissenso entre dois regimes de sensorialidade.

No entanto, é importante ressaltar que reconhecemos e valorizamos o lugar do mestre, do professor, e sabemos de sua importância na prática didática, por isso defendemos seu lugar na escola e não somos adeptos da pedagogia laissez-faire, que prega um não-diretivismo extremamente perigoso. A contribuição que o conceito de política literária nos traz é em relação ao movimento de atopia como proposto pela figura de Sócrates em O banquete, o mestre da estranheza, do desconhecido, um mestre excêntrico, que tem o poder das palavras. N'O Banquete, Platão retrata o diálogo entre Sócrates e Alcibíades, em que o próprio Sócrates se classifica dessa forma: "Eu sou totalmente esquisito (átopos) e não crio senão aporia" (149a). É esse tipo de mestre que defendemos, aquele que sabe surpreender e deslocar o aluno de seu lugar para transportá-lo ao universo das paixões, da aporia, do inusitado e do lúdico.

Rancière, assim como Schiller em seu tratado sobre a educação estética, defende a arte enquanto prática política e social, pois ela auxilia o reposicionamento de divisão das ocupações do sujeito no mundo, a partir de uma ação de partilhar configurações do que nos é sensível, dos nossos modos de fazer, dizer e ser. Podemos aproximar o que Schiller defendia enquanto exercício do impulso lúdico com o que Rancière teorizou como a partilha do sensível: um "sistema de evidências sensíveis que revela, ao mesmo tempo, a existência de um comum e dos recortes que nele definem lugares e partes respectivas. Uma partilha do sensível fixa, portanto, ao mesmo tempo, um comum partilhado e partes exclusivas" (2009: p. 17). O que a partilha do sensível proporciona no campo social é saber o que cada um pode tomar parte no que é de todos e qual é a função de suas atividades exercidas no mundo. Assim como o impulso lúdico, a partilha sensível oferece tanto um espaço, um tempo e uma palavra comuns, como estabelece o lugar em que sua função pode ser exercida ou não.

No campo da política, a partilha sensível também diz sobre uma questão estética que se aproxima dos conceitos kantianos da percepção universal pelo entendimento e sensibilidade do que é belo e do que desperta prazer. Retomando o que já discutimos no 
primeiro capítulo, a investigação sobre o juízo estético faz parte de uma investigação crítica maior sobre a razão. Kant procura sempre voltar ao momento da experiência para identificar de que modo pensamos os conceitos a partir dela, ou, como a experiência, por um lado, fornece um conteúdo para a razão e, pelo outro, aciona mecanismos que já estavam presentes a priori na razão, como característica universal.

O juízo de gosto, por exemplo, reflete também este conceito. Ao passarmos pela experiência do prazer do belo, estamos sofrendo um sentimento que se apresenta em toda a humanidade, é algo universal. Assim, essa sensação é, de certo modo, fornecida por uma faculdade da mente que é universal, ou seja, pré-determinada, o que também pode ser uma motivação à defesa do princípio de igualdade das inteligências de Rancière. A questão é que cada um sente o prazer do belo com objetos diferentes, o que mostra que, mesmo frente a essa universalidade, há espaço para a liberdade. Esta liberdade é mediada pelas faculdades intelectuais (do caso contrário não se poderia dizer: isto é belo) mas, por outro lado, não é determinada por estas, pois não há um belo único.

Assim, a sensibilidade não é uma sensibilidade pura, da ordem da natureza, mas também não é intelecção pura. Por isso, pode-se dizer que qualquer objeto é capaz de ser ocasião para uma experiência estética ou vir a ser transfigurado por ela, seja através da experiência de um mestre ou da experiência de um aluno. É isso que Kant chama de idealismo estético e o que Schiller defende como impulso lúdico: não o pensamento de que o mundo é belo, ou que há no mundo coisas belas, mas o dispor do espírito para transfigurar esteticamente e embelezar o mundo, o que cabe a todos, adultos e crianças.

Portanto, afirma-se a autonomia da subjetividade não só enquanto espontaneidade criadora de formas, mas também enquanto poder de reflexão sobre si própria e para si própria. Aquilo que na contemplação do objeto estético produz satisfação é a forma que o espírito nele vê refletida, mas como algo que pelo mesmo sujeito é atribuído ao objeto, sem outro intuito que não seja o da sua mera contemplação e fruição desinteressada. Quando oferecemos ao aluno a possibilidade de fruição estética, estamos lidando com a viabilidade da política da arte, que, no caso defendido nesta tese, seria a possibilidade da poesia em exercer sua dupla função, tanto no letramento como no auxílio à emancipação intelectual. Essa possibilidade é um modo de subjetivação contínuo do qual o aluno pode emergir sua própria subjetividade, uma vez que ele não deve seguir uma subjetividade dada, permanecendo subalterna às imposições que lhe são feitas dos modos de pensar e agir, mas sim ser capaz de entrar em um processo de subjetivação, caminhando, assim, para uma emancipação política. 
Logo, ao professor cabe a predisposição de ouvir e de permitir a emancipação da palavra de cada aluno até que ele mobilize seu desejo em prol de uma subjetividade que compreenda o jogo literário como um campo para onde poderá trazer e extrair suas expressões e, como consequência, ingressar na leitura e na escrita com entusiasmo. Assim, há a necessidade de um reposicionamento subjetivo também por parte do professor, já que este está inserido em uma trama complexa de relações e poderes difícil de ser desamarrada.

Falamos aqui da necessidade de desenvolver uma alteridade ancha, capaz de compreender o outro, desvencilhando-nos das relações de poder e reconhecendo aos poucos que a escuta de sua fala é, na verdade, um diálogo dentro de nós mesmos, com os diversos discursos que nos constituem. Contudo, sabemos que não é tarefa fácil lidar com essa alteridade, pois, como bem colocou Bondía (2003), temos uma visão adultocêntrica das etapas da adolescência, uma vez que ainda enxergamos os jovens como "seres selvagens" dos quais nada podemos capturar e identificar. Assim, o que ocorre no campo educacional é uma relação arrogante com os alunos: já que não conseguimos renunciar ao poder, agimos a partir de atos totalitários, não nos deixando aproximar do "enigma da adolescência", mantendo-nos cada vez mais distantes da compreensão desse imprevisível.

Faz parte de nosso desafio também nos valermos do processo emancipatório de subjetivação para pensarmos em estratégias de resgatar a importância do papel da literatura e possibilitar o entusiasmo à ficção, que é inerente ao aluno. Além da ficção, a essência poética também é inerente e, para além do gosto instintivo que o aluno tem pelos recursos sonoros do ritmo e da harmonia na poesia, isso também se faz notar nos instantes em que ele capta com entusiasmo o sentido do texto poético e sente prazer nesse contato com os versos de um outro desconhecido a ser traduzido e contra-traduzido para melhor compreender a si mesmo. Nesse sentido, seguiremos com a exposição e análise da metodologia e didática do curso de Língua Portuguesa e suas reverbarações na produção escolar, subjetiva e política dos alunos do Ensino Médio na escola-campo de Paraisópolis. 


\section{Capítulo 4. A palavra poética em sala de aula: uma experiência metodológica a}

partir da dimensão oral, estética e emancipatória da poesia

Como o título deste capítulo já aponta, nossa intenção nesta última etapa de escrita da tese é relatar os encontros com os alunos ao longo do percurso metodológico da experiência poética em sala de aula, a partir dos quais nos foram permitidas reflexões sobre suas criações poéticas e sobre seu reconhecimento diante da necessidade de emancipação, afirmação ética e autoconhecimento. A escolha da palavra experiência empregada no título deste capítulo não surge meramente da acepção do método científico, de experimento ou experimentação, e tampouco somente da acepção filosófica de experiência como forma de conhecer o mundo através dos sentidos. A preferência pela palavra experiência se deve principalmente ao fato de essa ser a tradução da palavra alemã Erfahrung, cuja raiz tem o morfema Fahr que permite a construção do verbo fahren (viajar, percorrer), do substantivo Gefahr (perigo) e do adjetivo gefährlich (perigoso), entre outros vocábulos vinculados à ideia de percorrer e a concepção de perigo. Afinal, a experiência é um trajeto a ser percorrido para se alcançar conhecimento, sublimações, vínculos intersubjetivos e, ao mesmo tempo, é fruto de uma perigosa travessia.

Nessa direção, nossos alunos atravessaram um longo percurso em busca da tomada da palavra poética, encarando corajosamente os desafios da leitura e escrita desta palavra esperta, mágica, entusiasmada e enfrentando todos os seus perigos psíquicos, políticos e culturais. Assim como a necessária travessia da vida, a poesia pode ser perigosa, é potencialmente transgressora e capaz de provocar dores. O poeta maneja as palavras, conduzindo-as ao lugar onde pulsam, pesam e ardem. Na tentativa de desvelar seus sentidos, desvelamos uma parte oculta de nós mesmos, ao aprender a nomear, reconhecer e distinguir nossos sentimentos, o amor, a dor, a perda, a separação, a morte. Acompanhar de perto, ombro a ombro, esse reposicionamento subjetivo, cultural e político dos alunos do Ensino Médio de Paraisópolis nos gerou valorosas reflexões e análises a serem apresentadas neste capítulo. $\mathrm{O}$ corpus da escola-campo, dos sujeitos (parceiros) da pesquisa, de suas trajetórias familiares, da conjuntura política e econômica, do currículo do curso de Língua Portuguesa e das atividades aplicadas a partir da performance, leitura e escrita de textos poéticos ocupando o espaço escolar e a periferia nos serviram de norte para a elaboração desta tese. Analisaremos as entrevistas, os exercícios de inferência das poesias trabalhadas, as produções de texto e as performances no sarau literário que ocorreu a cada semestre letivo. Antes disso, é preciso discorrer brevemente sobre a metodologia de pesquisa-ação aplicada para esclarecer alguns 
princípios que nos guiaram em sala de aula.

\section{Sobre a metodologia da pesquisa-ação}

Antes de especificar e analisar os desdobramentos das atividades elaboradas e aplicadas às $1^{\mathrm{a}}$ e $2^{\mathrm{a}}$ séries do Ensino Médio de Paraisópolis, devemos reconhecer a heterogeneidade do grupo-classe e determinadas características e aspectos de classe, estrutura familiar e cultura dos sujeitos da pesquisa e do ensino, uma vez que compreendemos a metodologia de pesquisa como tentativa de transformação e aprimoramento da prática de ensino, bem como de orientação emancipatória e de crítica social. Nossa pesquisa foi participativa, interventiva, iterativa, problematizadora e carregada de intenções transformadoras para o campo educacional e social.

Portanto, é significativo refletir que, ao pensarmos nos alunos como sujeitos-efeitos, ou seja, em um conceito de sujeito a partir de sua relação com o entorno social, cultural e ideológico, devemos ser capazes de apresentá-los em nossas pesquisas por meio das variadas posições que elas ocupam enquanto sujeitos em aprendizagem, conhecendo-as e revelando-as em sua realidade histórica. Nas pesquisas em educação, por estarmos necessariamente no meio da cena investigada, atuando e intervindo, tanto como professores, quanto pesquisadores, sabemos que não é possível nos separar dos sujeitos da pesquisa, como já foi proposto em outras metodologias de pesquisa, na tentativa de garantir que o vínculo criado pelas relações entre professor e aluno não influenciasse as análises dos dados coletados. No entanto, em nossa pesquisa, essa inserção direta em sala de aula e nossa relação estreita com os sujeitos da pesquisa são, além de inevitáveis, elementos constitutivos de nossa metodologia de pesquisa, e, consequentemente, de nossa metodologia de ensino.

Desde a pesquisa do mestrado, identificamos um problema global na forma como o sistema dominante enxerga e age sobre as práticas educacionais a partir de uma visão tecnicista do saber. Logo, com o desdobramento positivo dos resultados da pesquisa no campo da alfabetização, decidimos dar continuidade ao projeto metodológico de ensino da Língua Portuguesa, expandindo-o para um novo núcleo pedagógico, o Ensino Médio, a fim de buscar soluções para os entraves na leitura e escrita dos jovens de Paraisópolis. Portanto, não se trata exatamente da aplicação de uma nova prática de ensino, mas de uma adaptação do método que trouxe transformações significativas no tocante às habilidades das crianças em 
processo de alfabetização (Joaquim, 2016).

Como toda pesquisa-ação que pretende intervir em seu meio, aprimorando seu objeto para possivelmente efetuar melhorias nas práticas escolares, também encontramos em nossa travessia limitações dadas pelo contexto político-social, pedagógico, bem como pela ética da prática. Tivemos que lidar com os projetos governamentais de desmonte do currículo das Ciências Humanas do Ensino Médio, com a nova BNCC, tivemos que enfrentar as desigualdades, as injustiças sociais e o conservadorismo das antigas concepções discriminatórias e preconceituosas, tivemos que nos enquadrar no calendário escolar e apertar o passo para acompanhar a pressa dos cronogramas de avaliação e, naturalmente, tivemos que ouvir, respeitar e aceitar os desejos de nossos alunos em não querer divulgar ou expor, em alguns casos, seus trabalhos e textos poéticos nesta pesquisa, mesmo que a identidade de cada um estivesse preservada.

Entendemos essa pesquisa como um trabalho coletivo que, em busca da resolução de um problema de alfabetização considerada frágil pelas avaliações externas do Ensino Médio, procurou implementar um plano de ação de ensino e de transformação social com compromissos compartilhados e associados à participação, cooperação e ao desejo de nossos alunos. A partir de uma base empírica, relatamos e avaliamos ao longo de dois anos os efeitos e resultados dessa ação, garantindo sempre o compartilhamento e a revisão dos documentos coletados pelos nossos pares, principalmente quanto aos procedimentos adotados para a continuidade do projeto metodológico de ensino da Língua Portuguesa. Junto a esse método de pesquisa compreendido como pesquisa-ação, concebemos como mútuo empenho o combate às desigualdades e ao preconceito étnico, racial, de gênero e orientação sexual, tendo em vista ações coletivas que intentam melhorar o atendimento às necessidades dos alunos, $\mathrm{o}$ acesso às oportunidades e a valorização das diferentes culturas e singularidades de cada sujeito.

Para isso, foi necessário o reconhecimento do contexto político-pedagógico a fim de adquirir uma ampla visão das práticas atuais a que os sujeitos/ parceiros da pesquisa estavam submetidos, o corpus a ser exposto nos próximos itens desta seção.

\section{Sobre a escola-campo}

A pesquisa parte da investigação do trabalho com a poesia aplicado na primeira e segunda séries do Ensino Médio da Escola Alef Peretz, instituição judaica da rede privada de 
ensino, na unidade localizada na comunidade de Paraisópolis, município de São Paulo. Desde 2012, o Colégio Bialik passou a se chamar Escola Antonietta e Leon Feffer (Alef) e ganhou uma nova sede dentro do clube A Hebraica. A escola existe desde 1943, foi fundada por um grupo de imigrantes judeus vindos da Europa e passou por alguns processos de fusão com outras escolas judaicas, como o Colégio I. L. Peretz, que desde 2017 faz parte do mesmo projeto pedagógico da Escola Alef. A instituição é uma associação beneficente sem fins lucrativos e elege uma mantenedora a cada dois anos. A Escola Alef Peretz foi reconhecida legalmente como entidade filantrópica principalmente pelo projeto de extensão de ensino para a Unidade Paraisópolis que existe desde 2013 e oferece bolsa integral para mais de 90 jovens da comunidade. A Escola Alef Peretz Paraisópolis conta com o mesmo projeto políticopedagógico e o mesmo corpo docente que a Unidade Hebraica, além de receber verbas de projetos educacionais do Banco Santander e outros doadores da comunidade judaica.

Primeiramente, cabe esclarecer a realização da pesquisa nessa escola-campo, já que, inicialmente, a ideia era desenvolvê-la em uma escola pública estadual na mesma comunidade da zona Sul de São Paulo. No entanto, devido ao contexto pessoal em que me encontrava no decorrer do curso do Doutorado, não pude abrir mão da carga horária completa de trabalho de 46 horas semanais na Escola Alef Peretz por razões financeiras. Como a pesquisa não havia sido contemplada com bolsa de estudo do programa da pós graduação (iniciada justamente no ano em que o governo cortou milhares de bolsas para pesquisa científica), não pude reduzir minha jornada de trabalho assalariado para aplicar a pesquisa fora do meu local de trabalho. Como professora de quatro séries (do Ensino Fundamental I ao Médio) em duas unidades diferentes, como mãe e pesquisadora sem verba para a realização da pesquisa, a solução que encontramos para dar continuidade ao projeto do Doutorado foi aplicar a metodologia a ser investigada na unidade de Paraisópolis, onde eu já trabalhava, constituía vínculos e desenvolvia projetos. Foi uma honra e um privilégio poder conviver ainda mais com os alunos dessa unidade.

Além do mais, Paraisópolis é uma comunidade onde a tradição oral e a poesia pulsam em velocidade acelerada. Com o ritmo do repente, maracatu, rap e funk, as associações de moradores de uma das maiores favelas paulistas organizam periodicamente festivais de música, dança, arte de rua, rinha de rap, sarau literário, entre outras diversas manifestações culturais subsidiadas pelas dezenas de ONGs do bairro. A riqueza e o hibridismo cultural da região vêm da história dos imigrantes nordestinos que, entre as décadas de 50 e 60, ocuparam as terras vazias do morro de Paraisópolis em busca de empregos na construção civil de 
suntuosos projetos, como os do Palácio dos Bandeirantes, Hospital Albert Einstein e do estádio de futebol Cícero Pompeu de Toledo. Os novos trabalhadores que iam chegando de diferentes estados do Nordeste com suas famílias se instalavam nos arredores das obras em moradias de papelão e madeira. No final da década de 70 , a elite paulistana começou a ter interesse pela região do Morumbi e, ao construir suas mansões ao redor do Palácio do Governo, passou a brigar na justiça para que as famílias da comunidade de Paraisópolis fossem expulsas dali. Desde sua origem, a população resiste à elitização e à especulação imobiliária do entorno. Seu crescimento foi desenfreado e desorganizado, como a maioria das favelas das grandes cidades, mas, recentemente, passou por um processo de urbanização para canalização da água e do esgoto. Mesmo assim, os 100 mil habitantes da comunidade ainda enfrentam em muitas áreas a dificuldade de acesso aos serviços sanitários. Além disso, a violência e repressão policial aumentam a cada ano na região, principalmente porque, diferentemente de outras favelas, Paraisópolis não se encontra na periferia da cidade, em terras mais afastadas do centro com pouco valor imobiliário, mas está no coração de um dos bairros mais nobres da cidade. Para defender os interesses da elite e com o pretexto de combater a ocupação do tráfico de drogas, a polícia militar age a partir de uma política genocida do Estado que toma a vida de centenas de jovens, como vimos no trágico episódio de 2019 em que nove adolescentes morreram após uma ação policial em um baile funk.

É nesse contexto de muita contradição e desigualdade que os sujeitos desta pesquisa se encontram. Ao mesmo tempo em que eles se sentem alvo da política racista do Estado, nossos alunos do Ensino Médio de Paraisópolis se orgulham muito de sua história de resistência e de sua cultura plural. De acordo com as entrevistas realizadas, 73\% vêm de famílias nordestinas que buscaram naquelas terras uma fonte de renda e de sobrevivência, mas não deixaram totalmente de lado suas tradições. Tendo isso em vista, analisaremos alguns dados do perfil socioeconômico e cultural dos sujeitos pesquisados e, em seguida, apresentaremos as atividades propostas a partir do texto poético e seus desdobramentos dentro e fora da sala de aula.

\section{Breve perfil socioeconômico e cultural dos sujeitos da pesquisa e do ensino}

Os dados socioeconômicos coletados para esta pesquisa foram retirados do Termo de Requerimento de Bolsa (Anexo 1) aplicado pela direção da escola aos pais dos alunos candidatos ao processo de seleção. No entanto, o formulário preenchido pelos pais ou 
familiares não respondeu a todas as questões que gostaríamos de investigar sobre a formação escolar da família e sobre o acesso à cultura e à informação no dia a dia. Assim, no início do ano, foi enviado um e-mail aos alunos com algumas questões que poderiam nos ajudar a pensar a realidade de cada família, como i) quantos livros a família tem em casa; ii) se há acesso à internet diariamente; iii) quais são os hábitos comuns na família; iv) quais hábitos eles gostariam de ter e por que não os têm; v) onde nasceram os pais ou responsáveis e, por fim, vi) qual o grau de escolaridade deles.

Nem todos os alunos e seus pais ou responsáveis responderam a todas as perguntas propostas no questionário, além disso, alguns critérios do questionário passaram a nos interessar mais ao pensar a recepção dos textos poéticos em sala de aula e em seus desdobramentos fora da escola (como a quantidade de livros que os alunos têm em casa, o acesso à internet e os hábitos familiares), tendo em vista o possível encantamento com a poesia e como isso é favorecido para além dos aspectos didáticos e pedagógicos. Por isso, foram tabulados nas tabelas abaixo os dados mais relevantes e completos. Selecionamos as respostas sobre renda familiar, quantos livros os pais e o aluno têm em casa, qual o grau de escolaridade dos pais e sobre a conexão Wi-Fi à internet em casa para projetarmos em gráficos e visualizarmos melhor as respostas. Vejamos a seguir as tabelas e os gráficos com a síntese dos dados coletados:

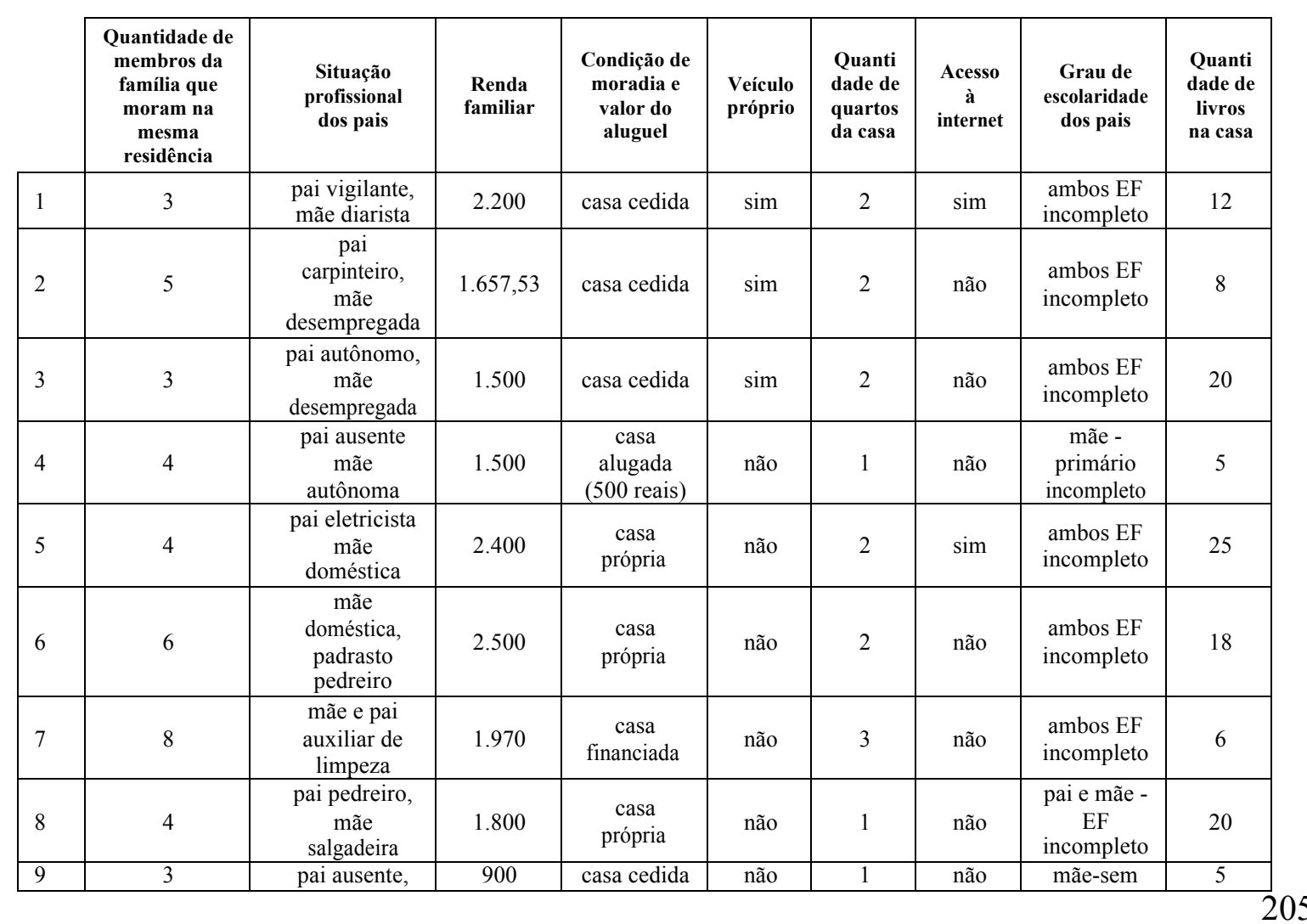




\begin{tabular}{|c|c|c|c|c|c|c|c|c|c|}
\hline & & $\begin{array}{c}\text { mãe } \\
\text { autônoma }\end{array}$ & & & & & & $\begin{array}{c}\text { escolaridad } \\
\mathrm{e}\end{array}$ & \\
\hline 10 & 4 & $\begin{array}{c}\text { pai autônomo, } \\
\text { mãe } \\
\text { desempregada }\end{array}$ & 1.000 & casa cedida & não & 1 & não & $\begin{array}{l}\text { pai e mãe - } \\
\text { EF } \\
\text { incompleto }\end{array}$ & 10 \\
\hline 11 & 4 & $\begin{array}{l}\text { pai porteiro } \\
\text { mãe } \\
\text { desempregada }\end{array}$ & $1.263,66$ & $\begin{array}{c}\text { casa } \\
\text { própria }\end{array}$ & não & 2 & $\operatorname{sim}$ & $\begin{array}{c}\text { pai EM, } \\
\text { mãe EF } \\
\text { incompleto }\end{array}$ & 30 \\
\hline 12 & 2 & $\begin{array}{l}\text { pai ausente, } \\
\text { mãe doceira }\end{array}$ & 900 & $\begin{array}{c}\text { casa } \\
\text { própria }\end{array}$ & não & 1 & não & $\begin{array}{c}\text { mãe não } \\
\text { frequentou } \\
\text { escola }\end{array}$ & 5 \\
\hline 13 & 7 & $\begin{array}{l}\text { pai garçom } \\
\text { mãe diarista }\end{array}$ & $1.439,67$ & $\begin{array}{c}\text { casa } \\
\text { alugada } \\
\text { (300 reais) } \\
\end{array}$ & não & 2 & não & $\begin{array}{l}\text { ambos EF } \\
\text { incompleto }\end{array}$ & 15 \\
\hline 14 & 4 & $\begin{array}{l}\text { pai motorista } \\
\text { mãe } \\
\text { desempregada }\end{array}$ & 1324,3 & casa cedida & não & 2 & $\operatorname{sim}$ & $\begin{array}{l}\text { ambos EF } \\
\text { incompleto }\end{array}$ & 8 \\
\hline 15 & 6 & $\begin{array}{l}\text { pai gerente de } \\
\text { restaurante } \\
\text { mãe } \\
\text { desempregada }\end{array}$ & 2.000 & $\begin{array}{c}\text { casa } \\
\text { financiada }\end{array}$ & $\operatorname{sim}$ & 2 & $\operatorname{sim}$ & $\begin{array}{c}\text { pai EM } \\
\text { incompleto } \\
\text { mãe EF } \\
\text { incompleto }\end{array}$ & 12 \\
\hline 16 & 4 & $\begin{array}{l}\text { pai pedreiro } \\
\text { mãe } \\
\text { doméstica }\end{array}$ & 1.500 & $\begin{array}{c}\text { casa } \\
\text { alugada } \\
(600)\end{array}$ & não & 2 & não & $\begin{array}{l}\text { ambos EF } \\
\text { incompleto }\end{array}$ & 25 \\
\hline 17 & 2 & $\begin{array}{l}\text { pai ausente } \\
\text { mãe } \\
\text { secretária }\end{array}$ & 1.826 & casa cedida & não & 1 & não & $\begin{array}{c}\text { mãe EF } \\
\text { completo }\end{array}$ & 30 \\
\hline 18 & 4 & $\begin{array}{l}\text { pai autônomo } \\
\text { mãe } \\
\text { desempregada }\end{array}$ & 1.500 & $\begin{array}{c}\text { casa } \\
\text { própria }\end{array}$ & não & 2 & $\operatorname{sim}$ & $\begin{array}{l}\text { ambos EF } \\
\text { incompleto }\end{array}$ & 14 \\
\hline 19 & 5 & $\begin{array}{l}\text { pai porteiro, } \\
\text { mãe frentista }\end{array}$ & 2.340 & $\begin{array}{c}\text { casa } \\
\text { própria }\end{array}$ & não & 2 & $\operatorname{sim}$ & $\begin{array}{l}\text { ambos EF } \\
\text { incompleto }\end{array}$ & 20 \\
\hline 20 & 6 & $\begin{array}{l}\text { pai ajudante } \\
\text { de pedreiro, } \\
\text { mãe diarista }\end{array}$ & 2.000 & $\begin{array}{c}\text { casa } \\
\text { alugada } \\
\text { (500 reais) } \\
\end{array}$ & não & 2 & não & $\begin{array}{l}\text { ambos EF } \\
\text { incompleto }\end{array}$ & 15 \\
\hline 21 & 5 & $\begin{array}{c}\text { pai } \\
\text { comerciante, } \\
\text { mãe } \\
\text { telemarketing }\end{array}$ & 2.500 & $\begin{array}{c}\text { casa } \\
\text { própria }\end{array}$ & não & 2 & $\operatorname{sim}$ & $\begin{array}{c}\text { pai EM } \\
\text { incompleto } \\
\text { mãe EF } \\
\text { incompleto }\end{array}$ & 30 \\
\hline 22 & 3 & $\begin{array}{c}\text { pai ausente } \\
\text { mãe } \\
\text { autônoma }\end{array}$ & 1.300 & $\begin{array}{c}\text { casa } \\
\text { própria }\end{array}$ & não & 1 & não & $\begin{array}{c}\text { mãe EF } \\
\text { completo }\end{array}$ & 25 \\
\hline 23 & 4 & $\begin{array}{c}\text { pai } \\
\text { desempregad } \\
\text { o mãe } \\
\text { monitora }\end{array}$ & 750 & casa cedida & não & 1 & não & $\begin{array}{l}\text { ambos EF } \\
\text { incompleto }\end{array}$ & 10 \\
\hline 24 & 6 & $\begin{array}{l}\text { pai técnico } \\
\text { eletrônico tio } \\
\text { pedreiro, mãe } \\
\text { não trabalha }\end{array}$ & 2.600 & $\begin{array}{c}\text { casa } \\
\text { própria }\end{array}$ & $\operatorname{sim}$ & 3 & $\operatorname{sim}$ & $\begin{array}{c}\text { pai EM } \\
\text { incompleto } \\
\text { mãe EF } \\
\text { incompleto }\end{array}$ & 40 \\
\hline 25 & 3 & $\begin{array}{l}\text { pai ausente } \\
\text { mãe } \\
\text { doméstica }\end{array}$ & 1.200 & $\begin{array}{c}\text { casa } \\
\text { própria }\end{array}$ & não & 1 & não & $\begin{array}{c}\text { mãe não foi } \\
\text { à escola }\end{array}$ & 5 \\
\hline 26 & 3 & $\begin{array}{l}\text { pai ausente } \\
\text { mãe auxiliar } \\
\text { adm. }\end{array}$ & 1.500 & casa cedida & não & 1 & não & $\begin{array}{l}\text { mãe EF } \\
\text { completo }\end{array}$ & 8 \\
\hline 27 & 5 & $\begin{array}{c}\text { mãe recebe } \\
\text { benefício, pai } \\
\text { desempregad } \\
\text { o }\end{array}$ & 1.000 & $\begin{array}{c}\text { casa } \\
\text { própria }\end{array}$ & não & 2 & não & $\begin{array}{l}\text { ambos EF } \\
\text { incompleto }\end{array}$ & 10 \\
\hline 28 & 8 & $\begin{array}{c}\text { mãe } \\
\text { manicure, pai } \\
\text { frentista }\end{array}$ & 2.000 & casa cedida & não & 3 & $\operatorname{sim}$ & $\begin{array}{l}\text { ambos EF } \\
\text { incompleto }\end{array}$ & 15 \\
\hline 29 & 5 & $\begin{array}{c}\text { padrasto } \\
\text { desempregad } \\
\text { o, mãe } \\
\text { doméstica }\end{array}$ & 1.500 & $\begin{array}{c}\text { casa } \\
\text { alugada } \\
\text { (300 reais) }\end{array}$ & não & 2 & não & $\begin{array}{l}\text { ambos EF } \\
\text { incompleto }\end{array}$ & 20 \\
\hline 30 & 4 & $\begin{array}{c}\text { pai ausente, } \\
\text { mãe } \\
\text { doméstica }\end{array}$ & 1.300 & $\begin{array}{c}\text { casa } \\
\text { própria }\end{array}$ & não & 2 & $\operatorname{sim}$ & $\begin{array}{c}\text { mãe } \\
\text { primário } \\
\text { incompleto }\end{array}$ & 10 \\
\hline 31 & 7 & $\begin{array}{c}\text { mãe } \\
\text { funcionária }\end{array}$ & 2.400 & casa cedida & $\operatorname{sim}$ & 2 & $\operatorname{sim}$ & $\begin{array}{l}\text { mãe EF } \\
\text { completo }\end{array}$ & 35 \\
\hline
\end{tabular}




\begin{tabular}{|c|c|c|c|c|c|c|c|c|c|}
\hline & & $\begin{array}{l}\text { pública, avô } \\
\text { aposentado }\end{array}$ & & & & & & & \\
\hline 32 & 2 & $\begin{array}{l}\text { pai ausente, } \\
\text { mãe } \\
\text { doméstica }\end{array}$ & 1.200 & $\begin{array}{c}\text { casa } \\
\text { própria }\end{array}$ & não & 1 & não & $\begin{array}{c}\text { mãe } \\
\text { primário } \\
\text { incompleto }\end{array}$ & 7 \\
\hline 33 & 4 & $\begin{array}{l}\text { pai porteiro, } \\
\text { mãe } \\
\text { desempregada }\end{array}$ & 1.100 & casa cedida & não & 1 & não & $\begin{array}{l}\text { ambos EF } \\
\text { incompleto }\end{array}$ & 10 \\
\hline
\end{tabular}

\section{TABELA 1. DADOS SOCIOECONÔMICOS DOS ALUNOS DA $1^{\mathrm{A}}$ SÉRIE DO EM}

\begin{tabular}{|c|c|c|c|c|c|c|c|c|c|}
\hline & $\begin{array}{l}\text { Quantidade de } \\
\text { membros da } \\
\text { família que } \\
\text { moram na } \\
\text { mesma } \\
\text { residência }\end{array}$ & $\begin{array}{c}\text { Situação } \\
\text { profissional dos } \\
\text { pais }\end{array}$ & $\begin{array}{c}\text { Renda } \\
\text { familiar }\end{array}$ & $\begin{array}{c}\text { Condição } \\
\text { de } \\
\text { moradia e } \\
\text { valor do } \\
\text { aluguel }\end{array}$ & $\begin{array}{l}\text { Veículo } \\
\text { próprio }\end{array}$ & $\begin{array}{l}\text { Quanti } \\
\text { dade de } \\
\text { quartos } \\
\text { da casa }\end{array}$ & $\begin{array}{l}\text { Acesso } \\
\text { à } \\
\text { internet }\end{array}$ & $\begin{array}{c}\text { Grau de } \\
\text { escolaridade } \\
\text { dos pais }\end{array}$ & $\begin{array}{c}\text { Quanti } \\
\text { dade de } \\
\text { livros } \\
\text { na casa }\end{array}$ \\
\hline 1 & 4 & $\begin{array}{l}\text { pai secretário } \\
\text { mãe diarista }\end{array}$ & 2.400 & $\begin{array}{l}\text { casa } \\
\text { cedida }\end{array}$ & $\operatorname{sim}$ & 2 & $\operatorname{sim}$ & $\begin{array}{c}\text { pai- EM } \\
\text { incompleto } \\
\text { mãe- EF } \\
\text { incompleto }\end{array}$ & 20 \\
\hline 2 & 3 & $\begin{array}{c}\text { pai ausente mãe } \\
\text { doméstica }\end{array}$ & $1.300,00$ & $\begin{array}{l}\text { casa } \\
\text { cedida }\end{array}$ & não & 1 & não & $\begin{array}{c}\text { mãe EF } \\
\text { completo }\end{array}$ & 5 \\
\hline 3 & 8 & $\begin{array}{c}\text { pai frentista } \\
\text { mãe autônoma }\end{array}$ & 1.800 & $\begin{array}{l}\text { casa } \\
\text { cedida }\end{array}$ & não & 3 & não & $\begin{array}{l}\text { ambos EF } \\
\text { incompleto }\end{array}$ & 10 \\
\hline 4 & 4 & $\begin{array}{c}\text { pai ausente mãe } \\
\text { autônoma }\end{array}$ & 800 & $\begin{array}{l}\text { casa } \\
\text { própria }\end{array}$ & não & 1 & não & $\begin{array}{c}\text { mãe - } \\
\text { primário } \\
\text { incompleto }\end{array}$ & 5 \\
\hline 5 & 4 & $\begin{array}{l}\text { pai mecânico } \\
\text { mãe doméstica }\end{array}$ & 2.400 & $\begin{array}{c}\text { casa } \\
\text { própria }\end{array}$ & $\operatorname{sim}$ & 2 & $\operatorname{sim}$ & $\begin{array}{l}\text { ambos EF } \\
\text { incompleto }\end{array}$ & 15 \\
\hline 6 & 4 & $\begin{array}{l}\text { pai autônomo } \\
\text { mãe } \\
\text { desempregada }\end{array}$ & 1.000 & $\begin{array}{l}\text { casa } \\
\text { cedida }\end{array}$ & não & 1 & não & $\begin{array}{l}\text { ambos EF } \\
\text { incompleto }\end{array}$ & 10 \\
\hline 7 & 8 & $\begin{array}{l}\text { pai autônomo } \\
\text { tia secretária }\end{array}$ & 1.970 & $\begin{array}{c}\text { casa } \\
\text { própria }\end{array}$ & não & 3 & não & $\begin{array}{l}\text { ambos EF } \\
\text { incompleto }\end{array}$ & 6 \\
\hline 8 & 2 & $\begin{array}{c}\text { pai ausente mãe } \\
\text { vendedora }\end{array}$ & 1.200 & $\begin{array}{l}\text { casa } \\
\text { cedida }\end{array}$ & não & 1 & não & $\begin{array}{c}\text { mãe - EF } \\
\text { incompleto }\end{array}$ & 8 \\
\hline 9 & 4 & $\begin{array}{c}\text { pai pedreiro } \\
\text { mãe cozinheira }\end{array}$ & 1.800 & $\begin{array}{c}\text { casa } \\
\text { própria }\end{array}$ & não & 1 & não & $\begin{array}{l}\text { ambos EF } \\
\text { incompleto }\end{array}$ & 20 \\
\hline 10 & 3 & $\begin{array}{c}\text { pai autônomo } \\
\text { mãe não } \\
\text { trabalha }\end{array}$ & 1.000 & $\begin{array}{l}\text { casa } \\
\text { cedida }\end{array}$ & não & 1 & não & $\begin{array}{l}\text { ambos EF } \\
\text { incompleto }\end{array}$ & 12 \\
\hline 11 & 5 & $\begin{array}{c}\text { pai frentista } \\
\text { mãe } \\
\text { desempregada }\end{array}$ & $1.263,66$ & $\begin{array}{c}\text { casa } \\
\text { própria }\end{array}$ & não & 2 & $\operatorname{sim}$ & $\begin{array}{l}\text { ambos EF } \\
\text { incompleto }\end{array}$ & 5 \\
\hline 12 & 2 & $\begin{array}{c}\text { pai ausente mãe } \\
\text { doméstica }\end{array}$ & 900 & $\begin{array}{c}\text { casa } \\
\text { própria }\end{array}$ & não & 1 & não & $\begin{array}{c}\text { mãe não } \\
\text { frequentou } \\
\text { escola }\end{array}$ & 5 \\
\hline 13 & 4 & $\begin{array}{c}\text { pai motorista } \\
\text { mãe não } \\
\text { trabalha }\end{array}$ & 1350 & $\begin{array}{l}\text { casa } \\
\text { cedida }\end{array}$ & não & 2 & $\operatorname{sim}$ & $\begin{array}{l}\text { ambos EF } \\
\text { incompleto }\end{array}$ & 10 \\
\hline 14 & 3 & $\begin{array}{l}\text { pai manobrista } \\
\text { mãe } \\
\text { desempregada }\end{array}$ & 1100 & $\begin{array}{l}\text { casa } \\
\text { cedida }\end{array}$ & não & 2 & $\operatorname{sim}$ & $\begin{array}{l}\text { ambos EF } \\
\text { incompleto }\end{array}$ & 8 \\
\hline 15 & 3 & $\begin{array}{c}\text { pai ausente, } \\
\text { mãe - manicure }\end{array}$ & 1.000 & $\begin{array}{c}\text { casa } \\
\text { própria }\end{array}$ & não & 1 & não & $\begin{array}{c}\text { mãe EF } \\
\text { incompleto }\end{array}$ & 14 \\
\hline 16 & 7 & $\begin{array}{l}\text { pai eletricista } \\
\text { mãe diarista }\end{array}$ & $1.750,00$ & $\begin{array}{l}\text { casa } \\
\text { alugada } \\
(300 \\
\text { reais })\end{array}$ & não & 2 & não & $\begin{array}{l}\text { ambos EF } \\
\text { incompleto }\end{array}$ & 15 \\
\hline 17 & 2 & $\begin{array}{c}\text { pai ausente } \\
\text { mãe secretária }\end{array}$ & 1.700 & $\begin{array}{l}\text { casa } \\
\text { cedida }\end{array}$ & não & 1 & não & $\begin{array}{l}\text { mãe - EF } \\
\text { completo }\end{array}$ & 25 \\
\hline 18 & 4 & pai-autônomo, & 1.500 & casa & não & 2 & $\operatorname{sim}$ & ambos EF & 14 \\
\hline
\end{tabular}




\begin{tabular}{|c|c|c|c|c|c|c|c|c|c|}
\hline & & $\begin{array}{c}\text { mãe- } \\
\text { desempregada }\end{array}$ & & própria & & & & incompleto & \\
\hline 19 & 5 & $\begin{array}{l}\text { pai-porteiro, } \\
\text { mãe- } \\
\text { desempregada }\end{array}$ & 1.450 & $\begin{array}{c}\text { casa } \\
\text { própria }\end{array}$ & não & 2 & $\operatorname{sim}$ & $\begin{array}{l}\text { ambos EF } \\
\text { incompleto }\end{array}$ & 12 \\
\hline 20 & 6 & $\begin{array}{l}\text { pai- pedreiro, } \\
\text { mãe-diarista }\end{array}$ & 2.800 & $\begin{array}{l}\text { casa } \\
\text { alugada } \\
(500 \\
\text { reais })\end{array}$ & não & 2 & não & $\begin{array}{l}\text { ambos EF } \\
\text { incompleto }\end{array}$ & 18 \\
\hline 21 & 5 & $\begin{array}{l}\text { pai vendedor } \\
\text { mãe } \\
\text { telemarketing }\end{array}$ & 2.500 & $\begin{array}{c}\text { casa } \\
\text { própria }\end{array}$ & não & 2 & $\operatorname{sim}$ & $\begin{array}{c}\text { pai EM } \\
\text { incompleto } \\
\text { mãe EF } \\
\text { incompleto }\end{array}$ & 30 \\
\hline 22 & 3 & $\begin{array}{c}\text { pai ausente mãe } \\
\text { garçonete }\end{array}$ & 1.000 & $\begin{array}{c}\text { casa } \\
\text { própria }\end{array}$ & não & 1 & não & $\begin{array}{l}\text { mãe - EF } \\
\text { completo }\end{array}$ & 10 \\
\hline 23 & 4 & $\begin{array}{c}\text { pai } \\
\text { desempreado, } \\
\text { mãe babá }\end{array}$ & 950 & $\begin{array}{l}\text { casa } \\
\text { cedida }\end{array}$ & não & 1 & não & $\begin{array}{l}\text { ambos EF } \\
\text { incompleto }\end{array}$ & 5 \\
\hline 24 & 6 & $\begin{array}{l}\text { pai segurança } \\
\text { mãe doméstica }\end{array}$ & 2.600 & $\begin{array}{c}\text { casa } \\
\text { própria }\end{array}$ & $\operatorname{sim}$ & 3 & $\operatorname{sim}$ & $\begin{array}{c}\text { pai EM } \\
\text { incompleto } \\
\text { mãe-EF } \\
\text { incompleto }\end{array}$ & 15 \\
\hline 25 & 3 & $\begin{array}{c}\text { pai ausente mãe } \\
\text { doméstica }\end{array}$ & 1.200 & $\begin{array}{l}\text { casa } \\
\text { própria }\end{array}$ & não & 1 & não & $\begin{array}{l}\text { mãe não } \\
\text { frequentou } \\
\text { escola }\end{array}$ & 5 \\
\hline 26 & 3 & $\begin{array}{l}\text { pai ausente mãe } \\
\text { auxiliar de } \\
\text { creche }\end{array}$ & 1.400 & $\begin{array}{l}\text { casa } \\
\text { cedida }\end{array}$ & não & 1 & não & $\begin{array}{l}\text { mãe EF } \\
\text { completo }\end{array}$ & 8 \\
\hline 27 & 4 & $\begin{array}{c}\text { pai e mãe } \\
\text { desempregados }\end{array}$ & 800 & $\begin{array}{c}\text { casa } \\
\text { própria }\end{array}$ & não & 2 & não & $\begin{array}{l}\text { ambos EF } \\
\text { incompleto }\end{array}$ & 14 \\
\hline 28 & 8 & $\begin{array}{c}\text { mãe-manicure, } \\
\text { pai-frentista }\end{array}$ & 2.000 & $\begin{array}{c}\text { casa } \\
\text { cedida }\end{array}$ & não & 3 & $\operatorname{sim}$ & $\begin{array}{l}\text { ambos EF } \\
\text { incompleto }\end{array}$ & 15 \\
\hline 29 & 3 & $\begin{array}{l}\text { padrasto- } \\
\text { desempregado, } \\
\text { mãe-doméstica }\end{array}$ & 1.500 & $\begin{array}{l}\text { casa } \\
\text { alugada } \\
(300 \\
\text { reais }) \\
\end{array}$ & não & 2 & não & $\begin{array}{l}\text { ambos EF } \\
\text { incompleto }\end{array}$ & 25 \\
\hline 30 & 5 & $\begin{array}{c}\text { pai ausente, } \\
\text { mãe-doméstica }\end{array}$ & 1.300 & $\begin{array}{l}\text { casa } \\
\text { própria }\end{array}$ & não & 2 & $\operatorname{sim}$ & $\begin{array}{c}\text { mãe - } \\
\text { primário } \\
\text { incompleto }\end{array}$ & 8 \\
\hline 31 & 4 & $\begin{array}{c}\text { mãe aposentada } \\
\text { pai } \\
\text { desempregado }\end{array}$ & 700 & $\begin{array}{l}\text { casa } \\
\text { cedida }\end{array}$ & $\operatorname{sim}$ & 2 & $\operatorname{sim}$ & $\begin{array}{l}\text { mãe - EF } \\
\text { completo }\end{array}$ & 12 \\
\hline
\end{tabular}

TABELA 2. DADOS SOCIOECONÔMICOS DOS ALUNOS DA $2^{\mathrm{A}}$ SÉRIE DO EM 
- Gráficos gerados a partir dos dados tabulados:

a) Renda Familiar

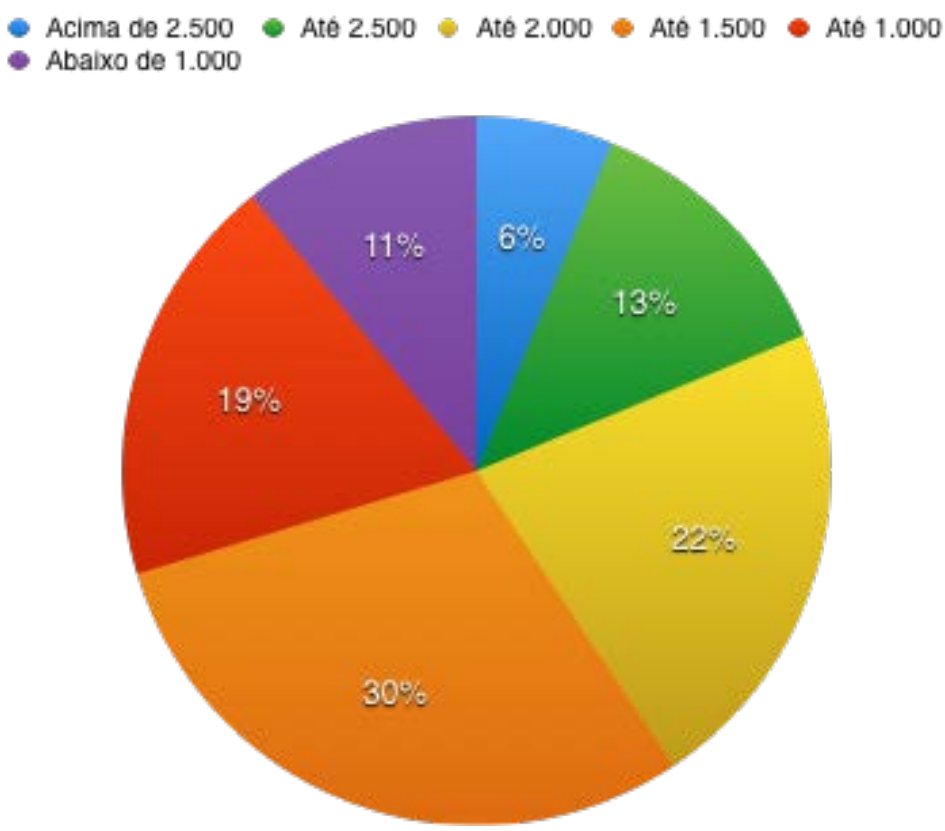

b) Grau de escolaridade dos pais ou responsáveis

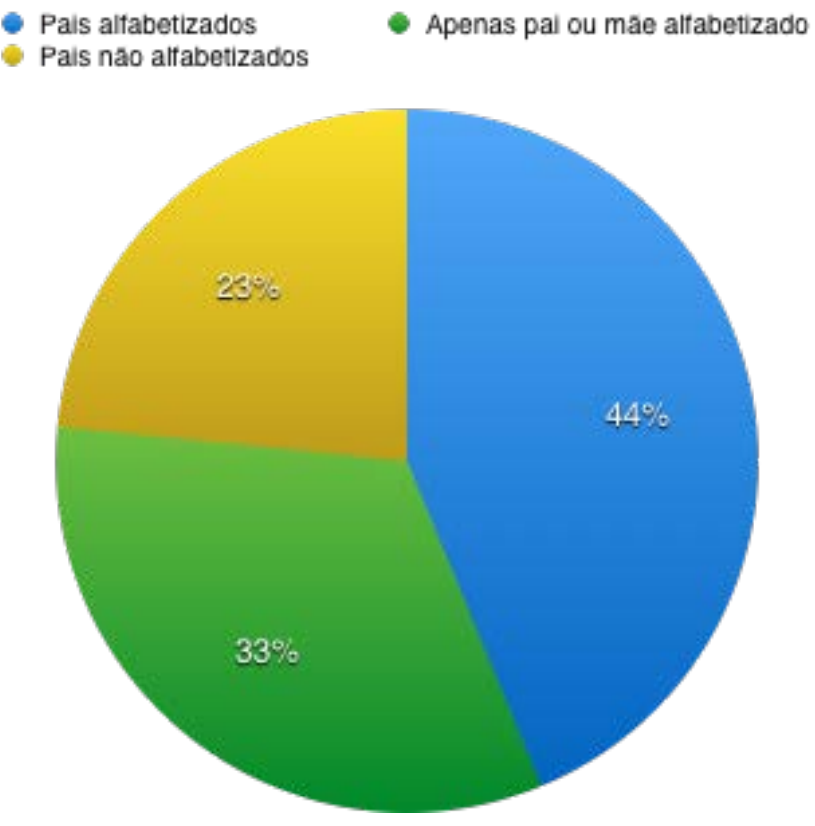


c) Conexão Wi-Fi à internet em casa

- Tem acesso à intemet Nao tem acesso a internet

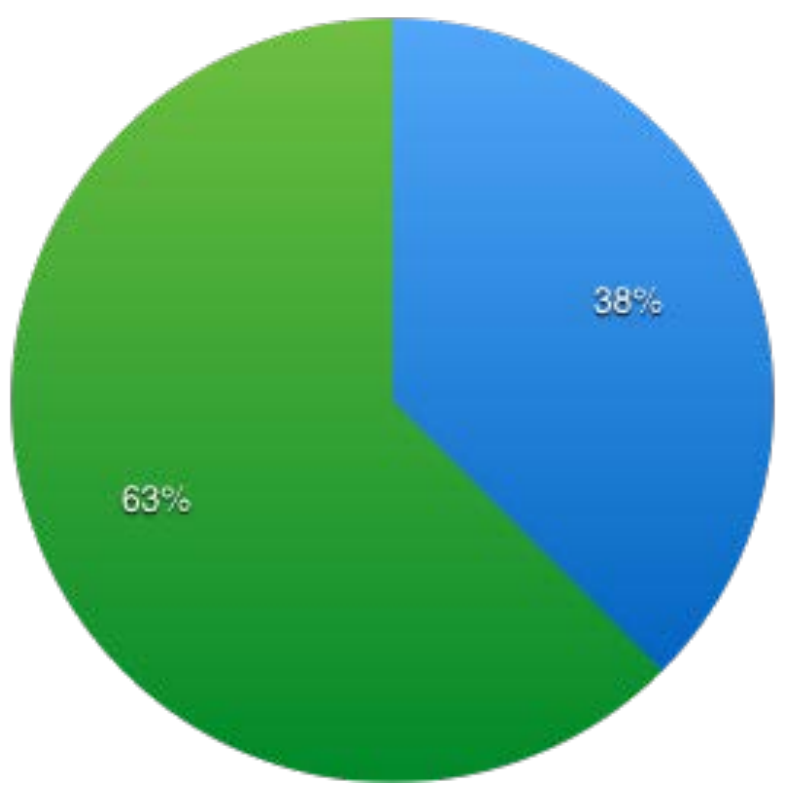

d) Quantidade de livros em casa:

- Acima de 30 livros ate 30 livros ate 20 livros ate 10 livros

- Até 5 livros

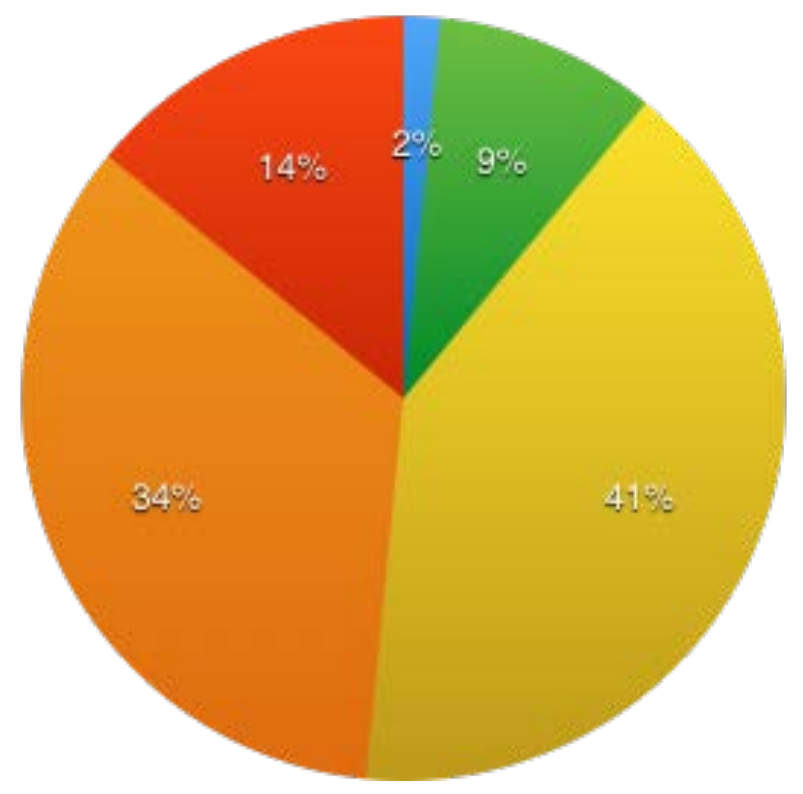


A partir desses gráficos e tabelas, podemos observar a condição heterogênea, dentro de uma mesma classe social, dos 64 alunos da comunidade de Paraisópolis que acompanhamos durante a pesquisa. $O$ gráfico de renda familiar demonstra a situação financeira escassa das famílias: apenas $6 \%$ das famílias vivem com mais de $\mathrm{R} \$ 2.500,00$ por mês, sendo que mais de $60 \%$ vivem com três a cinco pessoas na mesma residência. $30 \%$ das famílias vivem com renda de até mil reais, abaixo do salário mínimo do município de São Paulo que ainda não garante os direitos básicos de saúde, educação, moradia e alimentação em uma comunidade que já sofre com a especulação imobiliária.

O gráfico sobre a quantidade de livros que os alunos possuem em casa também demonstra um fenômeno curioso e preocupante, reflexo da nossa sociedade contemporânea: $75 \%$ dos alunos têm menos ou até 20 livros em casa, sendo que $90 \%$ das famílias responderam que um dos hábitos familiares comuns é assistir à televisão nos fins de semana. Independentemente da situação econômica das famílias, a presença de aparelhos eletrônicos e a ausência de uma quantidade maior de livros é um aspecto cultural recente importante de ser considerado nas escolas. O maior contato que nossos alunos têm com os recursos midiáticos e as novas tecnologias $(38 \%$ das famílias têm acesso à internet com recursos de Wi-Fi, ou seja, não apenas pelo plano do telefone celular), em detrimento do uso do livro, é um movimento que influencia o dia a dia escolar e, consequentemente, os caminhos pedagógicos do letramento. A cultura letrada da família é outro aspecto importante de ser analisado: $23 \%$ dos alunos têm pai e mãe não alfabetizados e 33\% têm apenas o pai ou mãe alfabetizados. Além disso, apenas quatro alunos têm pai ou mãe com ensino superior completo, o que aponta para uma situação ainda muito privilegiada das classes sociais mais elevadas que têm condições garantidas para frequentar cursos universitários.

Além desses dados, uma outra informação coletada no questionário socioeconômico nos chamou a atenção: $41 \%$ dos 64 alunos pesquisados não têm o pai presente, devido a diferentes situações, como abandono durante ou logo depois da gestação, distância entre as residências do aluno e do pai e falecimento precoce. Esse dado reflete a realidade de muitas mulheres jovens que tiveram que criar seus filhos sozinhas ou com ajuda de seus pais, pois não puderam contar com a presença do pai da criança na estruturação familiar: 


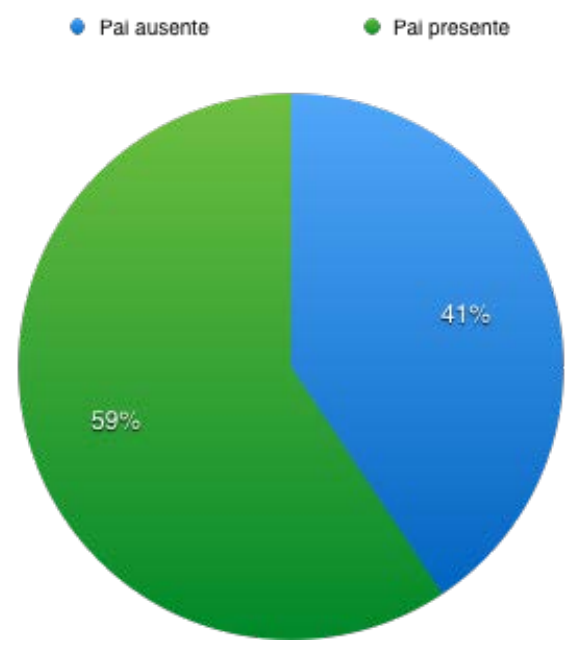

Não pretendemos nos estender na análise dos gráficos, pois o objetivo é traçar o perfil socioeconômico dos sujeitos pesquisados a fim de evidenciar e compreender as possíveis adversidades para o letramento decorrentes das condições impostas pela classe e pela falta de direitos que o Estado deveria garantir aos trabalhadores. Alguns aspectos desses percalços serão levados em consideração na análise das atividades com poesia, nos próximos itens. Os dados quantitativos não nos interessam isoladamente, mas, ao evidenciar a debilidade financeira das famílias que estão subjugadas pelo modo de vida neoliberal, propusemo-nos a traçar uma metodologia de pesquisa com jovens que não ignorasse a relação de nossos alunos com o entorno social, cultural e ideológico em que estão inseridos e uma metodologia de ensino capaz de escutá-los em suas demandas singulares e de traçar caminhos alternativos para alcançar o maior número de alunos no processo de letramento e emancipação.

Em conversa com os alunos durante as aulas sobre poesia oral e cantada no Brasil, atestamos que a maioria deles já conhecia ou já teve contato com manifestações artísticas de moda de viola, repente ou literatura de cordel atreladas à cultura popular nordestina. De certa forma, a veia histórica de suas famílias e a curiosidade sobre a terra natal de seus familiares transmitiram e preservaram traços da tradição afro-brasileira que muito influenciaram os gêneros musicais pelos quais nossos alunos se interessam. Retomar a tradição da cultura oral nordestina de seus antepassados foi um caminho profícuo para aproximá-los dos textos poéticos, principalmente ao evidenciar em nosso curso a formação híbrida do rap que eles tanto escutam com a composição poética do repente. Em uma sociedade em que a indústria cultural norte-americana domina também as massas brasileiras, vimos que a estratégia de se 
valer das semelhanças entre o rap nacional e os gêneros anteriores da poesia oral nordestina é eficaz para resgatar a história da cultura de Paraisópolis e a influência da métrica, das batidas, das figuras sonoras da aliteração e assonância e do uso rico de metáforas dos repentistas e cordelistas. Essa aproximação entre a tradição do repente, dos cantadores sertanejos e da literatura de cordel e o gênero musical do rap nacional serviu como pano de fundo para a elaboração do plano didático do curso de Língua Portuguesa, em especial porque o rap é um estilo cultural aceito e fluído pela ampla maioria dos alunos, além de ser marcado pela tradição oral que reproduz a história das favelas, da resistência, da abolição e da necessidade de crítica e reparação das injustiças sociais.

A cultura da comunidade de Paraisópolis e da geração dos nossos alunos carrega forte influência dos artistas e compositores do rap nacional da década de 90 e dos anos 2000, nomes como Racionais MC's, Sabotage, Trilha Sonora do Gueto, Pavilhão 9, Criolo, Rappin' Hood, Thaíde, entre outros rappers que nasceram nas grandes periferias da zona Sul de São Paulo, como Grajaú, Capão Redondo e Heliópolis, marcaram o início de um movimento artístico que envolvia dança (break), pintura (grafite), música, poesia, improviso e até moda. Como já mencionamos no primeiro capítulo, a vinda do rap para o Brasil está conectada com a história do hip-hop norte-americano e com a dimensão da luta do povo negro contra o passado escravocrata e o racismo estrutural presente em todo continente americano. Como um grito de sobrevivência e de denúncia, o hip-hop caminhou em expansão aos territórios periféricos onde jovens haitianos, jamaicanos, brasileiros, entre outras ramificações pela América Latina, encontravam formas de resgatar a cultura africana e se identificar com a estética dos novos tempos. Nesta tese, não teremos condições de nos debruçar profundamente sobre as características específicas da história do rap nacional, mas abordaremos sua técnica (com relação à métrica, rima e cadência rítmica) para compreender as composições poéticas dos nossos alunos do Ensino Médio. Vale lembrar que o rap se difundiu rapidamente na cultura brasileira e hoje não é um fenômeno concentrado apenas nos bairros pobres das grandes cidades, mas alcançou outras formas estéticas e outras classes sociais. Mesmo assim, firmaremos aqui o lugar do rap como arte conquistada pelos povos oprimidos como forma de resistência, visibilidade e emancipação, pertencente à história de luta contra o genocídio étnico-social, a discriminação e os resquícios na estrutura escravocrata do Brasil. Nesse sentido, vimos como o rap contribuiu para a formação subjetiva e política dos nossos alunos e para a ressignificação do seu lugar de fala, favorecendo também a valorização da linguagem poética. 


\section{Sobre o curso de Língua Portuguesa}

O trabalho docente que realizei na Escola Alef Peretz teve início no ano de 2015, mas apenas em 2017 pude desenvolver projetos e dar aulas na Unidade de Paraisópolis. Em 2018, ministrei o curso de Língua Portuguesa para os alunos de $4^{\circ}$ e $5^{\circ}$ anos do Ensino Fundamental I da Unidade Hebraica e para os alunos de $1^{\mathrm{a}}$ série do Ensino Médio na Unidade Paraisópolis. O contato com os alunos da $2^{\text {a }}$ série do Ensino Médio da Unidade Paraisópolis se dá por meio das orientações de projetos de iniciação científica, chamados de síntese, em que os alunos devem realizar um trabalho de monografia aplicado a questões teóricas e práticas da vida dentro da comunidade. Essas orientações para o projeto monográfico também são feitas com alunos de $1^{\mathrm{a}}$ e $2^{\mathrm{a}}$ séries do Ensino Médio da Unidade Hebraica, uma vez por semana, quando todos os alunos do Ensino Médio das duas unidades se reúnem no prédio do clube A Hebraica para o encontro com seus orientadores nos centros de pesquisa, que são divididos em quatro grandes áreas: Linguagens e Expressões Artísticas, Ciências Humanas, Matemáticas e suas Tecnologias e Ciências Naturais. As atividades que serão analisadas neste capítulo envolvendo os textos poéticos foram aplicadas à $1^{\text {a }}$ série durante o curso de Língua Portuguesa. Com os alunos de $2^{\mathrm{a}}$ série, as atividades foram feitas no contraturno nos momentos de monitoria e orientação educacional.

Durante o estudo de campo, o projeto pedagógico da Escola Alef Peretz demonstrou valorizar a pesquisa científica, baseando-se em quatro instrumentos de avaliação cuja nota de cada instrumento correspondia a $25 \%$ da nota total do aluno em cada disciplina: a prova, o caderno, a síntese e uma avaliação não escrita (ANE). A prova avaliava os conteúdos disciplinares dados em cada bimestre, o caderno avaliava as habilidades de registro e produção autoral dos alunos a partir das propostas de atividades dadas em aula, a síntese era um trabalho de monografia a partir de uma pesquisa científica elaborada ao longo de dois anos, não vinculado a uma disciplina específica, acompanhado de orientação de um professor e avaliada três vezes por semestre e, por fim, a ANE era a expressão de um conteúdo disciplinar por meio de outro recurso que não a escrita, avaliada em uma apresentação oral performática, acompanhada ou não de uma plataforma artística ou midiática. A diversidade de instrumentos de avaliação possibilitava um olhar multifacetado sobre os alunos, no entanto, pude perceber que eles se sentiam muito pressionados com tantas entregas avaliativas, principalmente as turmas de Paraisópolis que não estavam acostumadas com esse modelo de ensino e precisaram se adaptar rapidamente, ao ingressar na $1^{\text {a }}$ série, a uma dinâmica escolar 
completamente diferente do funcionamento das escolas públicas de onde vieram.

Era evidente a importância dos quatro instrumentos de avaliação para o projeto pedagógico da Escola Alef Peretz, no entanto, a meu ver, partir das avaliações para se pensar um projeto, como o que vem acontecendo nos últimos anos também em outros contextos escolares (principalmente apoiados nos resultados das avaliações externas), pode ser um tanto infrutífero para a educação estética que almejamos. Acreditamos que as escolas poderiam primeiro refletir sobre os alunos que querem formar, seus princípios e valores, para depois pensar em como avaliá-los e como julgar se estão alcançando seus objetivos. O que observamos durante a aplicação da pesquisa e também no diálogo com outras escolas particulares é uma inversão das ideias pedagógicas, em que as avaliações pautam os projetos didáticos, e, por conseguinte, não sobra espaço suficiente para o desenvolvimento de novas concepções de ensino. Ainda assim, há muitos pontos positivos que devem ser reconhecidos no projeto da escola Alef Peretz, como a liberdade de cátedra que permitiu a elaboração de um planejamento autoral, sem a obrigatoriedade do uso de livros didáticos ou apostilas prédeterminadas e o investimento nos projetos de síntese, de pesquisa e investigação monográficas e científicas.

O Ensino Médio na Alef Peretz (tanto na Hebraica quanto em Paraisópolis) contava com 18 professores por série que ministravam uma aula de uma hora e meia por semana, ou seja, os alunos deviam apresentar 18 cadernos completos e organizados nas duas etapas avaliativas ao longo do semestre, além de realizar 18 provas diferentes a cada bimestre. As etapas avaliativas da síntese (pesquisa científica) ocorriam três vezes por semestre e acompanhavam os critérios de cada centro de pesquisa. Os cursos eram fragmentados em várias frentes e cada frente era ministrada por um professor diferente. O curso de Língua Portuguesa contava com uma frente de Análise Linguística e Produção de Texto, outra de Leitura e Interpretação dos Clássicos e outra de Língua Portuguesa Básica (o curso em que foi aplicada a pesquisa). O mesmo acontecia com as disciplinas de Matemática, Física, Biologia e História. Nas reuniões pedagógicas entre professores e coordenação, discutimos a necessidade de diminuir as tarefas e avaliações na $1^{\text {a }}$ série para que os alunos pudessem se vincular e se adaptar ao projeto em um ritmo mais possível. A carga horária era integral e o funcionamento das atividades escolares era das $7 \mathrm{~h}$ às $18 \mathrm{~h}$, no entanto, os alunos poderiam realizar atividades mais fluídas no período vespertino, cursar disciplinas eletivas, organizar grupos de estudos, entre outras atividades que não demandassem tantas avaliações como as que estavam previstas na grade curricular. Em 2018, como professora-pesquisadora, tive a sensação de que 
a fragmentação dos cursos e a dispersão decorrente da quantidade de professores acarretaram em obstáculos para a constituição de vínculos entre alunos e professores, alunos e conteúdos dos cursos, bem como entre professores e seus pares, além de dificultar a comunicação entre corpo docente e coordenação, devido a disciplinarização extensiva do projeto pedagógico.

Como a escola era presidida por uma mantenedora que subsidiava todos os gastos da Unidade Paraisópolis, frequentemente me era solicitado o envio de relatórios atestando e justificando o trabalho que era feito com os alunos bolsistas a fim de garantir a continuidade e permanência do projeto. O primeiro relatório escrito por mim, enviado aos mantenedores da escola, teve o intuito de justificar a decisão de se abrir uma nova frente de Língua Portuguesa na $1^{\mathrm{a}}$ série do Ensino Médio de Paraisópolis. Por meio do documento, informei à direção que, tendo em vista as questões de leitura e escrita com as quais os alunos da $1^{\mathrm{a}}$ série ingressaram na escola, planejei um curso que pretendia oferecer um subsídio a mais para o domínio do código, para a leitura inferencial e a escrita criativa. Para tanto, junto às diretrizes da coordenação, retomamos nas aulas, a partir da poesia e da oralidade poética, os elementos menores da língua, as formações de palavras e as regularidades morfossintáticas, a fim de dar continuidade ao letramento dos alunos, aprimorando seu conhecimento linguístico. Relatei também que os resultados da primeira avaliação trouxeram dados importantes com relação às habilidades de leitura e interpretação de texto, bem como a escrita convencional da língua, apontando para uma defasagem acentuada para a faixa etária. Ao mesmo tempo, as produções de texto dos alunos e os desdobramentos dos exercícios aplicados em aula evidenciaram características interessantes sobre a turma: disposição e engajamento para a escrita de textos autorais e subjetivos, que abordem aspectos de sua vida e realidade; bom repertório para argumentar e justificar oralmente posicionamentos e afirmações; interesse em poesias e outros textos versificados que carregam uma mensagem implícita, ou seja, algo a ser decifrado ou deslocado de um lugar normatizado; dedicação nos registros do caderno e preocupação com a completude das aulas e dos exercícios; por fim, gosto pela leitura em voz alta e dinâmicas de leitura compartilhada como jogral ou leitura performática.

Justifiquei ainda que a turma era bastante heterogênea: tínhamos em sala alunos de 15 a 17 anos, oriundos de diferentes escolas públicas, com habilidades e competências bem distintas no que diz respeito ao nível de leitura (alguns ainda efetuavam leituras de maneira fragmentária, mas a maioria já apresentava leitura fluente) e de escrita (notei que alguns alunos ainda escreviam textos curtos, de parágrafo único, outros já eram capazes de escrever textos mais extensos). Pude observar que, após os resultados da primeira prova, houve um 
reposicionamento de alguns alunos que estavam um pouco descolados do cotidiano escolar e demonstraram certa apatia com o curso. Eles passaram a intervir mais durante as aulas, participando das discussões, tirando suas dúvidas. Na correção de caderno, notei grande empenho na elaboração de registros autorais, adicionando às anotações de aula citações, exemplos e referências de material complementar. Expliquei, em seguida, que o grande desafio que tínhamos com os alunos da primeira série do Ensino Médio era dar continuidade ao letramento de jovens diagnosticados com uma base de alfabetização considerada ainda frágil. Para enfrentá-lo, mencionei que, como tarefa sine qua non, tínhamos que possibilitar a ampliação de um repertório de textos diversos, criando, assim, uma matriz de narrativas e outros gêneros que os capacitassem aos exercícios de intertextualidade, enredamento e inferência. Em abril, alguns meses após o início do curso, já havia experienciado um bom método de envolvê-los na palavra poética, na estética e na literatura presentes no curso, reposicionando-os como sujeitos ativos de cada interpretação e análise dos textos, desestigmatizando-os do lugar de não saber.

Desde o início do ano letivo, observei que a turma vinha se consolidando enquanto grupo-classe, com vínculos bem constituídos, além de terem demonstrado estar já no segundo bimestre, mais bem apropriados do projeto pedagógico da Escola Alef Peretz. Ao final do relatório, ainda citei acreditar ser necessário rever a quantidade de disciplinas e instrumentos de avaliação para esse primeiro ano e repensar as entradas dos professores durante a semana. A meu ver, os cursos estavam muito fragmentados. Além disso, havia um desejo pessoal de poder ver os alunos mais de uma vez por semana e poder avançar com o curso de maneira mais fluída, além de estabelecer mais vínculo e rotina com eles.

Isto posto, acredito que o motivo principal que levou a coordenação à decisão de acrescentar uma nova frente de Língua Portuguesa à grade curricular da $1^{\mathrm{a}}$ série do Ensino Médio de Paraisópolis foi a frágil estrutura de alfabetização com a qual os alunos ingressavam na escola. O convite feito a mim, professora do Ensino Fundamental I, para assumir o curso básico de Língua Portuguesa sucedeu em grande parte devido as minhas experiências no processo de alfabetização e às possibilidades de se pensar em um trabalho de letramento mais dinâmico, menos engessado ao ensino dos conteúdos voltados para o vestibular. Acreditou-se que seria possível rever e trabalhar as dificuldades decorrentes de uma má consolidação da alfabetização a partir de um curso que não estava presente na grade curricular do Ensino Médio da Unidade Hebraica, por isso, criou-se uma nova frente de Língua Portuguesa apenas para a Unidade Paraisópolis. 
Este curso ocorreu sempre de forma presencial e cada aula teve duração de uma hora e meia. Os alunos acompanhavam as propostas de atividades, o material selecionado e os links utilizados em aula através do Moodle, plataforma digital adotada por todo corpo docente da escola, esquematizada conforme a imagem abaixo: 


ALEF PERETZ Ensino Fundamental I - Ensino Fundamental II - $\quad$ moodle.alefperetz.org.br

\section{Língua Portuguesa}

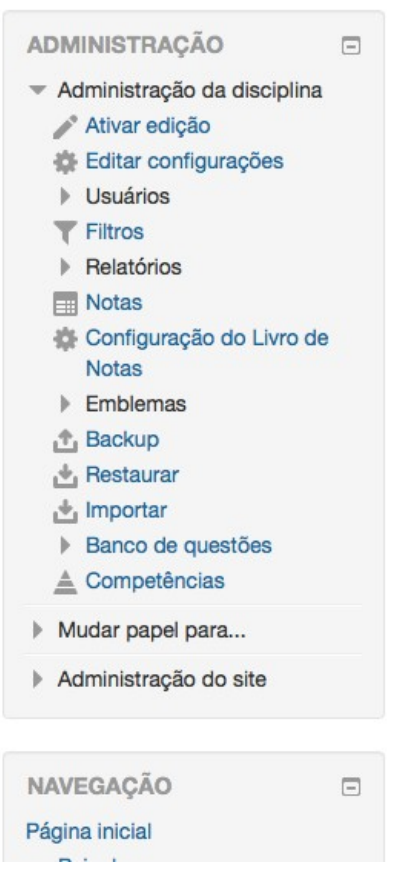

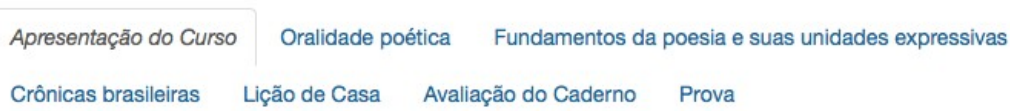

Por aqui, iniciaremos nossos estudos analisando a função poética da língua, os fundamentos do poema e suas unidades expressivas, dando especial atenção à tradição oral da cultura brasileira, a partir de textos literários que explorem o ritmo, a rima, a métrica, as figuras sonoras e outros recursos estéticos e estilísticos. Neste primeiro momento, vamos analisar diferentes textos versificados como as quadras, poemas com mote e glosa, literatura de cordel, emboladas, entre outros.

Vocês serão convidados a produzir textos versificados e treinar técnicas de improviso e memorização a partir do estudo aprofundado em poesia. Enriqueceremos nossas experiências autorais por meio de outras manifestações artísticas como o rap, o repente e a moda de viola.

Como vocês sabem, para escrever bem é preciso ter um bom domínio de vocabulário e conhecimento de algumas normas da língua. Portanto, trabalharemos alguns conteúdos gramaticais para que seus textos fiquem melhores a cada revisão.

Ainda neste semestre, daremos continuidade aos estudos de outros gêneros literários e leremos crônicas brasileiras de escritores modernos e contemporâneos. Analisaremos os diferentes tipos de crônicas, de formas de uso da língua (formal e informal), de figuras de linguagem (metáforas e comparações), de discursos (direto e indireto) e de criações estéticas. Pensaremos no papel das crônicas nos dias de hoje, buscando compreender como as manifestações na era virtual, das redes sociais e dos blogs, se aproximam do gênero em estudo.

A ideia é que, ao final do semestre, possamos produzir e publicar um fanzine com nossos textos em verso, prosa, quadrinhos, ilustrações, músicas, paródias, entre outras criações que certamente virão de maneira bem criativa e divertida. Espero que nosso percurso juntos seja bastante produtivo, compartilhado e enriquecedor.

\section{FIGURA 10. PLATAFORMA MOODLE}

Os conteúdos das aulas e seus materiais foram organizados nos módulos representados em cada aba do curso, bem como as lições de casa e os critérios para os instrumentos de avaliação. No caderno, os alunos registravam as anotações da lousa, as discussões, os exercícios propostos e suas resoluções e, ao final de cada dia, deviam sintetizar de forma autoral em um ou dois parágrafos comentários e reflexões sobre o aprendizado das aulas (essa era uma exigência institucional para o uso do caderno e serviu como critério de avaliação do instrumento).

Assim que assumi o curso, apresentei à coordenação pedagógica o planejamento com base na metodologia estudada no mestrado, que tomou como ponto de partida a oralidade poética (junto ao conceito de corporalidade) e as concepções de sujeito e letramento que foram apresentadas nos capítulos anteriores. Abaixo, segue como exemplo de plano didático o resumo dos objetivos e conteúdos do curso no primeiro semestre de 2018, o qual consideramos importante expor direto no corpo do capítulo para permitir o contato com os dados durante a explanação desta seção da tese e, assim, já seguir com a discussão da metodologia de ensino do curso de Língua Portuguesa. 
PLANEJAMENTO 2018

$1^{\circ}$ Semestre

Disciplina: Língua Portuguesa

Professora:: Isadora Rebello

Ano/Série: $1^{\mathrm{a}}$ série Ensino Médio - Paraisópolis

\section{BLOCO 1: ORALIDADE POÉTICA}

\section{APRESENTAÇÃO DO CURSO}

A área de Língua Portuguesa, no Ensino Médio da unidade Paraisópolis, conta com três diferentes entradas para o desenvolvimento das habilidades de leitura, análise linguística e produção textual, uma vez que foi avaliada a necessidade de aprofundar o trabalho com inferência textual a partir de diferentes gêneros literários. Para tanto, no primeiro semestre deste curso, iniciaremos os estudos sobre a língua e o texto analisando a função poética da língua, os fundamentos do poema e suas unidades expressivas, dando especial atenção à tradição oral da cultura brasileira, a partir de textos literários que explorem o ritmo, a rima, a métrica, as figuras sonoras, as metáforas e metonímias e outros recursos estéticos, mnemônicos e estilísticos. Traçaremos uma perspectiva histórica da literatura oral no Brasil, desde o repertório de mitos e lendas dos povos originários, da entrada da poesia trovadoresca, dos romanceiros e cancioneiros portugueses, até os vaqueiros, cantadores e repentistas do sertão.

A partir do estudo aprofundado em poesia, os alunos serão motivados a fruir e inferir os sentidos implícitos nos textos poéticos, a comparar e se apropriar de diferentes manifestações literárias, caminhando entre a produção canônica e a poesia não-canônica, o erudito e o popular, a poesia oral e escrita, refletindo também sobre a problematização desses conceitos. Os alunos também serão estimulados a produzir textos versificados e treinar técnicas de improviso e memorização a partir de gostos e preferências artísticas de cada um. Enriqueceremos nossas experiências autorais por meio da análise de outras manifestações artísticas como o cordel, o repente, a moda de viola, as emboladas, o rap, a poesia concreta, os haicais, entre outros hibridismos culturais.

A partir do estudo sobre a sílaba poética, a rima e a métrica na poesia, revisaremos a classificação e os grupos dos fonemas, acentuação gráfica, regras de ortografia e pontuação. A partir do conceito de Roman Jakobson sobre a função poética da língua em que há a prevalência do eixo paradigmático sobre o eixo sintagmático, revisaremos a morfologia das palavras (formação, estrutura e classificação). A ideia é que, ao final do semestre, possamos produzir e publicar um fanzine com os textos em verso, poemas, repentes, cordéis, músicas, paródias, poesias concretas, entre outras criações de nossos alunos. Organizaremos também um encontro para compartilhar suas produções artísticas e literárias, como um sarau, e retomaremos o site criado em 2016 com poemas e músicas de ex-alunos de Paraisópolis, alimentando-o com as novas criações. 


\section{APRESENTAÇÃO}

Nossa escrita nasce da oralidade poética, das linguagens artísticas, dos recursos estéticos da língua e não da fala cotidiana e pragmática. Por isso, iniciaremos o curso refletindo sobre a origem das línguas e da comunicação humana, retomando alguns conceitos filosóficos sobre natureza e cultura, razão e paixão. Em seguida, analisaremos o ritmo como elemento fundante da linguagem e um de nossos recursos expressivos mais antigos. Como o ritmo auxiliou o ser humano a organizar a prosódia da língua e memorizar versos que narraram seus grandes feitos e fatos históricos desde a origem das civilizações, trataremos da tradição oral e da importância dos recursos poéticos para a oralidade. Estudaremos a função poética da língua para compreender que a linguagem organizada em discurso poético possui fórmulas que se repetem, que seguem "leis" e regularidades morfossintáticas, correspondências semânticas, do metro, da rima, das figuras de linguagem, que precisam ser analisadas para que as relações de sentido apareçam. A partir desse estudo, retomaremos os conceitos da formação e estrutura de palavras e as classes gramaticais. Com uma coletânea de textos poéticos diversificados, estudaremos o sentido literal e figurado, a ambiguidade e a construção de sentido na poesia, bem como as figuras de sentido, principalmente a metáfora e a metonímia.

\section{CONTEÚDOS}

- Linguagem e ritmo

- Natureza e cultura

- Oralidade poética e performance

- Nascimento do Romanceiro e sua difusão pelo Brasil

- A poesia dos cantadores com refrão

- Teoria da comunicação - função poética da língua

- Paradigma e sintagma (eixo de combinação e eixo de seleção)

- Sentido literal e sentido figurado

- Ambiguidade e construção de sentido na poesia

- Figuras de sentido: metáfora, metonímia, antítese

- Estrutura das palavras: radical, desinência, afixo, vogal temática e vogal e consoante de ligação

- Formação de palavras: primitivas e derivadas, simples e compostas

- Classes gramaticais (substantivo, adjetivo, verbo, artigo, pronome)

\section{EXPECTATIVAS DE APRENDIZAGEM}

- Identificar, fruir e apreciar o ritmo nas diferentes formas de linguagem

- Reconhecer a diferença entre natureza e cultura

- Analisar a diferença entre a linguagem cotidiana e a linguagem poética

- Compreender e apreciar a riqueza da tradição oral

- Ampliar o repertório sobre os diferentes gêneros da oralidade poética

- Compreender a importância dos cantadores e romanceiros na tradição oral do Brasil

- Identificar e fruir a função poética da língua

- Analisar a estrutura sintática da linguagem poética 
- Compreender os recursos de figuras de linguagem como metáfora e metonímia

- Identificar a projeção do eixo de combinação sobre o eixo de seleção na função poética da língua

- Diferenciar o sentido literal do sentido figurado

- Compreender a ambiguidade em um texto poético

- Analisar a construção de sentido no texto poético

- Comparar as manifestações artísticas entre o que é tido como erudito e popular

- Problematizar os conceitos de erudito e popular

- Compreender e identificar as figuras de sentido, como a metáfora, a metonímia e a antítese

- Classificar e identificar a estrutura das palavras: radical, desinência, afixo, vogal temática e vogal e consoante de ligação

- Reconhecer as diferentes formações de palavras: primitivas e derivadas, simples e compostas

\section{MATERIAIS DO CURSO}

1) Ensaio sobre a origem das línguas - J.J. Rousseau

2) Literatura oral no Brasil - Luís Câmara Cascudo

3) Contando histórias em versos. Poesia e Romanceiro popular no Brasil - Bráulio Tavares

4) Nova gramática do Português Contemporâneo - Celso Cunha \& Lindley Cintra

5) Coletânea de textos poéticos: Patativa do Assaré, Zé da Luz, Cego Aderaldo, Pinto do Monteiro e Geraldinho Nogueira, Solano Trindade, textos coletados por Luís Câmara Cascudo, Henriqueta Lisboa, Silvio Romero, Almeida Garrett, Cecília Meireles, Affonso Arinos, Coutinho Filho, Cavalcanti Proença, Leonardo Mota, Amadeu Amaral, Cornélio Pires, Carlos Drummond de Andrade, Manoel de Barros, Racionais MC's, Sabotage e Mv Bill.

\section{MATERIAIS COMPLEMENTARES}

1) Veredas da Palavra - Roberta Hernandes e Vima Lia Martin

2) Filosofia: temas e percursos - Vinicius de Figueiredo (org.)

\section{RESUMO DO PERCURSO}

Indique quantas aulas serão necessárias para a realização do bloco e quais serão os principais marcos desse percurso.

\begin{tabular}{|c|l|}
\hline Aula & \multicolumn{1}{c|}{ Percurso } \\
\hline 01 e 02 & $\begin{array}{l}\text { Apresentação do curso e dinâmica de apresentação da turma. A partir da dinâmica (composição de } \\
\text { versos com palavras norteadoras), produzimos um texto coletivo, reunindo os versos criados. Em } \\
\text { seguida, refletimos sobre a estrutura poética do texto: há ritmo? Cadência? Métrica? Rimas? Os } \\
\text { alunos são convidados a reestruturar o texto para que ele apresente um bom encadeamento de } \\
\text { versos e ritmo e assim iniciamos a apresentação do objeto de estudo do curso: a poesia. Lemos } \\
\text { algumas passagens do ensaio de Rousseau sobre a origem das línguas, em que ele defende a tese }\end{array}$ \\
\hline
\end{tabular}




\begin{tabular}{|c|c|}
\hline & $\begin{array}{l}\text { de que os primeiros discursos se constituíram a partir de repetições, medidas do ritmo e inflexões } \\
\text { melodiosas dos acentos e que as primeiras histórias foram em versos. A partir da discussão sobre } \\
\text { o texto, os alunos podem compreender a importância de se estudar a dimensão da oralidade em } \\
\text { uma perspectiva de leitura expressiva do texto poético. }\end{array}$ \\
\hline 03 & $\begin{array}{l}\text { Em continuidade à leitura dos ensaios de Rousseau sobre o surgimento das línguas, discutimos a } \\
\text { contraposição entre as necessidades e as paixões para compreender as motivações do } \\
\text { desenvolvimento da comunicação humana. São apresentados os conceitos de linguagem, gesto, } \\
\text { língua e fala; voz, melodia e harmonia; natureza e cultura; desejo e primórdios da razão e o } \\
\text { conflito gerado a partir da tentativa de se comunicar. Com a leitura de excertos literários, provoca- } \\
\text { se a reflexão sobre as dificuldades de expressão e compreensão do outro e de si mesmo. Os alunos } \\
\text { registram no caderno pontos da discussão e suas reflexões sobre a linguagem e comunicação. }\end{array}$ \\
\hline 04 e 05 & $\begin{array}{l}\text { Introdução à oralidade poética: literatura oral, performance e tradição. A aula apresenta os } \\
\text { conceitos de literatura oral, exemplificando a tradição a partir dos textos gregos, orientais, contos } \\
\text { universais europeus, origem dos griots africanos, mitos e lendas indígenas até chegar nos } \\
\text { trovadores, romanceiros e cancioneiros portugueses e nos vaqueiros e cantadores sertanejos. Esses } \\
\text { últimos serão estudados com mais profundidade nas aulas seguintes. Leitura do poema "Cante lá, } \\
\text { que eu canto cá", de Patativa do Assaré para discussão sobre o erudito e o popular, a variação e o } \\
\text { preconceito linguístico e a voz do eu-lírico do sertão. Os alunos registram no caderno pontos da } \\
\text { discussão e de interpretação do poema lido. }\end{array}$ \\
\hline 06 e 07 & $\begin{array}{l}\text { Nascimento do Romanceiro, sua difusão pelo Brasil e a poesia dos cantadores com refrão: a partir } \\
\text { de uma coletânea de poemas narrativos cantados, os alunos devem compreender a origem da } \\
\text { literatura popular dos romanceiros e cancioneiros portugueses e como ela foi difundida pelo } \\
\text { Brasil, analisando os textos poéticos, o uso dos instrumentos, a repetição do refrão, os temas } \\
\text { abordados, os elementos básicos da história, o contexto histórico-cultural da época e o panorama } \\
\text { social brasileiro. Os alunos devem comparar a poesia narrativa de romances antigos com uma } \\
\text { poesia narrativa de um romance brasileiro moderno, compreendendo a fusão dos elementos } \\
\text { tradicionais e dos elementos modernos. A poesia narrativa se mantém até hoje no rap, como nas } \\
\text { músicas dos Racionais. Como lição de casa, os alunos deverão analisar a música "Fim de semana } \\
\text { no parque" para refletir sobre as semelhanças de forma e conteúdo entre o rap e a poesia dos } \\
\text { romanceiros. }\end{array}$ \\
\hline 08 e 09 & $\begin{array}{l}\text { Discussão sobre as reflexões trazidas pela lição de casa. Compreensão da estrutura da função } \\
\text { poética da língua: teoria da comunicação de Jakobson com foco na prevalência do eixo } \\
\text { paradigmático sobre o sintagmático. Após algumas análises de textos poéticos ("Procura da } \\
\text { poesia" e "O delírio do verbo"), com foco na discussão sobre o trabalho meticuloso do poeta em } \\
\text { busca da palavra exata, discutiremos as leis e regularidades morfossintáticas da linguagem poética } \\
\text { e da estrutura linguística do eixo de seleção e de combinação. Para isso, revisaremos os conceitos } \\
\text { básicos de morfologia e sintaxe, retomando classes de palavras e a organização das frases. } \\
\text { Faremos exercícios em ficha e registro no caderno, a partir da análise de sonetos e substituições }\end{array}$ \\
\hline
\end{tabular}




\begin{tabular}{|c|l|}
\hline 10 & $\begin{array}{l}\text { de termos por sinônimos e antônimos, fixando a ideia do eixo paradigmático se projetar sob o eixo } \\
\text { sintagmático no texto poético. }\end{array}$ \\
\hline $\begin{array}{l}\text { Leitura em jogral de poesia a partir da coletânea de literatura oral: Zé da Luz ("Ai, se sêsse"), } \\
\text { Cego Aderaldo e Pinto do Monteiro. Análise morfológica do eixo de seleção e análise sintática do } \\
\text { eixo de combinação de poemas selecionados. Revisão dos conceitos de estrutura e formação de } \\
\text { palavras: os alunos devem analisar a estrutura de palavras selecionadas, por meio da identificação } \\
\text { do radical, da desinência, afixo, vogal temática e vogal e consoante de ligação. Identificação da } \\
\text { formação de palavras a partir de exemplos retirados dos textos: palavras primitivas e derivadas, } \\
\text { simples e compostas. }\end{array}$ \\
\hline 11 e 12 & $\begin{array}{l}\text { Leitura dos textos: "Xácara da Bela Infanta" e "Romance da donzela guerreira" com o intuito de } \\
\text { diferenciar o sentido literal do sentido figurado, compreender a ambiguidade em um texto poético } \\
\text { e comparar as manifestações artísticas entre o que é tido como erudito e popular. A leitura será } \\
\text { performática e teatralizada. Os alunos deverão incorporar as vozes do poema e inferir os sentidos } \\
\text { das figuras de linguagem e comparações utilizadas pelos poetas para descrever as ações das } \\
\text { personagens. Os conceitos de sentido literal, sentido figurado e ambiguidade serão revistos } \\
\text { previamente. }\end{array}$ \\
\hline 13 e 14 & $\begin{array}{l}\text { Estudo das figuras de sentido a partir dos textos da literatura oral selecionados na coletânea: a } \\
\text { metáfora, a metonímia e a antítese. Leitura dos poemas e dos repentes e análise das construções } \\
\text { de sentido. Em duplas, os alunos devem registrar as possíveis interpretações dos versos. } \\
\text { Compartilharemos as respostas e, em seguida, analisaremos as expressões idiomáticas utilizadas } \\
\text { por alguns poetas em seus versos. Retomando a discussão sobre o que é "popular", faremos um } \\
\text { levantamento das expressões conhecidas pelos alunos e analisaremos seu sentido figurado. }\end{array}$ \\
\hline
\end{tabular}

\section{REFERÊNCIAS}

1) Introdução à poesia oral - Paul Zumthor

2) Linguística e comunicação - Roman Jakobson

3) O ser e o tempo da poesia - Alfredo Bosi

4) Abc da Literatura - Ezra Pound

5) Na sala de aula: caderno de análise literária - Antonio Candido

\section{BLOCO 2: FUNDAMENTOS DO POEMA E SUAS UNIDADES EXPRESSIVAS}

\section{APRESENTAÇÃO}

A poesia é a forma mais condensada de expressão verbal, em que há uma voz central que pretende exprimir seu estado de espírito. Nela, há uma unidade de som e sentido em que analogias, cruzamentos de sons e repetições são elementos de apoio substanciais ao poema. Para que possamos nos aprofundar no estudo dos 
diversos textos versificados, estudaremos os fundamentos da poesia e suas unidades expressivas. Realizaremos a leitura de diferentes tipos de textos versificados, como cordéis, poemas modernistas, poemas com mote e glosa, quadras, poesia concreta e haicais, e conversaremos bastante sobre as possíveis análises e interpretações de cada obra. Analisaremos os recursos estéticos e mnemônicos como a métrica, a cadência rítmica, a rima, as figuras sonoras (aliteração, assonância, paronomásia), bem como a estrutura do texto poético com o estudo dos versos, da estrofe e suas várias formas.

Retomando a discussão polêmica sobre a poesia canônica e não-canônica, faremos uma análise sobre as diferentes manifestações artísticas e literárias de obras selecionadas e realizaremos exercícios de inferência textual com base nos estudos das figuras de linguagem.

Produziremos nossa própria poesia, articulada a outras manifestações artísticas como o rap, os versos de improviso ou modas de viola, garantido uma reflexão individual e/ ou coletiva em cada processo de escrita: seu planejamento, a escrita da primeira versão, a revisão e a escrita da versão final de cada texto produzido.

\section{CONTEÚDOS}

- Acento e sílaba tônica poética

- Dígrafos consonantais e vocálicos

- Classificação e grupos de fonemas

- Verso, estrofe, rima, cadência rítmica

- Prática da redondilha e da quadra

- Prática das várias formas de sextilhas

- Figuras sonoras: aliteração, assonância e paronomásia

- Nascimento da literatura de cordel no Brasil

- Classificações da literatura de cordel

- Análise e criação de um "folheto"

- Exercícios mnemônicos para o exercício do improviso poético

- Poesia modernista

- Poesia concreta

- Haicais e outros hibridismos literários

- Produção de textos versificados

\section{EXPECTATIVAS DE APRENDIZAGEM}

- Compreender e fruir os fundamentos da poesia: as rimas, a métrica e a divisão em versos e estrofes

- Identificar a sílaba tônica poética e não-poética

- Reconhecer os dígrafos consonantais e vocálicos

- Classificar foneticamente as palavras em um poema

- Explorar e apreciar as diferentes estruturas de um texto versificado: quadras, sextilhas, redondilhas maiores e menores

- Identificar e sentir as figuras sonoras estudadas: aliteração, assonância e paronomásia

- Reconhecer as características da literatura de cordel e entender suas origens no Brasil

- Analisar e produzir folhetos de cordel

- Participar de exercícios de improviso poético e memorização 
- Reconhecer e apreciar as características da poesia moderna e contemporânea brasileira e luso-africana

- Analisar os diferentes sentidos e recursos estéticos e de estilo da poesia moderna e contemporânea

- Inferir sentidos implícitos no texto poético

- Analisar e fruir a forma e o conteúdo da poesia concreta e do haicai

- Produzir textos versificados utilizando os recursos estéticos e estilísticos estudados

- Planejar, revisar e reescrever os textos de produção autoral

\section{MATERIAIS DO CURSO}

1) Estudo analítico do poema - Antonio Candido

2) Cordel do ciclo do cangaço - diversos autores

3) Nova gramática do Português Contemporâneo - Celso Cunha \& Lindley Cintra

4) Coletânea de textos poéticos: Carlos Drummond de Andrade, Manuel Bandeira, João Cabral de Melo Neto, Oswald de Andrade, Murilo Mendes, Adélia Prado, Fernando Pessoa, Casimiro de Abreu, Chico Buarque, GOG, entre outros.

5) Coletânea de textos poéticos luso-africanos: Ana Paula Tavares, Luandino Vieira, Agostinho Neto, Ondjaki.

6) Poesia concreta: irmãos Campos, Arnaldo Antunes, Paulo Leminski

7) Haicais: Alice Ruiz e Pedro Xisto

\section{MATERIAIS COMPLEMENTARES}

Veredas da Palavra - Roberta Hernandes e Vima Lia Martin

\section{RESUMO DO PERCURSO}

Indique quantas aulas serão necessárias para a realização do bloco e quais serão os principais marcos desse percurso.

\begin{tabular}{|c|l|}
\hline Aula & \multicolumn{1}{c|}{ Percurso } \\
\hline 01 e 02 & $\begin{array}{l}\text { Apresentação da segunda coletânea de poemas: leitura do poema "José" e questões de } \\
\text { interpretação da forma e conteúdo. Análise dos recursos sonoros sem nomeação das } \\
\text { figuras. Introdução ao conceito de acento e sílaba tônica poética para o estudo da } \\
\text { métrica. Escuta da música "A sílaba" de Luiz Tatit e discussão sobre os morfemas e } \\
\text { fonemas: dígrafos consonantais e vocálicos e classificação e grupos de fonemas. } \\
\text { Exercício de paródia escrita. }\end{array}$ \\
\hline 03 e 04 & $\begin{array}{l}\text { Análise de seis textos poéticos de formas (métrica, número de versos e estrofes) } \\
\text { diferentes: introdução ao conceito de redondilhas, quadras, sextilhas, etc. Exercícios } \\
\text { de leitura, inferência e correção coletiva com discussão das diferentes interpretações e } \\
\text { problematizações. Produção de texto: criação de quadras e sextilhas a partir de mote e }\end{array}$ \\
\hline
\end{tabular}




\begin{tabular}{|c|c|}
\hline & $\begin{array}{l}\text { glosa e contagem precisa de sílabas tônicas poéticas. Brincadeira de declamações e } \\
\text { técnicas de memorização. }\end{array}$ \\
\hline 05 & $\begin{array}{l}\text { As figuras sonoras: aliteração, assonância e paronomásia. Leitura da coletânea de } \\
\text { poemas e análise dos versos. Revisão dos grupos de fonemas e encontros consonantais } \\
\text { e vocálicos. Música do GOG "Brasil com P" e leitura performática de textos com } \\
\text { repetições sonoras. A partir da análise da música, realizaremos exercícios de } \\
\text { aprimoramento linguístico, de revisão de classes de palavras e substituição de termos } \\
\text { por sinônimos e antônimos. Como lição de casa, os alunos deverão realizar uma } \\
\text { análise semelhante a partir da música "Cálice", extraindo os sentidos implícitos, } \\
\text { reconhecendo as figuras de linguagem e as figuras sonoras, bem como responder } \\
\text { questões de gramática e ortografia. }\end{array}$ \\
\hline 06 e 07 & $\begin{array}{l}\text { Nascimento da literatura de cordel no Brasil, história, tipos de cordel, divulgação, } \\
\text { xilogravura e temáticas. O ciclo do gado e o ciclo do cangaço. Exibição de vídeos e } \\
\text { leitura da história de Lampião e Maria Bonita. Criação de folhetos: produção literária } \\
\text { a partir de temas motivadores. Trabalho a partir dos procedimentos de escrita. } \\
\text { Ilustração como lição de casa. Exibição dos folhetos em barbantes distribuídos pela } \\
\text { escola. }\end{array}$ \\
\hline 08 e 09 & $\begin{array}{l}\text { A poesia moderna: análise do movimento modernista, rupturas e inovações, temas e } \\
\text { comparações. A poesia e a arte plástica em consonância. A poesia como arte } \\
\text { revolucionária. O contexto sócio-cultural do mundo e do Brasil. Leitura de poemas } \\
\text { consagrados, análise e inferência de sentidos. Revisão das figuras de sentido e das } \\
\text { figuras sonoras. }\end{array}$ \\
\hline 10 e 11 & $\begin{array}{l}\text { Coletânea de textos poéticos luso-africanos: Ana Paula Tavares, Luandino Vieira, } \\
\text { Agostinho Neto, Ondjaki. Estudo dos estilos dos autores e contexto histórico, } \\
\text { geográfico, político e cultural. Produção de glossário literário e acepção de palavras. } \\
\text { Exercícios de revisão para a prova. }\end{array}$ \\
\hline 12 e 13 & $\begin{array}{l}\text { Poesia concreta e haicai: Augusto e Haroldo de Campos, Arnaldo Antunes, Alice } \\
\text { Ruiz, Paulo Leminski, Pedro Xisto. A poesia em movimento, a palavra-valise, os } \\
\text { jogos linguísticos e a composição gráfica dos poemas. Análise de cinco poemas } \\
\text { concretos e atividade de criação artística: produção de um poema visual com base na } \\
\text { observação de um objeto. }\end{array}$ \\
\hline 14 e 15 & $\begin{array}{l}\text { Preparação para o sarau e organização do site: seleção dos trabalhos a serem } \\
\text { publicados e exibidos, ensaio, compartilhamento, produção gráfica e visual. }\end{array}$ \\
\hline
\end{tabular}




\section{REFERÊNCIAS}

1) Estudo analítico do poema - Antonio Candido

2) O poema: leitores e leituras - Viviana Bosi

3) Estrutura linguística em poesia - Samuel R. Levin

4) Teoria da poesia concreta - A. Campos, D. Pignatari e H. Campos

\section{TABELA 3. PLANEJAMENTO DO CURSO DE LÍNGUA PORTUGUESA PARA A $1^{\mathrm{a}}$ SÉRIE DO ENSINO MÉDIO}

A partir do que Saussure (2006) apresentou nos Cursos de Linguística Geral afirmando que "a linguagem humana é pensamento-som", ou seja, é a cadeia sonora enlaçada em matéria significada e, a partir do que Alfredo Bosi (2000), ao considerar a poesia, complementou à afirmação de Saussure com a tríade som-imagem-pensamento como o processo fundante da linguagem poética, propusemos o planejamento do curso de Língua Portuguesa alicerçado na poesia e na função poética da língua. Assim, foi possível nos aproximar de um material didático que desse conta de encarar os versos de um poema a partir do som, da imagem e do pensamento, após ter aprofundado conceitos tão caros para o entendimento do gênero lírico, como os recursos estéticos e mnemônicos presentes nos textos poéticos.

Além disso, o planejamento do curso vislumbrou dar conta de atividades que pudessem envolver o trabalho de leitura de poesias a partir de uma diversidade de autores, de volume de texto e de recursos estéticos explorados. Infelizmente, não foi possível encontrar nos materiais didáticos elaborados para o Ensino Médio uma antologia abrangente de nossos poetas, com exceção do livro do PNLD intitulado Veredas da Palavra, da editora Ática, que traz propostas interessantes no módulo de atividades com poesia. Mesmo assim, o mais frequente nos livros didáticos é que, quando há algum trabalho com poesia, geralmente ele é desenvolvido a partir de um único autor, devido a certos modismos e tendências do mercado editorial de divulgar cada ano um nome que está em voga. O que vemos nas escolas é uma certa propensão de se trabalhar durante todo o ano apenas os poemas de Vinicius de Moraes, ou os poemas de Mário Quintana, por exemplo. Quase não vemos uma antologia poética que 
diversifique a abordagem dos textos literários, ainda mais no Ensino Médio em que as leituras são pautadas pelas exigências dos exames vestibulares. Nessa direção, nossa intenção foi trazer autores que pudessem apresentar aos alunos novos repertórios, oriundos de diferentes tempos e linguagens, derivados de múltiplos olhares e vivências, para um movimento amplo de imersão na voz do outro e de identificação e compreensão do sujeito cindido que deve reconhecer seu lugar de fala. Não podemos negar o fato de que a antologia poética também foi criada com base em preferências e gostos particulares da professora, o que parece ser inevitável quando lidamos com um processo afetivo de educação por meio da arte literária.

Além disso, acreditamos ser importante que o professor, cuja função também cobre a mediação dos textos adotados, tenha uma admiração e afeição pelas obras que pretende apresentar aos seus alunos. A sua relação de respeito e dedicação com o conhecimento a ser trabalhado em sala de aula e suas experiências singulares com a leitura dos textos poéticos se expõem e se tornam visíveis aos alunos no espaço de interlocução sobre as obras. Logo, foi preciso pensar em uma coletânea de textos que transportasse consigo não apenas sua riqueza estética, mas que também encorajasse e desse confiança aos nossos alunos para que eles se sentissem, assim como eu, capazes de acessar, compreender, apreciar, fruir e se apropriar daquelas palavras. É claro que o planejamento a partir do material didático selecionado não funcionou a todo momento. Algumas obras escolhidas para o trabalho poético no curso não despertaram interesse ou não tocaram os alunos como eu acreditei ser possível. Isso é natural, já que, por maior que fosse meu esforço em compreender e me aproximar da geração e da cultura dos alunos, nossas histórias são muito distintas e somos sujeitos separados por classes sociais e direitos desiguais. Além disso, como bem afirmou Pound (2006: p. 81): "não há nenhuma razão para que um homem goste dos mesmos livros aos 18 e aos 48 anos. Graças a Deus há livros que a gente aprecia mais antes dos 25 e há outros livros que a gente ainda lê aos 45 e ainda espera ser capaz de ler quando estiver batendo os pinos". Apresentar obras como essas, que podem acompanhar os alunos por um longo tempo nas travessias da vida, foi um dos grandes desafios do projeto, mas, ao mesmo tempo, o gênero em foco nos auxiliou nesse objetivo, pois, como vimos, a poesia tende a ser duradoura e memorável.

Não obstante, elaboramos o planejamento e o material didático com a intenção de abrir espaço, construir pontes e meios para que os alunos tivessem maior familiaridade com o gênero poético, apreciando sua diversidade e sentindo confiança em explorar textos antigos, textos novos, daqui ou de outros lugares que possivelmente dispunham de discursos estimulantes e provocativos que poderiam tratar de forma semelhante traços de sua própria 
história. E eles nos surpreenderam positivamente a cada aula com a disposição e entusiasmo para conhecer novas obras e novos poetas.

Outro aspecto que nos guiou no planejamento foi a percepção de que o trabalho com poesia em sala de aula hoje ainda está muito apegado a interpretações meramente racionais ou usos instrumentais do texto para o ensino de gramática, de regras ortográficas ou de reconhecimento de funções da linguagem e de elementos retóricos. Desconsidera-se, assim, a valorização do lado lúdico da linguagem poética que ainda é muito atrativo aos jovens, reduzindo a abordagem do texto poético a exercícios que devam conter uma resposta correta e exata acerca das reflexões coletivas sobre o poema, muitas vezes impostas pelo professor ou mesmo pelo livro didático. Procurando contrapor-se a essa realidade, selecionamos alguns poemas trabalhados em sala de aula que foram apreciados pelos alunos e propiciaram desdobramentos instigantes no ensino literário e serão narrados na seção 4.1 deste capítulo.

Ainda cabe aqui salientar que este planejamento teve de seguir o modelo exigido pela coordenação pedagógica da escola e teve que se enquadrar no cronograma de avaliações e exigências do projeto de diferentes instrumentos diagnósticos, como explicado acima, além de corresponder às expectativas de aprendizagem e aos conteúdos propostos para essa frente do curso de Língua Portuguesa. Por mais que nosso desejo - e aqui falo do meu desejo como professora e também do desejo manifestado pelos alunos durante o curso, fosse de investir mais tempo na fruição poética e na preparação dos saraus literários, o calendário escolar impunha um andar apressado com prazos bem rígidos, bem como exigia que as provas acontecessem em uma determinada data, fazendo com que conteúdos a serem cobrados tivessem de ser ensinados exatamente nas aulas planejadas. Ou seja, como havia pouca maleabilidade no cronograma do curso, discussões mais acaloradas sobre uma determinada obra ou um entusiasmo espontâneo sobre determinada atividade tinham de ser, por vezes, entrevados e interrompidos por conta do calendário de avaliações a ser seguido. Nesses momentos, infelizmente, os alunos sentiram suas ideias tolhidas e foram vítimas do tempo e das demandas neoliberais de quantificação que desenham a escola de hoje em dia e a fazem cumprir tantas etapas avaliativas. Consideramos as avaliações de suma importância para compreender a heterogeneidade do grupo-classe, diagnosticar as dificuldades de aprendizagem e repensar as práticas educativas, no entanto, elas poderiam estar menos subordinadas aos conteúdos exigidos pelo vestibular e estar mais contextualizadas com as propostas do curso e com as aspirações expostas pela turma de alunos. Por mais que a escola limitasse o espaço para as experiências poéticas e emancipatórias, conseguimos trabalhar mais 
sob a perspectiva de um processo de criação do que sob a lógica de resultados quantificáveis. No entanto, justamente porque defendemos a premissa de que diagnósticos bem aplicados podem nos auxiliar na elaboração da metodologia e da didática do curso, antes de iniciarmos o cronograma, realizamos a leitura do poema "O menino que carregava água na peneira", de Manoel de Barros (Anexo 2), e propusemos uma atividade de interpretação que pudesse nos trazer dados importantes sobre o letramento dos alunos até o momento. Consideramos essa primeira atividade como um primeiro diagnóstico.

\section{Um primeiro diagnóstico}

Retomando brevemente o que dissemos anteriormente sobre a metodologia do mestrado e os principais posicionamentos teóricos com os quais o trabalho se sustentou para dar continuidade à pesquisa atual do doutorado, deslocamos o foco que antes estava nos sujeitos em processo de alfabetização, apoiados na oralidade primária, para os sujeitos que não mais se encontram nesse cenário inédito da descoberta da linguagem poética que se dá na infância, tampouco, em sua maioria, estão inseridos na oralidade formular de maneira ativa capaz de fazer a escrita e o registro dos textos orais acontecerem. Para muitos alunos que compuseram as salas de aula nas quais a pesquisa aconteceu, ainda não havia atribuição de valor da escrita a partir de um reposicionamento subjetivo diante do domínio do código, dos meios sociais de expressão verbal, da escola e de suas relações com a família contemporânea. Constatamos por meio de conversas sobre as experiências que tiveram com a oralidade poética e a literatura até o nono ano do Ensino Fundamental nas escolas municipais ou estaduais de onde vieram, por meio das atividades com poesia e das avaliações iniciais a existência de uma brecha que se abriu na transição da oralidade para a escrita.

Os dados coletados com 64 alunos de 14 a 17 anos a partir da leitura e interpretação do poema de Manoel de Barros (Anexo 2) - de certa forma alegoricamente sutil, no entanto, com metáforas intrigantes, apontam para a seguinte situação de leitura e escrita: 
1) LEITURA:

\begin{tabular}{|c|c|c|c|c|}
\hline Níveis & 1 & 2 & 3 & 4 \\
\hline $\begin{array}{c}\text { inferência de sentido: } \\
\text { não identificou o } \\
\text { tema do poema e não } \\
\text { compreendeu a } \\
\text { metáfora }\end{array}$ & $\begin{array}{c}\text { Leitura com } \\
\text { mínima inferência } \\
\text { de sentido: } \\
\text { identificou o tema } \\
\text { do poema, mas } \\
\text { não compreendeu } \\
\text { a metáfora }\end{array}$ & $\begin{array}{c}\text { Leitura com } \\
\text { inferência de sentido: } \\
\text { identificou o tema do } \\
\text { poema e } \\
\text { compreendeu a } \\
\text { metáfora }\end{array}$ & $\begin{array}{c}\text { Leitura com inferência } \\
\text { e análise de sentido: } \\
\text { identificou o tema do } \\
\text { poema, compreendeu a } \\
\text { metáfora e analisou os } \\
\text { recursos expressivos } \\
\text { da linguagem poética }\end{array}$ \\
\hline $\begin{array}{c}1^{\circ} \text { ano do } \\
\text { EM-33 }\end{array}$ & 12 & 11 & 8 & 2 \\
\hline $\begin{array}{c}2^{\circ} \text { ano do } \\
\text { EM }-31 \\
\text { alunos }\end{array}$ & 8 & 12 & 6 & 5 \\
\hline
\end{tabular}

\section{TABELA 4. DIAGNÓSTICO DOS NÍVEIS DE LEITURA DOS ALUNOS}

2) ESCRITA:

\begin{tabular}{|c|c|c|c|c|}
\hline Níveis & 1 & 2 & 3 & 4 \\
\hline $\begin{array}{c}\text { Escrita sem } \\
\text { poerência, coesão e } \\
\text { padronização textual } \\
\text { (parágrafo, } \\
\text { pontuação e } \\
\text { ortografia) }\end{array}$ & $\begin{array}{c}\text { Escrita com } \\
\text { padronização } \\
\text { textual (parágrafo, } \\
\text { pontuação e } \\
\text { ortografia), mas } \\
\text { sem coerência e } \\
\text { coesão }\end{array}$ & $\begin{array}{c}\text { Escrita com } \\
\text { coerência, coesão e } \\
\text { padronização textual } \\
\text { (parágrafo, } \\
\text { pontuação e } \\
\text { ortografia) }\end{array}$ & $\begin{array}{c}\text { Escrita com coerência, } \\
\text { coesão, padronização } \\
\text { textual (parágrafo, } \\
\text { pontuação e } \\
\text { ortografia), bom } \\
\text { repertório e articulação } \\
\text { de ideias }\end{array}$ \\
\hline $\begin{array}{c}1^{\circ} \text { ano do } \\
\text { EM-33 } \\
\text { alunos }\end{array}$ & 12 & 11 & 9 & 2 \\
\hline $\begin{array}{c}2^{\circ} \text { ano do } \\
\text { EM-31 } \\
\text { alunos }\end{array}$ & 8 & 12 & 5 & 5 \\
\hline
\end{tabular}

\section{TABELA 5. DIAGNÓSTICO DOS NÍVEIS DE ESCRITA DOS ALUNOS}

Como professora de Língua Portuguesa de adolescentes do primeiro e segundo ano do Ensino Médio da comunidade de Paraisópolis, pude atestar, ao longo das práticas de ensino e por meio do corpus levantado com a pesquisa, que há uma ausência do lugar da leitura e escrita e dos meios de expressão verbal do código de maneira clara, coerente e autônoma na 
vida de alguns jovens, cujos processos de escolarização fragmentaram ou interromperam a transição da oralidade para a escrita. Os resultados da primeira avaliação trouxeram dados importantes com relação às habilidades de leitura e interpretação de texto, bem como a escrita convencional da língua, apontando para uma defasagem acentuada para a faixa etária. Ao mesmo tempo, as produções de texto dos alunos no decorrer do curso e os desdobramentos dos exercícios aplicados em aula evidenciaram características interessantes sobre a turma: disposição e engajamento para a escrita de textos autorais e subjetivos, que abordem aspectos de sua vida e realidade; aquisição rápida de um bom repertório para argumentar e justificar oralmente posicionamentos e afirmações; interesse em poesias e outros textos versificados que carregam uma mensagem implícita, ou seja, algo a ser decifrado ou deslocado de um lugar normatizado e gosto pela leitura em voz alta e dinâmicas de leitura compartilhada como jogral ou leitura performática.

As turmas se mostraram bastante heterogêneas: tivemos alunos de 14 a 17 anos, oriundos de diferentes escolas públicas, com habilidades e competências bem distintas no que diz respeito ao nível de leitura (alguns ainda liam de maneira fragmentária) e de escrita (muitos alunos ainda escreviam textos curtos, de parágrafo único, sem as convenções de escrita ensinadas no Ensino Fundamental). Uma segunda coleta de dados realizada com os alunos investigou os resquícios da oralidade poética primária (os textos orais da infância) que os alunos dominavam e carregavam na memória, a fim de identificar o primeiro contato que tiveram com o patrimônio da cultura oral de nossa sociedade. Em seguida, verificou-se como esses textos puderam influenciar a compreensão do ritmo e da estrutura dos versos das obras propostas para análise no curso de Língua Portuguesa do primeiro ano do Ensino Médio e como os alunos foram capazes de perceber as unidades expressivas do poema através dos jogos linguageiros também presentes na infância.

Assim, o que diagnosticamos de antemão foi um distanciamento radical entre os sujeitos e a oralidade poética trabalhada na infância e que, mesmo após esse distanciamento inevitável no processo de aquisição da escrita, não foi possível observar uma aproximação mais sólida dos alunos com a leitura inferencial e a escrita convencional ou autoral. Ou seja, como dito acima, verificamos por meio das avaliações diagnósticas e das atividades que serão expostas adiante que a maioria dos alunos que compuseram as turmas investigadas nesta pesquisa não se encontrava subjetivamente na oralidade poética, tampouco no domínio da escrita. 
No entanto, foi interessante observar neste primeiro diagnóstico a partir da leitura e interpretação do poema de Manoel de Barros as reflexões que os alunos registraram na última questão da ficha de exercícios (Anexo 2, questão 9). O poema narra a história de um menino que carregava água na peneira e era julgado por seus despropósitos. Um menino que gostava mais do vazio do que do cheio, pois eles são maiores e infinitos, e que, com o tempo, descobriu que escrever seria o mesmo que carregar água na peneira, pois ele poderia fazer as palavras escoarem, da maneira que quisesse, por entre os vazios de cada um. No final do exercício de interpretação, há uma questão sobre como os alunos achariam possível preencher os seus próprios vazios, relacionando ou não com a sugestão do poema sobre esse vazio e essa forma de trabalhá-lo ou explorá-lo. A maioria dos alunos relatou na ficha que, para se sentirem bem diante dos vazios, eles procuram se encontrar com amigos, jogar bola ou videogame, assistir televisão, ouvir música, comer e dormir. Eles compreenderam que o vazio era sinônimo de tristeza, angústia, solidão e desilusão, por isso, precisariam preenchê-lo de forma a se distrair e se esquecer dos problemas. Contudo, alguns alunos se destacaram na formulação do registro da questão:

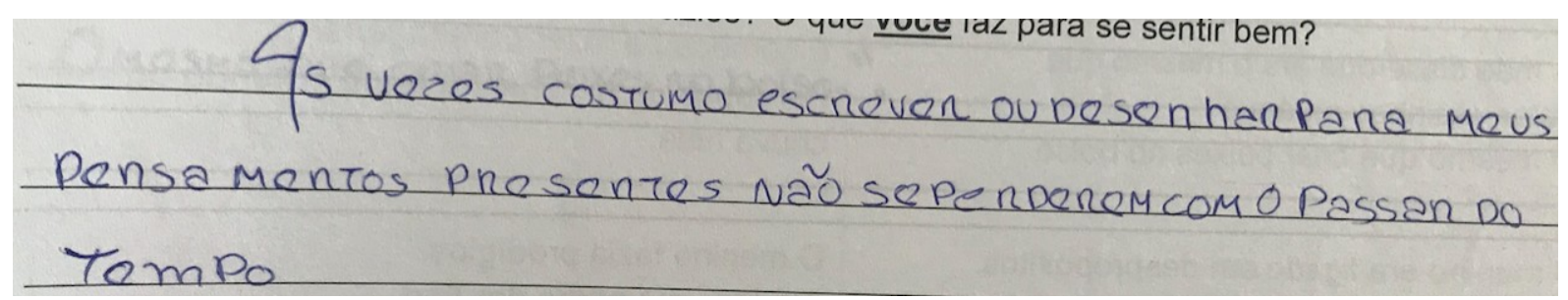

"Às vezes costumo escrever ou desenhar para meus pensamentos presentes não se perderem com o passar do tempo".

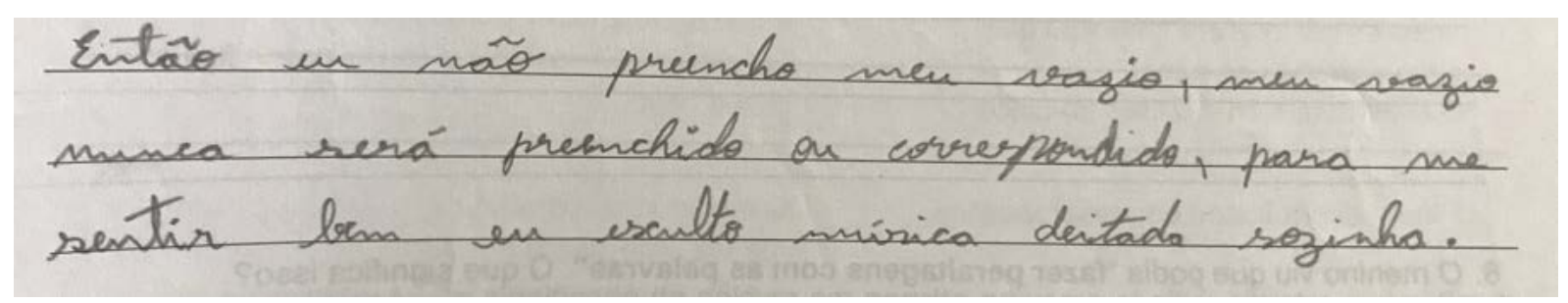

"Então, eu não preencho meu vazio, meu vazio nunca será preenchido ou correspondido, para me sentir bem eu escuto música deitada sozinha". 
Quando me sinto vazia eu costumo picar pensatiwa, le pernsando exatarmen the sobre esse wazio... haĩ os preencib. Parra me sentir bem en coloco fones yara escutar muvieas alegres berm alto, es canto, e dange. Isso aumenta a minta audoestima. Gosto tam erem de me cuidan fisícarmentei Pinto as untas, leso cosmédicios eomo eremer, esfoliantes ete, arrume as caubelos e in rento quarquer coisas yarau realizar ava minta arparéneia. Qucredito que um" trazio" nas atma, é impossivel de se preematter,

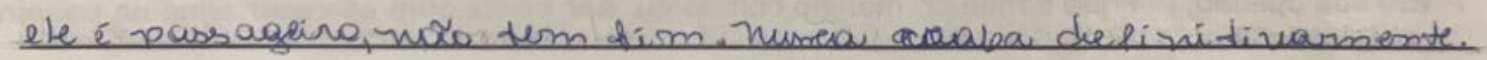

"Quando me sinto vazia eu costumo ficar pensativa e pensando exatamente sobre esse vazio... não o preencho. (...) Acredito que um "vazio" na alma é impossível de se preencher, ele é passageiro, não tem um fim. Nunca acaba definitivamente".

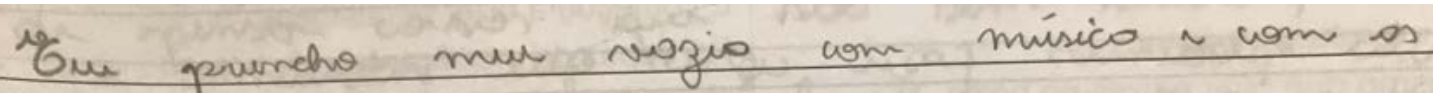
escitos pres usses do's inmentes $\approx$ copoz de te duxer olveimodo silo nelo prti.

Th sodow uscruven e pdove a arte de vivir.

Quondo un ustou taiste un aprocuro fozer coison

qui vāo tiro squela tristiza, foso com ogur en me sinto Vburto a liver de tudo qur ritai do nur olconce, prosauro soir do mundo nul $\lambda$ in growo o meur mundo, em nundo qu só ue pona hobitar, e poro que ul posso rualizar todos usos coisas un uso a sscrito squ o músico como uma bose estrutural,

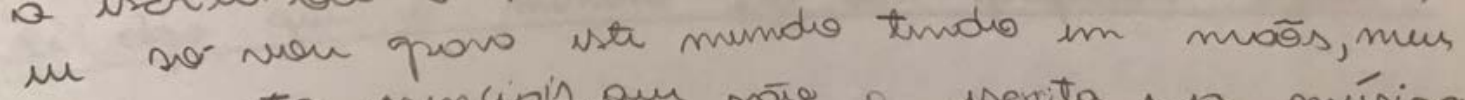
instrumentor ssencisis, que mote s userita ra músico. 
"Eu preencho meu vazio com música ou com as escritas, pois esses dois elementos são capazes de te deixar alucinado pela arte. (...) procuro sair do meu mundo real e ir para um mundo que só eu posso habitar, e para que eu possa realizar todas essas coisas eu uso a escrita ou a música como uma base estrutural (...)".

Esses alunos que relacionaram o vazio com a escrita, com a arte e a impossibilidade de preenchimento se destacaram também pelo desempenho nas atividades com o texto poético propostas ao longo do curso, principalmente na organização do sarau e na elaboração dos poemas autorais. Reconhecemos logo de início não apenas as potências desses alunos que refletiram de maneira mais sensível e profunda sobre o significado do vazio no poema, mas também do conjunto todo de adolescentes que se mostrou disposto a descobrir novas formas de investigar e de se beneficiar com a linguagem poética.

Assim, nesses exercícios iniciais, percebemos que a falta de aproximação da linguagem em sua dimensão inconsciente e dos processos primários da língua ao fato poético poderia prejudicar o domínio da leitura e da escrita no contexto dos jovens que se encontram nos anos finais de sua escolarização, verificando-se, portanto, como as metodologias que pautam a oralidade poética podem facilitar o reposicionamento subjetivo dos alunos diante do processo de letramento contínuo.

Ainda sob a perspectiva de um primeiro diagnóstico, analisamos também as avaliações realizadas pelos alunos bolsistas no processo seletivo de ingresso na Escola Alef Peretz, elaboradas pela coordenação do Ensino Médio (Anexo 3), cujas questões eram de interpretação de um texto de João Guimarães Rosa, intitulado "Fita verde no cabelo (nova velha história)", que traz uma reflexão sobre um doloroso fato da vida real: a morte de um ente querido. Dos 33 alunos que foram aprovados no processo seletivo, apenas 4 acertaram mais de $80 \%$ das questões e a maioria acertou entre 5 e 6 questões dos testes indicados na primeira parte da prova. As questões - algumas, a meu ver, com formulações bastante complexas, exigiam o reconhecimento da intertextualidade entre a história de João Guimarães Rosa e o conto tradicional da Chapeuzinho Vermelho, a identificação da sequência narrativa e compreensão de seu conflito, a interpretação das marcas expressivas autorais do texto, além de análises dos recursos de oposição, neologismos e outros usos de figuras de linguagem mais sofisticadas, bem como a relação de causa e consequência entre as ações das personagens. As questões com maior índice de distratores foram a segunda, que exigia a identificação da intertextualidade estabelecida, a sétima, que exigia uma inferência de sentido conotativo das 
palavras destacadas e a oitava, que exigia a interpretação do desfecho da história. Com esses primeiros diagnósticos, notamos que a maior dificuldade que os alunos encontraram ao interpretar os textos foi com relação ao conteúdo lexical e aos recursos linguísticos da intertextualidade entre duas histórias.

Na segunda parte da avaliação, os alunos redigiram uma produção de texto com base na história lida e tiveram que escolher um acontecimento de sua vida para ser narrado em uma sequência lógica e coerente dos fatos. Os resultados obtidos a partir das redações apontaram para os seguintes números:

\begin{tabular}{|c|c|c|}
\hline \multicolumn{2}{|c|}{ Categoria de análise } & Número de produções de texto \\
\hline \multirow[t]{2}{*}{ Vozes do texto } & $\begin{array}{l}\text { Narrador/ Personagem: } \\
\text { As vozes de narrador e } \\
\text { personagens se } \\
\text { confundem, sem que haja } \\
\text { uma marcação de } \\
\text { alternância. }\end{array}$ & \multirow{2}{*}{ 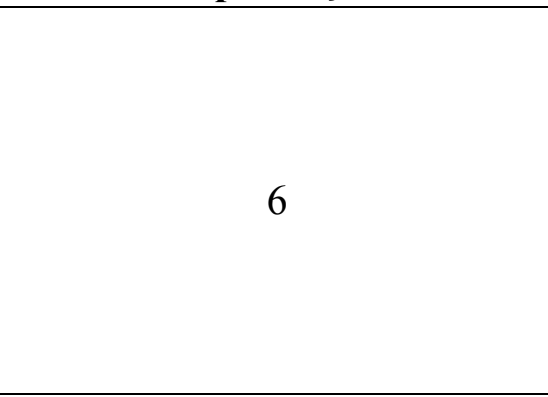 } \\
\hline & $\begin{array}{l}\text { Falta de discurso direto/ } \\
\text { indireto }\end{array}$ & \\
\hline Coerência & $\begin{array}{l}\text { Faltam descrições, faltam } \\
\text { ações (verbos que fazem } \\
\text { passagens de um } \\
\text { ambiente a outro). Nota- } \\
\text { se que, em muitos casos, a } \\
\text { falta de coesão leva a falta } \\
\text { de coerência. }\end{array}$ & 11 \\
\hline Coesão & $\begin{array}{l}\text { Falta de conectores e de } \\
\text { recursos coesivos no } \\
\text { plano nominal e } \\
\text { sequencial }\end{array}$ & 22 \\
\hline \multirow[b]{2}{*}{$\begin{array}{l}\text { Elementos de } \\
\text { textualização }\end{array}$} & Paragrafação & 4 \\
\hline & $\begin{array}{l}\text { Pontuação } \\
\text { Ainda que o aluno não } \\
\text { utilize a pontuação } \\
\text { correta, se houver algum } \\
\text { tipo de marcação, } \\
\text { considera-se que ele tenha } \\
\text { uma "consciência de } \\
\text { pontuação"; } \\
\text { Pontuação de diálogos } \\
\text { (dois pontos, travessão, } \\
\text { interrogação, exclamação) } \\
\text {-quando há discurso } \\
\text { direto; }\end{array}$ & 8 \\
\hline
\end{tabular}




\begin{tabular}{|l|l|l|}
\hline & $\begin{array}{l}\text { Ponto final no final do } \\
\text { parágrafo. Dentro do } \\
\text { parágrafo, foi exigido } \\
\text { apenas a "consciência de } \\
\text { pontuação". }\end{array}$ & \\
\hline & Pares homorgânicos & 1 \\
\hline & Dígrafos & 2 \\
\hline & Divisão silábica & 4 \\
\hline Sílabas complexas & 3 \\
\hline Aglutinação & 4 \\
\hline Ortografia & Hiper-segmentação & 6 \\
\hline & Letra maiúscula & 1 \\
\hline & ÃO e AM & \\
S/Z & 7 \\
\hline & CH/X & \\
\hline
\end{tabular}

TABELA 6. DIAGNÓSTICO DOS ELEMENTOS DE TEXTUALIZAÇÃO DAS PRODUÇÕES DE TEXTO DOS ALUNOS DE 1ª́ SÉRIE DO ENSINO MÉDIO

O número alto de alunos (22 de 33 alunos) que não demonstraram saber utilizar recursos coesivos em uma dissertação e apresentaram dificuldade em estabelecer a sequência narrativa da história nos levou a crer que, no Ensino Fundamental, eles devem ter realizado atividades pouco eficazes para a elaboração de textos coerentes e coesos, uma vez que apenas onze alunos demonstraram conhecimento de alguns elementos de textualização mais bem desenvolvidos. A quantidade de erros ortográficos, caligrafia ilegível e problemas na estrutura do parágrafo também nos chamaram a atenção e apontaram para questões de alfabetização mal consolidadas, como nos exemplos abaixo: 


\section{Quonglo ü ü gla lej con un}

Era una quarta-diera, quomdo lle, Minho urnô, l minho mäe ustontomos arrumondo as malas

5 Paro kigfar Paro Bahia. Durais de algumas horas a carro chegun Paro nos levar Paro ridovióvira, quomolo entromos tinho mais dudes pussalas, que toneren irion Para Bania.

DuRais de algumas haras chegomas no radoriaria, itonto cheut te Pessaos...

r... rmmir.:

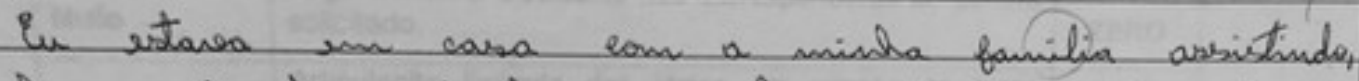

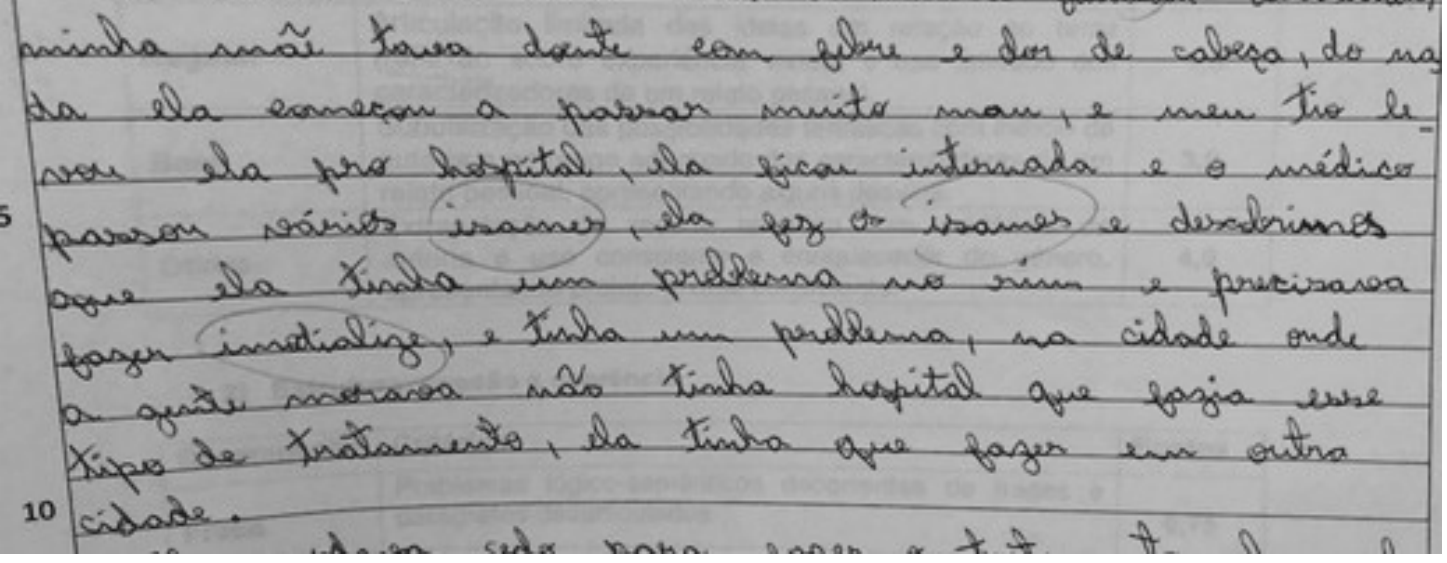




\section{A bela caba alondernada}

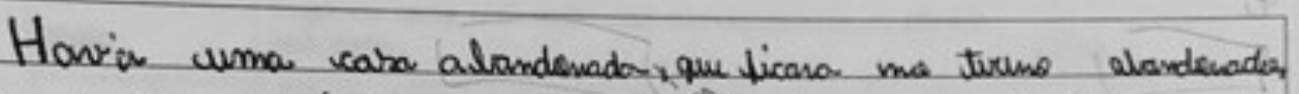

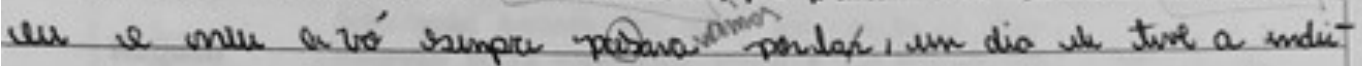
a de untra to treme prea ver a cabo alin da caba sae tedo

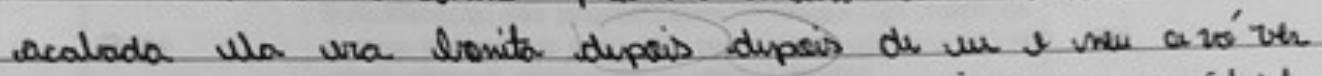

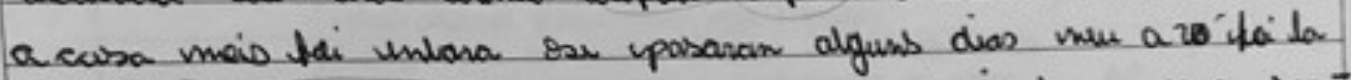

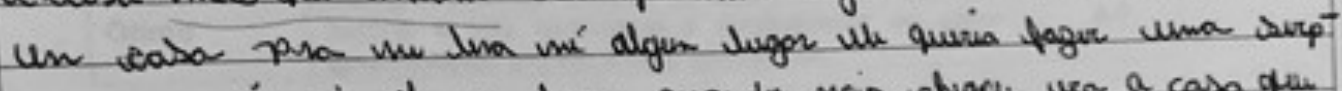

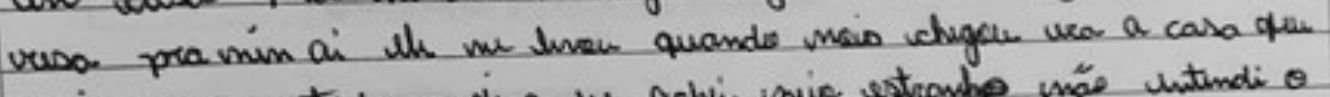

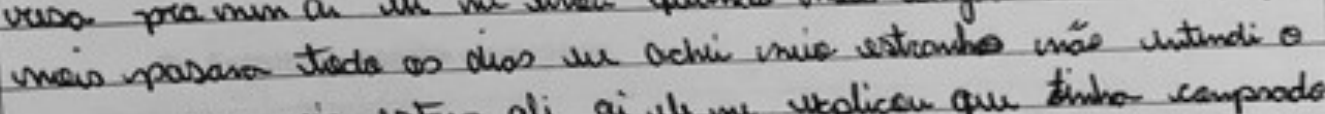

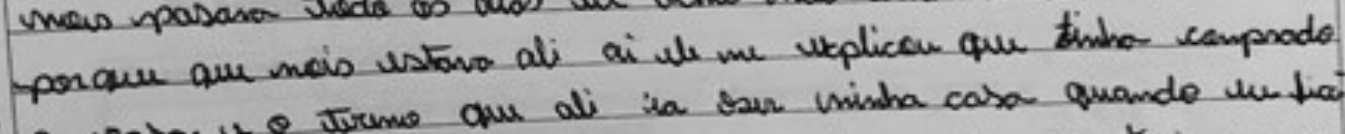

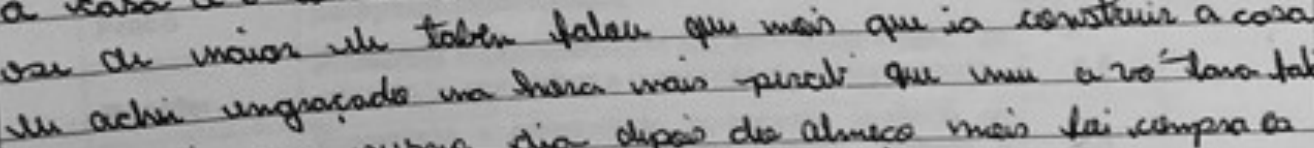
undo sestio uno unsmo dia dipes de almece mais tai compra a

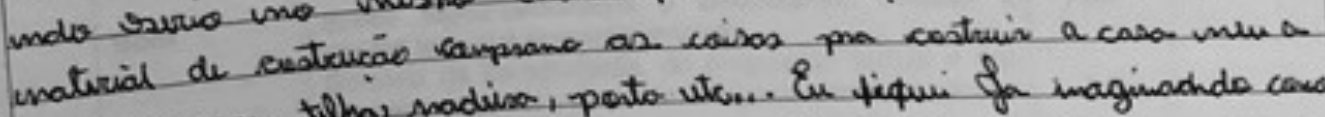

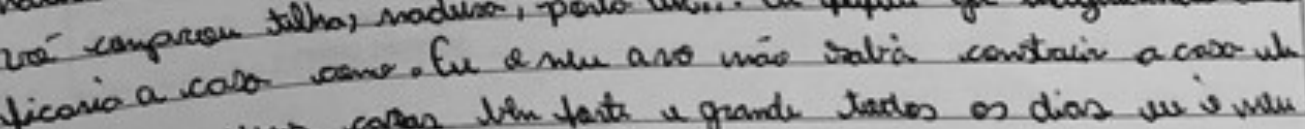

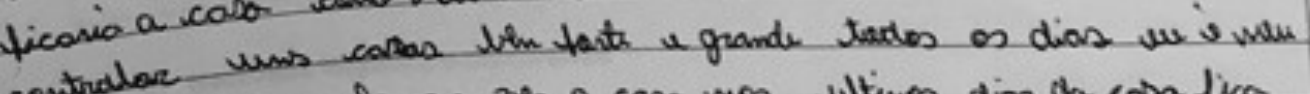
a vo pasarames la prom ver a caso mos ultines dias da cosa fica

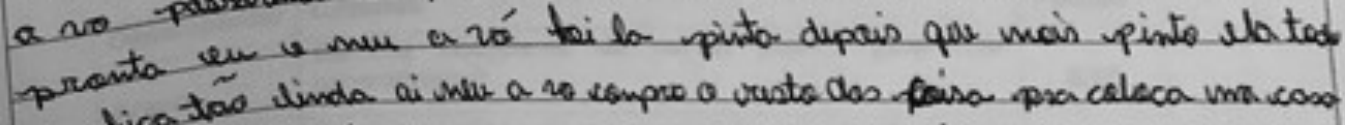

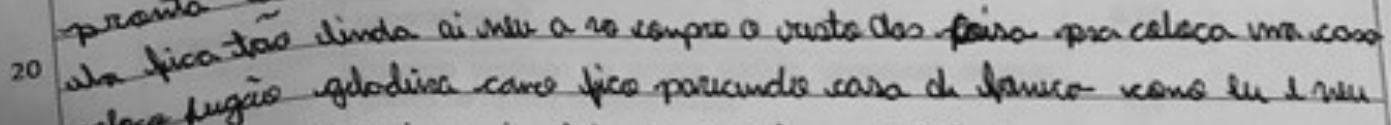

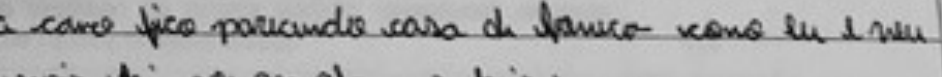

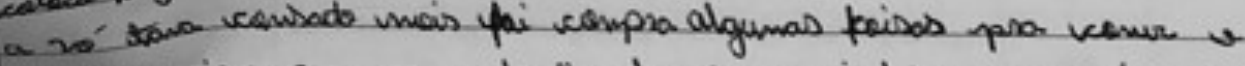

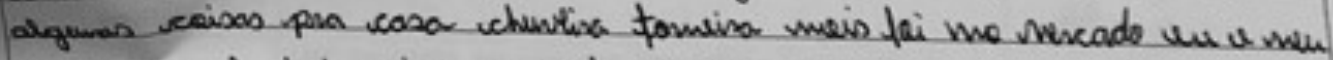

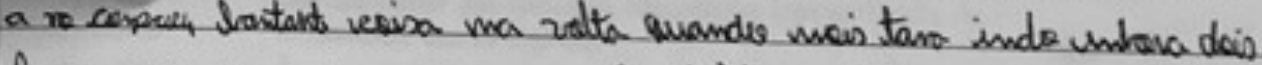

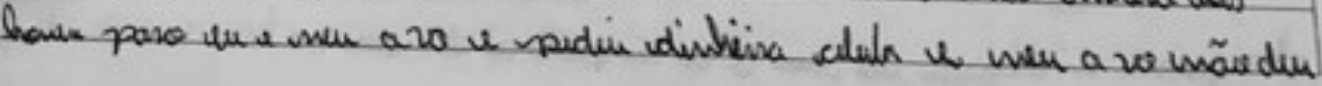

(Texto sem divisão em parágrafos) 
VERSÃO FINAL

Alegriar ou Trinteza

s.pere

Havia um minimo, que morava perto dos eu primas, o mame dele era terick, ele gantana unta de linear, lazia diveresas coinzas

Serta dia Herick entara em casa, lazendo un alrigaçãce, quandos rua mä folour.

Who mais tarde leva a remedio para suavo', tai má, mais el nou souta pipa depoirs ew lenre.

Herick fai naltal pipa com news primos quando ele venta está Tarde, jä era 4:30 main ele ese enqueceu de leval o remedio en vai andar de Bik en, quando vauta para cana ele fala para máe.

- Haje fai muito legal a dia.

- Mais vace levar o remédia, dice a mãe?

- Eita! un esqueni. Vou pegol mimha Bithe, itura é lena co remediro.

Quando ele tara sie aprocimando um monte de policia estarra lá, imvouta uma multidor le corre para ver.

20 Ele chegou lá é perguntau para o palicial. - Oque ourve?

- Um aridente de carro, dise o palicial.

- Hericl core para ve quem exa no carres, é comes a chorar parque era a tia dele que erstava lá. Ela nair para a tlárpital, e depais de do

241 
VERSAO FINAL

Lule esw proen

Roulone deños terver

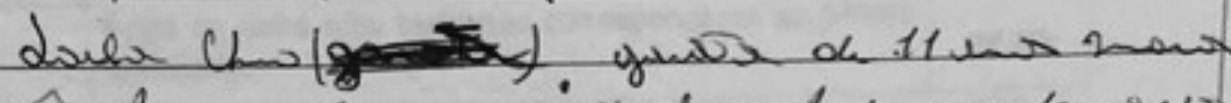

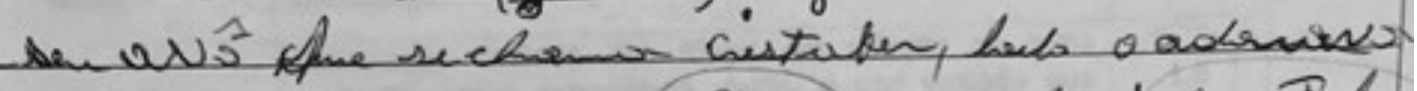

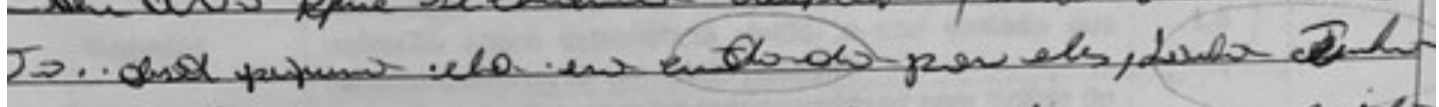

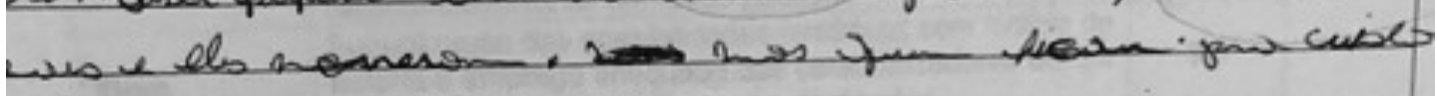
hla pri ouns aushater.

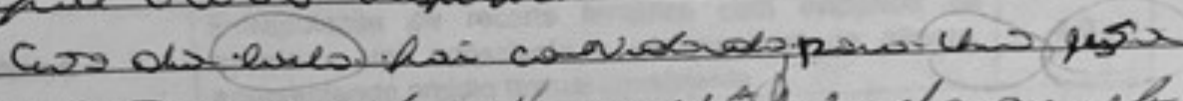

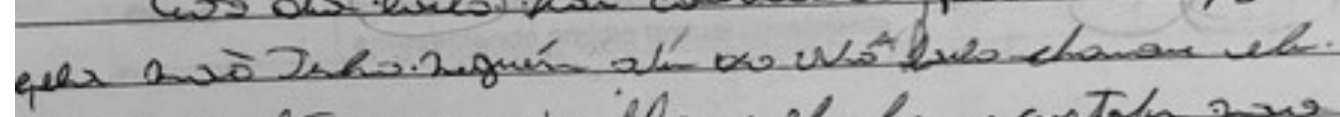

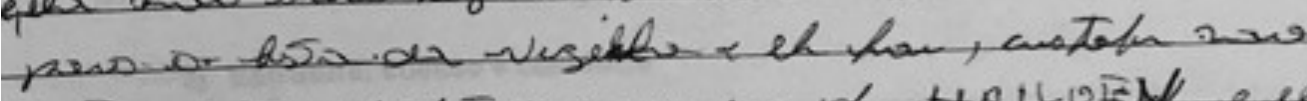

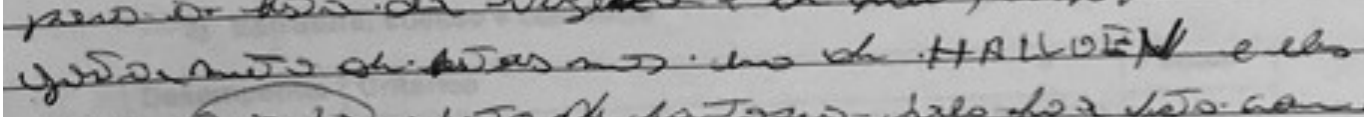

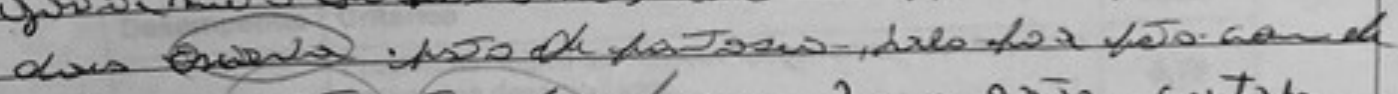

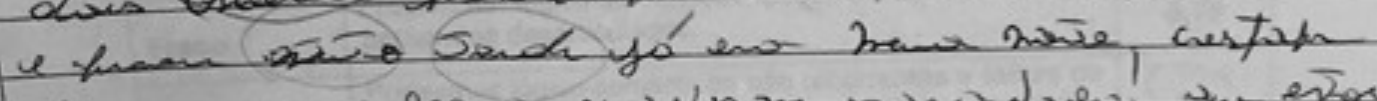

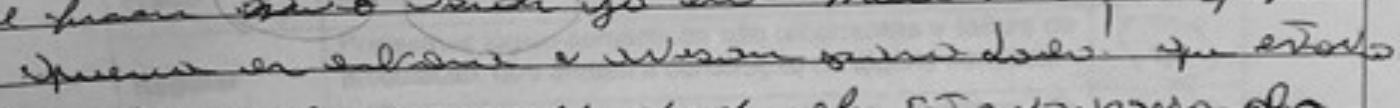

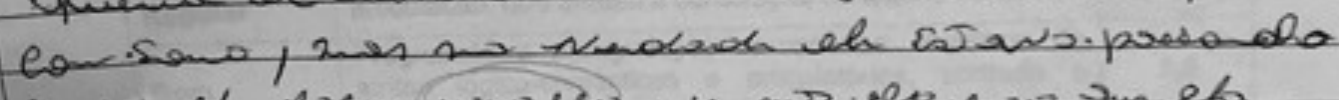

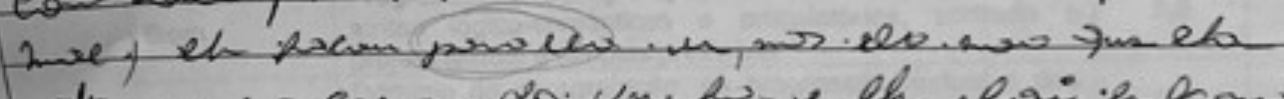

$5 \longdiv { 1 }$

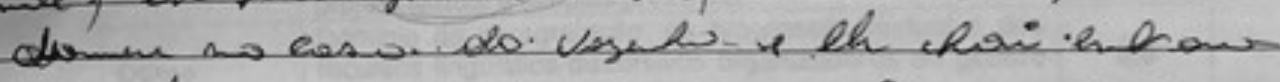

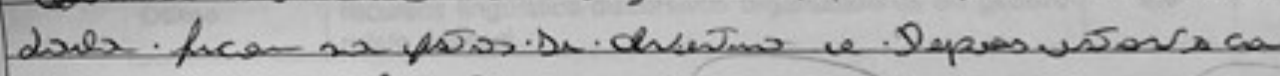

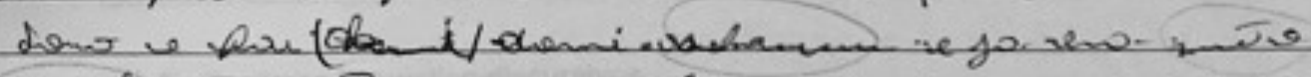

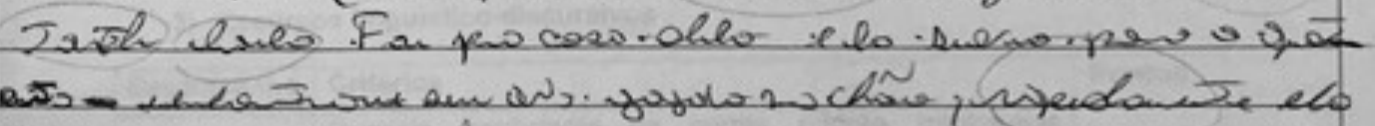

20

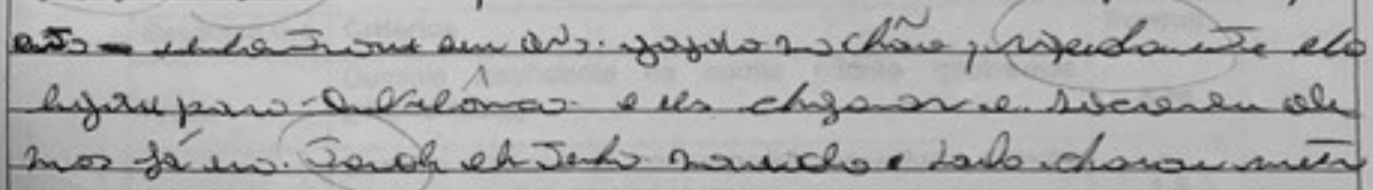
ifurariembo Jiesse.

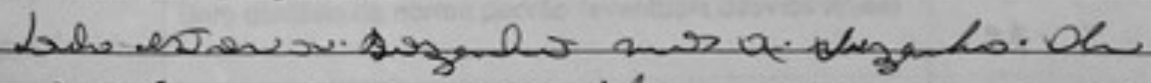

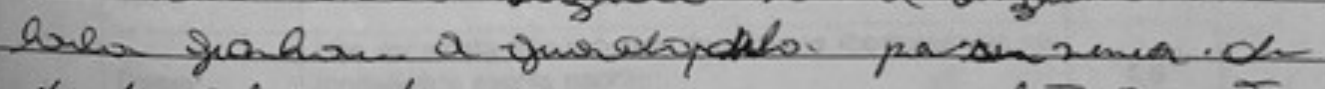
25

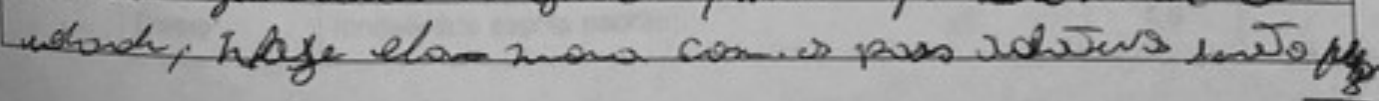

242 


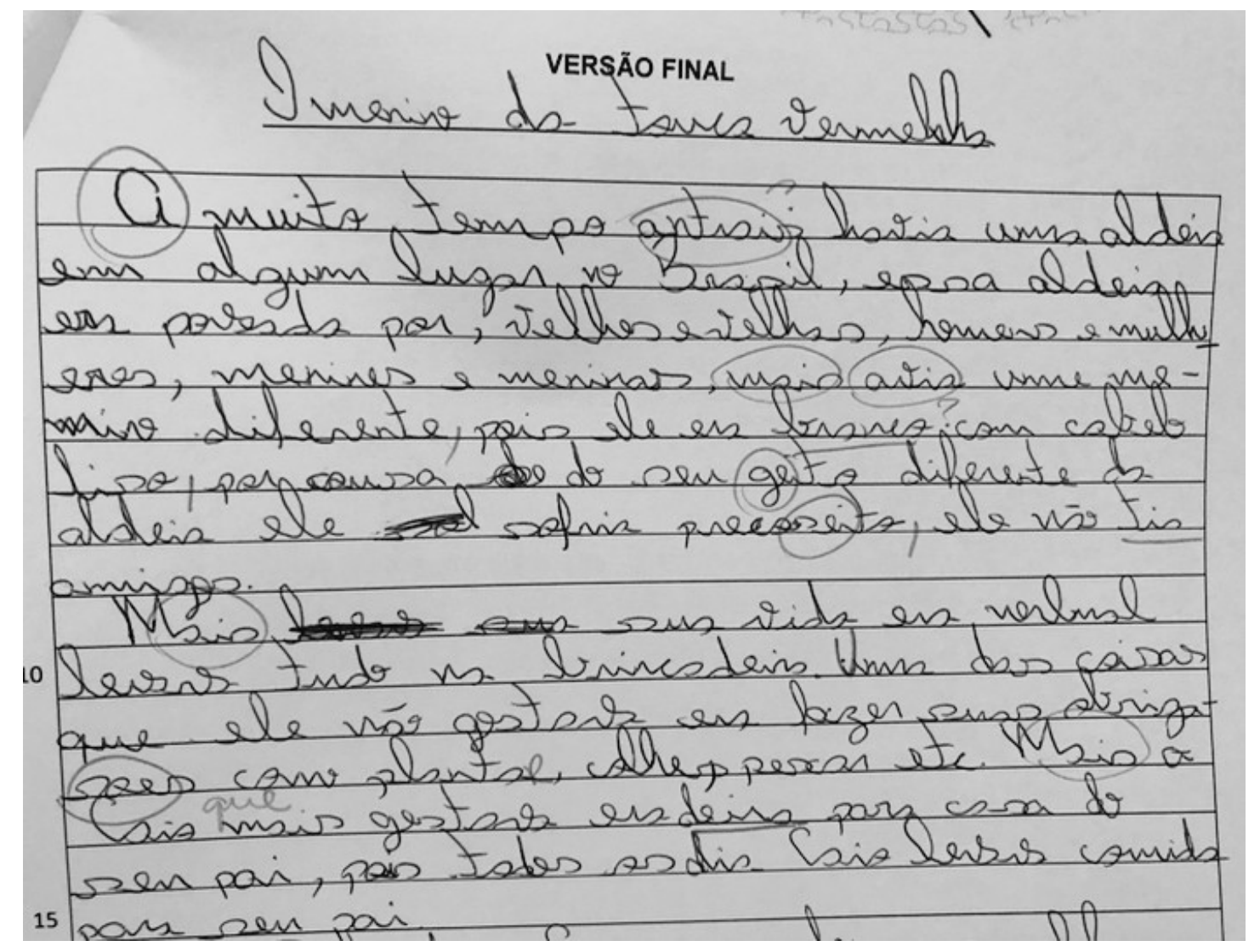

Consideramos importante evidenciar alguns tópicos dos processos debilitados de alfabetização confirmados nessa prova de seleção para compreender melhor o domínio de escrita dos alunos, mas reconhecemos que ao expor os dados dessa forma, apontando somente as "falhas", deixamos de evidenciar as potências dos alunos, como a capacidade de lidar, por meio da escrita, com as contradições sociais, de elaborar reflexões pertinentes sobre o contexto político do país e de narrar experiências de forma sensível e criativa. No entanto, para esse tipo de revelação, selecionamos outras atividades planejadas em nosso percurso didático, uma vez que não é possível apresentar cada etapa de produção dos alunos nesta tese, foram mais de 600 produções ao longo da pesquisa, sequer abordar todas as descrições oportunas para cada análise de dados. Como tivemos que realizar escolhas para a exibição das práticas e ações substanciais para as reflexões propostas aqui, não realizamos uma análise aprofundada da prova de seleção, principalmente por ela não fazer parte do nosso material didático, tampouco do nosso planejamento ${ }^{35}$.

\footnotetext{
${ }^{35}$ A prova de seleção para distribuição de bolsas da Escola Alef Peretz - Unidade de Paraisópolis foi elaborada pela coordenação pedagógica e aplicada no ano anterior ao início do estudo de campo da tese.
} 
Neste sentido, discorreremos a seguir sobre os aspectos da língua e da poesia trabalhados no curso de Língua Portuguesa, não mais sob a intenção de quantificar problemas de escrita e leitura como fizemos neste item (ação justificada pela finalidade de compreender o estágio de domínio do código dos alunos), mas sim sob a intenção de expor e analisar o processo autoral, criativo e inusitado das reflexões e produções poéticas dos sujeitos da pesquisa, bem como os trabalhos monográficos do projeto de síntese elaborados nas $1^{\mathrm{a}}$ a $2^{\mathrm{a}}$ séries do Ensino Médio.

\section{Os principais desdobramentos com o texto poético}

Ao longo de todo o curso de Língua Portuguesa oferecido aos alunos do Ensino Médio de Paraisópolis, reiteramos constantemente que a linguagem não é apenas um meio de comunicação, mas uma possibilidade de ampliação da experiência humana pela via artística, na qual ela pode ser carregada de significado até o máximo grau possível, por meio dos recursos da fanopeia, melopeia e logopeia (Pound, 2006). Para os alunos, os conceitos em si não explicavam muita coisa, no entanto, conforme fomos exercitando a linguagem poética, provocamos uma importante reflexão oriunda da tríade de Pound sobre a necessidade de verificar as palavras que podem não funcionar nesse novo modo de pensar a articulação da língua, como aquelas que "não contribuem para o significado ou que distraem do fator mais importante do significado em favor de fatores de menor importância" (p. 63). Isso porque sempre colocamos em destaque a sabedoria dos versos de Drummond que nos ensinou que a chave da composição poética está nas palavras, em sua perseguição pela condensação de sentido e em sua figurabilidade delirante.

Logo, do ponto de vista didático, um dos principais desdobramentos do trabalho com o texto poético em sala de aula foi o desenvolvimento e aprimoramento de um olhar crítico para suas próprias criações e também o amadurecimento da segurança e confiança nos colegas para expor e compartilhar suas produções, com a finalidade de debater sobre os comentários e sugestões acerca dos arranjos sintagmáticos e paradigmáticos e, se necessário, modificá-los e aperfeiçoá-los coletivamente.

Para demonstrar dinâmicas como essa, descreveremos nesta seção trechos da sequência didática proposta para o trabalho com o texto poético em sala de aula e alguns exercícios realizados, com o intuito de evidenciar as escolhas feitas a partir do objetivo de ampliar o estatuto reconhecido pelos alunos acerca da linguagem, do repertório de textos 
poéticos, dos conteúdos gramaticais e de domínio do código escrito, possibilitando experiências estéticas que auxiliem na motivação para se explorar os recursos mnemônicos, as formas e os conteúdos da poesia:

- Dinâmica de apresentação - iniciamos o curso com a discussão sobre o ritmo da fala, a prósodia e a entonação. Como atividade, os alunos deveriam escrever uma palavra que representasse algum desejo para o futuro e, em dupla, deveriam elaborar um ou dois versos que contivessem as duas palavras escolhidas. Cada dupla apresentou seus versos, os redigimos e projetamos na lousa. Em seguida, a turma foi convidada a ler o conjunto de versos em voz alta e a pensar em uma organização que pudesse aproximar forma e conteúdo em estrofes. $\mathrm{O}$ resultado foi o poema coletivo abaixo:

Eu me sinto incomodado

Com o seu conservadorismo

Que já está ultrapassado

Seja gay, seja trans

Negro ou oriental

Coração que pulsa no peito

É de igual pra igual

Sem nunca depender de homem

Para ter minhas paradas

Faço longa minha caminhada

Sei que se eu não contar o segredo

Sempre terei medo

E já aprendi:

"Não tenha medo do pior"

Pois tudo vai mudar

Você vai transformar

O mundo ao seu redor

Mas hoje em dia tanto faz

Putaria tá demais

E ninguém tem o respeito

Pelo próximo e por seus pais

Só que o futuro e a esperança

São essenciais para a criança

Sucesso e felicidade

Só se tem com liberdade 
Prosperidade, vontade de crescer

De tentar ser alguém antes de morrer

Mas fazer isso sozinho, não

Não é legal

Quero ter uma família

A qual ame sem igual

Para ter sucesso e felicidade

Tem que agir com responsabilidade

Sem protesto e sem otimização

Não se constrói uma nação.

Ao dizer que os alunos deveriam criar versos, todas as duplas subentenderam que eles deveriam rimar, mas essa não era uma exigência da atividade. No sentido de contemplar a composição coletiva e exercitar uma análise crítica, debatemos sobre as seguintes questões:

1) Há palavras fora da sua posição usual? Essa mudança torna o verso de algum modo mais interessante? Por quê?

2) Há palavras que combinadas de uma certa maneira proposta nos versos não transmitem nada de novo, ou seja, estão sem graça ou sem energia?

A partir dessas primeiras provocações, os alunos foram capazes de reconhecer arranjos sintagmáticos não usuais na fala prosaica, como a topicalização à esquerda, a inversão da ordem sintática comum de sujeito na posição um e objeto na posição dois, bem como a antecipação do adjetivo para caracterizar o substantivo dos versos. Naquele momento, não vimos a necessidade de já nomear tais recursos da sintaxe, mas elencamos algumas figuras da linguagem que eles conheciam e retomamos seus significados oralmente, valendo-nos de outros exemplos para ilustrar os seus diversos usos, o que nos serviu também de diagnóstico para compreender melhor o que os alunos aprenderam sobre o assunto. Sobre a segunda questão colocada, os alunos criticaram a última estrofe, pois não conseguiram ver uma conexão clara entre as palavras "protesto" e "otimização", mas como estávamos no final da aula, não nos restou tempo para elaborar uma proposta de modificação do verso.

Os temas abordados nos versos criados coletivamente variaram entre amor pelo próximo, resistência contra a opressão, busca pela felicidade e necessidade de transformação e independência. Veremos adiante que os poemas que os alunos criaram na atividade final para a apresentação no sarau literário também apresentaram conteúdos semelhantes, mas foram enriquecidos por figuras e alegorias mais sofisticadas. Como lição de casa a partir dessa primeira atividade, os alunos tiveram que responder a duas questões sobre o poema: 1) Em 
sua opinião, qual ritmo caberia no poema? Por quê?; 2) O que ainda é preciso revisar no texto para que se estabeleça uma unidade rítmica? Pense na estrutura dos versos, na quantidade de palavras e sílabas tônicas.

As perguntas não foram facilmente respondidas, pois os alunos ainda não haviam compreendido o significado de ritmo e unidade rítmica, tampouco sabiam sobre metrificação, elementos do poema que seriam estudados nas próximas aulas. No entanto, dois alunos alegaram ser necessário determinar o número de sílabas em cada verso e diminuir versos com muitas palavras, outro disse que o poema precisava de mais repetições para ser mais fácil memorizar e a maioria respondeu que o ritmo que eles identificavam no poema era o ritmo do rap, muito provavelmente pela aproximação que fizeram com o conteúdo de luta e resistência contido nas músicas dos rappers e no poema criado coletivamente.

- $\quad$ Linguagem e ritmo - nas aulas seguintes, a discussão sobre o ritmo tomou dimensões mais profundas após a leitura do capítulo XII "Origem e relações da música", em Ensaio sobre a origem das línguas, de Jean Jacques Rousseau. Ressaltamos o trecho em que, por volta de 1759, Rousseau afirmou: "Pode-se, pois, crer que as necessidades ditam os primeiros gestos e que as paixões arrancaram as primeiras vozes. Seguindo a trajetória dos fatos com base nessas distinções, seria talvez preciso raciocinar sobre a origem das línguas de um modo totalmente diverso do que se fez até hoje". Em seu ensaio, Rousseau defende que a origem das línguas tem estreita relação com a música e com as paixões. A partir dessa concepção, discutimos que as repetições periódicas e as medidas do ritmo de sílabas, segundo o filósofo, possibilitaram o nascimento da língua, por isso, teria sido a música e não a gramática que impulsionou a invenção das palavras. Para ele, as palavras não são instrumentos do conhecimento ou o espelho da razão, mas sim uma tentativa de imitar os sentimentos. Assim, Rousseau afirmava que a invenção das primeiras palavras não veio das necessidades e sim das paixões, uma vez que o ser humano, antes de começar a raciocinar, experimentou sensações, como amor e ódio, que precisavam ser nomeadas e explicadas. Segundo sua teoria, foi a vontade de exprimir suas paixões ao outro e foi o desejo de compartilhar ideias e pensamentos que impulsionaram o ser humano a inventar as palavras. A fome ou a sede não precisavam de palavras para serem extintas, pois os frutos e a água não fugiriam de nossas mãos. Podemos alcançá-los sem precisar dizer palavra alguma, enquanto as paixões não podem ser comunicadas sem o desenvolvimento da língua. 
No momento em que discutíamos a necessidade do homem em se relacionar com seus pares, um aluno perguntou o que aconteceria se conseguíssemos ter acesso direto aos pensamentos e sentimentos dos outros: "não precisaríamos desenvolver a fala e a comunicação em palavras?". A discussão continuou com questões bastante interessantes e uma outra mão levantada questionou: "se pensamos por meio de palavras, como os homens pensavam quando não haviam ainda criado nomes para as coisas?”. Logo em seguida outro aluno indagou: "podemos dizer, então, que a música é a primeira arte do homem, já que antes da fala a expressão corporal com gestos e ritmos também comunicavam algo?’. O texto de Rousseau suscitou diversos questionamentos que nos guiaram para discussões ainda mais profundas, como os traços distintivos entre o homem e o animal, a noção do ser humano sensível, pensante e semelhante a ele próprio que culminou, assim, no desejo e na necessidade de comunicar seus sentimentos e pensamentos na relação com o outro. Em seguida, conceituamos os termos linguagem, gesto, língua e fala e chegamos nos mitos de origem da voz: os alunos ouviram a história de Ulisses e o canto da sereia que contei apenas de corpo e voz e a citação breve sobre a história de Abraão e o sacríficio de Isaac, presente na Gênesis. Discorremos também sobre o mito da Mnemosine, sobre a existência dos aedos e rapsodos e com eles, chegamos ao tema do desejo pela palavra, pela expressão que poderia ir além dos limites dos gestos e buscar representar os traços mais profundos e primitivos da própria expressão de si.

Lemos o poema "O outro", de Carlos Drummond de Andrade para discutir sobre os conflitos da linguagem:

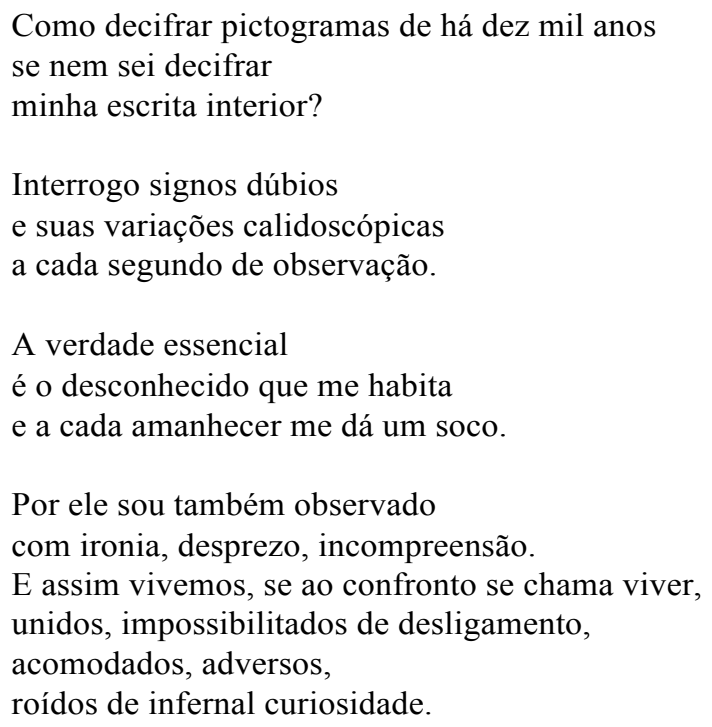


Em seguida, lemos um trecho da obra Um, nenhum e cem mil, de Luigi Pirandello para enriquecer o debate sobre as dificuldades da expressão por meio de "signos dúbios":

Depois de uma hora de boa conversa, nos entendemos perfeitamente.

Amanhã vocês retornam, com o dedo em riste, gritando:

- Como assim? O que você entendeu? Você não me disse isso e aquilo?

Isso e aquilo, perfeitamente. Mas o problema é que vocês, meus caros, nunca entendem; e eu nunca vou poder explicar-lhes como se traduz em mim aquilo que vocês me dizem. Sei que vocês não falaram turco, sei disso. Usamos, eu e vocês, a mesma língua, as mesmas palavras. Mas que culpa temos, eu e vocês, se as palavras, em si, são vazias? Vazias, meus caros. E vocês as preenchem com o seu sentido, ao dizê-las a mim; e eu, ao recebê-las, inevitavelmente as preencho com o meu sentido. Pensamos que nos entendemos, mas não nos entendemos de modo nenhum.

Após a leitura e discussão ao intepretar o poema de Drummond e o trecho de Pirandello, coloquei algumas questões na lousa: "você tem a sensação de que se expressa bem oralmente, de que as pessoas entendem o que você quer dizer? Você se sente compreendido? Você tem dificuldade de expressar algum sentimento, desejo, angústia? Por que você acha que isso ocorre?". Na maioria das respostas, os alunos afirmaram que não se sentem bem falando de sentimentos e que sentem que lhes faltam palavras para expressar o que gostariam. Algumas respostas nos chamaram a atenção:

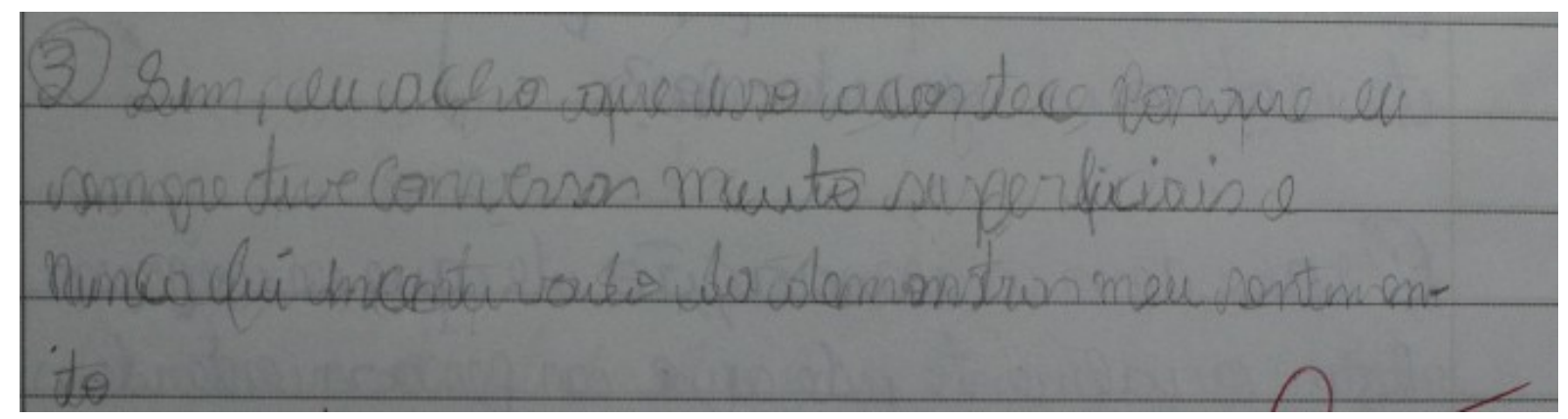

"Sim, eu acho que isso acontece porque eu sempre tive conversas muito superficiais e nunca fui incentivado a demonstrar sentimento." 


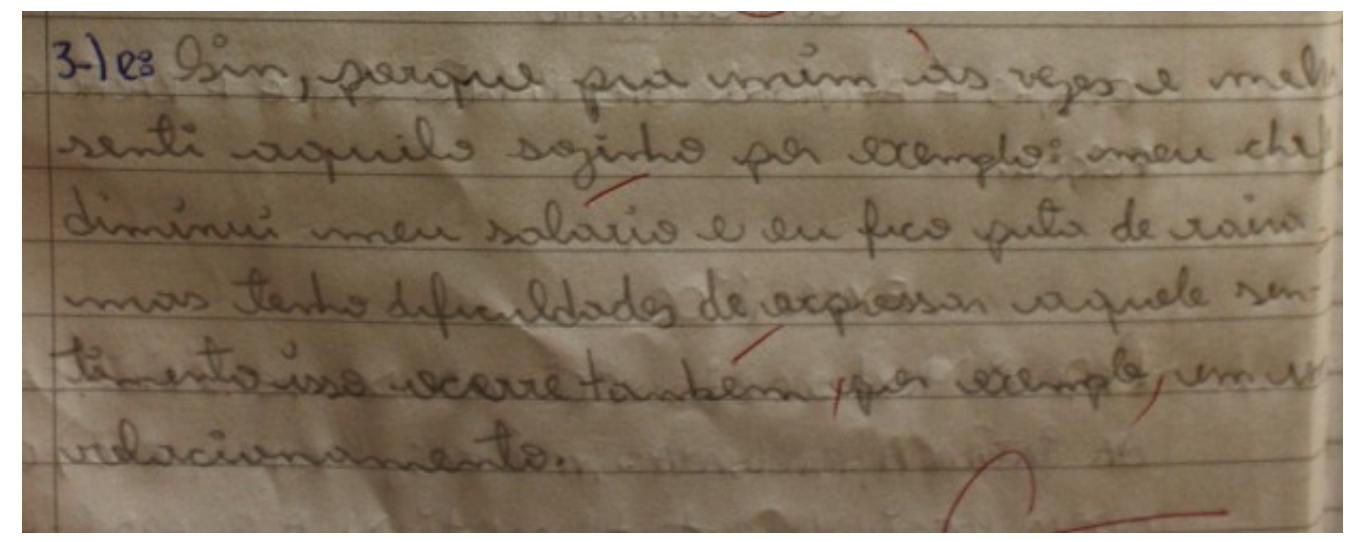

"Sim, porque pra mim às vezes melhor sentir aquilo sozinho por exemplo: meu chefe diminui meu salário e eu fico puto de raiva, mas tenho dificuldades de expressar aquele sentimento, isso ocorre também por exemplo em um relacionamento".

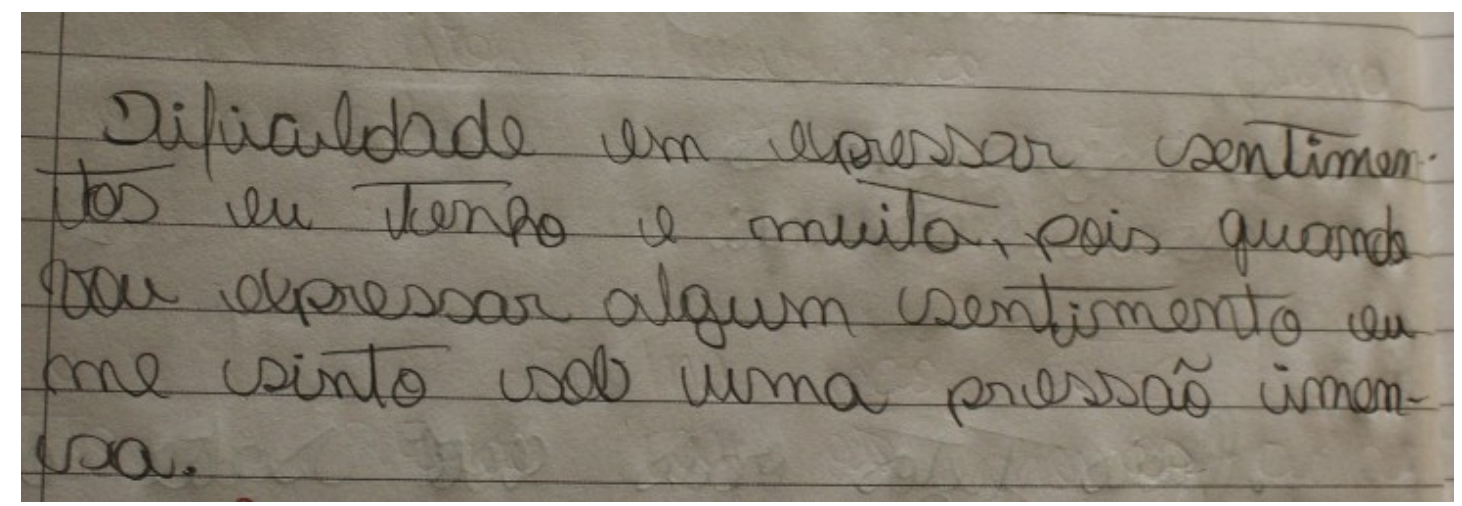

"Dificuldade em expressar sentimentos eu tenho e muita, pois quando vou expressar algum sentimento eu me sinto sob uma pressão imensa."

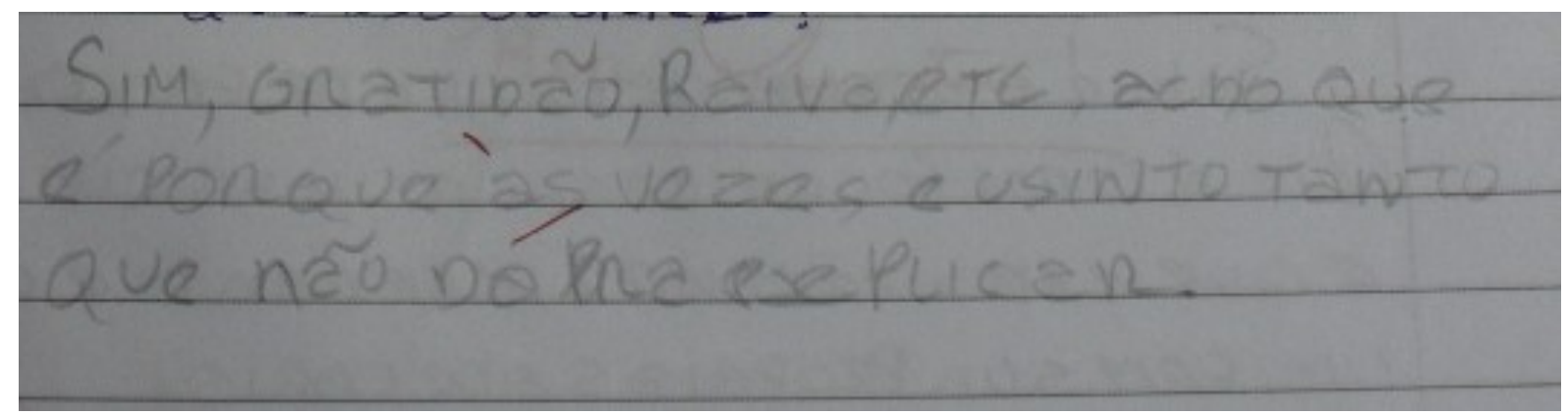

"Sim, gratidão, raiva, etc., acho que é porque às vezes eu sinto tanto que não dá pra explicar." 


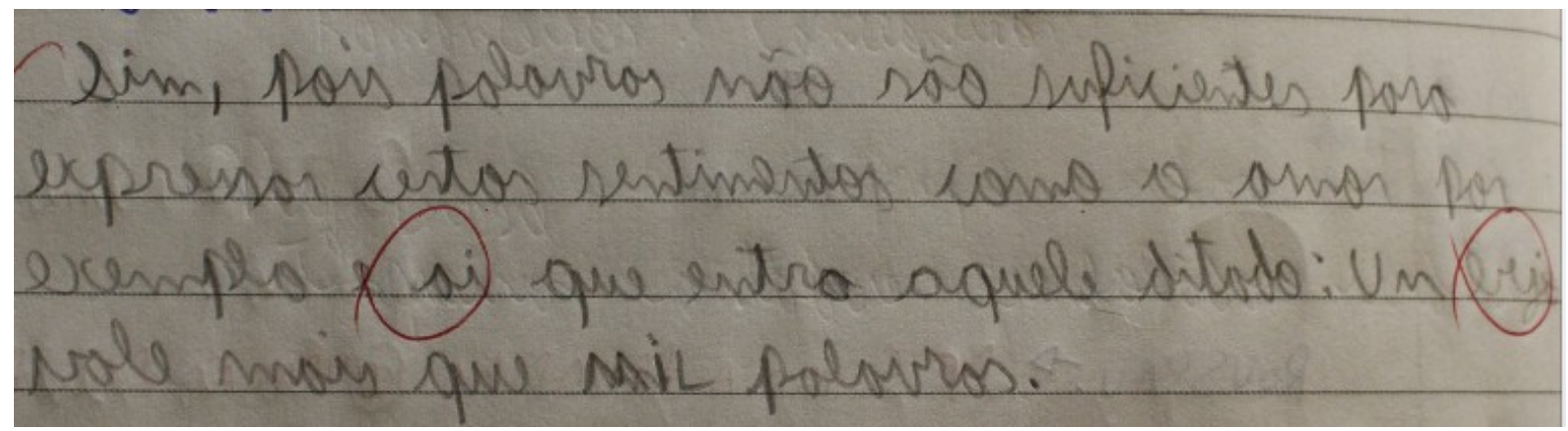

"Sim, pois palavras não são suficientes para expressar certos sentimentos como o amor por exemplo e aí que entra aquele ditado: um beijo vale mais que mil palavras."

A partir das respostas formuladas pelos alunos, discutimos sobre o aspecto da memória e sobre as possíveis razões para a sensação que demonstraram de não carregarem consigo repertório suficiente de palavras para nomear os sentimentos e desejos. No desenrolar das argumetações dos alunos, tive a sensação de que o tema e o reconhecimento da dificuldade de dominar as palavras geraram grande desconforto e angústia por eles não saberem explicar o porquê desse fenômeno. Um aluno perguntou se isso ocorre com todas as pessoas ou apenas com as mais pobres. Na hora, veio-me à mente a figura de Fabiano, personagem da obra "Vidas Secas", de Graciliano Ramos. No entanto, naquele instante, escolhi não responder diretamente com os argumentos da exclusão das camadas menos favorecidas do acesso ao capital cultural, das oportunidades desiguais de se servir da linguagem, da privação de conhecer palavras por meio de leituras e debates para dar sentido ao que vivemos, embora estes argumentos fossem assomados logo em seguida. No primeiro momento, questionei os alunos se eles acreditavam que as palavras são suficientes para explicar tudo o que sentimos, para descrever tudo o que vivemos, para resolver todos os conflitos. A maioria respondeu que não, e uma aluna logo argumentou que, se isso fosse possível, não teria havido tantas guerras, pois os seres humanos conseguiriam resolver os embates por meio de conversas com palavras que pudessem significar tudo.

Em seguida, comentei sobre o fato de que a incapacidade de nos expressarmos somente com palavras nos deixa uma sensação de incompletude importante para operarmos como seres sensíveis, capazes de buscar nas artes outros meios de expressão. Uma aluna, então, concordou com a minha afirmação dizendo que muitas vezes identifica seus sentimentos em uma letra de música, em uma melodia, em um poema, ou seja, nas palavras de um outro. Por um lado, a aluna mencionou que esse reconhecimento a deixa mais calma ao 
perceber que o autor da obra deve ter sentido algo parecido com o que ela sentiu, mas por outro lado, ficou para si a impressão de que este outro sempre saberá se expressar melhor do que ela e isso gerou um sentimento de diminuição, de falta. Novamente, a figura de Fabiano me invadiu o pensamento e me lembrei de um poema de João Cabral de Melo Neto (1986) que não estava previsto no planejamento da aula, mas me pareceu oportuno para a discussão. Os alunos não haviam lido Vidas Secas, então narrei brevemente a história da família retirante, da miséria na caatinga, da fome e da sede, da saga pela sobrevivência e das dificuldades de sinhá Vitória e Fabiano em se reconhecerem mais como seres humanos do que como bichos. Expliquei, então, porque nossa discussão havia me remetido aos personagens dessa obra, justificando que eles, mais que meros retirantes humilhados e explorados, buscavam compreender a razão pela qual estavam presos naquele (sub)mundo, mas, nessa tentativa de elaborar suas dores e experiências, encontravam bloqueios pela falta de palavras e sofriam assédio dos policiais que os marginalizavam ainda mais, já que Fabiano não conseguia argumentar contra os ataques do poder. Ele sabia que sofria injustiças, mas não sabia se defender devido à dificuldade de encontrar as palavras e se fazer entender. Em seguida, projetei o poema "Graciliano Ramos" ${ }^{36}$, de João Cabral, e pedi para os alunos lerem em voz alta:

\footnotetext{
Falo somente com o que falo: com as mesmas vinte palavras girando ao redor do sol que as limpa do que não é faca:

de toda uma crosta viscosa, resto de janta abaianada, que fica na lâmina e cega seu gosto da cicatriz clara.

Falo somente do que falo: do seco e de suas paisagens, Nordestes, debaixo de um sol ali do mais quente vinagre: que reduz tudo ao espinhaço, cresta o simplesmente folhagem, folha prolixa, folharada,
}

\footnotetext{
${ }^{36}$ In: MELO NETO, João Cabral de. Obra completa: volume único. Org. Marly de Oliveira. Rio de Janeiro: Nova Aguilar, 1994. p.311-312.
} 
onde possa esconder-se a fraude.

\begin{abstract}
Falo somente por quem falo: por quem existe nesses climas condicionados pelo sol, pelo gavião e outras rapinas:

e onde estão os solos inertes de tantas condições caatinga em que só cabe cultivar o que é sinônimo da míngua.
\end{abstract}

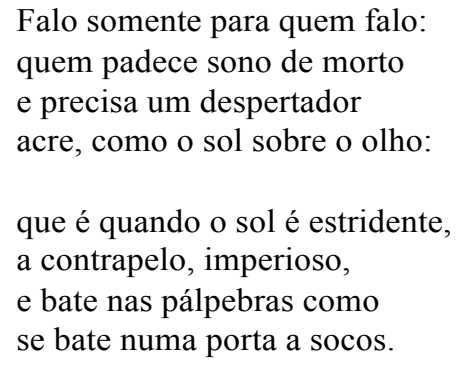

Analisamos alguns trechos do poema, destacando os versos que mais se aproximavam de nossa discussão e da fala da aluna sobre a sensação de diminuição devido à falta de palavras. Os alunos identificaram o primeiro verso de cada seção do poema como uma síntese de seu conteúdo. Segundo eles, "falo somente com, do que, por quem e para quem falo" resumiria a postura dos excluídos das habilidades com a linguagem, do que lhes restaria fazer diante da ausência de recursos linguísticos: expressar-se com o que se tem para sobreviver. Perguntei, então, se eles se viam nessa situação de exclusão, de marginalização profunda das formas de expressão. A resposta negativa foi quase unânime, apenas dois alunos disseram que se sentiam como Fabiano, mas, no geral, a turma afirmou que seus antepassados conseguiram superar a pobreza extrema e sua geração foi beneficiada pela força de vontade de suas famílias para eles estarem onde estão, tendo acesso à escola de qualidade. Uma aluna comentou que eles não "têm nada a ver com o Fabiano", pois eles sabem ler e escrever, sabem contar e falar por si. As reflexões dos alunos nessa aula me surpreenderam muito positivamente, pois, por trás de suas colocações, estava a consciência de que ser privado das palavras, do conhecimento, até da poesia, significa ficar de fora das trocas simbólicas em torno dos bens culturais que muito nos ajudam a compreender o mundo e nós mesmos.

Procurei continuar a conversa apelando para a importância dos poetas, de uma voz que nomeia o sofrimento, retrata o amor, ressignifica a morte com o peso de palavras exatas, e, 
por meio dessas escutas e leituras poéticas, podemos conseguir reorganizar a compreensão de nós mesmos, investir em nosso universo simbólico e, quem sabe, apropriar-nos dessa palavra, levando-a em nossa bagagem cultural. Com esse valor da tomada da palavra, entramos em um outro ponto para a discussão da próxima aula: o papel da memória.

Após retomar o mito da Mnemosine, discutimos sobre a memória dos textos e o auxílio do ritmo, a partir de mais uma provocação: "quais textos você sabe de memória (cantigas da infância, parlendas, músicas, poemas, etc)? O que/ quem possivelmente te motivou a guardá-los?". Muitos alunos responderam que não se lembram de nenhum texto por inteiro e assumiram estar acostumados a consultar a escrita para estimular a memória. Os alunos que conseguiram retomar de memória algum texto da tradição oral registraram cantigas de ninar e disseram que se lembram delas, pois suas mães as cantavam antes de dormirem ou foram brincadeiras marcantes na infância. Apenas três alunos citaram este aprendizado como algo vindo da escola e dos professores: 


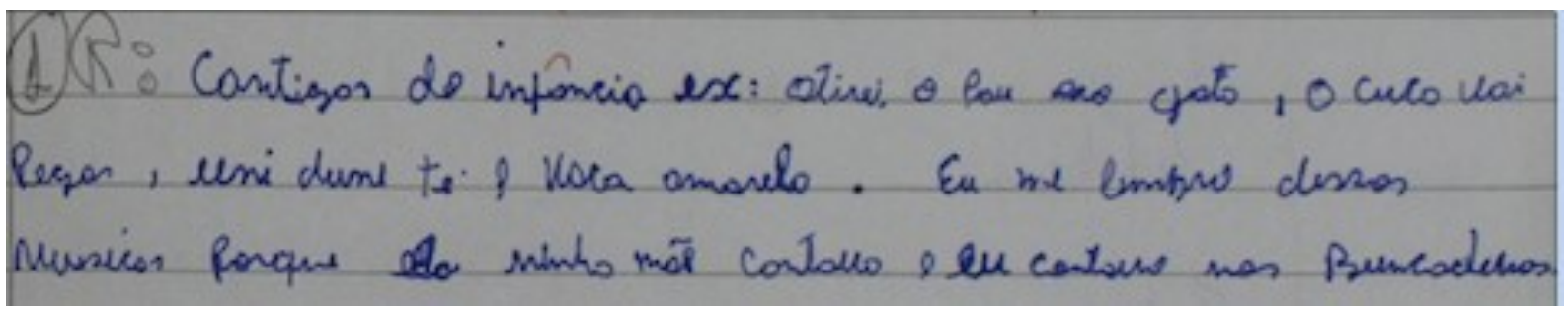

"Cantigas da infância ex: atirei o pau no gato, a cuca vai pegar, uni dune te e vaca amarela. Eu me lembro dessas músicas porque minha mãe cantava e eu cantava nas brincadeiras."

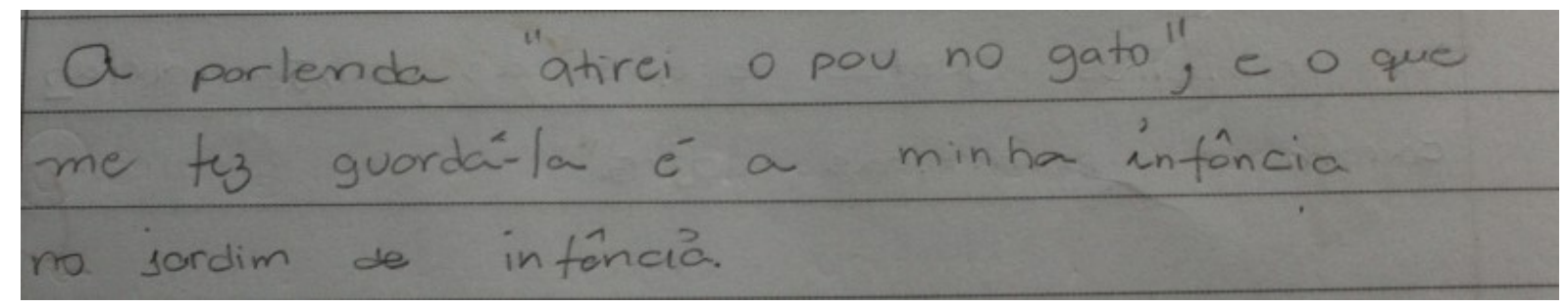

"A parlenda "atirei o pau no gato", e o que me fez guardá-la é a minha infância no jardim de infância.”

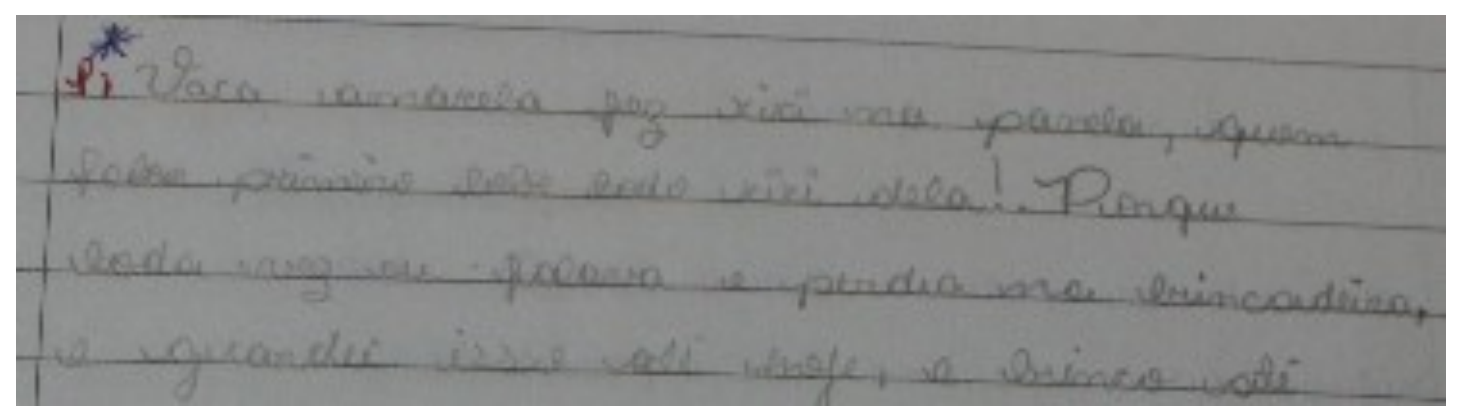

"Vaca amarela fez xixi na panela, quem falar primeiro bebe todo xixi dela, porque toda vez eu falava e perdia na brincadeira, e guardei isso até hoje e brinco até hoje."

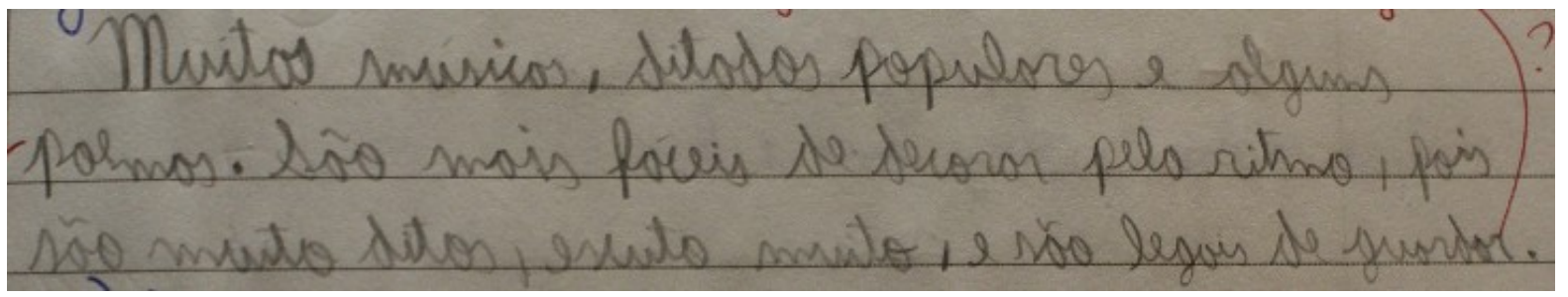


"Muitas músicas, ditados populares e alguns poemas. São mais fáceis de decorar pelo ritmo, pois são muito ditos, escuto muito e são legais de guardar."

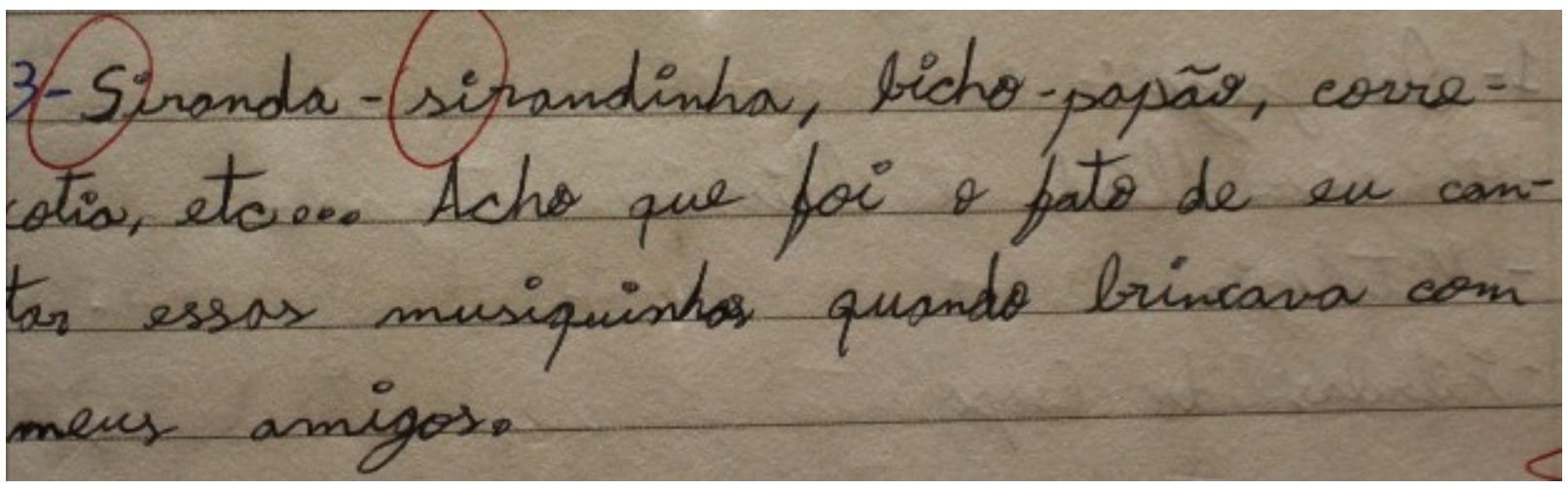

"Ciranda-cirandinha, bicho-papão, corre-cotia, etc... acho que foi o fato de eu cantar essas musiquinhas quando brincava com meus amigos."

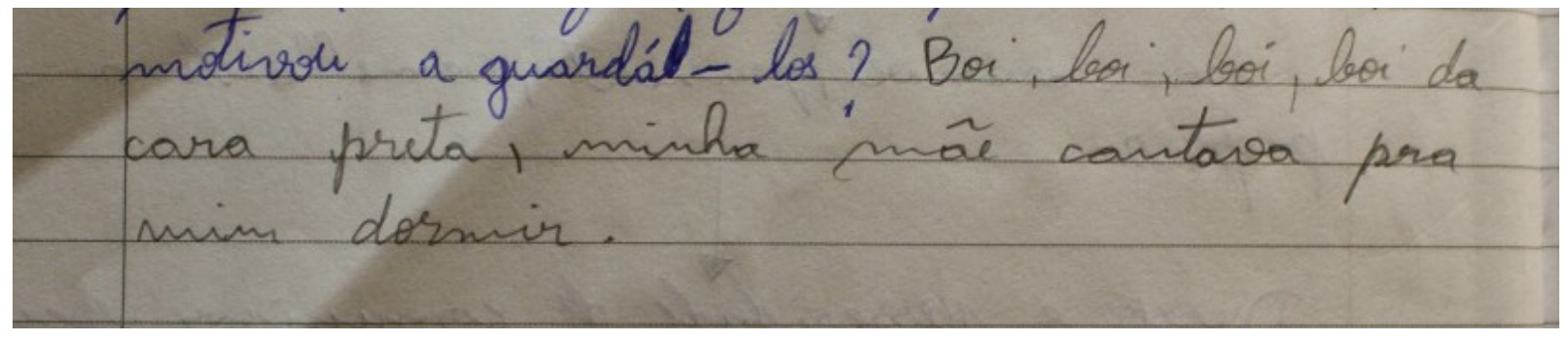

"Boi, boi, boi da cara preta, minha mãe cantava pra mim dormir."

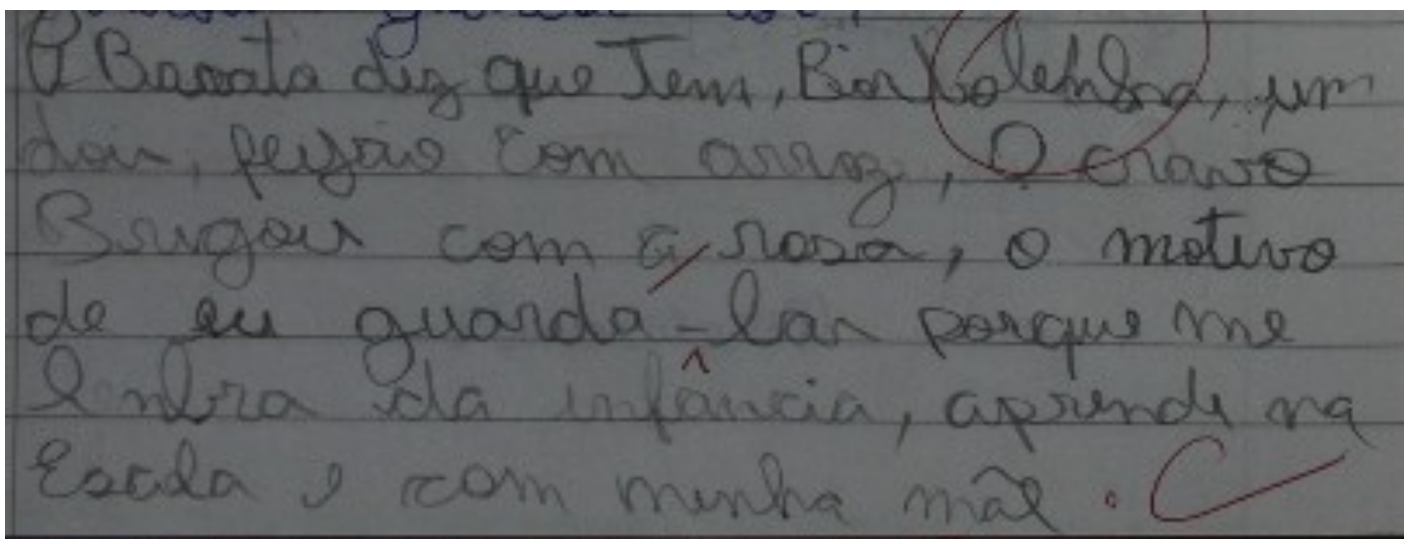

A barata diz que tem, borbotelinha, um dois, feijão com arroz, o cravo brigou com a rosa, o motivo de eu guardá-las porque me lembra da infância, aprendi na escola e com a minha mãe." 


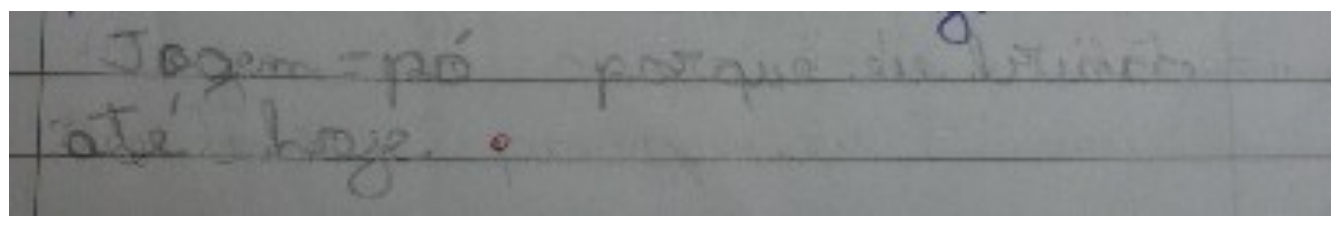

“Jogem-pó” [jokenpo] porque eu brinco até hoje."

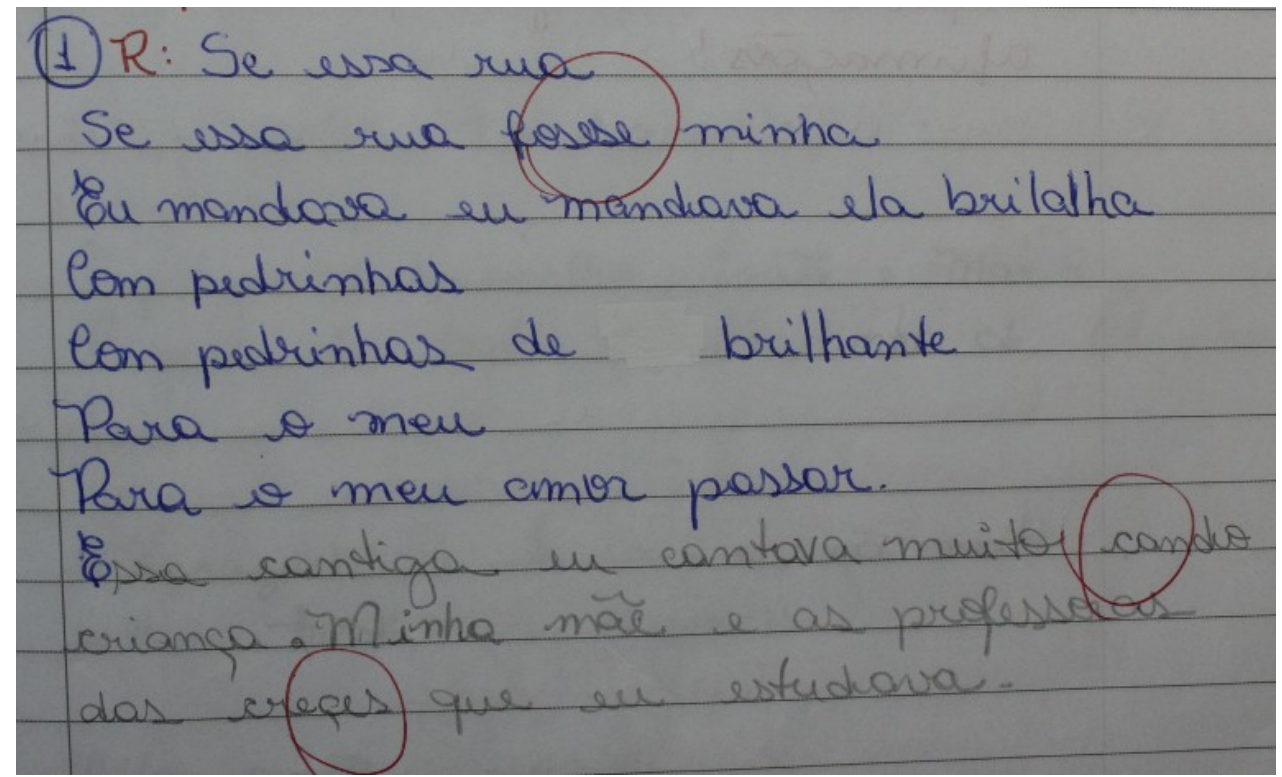

"Essa cantiga eu cantava muito quando criança. Minha mãe e as professoras das creches que eu estudava."

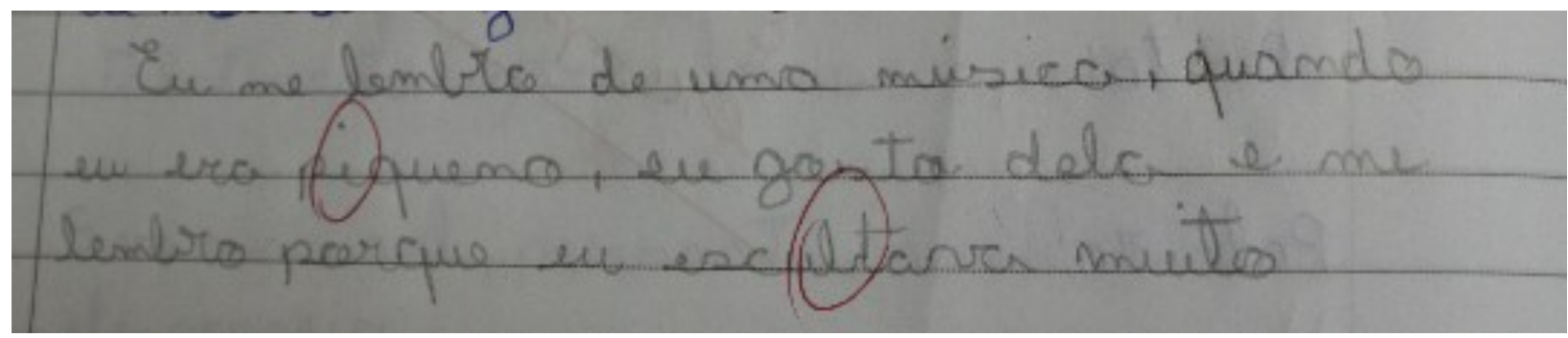

"Eu me lembro de uma música, quando eu era pequeno, eu gosto dela e me lembro porque eu escutava muito" - ao ser indagado qual era a música de que gostava tanto e mantinha na memória, o aluno não soube responder. 


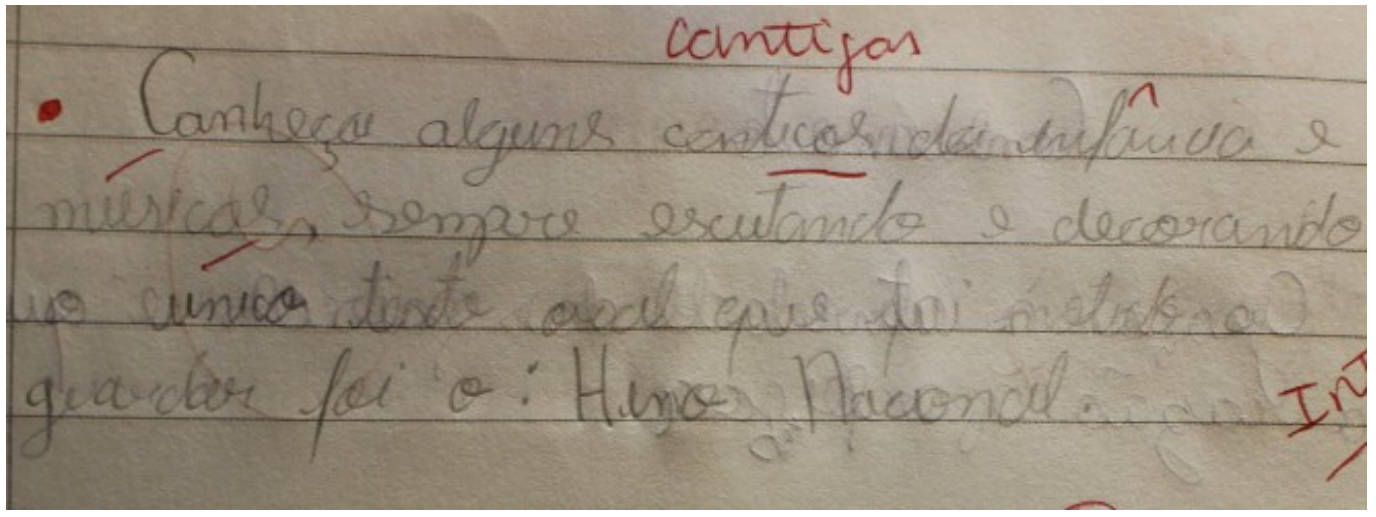

“Conheço alguns cânticos da infância e músicas sempre escutando e decorando o único texto oral que fui motivado a guardar foi o Hino Nacional"

Nesta última resposta, foi interessante notar a observação do aluno que não se viu motivado a memorizar nenhum outro texto oral que o hino nacional, refletindo sintomas de um ensino pautado no uso pragmático da língua. Observamos com esse exercício que os alunos trouxeram a ideia de repetição como forma de memorizar textos e se lembraram de que, quando crianças, gostavam muito de ouvir as mesmas cantigas, as mesmas brincadeiras de roda, pois se encantavam com a sonoridade das palavras toda vez em que elas eram performatizadas. Como vimos anteriormente ao abordar o conceito de corporalidade, as crianças se envolvem com a palavra poética espontaneamente, pois a enxergam como objeto lúdico. Além disso, a matriz de textos orais vem, geralmente, do colo da mãe e do aconchego familiar, o que lhes concede um valor afetivo, facilitando a retenção desses textos na memória. No entanto, sabemos também que uma criança sensibilizada no prazer de brincar com as palavras poéticas, de escutar histórias e que se sustenta em uma relação mais profunda com a tradição oral não necessariamente terá sucesso imediato na leitura e escrita se não continuar motivada para a busca constante por conhecimento. Muitos de nossos alunos em seu percurso escolar podem ter se sentido desmotivados a manter aceso o entusiasmo pela tomada da palavra poética, principalmente por se sentirem tensionados pelas mídias e tecnologias e pelas demandas da sociedade neoliberal.

Para explorar um pouco a capacidade de memorizar textos e reativar essa habilidade dos alunos, realizamos um exercício com o ritmo e a métrica, recursos fundamentais do texto poético. Os alunos deveriam pensar em qualquer texto da tradição oral ou em qualquer melodia bem conhecida, extrair seu ritmo e/ ou métrica e criar seus próprios versos ou uma nova letra para a melodia escolhida, desde que as palavras se encaixassem em uma cadência 
harmônica e rímica quando cantadas. Apenas três alunos se valeram de uma parlenda ou cantiga da infância, como "Batatinha quando nasce", "Ciranda-cirandinha" e "Atirei o pau no gato", todos os outros criaram versos com base na melodia de jingles, reclames ou músicas conhecidas, como "Dolly-Guaraná", propaganda do Mc Donald's e ritmos do funk e do rap que estavam na moda. Mesmo com pouca adesão para se pensar em textos da tradição oral, os alunos gostaram muito da atividade e criaram versos bem metrificados, com alternância entre sílabas fortes e fracas, e rimas ricas que se encaixavam na melodia escolhida.

A proposta era improvisar a nova letra sem o recurso da escrita, então, como eles não tiveram acesso ao caderno para registrar a criação, precisavam memorizá-la com as técnicas da corporalidade para, em seguida, apresentarem-se à turma. Permiti que eles circulassem pelo pátio da escola para oralizarem a criação e deixarem o corpo fruir junto, além de utilizarem o espaço externo à sala de aula para não provocar ruídos excessivos que pudessem distraí-los no momento de reflexão. Os temas das paródias melódicas foram principalmente desabafos sobre o cansaço devido às tarefas escolares, a desilusão amorosa, os preconceitos e injustiças sociais. Nas apresentações, tive que pedir para que eles evitassem o uso de palavrões e palavras muito obcenas, pois enquanto eu circulava e acompanhava a corporalidade em criação, já havia notado uma tendência para esse tipo de expressão. Na hora da apresentação, os menos tímidos utilizaram o corpo para manter a métrica e o ritmo, como os recursos sonoros das palmas, dos pés e do batuque no peito. Um aluno até se valeu de uma coreografia para fluir melhor no "palco". Foi uma aula muito divertida, que provocou uma reflexão sobre a importância da memória, do auxílio do ritmo, das rimas e da métrica bem definida para evocar, sem a técnica da escrita, criações próprias.

- Literatura oral, tradição e performance - assim, após tantas conversas sobre a linguagem, a língua, a fala e seus recursos mnemônicos, entramos no assunto sobre a literatura oral em uma perspectiva histórica a partir de diferentes exemplos. Apresentamos brevemente os gregos a partir de trechos da Ilíada e da Odisseia, de alguns mitos mais conhecidos e fábulas de Esopo. Em seguida, falamos dos contos tradicionais universais, como a Chapeuzinho Vermelho, João e Maria e O Gato de Botas. Lemos trechos da obra Mil e uma noites e vimos imagens da Sherazade e de outras personagens dos contos orientais tradicionais. Não deixamos de lado os griots africanos e suas histórias, os mitos de origem indígenas e as lendas regionais e, para finalizar, abrimos uma roda de contação de histórias por meio de performances improvisadas dos alunos que foram se lembrando de narrativas que 
traziam na memória, como forma de retomar o exercício proposto anteriormente. Na aula seguinte, apresentamos um pouco da história dos trovadores portugueses, os romanceiros e cancioneiros e abrimos o debate sobre os conceitos de erudito e popular. Realizamos na sequência uma atividade de interpretação do poema de Patativa do Assaré, "Cante lá, que eu canto cá" e os alunos tiveram que responder às seguintes questões para exercitar a leitura inferencial, intertextualidade do poema e o conceito de preconceito linguístico: 1) Sobre qual situação o eu-lírico está versando?; 2) Que dificuldades o eu-lírico enfrenta?; 3) Onde vive o eu-lírico do poema? 4) Por que o poema não está escrito de acordo com as normas cultas e padrões da Língua Portuguesa? 5) Qual o objetivo do poeta em escrever o poema respeitando a variedade dialetal da região?

Você é muito ditoso,

Sabe lê, sabe escrevê, Pois vá cantando o seu gozo,

Que eu canto meu padecê. Inquanto a felicidade Você canta na cidade, Cá no sertão eu infrento A fome, a dô e a misera. Pra sê poeta divera,

Precisa tê sofrimento.

\section{Sua rima, inda que seja}

Bordada de prata e de ôro,

Para a gente sertaneja

É perdido este tesôro.

Com o seu verso bem feito,

Não canta o sertão dereito,

Porque você não conhece

Nossa vida aperreada.

E a dô só é bem cantada,

Cantada por quem padece.

Só canta o sertão dereito,

Com tudo quanto ele tem,

Quem sempre correu estreito,

Sem proteção de ninguém,

Coberto de precisão

Suportando a privação

Com paciença de Jó,

Puxando o cabo da inxada,

Na quebrada e na chapada, Moiadinho de suó.
Amigo, não tenha quêxa, Veja que eu tenho razão Em lhe dizê que não mêxa Nas coisa do meu sertão. Pois, se não sabe o colega De quá manêra se pega Num ferro pra trabaiá, Por favô, não mêxa aqui, Que eu também não mêxo aí, Cante lá que eu canto cá.

Repare que a minha vida É deferente da sua.

A sua rima pulida

Nasceu no salão da rua.

Já eu sou bem deferente,

Meu verso é como a simente

Que nasce inriba do chão;

Não tenho estudo nem arte,

A minha rima faz parte

Das obra da criação.

Mas porém, eu não invejo

O grande tesôro seu,

Os livro do seu colejo,

Onde você aprendeu.

Pra gente aqui sê poeta

E fazê rima compreta,

Não precisa professô;

Basta vê no mês de maio,

Um poema em cada gaio

E um verso em cada fulô.
Poeta, cantô de rua,

Que na cidade nasceu,

Cante a cidade que é sua,

Que eu canto o sertão que é meu.

Se ai você teve estudo,

Aqui, Deus me ensinou tudo,

Sem de livro precisá

Por favô, não mêxa aqui,

Que eu também não mexo aí,

Cante lá, que eu canto cá.

Você teve inducação,

Aprendeu munta ciença,

Mas das coisa do sertão

Não tem boa esperiença.

Nunca fez uma paioça,

Nunca trabaiou na roça,

Não pode conhecê bem,

Pois nesta penosa vida,

Só quem provou da comida

Sabe o gosto que ela tem.

Pra gente cantá o sertão,

Precisa nele morá,

Tê armoço de fejão

E a janta de mucunzá,

Vivê pobre, sem dinhêro,

Socado dentro do mato,

De apragata currelepe,

Pisando inriba do estrepe,

Brocando a unha-de-gato.
Seu verso é uma mistura,

É um tá sarapaté,

Que quem tem pôca leitura

Lê, mais não sabe o que é.

Tem tanta coisa incantada,

Tanta deusa, tanta fada,

Tanto mistéro e condão

E ôtros negoço impossive.

Eu canto as coisa visive

Do meu querido sertão.

Canto as fulô e os abróio

Com todas coisa daqui:

Pra toda parte que eu óio

Vejo um verso se bulí.

Se as vêz andando no vale

Atrás de curá meus male

Quero repará pra serra

Assim que eu óio pra cima,

Vejo um divule de rima

Caindo inriba da terra.

Mas tudo é rima rastêra

De fruita de jatobá,

De fôia de gamelêra

E fulô de trapiá,

De canto de passarinho

E da poêra do caminho,

Quando a ventania vem,

Pois você já tá ciente:

Nossa vida é deferente

E nosso verso também.

Os alunos alegaram nunca terem lido antes um poema com a manutenção dos traços da oralidade e da variação regional da língua. Após refletir sobre as questões colocadas na 
lousa, conversamos sobre a importância das obras do poeta Patativa do Assaré para combater a visão de que a poesia apenas acontece dentro de determinadas normas de escrita e o preconceito de que existe um único modo de falar. Retomamos a noção de que a língua não é um sistema fechado e imutável, de que ela sofre diversas variações de acordo com as condições sociais, culturais, regionais e históricas em que é utilizada e, por isso, ela está em permanente evolução e transformação. Como os alunos se referiram à forma poética como uma "obra cheia de erros", conversamos também sobre as variações não serem consideradas erros, e sim diferentes formas de manifestação da língua.

- Poemas narrativos e o romanceiro ibérico - nesta etapa do curso, apresentamos o conceito de poema narrativo que propõe contar histórias cujas formas em geral têm métrica e rima. No Brasil, herdamos dos portugueses e espanhóis um enorme conjunto de poemas cantados e falas a que demos o nome de Romanceiro. Uma parte desse conjunto enraizou-se no interior do Nordeste. Os poemas mais antigos são histórias de batalhas, explicações sobre a criação do mundo, memórias de um povo, além das façanhas de líderes e heróis. Lemos a segunda parte do livro de Braulio Tavares (2009) para aprofundar os estudos sobre o poema narrativo e voltamos a discutir o papel da literatura oral para a disseminação da cultura e da tradição dos povos em um tempo que não havia literatura escrita. Os versos são criações muito antigas que tinham por objetivo partilhar histórias e seguir na memória do povo. Eles acompanhavam os movimentos rítmicos dos trabalhadores da lavoura ou das máquinas rudimentares. Um vestígio desses cantos em versos é a brincadeira infantil "Escravos de Jó", em que se narra uma história a partir de movimentos corporais ritmados, seguindo a cadência do canto. Assim, retomamos de memória a letra da cantiga e, em roda, performatizamos os movimentos da brincadeira, refletindo sobre o conteúdo dos versos.

Analisamos também o poema "Romancinho", de Cecília Mereiles, e buscamos identificar as características comuns entre os poemas narrativos presentes no livro: geralmente, eles têm um começo, meio e fim, personagens, suspense, são extensos, possuem rimas e versos metrificados em sete sílabas poéticas. Após a leitura de "Romancinho", os alunos deveriam discutir sobre os papéis de personagem na história e identificar quais elementos de forma e conteúdo Cecília Meireles (1942) recuperou dos romanceiros de antigamente para escrever seu poema, séculos depois.

Em seguida, lemos alguns outros poemas que foram identificados como poesia narrativa do romanceiro popular do Nordeste a partir da coletânea de Câmara Cascudo (2012) 
em Histórias de Vaqueiros e Cantadores. Reconhecemos alguns traços dos personagens do cangaço que foram retomados nas aulas seguintes sobre literatura de cordel, ciclo do gado e do cangaço. Ainda neste tópico, fizemos um exercício de análise comparativa entre a poesia narrativa e as músicas de rap. Ouvimos algumas canções compostas pelos Racionais MC's, como "Diário de um detento", "Negro drama" e "Fim de semana no parque" e procuramos discutir o que essas músicas teriam em comum com os poemas narrativos dos romanceiros populares. Exemplo de análise com a música Diário de um detento - Racionais MC (1992):

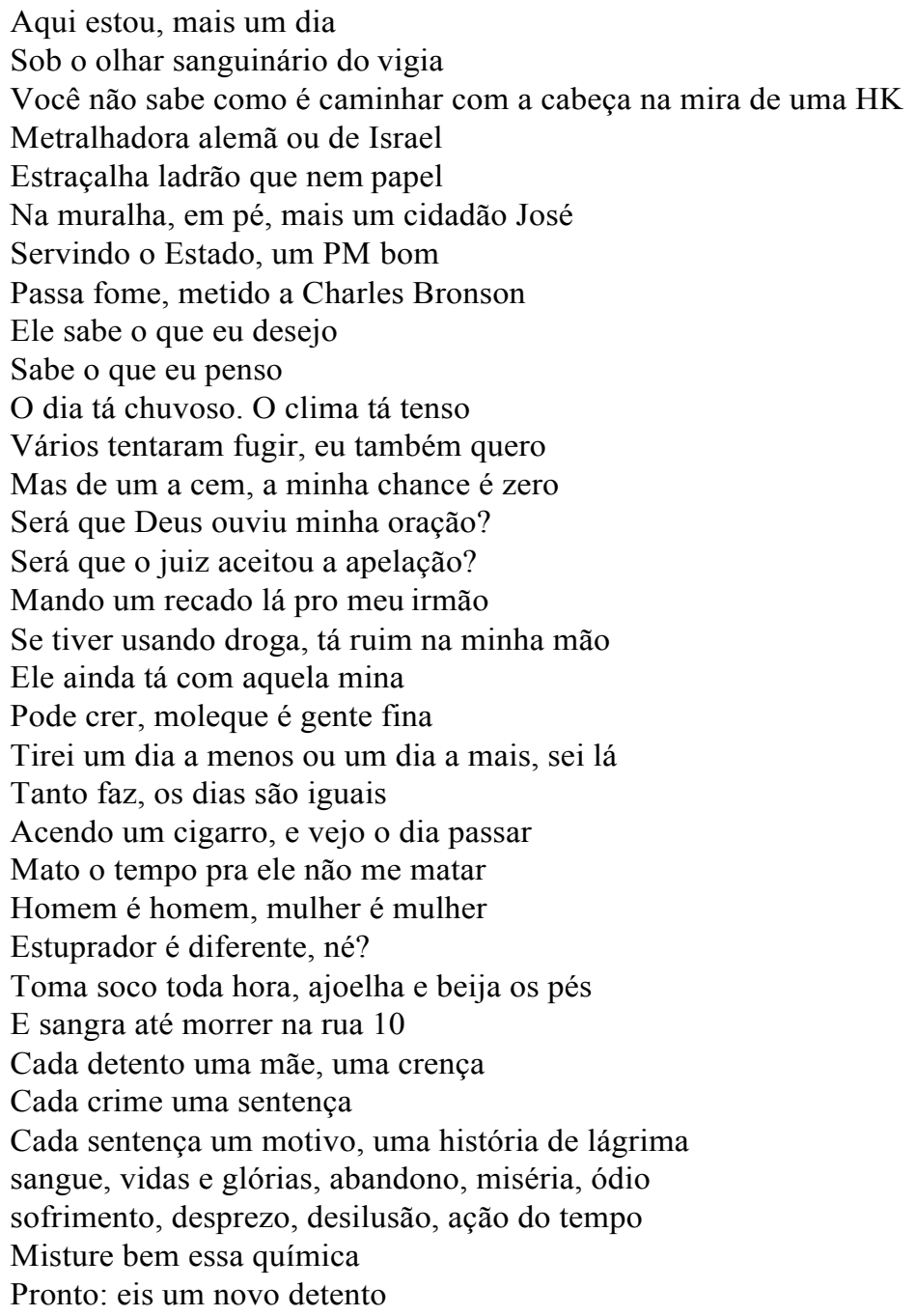

Os alunos acharam muito interessante procurar traços comuns entre obras tão distintas e trouxeram novos exemplos de outros raps que retratavam a realidade do trabalhador e da população periférica oprimida. Identificaram o sistema de rimas desses textos e discutiram sobre seu caráter narrativo, reconhecendo a situação inicial, o desenvolvimento dos conflitos, o clímax e o desfecho das histórias narradas em versos. Mais uma vez, foi possível dar espaço 
aos alunos para exporem o valor das canções que gostam de escutar em casa ou com os amigos, nas quais se sentem representados pela própria problemática do preconceito, da discriminação e dos desdobramentos do passado escravocrata brasileiro. Nesse sentido, o rap não é apenas um gênero musical, mas também um movimento de apropriação e reinvenção da cultura afro-americana.

Com o intuito de explorar outras formas de poema que não eram tão comuns aos alunos, eles levaram como tarefa de casa o poema "Os ninguéns" ${ }^{37}$, de Eduardo Galeano, para analisá-lo conforme os exercícios realizados em sala de aula:

\section{Os ninguéns}

As pulgas sonham em comprar um cão, e os ninguéns com deixar a pobreza, que em algum dia mágico de sorte chova a boa sorte a cântaros; mas a boa sorte não chova ontem, nem hoje, nem amanhã, nem nunca, nem uma chuvinha cai do céu da boa sorte, por mais que os ninguéns a chamem e mesmo que a mão esquerda coce, ou se levantem com o pé direito, ou comecem o ano mudando de vassoura.

Os ninguéns: os filhos de ninguém, os dono de nada.

Os ninguéns: os nenhuns, correndo soltos, morrendo a vida, fodidos e mal pagos:

Que não são embora sejam.

Que não falam idiomas, falam dialetos.

Que não praticam religiões, praticam superstições.

Que não fazem arte, fazem artesanato.

Que não são seres humanos, são recursos humanos.

Que não tem cultura, têm folclore.

Que não têm cara, têm braços.

Que não têm nome, têm número.

Que não aparecem na história universal, aparecem nas páginas policiais da imprensa local.

Os ninguéns, que custam menos do que a bala que os mata.

$\mathrm{Na}$ aula seguinte, o resultado das análises suscitou em um debate sobre a violência policial nas periferias e o genocídio da população negra. Os alunos trouxeram os exemplos dos assassinatos bárbaros de alguns jovens considerados pelo Estado como "ninguéns", como Claúdia Silva Ferreira, arrastada por uma viatura policial após ser baleada, Marcos Vinícius da Silva, menino atingido por ação policial em seu uniforme escolar e Amarildo Dias de Souza, pedreiro desaparecido após abuso de autoridade da Polícia Militar do Rio de Janeiro. O último verso do poema gerou grande desconforto e um sentimento de revolta, de necessidade de mudança urgente do sistema dominante, de luta contra a militarização ascendente do Estado que atinge principalmente os jovens das favelas. Um dos alunos mais politizados da turma fez um discurso articulado e aguerrido sobre sua realidade, alegando que os políticos reproduzem propagandas vazias voltadas aos jovens pobres, assegurando a

\footnotetext{
${ }^{37}$ In: O livro dos abraços. Porto Alegre: LP\&M, 2002, p.17.
} 
importância dos cuidados para mantê-los ativos e felizes, sendo que cada vez mais não há espaço para que vivam sem medo. Eles (em seu discurso ele dizia "nós") são as principais vítimas do desemprego, da marginalização, das drogras, da guerra contra o tráfico. A aula terminou sem muito sinal de esperança, num silêncio triste e fúnebre.

- Literatura de cordel e repente - ainda sobre o tema das narrativas poéticas, introduzimos no curso algumas leituras de folhetos de cordel nordestinos, dando ênfase às histórias épicas do cangaço com as obras de Zé da Luz e com o ciclo dos vaqueiros e dos valentes como as histórias de Vilela e Guabiraba. Diferentemente do ritmo ibérico, os folhetos de cordel no Brasil não se fixaram nas formas da literatura oral difundida em Portugal no século $\mathrm{XV}$, mas criaram sua própria estética mnemônica baseada na conjuntura política e cultural do Nordeste. Os sentimentos de valentia, honra, vingança e desejo por justiça motivaram os versos mais conhecidos que outrora foram transmitidos por meio de uma memória prodigiosa e de uma agilidade no improviso. Os alunos ficaram atônitos com a história de Cirino Guabiraba que, cercado por dez homens comandados pelo delegado Liberato, não se rendeu, lutou até o final e ainda arrancou o próprio intestino que havia sido baleado a fim de encurtar o processo lento de sua morte: "Cirino foi se arrastando/ numa pedra se sentou,/ e as tripas dependuradas,/ meteu as mãos, arrancou". Muitos guerreiros como Guabiraba foram retratados pelas gestas, poesia de ação, de luta e movimento que tinham como foco cantar a glória desses valentes com a finalidade de perpetuar seus feitos para a comunidade. Eram canções de ordem social, não traziam descrições sobre a paisagem ou o cenário da Caatinga, mas evidenciavam com gosto a vida tempestuosa dos cangaceiros.

Pudemos associar a performance da literatura de cordel escrita como se a história estivesse sendo cantada em voz alta às habilidades dos repentistas sertanejos, que com a rapidez do pensamento improvisam os versos com sua viola para dar uma resposta à altura do desafio proposto. Ouvimos gravações de Pena Branca e Xavantinho e de Terezinha e Lindalva com o intuito de demonstrar aos alunos a admirável capacidade de improviso a partir de fórmulas e métricas fixas, a vitalidade do repertório de rimas e arranjos harmônicos e o humor, o sarcamos, as sátiras, o brinco e a ludicidade presentes nos versos. Como exercício de poesia mnemônica, trouxemos o exemplo dos desafios com mote e a construção de décimas em forma de glosa para que os alunos já tivessem uma inspiração na hora de brincar com a poesia oral. Os motes criados coletivamente pelos alunos foram: 1) Vivo debruçado na janela/ a espera de algo que nem sei; 2) O relógio não sabe parar/ e as horas nunca bastam; 3) 
Lá vem a bala perdida/ veja o que tem na mira; 4) Qual é o nosso destino/ nessa selva de pedras. Em duplas, os alunos desafiaram uns aos outros e, sem a possibilidade de registro escrito, deveriam improvisar oralmente, não necessariamente com um esquema de rimas fixo, mas procurando estabelecer cadência sonora com a repetição do mote nos dois últimos versos da décima glosada. Foi interessante observar como os alunos retomaram expressões nordestinas e sertanejas lidas nos versos de cordel e ouvidas no repente que ainda estavam frescas na memória. Eles reconheceram a dificuldade de ser ágil no improviso e na escolha de palavras que rimam e ainda alegaram que versos já "batidos" e "comuns" de músicas conhecidas "martelavam na cabeça", impedindo-os de serem criativos. Ao escutar as duplas improvisando, notei que alguns alunos tiveram dificuldade de escapar dos "clichês" e de manter a coerência do mote.

$\mathrm{Na}$ aula seguinte, uma aluna me entregou espontaneamente um cordel que produziu em casa baseado no curso e em nossas discussões. Por mais que hajam questões formais da poesia mnemônica dos cordelistas a serem contempladas e retrabalhadas no poema da aluna, como a métrica e a estrutura das rimas, a produção foi bastante expressiva pela sua capacidade de apropriação e reprodução de uma história triste muito próxima a sua realidade e que está longe de estar superada. Outro aspecto que nos chamou atenção foi seu posicionamento subjetivo aguerrido nas últimas três sextilhas:

\author{
A Escravidão No Brasil \\ Por interesse português \\ A história começou \\ Em uma sociedade de guerreiros \\ A discórdia se espalhou \\ Foram guerras atrás de guerras \\ Até o problema se iniciar \\ E os prisioneiros dessas guerras \\ Portugal escravizar \\ A escravidão no Brasil \\ A humanidade do negro destruiu \\ E mesmo quando "acabou" \\ Foram alvos da dor \\ O Brasil foi o último país \\ a abolir a escravidão \\ E inserir os negros na sociedade \\ não foi levado em consideração
}


Deram liberdade

Mas trabalho não

Quiseram estudar

Mas não deixaram

E os guerreiros estavam, desarmados para lutar

O racismo é apenas mais uma batalha

entre várias a enfrentar

Com a escravidão

O traficante foi quem lucrou

Vendendo escravos como mercadoria

Os desumanizou

Os africanos tinham experiência com machados e ferramentas

E saber que a igreja legitimou, que tormenta.

Os Portugueses,

Os índios queriam escravizar

A Igreja impediu "São ingênuos, dá pra catequizar"

Ao precisar de escravos,

A igreja acalma

"Escravizem os negros, eles não têm pureza na alma."

A igreja

Os negros desumanizou

E Portugal? Bem, ajudou

Guerreiros no fundo de um navio foram colocados

Durante três meses,

Em uma situação miserável.

Estão mudados,

De guerreiros à escravos,

De guerreiros à desalmados.

Lá no fundo do navio, a água do mar entrava

O lugar onde o negro fazia suas necessidades

Comia, Dormia, Ficava.

Lá ficavam durante três meses

$\mathrm{O}$ navio negreiro atormentava

Era conhecido como tumbeiro

Pois com negros mortos navegava.

Não bastou desalmar

Trataram como mercadoria também

"Todos os tipos de negros aqui no mercado de escravos têm"

Os escravos mais fortes e saudáveis eram caros

Mas a escrava africana era a peça mais cara do mercado

$\mathrm{Na}$ casa grande ficavam cuidando de domésticos afazeres 
A noite eram obrigadas por seus chefes

Através de sexo lhe proporcionarem prazeres

Ela era estuprada

Nesse momento sim

Assassinaram sua alma

E para a Sinhá,

A escrava é sempre a culpada

A sinhá não gostava do marido preferir a escrava

E depois de estuprada

A escrava ainda era maltratada

A Sinhá lixava os dentes

Cortava os bicos do peito

Cortava os cabelos

Arranhava o rosto

Entre outros

Apenas de imaginar sinto um enorme desgosto.

Alimentavam o escravo

Para não morrer e ter forças para trabalhar

Educavam o escravo com violência

Mas sem o incapacitar

Aliás, escravo só serve para trabalhar

Vestiam o escravo

Só para pelado não andar.

A escravidão

Tal como os índios

Os africanos resistiram

Pensar ao contrário é totalmente equivocado

Os escravos africanos lutaram

Mas somente no fim foram libertados

Quando os escravos fugiam

Pra matar iam

Nós quilombos se escondiam

Se protegiam

Mas tinham que tomar cuidado

Com os capitães do mato.

As festas existiam para que não houvesse revolta

Caso alguém tentasse fugir

O senhor era alertado na hora

No meio disso a capoeira surgiu

Era uma luta

Porém como dança se assumiu

Os escravos tinham que abandonar sua religião 
Aceitavam que católicos tinham que se tornar

Mas eles buscavam aspectos das duas crenças

Para o sincretismo religioso as duas religiões juntar

Ainda temos vestígios da escravidão

Juntos encontraremos a solução

Ainda temos racismo e preconceito

Talvez a resposta seja o amor e o respeito

Eu fui escravizada juntos com os negros

Eu fui estrupada junto com a escrava

No navio negreiro, eu viajava

E tal como os negros, todas as tempestades, eu enfrentava.

Não cheguei a viver a época mas vivi a história

Comemorei a liberdade da mesma forma

Hoje luto a mesma guerra com eles

Porque quero um mundo sem preconceito e mais consciente.

O negro é lindo, forte e inteligente

Ninguém deveria odiar alguém por causa da cor

Deveriam odiar tudo que a escravidão causou

Nesse mundo perdido

É preciso encontrar

Mais empatia, respeito e amor ${ }^{38}$

- Interpretação e análise de poemas modernos e contemporâneos - pedimos aos alunos que trouxessem poemas modernos e contemporâneos de autores canônicos e não canônicos que eles já conheciam para a elaboração de uma coletânea de poemas e para dar continuidade à discussão sobre erudito e popular. Eles trouxeram muitas músicas de rap, classificando-as como poemas. Apresentamos alguns outros autores e poesias sem autoria reconhecida e reunimos poemas de Patativa do Assaré, Zé da Luz, Cego Aderaldo, Pinto do Monteiro, Solano Trindade e Geraldinho Nogueira, textos poéticos coletados por Luís Câmara Cascudo, Henriqueta Lisboa, Silvio Romero, Almeida Garrett, Affonso Arinos, Coutinho Filho, Cavalcanti Proença, Leonardo Mota, Amadeu Amaral e Cornélio Pires, além de poemas de Carlos Drummond de Andrade, Manuel Bandeira, João Cabral de Melo Neto, Manoel de Barros, Oswald de Andrade, Murilo Mendes, Adélia Prado, Fernando Pessoa, Casimiro de Abreu, entre outros. Acrescentamos também alguns poemas concretos dos irmãos Campos, Arnaldo Antunes, Paulo Leminski e haicais da Alice Ruiz e Pedro Xisto. A ideia da coletânea era mesclar em um mesmo material poemas considerados canônicos e poemas com menos

\footnotetext{
${ }^{38}$ Grifo nosso para destacar o ponto de giro da aluna na produção do cordel.
} 
representatividade na crítica literária tradicional. Isso porque, desde que trabalhamos com os poemas de Patativa do Assaré, os alunos demonstraram certa resistência em dar valor às obras com traços da oralidade e com predomínio de vozes marginais da literatura, já que estavam acostumados com o ensino da Língua Portuguesa pautado em textos "difíceis", "eruditos", que "respeitavam a gramática". Alguns alunos já conheciam os poemas de Férrez e Sérgio Vaz, ambos poetas oriundos de regiões periféricas da zona Sul de São Paulo que exploram em seus textos a variação linguística das comunidades onde cresceram, mas a maioria ainda não considerava como literatura manifestações poéticas como essas.

Nesse sentido, me pareceu benéfico explorar a discussão sobre a chamada "literatura marginal", procurando evitar tal nomeação devido à polêmica sobre o termo. Sem o intuito de classificar cada autor estudado na ordem tradicional do canône, procuramos abordar as diferenças de forma e conteúdo entre as obras de poetas como Oswald de Andrade, Manuel Bandeira, Hilda Hilst, entre outros, e as obras de escritores como Lima Barreto, João Antonio Ferreira Filho, Férrez, etc, a fim de identificar os acontecimentos históricos e culturais que expõem seus traços distintivos. Nesse trabalho investigativo a partir da coletânea organizada, os alunos reconheceram nos chamados "poetas populares do Nordeste" uma escrita interessada nos problemas sociais do sertão bem próxima à escrita dos "poetas marginais" cujo foco também são os problemas sociais, porém, aqueles localizados nos grandes centros urbanos e nas periferias. Por mais que os alunos tenham reconhecido uma intenção política pulsante nos versos de poemas do Drummond, João Cabral e Murilo Mendes, eles distinguiram por meio da linguagem oral e das expressões idiomáticas características da periferia um certo lugar de fala dos poetas não considerados canônicos. Os alunos acentuaram que a forma e o estilo como Patativa do Assaré, Cego Aderaldo, João Antônio, Solano Trindade, Giovani Martins descrevem a miséria, a repressão, os resquícios da escravidão e o preconceito parecem ser mediadas pelas suas próprias experiências e relações sociais ligadas à violência de classe, como se nessas obras, forma literária e realidade vivida estivessem mais nítidas e representadas que nas outras obras estudadas. Ou seja, os alunos identificaram nesse conjunto de produção literária uma relação intrínseca entre literatura e vida social que condensa na forma e conteúdo as questões da pobreza e da injustiça que eles próprios (alunos) sentem na pele. Devido ao uso das variantes da língua, aos temas abordados e às imagens construídas nos poemas, a literatura de Solano Trindade, Férrez e João Antônio, por exemplo, representou o sistema simbólico dos nossos alunos receptores de maneira muito mais convincente (na perspectiva deles) do que outras obras estudadas na coletânea. Foi como se 
eles compreendessem, mesmo que inconscientemente, a necessidade recíproca entre sujeito leitor e obra, entre literatura e vida social. Ao mesmo tempo em que havia uma maior proximidade entre os alunos e esses textos, eles custaram a concordar que esse tipo de produção literária também deveria ser valorizada e reconhecida como arte como qualquer outra obra da coletânea produzida por nós, como se, ao avaliar a relevância e legitimidade de obras poéticas em um curso de Língua Portuguesa, aquelas que não se ajustam e obedecem as normas da língua e as formas do canône não deveriam ser colocadas no mesmo patamar (nesse caso, em uma mesma antologia poética) de obras consideradas eruditas.

Esse posicionamento desconfiado e essa divergência dos alunos com relação ao valor das diferentes manifestações artísticas nos pareceram sintomas de uma auto diminuição, de um rebaixamento e subjugação de sua própria cultura. Quando os alunos se identificam com os modos de dizer de um determinado discurso poético, de uma escolha de palavras menos rebuscadas e de imagens de sua vida social representadas nos versos lidos e, ao mesmo tempo, dizem que essas obras não podem pertencer ao mesmo conjunto de produção literária que outros poetas mais aclamados pela crítica literária, há claramente uma postura de submissão de seu capital cultural à cultura dominante e elitista. É como se os alunos pensassem que a poesia com a qual eles se identificam, na qual eles se enxergaram, é menor e tem menos valor, pois eles foram capazes de compreendê-la, de decifrá-la sem ajuda de um dicionário, sem uma mediação da professora e também porque ela retrata a periferia e a vida dos sujeitos marginalizados pela desigualdade social. Logo, a sensação que tivemos após a discussão sobre a organização dessa coletânea foi de que os alunos se indagaram como essa mesma poesia "marginal" poderia ser promovida como arte da mesma forma que aquela "erudita" que eles não compreendem sem o auxílio de um outro que domina melhor os bens culturais? De certo modo, nessa discussão, era possível perceber uma premissa implícita no discurso dos alunos de que morar na periferia é estar destinado a consumir um tipo de cultura que nunca terá o mesmo valor que a cultura da classe dominante e, por isso, ela deveria ser mais simples, menos sofisticada, para que os não favorecidos pela educação de qualidade pudessem fruí-la e compreendê-la. No contato com as diferentes obras poéticas, os alunos se sentiam impotentes e incapazes para lidar com alguns textos, mas reconheciam certa autonomia ao mergulhar nas obras de outros poetas. Nesse percurso de caminhar pelos poemas da antologia compilada por nós, os alunos foram ganhando confiança e desejo para se desafiarem com outros tipos de autores não tão "populares". 
Procurando compreender a postura dos alunos nessa sequência didática, percebemos que o ensino instrumental da língua é um dos grandes vilões que contribuem para esse pensamento de auto submissão. Ao longo da trajetória escolar, os alunos introjetam em si a ideia de que há um modo correto de usar a língua e de pronunciá-la, que há um modo melhor de fazer arte, que há uma maneira certa de juntar as palavras e produzir discursos, afastandose de sua cultura, de seu sistema simbólico, de sua história. Nesse sentido, foi importante apontarmos para a necessidade de eles reconhecerem as relações sociais do poeta com o seu estilo, sua forma e conteúdo para representar sua realidade e que esse trabalho também é um trabalho artístico denso, relevante e influente, é uma narrativa que reflete a história de exploração a qual esses poetas estão ainda submetidos, afinal, esse tipo de produção literária é também um ato socialmente simbólico que procura seu lugar na sociedade pela forma como a bem representa e pela sua configuração estética radical e transformadora.

- Figuras sonoras - Realizamos diversos exercícios de interpretação dos poemas e análises das figuras sonoras e estilísticas, de produções a partir de paródias e, após o trabalho de aumentar o repertório dos diversos tipos de textos poéticos e em diálogo com os textos que eles trouxeram, analisamos também a música "Brasil com p", do rapper GOG, para introduzir o conceito de aliteração. A letra da canção é composta apenas por palavras iniciadas com a letra $\mathrm{P}$ e traduz a dura realidade dos jovens da periferia. Os alunos trabalharam em grupos para discutir os elementos de forma e conteúdo da música e responderam as seguintes questões: 1) Qual é o principal recurso sonoro usado na construção do texto? 2) Que efeito de sentido produz no texto o uso desse recurso sonoro? 3) Em sua opinião, por que o verbo “prometer" aparece repetido em "Pelos palanques políticos prometem prometem"? 4) No verso "pânico, pólvora pa pa pa" a sílaba "pa" é utilizada como onomatopeia, ou seja, como palavra que apresenta determinado som. Que som é esse? 5) Segundo o texto, como são tratados os habitantes das periferias das grandes cidades brasileiras? 6) Uma das características do rap é a denúncia das desigualdades e injustiças sociais, principalmente aquelas sofridas por pessoas menos favorecidas economicamente e/ ou marginalizadas socialmente. Identifique, na letra da canção, referências explícitas aos desfavorecidos. Trecho da música "Brasil com P": 
Pare, pense, por quê?

Prossigo,

Pelas periferias praticam perversidades: PMs!

Pelos palanques políticos prometem, prometem,

Pura palhaçada. Proveito próprio?

Praias, programas, piscinas, palmas...

Pra periferia? Pânico, pólvora, pápápá!

Primeira página.

Preço pago?

Pescoço, peito, pulmões perfurados.

Parece pouco?

Pedro Paulo,

Profissão: pedreiro,

Passa-tempo predileto: pandeiro,

Preso portanto pó, Passou pelos piores pesadelos.

Presídios, porões, problemas pessoais, psicológicos...

Perdeu parceiros, passado, presente,

País, parentes, principais pertences.

PC: político privilegiado

Preso, parecia piada.

Pagou propina pro plantão policial,

Passou pela porta principal.

Posso parecer psicopata,

Pivô pra perseguição,

Prevejo populares portanto pistolas,

Pronunciando palavrões,

Promotores públicos pedindo prisões...

Pecado, pena,

Prisão perpétua!

O GOG (Genivaldo Oliveira Gonçalves) foi um rapper famoso do Distrito Federal na década de 90, por isso, não foi um músico com o qual a geração dos nossos alunos teve tanto contato como com os Racionais MC's, que, apesar de também surgirem na década de 90, continuam lançando discos até hoje. Logo, eles se surpreenderam com a qualidade da composição e, mesmo sendo muito experientes com as produções do rap, entusiasmaram-se por conhecer uma música que para eles era inédita. A partir dos versos da música e de outros poemas que exploram a melopeia, aprofundamos o estudo sobre as figuras sonoras e encerramos este bloco com exercícios de criação poética para os alunos criarem suas próprias aliterações a assonâncias. A maioria apresentou estrofes com uma profusão de palavras iniciadas com a mesma letra, seguindo o exemplo da música "Brasil com P", mas com pouco engajamento para se pensar em uma articulação interessante entre forma e conteúdo. Acredito que a falta de disposição para o exercício foi combinado com o difícil calendário da escola, pois os alunos estavam em semana de provas, exaustos e sem motivação para outras propostas. 
- Teoria da Comunicação e a função poética segundo Jakobson - após introduzir um repertório de poesia oral e escrita aos alunos, iniciamos o estudo da função poética da linguagem. Primeiro, discutimos sobre cada função predominante nos textos e os seis fatores constitutivos do ato de comunicação verbal, teoria desenvolvida por Roman Jakobson (2010). Apresentamos o esquema proposto pelo linguista e realizamos exercícios com textos que representassem cada fator constitutivo (as funções de cada texto).

Aprofundamos o conceito de função poética com base na teoria dos eixos de seleção e combinação e realizamos o seguinte exercício: 1) Retome o conceito de função poética segundo Jakobson e a ideia de prevalência do eixo de seleção sobre o eixo de combinação; 2) Faça uma paródia do poema "José”, de Carlos Drummond de Andrade, substituindo as palavras destacadas por outras palavras com significados parecidos. A ideia é que, nessa paródia, o eixo de combinação das palavras não mude. Você deverá alterar apenas o eixo de seleção (alguns substantivos e adjetivos), conforme exemplos vistos em aula, mantendo o sentido do poema; 3) Redija um comentário pessoal interpretando o poema "José", de Carlos Drummond de Andrade.

\footnotetext{
E agora, José?

A festa acabou,

a luz apagou,

o povo sumiu,

a noite esfriou,

e agora, José?

e agora, você?

você que é sem nome,

que zomba dos outros,

você que faz versos,

que ama, protesta?

e agora, José?

Está sem mulher, está sem discurso, está sem carinho, já não pode beber, já não pode fumar, cuspir já não pode, a noite esfriou, o dia não veio, o bonde não veio, o riso não veio, não veio a utopia e tudo acabou e tudo fugiu

e tudo mofou,

e agora, José?
} 


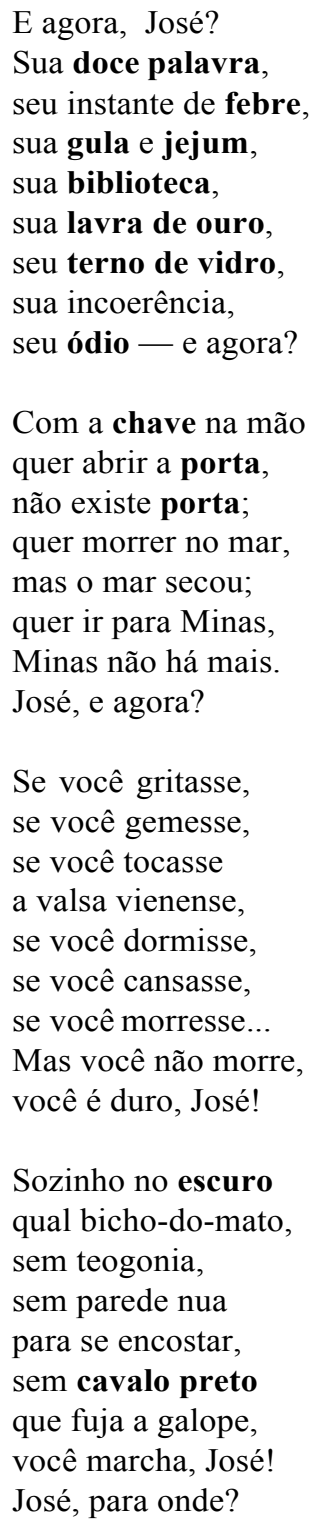

Consideramos esse e outros exercícios de paródias como incentivos importantes para a produção autoral de poemas a partir do trabalho de reconhecimento e análise da função poética. Vemos aqui um exemplo de contribuição do par alienação e separação, já conceituado anteriormente no processo de emergência de uma subjetividade entre-textos. A alienação seria esse primeiro momento de contato com o texto poético, em que é possível trabalhar o processo de subjetivação a partir de equívocos na leitura do texto do outro, e a separação seria esse segundo momento de produção textual a partir da obra do outro, em que o indivíduo que escreve passa a imitar e subverter o discurso do outro. Aqui, na proposta de paródia na modalidade escrita, pudemos observar o processo de alienação do indivíduo que se fixa à demanda de um outro para, a partir de seu repertório (no movimento de separação), 
poder criar seu próprio texto. Ou seja, o aluno partiu daquilo que lhe foi mostrado e se apoiou em um molde bem estruturado para dar espaço a sua própria criação e, assim, foi capaz de colocá-la no papel. As produções de texto que resultaram deste exercício ilustraram bem esse processo de emergência de subjetividade rumo ao processo de subjetivação, uma vez que tanto as rimas imitando as palavras destacadas no poema "José", como a troca de palavras a partir de uma identificação semântica ou de neologismos no contexto contemporâneo do léxico da língua portuguesa, apontam para a fixação de uma demanda do outro junto a traços de desejos e de rememorização dos sujeitos escreventes. O aluno que decidiu trocar as palavras "festa", "luz", "povo" e "noite" por "balada", "neon", "galera" e "rolê" dialogou com suas escolhas no eixo paradigmático das palavras selecionadas pelo poeta e atribuiu um novo conjunto lexical sem alterar a semântica dos versos. Em cada uma das paródias produzidas, pudemos notar fortes indícios de subjetividade de nossos alunos e boa capacidade de buscar, em um mesmo campo semântico, palavras que contribuíssem para a contextura do poema. Outros exemplos foram: "esperança", "chama", "namorada", "coração", "você que é sem noção", "você que faz palhaçada". A aluna justificou suas escolhas como protesto contra as piadas, o humor ofensivo e sem limites que atacam as minorias, que, segundo ela, o alvo é principalmente as mulheres. Outro aluno utilizou a sequência "churrasco", "carvão", "convidado", "tempo", caráter", "diversão", pois interpretou José como alguém que tinha tudo de que precisava para se promover socialmente, mas não soube manter seu "status" e colocou tudo a perder.

O comentário abaixo, fruto da reflexão de uma aluna após o resultado de sua produção parodiada, nos fez perceber também que exercícios como esse contribuem no desenvolvimento da confiança de alguns alunos que se sentem em defasagem e destituídos de conhecimentos básicos para a escrita de textos poéticos. Ao exercitar a troca de palavras no eixo de seleção do poema "José", a aluna percebeu que a paródia pode facilitar o domínio para a escrita: 


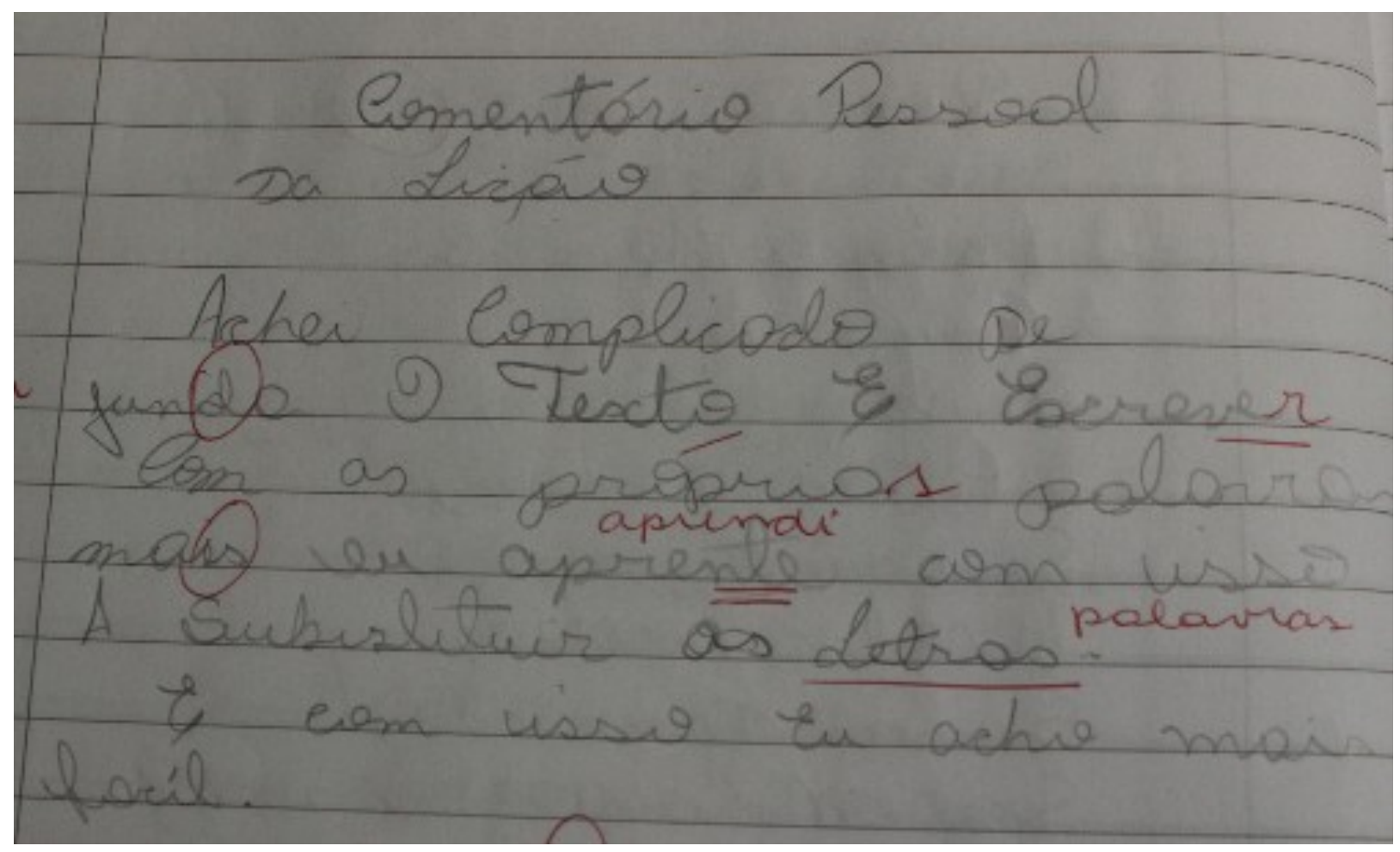

"Achei complicado de juntar o texto e escrever com as próprias palavras, mas eu aprendi com isso a substituir as letras [palavras]. E com isso eu acho mais fácil.”

Outro exercício de paródia interessante foi a partir do poema "Vou-me embora para Pasárgada", de Manuel Bandeira. Os alunos deveriam alterar o local de destino do eu-lírico, indicando um outro lugar para o qual eles desejassem fugir, justificando nos versos seguintes por que esse lugar seria um bom refúgio. Alguns alunos indicaram a cidade natal de seus pais, onde uma vez puderam visitar os avós e conhecer melhor seus parentes e sua história, outros indicaram cidades que imaginavam ser paradisíacas, onde eles poderiam relaxar em vez de ter que trabalhar e estudar ao mesmo tempo e ainda tivemos exemplos de alunos que escolheram retratar cidades imaginárias que engoblavam uma organização social e política correspondente ao seus ideais de justiça e igualdade.

- Sílaba e tonicidade - a partir dos resultados das primeiras produções escritas, avaliamos a quantidade de erros ortográficos, problemas de divisão silábica e falta de acentuação gráfica. Notamos que as principais recorrências na grafia correta das palavras se encontravam na transcrição da fala, suprimindo as letras $r$, s ou u ao final das palavras, respectivamente no uso de verbos infinitivos, na declinação do plural e na conjugação do tempo passado dos verbos, além da redução da letra d nos gerúndios. Com relação às 
regularidades contextuais, os principais equívocos estavam na grafia de palavras com $\mathrm{S}, \mathrm{SS}$, Ç, Z e X e nas trocas homorgânicas entre as articulações surdas e sonoradas, como p/b, d/t, v/f e $\mathrm{g} / \mathrm{k}$. Notamos também uma grande dificuldade na segmentação das palavras e em algumas regularidades morfológicas como no final dos verbos com -ão e -am.

Levando em consideração tais recorrências ortográficas na escrita convencional da língua, retomamos os elementos menores com o intuito de rever as regularidades contextuais e morfológicas, além das regras do uso de acentuação gráfica. Revisamos o conceito de sílaba, vogal, semivogal, ditongo, tritongo, hiato e tonicidade. Poucos alunos se lembravam do que eram palavras oxítonas, paroxítonas e proparoxítonas, então, realizamos uma atividade a partir da música "O pulso", de Arnaldo Antunes. Seguem alguns exemplos de exercícios propostos:

1) No verso "o pulso ainda pulsa”, há três palavras em que a posição da sílaba tônica é a mesma. Classifique-as quanto à posição da sílaba tônica.

2) No texto, são citados os nomes de várias doenças. Encontre três delas que sejam proparoxítonas.

3) Separe as sílabas dos substantivos: pneumonia, cleptomania, ciúmes, trombose, faringite, leucemia e arteriosclerose.

4) Em "o corpo ainda é pouco", temos dois monossílabos. Os dois são átonos? Justifique. Mesmo não sendo conteúdos gramaticais do Ensino Médio, tivemos que realizar os exercícios coletivamente, pois os alunos não estavam confiantes quanto ao reconhecimento da tonicidade das sílabas. Fizemos algumas brincadeiras com os nomes próprios dos alunos para identificar a sílaba tônica de cada um e eles se animaram em se autoclassificar enquanto portadores de nomes em oxítona, paroxítona ou proparoxítona. Mesmo assim, após a avaliação, comentários como os exemplificados abaixo apareceram registrados no caderno: 


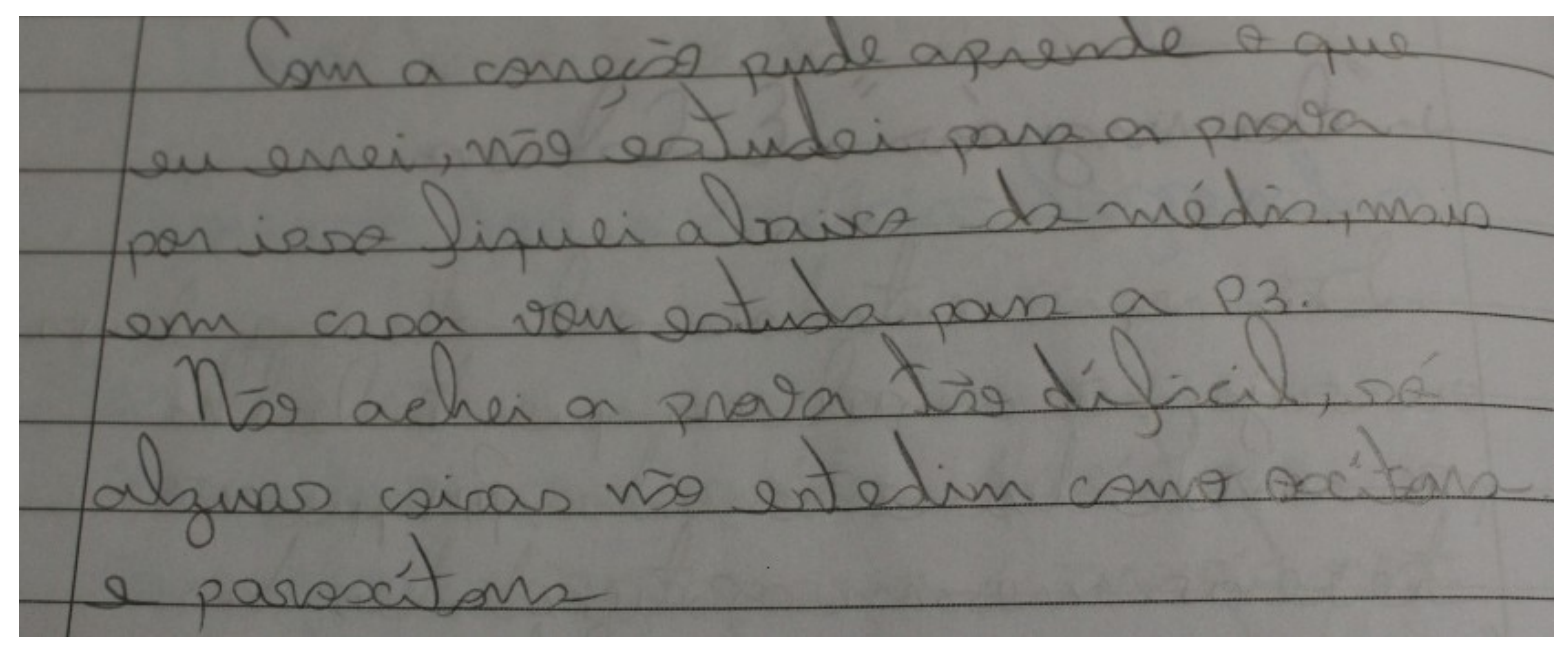

"Com a correção pude aprender o que eu errei, não estudei para a prova por isso fiquei abaixo da média, mas em casa vou estudar para a P3. Não achei a prova tão difícil, só algumas coisas não entendi como oxítona e paroxítona".

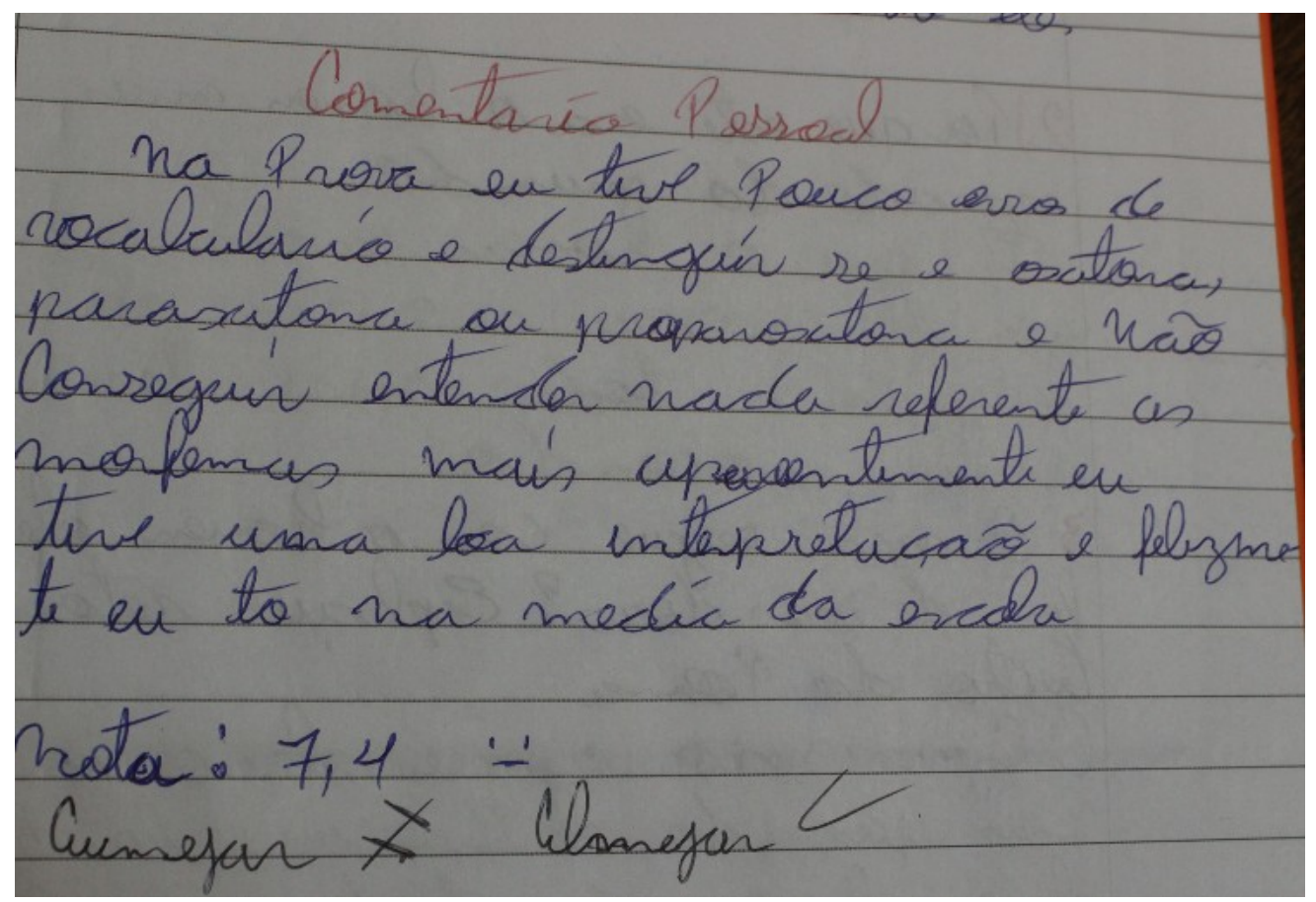

"Na prova eu tive pouco erro de vocabulário e distingui se é oxítona, paroxítona ou proparoxítona eu não consegui entender nada referente aos morfemas mas aparentemente eu tive uma boa interpretação e felizmente eu estou na média da escola".

Em seguida, aproveitamos a revisão sobre sílaba tônica e átona para introduzir o conceito de sílaba poética nas aulas seguintes. 
- $\quad$ Formação do verso e estudo da estrutura das palavras - ao explicar o conceito de sílaba poética, tivemos que retomar os conceitos de ritmo e metro na formação dos versos em que há uma cadência de sons produzida pela sucessão de sons fortes (sílabas tônicas) e sons fracos (sílabas átonas). Relemos o poema "Vou-me embora pra Pasárgada", de Manuel Bandeira, para agora exercitar a identificação das sílabas fortes e fracas na metrificação precisa do poema em redondilha maior. Além disso, os alunos registraram pequenas análises sobre o poema, como estas:

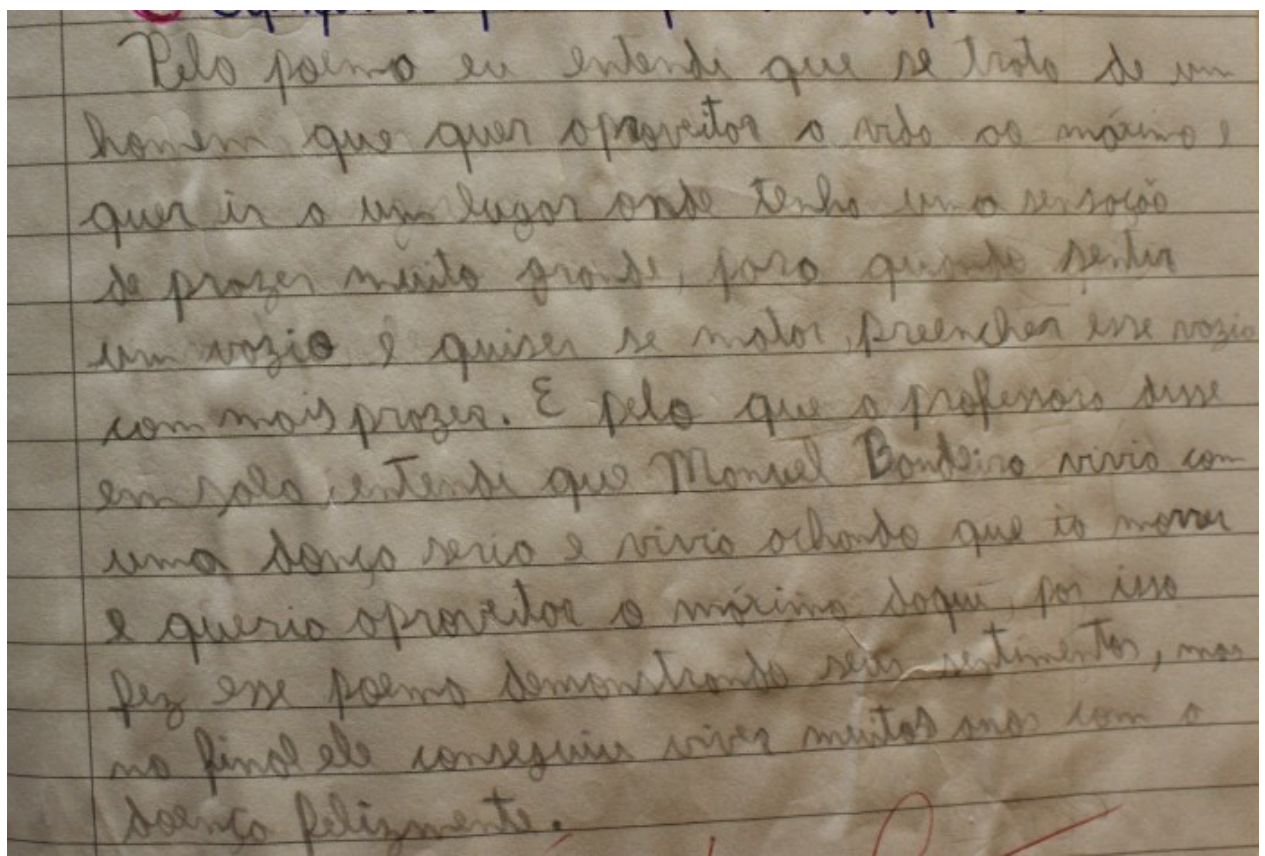

"Pelo poema eu entendi que se trata de um homem que quer aproveitar a vida ao máximo e quer ir a um lugar onde tenha uma sensação de prazer muito grande, para quando sentir um vazio e quiser se matar, preencher esse vazio com maiz prazer. E pelo que a professora disse em sala, entendi que o Manuel Bandeira vivia com uma doença séria e vivia achando que ia morrer e queria aproveitar o máximo daqui, por isso fez esse poema demonstrando seus sentimentos, mas no final ele conseguiu viver muitos anos com a doença felizmente".

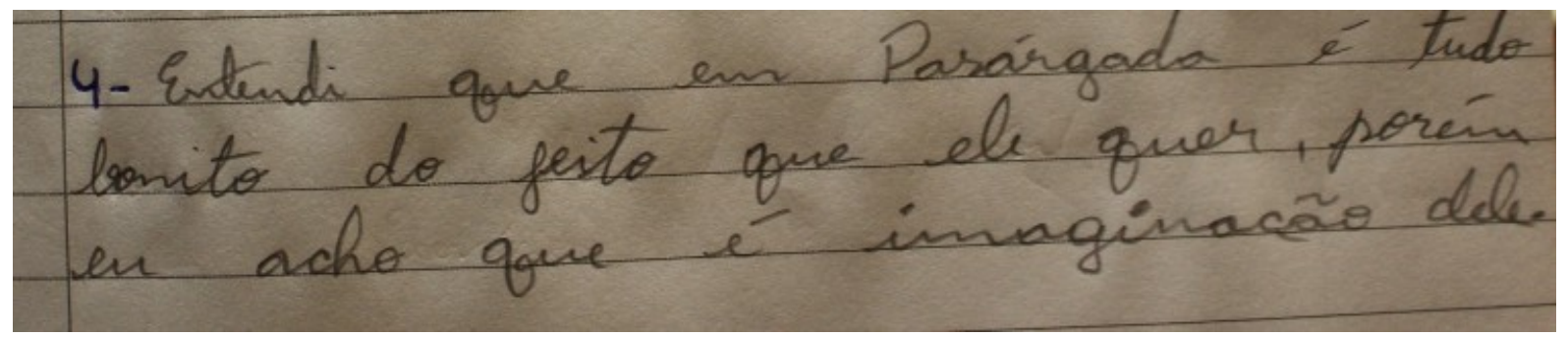


"Entendi que em Pasárgada é tudo bonito do jeito que ele quer, porém eu acho que é imaginação dele".

- $\quad$ Roda de conversa sobre leitura ${ }^{39}$ - o que mais me inquietava na estrutura da Unidade de Paraisópolis era a falta de biblioteca. Ao longo de todo meu trajeto como professora de Língua Portuguesa, sempre planejei e apreciei aulas no espaço da biblioteca, principalmente com propostas de contação de história e compartilhamento de leituras realizadas em casa. Senti muita falta deste espaço para desenvolver dinâmicas como estas, afinal, o bloqueio em relação aos hábitos de leitura era também uma realidade de nossos alunos e poderia ser melhor trabalhado com o auxílio do serviço de organização e empréstimo de livros proporcionado pelas bibliotecárias. A aproximação dos alunos com os livros não era algo natural no contexto da escola em Paraisópolis, pois, além da ampla difusão das novidades tecnológicas e do acesso à informação por outros meios, havia uma hostilidade à leitura, como se aquela prática não fosse destinada a eles. Nessa direção, propus aos alunos uma campanha para organizarmos uma solução para a ausência de biblioteca, um trabalho voluntário para que tivéssemos ao menos um pequeno acervo para troca de livros. Essa tarefa não poderia depender de esforços da coordenação da escola na Unidade Hebraica, pois um conjunto de professores já havia feito o pedido para considerarem a implementação de uma biblioteca, mesmo que fosse, a princípio, algo pequeno e organizado pelos alunos, mas a resposta que recebemos indicava uma boa perfomance dos alunos com os tablets disponibilizados pela escola, cujo acesso permitia a leitura dos materiais didáticos e complementares, inclusive o alcance de um amplo acervo em bibliotecas digitais. Por essa perspectiva, os alunos se sentiam contemplados e satisfeitos com o uso dos tablets, e, talvez por outros motivos além da própria postura da escola não tão afirmativa em relação à construção de uma biblioteca, a proposta de auto-organização do acervo em Paraisópolis não foi reverenciada pelos alunos e, consequentemente, não seguiu em frente.

Diante desta falta de sucesso com a tentativa de erguer uma pequena biblioteca, conversamos com os alunos, de forma espontânea, sobre seus hábitos de leitura. Nesta roda de conversa, ouvimos relatos contraditórios que oscilavam entre demonstrar muita dificuldade em sentir prazer com os livros e expor imensa curiosidade sobre romances e aventuras que já

\footnotetext{
${ }^{39}$ Um trecho da repercussão desta roda de conversa sobre leitura já foi descrita na seção 2.2 do segundo capítulo.
} 
ouviram falar, mas ainda não tiveram acesso. Alguns dos alunos reconheceram em seus discursos a importância do capital cultural que os livros carregam consigo, um aumento nas chances de melhorar o domínio da oratória e do código escrito e conseguir ter acesso a um curso universitário, ter um emprego bem remunerado e se posicionar com mais facilidade diante das escolhas políticas necessárias na vida em sociedade.

Ao mesmo tempo, uma aluna fez uma colocação que teve o apoio dos demais alunos sobre as narrativas serem hoje consumidas de outra forma, já que em sua opinião, os livros ficaram ultrapassados na disputa com outras mídias. Ela disse que não é porque eles não leem livros que eles não gostam de histórias. Segundo a aluna, as histórias das séries de televisão, das novelas e dos filmes são muito atrativas e satisfazem o anseio pelas narrativas. A questão seguinte colocada por outro aluno foi: "se já estamos em contato com as histórias da nossa cultura vendo televisão e Netflix, por que ainda temos que ler histórias em livros?".

Pelos argumentos que foram se sobrepondo, ficou clara a dicotomia entre televisão e livro, como se um meio substituísse o outro, como se a televisão já cumprisse com a formação subjetiva, política e histórica dos alunos, como recurso de fácil acesso à informação, pois é passiva, prática e diversificada. De fato, alguns filmes despertam em nós sensações semelhantes à leitura de um livro, ativando regiões do nosso corpo que até então estavam adormecidas ou sentimentos que não saberíamos expressar como a cena assistida. Mas, como vimos com Iser e Zumthor nos primeiros capítulos, a leitura, quando é realizada, depende de uma disposição para se relacionar com a obra que outras artes não exigem de maneira tão ativa, participativa e atenta. Procurei expressar isso aos alunos sem parecer dogmática, buscando questioná-los mais sobre suas experiências do que insistir na importância da leitura. Mesmo assim, comentei que, ao ler boa literatura, identifico um efeito gerado pelos livros que não sinto de forma tão profunda em outros intercâmbios culturais e ele tem a ver com o tempo para a reflexão que o ato de ler me permite, um tempo que as imagens aceleradas da televisão e a fotografia em série do filme não garantem no momento exato em que me tocam a vista. Quando as palavras da leitura me tocam, sinto que se abre um espaço para a reorganização do meu ponto de vista (movimento próximo ao ponto-de-giro, explicado anteriormente), de maneira que os sentidos se ressignificam e eu posso me reposicionar diante de um significado que não está dado, não foi completamente interpretado, julgado, escancarado. As palavras do livro me dão a chance de me distanciar e me aproximar em um movimento de elaboração subjetiva, no meu tempo, a partir dos meus modelos de representação. Eu imagino a cena, os personagens, a paisagem, o toque, a entonação dos diálogos, o ritmo dos passos de acordo 
com o meu jogo imaginário, de acordo com a minha investigação intelectual. Nas telas, todo esse acontecimento já está pré-estabelecido, já está montado diante dos meus olhos.

Em seguida, um aluno levantou a mão e comentou que adorava escutar histórias gravadas somente por áudio (como nas gravações da antiga coleção Disquinho), justamente porque elas lhe permitiam imaginar e ir além das imagens pré-estabelecidas nos filmes. Com esse exercício de escuta, o aluno disse que a imaginação e reflexão provocadas pela leitura poderiam ser abastecidas pelos audiobooks. Nessa conversa, compreendi melhor que, para muitos ali, ler era maçante demais para que a compensação em troca de grande esforço fosse apenas aflorar a imaginação. Então, pedi para que eles pensassem em outras vantagens que acreditavam ser possível extrair por meio de boas leituras. As seguintes premissas foram colocadas em debate e foram aqui reformuladas para sintetizar as ideias centrais trazidas pelos alunos:

1) Ler diferentes opiniões nas colunas e artigos do jornal e não apenas ouvir a informação transmitida por uma única emissora de televisão pode contribuir para ganhar mais argumentos e não parecer massa de manobra da ideologia dominante, escolhendo seu próprio ponto de vista;

2) Ler pode trazer outras verdades, outras palavras que não são sempre as mesmas proferidas no discurso televisivo;

3) Lendo fica mais fácil pensar em outras formas de interpretação e de posicionamentos políticos;

4) Ler livros difíceis pode nos aproximar de uma cultura que nos foi negada;

5) Ler nos deixa em paz e mais tranquilos, pois só escutamos a voz que ressoa em nossa cabeça e ficamos livres de ruídos extremos e super estímulos como os gerados pela televisão;

6) Ler nos permite ter tempo a sós com nossos próprios pensamentos.

Para encerrar a roda de conversa sobre o tema, solicitei que os alunos refletissem sobre experiências que eles tiveram com algum livro ou alguma leitura realizada até o momento e que não teria sido possível chegar a essa experiência por meio de qualquer outro objeto ou prática. Na aula seguinte, nenhum aluno identificou algo parecido, pois a turma alegou que as músicas e os filmes que consumiam já propiciavam experiências muito próximas, ou seja, não era possível atribuir aos livros o estatuto de instrumento e meio insubstituível, singular, 
especial, incomparável, inigualável, raro, único, além de outras várias palavras que os alunos proliferaram para desbancar a ideia que concebi previamente sobre a leitura. Mesmo assim, minha confiança na continuidade dos hábitos de leitura se apoiou no fato de que as mídias também podem explorar uma forma de ler o mundo e estimular os alunos a buscarem na literatura reflexões sobre inquietudes e indagações que não seriam desveladas nas telas ou seriam levantadas de modo superficial e pouco subjetivo, que não contentariam aqueles que buscam investigar mais a fundo sua invidualidade, seu caráter e sua história.

Por fim, ainda cabe dizer que, além de rodas de conversa e atividades como as que citamos até agora, realizamos muitas outras propostas de performance, leitura, produção escrita e debates acerca dos textos poéticos que, no entanto, não poderiam ser descritas etapa a etapa nesta tese pela quantidade exacerbada de dados que geraram. Por isso, demos destaque aos principais desdobramentos deste trabalho para demonstrar minimamente a intenção didática e metodológica do curso de Língua Portuguesa. Como finalização deste percurso, nossos alunos organizaram o sarau literário para apresentar suas produções poéticas, evento que arrematou os passos dessa longa travessia em busca da tomada da palavra poética.

\section{A organização do sarau literário}

Para encerrar o curso, realizamos o sarau intitulado "O que te move?", que ganhou este título por escolha dos alunos, uma vez que as poesias produzidas trouxeram questões sobre a motivação de cada um para a realização de seus desejos e sonhos. Os resultados das produções no sarau foram expostos no evento aberto a todas as famílias dos alunos da escola e a exposição contou com um vídeo de reprodução do sarau e das declamações dos poemas criados, além de fotografias tiradas pelos próprios alunos. A produção de texto foi proposta a partir das interpretações dos poemas que estudamos e que deveriam motivar a escrita autoral dos alunos. O exercício partiu da escrita de um poema com base em um dos versos apresentados a seguir, que deveria ser o primeiro verso do texto. Em seguida, os alunos deveriam explicar o que motivou a criação dos poemas. Os versos eram:

a) "Um horror grande e mudo, um silêncio profundo" - Olavo Bilac, A alvorada do amor

b) "Eu voltava cansado como um rio" - P. Mendes Campos - Litogravura

c) "Quem faz um poema abre uma janela" - Mário Quintana, Emergência

d) "Eu sou como eu sou" - Torquato Neto, Cogito 
e) "Assim como uma bala" - João Cabral de Melo Neto, Serventia das ideias fixas

f) "Mandei-lhe uma carta em papel perfumado" - Viriato Cruz, Namoro

A produção dos primeiros versos foi realizada ao ar livre, para que os alunos pudessem se deslocar pelo espaço da escola, trocar ideias com os amigos ou simplesmente sentir o sol e o vento no rosto e se inspirarem a criar o texto poético. 
- Primeiro momento: registro das ideias
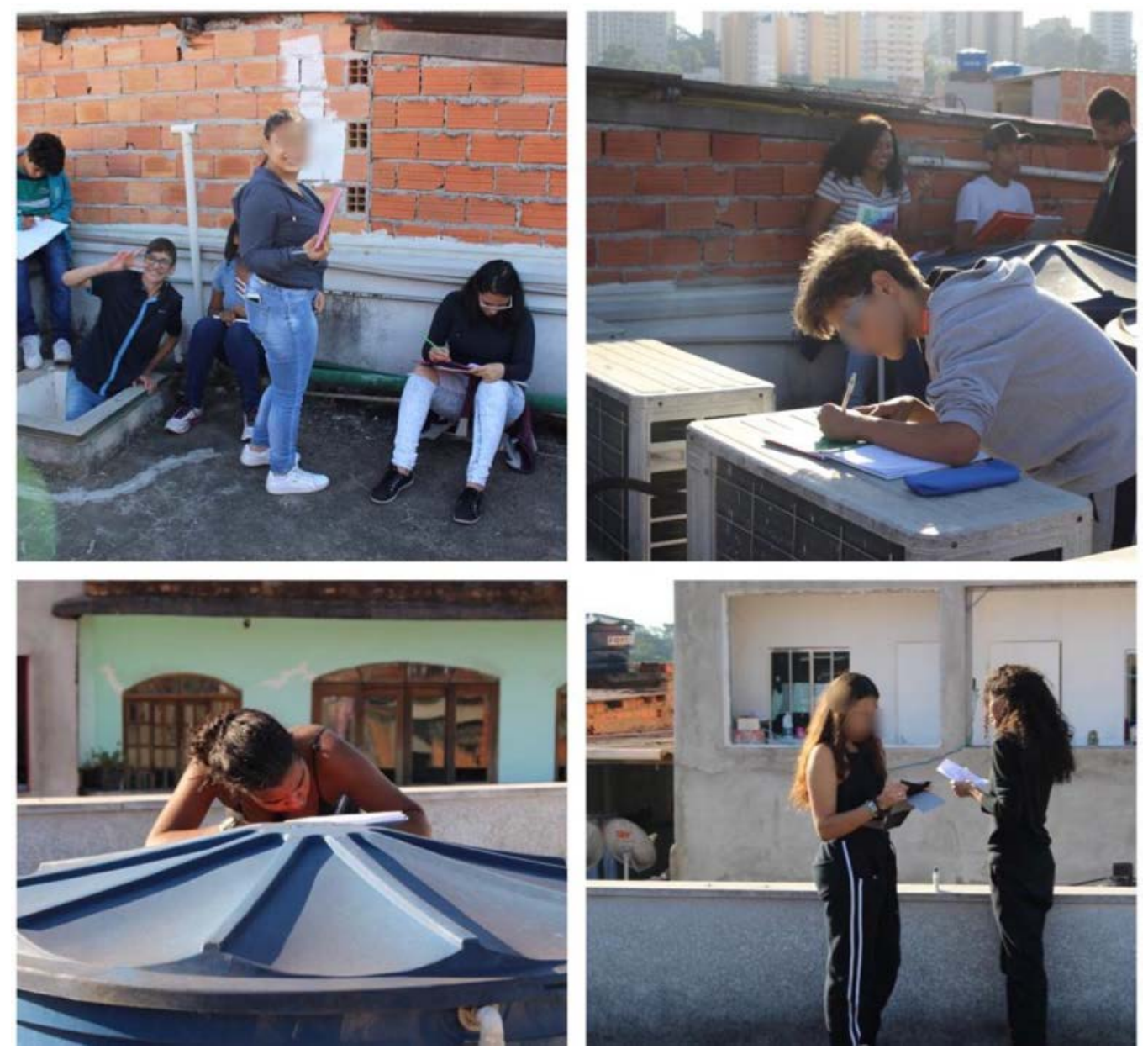
- Segundo momento: primeira versão do poema
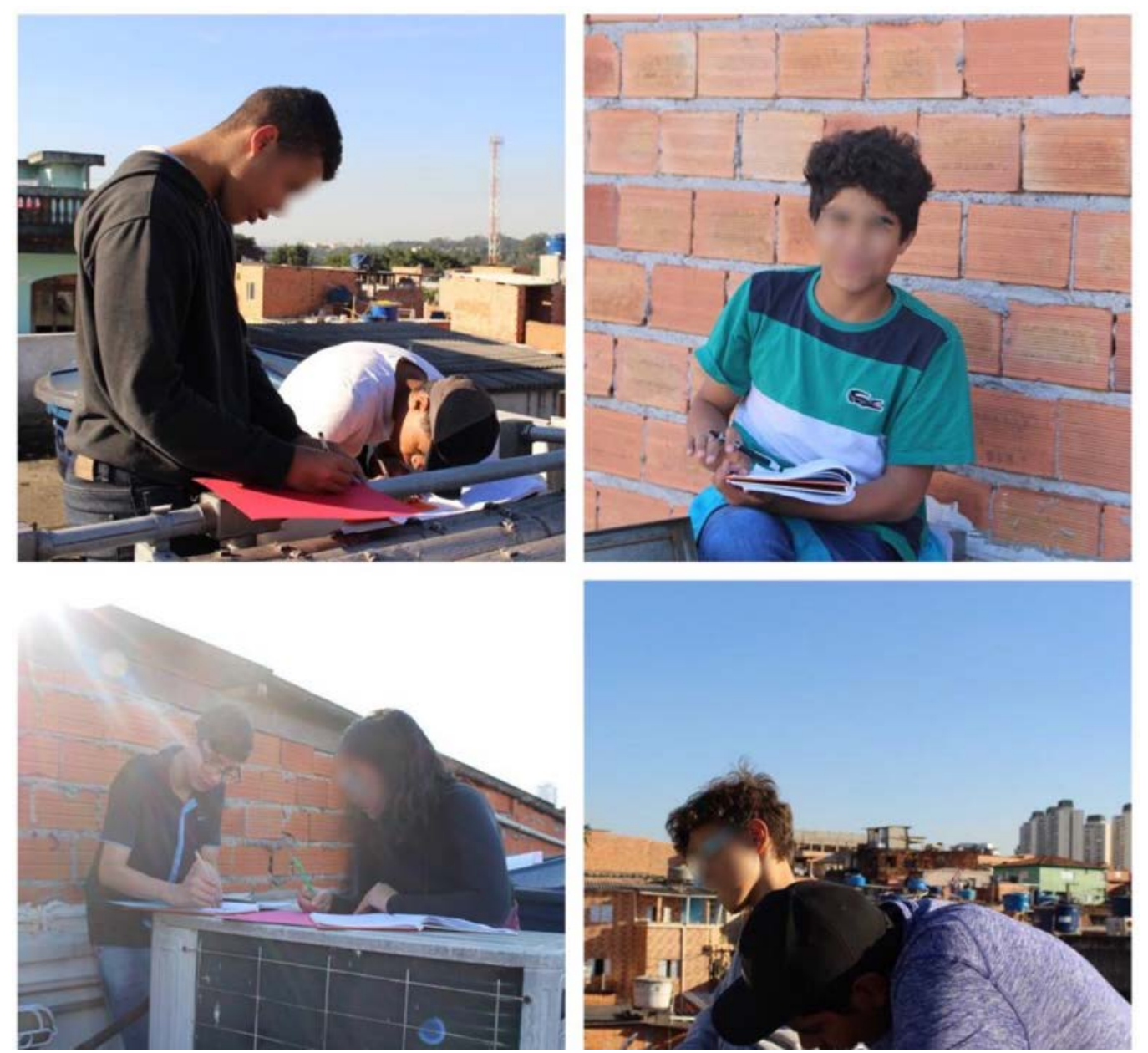
- Terceiro momento: compartilhamento da primeira versão do poema
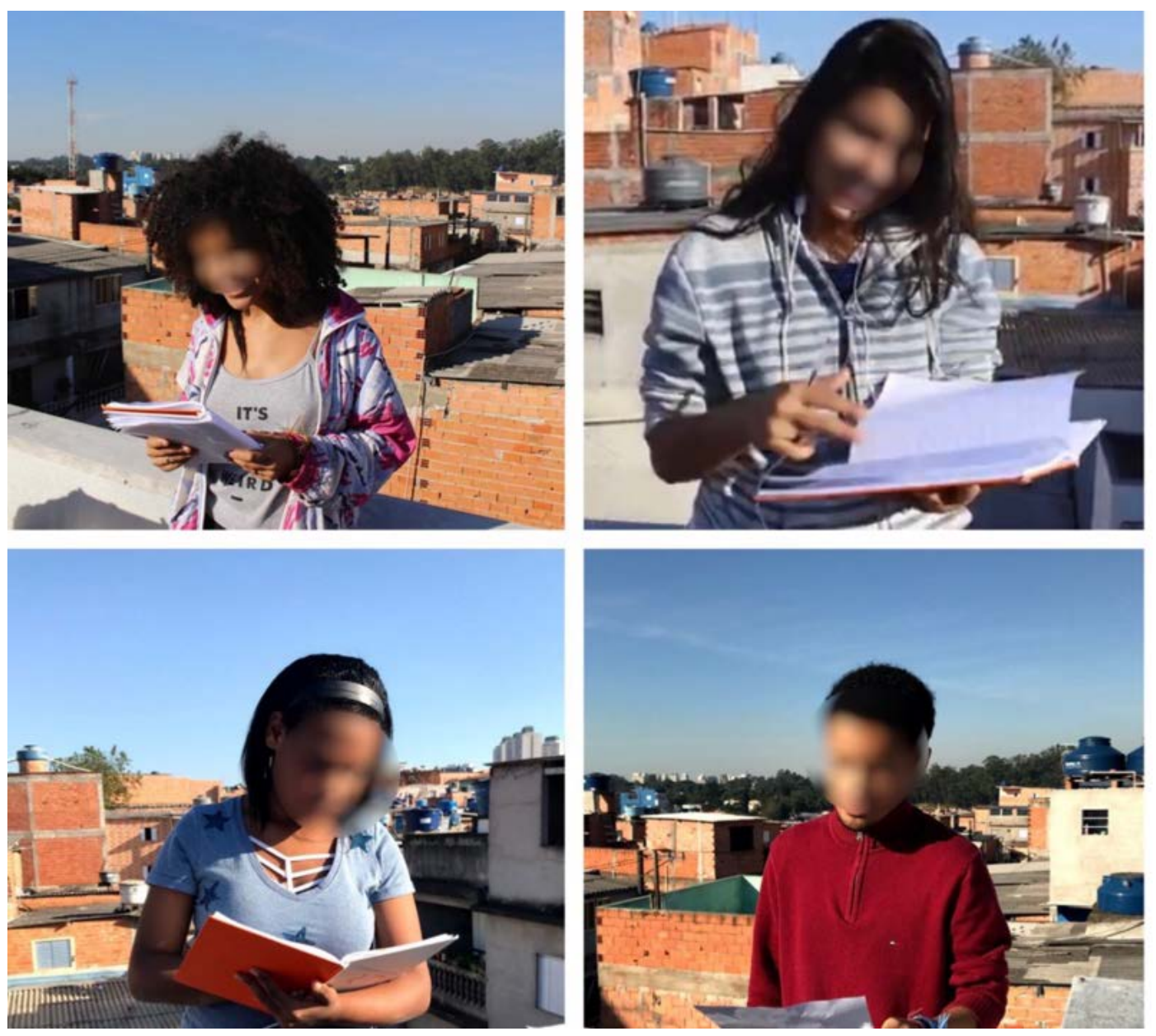

- Quarto momento: a revisão e reescrita

Os poemas foram entregues para que eu lesse e apresentasse sugestões. Pedi para que os alunos registrassem também os fatores que os motivaram a criar os versos para que eu pudesse compreender minimamente a inspiração original e tivesse mais elementos para ajudálos na escrita final do poema. Seguem alguns relatos apresentados:

"O que me motivou foi uma pessoa que usou-me e parou de falar comigo, parou de falar após dizer que não dava para ficar perto de mim, mas isso era apenas um protesto para me diminuir. Quando nós ficamos, eu gostava muito dele, mas depois que ele fez isso, eu estou tomando nojo dele, mas apenas não demonstro." 
"O que me motivou a escrever este poema foi as minhas conversas com minha melhor amiga. Pensei em coisas que ela me falou e ainda fala. $\mathrm{O}$ poema pode ser interpretado como alguém que está conversando com outra pessoa em um ambiente aberto (por isso a ponte de nuvem). Todos os versos do poema são ou podem ser falas de alguém que está em um momento delicado e está dividindo com outras pessoas (assim como eu e minha amiga)".

"O que me motivou a fazer esse poema foi simplesmente a vida, que é cansativa, cheia de dúvidas e sempre tento fugir, mas será que tem como? Foi com essa dúvida que finalizei o poema, mesmo se puder fugir, correr cansa e alguma hora vou ter que parar e encarar esse "mar" que é a vida ou seu nome subliminar, nossa realidade".

"O motivo de eu ter criado o poema foi para tentar mostrar o que eu sinto, realmente, como as mulheres, sendo loiras, morenas ou negras, não importa a cor, são criticadas, violentadas. E acontece tudo isso e ainda tem gente que fala que é porque a mulher gosta e porque quer. Realmente não entendo a sociedade que vivemos. Muitas vezes as pessoas sofrem algo por causa da sua raça e que nessa tal sociedade ela não cabe. Pelo fato de eu já ter sofrido e sofro ainda e por ser mulher negra, eu tô a procura dos meus direitos, e não só os meus como de todas elas que passa por algo que não quer e que não adimiti ocorrer. Não posso ser negra, loira, ruiva, eu sou todas elas em uma só. A diminuição do ser humano por ele mesmo é triste".

"O que me motivou a fazer esse poema foi simplesmente o nada, estava entediado e tinha o poema para fazer. As palavras foram surgindo na minha mente aleatoriamente".

"Eu escrevi esse poema porque venho passando por situações muito difíceis na minha família. Sinto que ninguém me entende, que sou diferente de todos e não consigo me encaixar em lugar nenhum. Às vezes eu me encontro e sou feliz, mas na maioria das vezes não".

"O que me motivou a fazer esse poema foi um amigo que sofria de pré-julgamentos de outras pessoas sem o conhecer. Ele acabou sendo uma baita inspiração (apesar de não gostar), mas o que ele me contou me fez conseguir me expressar aqui". 
Após muitas aulas de exercícios com o texto poético e após um longo ano de intensa convivência, os alunos se sentiram confiantes e seguros para compartilhar suas inspirações, suas criações e suas experiências com a poesia. Nessa última proposta de atividade, tivemos a sensação de termos nos tornado cúmplices, coautores, aliados no processo de tomada da palavra e reposicionamento subjetivo diante dos desafios que tivemos que encarar para lidar com a linguagem poética. Os relatos acima demonstraram como os alunos colocaram tudo de si para que os poemas fossem criados, como eles lidaram com seu sofrimento, suas expectativas, suas histórias de vida em forma de versos.

No exercício de revisão e reescrita, pudemos atestar novamente um belo movimento de ponto-de-giro no momento em que os alunos finalmente demonstravam se dar conta de que estavam criando poesia e de que aquilo também tinha valor, quando eu intervinha com apontamentos positivos ou propostas de reformulação, ajuda com a nomeação de suas experiências cotidianas e intrapsíquicas. Na aproximação a partir da leitura de suas produções, percebi que era necessário alcançar novos significados no imaginário social daqueles alunos a respeito da escuta das vozes que gritavam sobre exclusão, injustiça, preconceito.

Algumas produções apresentaram expressões confusas e desarticuladas, no entanto, em conversas singulares com esses alunos, conseguimos juntos encontrar meios para aproveitar o que eles haviam exposto como potência para o entusiasmo poético, reformulando um ou outro verso. Percebemos que, com o trabalho de fruição e inferência do repertório poético trazido para sala de aula, os alunos se sentiram mais capazes de elaborar reflexões sobre seus próprios processos subjetivos, históricos e singulares, que se articulavam entre angústias sobre suas experiências amorosas e sobre a problemática social e política. Os temas que trouxemos para debate representaram de certa forma a maioria dos alunos. Assim, a partir das aulas do curso de Língua Portuguesa, apostei na possibilidade de recriação de si mesmos por meio da poesia, permitindo a elaboração psíquica necessária nesse delicado momento da adolescência e propiciando as experiências de pertencimento social e afirmação étnica. A poesia os colocou em contato com o preconceito e a discriminação a partir de um novo ponto de vista: criativo, estético e lúdico.

- Quinto momento: preparação para a exposição

Ao analisar os conteúdos dos poemas produzidos pelos alunos, pudemos dividi-los em quatro principais temáticas: i.) a desilusão amorosa; ii) a resistência às opressões, principalmente com relação às questões racial e de gênero; iii) a falta de projetos de vida, 
questões sobre a identidade e a tentativa e frustração em se auto conhecer e compreender; e iv) o suicídio. Esses temas estão constantemente presentes na vida dos adolescentes, principalmente nesta geração, tensionada pelas mídias e pela quantidade de informação que recebem de diversos canais. A compreensão de sua sensibilidade, concepção de mundo e postura em relação à ordem e ao controle oscilam e se transformam cotidianamente. Eles procuram demonstrar ao grupo social a que pertencem, e no qual afirmam seu lugar de fala, uma postura de resistência, força e coragem, mas, muitas vezes, estão por dentro enfraquecidos, sentindo-se sozinhos e incompreendidos. Acreditamos que dar vazão a essa contradição, à dor e às inúmeras incertezas que preenchem a cabeça do adolescente por meio das expressões artísticas e da criação poética pode ser uma via potente para manobrar impulsos de autodestruição, transgressão descontrolada ou depressão. Percebemos com os resultados da preparação e apresentação no sarau literário a possibilidade dos alunos de renovar suas histórias de vida e expressá-las de diferentes maneiras.

Sobre os aspectos formais dos textos, notamos que os alunos avançaram no manejo dos recursos sonoros, criando paronomásias interessantes, rompendo com a concepção prévia de que todo poema deve ser estruturado por rimas ao final dos versos, explorando aliterações e anáforas dentro do efeito de contextura. Eles aprenderam também a realizar quebras inusitadas nos versos (enjambement) para produzir efeitos de ruptura, encadeamentos e manutenção do ritmo do poema. Os poemas que tiveram a autorização dos alunos para a publicação na tese foram: 

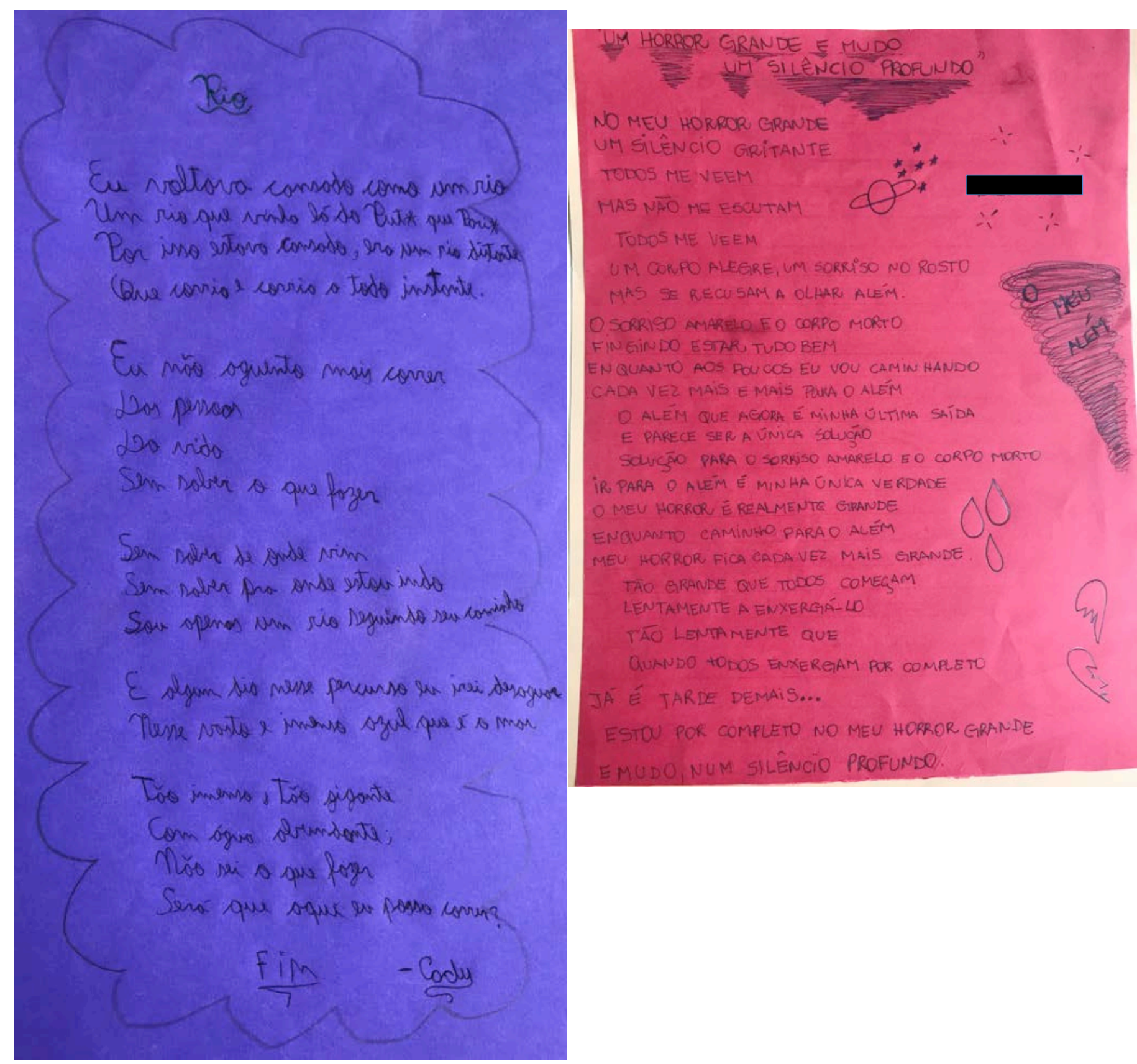

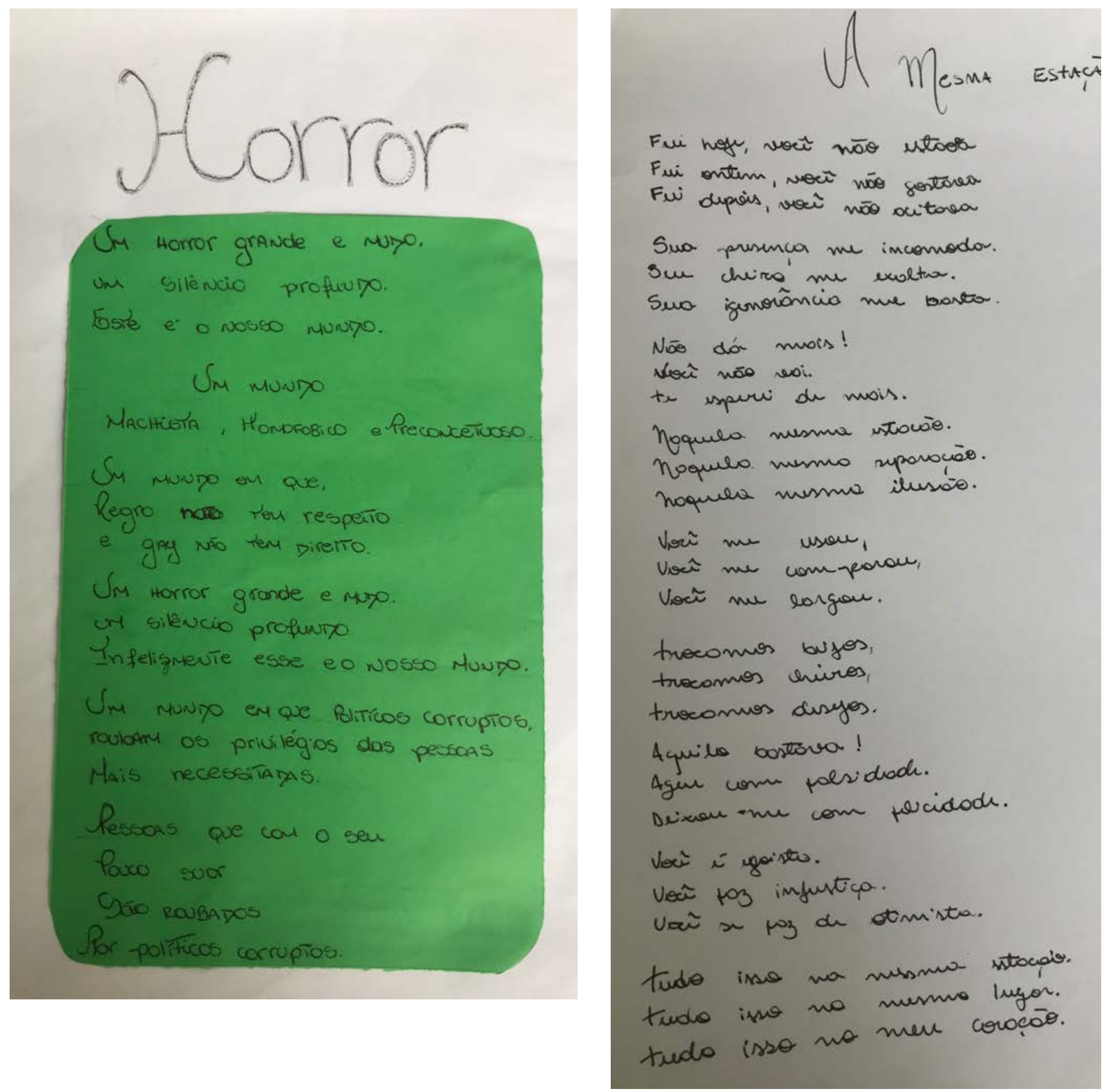
Eu sempre estáva lá

Eu sempre estive com você

Mas você nunca viu

Nunca sequer me notou.

Quando você chorou

Fui eu que sequei suas lágrimas,

Quando você caiu, fui eu que te levantei

Mas mesmo assim você nunca me viu.

Chegou um certo ponto que eu parei,

Parei de viver pra você

E comecei a viver pra mim

Fui embora, sai da tua vida,

nunca mais te vi

Muito menos soube alguma notícia tua.

E quer saber?

Eu tô bem.

Por quê ?

Porque eu sou como eu sou

E Não preciso viver pra você.

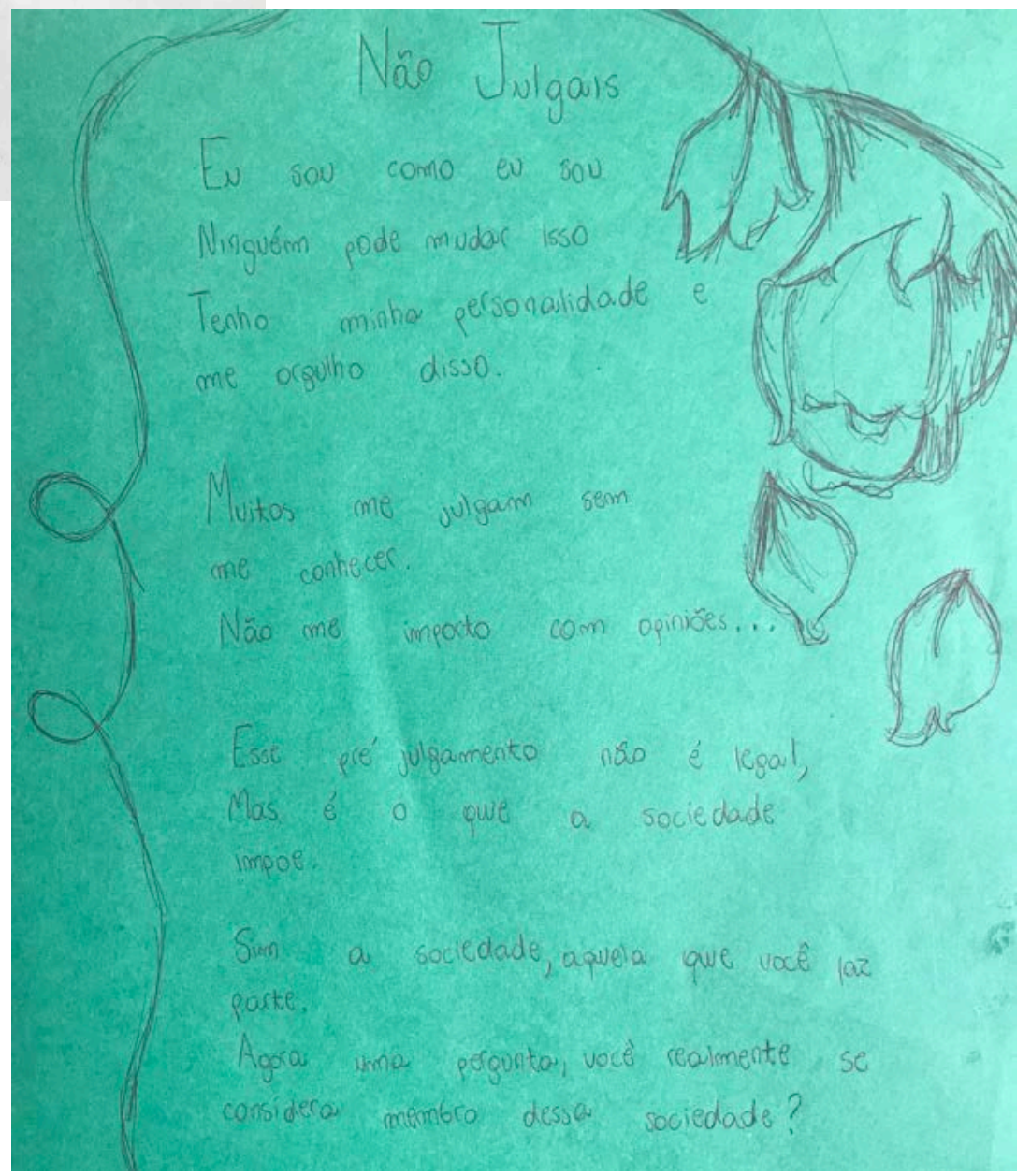


Um Horror granda e muds, Un biléncio profundo, Que abre $\theta$ escuro, Darse grande mundo

i) Grande mundo onde estró?

Aquele useu lindo ohary

O fronde mundo qui Aconteceu?

E a inocencio, desaporecen?

Por que a rrda se exconden? Aquela alma de crianca la perdens,

Por que será?

Que as criancos só querem celulor, \& nầ querem mais sobea de brincor, Será que isso nấs vai Mudory

Tudo Isso verve stó para lomplicas A vida que já nấ há, Em nentumo sergar,

Ese é grande horror mudo, Que abre o silencio profundos, Que abre no \&scura, Desse grande mundo.

294 


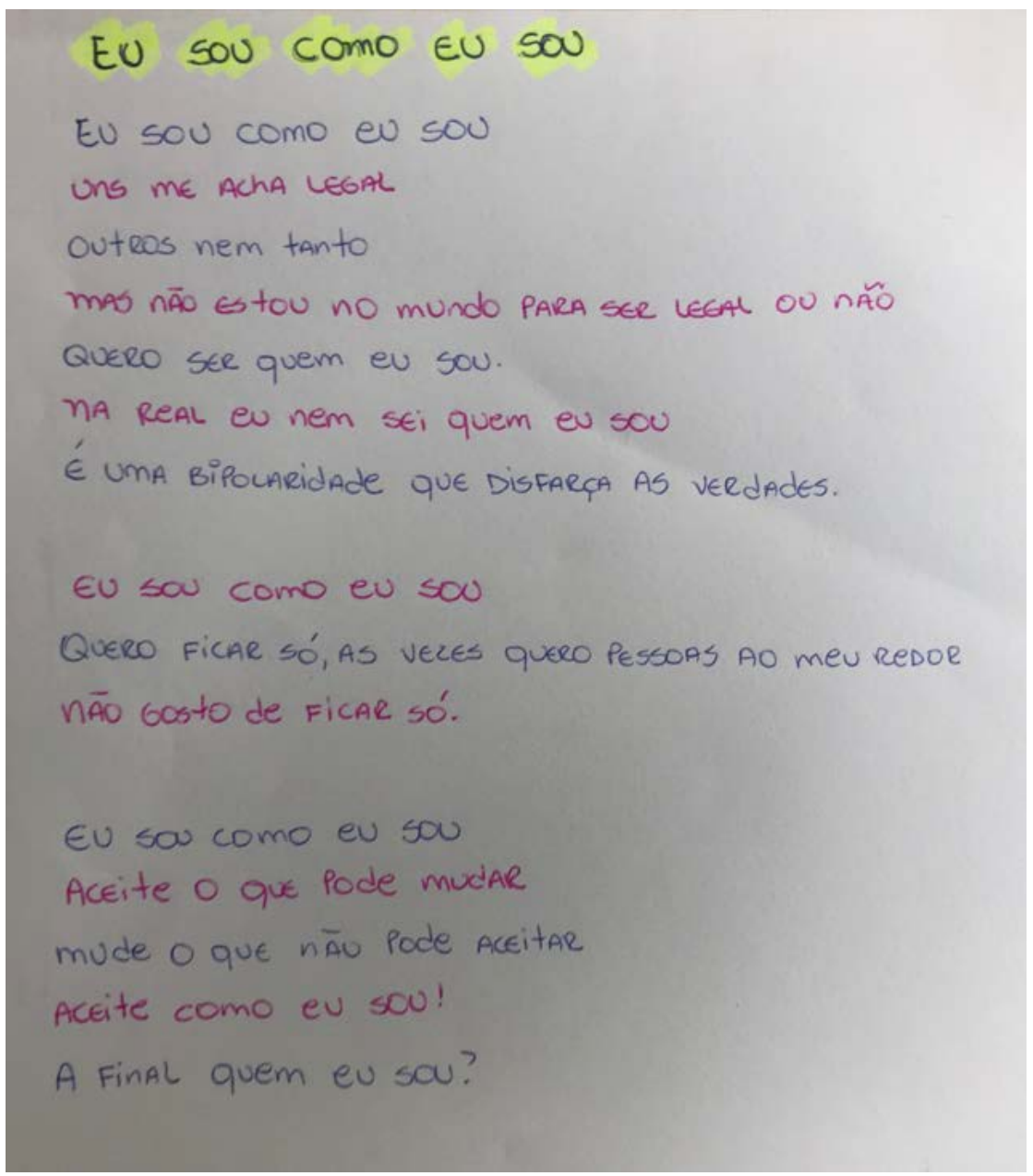

Ainda Viva

Eu estava completamente perdida

Me sentindo frágil e intensamente vazia

Uma lâmina estava em minha mão

Havia lágrimas nos meus olhos

Mas ainda não havia nenhuma gota de sangue no chão.

Viciado, meu corpo implorava por dor

Minha alma escura necessitava de cor

$O$ vermelho-sangue era a melhor opção

Mas ainda havia algo em meu coração.

Era ela, em meio ao meu caos

Ela era o único sentimento que não me deixava mal

Ela era o único sentimento que me faria desistir

E no fim, ainda estou viva, com ela dentro de mim. 


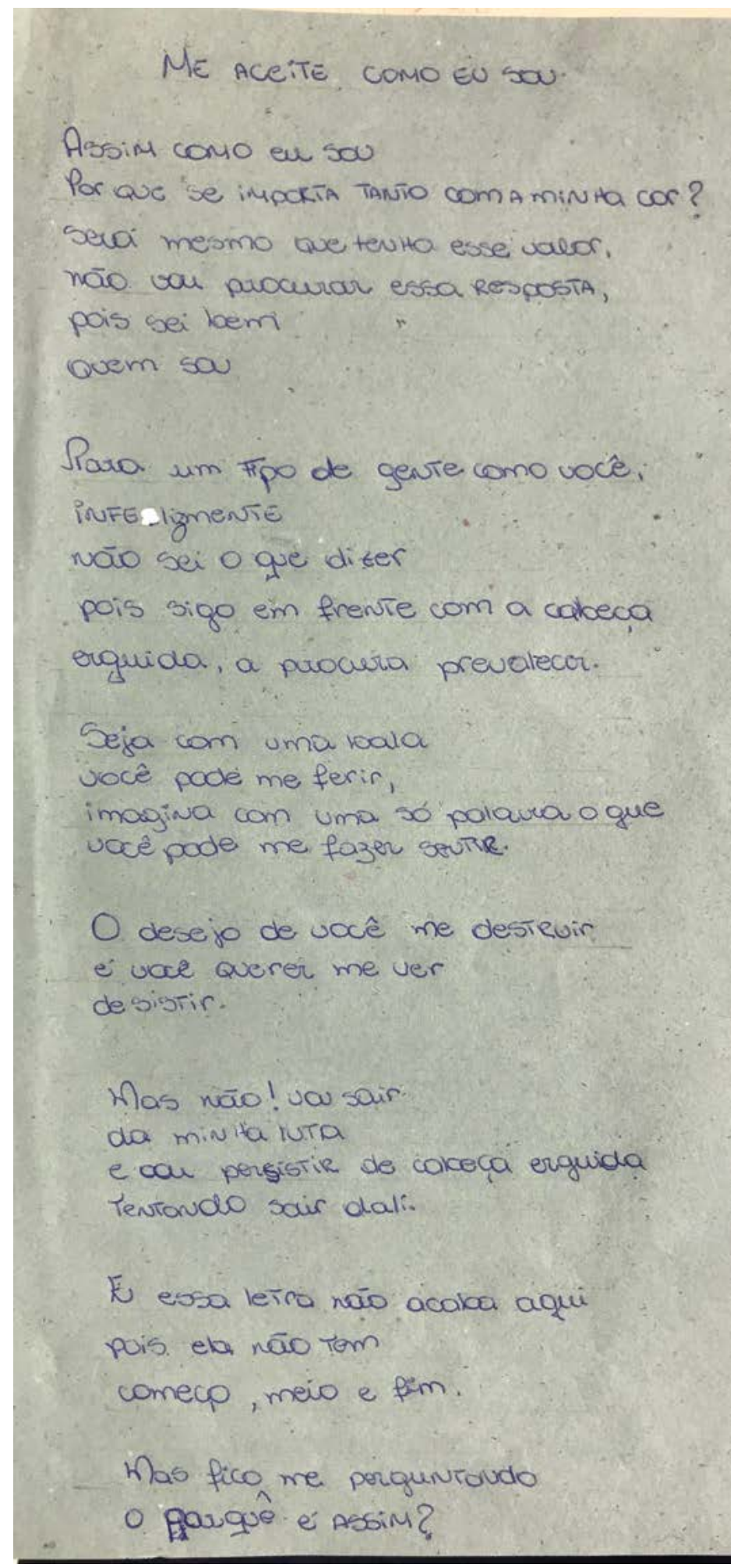




\section{Um poema e um café}

Quem faz um poema abre uma janela

Proporciona prazer a quem ler

Mostra a vida como uma flor amarela

Diferente para cada olho que a vê

Coloca sentimentos em palavras

Direciona choros e risos

Conforta a alma e até mesmo o coração

Dá novos sorrisos para rosto

Quem faz um poema mostra a vida de outro jeito

Nos proporciona momentos bons

Aqueles no qual só existe os poemas e o café

Afinal de contas, para que coisa melhor?

Poema é como libertação

Para quem escreve e para quem ler

Poemas servem como declaração

Servem para mostrar uma dor silenciosa

Quem escreve passa um sentimento

E quem ler o recebe e o reconhece em si mesmo.

Para quem escreve e para quem ler

Um poema e um café. 


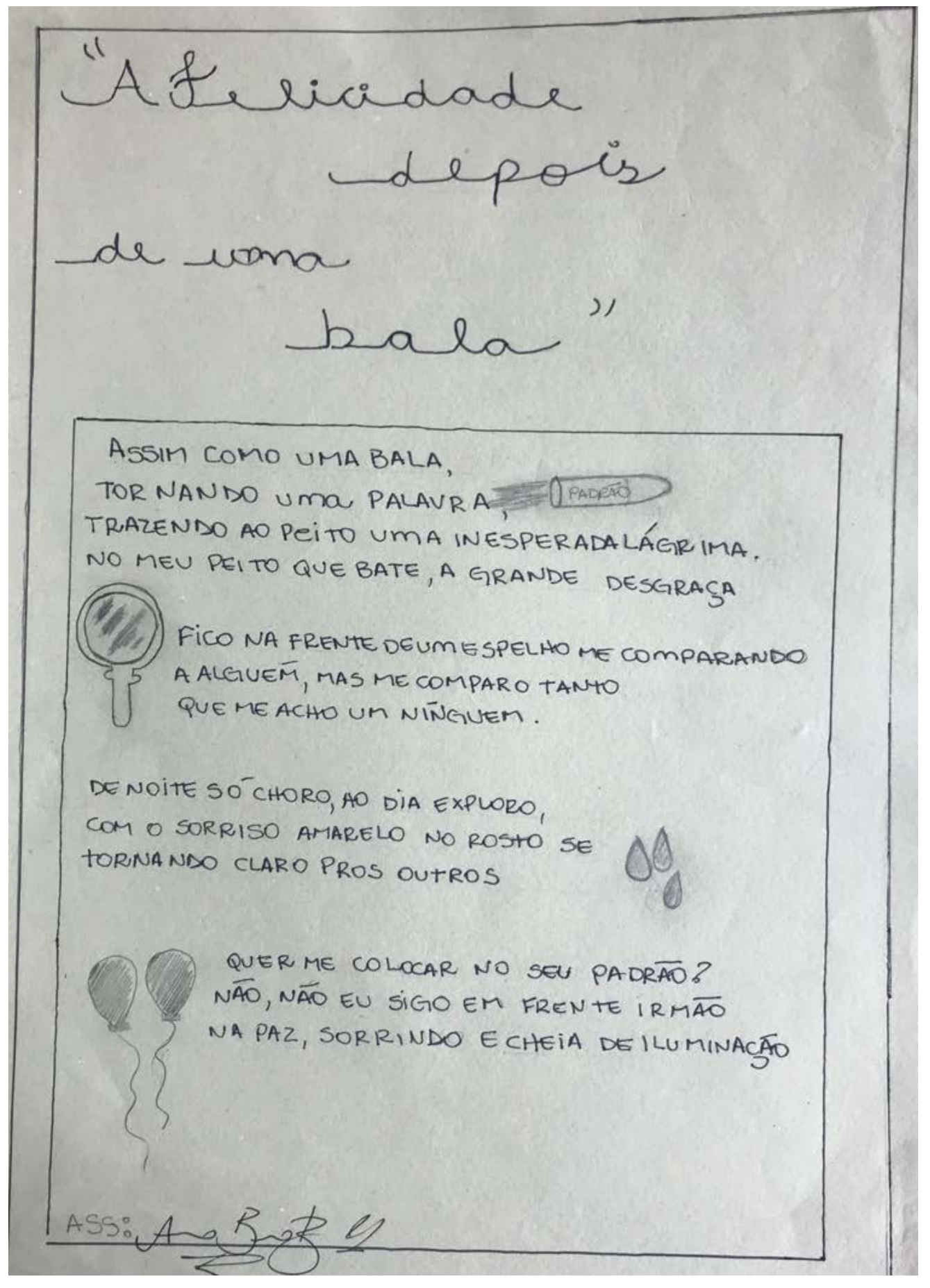

298 
Destacamos alguns versos dos poemas que testemunham o panorama temático elencado acima, como "Eu não aguento mais correr/ das pessoas/ da vida/ sem saber o que fazer" e "Fico na frente do espelho me comparando a algúem,/ mas me comparo tanto/ que me acho um ninguém", que apontam para a necessidade do eu lírico de encontrar um equilíbrio, um juízo e sensatez para tomar decisões, para se identificar enquanto sujeito ativo na sociedade e poder exercer sua individualidade, rompendo com a ordem estandardizada e normatizada de se portar, falar, atuar e desejar. Já os versos "porque eu sou como eu sou/ e não preciso viver para você", "me aceite como sou" e "quer me colocar no seu padrão?/ não, não, eu sigo em frente irmão" demonstram uma postura mais enérgica e incisiva de resistência e negação, de um eu lírico que não pretende se emoldurar e se encarcerar nos padrões impostos tanto pelos amigos, quanto pela sociedade em geral. Observamos nos poemas um movimento oscilatório de renúncia à tentativa de mudança e transformação e de levante e ímpeto à luta que despontou como estímulo para a produção poética. Reflexões como "esse pré julgamento não é legal/ mas é o que a sociedade impõe", "porque se importar tanto com a minha cor?" e "afinal, quem eu sou?" aparecem nos poemas como motivação para transfigurar a dor e para encarar a realidade que os assombra.

Assim, notamos a partir das produções apresentadas que, em muitos casos, o eu lírico demonstra um sentimento de desencanto e melancolia, vendo-se afastado das possibilidades de transformação, progresso e ascensão social. Por outro lado, em alguns poemas com vozes femininas, reparamos na postura intransigente diante dos problemas impelidos pela sociedade patriarcal, resultando na produção de versos insurgentes, radicais e transgressores. $\mathrm{O}$ extremo da desesperança pode ser experimentado nos versos "O além que é minha última saída/ minha única solução"e "Viciado, meu corpo implorava por dor/ minha alma escura necessitava de cor/ vermelho-sangue era a melhor opção". No desespero para encerrar o sofrimento e fazer a dor parar, o eu lírico encontra uma solução fatal, um impulso que substitui a palavra, o pedido de ajuda, o ato de ceder a crença de que ele não precisa recorrer a ninguém, pois é possível resolver tudo sozinho. A dor de viver na fase adolescente é difícil de ser declarada e confessada por um jovem a um adulto, principalmente quando esse adulto é o pai ou a mãe, pois o adolescente receia perder sua liberdade conquistada e, ao mesmo tempo, sofre com tantos arquétipos e exemplos que tem de seguir.

Nos versos "Um mundo em que/ negro não tem respeito/ e gay não tem direito", o eu lírico escancara a verdade do cotidiano de jovens que estão cada vez mais perdendo seu espaço, sua segurança, seus direitos, pois não podem ser o que desejam e não podem estar em 
lugares em que a ordem social e econômica os rejeita e os marginaliza. Assim, estimulado pela busca de seu lugar de fala e afirmação de sua cultura e tradição, o poema aparece para o eu lírico como potencial transgressor e libertário: "Quem faz um poema abre uma janela", "coloca sentimentos em palavras", "quem faz um poema mostra a vida de outro jeito", afinal, "poema é como libertação/ para quem escreve e para quem lê/ poemas servem como declaração/ servem para mostrar uma dor silenciosa".

Nesta proposta final de produção poética para o sarau, os alunos foram capazes de se reinventar através de recursos artísticos e performáticos, combinando a expressão política e engajada com a elaboração de versos intensos que os auxiliaram na extensão de seus princípios, na fecundação de suas raízes e na ramificação de suas dores, isto é, na concepção e no projeto coletivo bem representados na ilustração de um aluno, utilizada como capa para o convite do evento "O que te move?":

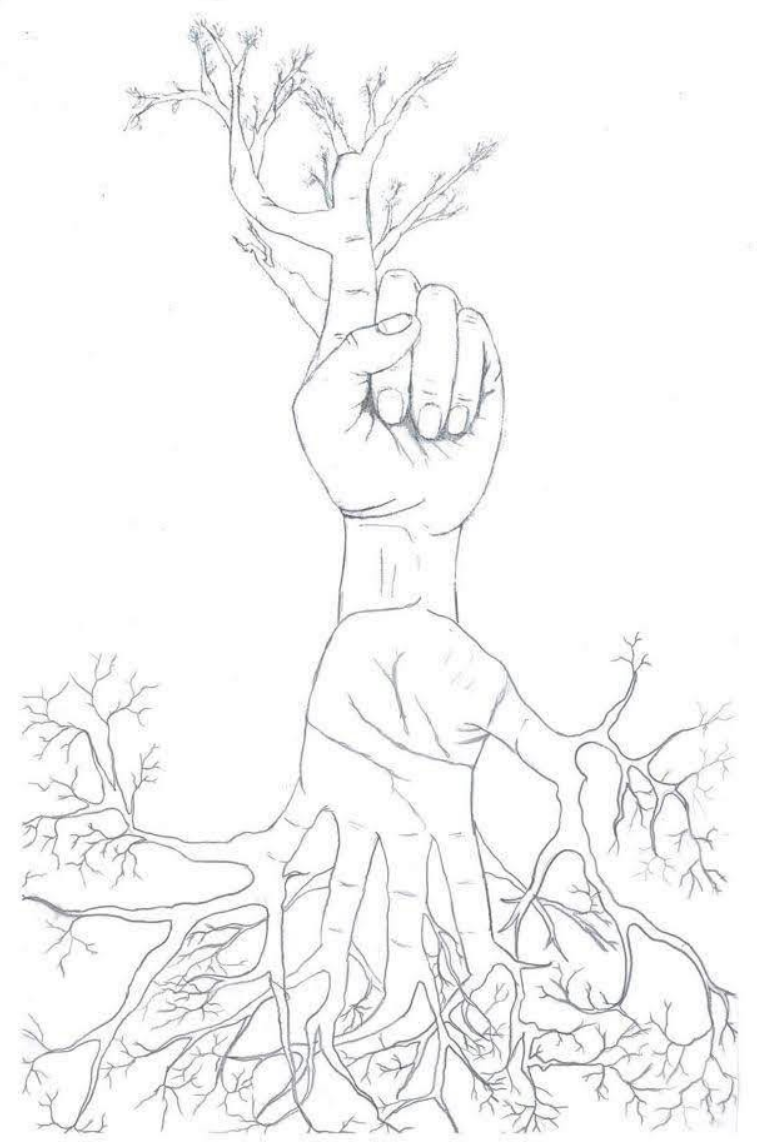

FIGURA 11. ILUSTRAÇÃO PARA O PANFLETO DO SARAU "O QUE TE MOVE?" 
O dedo em riste, tanto como sinal para pedir o direito à palavra, quanto para denunciar, apontar o problema e revelar a verdade, está apoiado na palma da mão aberta enraizada na tradição daqueles que representam a riqueza cultural de nosso país. Com essa ilustração, os alunos tiveram a intenção de simbolizar o vínculo da existência com a necessidade de resistência, de reinvenção do passado para se apropriar do futuro, combatendo a problemática do preconceito e da discriminação.

No total, foram produzidos trinta e oito poemas para a apresentação no sarau e, após o evento, tivemos a oportunidade de realizar outras atividades de troca entre os colegas e revisão para aperfeiçoamento das produções. Como resultado do primeiro sarau após a sequência didática aplicada, pudemos notar uma evolução na escrita e nas formas de expressão, principalmente na riqueza das figuras sonoras que os alunos procuraram explorar em seus poemas. No curso de Língua Portuguesa, pontuamos aspectos linguísticos a serem aprimorados no ano seguinte. Os alunos se sentiram bem representados pelas poesias e resolveram participar da Mostra de Artes e Ciências da Escola Alef Peretz na Unidade Hebraica, demonstrando grande interesse em montar novos projetos de escrita poética. $\mathrm{Na}$ Mostra, além dos poemas, exibimos também o vídeo que produzimos no dia do sarau na laje da escola, com as declamações e performances de todas as produções poéticas dos alunos que se sentiram à vontade para a exposição. 


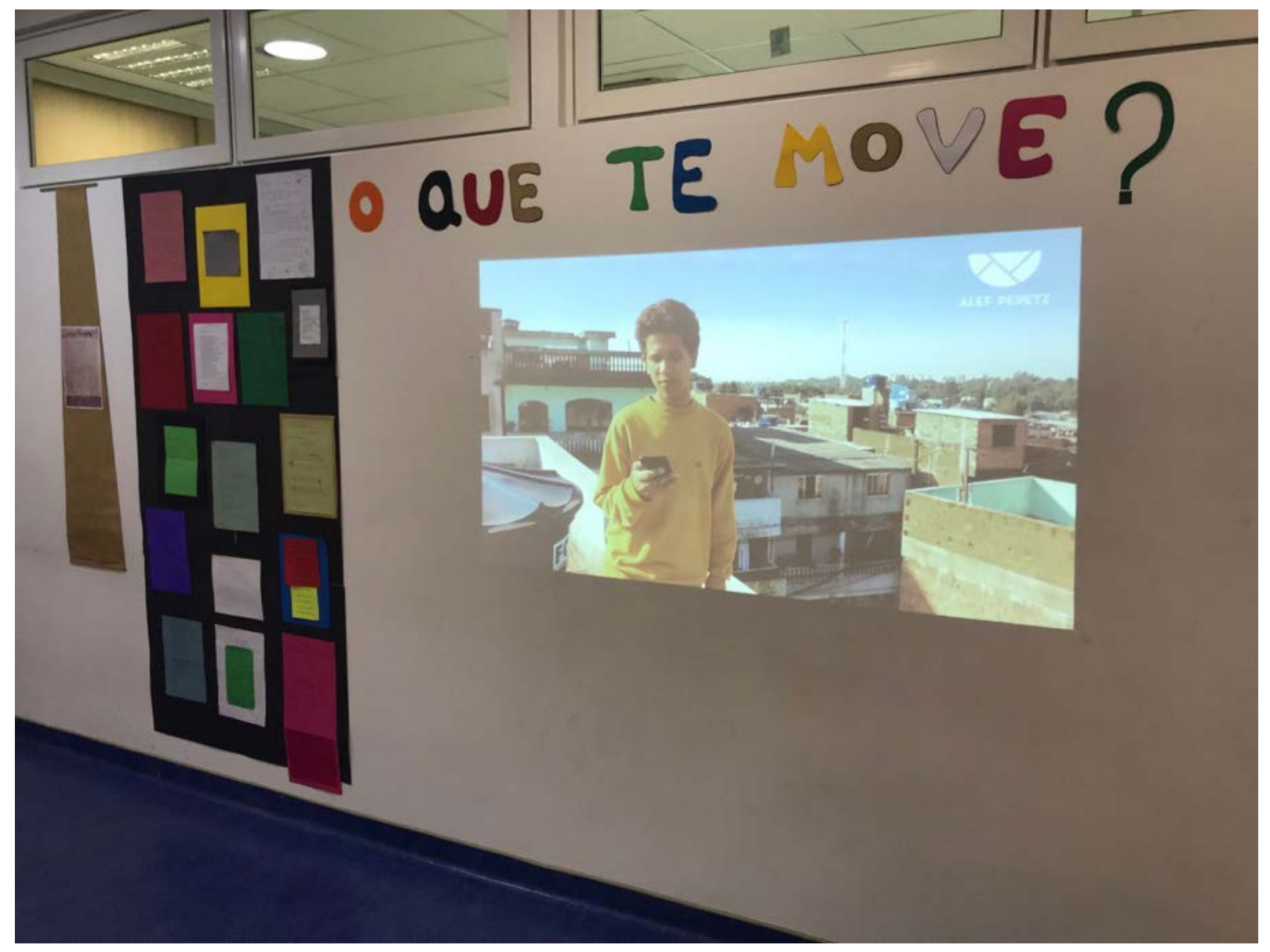

\section{FIGURA 12. FOTO DA EXPOSIÇÃO DE POEMAS NA MOSTRA DE ARTES E} CIÊNCIAS

No último dia de aula, os alunos resolveram grafitar o título do projeto na parede da escola, como relatou a aluna Raquel ${ }^{40}$ no e-mail enviado a mim: "Olá professora, hoje veio um grafiteiro aqui na escola e fizemos algumas grafitagens com ele. O mesmo pediu para escolhermos uma frase para fazer, eu sugeri a frase que a senhora utilizou no sarau (quis fazer uma pequena homenagem à senhora e ao nosso projeto de poemas). Com a concordância dos demais, a frase foi escrita na parede!".

\footnotetext{
${ }^{40}$ Os nomes dos alunos apresentados a seguir são fíctícios com o intuito de preservar a identidade dos sujeitos da pesquisa.
} 


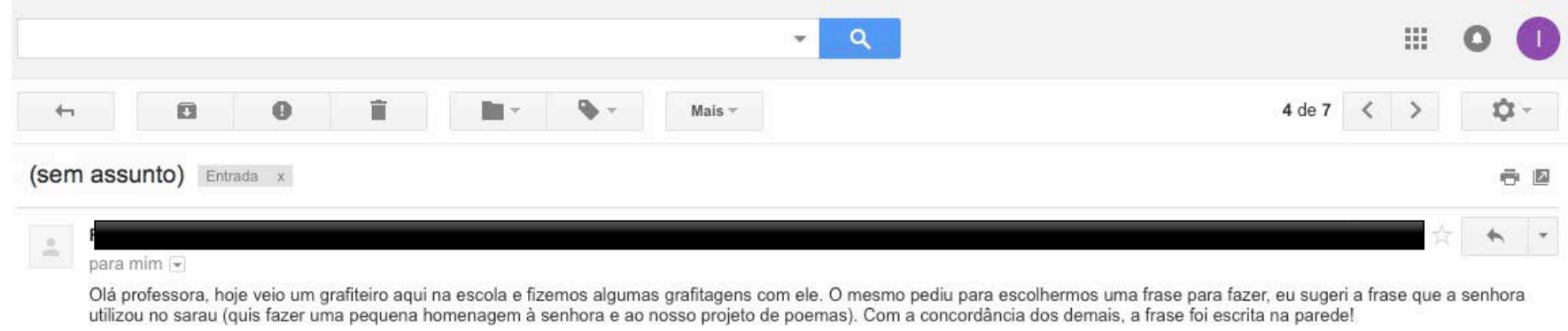

utilizou no sarau (quis fazer uma pequena homenagem à senhora e ao nosso projeto de poemas). Com a concordância dos demais, a frase foi escrita na parede!

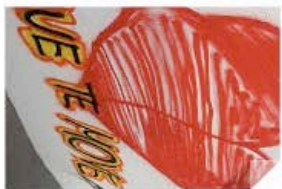

FIGURA 13. E-MAIL DA ALUNA RAQUEL

O evento condensou o esforço e a disposição para nomear a discriminação, a dor e os conflitos subjetivos dos nossos alunos diante dos desafios da leitura e escrita, trabalhados durante todo o ano letivo por meio de um repertório vasto, de inferências intrapsíquicas e de compartilhamento constante das experiências de aprendizagem, resultando em um belo trabalho de criação poética. Nesse movimento, a metodologia da corporalidade e do ponto-degiro foram fundamentais para que eu pudesse atuar, auxiliando na nomeação de um imaginário social por vezes confuso e na reelaboração psíquica necessária em um momento delicado de suas vidas.

Outro aspecto da proposta metodológica do curso destacado no sarau foi o investimento da performance oral e gestual presente nos exercícios das aulas. Os alunos se mostraram bastante envolvidos e soltos com a participação do corpo e da voz nos momentos de declamação, teatralização e percepção espacial diante de um público amplo, porém muito acolhedor e receptivo. No evento, eles puderam sentir na pele que a declamação oral da poesia nos permite tocar o outro e sentir nós mesmos de uma maneira mais implicada e sinestésica, pois quando o outro nos escuta, aproximamo-nos de uma escuta interna, de um retorno a nós mesmos, dinamizando corpo e sujeito em uma relação de alteridade viva na comunicação poética.

Por fim, na intenção de existir e resistir com o auxílio da tomada da palavra, os alunos foram capazes de compartilhar imponentemente suas produções, exercendo um distinto trabalho de emancipação intelectual, em que letramento, poesia e engajamento político se 
atrelaram em um só discurso, justamente no espaço e tempo que caminham progressivamente para o abandono da escuta dessas vozes, silenciando-as (através de uma política repressora do Estado) ou ignorando-as (através das novas demandas da Escola neoliberal).

\section{Veia artística, essência poética}

O poema é solitário. É solitário e vai a caminho. Quem o escreve torna-se parte integrante dele. Paul Celan (1958) ${ }^{41}$.

Paraisópolis, como já afirmado anteriormente, é um bairro onde a poesia pulsa e transborda pelas esquinas, sobretudo após a expansão dos saraus na década de noventa, nos quais a produção literária da cultura periférica pôde se apresentar a um público sedento por eventos em que corpo e voz estivessem livres para atuar, sem risco de serem silenciados pelo poder repressor. Logo, nossos alunos já haviam tido contato com algumas performances poéticas em sua própria comunidade ou em bairros próximos, como no Capão Redondo e na Vila das Belezas. A partir das vivências que acumularam nos saraus vizinhos enquanto iniciavam o Ensino Médio na Escola Alef Peretz, alguns alunos se juntaram para organizar, no ano de 2017, o sarau "Poerifa", espaço destinado aos alunos da escola para declamação de seus poemas e apresentação de suas letras de rap. Quando fui convidada para dar aula na unidade de Paraisópolis, os alunos Patrícia e Heitor, oriundos da EMEF Dom Veremundo Toth, compartilharam as experiências do sarau da escola e os desdobramentos decorrentes da presença frequente de nossos alunos no Sarau do Instituto Crescente e da Cooperifa. No ano em que nossos alunos atuaram no sarau "O que te move?", oriundo das produções realizadas no curso de Língua Portuguesa apresentado nesta tese, o sarau "Poerifa" já não contava com a mesma estrutura de organização, mas pudemos incluir a ajuda e a experiência dos alunos do segundo e terceiro ano do Ensino Médio para organizar um só sarau, convidando e reunindo todos os alunos da Unidade de Paraisópolis que tinham a intenção de compartilhar suas poesias ou de ver e ouvir a performance de seus colegas.

No projeto de síntese do Ensino Médio, a aluna Flávia e o aluno Heitor escolheram investigar o que era literatura marginal e quais eram as possibilidades de produção literária na

\footnotetext{
${ }^{41}$ In: Arte Poética. Meridiano e outros textos. Ed. Cotovia, Lisboa, 1996.
} 
comunidade de Paraisópolis. A aluna Flávia levou o projeto e a pesquisa científica adiante, orientanda pela professora Tatiana Albergaria, e pôde apresentar e defender seu trabalho (trechos no Anexo 4) em diversas feiras de ciências no Brasil, como a FEBRACE e a MILSET. O trabalho tinha como objetivo investigar e analisar as produções poéticas dos alunos de Paraisópolis e defender a hipótese de que há luta e resistência para os jovens da periferia produzirem poesia e arte. A pesquisa de síntese da aluna Flávia ganhou grande repercussão na comunidade e inaugurou o espaço para troca de produções poéticas com ajuda de outros alunos que passaram a se ver como autores.

A seguir apresentaremos alguns poemas ${ }^{42}$ dos alunos organizadores do Projeto Sarau Literário "Poerifa" que não estavam matriculados no curso de Língua Portuguesa (com excessão da aluna Raquel), pois eles já estavam no segundo ou terceiro ano do Ensino Médio, mas alguns participavam, como alunos convidados, ativamente de atividades com o texto poético e até mesmo frequentavam minhas aulas do primeiro ano devido a seu interesse pelo conteúdo do curso. Isso era possível, pois as aulas do primeiro ano eram no período da tarde em um dia que na grade do segundo não havia compromisso curricular. O contato disciplinar que tive com esses alunos foi através do projeto de síntese da escola, como orientadora ou arguidora nas bancas de avaliação dos trabalhos. Com frequência, também nos encontrávamos no pátio da escola para conversar sobre as produções que eles me enviavam para apreciação e correção e mantínhamos uma boa comunicação por e-mail. Heitor, Patrícia e Raquel me enviavam poemas todo mês, assim, nosso contato se estendeu para além do projeto de síntese, pois eu me encontrava semanalmente com eles para discutir suas produções, apresentando minhas análises e sugestões. Seguem exemplos desse diálogo e também de outras trocas com alunos que já estavam em contato com a produção poética:

\section{Autor: Heitor}

1) Sem título

Eu apenas com meu cigarro de canto de boca, tenho só o tabaquento desfigurado e retumbando solidão.

O gosto do prazer, Desprazerou em outros lábios.

\footnotetext{
${ }^{42}$ As variações ortográficas foram mantidas em respeito à versão original entregue. Como os poemas foram declamados e performatizados, não fiz apontamentos ortográficos na devolutiva dos trabalhos, apenas oralmente em conversas particulares com os alunos.
} 
Em outros corpos.

Cheio só meu pulmão que tragou a noite.

E o amanhecer degradê.

O que resta é sentir a realidade que beija meu rosto maquiado em momentos de euforia mental.

Venho lhe dizer sobre as peripécias dos desejos, em relação ao carnal e físico que foram frustrados.

Dói!

Dói, todos os atos que mói a libido não consentido.

O beijo olhar esperançoso, não visto, o sorriso de canto conversando com o teu sorriso.

Perdido.

$\mathrm{O}$ aceno de tchau na esquina.

- Você levando a menina, maquinando o conquistado.

- E eu aqui na ruela a margem com tragos, cara manchada de derrota e vergonha.

Tendo de companhia palavras que vem acompanhado a situação como um medíocre leitor... Amanhece tenho de ir para casa.

\section{2) Sem título}

Eu quero sentir a solidão do mundo enquanto ele está acordando.

Em que borboletas frias forram o asfalto em plena manhã de sábado.

Andorinhas fúnebres,

Trissam superficialmente sobre a pele da manhã cinzenta.

A qual está abarrotada pelo cheiro de enterro e imparcialidade carnal.

Pelo surto repentino do meu miocárdio incessante.

Peço que me deixe aproveitar a solidão do mundo, com minha saliva e dívida.

Para que eu possa cuspir na praça do meu próprio espetáculo de vida.

E arrotar mais vendo a azia da cidade.

Que de tão mundo tá cheio.

Vasto.

Eu sinto meu chegar ao mudo.

\section{3) Sem título}

Abrir o livro do passado.

Lê-lo deprimido.

Dar três passos na rua totalmente despido.

Despido de esperança, a paciência é importante, mas chega uma hora que cansa.

Acelera aí, tá muito devagar, os fatos não movem mais você que criou raizes no sofá.

Conhecer a realidade, porém fingir não ver.

Criar seu próprio alienador que só quer ferrar com você.

Eles têm dinheiro? Têm. Eles têm mansões? Têm.

Eles têm carrões, têm, então por que diabos iriam querer nos transformar em alguém.

Querem tudo do jeito que está.

Poluir a sua mente através do seu globo ocular, recorde mundial de audiência, na avenida

bandeirantes zumbis marcam presença.

Travaram o trânsito, o trânsito de emoção.

É muita concorrência aja coração. 
Enquanto o povo continua a sofre, paciência tá tendo no momento que não era pra ter, não se envolve, não mudam as atitudes, vamos cadê o gigante?

Perdeu suas virtudes.

Não sou eu quem vai responder, mas não volto pro sofá esperando alguém por mim fazer.

\section{4) Substância Política}

Não há em data certa o momento em que nos tornamos tristes e solitários.

Não há instante eminente que descasca a alegria e a comunhão da vida de nós

Há quem diga que basta qualquer choque e já está de fato diante do decair.

E outros que juram que é segredo, esse estado de ser e poeta.

Nem mesmo o assinar de caneta do papel é suficiente para dizer acerca do momento em que nos tornamos tristes e solitários.

\section{5) Sem título}

Não há mais nada sublime que os cantos dos bem-te-vis.

Que vê e não diz. (E se disses o que diria?)

Esta acima dos telhados e das cousas como a falsa certeza;

o anil que cobre o homem e a vida.

Sai por aí a gritar; bem te vi, bem te vi, bem te vi, eu ao olhar para os lados mal via nada.

Não, não há revelação! Por estar eu calcando

Simultâneamente o chão só, tenho de pomos o correr o além, que ali na frente não chega. Ter medo, eu? Não criei lealdade em nada.

Para que a única coisa que pudessem correr de mim, fosse a certeza de que nada poderiam cobrar.

Os pássaros não têm os pés no chão, não com canto e o vôo.

Pudesse eu ter a irmandade com liberdade, pudesse eu cantar com o mesmo tenor com que cantas e voa.

Bem que queria me ver, com a mesma dualidade do agir e ser.

Só espelhos e faces, quisesse eu me encontrar como coisa bem vista e não margem do que visto.

Não o cabe a mim dizer.

Porque bem vejo, mas não sou eu que bem me vê.

\section{Síntese da análise dos poemas discutida com o aluno}

Heitor foi o aluno-autor mais prolífico dentre seu gênero, mantendo uma produção regular ao longo de todo ano. Ele não mantinha assiduidade em todos os cursos, mas 
demonstrava grande interesse pelas aulas da área de Ciências Humanas. Pela quantidade de faltas e pela ausência nas avaliações, Heitor reprovou a segunda série e, no ano de 2018, passou por dificuldades em se adaptar à rotina escolar sem o acompanhamento de sua turma de amigos, mas continuou investindo em suas produções literárias. Pudemos, por isso, não apenas analisar seus poemas a partir de cada produção, mas lê-los de modo transversal, sendo possível até aferir uma transformação no interior de seu fazer poético. Em linhas gerais, o percurso delineado entre o primeiro e o último poema é claro: tem início na constatação da solidão, em um sentido amplo e ambíguo, e termina com a preocupação com a liberdade, que também vem expressa polissemicamente. Vejamos como em cada poema ele desenvolve sua temática para depois retomar o sentido de sua produção global.

Seu primeiro poema trata diretamente da solidão, uma solidão que aparece sempre em uma dimensão não apenas corporalizada, mas francamente libidinal. O enquadramento da ação da reflexão que move o eu lírico é extremamente precisa e situa este personagem entre o consumo de um cigarro até a constatação, cada vez mais clara, de que a manhã impõe um ato de despedida. Temos assim um arco de desenvolvimento que parte do sujeito mergulhado em uma experiência sensível e que, a partir desta experiência, toma conta de movimentos mais profundos de seu desejo até ser forçosamente contraposto à imposição da realidade implacável, que aparece sob o ritmo da natureza; sob o signo do nascer do sol. O primeiro verso, dividido em duas partes, já é síntese do que ocorrerá na passagem da experiência sensível para a experiência da consciência libidinal. O "cigarro de canto de boca", marcado pelo passo rápido das consoantes interpoladas pelo "de", cede lugar imediatamente a uma lamuriosa solidão, que se prolonga de modo "tabaquento" e "retumbante", prolongamento "desfigurado" da experiência do fumo, desnecessária até a inclusão da solidão, que em grande medida já fora circunscrita por todo o desenrolar deste quadro que se iniciou qualificando-se de "apenas". De qualquer modo, na medida em que o sujeito se alonga, o tabaco passa de objeto do prazer a conceito do prazer e os órgãos do corpo passam ao lugar dos objetos. $\mathrm{O}$ destino do sentimento de uma solidão impotente é o desejo em si, um desejo que se mobiliza pelo gosto e pela boca. Do cigarro vamos à boca, da boca ao gosto, do gosto ao prazer e do prazer ao corpo. Tudo aponta para um desejo vacilante, que quando tenta precisar o cerne de sua solidão, passa incessantemente do corpo ao sentido do desejo, e do desejo de volta ao corpo. O prazer do corpo, no entanto, não se realiza como o do cigarro, ou melhor, realiza-se apenas fora deste sujeito, de modo que se converte em seu oposto. Agora, no entanto, ao retomar o prazer do cigarro em um trago, o que advém não é a sensação da simples solidão, 
mas a solidão de estar em meio ao mundo, denunciada pela noite. "Tragar a noite" é perceberse da noite, dar-se conta da existência da noite como elemento externo a este sujeito. Interessante é, no entanto, que em contraposição ao tragar da noite, aparece o dégradé da manhã. Nota-se que o aparecimento da manhã vem após uma ação do sujeito, e não apenas como um reforço de sua impotência solitária. Ao intercalar o modo como o eu lírico traga a noite e enche os pulmões com um amanhecer que aparece lentamente, é como se a cada segundo de ar sugado se abrisse espaço, no mundo, para a luz. O princípio da realidade ("realidade") aparece ainda com mais clareza depois da entrada da manhã e parece mesclar confusamente os princípios de corpo ("beija meu rosto maquiado") e consciência ("momentos de euforia mental"). Tendo terminado neste ponto, talvez ligando-o diretamente ao último verso, teríamos já um poema completo. A realidade da manhã faria com que o sujeito se movesse e saísse de cena, consolidando o movimento iniciado pelo primeiro verso e mantendo a ambiguidade da despedida frente à realidade, em certa medida produzida pelo próprio sujeito. Os versos que aparecem entre a realidade das duas "manhãs" apenas repetem o mote da solidão, retirando, no entanto, o cerne do movimento do sujeito que animou o início do poema. O que "dói todos os atos que mói a libído não consentido" corre o risco, aí, de tornar-se mero lamento de um coração injustiçado, o que atesta contra o sujeito que produz sentidos do início do poema.

O segundo poema inicia, após a expressão de desejo do eu lírico (“quero"), com cinco versos pautados pela oposição, à semelhança do primeiro poema, entre a manhã e seu oposto. O mundo que acorda, as andorinhas e as borboletas e o sábado de manhã se opõem à frieza, à solidão e ao aspecto fúnebre. Toda essa solidão está atrelada, também de modo semelhante ao do poema anterior, à imparcialidade carnal, ou seja, na impossibilidade da realização libidinal do sujeito. A partir do desenrolar da manhã, volta a voz do sujeito, que agora, ao invés de querer, talvez a partir da constatação da impossibilidade de seu querer, "pede". Mas o que ele pede não é nada além do que o mundo já lhe reserva: a solidão. No entanto, agora, este eu lírico pretende atuar no mundo, através da exacerbação de seu próprio desejo interrompido. De sua boca sai o desejo que, em forma de saliva, já se torna imediatamente cuspe, escárnio do mundo que lhe imbuiu o desejo. É como se, diante da impossibilidade, ao invés de recuar, o sujeito avança com tudo o que lhe pertence, retorcendo escatologicamente aquilo que o mundo lhe provoca. Um ato de coragem que, apesar de substituir o ressentimento pelo heroísmo da decisão, atesta seu próprio desamparo ao "chegar ao mundo" apenas de modo como o mundo lhe permite. 
O quarto poema já mostra a passagem da solidão e falta de direção dos dois primeiros para a busca de um sentido de empoderamento. A solidão aparece apenas como momento, apesar de não identificável, e que deve ser tratado pelo poeta, que em sua tentativa procura dar sentido a esse momento indeterminado. Mais sugestivo ainda é o contraste entre o título (este foi o único poema que o autor mandou com título) e o conteúdo do poema. Apesar de não tocar diretamente no assunto, o título dá a entender que a substância política, talvez a substância da política, está justamente na tentativa de capturar o momento e elaborar a gênese da tristeza e da solidão. Assim, o trabalho deste luto não apenas diz respeito ao sujeito, ou mesmo ao poeta, e adquire um caráter, ainda que como indício, de uma preocupação social maior. O último poema é o único em que a possibilidade da liberdade aparece de maneira concreta, encarnada no voo do bem-te-vi. Ainda que se expresse na dimensão de um desejo de conquistar despreocupadamente os céus, a liberdade é vislumbrada pelo eu lírico com clareza, calcada no desejo de unificar "ser e agir". Toda a dualidade entre esses dois polos é atravessada pelo sentido da visão. O pássaro não é apenas aquele que canta bem, mas o que "vê bem". A dialética desse olhar que sabe que é preciso ver-se como algo que ainda não se vê nada mais é do que a tomada de consciência profunda do olhar. Assim, começa a se configurar não apenas uma nova imagem de si, que se reafirma enquanto apartado do mundo e, por isso mesmo, é crítico do mundo, mas também o objetivo de liberdade almejado.

No ano de sua formatura no Ensino Médio, foi com as características do bem-te-vi de seu poema que Heitor se mostrou aos professores. Enxergamos nitidamente em seu semblante a aspiração de uma emancipação conquistada, do tenor do canto e do voo do pássaro que o eulírico tanto quis experimentar, da leve dualidade do agir e ser em seu caminhar, agora presente em um chão firme que pôde guiá-lo para a liberdade. Observar Heitor alçando voo foi para mim uma forte emoção durante a pesquisa.

\section{Autor: Daniel}

Ítalo

A bala atravessou meu crânio

Não é a luz que permeia meus encantos

Ainda nem chegada a mim

Quando resistia ao atrito do gatilho,

Ao dedo desumano, levava eu, humano.

Quando a resistência se desfez e o 
Dedo deslizou, feito, feito a mão

Mergulhado em água

Nada impediria o destino da bala.

Destino esse traçado por um cara

Fio a fio, linha a linha, palavra a palavra, quando me simplifica

A marginal, a qualquer menino mal.

Mal vestido, mal educado, mal colocado,

Mal informado, mal encarado.

A bala tem destino certo quando você é revestido de mal

Suas asas se abrem para encontrar morada certa,

E pra não ter erro

É na cabeça que ela mira

É na cuca que ela se encaminha

É nas ideais que ela se finda

Pra não deixar vestígios de quem fui,

Eu perco nome, não figuro no mapa e se

Dou um ultimo suspiro, levo

Tapa na cara que é pra ser morte na certa.

É pra findar o molequinho é pra fazer o

Crânio ninho de bala

$\mathrm{Na}$ testa não bate na porta

Entra tirando sangue, e se sai,

Vai rasgando meus sonhos em estilhaços,

Não deixando um pedaço, se fica, são

Sobras dos pesadelos, meus medos.

Tão pequenos que se envolvem em meio ao Sangue que ainda desfila por dentro de mim Mas se tem bala voando pra fora de mim

Tem sangue espirando pelo ar

Tem por lá uns sonhos que queria te contar;

- Eu queria ser jogador de futebol - Goooool

- Eu queria ter uma mochila de rodinha

- Eu queria ir pra escola

- Eu queria conhecer meu pai

- Eu queria mistura todos os dias

- Eu queria crescer...

- Eu também!

Não sei se o joelho dobrou, ou se só

O corpo tombou, só sei que não tem

Mais eu em pé, não tem brilho no canto do rosto,

Nenhuma mão a secar e muito 
Menos um mundo pra olhar.

\section{Síntese da análise do poema discutida com o aluno}

Daniel, ao longo de todo percurso do Ensino Médio, foi um aluno considerado pelos professores como exemplar, com boas notas e ótimo desempenho em sala de aula. O contato que tive com sua produção poética foi através do trabalho de síntese da aluna Flávia. Ele escreveu um poema sobre Ítalo Ferreira de Jesus Siqueira, jovem de 10 anos assassinado com um tiro na cabeça pela Polícia Militar, em 2016. Todo o poema é pautado pela voz de Ítalo e tem como objetivo humanizar a voz do menino morto. A caracterização de seu corpo sendo afligido pela bala (Bala atravessou o crânio, sangue esvaiu, joelho dobrou, corpo tombou) se opõe à vida e à consciência de Ítalo (luz dos encantos, as ideias que a bala finda, o nome, o lugar no mapa, o brilho no olhar). Essa oposição é o que passa por todo o poema, como se fosse uma batalha, um esforço fadado ao fracasso, na luta material, mas que se fixa através das ideias consolidadas em poesia. A morte física é uma tentativa de morte ideal, contra qual o poema se eleva.

Se bala quer matar as ideias, "É na cabeça que ela mira/ É na cuca que ela se encaminha/ É nas ideais que ela se finda", é porque quer legitimar a violência que provoca, afirmando a desumanização de Ítalo em sua caracterização de um marginal definido pelo mal: "Mal vestido, mal educado, mal colocado,/ Mal informado, mal encarado". Interessante é que, no verso anterior, ele caracterizou o garoto como "menino mal", ao invés de menino mau. Para além do erro gramatical, a inversão de advérbio por adjetivo é sintomática. Com ela, a qualidade "maléfica" do menino não é caraterística do substantivo menino, como se fosse um traço moral de sua natureza, mas caraterística do ambiente social que o circunda. Ser malinformado e mal-educado adquirem o sentido de privação, no sentido de que essas possibilidades nunca estiveram a seu alcance, de modo que sua marginalização (não no sentido dado pelo léxico policial, é claro) é imposta a ele a partir de fora, em um processo que começa com seu abandono material e social e termina no ponto final de uma bala. Justamente por isso, junto com o sangue vazado pela bala, vão se dissolvendo os sonhos de desenvolvimento do menino, que mais uma vez reforçam a privação que o prenderam na margem da reprodução social da vida. É curioso que parece irromper, nesse momento de elaboração dos sonhos, a identificação entre o autor e o eu lírico na forma de um “- Eu 
também!". É como se o autor tivesse perdido aqui, por um momento, a divisão entre a sua voz e a voz do poema e rasgasse o tecido ficcional das palavras para se pronunciar.

\section{Autor: Wallace}

1) Sem título

ôôo paulista, São Paulo, cidade dos terrorista de spray, explodindo as pista de cor branca, preta e mista. caça ao tesouro sem nenhum mapa e nenhuma pista. vivendo de momentos sem postar no insta, vendo os machista se achando galo de briga por ter uma crista.

No mar com uma jangada sem arma e sem nada, só eu e meus pensamentos vis, errados, errada. sei o que vejo, sei meu desejo, talvez como o seu. percebeu ? gueto mudou de realidade, mas ainda não morreu. geral na estrada, acorde e tire sua venda, pois a revolução não será televisionada. noite fria, deixe de ameaça, cão que late não morde, e gato que ataca não mia.

\section{2) Sem título}

O menor começou de pequeno vivendo o veneno e crescendo foi vendo o que cada olhar está querendo dizer.

observando os barracos de pau, se amarrando na cara de mal, convidado pros corre e tal, assaltando você que acredita na favela da tv.

Porque aqui o bagulho é monstrão, os cara desce de moto a milhão, esgoto na rua buraco no chão, os Niemeyer

dos maderite e os futuros jogadores da seleção, que é filho da dona que trampa limpando chão.

Se liga na cena, deu pena, ligou no Datena, moio seu esquema, trocar é problema, é prisão ou chão, infelizmente esse é o lema.

mulekada se divirta e cuidado, que a malandragem não é só posse, não permita que um amigo seu se envolva no doze.

Se olhar para frente vai ver que tem gente, similar, cada favelado é um universo, todos conectados pique interestelar.

\section{Síntese da análise dos poemas discutida com o aluno}

Wallace apresenta uma produção poética ligada à denúncia social, com metrificação e rimas bem marcadas. Nessa toada, cada verso é uma pequena fotografia que se adiciona a outras para dar uma figura do quadro completo, em um procedimento bem próximo àquele utilizado no rap. Os dois poemas são marcados pela oposição entre a elite (em elipse) e 
moradores da periferia. No primeiro, a cidade aparece como a cidade dos "terrorista". Terrorista, aqui, tem o sentido de agentes contra o ideal de cidade vislumbrado pela elite. Ao invés da limpeza, "o spray", ao invés da brancura, a vida "mista" e ao invés do "insta", a “pista”. É interessante como a discussão de gênero tem lugar nessa oposição. Ao contrário do começo da tradição de denúncia social do rap, na qual a discussão de gênero aparecia apenas indiretamente, aqui o machismo aparece como conceito, e, além disso, ligado à elite branca do “insta”. O que não quer dizer, é claro, que o autor está dizendo que o machismo é característica exclusiva da elite, mas pelo modo como ele pareia sua crítica, é chamativa a conexão que se estabelece entre classe social e princípios machistas. A consolidação do "terrorismo", que adquire um sentido mais político apenas ao final do poema, é voltado de modo indeterminado para o despertar do gueto, para a "tirada de vendas" e para a "revolução". O interessante é que, na visão do autor, essa revolução se dê pela jangada dos pensamentos, de como que ele pode se considerar como um dos produtores dessa revolução.

Já o segundo poema trata da desnaturalização de um certo ideal do marginal. De modo sintético, o autor passa da descrição da miséria que funda a violência (“o esgoto na rua”, as casas de madeirite) à aproximação dessa como certo ideal de favela criado midiaticamente, apresentado como mentira. Esse ideal é constituído em duas concepções distintas: de um lado, a mentira da "favela da tv", que parece ser atribuído ao assaltado, não ao assaltante; do outro, a favela do Datena, que acomete o assaltante e é marcada pela prisão e morte. Entre essas duas favelas, o autor termina com um arremate moral, sugerindo aos moradores da favela uma saída dessa dualidade a partir da compreensão da complexidade daqueles que pertencem a essa comunidade e, subrepticiamente, identificando-se como exemplo de complexidade que foge à naturalização da marginalização e do crime como consequências direta da pobreza.

Em conversa particular com o aluno ${ }^{43}$, ele me contou que suas principais motivações para a escrita de poemas, valendo-me de suas próprias palavras, foram "o contraste social, a estabilidade das pessoas perante a esse contraste e as injustiças que ocorrem com os "menos favorecidos"'. Desde os oito anos, Wallace costumava brincar com os amigos de rimar, mas passou a ter mais consciência sobre o poder transformador da palavra poética na fase adolescente: "o olhar crítico foi acrescido em momentos de injustiça vividos por mim, como uma abordagem policial excessiva. Portanto, diria que no início da minha adolescência eu tive

\footnotetext{
${ }^{43}$ As conversas a serem apresentadas nessas análises foram gravadas com a autorização dos alunos e alguns trechos foram transcritos neste item já sem a presença das marcas da oralidade.
} 
consciência que poderia expressar o que eu sentia dessa forma". Para ele, a escola Alef Peretz foi essencial no aprimoramente de suas poesias, pois, nas palavras do aluno, "foi nela que eu tive a primeira oportunidade de mostrar o que eu fazia. Além disso, o incentivo e arsenal histórico e cultural me ajudaram demais na melhoria da minha escrita e expansão do modo crítico. As disciplinas de História, Literatura, Língua Portuguesa e Filosofia foram as que mais contribuíram para minha escrita. Essa trazia pontos de vista diferentes, indagações que eu não ainda tinha feito, palavras desconhecidas, culturas e outros modos de lutas contra as injustiças. As aulas eram grandes momentos para essas reflexões, porém eu sentia que mais alunos eram atingidos com os trabalhos mais interativos como teatros e músicas, pois eram algo mais atrativo pelo fato de que a pesquisa era necessária para auxiliar e ser foco da atividade, mas a interatividade é mais divertida". De acordo com Wallace, o sarau realizado na escola era o melhor espaço para a troca de produções entre os alunos e para a experiência com outros artistas da comunidade, pois o microfone permanecia aberto para quem quisesse se expressar e, assim, os moradores que passavam em frente à escola e escutavam as performances, sentiam-se atraídos e participavam espontaneamente do evento.

\section{Autora: Patrícia}

\section{O eterno outono}

Lá se foi a época na qual pouco me importava o que vestia, o que ouvia, o que via.

A época em que eu ria e sorria.

A época em que havia felicidade, tristeza, raiva, angústia.

A época na qual havia sentimentos, que iam e vinham como nas estações, e ainda assim, sentimentos.

Hoje sou como uma árvore permanentemente no outono.

Pedaços de mim se vão constantemente.

Dia após dia, perco parte da minha essência, de quem sou.

Não me sinto capaz de ter sentimentos novamente, não me parece que algum dia eu vá sair desse outono, que passarei pelo inverno, primavera, verão. 
Pergunto se algum dia

minhas folhas vão se acabar por completo

e serei obrigada a retirar meus troncos,

e então o inverno nunca vai tomar conta de mim.

Pergunto em busca de respostas,

respostas que nunca chegam.

Não há mais ninguém ao meu lado,

ninguém para me regar e me fazer crescer novamente,

para florescer,

para sentir.

Engraçado como nesse terrível outono

o céu se comporta como se fosse inverno,

tão frio, tão sem cor, tão sem vida.

É como se esse frio atingisse meu coração

em milhares de graus negativos,

se espalhando por todo meu corpo,

pelas minhas veias, meus nervos, meu cérebro,

minha visão.

Por que tudo que vejo instantaneamente se torna triste?

Por que tudo parece ser tão sem graça?

Por que mesmo as mais simples das tarefas,

me aborrecem de tal jeito?

São tantos "porquês" na minha cabeça,

tantas perguntas,

sempre sem respostas.

Mas será que eu realmente procurei por elas?

Será que alguém além de mim estará disposto a esclarecê-las?

Passo por esse outono cinzento sozinha

enquanto todos a minha volta

passam por suas outras estações;

estações pelas quais não acredito que

algum dia, serei capaz de passar novamente.

Ou talvez sim,

em um futuro distante.

Mas aguentarei até lá?

Ou vou acabar perdendo todas as minhas folhas, perdendo meus troncos, perdendo minha essência, quem sou?

Será que vou acabar me perdendo por completo?

Vou ter que ser retirada pela raíz?

Terei que fazer isso eu mesma? 


\section{Síntese da análise do poema discutida com a aluna}

A aluna Patrícia foi quem estabeleceu vínculo e contato de forma mais afetiva e intensa ao longo dos anos de 2017 e 2018, enviando-me, com frequência, e-mails e cartas escritas à mão, ora compartilhando poemas, ora falando sobre seus sentimentos e angústias. Quando nos encontrávamos nos corredores da escola, ela sempre me abraçava e me agradecia pelas trocas e conversas que mantínhamos. No início de seu percurso escolar na Escola Alef Peretz, a coordenação do Ensino Médio de Paraisópolis já havia compartilhado em reuniões pedagógicas um breve histórico da infância e adolescência de Patrícia, momentos conturbados em uma família com pouca estrutura financeira e emocional, um pai que abandonou seus filhos, uma mãe que trabalhava muitas horas por dia e pouco permanecia em casa e Patrícia, desde pequena, sentindo-se responsável pelos cuidados dos irmãos mais novos. O conjunto de professores sentia sua carência e, ao mesmo tempo, sua garra e disposição para os estudos.

Patrícia demonstrava ser uma leitora voraz, gostava de romances europeus contemporâneos, como a tetralogia de Elena Ferrante (Amiga Genial), escrevia dissertações e sínteses com muita facilidade, com poucos desvios gramaticais e um amplo repertório de palavras, metáforas e símiles, era extremamente participativa nas discussões em aula e engajada nos projetos extra-curriculares. No entanto, Patrícia reprovou a segunda série do Ensino Médio, pois não cumpriu com as exigências dos instrumentos de avaliação do projeto da escola, como a completude do caderno (a partir da realização das tarefas de casa e dos registros de aula) e a média das notas nas avaliações bimestrais não foi suficiente (principalmente na área das Ciências Exatas). Nas produções escritas e nos exercícios de interpretação de texto, a aluna evidenciava um desempenho excepcional.

Nos dois anos em que tivemos mais contato, Patrícia me enviou mais de trinta poemas para que eu pudesse comentar e analisar. Destaquei apenas um, cujo Leitmotiv revela devidamente o estado de espírito do eu-lírico, manifestado de forma análoga em todos os seus poemas. Em "O eterno outono", o eu-lírico inicia o poema expressando sentimentos nostálgicos e melancólicos de uma época em que não era preciso se preocupar com sua aparência. Isso não significa que o centro do poema é uma espécie de regressão a um passado perdido, pois a memória nostálgica serve mais como clivagem entre uma sensibilidade vista como parâmetro de normalidade e uma sensibilidade bloqueada pela depressão. A estrutura do poema dá enfoque a este estado depressivo por meio da metáfora de uma árvore que perde paulatinamente suas folhas e, em um movimento hiperbólico, deixa para trás partes que não 
deveriam se separar. Nessa toada, o centro da metáfora se descola da figura da árvore para aquela da qual a árvore é apenas metonímia: a progressão das estações do ano como marcas das transformações que dão o ritmo à vida. O bloqueio produzido pela falta da capacidade de sentir aparece mais no desespero de uma estação que não cede lugar à outra do que no processo de corrupção interno ao próprio outono. Caso a perda, tanto de folhas quanto de sentimentos, fosse apenas uma etapa temporária e necessária, seria esta a antesala do florescimento posterior. No entanto, se esse é o movimento das três primeiras estrofes, a quarta introduz um elemento que contradiz a construção imagética até o momento, já que, apesar de ter afirmado na estrofe anterior que o inverno nunca chegaria, na quarta estrofe ele aparece, não só de modo a afirmar o oposto do que havia sido defendido nas primeiras estrofes, mas também de modo a recuperar as emoções que, segundo o início do poema, estariam perdidas. O movimento pendular entre uma apatia dissociativa e uma tristeza pungente poderia ser mitigado caso houvesse, no poema, uma conexão entre elas. No entanto, por meio da contraposição entre o momento depressivo apático do outono e o momento de tristeza e dor aguda do inverno, essa conexão não se estabelece.

Talvez isso se dê em razão do desejo subjacente do eu-lírico que, apesar de afirmar a falta do desejo, a todo momento reafirma a vontade do florescimento e do movimento da progressão da experiência. O que pode significar que este estado de bloqueio é mais um estado de "confusão" do que de fato um estágio final de desesperança, conforme reafirmado na quinta estrofe com a necessidade de perguntas e respostas. Talvez isso também explique o tom sombrio com o qual o poema se encerra e adquire um sentido ambíguo. À primeira vista, a necessidade de retirada da raiz pode parecer referência a um impulso suicída, um desejo de terminar com o sofrimento que não mais se suporta. No entanto, se levarmos a sério a metáfora elaborada pela poeta, a interrupção desse processo de "descascamento" passa a ser o requisito essencial para que se possa passar à próxima estação. Se a eterna decadência era o sinal do bloqueio, a interrupção radical pode ser a condição para o início do movimento subjetivo que o eu-lírico tanto almeja. Nesse sentido, a radicalidade do movimento é simplesmente tomar as coisas pela raiz, como dizia astutamente Marx.

Em conversa com a aluna, ela mencionou que sua principal motivação para a escrita dos poemas era poder formular de um jeito mais sensível e inusitado o que sentia e o que desejava, podendo fugir das formas recorrentes de expressão da língua que não a contemplavam. Com suas palavras, ela afirmou: "Eu sempre guardei os meus sentimentos para mim e isso, de certa forma, me incomodava, porque eu queria transmitir o que eu estava 
sentindo e quando eu percebi que eu conseguia expressar todos os meus sentimentos através da escrita de poemas, isso me motivou a escrever, e de todas as outras formas de se expressar através da escrita (texto, conto, etc) a poesia sempre foi a forma pela qual eu conseguia me expressar com mais naturalidade e era verdadeiramente sincera com o que eu estava sentindo. Então o que me motivou a escrever poesias foi a vontade de transmitir, de forma sincera e natural, o que eu sinto".

Patrícia, sempre que podia, frequentava minhas aulas no período vespertino, tomando notas e contribuindo com as análises dos textos poéticos que líamos em sala. Durante o curso, ela disse que se sentiu inspirada a produzir muitos poemas a partir das discussões em aula, pois, segundo a aluna, "algumas situações me tocaram e eu senti vontade de transmitir o que eu estava sentido em relação a essas situações em forma de poesia. A maioria das disciplinas voltadas à linguagem contribuíram para minha escrita poética. Apesar de nunca se aprofundarem no assunto como você tem feito, em várias aulas que eu tive, os professores falavam sobre métrica, sobre ritmo, rima, estrofes, etc., e essas informações agregaram bastante para minha escrita. Infelizmente, antes do nosso sarau, não vivenciei momentos com compartilhamento de poesias dos alunos. Antes do seu curso, houve uma roda de leitura onde os alunos criaram contos e compartilharam uns com os outros durante uma aula, mas apenas essa. Geralmente os alunos que escrevem e querem declamar suas poesias fazem isso no sarau que ocorre agora na escola".

Em outra oportunidade, conversamos sobre o apoio que ela sentiu para dar continuidade à escrita poética: "É claro que eu sempre quis que tivéssemos aulas de poesia e fizéssemos mais produções escritas, porque eu, particularmente, achava interessante o tema e queria desenvolver com algum profissional que pudesse me auxiliar, mas não chegou a acontecer. Porém, por mais que não tenha acontecido antes do seu curso, eu nunca me senti desamparada em relação a escrita, pois sempre que escrevia e mostrava para algum professor, eu recebia ajuda e conselhos, então apoio não faltou". Patrícia concluiu o Ensino Médio com bastante êxito, alcançou bons resultados na prova do ENEM e foi aprovada em vigésimo quarto lugar no curso de Pedagogia da Unesp de Rio Claro. 


\section{Autora: Raquel}

Ei você mulher

Ei você mulher, sorria.

Cante, dance, pule e encante

Se sinta e se ame, tudo isso sem pensar na ida

Faça tudo e um pouco mais para melhorar esse semblante

Senta em frente ao espelho,

Agora me diga, esse sorriso é verdadeiro?

Por que as lágrimas caem do seu olho?

Olha só, todo esse sofrimento é passageiro.

Ei você mulher, como está a sua vida?

Você curte, dança e sorri de verdade?

Não se preocupe com a partida

E nem com toda essa maldade

O mundo é ruim, eu sei.

Mas, você já pensou em ser melhor que ele?

Em poder fazer tudo o que quiser e no final dizer "E daí se eu errei?"

Pule, caía e se rele, deixe marcas boas em sua pele.

Vamos lá, coma com vontade,

Não perca o seu apetite.

Use short curto, para com essa bobagem

Isso é normal, não se esqueça que é apenas celulite.

Sorria, não se preocupe com essa nova estria

Ela enaltece ainda mais a sua beleza!

Ei você mulher, curta muito a vida

E jamais se deixe levar pela tristeza.

Acredite em você, lute pelo que quer

Procure a sua felicidade.

É tão prazeroso ser mulher

O ruim é não existir igualdade.

\section{Síntese da análise do poema discutida com a aluna}

Raquel foi minha aluna no curso de Língua Portuguesa e foi também minha orientanda no projeto de Síntese. Mesmo bastante tímida, ela sempre tomou a palavra nas discussões em sala de aula, apresentando suas análises e interpretações dos poemas estudados, evidenciando 
uma avançada consciência de classe. Não por outro motivo, a maioria de seus poemas pauta a questão de gênero, o machismo e a estrutura patriarcal que oprime a mulher em nossa sociedade. Neste poema "Ei você mulher" a estrutura é quase como se fosse uma manifesto pelo empoderamento e emancipação do gênero feminino, escancarando a injustiça na qual a identidade social da mulher se sustenta nos padrões e na ordem pré-estabelecida. É por isso que cada estrofe parece uma mensagem destinada à mulher enquanto gênero, uma mensagem direta que busca fazer da mulher seu próprio sujeito. Também por isso, talvez, as rimas e o ritmo do poema dão a cadência de um tom maiakovskiano, em que perguntas e exclamações parecem pontuar a necessidade da transformação social e descentramento conceitual de um sujeito sem possibilidade de movimento e postura ativa na sociedade.

O poema questiona o público e o privado, a aparência e a essência, a postura pessoal e a política da vida social da mulher. Cada estrofe é um apelo para que o gênero feminino se desprenda dos padrões de beleza e dos julgamentos machistas, desprendimento muito sustentado entre os adolescentes desta geração que estão progredindo cada vez mais no debate sobre as pautas identitárias e o feminismo interseccional. Raquel procurou demonstrar esse avanço de consciência em seus versos e em sua postura militante. Assim que chegou à escola, ela se envolveu com os projetos do sarau literário com o intuito de investir na presença da voz da mulher em cada espaço de manifestação artística e política que deveria ser ocupado.

Em conversa particular com a aluna, ela disse que sua grande motivação para escrever poemas foi o poder de brincar com as palavras: "Desde que eu entrei em contato com textos literários em seu curso, me encantei com a forma que o autor brinca com as palavras, criando todo um ecossistema nas nossas cabeças, fazendo de palavras e frases poesia, música e tudo mais. Acho incrível todo o poder de transformar simples coisas em algo tão grandioso e mágico. Dessa forma eu tenho vontade de fazer também. Além disso, tem a parte pessoal, já que uso a poesia para expressar sentimentos, coisa que eu não consigo fazer "naturalmente" desde muito tempo".

Raquel também compartilhou a difícil travessia na fase adolescente, reconhecendo como podem ser confusos e contraditórios os sentimentos de uma jovem que ainda não sabe o que acontecerá com o seu futuro. Ela viu na poesia a possibilidade de elaborar e trabalhar essa oscilação de sentimentos, pois ora estava feliz e determinada, ora se sentia muito triste e perdida. Raquel afirmou acreditar no poder transformador da palavra poética, pois comprovou pela própria experiência como ela é carregada de sentido e profundidade, tornando-se para ela uma válvula de escape para suas dores. A aluna também afirmou que a Escola Alef Peretz foi 
o lugar onde ela pôde viver as potências da poesia de maneira mais orgânica e intensa, uma vez que, além da experiência no curso de Língua Portuguesa, viu despertar em seus colegas a inspiração para ouvir, ler, escrever ou performatizar a poesia. Segundo ela, o sarau "O que te move?" foi um grande momento em sua trajetória de aluna e a motivou a compilar em uma apostila os vinte poemas que havia produzido ao longo do curso de Língua Portuguesa da primeira série:

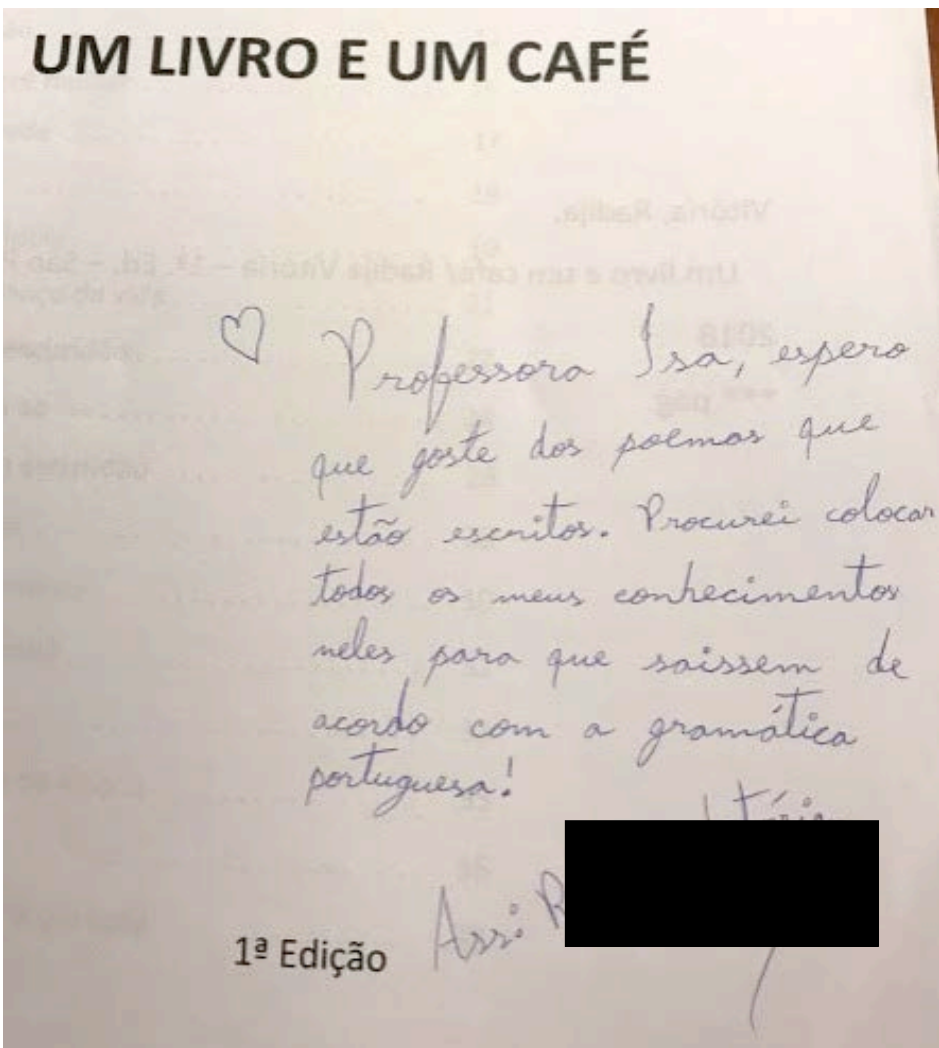

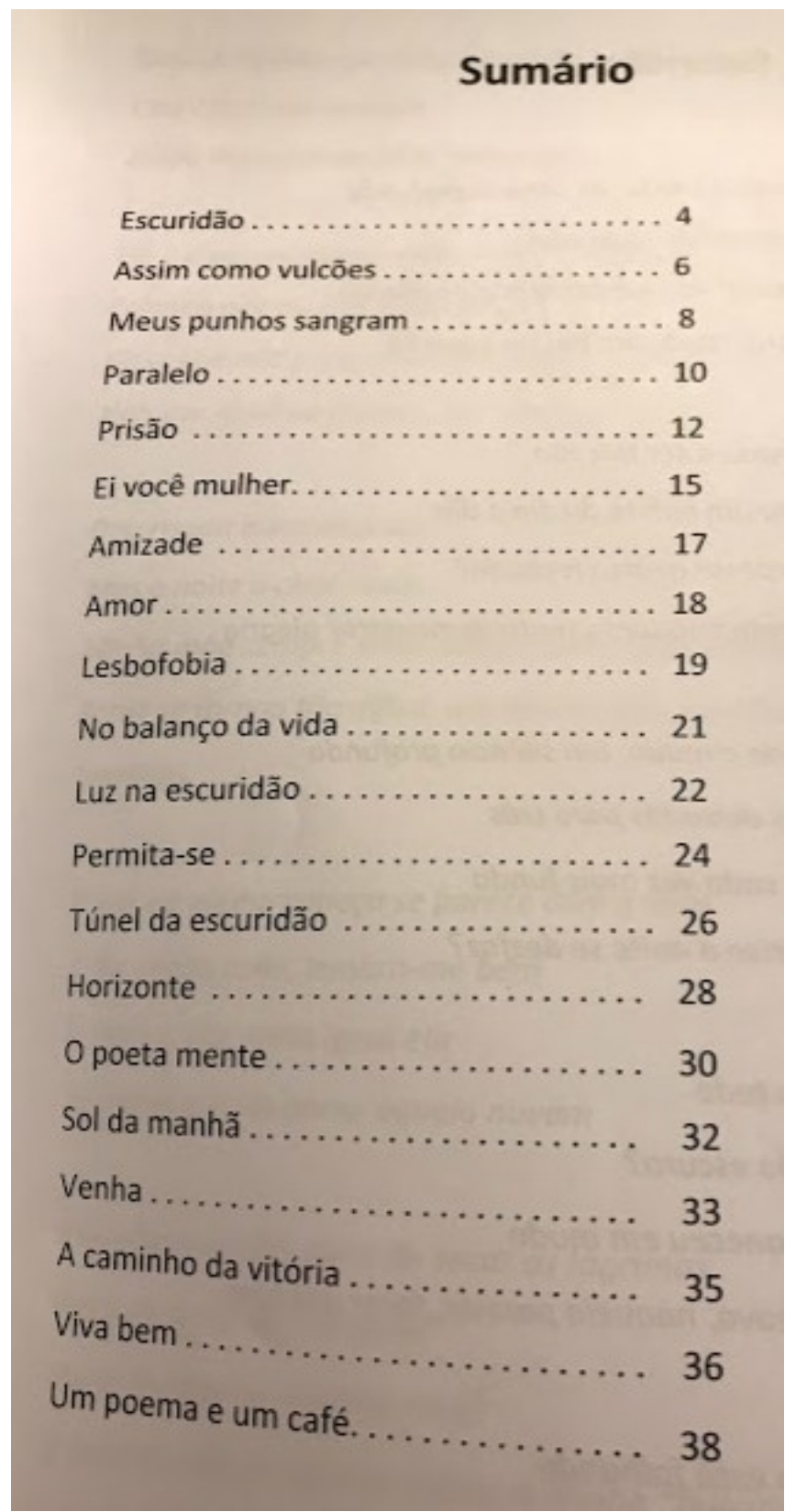

FIGURA 14. LIVRO DE POEMAS DA ALUNA RAQUEL 
Na dedicatória destinada a mim, Raquel demonstrou sua preocupação com as normas gramaticais ensinadas no curso, pois, em nossas conversas particulares e nas devolutivas da avaliação do caderno, tivemos a oportunidade de discutir sobre os traços autorais de sua escrita. Mesmo que eu tenha exposto minha opinião positiva sobre o papel da linguagem oral na escrita poética, a aluna solicitava ajuda para que seus poemas não demonstrassem um tom coloquial ou reproduzissem o que ela mesma chamou de "identidade da periferia". Raquel optou por tentar ocultar um "estilo de classe", pois considerava importante seguir as regras gramaticais. À vista disso, a aluna solicitava que eu, além de apontar as correções ortográficas, sugerisse mudanças quanto à estrutura sintática e à escolha lexical em seus versos. Constantemente, Raquel me enviava e-mails agradecendo as devolutivas e correções, dizendo que meus comentários esclareciam as ferramentas poéticas que ela utilizava em suas produções, das quais ela mesma não tinha consciência. Raquel afirmava não saber que, em seus poemas, empregava recursos poéticos recorrentes que eu demonstrava nas devolutivas como traços autorais e marcas de estilo. Com as minhas análises enviadas por e-mail, a aluna passou a reconhecer e ter mais orgulho de seu trabalho literário, tanto pelos elogios, como também pelas críticas, as quais, segundo ela, garantiam sua motivação para a escrita poética. O acompanhamento do progresso de escrita da aluna Raquel foi um belo exemplo de pontode-giro, de autopercepção de sua capacidade criativa e autoral e de reposicionamento subjetivo para lidar com os obstáculos da escrita normativa que tanto a assustavam.

\section{Reflexões acerca da metodologia proposta}

Acredito ser importante, ao final deste capítulo, expor que, mesmo considerando todas as expectativas de aprendizagem projetadas no plano de ensino, todas as habilidades e competências que tivemos que dar conta no campo dos conteúdos, todas as etapas avaliativas que estavam inseridas no calendário escolar e até o estudo que foi feito para realizar a preparação do curso de Língua Portuguesa, não teria como existir um planejamento que pudesse prever e antecipar o entusiasmo, a disposição e o engajamento com os quais os alunos da Escola Alef Peretz - Paraisópolis trabalharam ao longo dessa pesquisa. Eu fui surpreendida a cada aula pela força de vontade desses jovens em tomar a palavra poética como instrumento de aprendizagem e emancipação, ação também decorrente de uma metodologia de pesquisa e ensino que procurou focar nas estratégias de escuta acurada, ponto-de-giro, corporalidade e reposicionamento subjetivo. 
Em nosso estudo de campo, a metodologia da pesquisa-ação como estratégia do desenvolvimento da prática docente e do aprimoramento do ensino-aprendizagem dos jovens envolvidos na pesquisa nos trouxe resultados que não são possíveis de evidenciar objetivamente, com dados quantitativos e precisos, pois as conclusões justificáveis e passíveis de fundamentação advêm principalmente das trocas de experiências em sala de aula, das relações intersubjetivas dos alunos com os textos poéticos e suas reverberações singulares, como as produções autorais, as performances no sarau, as inferências e interpretações das leituras realizadas, bem como as polêmicas e discussões motivadas pelos temas das poesias trabalhadas e também meus aprendizados pessoais enquanto professora-pesquisadora. Nesse sentido, as considerações finais acerca da metodologia da pesquisa e do curso de Língua Portuguesa podem servir, eventualmente, como exemplo de práticas educativas, a partir do alcance de uma ação e movimentação coletiva no núcleo professor-aluno favoráveis à formação subjetiva, emancipatória, sensível e estética do corpo discente.

A potência e a coragem dos alunos geraram reflexões pautadas em novos discernimentos com relação à postura do professor em sala de aula, sobretudo no tocante às intervenções e ações didático-metodológicas mais assertivas, como a necessidade de uma percepção sensível para mediar nos momentos propícios, para atuar como ponto-de-giro ou, até mesmo, para deixar que eles levassem o curso de Língua Portuguesa para outros caminhos não previstos no planejamento. Assim, diante das consequências dessa proposta metodológica, foi possível exercitar a escuta pedagógica e expandir o espaço de transferência com mais cuidado, tanto sabendo relevar certas provocações e se deslocar da posição narcísica para uma posição de reconhecimento da alteridade como lugar do saber, quanto sabendo intervir diante dos preconceitos e estigmas. Nessa direção, foi possível também i) compreender melhor os conflitos da fase adolescente decorrentes de uma dura realidade, aquela do jovem negro da periferia que sofre diariamente com o racismo e a marginalização; ii) respeitar o tempo de elaboração de cada um, procurando o melhor manejo da heterogeneidade do grupo-classe, com ajuda da coordenação e dos auxiliares da escola e, acima de tudo, iii) apreender que nossas experiências poéticas em sala de aula nos permitiram abrir uma via criativa de transgressão e contestação da ordem estabelecida, ainda que ela não seja suficiente para a transformação mais direta das injustiças sociais.

Mesmo assim, o repertório poético trazido por cada um dos sujeitos da pesquisa nos fez capazes de elaborar reflexões de cunho subjetivo, histórico e político, tocando nossa identidade coletiva e singular, questionando nossa tradição, nossos valores culturais e a 
complexa problemática social, política e econômica que precisamos enfrentar. Das obras dos romanceiros ibéricos aos folhetos de cordel nordestinos, do repente e da moda de viola aos improvisos e batidas do rap nacional, dos poetas eruditos aos populares, das poesias metrificadas aos versos livres, moderna à concreta, do cânone ao marginal, nossos alunos lidaram com suas raízes, refletiram sobre os desdobramentos do passado escravocrata brasileiro, encararam a política neoliberal e discriminatória de nossa sociedade e, assim, estudaram meios e formas de renovar sua história, reinventar sua cultura, reposicionando-se subjetivamente diante do jogo simbólico, podendo, portanto, aprimorar suas técnicas de leitura e escrita e avançar em mais uma etapa de letramento contínuo no percurso escolar.

Ao longo da pesquisa, procuramos seguir atentos para não cair na ilusão e ingenuidade de que nossas propostas seriam a salvação para os problemas da educação, muito menos achar que os resultados de nossas atividades poderiam garantir a emancipação intelectual de nossos alunos a ponto de superar o conflito da luta de classes. Pelo contrário, sempre retomamos as palavras de Belintane (2017) sobre como nosso discurso não pode se revestir de sonhos irrealizáveis, nem assumir uma perspectiva redentora de educação. Buscamos trabalhar com os pés firmados no chão da escola, procurando maneiras de combater coletivamente a precarização do ensino. Em uma sociedade globalmente ditada por padrões e normas neoliberais na economia e conservadoras nos costumes, o modelo de educação teria de ser completamente reformulado para que ela pudesse servir como fator de emancipação. $\mathrm{O}$ modelo de educação que temos vigente em nossa sociedade pressupõe, como afirmou Rancière (2015), uma desigualdade das inteligências para que se mantenha a ordem da estratificação social, ou seja, o contrário do que pretendemos com as práticas emancipatórias a partir de diferentes maneiras de ser aluno, olhando o mundo através da perspectiva estética, em busca de formação cultural e política para atuar enquanto sujeito participante e contestador.

Enquanto o modelo predominante de educação continuar visando a apropriação de conhecimentos técnicos para o mercado, mais ele tenderá a contribuir para a perpetuação da injustiça social existente. Infelizmente, o que temos hoje em mãos ainda nos parece insuficiente para transformar as condições sociais e objetivas de toda população, alcançando a emancipação intelectual e política de todos para que se tornem sujeitos refletidos na história, capazes de enfrentar a dominação do sistema capitalista. Para isso, a sociedade teria que atravessar transformações radicais em toda esfera de sua organização política e econômica. Enquanto isso, o que já temos em mãos e pretendemos nunca largar é a política da literatura, 
da arte e da estética que nos fazem mais humanos, que nos trazem equilíbrio social, que nos conservam a liberdade necessária e nos oferecem o devaneio fundamental para nos refazermos e nos reerguermos após os ataques sofridos, as bárbaries experimentadas, o desmantelamento de nossa cultura. Como afirmou Candido (1978, p. 139), "a fantasia nos devolve sempre enriquecidos à realidade do cotidiano" e é por meio dela que, ao ter acesso a novas ordens imaginárias, recolocamos em movimento o nosso desejo, reinventando nossas possibilidades de ser e de atuar, tomando consciência da necessidade de transformação e revolução.

Por esse motivo, ao lançar mão do repertório poético do qual tratamos anteriormente, os alunos puderam criar seus próprios versos, improvisos, perfomances e leituras nascidas, em sua maioria, de uma transfiguração de suas perdas, dores e desilusões. Nesse movimento de criação, eles exploraram a riqueza da língua, das metáforas e dos sons, inventando formas de expor o dilema das questões raciais, de classe e gênero, reelaborando a submissão, a marginalização e a opressão vividas. Portanto, atestamos em nossa metodologia, tanto de pesquisa, quanto de ensino, que, ao permitir que os alunos descobrissem a partir do texto poético uma forma de compreender sua realidade circundante, sua história e tradição, sem que eu, professora oriunda de uma outra realidade socioeconômica, precisasse traduzi-la, foi possível que os próprios alunos verificassem sua inteligência, sua condição de compreender os poemas, sua vontade de se expressar, que, por sua vez, nada mais é que a própria vontade de traduzir o sofrimento, a angústia, o não-saber.

Nesse sentido, o devir social da escola cumpriu em parte sua tarefa de transformação e emancipação da liberdade do olhar, por meio da experiência estética, na qual os alunos puderam se enunciar subjetivamente e também coletivamente a partir de suas produções poéticas. Conforme afirmou Rancière (2009, p. 59), a política (no caso dos nossos alunos voltada principalmente sobre as pautas identitárias) e a arte (no caso da proposta do curso de Língua Portuguesa voltada para a poesia) possibilitam a construção de signos e imagens, a qual ele chamou de ficções, a fim de propiciar "relações entre o que se vê e o que se diz, entre o que se faz e o que se pode fazer". As ficções, segundo o filósofo, se entrelaçam na política por meio de suas práticas emancipatórias e na arte por meio da recomposição do tecido simbólico esgarçado pela sociedade neoliberal:

(...) as estratégias dos artistas que se propõem mudar os referenciais do que é visível e enunciável, mostrar o que não era visto, mostrar de outro jeito o que não era facilmente visto, correlacionar o que não estava correlacionado, com o objetivo de 
produzir rupturas no tecido sensível das percepções e na dinâmica dos afetos. Esse é o trabalho da ficção. Ficção não é criação de um mundo imaginário oposto ao mundo real. É o trabalho que realiza dissensos, que muda os modos de apresentação sensível e as formas de enunciação, mudando quadros, escalas, ritmos, construindo relações novas entre a aparência e a realidade, o singular e o comum, o visível e sua significação (RANCIÈRE: 2010, p. 64).

Dessa forma, procuramos traçar um plano metodológico e didático que favorecesse as diferenças (ou como nomeou Rancière, os dissensos), abrindo espaço para novos modos de apresentação sensível das várias referências sociais possíveis, tanto de visão como de enunciação singular e coletiva. Como resultado dessa estratégia, pudemos testemunhar a sensação de êxito e conquista dos alunos durante o evento do sarau literário. Ali, a partir das performances e das produções de texto que apresentaram, os alunos demonstraram ter se apoderado da oportunidade e das ferramentas para narrar em versos suas concepções de mundo, suas dores, seus desejos e medos, ocupando com palavras poéticas um espaço que já era deles, mas foi ressignificado através da tradição oral, da cultura e da educação estética experienciadas ao longo dos encontros com o texto poético. Nesses encontros, procuramos expandir a teoria da corporalidade para o desenvolvimento de uma metodologia de letramento contínuo com foco nos sujeitos escolares do Ensino Médio e também expandir a função da poesia como potencializadora do letramento para a ideia de emancipação social, ainda sob a premissa de que com a experiência poética há a possibilidade de uma subjetividade mais afeita ao domínio de outros aspectos da linguagem e da escrita, como os recursos estéticos e mnemônicos implícitos no texto que podem auxiliar no aprendizado da leitura inferencial e na escrita criativa.

Logo, iniciamos a pesquisa de campo coletando dados, relatos e experiências (perfil socioeconômico, avaliações diagnósticas, trabalhos de síntese, produções escritas, exercícios de leitura e interpretação e as performances orais envolvendo os textos poéticos) que poderiam trazer resultados relevantes para a investigação e análise do manejo didáticometodológico no ensino e aprendizagem da Língua Portuguesa no Ensino Médio. No entanto, como já mencionamos na introdução da tese, para a contribuição ao debate sobre os possíveis processos de emancipação intelectual e política dos alunos, estávamos conscientes, desde o início, de que não seria possível inferir resultados imediatos a partir do corpus reunido, por exemplo, lançando mão de dados quantitativos. Contudo, com a conclusão da pesquisa, consideramos possível refletir sobre os reposicionamentos subjetivos dos alunos diante dos desafios da leitura e da escrita e verificar positivamente nossa hipótese inicial de que a poesia 
é capaz de auxiliar no processo de emancipação, contribuindo para um novo posicionamento subjetivo dos alunos em relação à linguagem, a partir do domínio da palavra poética com vista também ao enfrentamento das adversidades e injustiças sociais.

Assim, diante do material coletado e do conjunto de experiências em sala de aula, julgamos razoáveis as seguintes conclusões:

i) a partir do questionário socioeconômico e das conversas com a coordenação da escola e com os alunos, pudemos compreender que nosso perfil de estudantes do Ensino Médio era de baixa renda, com uma média de 4,5 pessoas morando na mesma residência e 1.250 reais de renda familiar mensal. Diante desse cenário, muitos alunos tinham que contribuir com o faturamento, realizando trabalhos informais ou ajudando nos negócios da família, além de assumir parte da criação dos irmãos mais novos. Uma aluna já era mãe desde os catorze anos e a ampla maioria dos alunos tinha as tardes comprometidas com tarefas domésticas, ou seja, quase não lhes sobrava tempo para as atividades escolares, para os estudos ou outros eventos culturais. Além dos alunos não terem tempo e além de ficarem muito cansados com a sobrecarga de outras demandas não escolares, sua condição de classe não garantia a estrutura material necessária para um bom desempenho escolar, como um ambiente silencioso em casa para ler e estudar, o acesso a uma biblioteca de bairro, uma alimentação saudável, um programa de esporte ou educação física frequente, oportunidades de passeios e excursões para museus, cinema, teatro, etc. Ou seja, durante a pesquisa, grande parte do acesso material e cultural dos alunos foi fornecido pela escola. Os cadernos, tablets e materiais complementares eram distribuídos nos cursos, bem como lanche para o período integral e vale alimentação para os alunos em situação de extrema baixa renda. Eles também participavam de saídas pedagógicas semestrais e de um passeio de dois dias pelo centro de São Paulo para a realização do trabalho de campo. Mesmo com toda estrutura escolar da Alef Peretz, as condições de estudo desses jovens eram nitidamente desiguais quando comparadas às condições dos alunos das classes média e alta na Unidade Hebraica da mesma instituição de ensino. Por um lado, notamos que, durante o percurso escolar, além das dificuldades que os alunos enfrentavam no ensino e na aprendizagem cotidiana, havia também as adversidades socioeconômicas que restringiam o acesso à estrutura, aos materiais e às boas condições de estudo. Por outro lado, os alunos tinham que lidar com a visão preconceituosa, racista e elitista que fora construída entorno do espaço periférico onde vivem e que historicamente lhes atribui características essencialmente negativas e discriminatórias como o status da marginalidade, como se os alunos fossem pertencentes ao espaço de origem da violência, da 
falta de educação ou de cultura, além da infeliz crença preconceituosa que até hoje diz sobre a inferioridade do sujeito analfabeto e sobre o menor desenvolvimento intelectual do povo negro. Diante de tantos entraves sociais e políticos, nossos alunos se mostraram sobreviventes de uma política excludente, uma vez que não desistiram de conquistar o direito ao acesso à educação de qualidade e resistiram às precariedades de sua realidade para continuar frequentando assiduamente as aulas e os eventos da escola.

ii) a partir dos diagnósticos de leitura e escrita, verificamos uma defasagem acentuada para a faixa etária, sobretudo no que diz respeito à leitura com inferência de sentido, compreensão de recursos linguísticos expressivos e estilísticos, bem como à produção escrita coerente, coesa, com conhecimentos básicos de pontuação, paragrafação, ortografia e bom repertório e articulação de ideias. Mesmo assim, logo no início do curso, constatamos o imenso interesse dos jovens em falar sobre aspectos da sua vida adolescente, do seu cotidiano na comunidade e dos planos para o futuro. Diante desses temas, propusemos aos alunos exercícios de leitura de textos poéticos que pudessem incetivá-los a dar novos significados ao imaginário individual e coletivo da adolescência, bem como exercícios de produção de texto que os estimulassem a trabalhar as experiências vividas em forma de versos, refletindo sobre as pautas políticas e culturais abordadas e os aspectos estéticos e mnemônicos dos poemas analisados e produzidos. Exemplos desses exercícios foram as análises dos poemas modernos, contemporâneos e das letras de rap, os versos produzidos na dinâmica de apresentação e a discussão subsequente, a produção de folhetos de cordel (como o exemplo dado pela aluna que escreveu "A escravidão no Brasil"), a paródia do poema "José", de Carlos Drummond de Andrade, a produção autoral de poemas a partir da motivação de versos analisados no curso e, como consequência deste trabalho, a performance no sarau literário e na Mostra de Artes e Ciências da escola. No fim do ano letivo, notamos nos exercícios de escrita e reescrita dos poemas autorais maior domínio dos recursos expressivos da linguagem poética, tanto semântico-lexical, quanto morfossintático, além de um novo posicionamento subjetivo que deslocou os alunos de um lugar do não-saber para uma postura ativa, engajada e confiante frente ao uso do código escrito.

iii) a partir das discussões e reflexões sobre a linguagem, ritmo, oralidade, tradição e performance da voz, percebemos que os alunos carregavam poucos textos orais na memória, não se sentiam à vontade para se expressar oralmente, pois se reconheciam privados de repertório suficiente para nomear seus sentimentos e desejos e também se sentiam excluídos do capital cultural e do conhecimento amplo de textos literários. Realizamos diversos 
exercícios com o ritmo e a métrica de poemas e músicas conhecidas, brincamos com o improviso e as rimas, analisamos as figuras sonoras e a melopeia de textos versificados e trabalhamos a corporalidade de maneira heterogênea, por meio da performance oral, de jograis, leitura em voz alta, leitura teatralizada, memorização de poemas e versos, batalhas e rinhas de rap, entre outras propostas de atuação que puderam ampliar a confiança dos alunos em tomar a palavra poética pra si e fazê-la ecoar com sua própria voz. Na apresentação do sarau literário vimos todo o conjunto de alunos envolvido no evento, nenhum deles deixou de participar, mesmo com vergonha e com certo desconforto inicial, todos se sentiram motivados e capazes de subir no palco para declamar seus versos. Alguns leram, outros cantaram, um ou dois alunos foram acompanhados de um instrumento, mas independente das formas e meios, todos foram aplaudidos e respeitados pelo público do sarau que exerceu sua escuta atenta e demonstrou um olhar emotivo por estar diante de tantos jovens empoderados pela linguagem poética.

iv) a partir das produções poéticas dos alunos envolvidos na organização do sarau literário (Heitor, Daniel, Wallace, Patrícia e Raquel) e das nossas trocas sobre os aspectos da poesia, pudemos constatar que todos eles trouxeram a dor da opressão (sobretudo do racismo, da violência policial, da homofobia e do machismo) como tema disparador para a inspiração poética. Nossos alunos redigiram poemas narrativos, em versos livres (alguns rimados, outros não), demonstrando forte influência do ritmo e da cadência do rap brasileiro. Em conversas particulares com os alunos poetas, ouvimos de cada um que a poesia passou a ser o melhor meio para externar as dores e angústias e para compartilhar suas experiências com os outros jovens da comunidade que sofrem da mesma injustiça social. Reconhecemos em suas produções autorais não apenas a formação discursiva oral das crônicas do rap, mas também o esforço em alcançar uma sofisticação estilística por meio das figuras de linguagem, sobretudo lançando mão do uso de metáforas e de paronomásias. Os diversos recursos estéticos e mnemônicos utilizados pelos autores demonstraram certa apropriação das diferentes técnicas estudadas em aula, como a interlocução entre eu-lírico e leitor, as perguntas retóricas, a quebra de versos, as analogias e símiles e o leitmotiv da solidão.

Por fim, reconhecemos que a prática pedagógica, além de se orientar pelas demandas do letramento (com produções orais e escritas capazes de inferir e expressar os pensamentos de forma coerente e coesa), não deixou de ser uma atividade política que visou oportunizar formas de coletivizar as vozes de adolescentes que se julgavam incapazes de escrever poesia, se descreviam como ignorantes ou impossibilitados de aprender mais. Os dados coletados 
mostraram que, com o apoio da potência de sua tradição e cultura, os alunos se sentiram capazes de reencontrar sob as palavras poéticas laços afetivos, emoções compartilhadas e relações de pertencimento que, apesar das possíveis dificuldades com relação ao domínio da gramática da Língua Portuguesa e dos recursos textuais, lhes permitiram ser sujeitos de sua própria história.

\section{Considerações finais}

Em nosso percurso de escrita da tese, tivemos a intenção de refletir sobre o papel da linguagem poética no processo de letramento contínuo, investigando sua dimensão oral e estética no contexto do Ensino Médio de uma escola em Paraisópolis, na cidade de São Paulo. Nos dois primeiros capítulos, partimos da conceitualização de termos como oralidade, letramento, sujeito, autoria, subjetivação, alteridade, poesia e cultura estética, a fim de evidenciar a importância da palavra poética no letramento contínuo e a sua capacidade em provocar uma dupla ação nos sujeitos que se encontram na etapa final de seu percurso escolar: i) a experiência do indivíduo em se servir da linguagem poética, podendo ultrapassar os limites da comunicação pragmática, desvelando para si uma verdade singular, histórica e duradoura, escondida fora da consciência; ii) e a experiência potencialmente libertária e emancipatória que a poesia traz consigo, contribuindo para uma visão mais crítica sobre o assujeitamento diante dos desafios do domínio da leitura e da escrita. Já no terceiro capítulo, procuramos aprofundar o poder da palavra poética em sua função de laço social e de contestação às autoridades e à ordem vigente, problematizando a educação que não emancipa, que não almeja a "maioridade" dos jovens e que, em vez de trabalhar com a formação escolar como prática social e política, aprisiona os sujeitos em um espaço de mediação de conhecimentos técnicos e práticos, voltados para as atividades econômicas e profissionalizantes. Assim, tendo em vista as dinâmicas da corporalidade e da performance, de leituras inferenciais e do exercício de escrita criativa por meio dos textos poéticos, apresentamos no quarto capítulo os resultados de uma metodologia de letramento que possibilitou emergir potencialidades para a subjetivação política e emancipação intelectual dos alunos envolvidos no curso de Língua Portuguesa.

Para isso, foi necessário, ao longo da tese, esclarecer três importantes posicionamentos teóricos e metodológicos, com relação: i) à compreensão do sujeito moderno; ii) à potência da leitura e escrita literária em sala de aula e iii) ao reposicionamento subjetivo dos jovens diante 
da alienação e da opressão incutidas na sociedade contemporânea. Sobre o primeiro posicionamento, expusemos, com base no descentramento do sujeito segundo a psicanálise de Freud e a leitura linguística feita posteriormente por Lacan, a ideia de que a estrutura de nossos desejos e de nossas posturas subjetivas é formada por processos psíquicos e simbólicos do inconsciente que se afastam da lógica cartesiana de um sujeito cognoscente e racional, capaz de controlar seu discurso e suas marcas no mundo. Nessa direção, Tfouni e Belintane aproximam os conceitos da psicanálise às práticas da pedagogia e da educação, atribuindo especial atenção à entrada do sujeito na linguagem, a partir da sua relação com o sistema simbólico, ou melhor, a partir da formação do eu sob o "olhar" do Outro e de sua estrutura subjetiva intervalar como produto de processos psíquicos inconscientes. Isso porque Tfouni e Belintane, na perspectiva freud-lacaniana, compreendem o sujeito como excêntrico, como um eu fora de seu centro que, em vez de ser concebido como propenso a construir o conhecimento em uma posição de manejo direta, é compreendido como intervalar. Como explicamos anteriormente, o sujeito intervalar discursa e retroage sobre o processo de produção de sentido lançado por meio de sua enunciação, tornando-se capaz de controlar a deriva e amarrar a dispersão que está sempre virtualmente se instalando em seu corpo. Nesse sentido, para apresentar nossa metodologia de ensino, lançamos mão da ideia de letramento contínuo no contexto escolar que explora esse movimento de retroação, auxiliando o sujeito a retornar ao enunciado proferido e analisá-lo de um outro lugar. Dessa forma, vimos como ele se torna capaz de organizar o conteúdo de seu discurso em uma sequência com começo, meio e fim, estabelecendo coerência e coesão ao seu texto.

Logo, o conceito de corporalidade nos guiou justamente por representar a relação dos jovens com a linguagem, compreendendo como esta relação está cada vez mais tensionada por diversos recursos e meios de expressão dinâmicos. Nesse fenômeno intervalar de apropriação da linguagem e da dimensão da alteridade, evidenciamos a importância de os alunos se posicionarem subjetivamente para concentrar as energias do corpo (antes imerso apenas no oral e agora posto diante dos desafios da leitura e da escrita) para lidar com os enigmas dos textos poéticos. Vimos que esses desafios não poderiam ser superados e trabalhados se as condições em sala de aula não fossem favoráveis à percepção de que ela é composta não por sujeitos fixos e estáveis, mas sim por sujeitos divididos, fragmentados pelas contradições entre sua fantasia e realidade, incompletos por desejos impossíveis e sempre presentes em um processo contínuo de formação, de letramento e de subjetivação. E, assim como os sujeitos não são fixos e estáveis, os significados das palavras, os sentidos e as 
analogias também dependem das relações de similaridade e diferença que as palavras têm com outras palavras no interior do código da língua e do sistema cultural a qual ela pertence. Com a linguística, aprendemos que a língua preexiste a nós e seu sistema de significado não está implicado de forma individual e unívoca, mas sim de maneira coletiva, social e cultural.

A palavra é ambígua, figurável, maleável e sua estrutura é superior ao sujeito. Da mesma forma que tentamos nos comunicar por identificarmos as diferenças entre os sentidos das palavras, tentamos compreender nossa existência pela diferença com relação ao outro que não podemos ser. Por isso levamos tão a sério a afirmação de Lacan que o inconsciente está estruturado como a linguagem, já que o sujeito não pode fixar nem o significado das palavras nem o sentido de sua existência. Nós carregamos marcas em nosso corpo que não são de fácil acesso, assim como o sentido das palavras apenas se molda em uma cadeia significante, não se atrelando a um significado único, pois seu valor só pode se dar em termos relativos, a partir do deslocamento e da substituição dos termos na relação binária.

Com a teoria psicanálitica de descentramento do sujeito, isto é, de uma relação intervalar com o discurso e o corpo, aproximamos nossa essência instável ao sentido poético, que também tem sua base nos efeitos de ambiguidade, de transmutação dos sentidos das palavras, de semelhanças sonoras e trocas semânticas que mexem com a contextura dos textos. Da mesma forma que há em nós um vazio impossível de ser preenchido (responsável por nos manter na posição de desejo), os enigmas do texto poético nos movimentam para tentativas de decifração que procuram descobrir o que o Outro pretende com o seu discurso, aproximando-nos de um exercício de reflexão e de experiência com a leitura e a escrita capazes de ressignificar o mundo a nossa volta.

A partir da leitura que Lacan fez de Jakobson, tratamos também da questão do aluno ser efeito da intertextualidade (da metáfora e da metonímia) e do inconsciente (de livres associações), concluindo que essa identificação da nova situação do campo das artes, acompanhada de uma nova filosofia da subjetividade, recusa a adesão identitária imediata do sujeito autoconsciente e completo em sua corporeidade, caracterizando-o como sujeito cindido, que não escapa das trapaças da linguagem, dos lapsos e dos chistes que manifestam o desejo antes oculto e recalcado. Logo, o sujeito do inconsciente é formado, de um lado, pelas pulsões e desejos que se expressam em objetos fantasiados e representações manifestados no Imaginário, e de outro, pela linguagem originada no Simbólico. A importância dessa teoria para a prática docente se mostrou na percepção dos sujeitos escolares como sujeitos entretextos, que, na transição do Imaginário ao Simbólico, pode se surpreender com os efeitos da 
linguagem e incorporar os recursos metafóricos e metonímicos da expressão poética em sua dimensão linguística.

Assim, concluímos a partir desta compreensão de sujeito e linguagem que, se acessamos de alguma forma um espectro de sentido diante das coisas no mundo, essa compreensão se dá de modo poético, a partir do inesperado da poesia e de seus efeitos estéticos, daquilo que escapa de nós, mas mobiliza nossos desejos. Logo, nossa intenção com o trabalho poético no curso de Língua Portuguesa aplicado aos alunos do Ensino Médio de Paraisópolis foi, principalmente, desfocar a lacuna evidente ao sujeito que se instaura no interdito para refletir coletivamente sobre os métodos pelos quais sua subjetividade pode ir além dela, ou seja, como é possível reposicioná-la para que o sujeito se veja nas potências para além das lacunas. Essa premissa nos guiou tanto na prática do trabalho de campo, quanto na prática docente ao lidar com o letramento contínuo de adolescentes, abrindo possíveis caminhos para reformular e projetar uma metodologia ampla e efetiva para o manejo da heterogeneidade, a ressignificação da relação professor-aluno, a postura do professor como ponto-de-giro, o resgate das formas artísticas de expressão e compreensão da língua e a potência da corporalidade e da performance poética no reposicionamento subjetivo dos alunos diante dos desafios da leitura e da escrita.

Dessa forma, pudemos atestar a hipótese inicial deste trabalho sobre a necessidade do acesso à palavra poética, por meio da análise e inferência da poesia, que se mostrou capaz de mobilizar o desejo dos sujeitos escolares em busca da criação artística e da emancipação intelectual. Portanto, reafirmamos que nossa metodologia de pesquisa e de ensino buscou investir nas narrativas, na fantasia, na tradição oral e no ludismo literário da poesia para exercitar a leitura e escrita dos alunos no processo de letramento contínuo.

Destacamos, ao longo dos primeiros capítulos, descobertas e experiências que somente a arte e a poética podem nos proporcionar, como uma viagem para dentro de nós mesmos a partir da voz do outro, do olhar do outro, da visão de mundo do outro; como o despertar de sensações que estavam até então apagadas ou quietas em nós, sensações que não saberíamos expressar sozinhos, mas que, nas palavras do outro, revelam-se com uma nitidez surpreendente ou como uma abertura para ressignificações, acesso a caminhos e percepção de soluções que pareciam antes não existir.

Sob a intenção de proteger a literatura da indiferença e do desprestígio no contexto escolar, reafirmamos, a partir do campo da oralidade poética, sua importância em sala de aula, elucidando o valor do ritmo da poesia como elemento fundante da língua. Vimos que a poesia 
está no núcleo de toda atividade humana concebida como linguagem originária e dotada de um status mitológico, assim, analisamos as unidades expressivas da poética e a importância da poesia e da estética na aquisição da linguagem e no domínio do código escrito, pois essa percepção nos ajudou a conceber, em nossas práticas metodológicas e didáticas, a relevância dos textos poéticos na formação de leitores e escritores no processo de emancipação.

Nessa transição da linguagem oral para a linguagem escrita, retomamos os estudos de Ong, Zumthor, Tfouni e Belintane a fim de compreender o letramento de forma mais ampla, partindo da história da escrita e das relações entre culturas oralistas e culturas de escrita. Nesse movimento, pudemos compreender como o campo da poética se moveu e se identificou em uma nova situação no campo das artes que muito se transformou desde a Antiguidade Clássica e foi também acompanhada de uma nova filosofia do sujeito, o que nos coloca hoje outros desafios para a educação contemporânea.

No entanto, apesar de termos avançado na compreensão da identidade do sujeito contemporâneo, na valorização da educação sensível às artes e à formação como meio de emancipação e autonomia, estamos acompanhando reformas neoliberais nas políticas públicas educacionais que apontam para uma instrução escolar economicamente orientada pelos interesses do mercado e pela dominação da elite. Há décadas o conhecimento pedagógico vem sendo oferecido de maneira prática, tecnicista e utilitarista, para que os alunos tenham acesso rápido e de forma compacta às competências necessárias para as demandas do capitalismo. $\mathrm{A}$ política do novo Ministério da Educação, como a reforma da BNCC, os programas de militarização da escola, a supressão das Ciências Humanas no currículo do Ensino Médio, a regressão imposta na discussão das pautas identitárias das minorias, entre outras medidas, escancara a nova concepção de letramento que está em pauta: um movimento educacional totalmente desvinculado da literatura, da fruição estética e do olhar sensível sobre as artes, junto à transmissão pragmática de conteúdos instrumentalmente úteis para a vida profissional dos sujeitos recém formados na escola e à imposição pedagógica homogeneizada, que não sabe lidar com as diferenças e as singularidades dos jovens.

Hoje, se nossa formação docente dependesse apenas das intenções do governo federal, estaríamos construíndo centros de capacitação em vez de escolas, eliminando o espaço educativo, humanitário, questionador, criativo e libertador para dar lugar ao serviço necessário à futura mão de obra subserviente do sistema econômico vigente. Nesse centro de capacitação que o governo gostaria de instaurar no lugar das escolas, a literatura e as artes passariam a ser vistas com desconfiança ou como armadilhas para a insurgência contra o 
poder dominante, além de serem julgadas como manipuladoras e indecentes. No entanto, nossa tese pretendeu demonstrar a partir de nossas experiências em sala de aula, do acesso à literatura e à tomada da palavra poética por parte dos alunos que nunca é tarde para reconquistar o lugar das faculdades sensíveis e estéticas da experiência humana no contexto escolar e reconstruir o valor dos laços sociais que verdadeiramente importam. Notamos que foi a partir dos atributos da poesia, da arte e das representações simbólicas que, de fato, pudemos harmonizar e dinamizar as relações intersubjetivas dos alunos e contestar, no âmbito pessoal e coletivo, a submissão ao poder, procurando escapar das forças de alienação e de opressão.

Iniciamos a pesquisa com dados preocupantes sobre as habilidades e competências dos alunos, sobretudo diante das defasagens na escrita coerente e coesa e na leitura fluente e inferencial. Através da responsabilização coletiva do corpo docente e da coordenação pedagógica da escola Alef Peretz, das reuniões, conversas, e intervenções com os alunos e suas famílias e a partir do planejamento didático exposto no quarto capítulo (em parceria com as outras frentes de ensino da Língua Portuguesa), fomos, aos poucos, conseguindo:

i) superar o estigma do não-saber já gravado nos alunos desde o Ensino Fundamental, uma vez que, ao reconhecer a qualidade de suas produções, eles passaram a se ver como leitores e autores, capazes de verificar suas próprias inteligências e falar por si mesmos, exercendo sua "maioridade" [Mündigkeit];

ii) melhorar a falta de estrutura para os estudos, provendo lanches, materiais didáticos e complementares, tablets e sala de informática, além de espaços para a realização das tarefas e dos trabalhos propostos nos cursos, plantões de dúvida, monitorias e momentos para o compartilhamento de suas produções no pátio da escola. Com o questionário socioeconômico e os dados que levantamos a partir do diagnóstico inicial da estrutura familiar dos alunos realizada na pesquisa, pudemos lidar melhor com a heterogeneidade da turma e com as demandas singulares de cada um;

iii) apurar a postura desinteressada diante da leitura literária, a partir de vários exercícios coletivos de análise de poemas, explorando os recursos estilísticos e os enigmas dos versos, como um jogo de adivinha. Juntos, investigamos a riqueza das metáforas, das metonímias, das aliterações e assonâncias, dos jogos de palavras, das nuances sonoras e da melodia dos poemas. A partir do repertório já apresentado em aula, incentivamos os alunos a pesquisarem e trazerem para classe outros textos que julgavam pertinentes, poemas que contemplassem o gosto e o interesse da turma, além de letras de música e outros textos 
versificados para expandir o trabalho de leitura poética em sala de aula com a intervenção e atuação direta dos alunos. Nesse movimento, debatemos o estigma dos jovens sobre a leitura e externamos nossas dificuldades em compreender alguns versos. Com o trabalho da corporalidade, inventamos performances orais e lúdicas, como os improvisos a partir de uma melodia já conhecida, para que os alunos pudessem exercer a potência de sua voz e de sua gestualidade na declamação dos poemas, sentindo o ritmo dos versos em seu próprio corpo;

iv) exercitar a escrita coerente, coesa, ortográfica e normativa, por meio de exercícios gramaticais com os elementos menores da língua, associados ao ritmo e à métrica das poesias, de produções de textos com poemas motivadores e propostas de paródias, além do aperfeiçoamento das etapas de escrita autoral, como exposto na produção dos poemas para o sarau, a saber: um esboço das ideias e motivações para o poema, seguido da primeira versão do texto, da reescrita a partir das observações feitas pela professora e pelos colegas e, por fim, o compartilhamento performático, em voz alta, declamando ou cantando a poesia produzida. Outra intervenção importante foi o agendamento de conversas particulares com os alunos para tratar dos aspectos de sua produção, desde a abordagem sobre o tema escolhido, até os pormenores formais (semânticos e sintáticos) presentes na construção dos versos. Alguns exemplos desses atendimentos foram expostos na seção 4.3 do último capítulo, sob a intenção de ilustrar como os alunos apreciavam esses momentos de discussão focada nos traços singulares de sua escrita. Eles se sentiam valorizados pelo olhar personalizado e pela escuta atenta destinados a sua produção e, no final da conversa, havia ainda nosso parecer com análises, elogios, sugestões e possíveis correções no poema, incentivando a continuidade da criação poética;

v) e, por fim, promover encontros culturais e saídas pedagógicas, como a Mostra de Artes e Ciências, o Sarau "Poerifa" e "O que te move?" e o Estudo de Campo no Centro de São Paulo, que enriqueceu o trabalho em sala de aula e ajudou a promover a importância do acesso ao capital cultural como direito de todos.

A experiência vivida ao longo desta pesquisa não resultou em dados quantitativos, mas sim em descobertas decorrentes de nossa prática como pesquisadora e professora em um contexto social, cultural e econômico considerado adverso para o letramento baseado na arte e na educação estética. Os desdobramentos positivos dessa metodologia somente foram possíveis devido a nossa postura docente como ponto-de-giro, vislumbrando experiências emancipatórias e socialmente responsáveis e respeitosas com o próximo e suas diferenças, reconhecendo os valores de justiça e tolerância, na tentativa de reconstruir o contato dos 
jovens com à poesia e de retomar a importância da formação escolar voltada para a fruição estética.

Por termos oferecido ao aluno a possibilidade de fruição estética, vimos como necessário a lida com a estética não somente pela arte, mas também pela viabilidade da política da arte, conceito desenvolvido por Rancière, conforme apresentado no terceiro capítulo. Tratamos dessa possibilidade como um modo de subjetivação contínuo, do qual o jovem pôde emergir sua própria busca por novas interpretações e sentidos, isto é, por movimentos significantes, uma vez que neste processo não se seguiu uma subjetividade dada, subalterna às imposições que lhe eram feitas dos modos de pensar e agir, mas sim da capacidade de entrar em um processo de subjetivação, caminhando, portanto, para uma possível emancipação intelectual.

Nessa discussão, o par alienação e separação e o conceito de discurso e do Outro apresentados por Lacan entraram novamente em pauta para dialogar com os conceitos de tradução e contra-tradução de Rancière. Vimos que, no ato de aprender um novo saber, há o movimento de traduzir e contra-traduzir os pensamentos em palavras e as palavras em pensamento e, nesse exercício, nos inserimos nas relações humanas que são sempre permeadas pela linguagem. À vista disso, foi preciso mostrar aos alunos durante o curso de Língua Portuguesa que todos eram capazes de se colocar na realização deste movimento, já que, sem ele, não haveria possibilidade de interação social, de aproximação sensível ao texto poético e à fruição estética. Nesse sentido, Zumthor e Iser nos auxiliaram no trabalho de leitura poética a partir da teoria da performance e do efeito estético.

Tratamos da performance como parte de um momento da recepção do texto poético em que os versos são realmente recebidos pelo leitor, produzindo um efeito de transformação do conjunto de sensorialidade dos sujeitos, desde que sua leitura poética estivesse aberta para a reconstrução do sentido das experiências, cumprindo, assim, um papel fundamental no engajamento do corpo. Em nossas trocas em sala de aula, constatamos que a performance, em conjunto com o movimento de tradução e contra-tradução, pôde trabalhar a recepção do discurso poético ou da leitura de um poema no pensamento do aluno, de forma que eles se sentiram capazes de traduzir e contra-traduzir o conhecimento adquirido em palavras, em significantes próprios, retomando seus próprios processos de subjetivação em um movimento que Belintane chamou de ponto-de-giro.

Não por outro motivo, defendemos desde o início da tese que a leitura de poesia poderia ser um belo ponto de partida para o rompimento de barreiras pré-estabelecidas ou 
discursos sobre as práticas de leitura e escrita no Ensino Médio estigmatizados pelo conjunto dos sujeitos escolares (tanto alunos, quanto professores, pais e coordenação pedagógica). Logo, a partir de uma escuta atenta e do manejo da heterogeneidade do grupo-classe, lidamos com esse estigma que colocou os alunos em uma posição relutante, dificultando a superação de seus entraves, por meio das estratégias de ponto-de-giro. No quarto capítulo, vimos que o discurso e o lugar onde o aluno foi colocado tiveram de ser removidos para que uma nova predisposição se instalasse e para que houvesse a possibilidade de eu, como professora, colocar-me em diálogo com as mais complexas singularidades encontradas dentro das salas de aula. Demos exemplos desse movimento nos momentos de roda de conversa, de correção, compartilhamento e reescrita dos textos poéticos autorais, no sarau literário, entre outras experiências, cujo ponto-de-giro a partir da leitura poética e de sua necessidade de esvaziamento dos sentidos triviais das palavras pôde reposicionar os alunos no jogo de significantes lúdicos, misteriosos, ocultos e abertos aos vazios do leitor.

Em nossa metodologia voltada para o sujeito, vimos que a escuta pedagógica e a poesia se encontraram em um semelhante processo de efeitos retroativos, pois auxiliaram na compreensão do que está "escrito" nas entrelinhas (tanto nos versos analisados, quanto nas interações com os alunos envolvidos no processo de leitura). Assim como tentei ensinar os alunos sobre a torção dos sentidos das palavras em um poema, pude aprender com eles sobre minha disposição para ouvi-los e lê-los também pelas técnicas da poesia. O exercício de retroação coube tanto a mim, no cuidado com a forma de me relacionar com o aluno e de ajudá-lo a superar suas dificuldades, como ao próprio aluno ao deparar-se com a leitura de poesia, que, por sua vez, também retomou o ponto de partida de toda proposta metodológica em questão: a reimersão na oralidade poética e o aprofundamento do trabalho com textos literários no avanço de um ponto-de-giro emancipatório e de um progresso na sua formação como leitor fluente, capaz de compreender criticamente o mundo a sua volta por meio de palavras espertas da poesia.

Além disso, defendemos também que o trabalho com o texto poético seria um interessante ponto de partida na lida com as questões subjetivas dos jovens escolares de Paraisópolis, pois os sons que nele ecoam estão fortemente ligados ao sentido que estabelecem, constituindo vias de unidade entre expressão e conteúdo que, conforme mostramos no quarto capítulo, foram capazes de estimular os alunos a desvendar seus mistérios. Os exercícios de leitura poética realizados em sala de aula trabalharam com uma concepção de escrita não-linear, capacitando os alunos a estabelecerem retroações necessárias 
para a apreensão do todo do texto, decodificando as entrelinhas, os enigmas e as imagens instigantes. Assim, os movimentos e manejos didáticos baseados nessa concepção de ensino, as experiências com os poemas analisados e produzidos pelos alunos, a performance oral e o avanço da escrita expostos no sarau literário revelaram a metodologia de pesquisa e de ensino como resultado central dessa tese, podendo contribuir para as reflexões no campo da docência em Língua Portuguesa.

Portanto, em vias de conclusão, os resultados apontados no último capítulo puderam verificar nossa hipótese inicial: cultivar sentimentos estéticos por meio da linguagem poética pode ser um caminho perspicaz para reposicionar subjetivamente os jovens diante dos desafios da leitura e da escrita, bem como diante da consciência cindida e da alienação agravada pela sociedade contemporânea. A partir dessa hipótese, desenvolvemos uma contribuição metodológica de ensino de Língua Portuguesa visando um trabalho com a literatura, principalmente com o gênero lírico, que fortalecesse a oralidade poética e a performance da corporalidade com foco no letramento inferencial e autoral, buscando potencializar o desejo por emancipação intelectual e social através do efeito estético e da fruição poética. Para isso, a intervenção de pesquisa-ação com propostas de transformação do currículo de Língua Portuguesa em uma unidade filantrópica da Escola Alef Peretz na comunidade de Paraisópolis visou mudanças não apenas curriculares, mas também no espaço escolar, na formação dos jovens no que diz respeito às habilidades e competências de leitura e escrita, respeitando as necessidades da comunidade e do grupo de alunos implicados no cotidiano da pesquisa.

Nossos alunos provaram, a partir de uma nova motivação discursiva e do aperfeiçoamento da escrita criativa, que o movimento de reconstrução do eu em meio à palavra poética, à literatura, à arte e à fruição estética é um movimento naturalmente pertencente aos seres humanos e não deve ser substituído por nenhum outro pretexto de dominação do sistema econômico e da ordem disciplinar da escola e dos corpos. Dessa forma, ao longo da pesquisa, tivemos ainda mais certeza de que sempre há tempo e disposição para contestar o poder, a opressão, a injustiça e a desigualdade. Nessa travessia, os alunos conferiram ainda mais sentido aos versos de Maiakóvski, de que é preciso arrancar alegria ao futuro, pois, nessa vida, "morrer não é difícil, o difícil é a vida e seu ofício" ${ }^{4}$. Foi, portanto,

\footnotetext{
${ }^{44}$ Do poema "A Sierguéi Iessiênin", de V. Maiakóvski, traduzido por Haroldo de Campos. In: A operação do texto, Editora Perspectiva, São Paulo, 1976.
} 
na tentativa de existir resistindo à política opressora e injusta do poder dominante, que os jovens de Paraisópolis envolvidos na pesquisa testemunharam um de nossos grandes ofícios: o ofício de se entregar ao prazer da poesia, podendo fazer parte do domínio sensível da linguagem, da leitura, da escrita e da experiência de emancipação para nos fortalecermos e nos posicionarmos coletivamente contra os ataques da agenda neoliberal. 


\section{Referências Bibliográficas}

ADORNO, Theodor; HORKHEIMER, Max. Dialética do esclarecimento: fragmentos filosóficos. Rio de Janeiro: Jorge Zahar, 1985.

BANDEIRA, Manuel. Poesia Completa e Prosa. Rio de Janeiro: Nova Aguilar, 1996.

BAIRRÃO, José Francisco M. H. "A adolescência em transe". In: TFOUNI, Leda Verdiani (org.). Letramento, escrita e leitura: questões contemporâneas. Campinas: Mercado das Letras, 2010.

BARBOSA, Ricardo. Schiller \& A cultura estética. Rio de Janeiro: Jorge Zahar Ed., 2004.

BARROS, Manoel. Biblioteca Manoel de Barros. Obra Completa. São Paulo: Leya, 2013.

BARTHES, Roland. O Rumor da Língua. São Paulo: Martins Fontes, 2004.

O prazer do texto. São Paulo: Perspectiva, 2010.

BATTAGLIA, Laura. Das memórias narrativas às representações míticas: arte e desafios na alfabetização. Tese (Doutorado). Faculdade de Educação, Universidade de São Paulo, São Paulo, 2013.

BELINTANE, Claudemir. Oralidade e Alfabetização. Uma nova abordagem da alfabetização e do letramento. São Paulo: Cortez, 2013.

. "Subjetividades renitentes entre o oral e o escrito". In: REZENDE, N.;

RIOLFI, C. e SEMEGHINI-SIQUEIRA, I. (orgs). Linguagem e Educação: Implicações técnicas, éticas e estéticas. São Paulo: Humanitas / FFLCH/ USP, 2006.

Vozes da escrita - em tempos de crianças e menestréis. São Paulo: Revista Estilos da Clínica, 2008, Vol. X11l, n 25, 36-51.

. Da corporalidade lúdica à leitura significativa. São Paulo: Scortecci, 2017.

BENJAMIN, Walter. Magia e técnica, arte e politica: ensaios sobre literatura e história da cultura. São Paulo: Brasiliense, 1985.

"A tarefa-renúncia do tradutor". In: HEIDERMANN, Werner (org).

Clássicos da teoria da tradução. Florianópolis: UFSC, Núcleo de tradução, 2001.

BENTATA, Hervé. "O canto de sereia: considerações a respeito de uma incorporação

frequente da voz materna". In: Reverso [online]. 2009, vol.31, n.57, pp. 13-20.

BONDÍA, Jorge Larrosa. Pedagogia profana: danças, piruetas e mascaradas. Belo

Horizonte: Autêntica, 2003. 
BORTOLACI, Natalia. Alfabetização no ensino fundamental: novas bases curriculares. Dissertação de Mestrado. São Paulo: FEUSP, 2015.

BRASIL. Ministério da Educação. Secretaria da Educação Básica. Base nacional comum curricular. Brasília, DF, 2017. Disponível em: http://basenacionalcomum.mec.gov.br. Acesso em: dez. 2017.

BRASIL. Ministério da Educação. Secretaria da Educação Básica. Fundamentos pedagógicos e estrutura geral da BNCC. Brasília, DF, 2017. Disponível em: http://portal.mec.gov.br Acesso em: jan. 2018.

BORGES, Jorge Luis. Esse oficio do verso. São Paulo: Companhia das Letras, 2007.

BOSI, Alfredo. O ser e o tempo da poesia. São Paulo: Companhia das Letras, 2000.

CANDIDO, Antonio. Tese e Antitese. São Paulo: Editora Companhia Nacional, 1978. "O direito à literatura". In: Vários Escritos. São Paulo, Rio de Janeiro:

Duas cidades, Ouro sobre Azul, 2004, pp. 169-191. . O estudo analítico do poema. São Paulo: Editora Humanitas, 2006.

CARREIRA, Alessandra F. C. "Nada vale a pena - a escrita e o impossível". In: TFOUNI, Leda Verdiani (org.). Letramento, escrita e leitura: questões contemporâneas. Campinas: Mercado das Letras, 2010.

CASCUDO, Câmara. Histórias de Vaqueiros e Cantadores. São Paulo: Global Editora. CELAN, Paul. Arte Poética. Meridiano e outros textos. Ed. Cotovia, Lisboa, 1996. CERTEAU, Michel de. A invenção do cotidiano: 1. artes de fazer. Petrópolis: Vozes, 1994. CÉZAR, A. C.; SANTOS, V. E. O outro a despertar o mesmo: análise de "O afogado mais bonito do mundo", de Gabriel Garcia Márquez. Anais - ISSN 2177-6350. Maringá-PR. Junho, 2010 .

CÔRREA, Fernanda Silveira. "Impulso sexual: impulso lúdico e impulso estético". In: Dois pontos. Revista dos departamentos da Universidade Federal do Paraná e Universidade Federal de São Carlos. Curitiba, São Carlos, volume 13, número 3, p. 93-105, dezembro de 2016.

DALCHECO, Paulo Chagas. Autoria escolar: leitura e escrita como possibilidades de constituição do sujeito na linguagem. Dissertação de mestrado. São Paulo: FEUSP, 2016.

DRAAISMA, Douwe. Metáforas da memória: uma história das ideias sobre a mente. Bauru, SP: Edusc, 2005.

DRUMMOND, C. A. Poesia Completa. Volume Único. Rio de Janeiro: Editora Nova Aguilar, 2006.

ESCHER, Maurits Cornelis. Gravuras e desenhos. Köln: Taschen, 1994 
FREUD, Sigmund. Escritores criativos e devaneios (Volume XIX). Edição Standard Brasileira das Obras Psicológicas de Sigmund Freud. Rio de Janeiro: Imago, 1974. . A interpretação dos sonhos (Volumes IV e V). Edição Standard Brasileira das Obras Psicológicas Completas de Sigmund Freud. Rio de Janeiro: Imago, 1987. . Além do princípio do prazer. In: Edição Standard Brasileira das Obras Psicológicas Completas de Sigmund Freud. Volume XVIII. Rio de Janeiro: Imago, 1996. . O mal-estar na civilização e outros textos. São Paulo: Cia das Letras, 2010. GALEANO, Eduardo. "Os ninguéns". In: O livro dos abraços. Porto Alegre: LP\&M, 2002, p.17.

GOETHE, Johann Wolfgang. Máximas e Reflexões. Lisboa: Guimarães Editores, 2001.

GIORGION, Mariana de Campos Ferreira. Na trilha do desejo: o diagnóstico da subjetividade no Ensino Fundamental. Tese de Doutorado. São Paulo: FEUSP, 2018.

HABERMAS, Jürgen. “Conhecimento e interesse". In: Técnica e ciência como "ideologia”. São Paulo: Ed. Unesp, 2014, pp. 177-200.

HAVELOCK, Eric. Prefácio a Platão. Trad. E. A. Dobranszky. Campinas, SP: Papirus, 1996. HEGEL, G.W.F. Cursos de Estética. Vol. I. São Paulo: EDUSP, 2001.

HEIDEGGER, Martin. A caminho da Linguagem. Petrópolis, RJ: Vozes, Bragança Paulista, SP: Ed. Universitária São Francisco, 2011.

ISER, Wolfgang. O ato da leitura: uma teoria do efeito estético. Volume 1. São Paulo: Ed. 34, 1996. . O ato da leitura: uma teoria do efeito estético. Volume 2. São Paulo: Ed. 34, 1998.

JAKOBSON, Roman. Linguística. Poética. Cinema. São Paulo: Perspectiva, 2007. . Linguística e Comunicação. São Paulo: Cultrix, 2010.

JOAQUIM, Isadora Rebello. A criança entre o verso da voz e a letra do sentido: a poesia no processo de alfabetização. Dissertação de mestrado. São Paulo: FEUSP, 2016.

KANT, Immanuel. Réponse à la question: Qu'est-ce que le lumières? In: . Oeuvres philosophiques. traduction et notes par Heinz Wissmann Paris: Gallimard, 1985. . Crítica da razão pura. Petrópolis, RJ: Vozes, Bragança Paulista, SP: Ed. Universitária São Francisco, 2012.

LACAN, Jacques. O Seminário - Livro 1: Os escritos técnicos de Freud. Rio de Janeiro: Zahar, 1979. Escritos. Rio de Janeiro: Zahar, 1998. 
. O Seminário - Livro 3: As psicoses. Rio de Janeiro: Zahar, 1954.

. O Seminário - Livro 11: Os quatro conceitos fundamentais da psicanálise.

Tradução de M.D. Magno. Rio de Janeiro: Zahar, 1993.

O Seminário - Livro 5: As formações do inconsciente. Rio de Janeiro:

Zahar, 1999.

LORD, Albert B. The singer of Tales. Londres: Harvard University Press, 1997.

MACEDO, Elizabeth. Base Nacional Comum para currículos: direitos de aprendizagem e desenvolvimento para quem? Revista Educ. Soc., Campinas, v. 36, no. 133, p. 891-908, out.dez., 2015.

MARCUSCHI, L. A. Da fala para a escrita: atividade de retextualização. $4^{\mathrm{a}}$. ed. São Paulo: Cortez, 2003.

MARCUSE, Herbert. Ideologia da sociedade industrial. Rio de Janeiro: Jorge Zahar Ed., 1967.

Eros e Civilização. Uma interpretação filosófica do pensamento de Freud.

Rio de Janeiro: LTC, 2010.

MÁRQUEZ, Gabriel Gárcia. "O afogado mais bonito do mundo". In: A incrivel e triste história de Cândida Eréndira e sua avó desalmada. Tradução de Remy Força Filho. Rio de Janeiro: Record, 2009, pp. 46-55.

MELO NETO, João Cabral. Obra completa: volume único. Org. Marly de Oliveira. Rio de Janeiro: Nova Aguilar, 1994. p.311-312.

MENDES, Murilo. Tempo Espanhol. Rio de Janeiro: Record, 2001.

NANCI, Kátia A. F. Narrativas que evocam memórias e subjetividades: o reposicionamento do trabalho com a literatura de origem oral na alfabetização. Dissertação de mestrado. São Paulo: FEUSP, 2013.

Neves, C. A. B. "Slams - letramentos literários de reexistência ao/no mundo contemporâneo". In: Linha D’Água, v. 30, UNICAMP, 2017, pp. 92-112.

NIETZSCHE, Friedrich. "Curso de retórica". In: Cadernos de tradução. n. 4, São Paulo:

Edusp, 1999. p. 29-69.

OTERO, Louise A. Prol. O que (não) está escrito? Oralidade poética e leitura de processos de alfabetização e letramento. Dissertação de Mestrado. São Paulo: FEUSP, 2011.

ONG, Walter J. Oralidade e Cultura Escrita: a tecnologização da palavra. Trad. E. A.

Dobranszky. Campinas, SP: Papirus, 1998.

ORTEGA y GASSET, José. “El Quijote em la escuela”. In: Revista da Faculdade de 
Educação da Universidade de São Paulo, São Paulo, v. 19, n. 1, jan./jun. 1993, p. 11-38. PIRANDELLO, Luigi. Um, nenhum e cem mil. São Paulo: Cosac Naif, 2015. POUND, Ezra. A arte da poesia. Ensaios escolhidos. São Paulo: Cultrix, 1998. . Abc da Literatura. São Paulo: Cultrix, 2006.

RANCIÈRE, Jacques. A partilha do sensivel: estética e política. São Paulo: Ed. 34, 2009. . “O espectador emancipado". In: Revista Urdimento, São Paulo,

Outubro 2010 - No 15 (publicado originalmente na Revista Artforum em março de 2007). . O mestre ignorante: cinco lições sobre a emancipação intelectual.

Belo Horizonte: Ed. Autêntica, 2015. . "Hipóteses”. In: Criação \& Crítica. Número 16, Junho de 2016, pp. $108-127$. Políticas da escrita. São Paulo: Ed. 34, 2017.

ROJO, Roxane; MOURA, Eduardo. Multiletramentos na escola. São Paulo: Parábola, 2012. ROUSSEAU, Jean Jacques. Ensaio sobre a origem das línguas. In: Coleção Os pensadores. São Paulo: Ed. Abril Cultural, 1978.

SAUSSURE, Ferdinand. Curso de linguística geral. São Paulo: Cultrix, 2006.

SCHILLER, Friedrich. Cultura estética e liberdade. São Paulo: Hedra, 2009. . A educação estética do homem: numa série de cartas. São Paulo:

Iluminuras, 2017.

SIGNORINI, Inês. Estilo e Agentividade na escrita. In: TFOUNI, Leda Verdiani (org.). Letramento, escrita e leitura: questões contemporâneas. Campinas: Mercado das Letras, 2010 .

TAVARES, Braulio. Contando histórias em versos. Poesia e Romanceiro popular no Brasil. São Paulo: Ed. 34, 2005.

TFOUNI, Leda Verdiani. Letramento e Autoria: uma proposta para contornar a questão da dicotomia oral/escrito. In: Revista da ANPOLL, 18, 2005, p. 127-142. . Letramento e Alfabetização. São Paulo: Cortez, 2010. Letramento, escrita e leitura: questões contemporâneas. Campinas: Mercado das Letras, 2010a. . "A dispersão e a deriva na constituição da autoria e suas implicações para uma teoria do letramento". In SIGNORINI, I. (org.). Investigando a relação oral/escrito e as teorias do letramento. Campinas: Mercado de Letras. 2001. p. 77-96 MARTHA, Diana Junkes; CARREIRA, Alessandra Fernandes. "O 
inesgotável alcance da função poética". In: $O$ (in)esperado de Jakobson. TFOUNI, Leda Verdiani. MARTHA, Diana Junkes Bueno (organizadoras). Campinas, SP: Mercado de Letras: 2014.

VALÉRY, Paul. Variedades. São Paulo: Iluminuras, 1991.

WILliAMS, R. A cultura é de todos (Culture is Ordinary), 1958. Tradução Maria Elisa Cevasco, disponível em: http://pt.scribd.com/doc/68474445/A-Cultura-eOrdinaria1. Acessado em 20/01/2017 (Sem publicação).

ZUMTHOR, Paul. "O empenho do corpo". In: Performance, recepção e leitura. Trad. Jerusa Pires Ferreira e Suely Fenerich. São Paulo: Cosac Naify, 2007.

. Introdução à poesia oral. Trad. Jerusa Pires Ferreira, Maria Lucia Diniz Pochat e Maria Inês Almeida. São Paulo: Hucitec/Educ, 2010. 


\begin{abstract}
ANEXOS
ANEXO 1 - Termo de requerimento da bolsa de estudos

ANEXO 2 - Atividade diagnóstica de leitura e interpretação de poema

ANEXO 3 - Prova de seleção para concessão de bolsas

ANEXO 4 - Trechos do projeto de Síntese da aluna Flávia

ANEXO 5 - Autorização para a coleta de dados
\end{abstract}


ANEXO 1 - TERMO DE REQUERIMENTO DE BOLSA

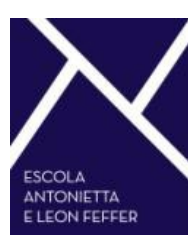

TERMO DE REQUERIMENTO DE BOLSA

( ) série - Ensino Médio

INFORMAÇÕES DO ALUNO

Nome completo:

Idade:

CPF:

RG:

Endereço:

Número:

CEP:

Cidade:

Escola de origem:

FILIAÇÃO

Nome do pai:

Idade:

$\mathrm{CPF}$ :

RG:

Endereço:

Número:

CEP:

Cidade:

Telefone: 
Celular:

Situação profissional:

( ) empregado

( ) autônomo

( ) desempregado

( ) aposentado

Nome da mãe:

Idade:

CPF:

RG:

Endereço:

Número:

CEP:

Cidade:

Telefone:

Celular:

Situação profissional:

( ) empregada

( ) autônoma

( ) desempregada

( ) aposentada

INFORMAÇÕES SOBRE O NÚCLEO FAMILIAR

Quantidade de membros da família que moram na mesma residência:

Quantidade de irmãos:

Idade dos irmãos:

Residência: ( ) própria ( ) financiada ( ) alugada ( ) cedida

Valor mensal do aluguel e/ ou financiamento do imóvel:

$\mathrm{R} \$$ 
Veículo próprio da família: ( ) não ( ) sim - modelo e ano:

\begin{tabular}{|c|l|l|l|l|}
\hline $\begin{array}{c}\text { Nome completo } \\
\text { (incluir o nome } \\
\text { do aluno) }\end{array}$ & Parentesco & Estado civil & Profissão & $\begin{array}{c}\text { Renda mensal } \\
\text { (preenchimento } \\
\text { obrigatório) }\end{array}$ \\
\hline & & & & \\
\hline & & & & \\
\hline & & & & \\
\hline
\end{tabular}

Atenção: para o reconhecimento do direito ao benefício, considera-se família para o cálculo da renda per capita, o conjunto de pessoas que residem na mesma moradia e sejam relacionadas ao aluno pelos seguintes graus de parentesco: pai, mãe, padrasto, madrasta, companheiro(a), filho(a), menor sob guarda, tutela e curatela, enteado(a), irmãos, avô ou avó.

\section{DECLARAÇÃO}

O signatário do presente declara, para todos os efeitos legais e jurídicos, que as informações prestadas para a obtenção da bolsa de estudo integral ou parcial na Escola Antonietta e Leon Feffer são verdadeiras. Na hipótese de constatação, a qualquer tempo, de inidoneidade dos documentos apresentados, bem como de falsidade nas informações prestadas, será o benefício imediatamente cancelado, conforme determinação disposta no Artigo 15. parágrafo $3^{0}$, da Lei $12.101 / 2009$, sem prejuízo da aplicação de sanções cíveis e penais cabíveis.

São Paulo, de de 20 
ANEXO 2: ATIVIDADE DIAGNÓSTICA DE LEITURA E INTERPRETAÇÃO DE POEMA

Nome: $n^{\circ}:$

Disciplina: LÍNGUA PORTUGUESA

Professora: Isadora Rebello

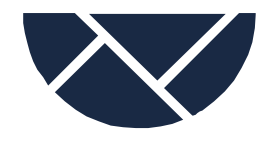

ALEF PERETZ

\section{O MENINO QUE CARREGAVA ÁGUA NA PENEIRA}

de Manoel de Barros

Tenho um livro sobre águas e meninos.

Gostei mais de um menino

que carregava água na peneira.

A mãe disse que carregar água na peneira

Era o mesmo que roubar um vento

e sair correndo com ele

para mostrar aos irmãos

A mãe disse que era o mesmo que

catar espinhos na água

O mesmo que criar peixes no bolso.

O menino era ligado em despropósitos.

Quis montar os alicerces de uma casa sobre orvalhos.

A mãe reparou que o menino gostava mais do vazio do que do cheio.

Falava que os vazios são maiores

e até infinitos.

Com o tempo aquele menino que era cismado e esquisito

porque gostava de carregar água na peneira
Com o tempo descobriu que escrever seria o mesmo que carregar

água na peneira

No escrever o menino viu

que era capaz de ser

noviça, monge ou mendigo

ao mesmo tempo.

O menino aprendeu a usar as palavras.

Viu que podia fazer peraltagens com as palavras.

Foi capaz de interromper o voo

de um pássaro

botando ponto final da frase

E começou a fazer peraltagens.

Foi capaz de modificar a tarde botando uma chuva nela.

O menino fazia prodígios.

Até fez uma pedra dar flor!

A mãe reparava o menino com ternura.

A mãe falou:

Meu filho você vai ser poeta.

Você vai carregar água na peneira

a vida toda

Você vai encher os

vazios com as suas peraltagens

e algumas pessoas

vão te amar por seus despropósitos.

Após a leitura do poema, formule respostas completas para as seguintes questões:

1. Sobre o que fala o poema acima?

2. Com o que a mãe do menino comparou "carregar água na peneira". 
3. Procure no dicionário o significado da palavra em negrito no verso abaixo, registre o significado que encontrou e escreva duas palavras que poderiam substituir "despropósitos" no contexto do poema.

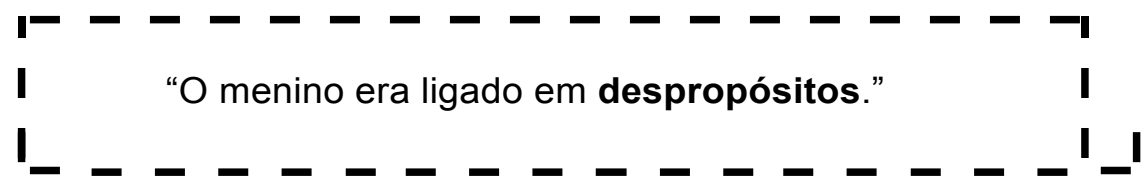

4. O que você entendeu a partir do verso "Falava que os vazios são maiores e até infinitos"?

5. Com o tempo o menino descobriu que poderia substituir o "carregar água na peneira "por outra coisa. Que coisa era essa?

6. O menino viu que podia "fazer peraltagens com as palavras". O que significa isso?

7. Em sua opinião, por que a mãe do menino comparou "ser poeta com carregar água na peneira a vida toda"?

8. O que você acha que a mãe do menino quis dizer com "você vai encher os vazios com as suas peraltagens e algumas pessoas vão te amar por seus despropósitos"?

9. Como você preenche os seus vazios? O que você faz para se sentir bem? 


\section{ANEXO 3 - PROVA DE SELEÇÃO PARA CONCESSÃO DE BOLSAS}

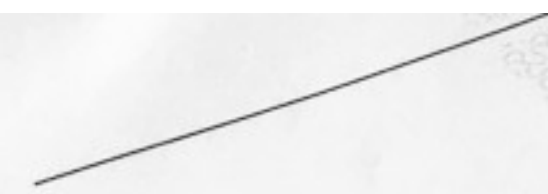

PROVA DE INGRESSO - ALEF PERETZ PARAISÓPOLIS

\section{LÍNGUA PORTUGUESA}

Inscrição:

Nome do Candidato(a):

Solmatan vecolato Silna RG: $50.367 .316-x$

Data: 04/11/2017

\section{PARTE 1: Língua e leitura literária}

No texto a seguir, Guimarăes Rosa recria uma narrativa popular muito conhecida. Leia-o para responder às questōes de 1 a 10.

\section{FITA VERDE NO CABELO}

(Nova velha estória)

Havia uma aldeia em algum lugar, nem maior nem menor, com velhos e velhas que velhavam, homens e mulheres que esperavam, e meninos e meninas que nasciam e cresciam. Todos com juizo, suficientemente, menos uma meninazinha, a que por enquanto. Aquela, um dia, saiu de lá, com uma fita verde inventada no cabelo.

Sua mãe mandara-a, com um cesto e um pote, à avó, que a amava, a uma outra e quase igualzinha aldeia. Fita-Verde partiu, sobre logo, ela a linda, tudo era uma vez. O pote continha doce em calda e o cesto estava vazio, que para buscar framboesas.

Dai, que, indo, no atravessar o bosque, viu só os lenhadores, que por lá lenhavam; mas o lobo nenhum, desconhecido, nem peludo. Pois os lenhadores tinham exterminado o lobo. Entăo, ela, mesma, era quem se dizia: "Vou à vovó com cesto e pote, e a fita verde no cabelo, o tanto que a mamãe me mandou. A aldeia e a casa esperando-a acolá, depois daquele moinho, que a gente pensa que vê, e das horas, que a gente não vê que não são.

E ela mesma resolveu escolher tomar este caminho de cá, louco e longo, e năo o outro, encurtoso. Saiu, atrás de suas asas ligeiras, sua sombra também vindo-the correndo, em pós. Divertia-se com ver as avelăs do chăo năo voarem com inalcançar essas borboletas nunca em buquê nem em botão, e com ignorar se cada uma em seu lugar as plebeinhas flores, princesinhas e incomuns, quando a gente tanto por elas passa. Vinha sobejamente.

Demorou, para dar com a avó em casa, que assim lhe respondeu, quando ela toque, toque, bateu:

- "Quem é?"

- "Sou eu..."? - e Fita-Verde descansou a voz - "Sou sua linda netinha, com cesto e pote, com a fita verde no cabelo, que a mamāe me mandou."

Vai, a avó, dificil disse: - "Puxa o ferrolho de pau da porta, entra e abre. Deus te abençoe."

Fita-Verde assim fez, e entrou e olhou. 

apanhado um ruim defluxo. rebuçada e só. Devia, para falar agagado e fraco e rouco assim de mim. enquanto é tempo."

Mas agora Fita-Verde se espantava alem caminho sua grande fita verde no cabelo atada: entristecer-se de ver que perdera além de entantou:

- "Vovozinha, que braços tăo magros, os seus, e que mãos tăo trementes!"

- "É porque não vou poder nunca mais te abraçar, minha neta..." - a avó murmurou.

- "Vovozinha, mas que lábios, ai, tâo arroxeados!

- "É porque não vou nunca mais poder te beijar, minha neta..." - a avó suspirou.

- "Vovozinha, e que olhos tão fundos e parados, nesse rosto tão encovado, pálido?"

- "É porque já não estou te vendo, nunca mais, minha netinha..." - a avó ainda gemeu.

Fita-Verde mais se assustou, como se fosse ter juizo pela primeira vez.

Gritou: - "Vovozinha, eu tenho medo do lobo!..." corpo.

Mas a avó nāo estava mais lá, sendo demasiado ausente, a năo ser pelo frio, triste e tão repentino

ROSA, Guimarães. Ave, palavra. 6. ed. Rio de Janeiro: Nova Fronteira, 2009, p. 90-92. [Epub]

1. O conto recria a tradicional história de Chapeuzinho Vermelho, citando suas marcas mais conhecidas e refazendo seu sentido original. Dentre essas caracteristicas, a que mais nos remete à história original está na seguinte passagem:

a) "Sua mãe mandara-a, com um cesto e um pote, à avó, que a amava, a uma outra e quase igualzinha à aldeia".

b) "Dai, que, indo, no atravessar o bosque, viu só os lenhadores, que por lá lenhavam; mas o lobo nenhum, desconhecido nem peludo".

c) "A aldeia e a casa esperando-a acolá, depois daquele moinho, que a gente pensa que vê, e das horas, que a gente năo vê que năo sāo".

d) "Demorou, para dar com a avó em casa, que assim Ihe respondeu, quando ela toque, toque, bateu".

e) "E ela mesma resolveu escolher tomar este caminho de cá, louco e longo, e não o outro, encurtoso".

2. Como se denomina a relaçäo estabelecida pelo autor ao recriar esse conto popular?

a) Metáfora (referente ao uso de palavra ou expressão em sentido incomum, revelando semelhança entre dois elementos).

b. Intertextualidade (referente à criaçăo de texto a partir de outro já existente).

c) Comparação (referente ao ato ou efeito de comparar),

d) Sinonimia (referente ao emprego de palavras ou expressర̋es com significaçø̋es próximas).

e) Paralelismo (referente à sequência de frases com estruturas linguisticas idênticas).

2 - Nome do candidato: Inscriçấ: Paraisópolis - NOV/2017 


\section{Sobre o texto, pode-se afirmar:}

a) Apesar de ser antagonista, o Lobo ê uma personagem secundária, pois a açăo se passa somente entre a menina e sua avó

b) Fita-Verde tem medo do Lobo, por isso vai depressa à casa de sua avo, onde se sente protegida.

c) Trata-se de uma nova versâo para o clássico Chapeuzinho Vermelho, atualizada de acordo com a realidade das novas geraç⿰丿е

(d) A morte da avó se relaciona com o fato de Fita-Verde adquirir juizo pela primeira vez, simbolizando seu distanciamento do universo da fantasia e sua aproximaçăo com a realidade.

e) Fita-Verde sente-se culpada por ter chegado tarde demais à casa de sua avó, pois havia tomado o caminho mais longo, ao invés de seguir "o outro, o encurtoso".

\section{Releia os seguintes trechos, observando as expressōes em destaque.}

I. "Fita-Verde partiu, sobre logo, ela a linda, tudo era uma vez".

II."Dai, que, indo, no atravessar o bosque, viu só os lenhadores, que por lá lenhavam; mas o lobo nenhum, desconhecido, nem peludo. Pois os lenhadores tinham exterminado o lobo.

III. "Fita-Verde se espantava, além de entristecer-se de ver que perdera no caminho sua grande fita verde"

Que expressరes marcam a ingenuidade de Fita-Verde?
a) apenas I
b) apenas II
c) apenas III
d) apenas I e II
b) em I, II e III

\section{Releia.}

"Mas agora Fita-Verde se espantava, além de entristecer-se de ver que perdera em caminho sua grande fita verde no cabelo atada; e estava suada, com enorme fome de almoço."

\section{Nesse momento do conto, constata-se}

a) a realidade se impondo à imaginaçăo.

b) a completa tomada de consciência de Fita-Verde.

c) a perda definitiva do juizo da protagonista.

d) o desencantamento provocado pelo trajeto em tudo diverso à expectativa da menina.

e) a superação do medo do desconhecido.

3- Nome do candidato: Inscriçăo: Paraisópolis - NOV/2017 
6. Ao lermos o texto, vamos percebendo um intrincado jogo de oposiçǒes, fundamentais para o levantamento temático do conto. Assinale a alternativa que melhor formula essas oposiçōes.

a) ilusăo/desilusăo; medo/enfrentamento; aconchego/desamparo; vida/morte

b) juizo/ausência de juizo; bem/mal; esperança/desesperança; alegria/ tristeza

c) presença/ausência; vermelho/verde; próximo/distante; ignorância/conhecimento

d) juizo/ausência de juizo; imaginaçăo/ realidade; vida/morte; conhecido/ desconhecido

e) bem/mal; ilusăo/desilusăo; vermelho/verde; responsabilidade/irresponsabilidade

7. No texto, as expressōes juizo, fita verde e lobo têm, respectivamente, a seguinte conotaçăo:

a) maturidade, insânia e mal.

b) responsabilidade, inocência e morte.

b) discernimento, fantasia e desconhecido.

d) capacidade de julgar, liberdade e perigo.

e) conhecimento, maturidade e violência.

8. Releia o excerto.

"Mas a avó não estava mais lá, sendo que demasiado ausente, a não ser pelo frio, triste e tão repentino corpo."

A morte da avó representa para Fita-Verde

a) a ruptura com o universo humano, com toda a sua complexidade.

b) a quebra da relação do individuo com o seu lugar de origem e suas raizes.

c) a perda da segurança, o sentimento de fragilidade ante um mundo novo e incógnito.

d) o rompimento com a sociedade na qual, por meio dela e nela, o individuo se expōe e vive seus dramas coletivos.

e) a desesperança no futuro, já que a avó representa no conto a fé da garotinha no mundo.

9. Uma das principais características do estilo de João Guimarăes Rosa é o uso de neologismos (fenômeno linguístico que consiste na criação de uma palavra ou expressão nova), como se observa no conto em análise. Releia os seguintes excertos:

I. "com velhos e velhas que velhavam"

II. "havia tomado o caminho mais longo, ao invés de seguir "o outro, o encurtoso".

III. "Vovozinha, que braços tåo magros"

Quanto aos termos grifados, tem-se presença de neologismo em:
a) apenas I
b) apenas II
c) apenas III
d) apenas I e II
e) em I, II e III
4 - Nome do candidato: Inscriçăo: Paraisópolis - NOV/2017 
10. Leia as frases abaixo.

Fita-Verde resolveu tomar este caminho de cá, louco e longo, e não o outro, encurtoso. Fita-Verde encontrou borboletas, avelās e plebeiinhas flores.

Assinale a alternativa em que as ideias acima estăo organizadas em uma única frase, de modo coerente, $e$ expressam relação de causa e consequência.

a) Assim que Fita-Verde resolveu tomar este caminho de cá, louco e longo, e não o outro, encurtoso. encontrou borboletas, avelăs e plebeiinhas flores.

b) Fita-Verde encontraria borboletas, avelãs e plebeiínhas flores, se resolvesse tomar este caminho de cá, louco e longo, e não o outro, encurtoso.

c) Ainda que Fita-Verde resolvesse tomar este caminho de cá, louco e longo, e năo o outro encurtoso, encontraria borboletas, avelăs e plebeiinhas flores.

d) Como resolveu tomar este caminho de cá, louco e longo, e não o outro, encurtoso, Fita-Verde encontrou borboletas, avelăs e plebeiínhas flores.

e) Fita-verde resolveu tomar este caminho de cá, louco e longo, e năo o outro, encurtoso, para encontrar borboletas, avelās e plebeiinhas flores. 


\section{PARTE 2: Produção de texto}

No conto analisado, Guimarães Rosa recria uma narrativa popular, transformando o conto infantil em uma história que traz uma reflexão sobre um doloroso fato da vida real: a morte de um ente querido.

Escolha um acontecimento de sua vida e elabore uma pequena narrativa sobre tal fato. O seu objetivo é produzir um texto em que se possa fazer uma reflexăo sobre uma experiência da sua vida, seja ela alegre, triste, engraçada, constrangedora, inusitada etc.

Você tem liberdade de criaçầ, contudo, procure organizar o texto em parágrafos, apresentando uma sequência lógica coerente para os fatos narrados. Para isso:

- Organize o texto de modo coerente: (1) sequencia inicial da narrativa, (2) desenvolvimento dos fatos e (3) desfecho da história.

- Utilize seus conhecimentos sobre a modalidade padrăo da lingua portuguesa.

- Construa o texto com no máximo 25 linhas, organizadas em parágrafos e periodos bem estruturados.

- Utilize a folha de rascunho para planejar e preparar o texto.

- Passe a limpo a redaçăo, devidamente revisada, no local especificado como versăo final.

- O texto deve receber um título.

\section{RASCUNHO}

5

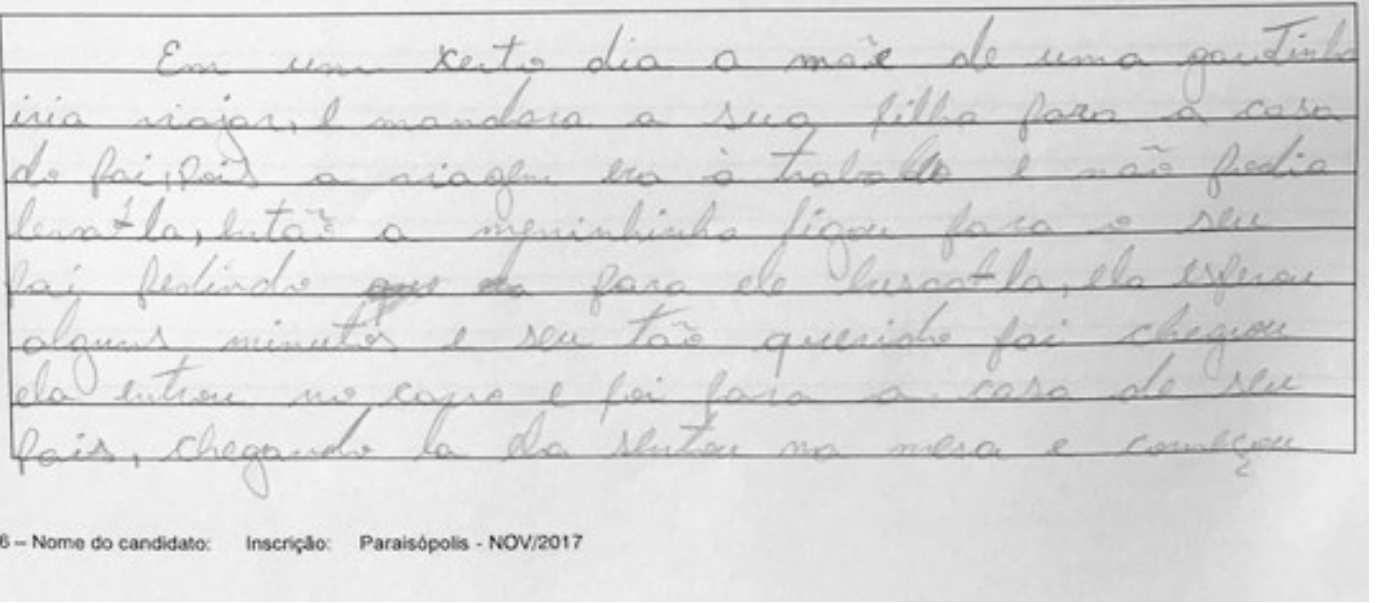




\section{CRITÉRIOS DE CORREÇÃO: PRODUÇÃO DE TEXTO \\ Prova de seleção - ALEF PARAISÓPOLIS}

1) Adequaçăo ao tema e ao gênero relato pessoal

\begin{tabular}{|l|l|c|}
\hline Desempenho & Critérios & Pontos \\
\hline Nulo & $\begin{array}{l}\text { Fuga do tema e/ou texto não correspondente ao gênero } \\
\text { solicitado. }\end{array}$ & ZERO \\
\hline Regular & $\begin{array}{l}\text { Articulação limitada das ideias em relação ao tema } \\
\text { (reflexão sobre experiência vivida) e uso limitado dos } \\
\text { caracterizadores de um relato pessoal. }\end{array}$ & 1,5 \\
\hline Bom & $\begin{array}{l}\text { Subutilizaçāo das possibilidades temáticas com indicio de } \\
\text { autoria e emprego adequado dos caracterizadores de um } \\
\text { relato pessoal, apresentando alguns desvios. }\end{array}$ & 3,0 \\
\hline Ótimo & $\begin{array}{l}\text { Extrapolaçāo de recorte temático com evidência de de } \\
\text { autoria e uso consciente e enriquecedor do gênero, } \\
\text { apresentando projeto textual consistente. }\end{array}$ & 4,0 \\
\hline
\end{tabular}

2) Estrutura: coesăo e coerência

\begin{tabular}{|l|l|c|}
\hline Desempenho & Critérios & Pontos \\
\hline Fraco & $\begin{array}{l}\text { Problemas lógico-semânticos decorrentes de frases e } \\
\text { parágrafos desarticulados. }\end{array}$ & 0,75 \\
\hline Regular & $\begin{array}{l}\text { Problemas lógico-semânticos não recorrentes e falhas de } \\
\text { articulação, que afetam a construção de alguns sentidos. }\end{array}$ & 1,5 \\
\hline Bom & $\begin{array}{l}\text { Progressão e paragrafação apropriadas, ausência de } \\
\text { atritos lógico-semânticos e articulatórios, contudo o } \\
\text { projeto textual é simples/previsivel. }\end{array}$ & 2,5 \\
\hline Ótimo & $\begin{array}{l}\text { Domínio da paragrafação, da progressăo textual e dos } \\
\text { recursos linguistico-discursivos organizadores do gênero } \\
\text { relato pessoal. }\end{array}$ & 3,0 \\
\hline
\end{tabular}

3) Recursos linguistico-discursivos

\begin{tabular}{|l|l|c|}
\hline Desempenho & Critérios & Pontos \\
\hline Fraco & $\begin{array}{l}\text { Domínio insuficiente da norma padrão (problemas } \\
\text { generalizados). }\end{array}$ & 0,75 \\
\hline Regular & $\begin{array}{l}\text { Domínio mediano da norma padrão (eventuais desvios } \\
\text { graves ou muitos desvios leves). }\end{array}$ & 1,5 \\
\hline Bom & Bom dominio da norma padrão (eventuais desvios leves) & 2,5 \\
\hline Ótimo & $\begin{array}{l}\text { Uso excelente dos recursos linguisticos (competência na } \\
\text { modalidade escrita padrão). }\end{array}$ & 3,0 \\
\hline
\end{tabular}




\section{ANEXO 4 - TRECHOS DO PROJETO DE SÍNTESE DA ALUNA FLÁVIA}

\section{Resumo}

Este trabalho tem como objetivo ressaltar produções literárias feitas por moradores de Paraisópolis e torná-las acessíveis para aqueles que não têm conhecimento destas. Visamos desconstruir discursos criados pelo senso comum de que moradores de favelas não têm capacidade de produzir literatura pela sua posição social.

Com base na premissa do trabalho, deparamo-nos com as questões: Será que em Paraisópolis existem produções literárias? Como podemos avaliar por meio das ferramentas da crítica literária tais produções?

Durante a pesquisa foi usado como base teórica o texto direito à literatura, do livro Vários Escritos, de Antônio Cândido, sobretudo a concepção de literatura do autor. O segundo texto lido foi Os pobres na literatura brasileira de Roberto Schwarz, que trata da pouca representação dos pobres na literatura e estes, quando são citados, acabam sendo difamados. A terceira leitura foi do livro Vários Contos Reunidos, de João Antônio, no qual um autor marginal/pobre fala de sua própria realidade e do que está a sua volta.

A metodologia deste trabalho envolverá a localização dos poetas de Paraisópolis e, com o consentimento deles, recolher as suas produções e analisá-las, assim reunido todas em uma coletânea.

\section{Introdução e justificativa}

Este projeto surgiu com um desejo pessoal de mostrar produções literárias - prosas poemas e poesias - feitas por moradores de Paraisópolis. No entanto, posição social e poder econômico na maioria das vezes acabam vindo à frente da capacidade, pois alguns têm mais acesso à educação, à informação e a melhores condições de vida do que outros. Com isso, muitos consideram que moradores de periferia não conseguem produzir literatura por vivenciarem tal contexto. Mas, segundo Antônio Candido no texto "Direito à literatura", qualquer pessoa produz literatura, porque é uma das formas que o homem encontrou para se se manifestar, e a produzimos o tempo todo. Então podemos dizer que, independente de classe social, todos têm capacidade de produzi-la. 
Muitas pessoas acreditam que só a ciência tem a função de retratar a realidade, mas ao longo do tempo a literatura ganhou essas funções, só que ela retrata de maneira disfarçada, usando metáforas, paradoxos, analogias e outros métodos linguísticos e estilísticos. Ao longo deste projeto, vamos trabalhar com a literatura para retratar a realidade literária e cultural dos moradores de Paraisópolis e saber se há uma produção ativa e se ela é passada para outras pessoas.

Desde o início do projeto, na parte teórica, foram lidos alguns textos, que concebem a literatura como essencial na vida do homem, como as camadas pobres são representadas na cultura letrada, o meio que essa classe encontra para se expressar, análise de escritores importantes.

\section{Objetivos}

O objetivo deste trabalho é localizar e reunir produções literárias feitas por moradores de Paraisópolis, fazendo com que aqueles que não têm conhecimento desta produção possam ter acesso por meio de uma coletânea online. O objetivo final deste projeto é fazer a primeira antologia de poesia e prosa dos escritores de Paraisópolis, seguida de um estudo acerca do material literário.

\section{Questão norteadora}

Pensando exatamente no problema que impulsionou esse trabalho - a desvalorização da produção literária na comunidade - a seguinte questão norteadora foi desenvolvida: será que em Paraisópolis tem produções literárias? Como podemos avaliar por meio das ferramentas da critica literária

\section{Discussões teóricas}

\section{A literatura na concepção de Antônio Candido}

No texto de Antônio Candido "O Direito à Literatura”, do livro Vários Escritos, um dos temas tratados é o dos Direitos Humanos, que são direitos indispensáveis para todos e não podem ser negados a ninguém. O artigo XXV da Declaração Universal dos Direitos Humanos 
(DUDH), elaborado no dia 10 de dezembro de 1948, garante educação, alimento, moradia entre outras coisas:

“Art. XXV. Todo ser humano tem direito a um padrão de vida capaz de assegurar-lhe, e a sua familia, saúde e bem-estar, inclusive alimentação, vestuário, habitação, cuidados médicos e os serviços sociais indispensáveis, e direito à segurança em caso de desemprego, doença, invalidez, viuvez, velhice ou outros casos de perda dos meios de subsistência em circunstâncias fora de seu controle. "

Quando falamos neste assunto ninguém imagina que a literatura esteja incluída a esses direitos, mas Cândido fala que a literatura faz parte sim, porque é a manifestação dos homens desde sua existência na Terra. Não existe ninguém que viva sem ela, pois entramos em contato o tempo todo, tanto conscientemente, em textos e em outros meios, quanto inconscientemente, pensamentos que produzimos o tempo todo e os sonhos enquanto dormimos.

A literatura é indispensável à humanização e, se a retirarmos do homem, tiramos dele o direito de viver, pois ao longo da nossa vida produzimos a própria literatura, sendo assim um bem incompressível - termo criado pelo sociólogo Louis Joseph Lebret, que é usado por Cândido - que não pode ser negado a ninguém, mas essas as necessidades básicas depende da época, camada social e do ponto de vista social e individual.

No artigo XXVII da declaração, ressalta-se ainda que todo ser humano tem direito ao acesso à cultura em sua comunidade. Mas esse artigo acaba sendo violado, no caso de Paraisópolis, ao proporcionarem poucas e mal divulgadas ações culturais.

\section{A representação das camadas menos favorecidas na cultura letrada}

Os pobres na literatura brasileira

Roberto Schwarz discute a representação do pobre na literatura brasileira. No livro $O s$ Pobres na Literatura Brasileira, Schwarz afirma que no século XIX existia um receio de retratar a realidade das camadas desfavorecidas em textos literários; a exceção de alguns autores da época, Machado de Assis em seus textos procurava a compreensão da realidade por outros meios, especialmente porque tinha um maior conhecimento da realidade das pessoas pobres. Um exemplo desse procedimento, no livro "Memorias póstumas de Brás Cubas" ele mostra a realidade por meio da falta de compreensão do narrador Brás Cubas, o qual 
maltratava pessoas inferiores a ele economicamente - se reconhecido, isso trazia um incômodo no leitor, provocando revolta. Assim o tema tratado não era revelado cruamente para seus leitores.

No texto "A velha pobre e o retratista", Schwarz analisa uma personagem do livro Memórias póstuma de Brás Cubas, de Machado de Assis. Em uma parte do texto é falado do caso de Brás Cubas com sua amante, de modo que o leitor não repara muito na personagem secundária Dona Plácida, que, por ser pobre e não estar mais conseguindo se sustentar, acaba alugando o quartinho dos fundos para casais namorarem escondidos. Ela faz esse trabalho para não passar fome, só que acaba sendo mal vista pela sociedade. Quanto a isso, vemos que a Dona Plácida é a representação da frustação dupla do pobre: a primeira frustação é que ela se encontra inferior ao rico aos olhares da sociedade em que vive; a segunda é por trabalhar muito e não ter reconhecimento do seu esforço, enquanto quem pouco faz acaba tendo status perante outros pela obtenção de poder econômico.

Com a falta da representação das classes menos favorecidas na literatura, começa a surgir no século XX autores pobres, na maioria moradores de comunidade, que são conhecidos como escritores marginais. Alguns retratam em suas produções o lugar onde vivem e histórias de pessoas à sua volta, que estão em situações semelhantes à do escritor ou até mesmo piores; outros buscam falar de amor, aventura e outros temas. Alguns autores representantes das classes pobres mais conhecidos a partir do século XX são Carolina de Jesus, João Antônio, Sergio Vaz, Reginaldo Ferreira da Silva (Ferrez), entre muitos outros. E por mencionar o escritor João Antônio, vamos falar um pouco da sua literatura, analisando temas e estrutura.

\section{Análises do livro Vários contos reunidos}

João Antônio nasceu no dia 27 de janeiro de 1937, era paulistano de origens humildes, boêmio, escritor e jornalista. Antônio escrevia contos que, depois de sua morte, foram reunidos no livro "Contos reunidos". Nessas narrativas curtas, ele falava e dava voz às classes mais desfavorecidas, que eram e ainda são vistas como marginalizadas na sociedade, por sua posição social inferior às demais.

Em cada conto ele abordava os vícios que geralmente eram relacionados a jogos e bebidas alcoólicas e o que levava essas pessoas a terem esses vícios. Apesar de sua origem, conseguiu um espaço na industria cultural e mostrou seu talento quebrando muitos 
preconceitos. Dois escritores e críticos literários importantes para a literatura brasileira, Antônio Candido e Alfredo Bosi, fizeram análises sobre os contos de João Antônio.

\section{Antônio Candido}

A análise feita por Candido se relaciona mais à estrutura dos contos. $\mathrm{O}$ autor começa falando que em sua época de ginásio era imposto pelos professores o uso da escrita rebuscada na construção de textos, o que desencorajava e afastava muitos da escrita. Essa questão se relaciona a uma das hipóteses desta pesquisa. Um dos aspectos que diferenciavam João Antônio dos demais escritores era a estrutura que ele fazia ao escrever. Ele começava com uma linguagem mais fácil, contendo em algumas partes do texto linguagem oral, para aproximar pessoas que não estão habituadas com a leitura, depois ia aumentando os graus de dificuldade. Tudo isso de forma proposital.

Segundo Cândido, muitos autores costumam dizer que é preciso escrever usando a norma culta, e deixar de lado a forma como se fala, porque isso reduz a qualidade e o entendimento do texto, mas João Antônio fazia diferente. Este autor costumava escrever como se falava, por isso, por exemplo, costumava repetir palavras, frases e ter apresença de gírias, "Tanto sono, muita gana, grana pouca ou nenhuma naquela roda de sinuca". Com isso, construiu um dicionário das ruas - com girias da sua época - para o caso de o leitor não conhecer as palavras. Não se pode dizer, porém, que esse recurso de linguagem prejudique a qualidade de seus textos.

\section{Alfredo Bosi}

Alfredo Bosi fala que mesmo que João Antônio seja considerado autor marginal, conseguiu um espaço no mercado cultural, superando de alguma forma esse estigma. Escrevendo com rancor sobre a posição social de seus personagens, que foram largados à margem pela cidade ingrata, que é amada por aqueles que não sofrem muito com o poder econômico, João Antônio marca seu lugar no cenário literário de seu tempo.

Ao longo da análise, Bosi descreve muito as transformações que a cidade sofreu com o avanço do capitalismo, que vai acabando com a tranquilidade e a paz e dando espaço à correria, ao tempo agitado, que no seu ver não é o mais o mesmo tempo de sua infância, porque ele não espera mais ninguém e não está mais dentro do ritmo da literatura, uma vez que a escrita necessita de períodos mais longos. 
Após a leitura dos textos tratados acima, e com o argumento de Cândido, pode-se dizer que existe literatura na comunidade de Paraisópolis, em cada esquina, em todos os becos e vielas; e, por mais que seja pequena e fique limitada aos saraus, existe produção literária escrita. Vale dizer que essa produção pode se tornar intensa. Se alguns autores conseguiram um espaço, outros também podem conseguir. João Antônio conseguiu seu espaço, mostrou o talento e produziu seus textos com o objetivo de trazer as pessoas para a leitura, principalmente quem não tem muito acesso a ela. Não podemos esquecer que a literatura, como vimos nas leituras selecionadas, está o tempo todo retratando a realidade.

\section{A manifestação da cultura letrada na comunidade}

No Capão Redondo, no ano de 2000 Ferrez junto com outros escritores fizeram três edições sobre a literatura marginal na revista Caros Amigos. Era o grande sonho de muitos mostrar seu trabalho, uma realidade que não é muito retratada, que acabou sendo alvo para muitas críticas ruins, como falam nas apresentações da segunda e terceira edição. Mas o que é literatura marginal? Segundo Ferrez, um escritor da literatura marginal a define da seguinte forma:

"A literatura Marginal, sempre é bom frisar, é uma literatura feita por minorias sejam elas raciais ou socioeconômicas. Literatura feita a margem dos núcleos centrais do saber e da grande cultura nacional, ou seja, os de grande poder aquisitivo. "

Ao discutirmos a representação da população pobre na literatura brasileira, havia dito que os pobres não costumam ser retratados e quando o são, isso é feito por escritores que não sabem a fundo a realidade vivida por essa população. A literatura marginal ganha relevância, pois ela é feita por escritores periféricos e muitos deles retratam o lugar onde vive, no caso, a comunidade, as pessoas que moram naquele lugar, e mostram sua visão como marginalizados socialmente e culturalmente. E o que torna uma pessoa participante deste movimento é o fato dela produzir fora dos núcleos centrais, não ter muitas oportunidades de mostrar seu trabalho e quando tem fica muito restrito, não ter muitos recursos econômicos para produzir e publicar seus próprios livros.

Na comunidade de Paraisópolis, os moradores encontraram uma maneira de expor produções culturais do bairro e mostrar seus talentos para as pessoas, por exemplo, por meio do sarau do Einstein. O sarau do Einstein ocorre todo último sábado do mês a parti das 
$18 \mathrm{~h} 00 \mathrm{~min}$ horas à $22 \mathrm{~h} 00 \mathrm{~min}$, é aberto para todos os moradores e visitantes de qualquer idade da comunidade para se apesentar e assistir as apresentações. Nesses eventos. As apresentações costumam ser recitações de poesias, teatrais e musicais.

\section{Metodologia}

Foram recolhidas as produções dos poetas, que são; Jussara Carvalho, que já é escritora alguns anos e têm três livros publicados por ela mesma. Henrique Cardoso, William Douglas e Danilo Guerra esses três não têm nenhum livro publicado, mas tem várias produções avulsas.

Após o recolhimento foi feito as análise das poesias e para essas analises foi criado critérios norteadores, tais como: se trata de literatura marginal ou não, recursos formais para saber a forma da construção das poesias, matéria lírica (presença do eu lírico, subjetividade do autor) ou temática e motivos centrais. Após as análises as poesias serão reunidas na primeira antologia de Paraisópolis, fazendo que os moradores do local tenham acesso a ela.

A antologia será publicada em um site, mas na página não vai ter todas as poesias analisadas, por isso a antologia completa vai estar disponível em pdf. Na página inicial terá um vídeo da pesquisadora falando um pouco sobre o trabalho e em baixo o resumo com linguagem não formal.

Ao lado disso terá um menu que vai ser organizado pelos títulos das poesias e ao clicar em alguma abrira na página do menu, onde haverá poesias e em baixo um podcast com a pesquisadora recitando, ao lado vai ter um vídeo com até um minuto e meio com o poeta falando porque criou a poesia, quando começou a escrever e quais são as inspirações, para que as pessoas conheçam um pouco mais de quem está por trás de cada criação e com isso em baixo do vídeo vai ter uma breve biografia do poeta.

\section{Resultados}

\subsection{Primeira análise}

A primeira análise foi do livro Quando o Coração Fala da Jussara Carvalho. O primeiro contato com a escritora Jussara Carvalho e suas produções foram no sarau de Paraisópolis, organizado pela instituição Einstein, quando ela recitou alguns de seus poemas. 
Esta autora começou a escrever romances e narração em versos com 14 anos; aos 20 anos passou a escrever poesias, crônicas e contos. Hoje já tem três livros publicados. É uma escritora independente, pois usa meios próprios para imprimir seus livros, em uma gráfica improvisada que fez em casa. Seu livro é construído de maneira simples, sendo impresso em folha sulfite. Na capa tem a imagem de dois pêssegos que estão grudados. Analisando a capa da obra, aparentemente os pessegos estão representando um casal se beijando. Segundo a autora, até as frutas se amam. Na capa ela se identifica como escritora de Paraisópolis, o que também nos chamou atenção.

O livro é composto por vinte e oito poemas, mas apenas quatro foram analisadas e na ordem escolhida pela autora de forma propositalmente, pois as três primeiras poesias são ligadas a romance entre homem e mulher e a última não. Além disso, a primeira e a segunda têm ligação por falarem do mesmo assunto, acabando sendo o complemento da outra, enquanto as demais não.

\section{Da mesma escritora de "Demolidor de Corações"}

\section{Jussara Carvalho}

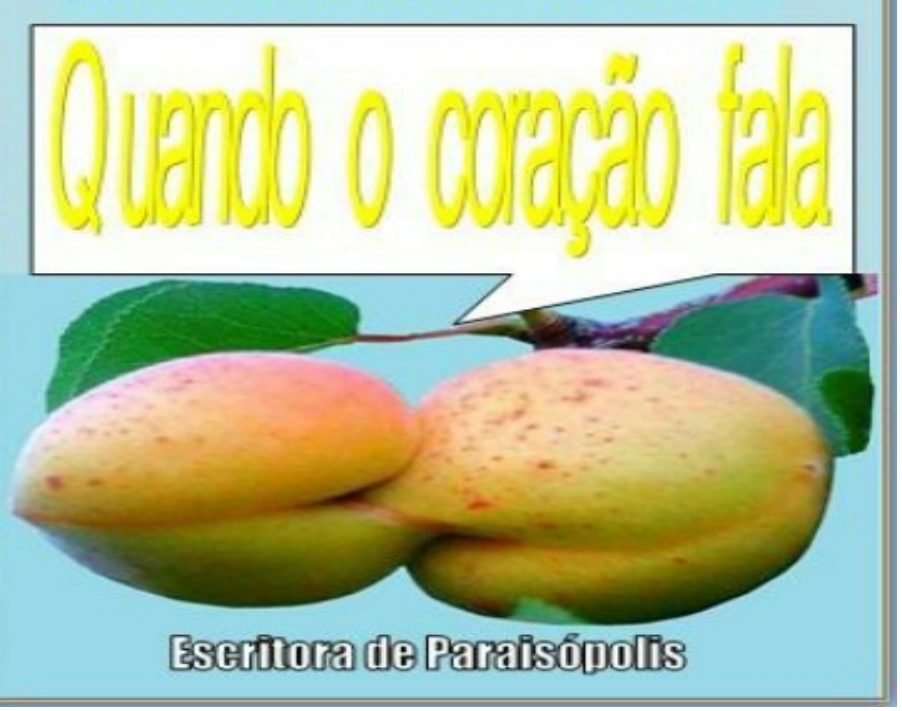

\subsubsection{Nem em outra fantasia}

Nem em outra fantasia

Nem em sua promessa de amor

Eu não acredito que exista

Então não insista, por favor!

Não precisa me oferecer nada

Eu sei que não vai cumprir

Isso só vai roubar o meu tempo 
Ou então me fazer rir

Nem em outra fantasia

Nem em sua conversa fiada

Eu já disse que não acredito

Em sua desculpa esfarrapada

Conheço o seu tipo

Mente sorrindo ou chora de dor

Mas não me engana com esse teatro

Por que conheço a técnica do ator.

Os recursos formais utilizados na construção da poesia são desenvolvidos por meio de quatro estrofes compostas por quatro versos. As estrofes aparentam ser do mesmo tamanho. $\mathrm{O}$ poema contém rimas, sendo no primeiro e últimos versos, no esquema de $\mathrm{A} / \mathrm{B} / \mathrm{C} / \mathrm{B}$, que é regular em todas as estrofes. Tem a presença de anáfora (repetição de frases para dá ênfase no texto) no primeiro verso da primeira e terceira estrofe. O poema é direto em seu assunto porque usa o sentido denotativo das palavras, que é o significado literal, assim não tem o uso de metáforas, que se valem da linguagem figurada, que não tem um sentido literal e sempre vai depender do seu contexto.

O tema que levou ao motivo central da poesia é o eu lírico dizendo para o interlocutor (a) que não acredita em suas desculpas “esfarrapadas”, porque não tem mais confiança nessa pessoa, que só quer iludi-la. A forma usada para dizer isso é usando a linguagem debochada para criticar a dissimulação do interlocutor: "Isso só vai roubar o meu tempo / Ou então me fazer rir" (segunda estrofe). O que cria essa ideia de dissimulação é a presença das construções "roubar meu tempo" e "me fazer rir". 


\section{ANEXO 5 - AUTORIZAÇÃO PARA COLETA DE DADOS}

\section{AUTORIZAÇÃO PARA COLETA DE DADOS}

São Paulo, 20 de abril de 2018.

Venho por meio deste documento solicitar à Escola Alef Peretz autorização para a realização da coleta de dados para minha pesquisa de doutorado intitulada "O papel da palavra poética no letramento continuo", com a participação dos discentes da $1^{\text {a }}$ e $2^{a}$ séries do Ensino Médio da Escola Alef Peretz - Unidade de Paraisópolis.

A tese de doutorado em questão tem como objetivo central investigar e analisar o trabalho de letramento continuo que envolve a poesia e os textos poéticos da tradição oral, bem como as práticas metodológicas adotadas para a aplicação deste trabalho no contexto do Ensino Médio da Escola Alef Peretz - Unidade Paraisópolis. A pesquisa terá basicamente dois focos: (1) investigar o processo de letramento continuo de jovens de 15 a 17 anos nos anos finais da Educação Básica no que diz respeito às habilidades de leitura inferencial e escrita autoral a partir de um repertório literário de textos poéticos orais e escritos; (2) analisar o reposicionamento subjetivo dos alunos a partir do trabalho com a estética da poesia e o que ela desperta na formação das capacidades de leitura e sensibilização artísticas e de posicionamentos políticos diante dos desafios da sociedade contemporânea.

A pesquisadora se compromete a:

1- Obedecer às disposições éticas de proteger os participantes da pesquisa, garantindo-lhes o máximo de benefícios.

2- Assegurar a privacidade das pessoas citadas nos documentos institucionais e/ou contatadas diretamente, de modo a proteger suas imagens, bem como garantir que não utilizará as informações coletadas em prejuizo dessas pessoas e/ou da instituição, respeitando deste modo as Diretrizes Éticas da Pesquisa Envolvendo Seres Humanos, nos termos estabelecidos na Resolução CNS No 466/2012, e obedecendo as disposições legais estabelecidas na Constituição Federal Brasileira, artigo $5^{\circ}$, incisos X e XIV e no Novo Código Civil, artigo 20.

Desde já, coloco-me à disposição para esclarecimentos de quaisquer dúvidas. Antecipadamente agradeço à colaboração.

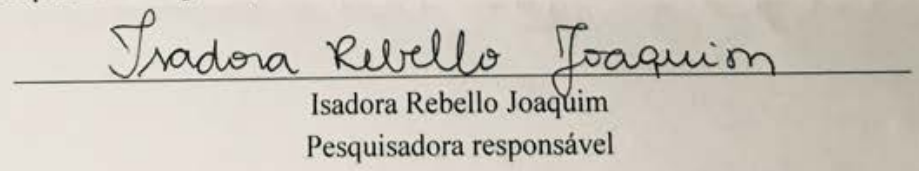

Para Preenchimento da Instituição Coparticipante

\section{Deferido $(\sqrt{)}$}

Indeferido ( )

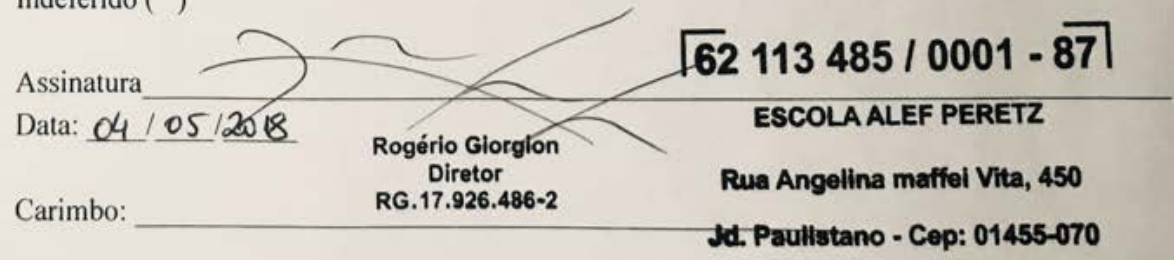

L Săo Paulo - sp 